SAMIR HERNANDES TENÓRIO GOMES

\title{
EDIFÍCIOS PARA BIBLIOTECAS UNIVERSITÁRIAS: PERSPECTIVAS E DIRETRIZES A PARTIR DA AVALIAÇÃO PÓS-OCUPAÇÃO
}

Tese apresentada ao Programa de

Pós-Graduação da Faculdade de Arquitetura e Urbanismo da Universidade de São Paulo, área de concentração Tecnologia da Arquitetura sob a orientação da Prof ${ }^{a}$. Dr ${ }^{\mathrm{a}}$ Sheila Walbe Ornstein como parte dos requisitos para a obtenção do título de Doutor. 


\section{FICHA CATALOGRÁFICA}

AUTORIZO A REPRODUÇÃO E DIVULGAÇÃO TOTAL OU PARCIAL DESTE TRABALHO, POR QUALQUER MEIO CONVENCIONAL OU ELETRÔNICO, PARA FINS DE ESTUDO E PESQUISA, DESDE QUE CITADA A FONTE.

E-MAIL: samir_arq@flash.tv.br

Gomes,Samir Hernandes Tenório

G633e Edifícios para bibliotecas universitárias: perspectivas e diretrizes a partir da avaliação pós-ocupação / Samir Hernandes Tenório Gomes. --São Paulo, 2007.

550 p. : il.

Tese (Doutorado - Área de Concentração: Tecnologia da Arquitetura) - FAUUSP.

Orientadora: Sheila Walbe Ornstein

1.Avaliação pós-ocupação 2.Bibliotecas (Arquitetura) I.Título

CDU 727.8.004.14 


\section{DEDICATÓRIA}

À Deus, por ter-me dado forças
nos momentos de dificuldades, permitindo
que estas fossem superadas.

Aos meus pais Irineu e Luiza, e ao meu irmão Marcos, pelo apoio, amor e incentivo e, principalmente, por ter me ensinado em nunca desistir desse sonho. 


\section{AGRADECIMENTOS}

À minha orientadora, Professora Doutora Sheila Walbe Ornstein, que assumiu com responsabilidade e capacidade todos os difíceis momentos dessa caminhada. A você minha admiração, meu respeito e carinho.

Aos funcionários da Biblioteca da Unesp de Marília e da Biblioteca do Senac em Santo Amaro, São Paulo, pela colaboração com insumos preciosos e informações sobre os estudos de caso, toda a minha gratidão.

Às bibliotecárias Estelita Lima Santos e Maria José Polletti, da Biblioteca da FAUUSP/Maranhão, que não pouparam esforços com dados e pesquisas correlatas, decisivas nas contribuições desta pesquisa.

Aos colegas professores do Departamento de Engenharia, Arquitetura e Urbanismo da Universidade de Marília, pelo apoio durante os quatro anos do desenvolvimento da pesquisa.

À Professora Maria de Lurdes Bertachini da Fundepe - Fundação para o Desenvolvimento do Ensino, Pesquisa e Extensão, pela idealização gráfica e pelas sugestões deste trabalho.

À professora Maria Derci da Fundepe - Fundação para o Desenvolvimento do Ensino, Pesquisa e Extensão, pela compreensão e contribuição no trabalho de revisão gramatical do texto.

À Mavi Polo, gerente da Cengage Learning, pelo oferecimento do material de apoio e pesquisa a este trabalho, meu carinho.

Ao Programa de Pós-Graduação da UNESP/Marília, pela oportunidade de dados em prol de realização deste trabalho, encorajando-me a prosseguir na execução desta tese.

Ao Programa de Pós-Graduação da FAUUSP, professores, colegas e funcionários, pelo companheirismo, amizade e troca constante de informações. 
À Professora Doutora Maria Helena T.C. de Barros, que não poupou esforços para ajudar, contribuindo com conceitos, com propostas e com bibliografia na área da Ciência da Informação.

Ao David Lee Heddy, amigo e irmão querido de longa data, sempre prestativo na revisão de meus textos em Inglês.

Á Tia Ivone por ter dedicado boa parte do seu tempo dando-me carinho, casa e amor.

À Bruna pela paciência, incentivo e ajuda na busca de novos caminhos e crescimento. 


\section{LISTA DE FIGURAS}

Figura 01 Biblioteca de Éfeso $\quad 50$

Figura 02 Biblioteca Laurenziana-1523-1571 52

Figura 03 Biblioteca Laurenziana-1523-1571 52

Figura 04 Biblioteca do Escorial/Madri 52

Figura 05 Biblioteca Ambrosiana de Milão (1603-1609) 53

Figura 06 Biblioteca Nacional da França/Etienne-Louis Boullée (1784) 55

Figura 07 Biblioteca de Sainte-Genevieve 56

Figura 08 Biblioteca de Sainte-Genevieve 56

$\begin{array}{ll}\text { Figura } 09 \text { Biblioteca de Sainte-Genevieve } & 57\end{array}$

Figura 10 Biblioteca de Sainte-Genevieve $\quad 57$

Figura 11 Biblioteca Pública de Boston $\quad 58$

Figura 12 Biblioteca Pública de Boston $\quad 58$

Figura 13 Biblioteca Municipal de Estocolmo/Vista Externa 58

$\begin{array}{ll}\text { Figura } 14 \text { Biblioteca Municipal de Estocolmo/Planta } & 58\end{array}$

Figura 15 Biblioteca Municipal de Viipuri/Vista Interna 59

Figura 16 Biblioteca Municipal de Viipuri/Vista Interna 59

Figura 17 Biblioteca Municipal de Viipuri/Vista Interna 59

Figura 18 Biblioteca Municipal de Viipuri/Vista Interna $\quad 59$

$\begin{array}{ll}\text { Figura } 19 \text { Biblioteca Pública de Seinäjoki/Vistas } & 60\end{array}$

$\begin{array}{ll}\text { Figura } 20 \text { Biblioteca Pública de Seinäjoki/Vistas } & 60\end{array}$

$\begin{array}{ll}\text { Figura } 21 \text { Biblioteca Pública de Seinäjoki/Vistas } & 60\end{array}$

$\begin{array}{ll}\text { Figura } 22 \text { Biblioteca Pública de Seinäjoki/Vistas } & 60\end{array}$

Figura 23 Planta Bibliot. Regional Technical College 63

Figura 24 Corte Esquemático, Biblioteca Regional Technical College 64

Figura 25 Vista Externa da Biblioteca Regional Technical College 65

Figura 26 Vista Interna da Biblioteca Regional Technical College 65

Figura 27 Vista Interna da Biblioteca Regional Technical College 65

Figura 28 Vista Axonométrica Interna/ Biblioteca Darwin College Study Centre 67

Figura 29 Vista Externa, Darwin College Study Centre 68

Figura 30 Sala de leitura e pesquisa, Darwin College Study Centre 69

Figura 31 Sala de leitura e pesquisa, Darwin College Study Centre 69

$\begin{array}{ll}\text { Figura } 32 \text { Planta Térreo / Biblioteca Cranfield } & 71\end{array}$

$\begin{array}{ll}\text { Figura } 33 \text { Planta Pavimento Superior / Biblioteca Cranfield } & 71\end{array}$

$\begin{array}{ll}\text { Figura } 34 \text { Fachada principal Biblioteca Cranfield } & 72\end{array}$

$\begin{array}{ll}\text { Figura } 35 \text { Vista Interior Biblioteca Cranfield } & 72\end{array}$

Figura 36 Corte/Biblioteca Cranfield $\quad 72$

Figura 37 Planta Pavimento Térreo / Biblioteca de Direito Squire 74

$\begin{array}{ll}\text { Figura } 38 \text { Corte Biblioteca de Direito Squire } & 75\end{array}$

Figura 39 Vista Externa Biblioteca de Direito Squire 76

Figura 40 Vista Externa Biblioteca de Direito Squire 76

Figura 41 Vista Interna Biblioteca de Direito Squire 76

Figura 42 Vista Interna Biblioteca de Direito Squire 76

Figura 43 Fachada Principal Biblioteca Nacional/Universitária Gottingen $\quad 78$

Figura 44 Primeiro Pavimento/Biblioteca Nacional/ Universitária Gottingen $\quad 79$

Figura 45 Vista Externa/Biblioteca Nacional/Universitária Gottingen 79

$\begin{array}{ll}\text { Figura } 46 \text { Vista Externa/Biblioteca Nacional/Universitária Gottingen } & 79\end{array}$

Figura 47 Vista Interna/Biblioteca Nacional/Universitária Gottinge $\quad 80$

Figura 48 Vista Interna/Biblioteca Nacional/Universitária Gottinge 80 
Figura 49 Planta/Biblioteca Uned

Figura 50 Vista Interna e Externa/ Biblioteca Uned 82

Figura 51 Vista Interna e Externa/ Biblioteca Uned 82

Figura 52 Vista Externa Biblioteca Learning Resouces Centre 84

Figura 53 Vista Externa /Biblioteca Learning Resouces Centre 84

Figura 54 Planta/Biblioteca Learning Resouces Centre 85

Figura 55 Corte/Biblioteca Learning Resouces Centre 85

Figura 56 Vista Interna/Biblioteca Learning Resouces Centre 86

Figura 57 Vista Interna/Biblioteca Learning Resouces Centre 86

Figura 58 Planta/Térreo Primeiro Pav. /Biblioteca John J Ross, Willian Blaklly 87

Figura 59 Vista Externa Biblioteca John J Ross, Willian Blaklly 88

Figura 60 Vista Externa Biblioteca John J Ross, Willian Blaklly 88

Figura 61 Vista Interna Biblioteca John J Ross, Willian Blaklly 88

Figura 62 Vista Interna Biblioteca John J Ross, Willian Blaklly 88

Figura 63 Biblioteca Central Universidade Federal de Minas Gerais 113

Figura 64 Biblioteca Central Universidade Federal de Minas Gerais 113

$\begin{array}{ll}\text { Figura } 65 \text { Biblioteca Setorial de Ciências/ UFSC } & 114\end{array}$

$\begin{array}{ll}\text { Figura } 66 \text { Biblioteca Setorial de Ciências/ UFSC } & 114\end{array}$

$\begin{array}{ll}\text { Figura } 67 \text { Biblioteca Central/ UFPB } & 114\end{array}$

$\begin{array}{ll}\text { Figura } 68 \text { Biblioteca Central/ UFMT } & 115\end{array}$

Figura 69 Biblioteca Central/ Unb 116

$\begin{array}{ll}\text { Figura } 70 \text { Biblioteca Central/ Unb } & 116\end{array}$

Figura 71 Implantação /Biblioteca/ Instituto de Economia da UNICAMP 124

Figura 72 Planta Térreo Biblioteca/ Instituto de Economia da UNICAMP 125

Figura 73 Planta Superior Biblioteca/ Instituto de Economia da UNICAMP 125

Figura 74 Corte/Biblioteca/ Instituto de Economia da UNICAMP 126

Figura 75 Entrada Lateral / Instituto de Economia da UNICAMP 126

Figura 76 Vista Interna/ Instituto de Economia UNICAMP 126

Figura 77 Vista Externa / Instituto de Economia da UNICAMP 126

Figura 78 Vista Externa / Instituto de Economia da UNICAMP 126

Figura 79 Escada Metálica/ Instituto de Economia da UNICAMP 127

$\begin{array}{ll}\text { Figura } 80 \text { Corte / Instituto de Economia da UNICAMP } & 127\end{array}$

$\begin{array}{ll}\text { Figura } 81 \text { Vista Interna / Instituto de Economia da UNICAMP } & 127\end{array}$

Figura 82 Vista Interna / Instituto de Economia da UNICAMP 127

Figura 83 Visão da fachada/ Biblioteca do Centro Universitário Positivo - UNICENP

Figura 84 Visão da fachada/ Biblioteca do Centro Universitário Positivo - UNICENP

$\begin{array}{ll}\text { Figura } 85 \text { Vista Interna/Centro Universitário Positivo - UNICENP } & 129 \\ \text { Figura } 86 \text { Vista Interna/Centro Universitário Positivo - UNICENP } & 129\end{array}$

Figura 87 Vista Interna/Centro Universitário Positivo - UNICENP 130

Figura 88 Vista Interna/Centro Universitário Positivo - UNICENP 130

Figura 89 Planta Biblioteca FAUUSP - Maranhão 131

Figura 90 Fixação das prateleiras nas paredes /FAUUSP - Maranhão 132

Figura 91 Fixação das prateleiras nas paredes /FAUUSP - Maranhão 132

Figura 92 Vista Interna /FAUUSP - Maranhão 132

Figura 93 Vista Interna /FAUUSP - Maranhão 132

Figura 94 Vista Interna /FAUUSP - Maranhão 133

Figura 95 Biblioteca Universitária de Pequeno Porte/Colômbia 140

Figura 96 Biblioteca da Universidade de Seijo/Japão 142 
Figura 97 Biblioteca da Universidade de Seijo/Japão

Figura 98 Acervo da Biblioteca Pública de Gentofte/ Conpenhage/Dinamarca 145

Figura 99 Estantes da Biblioteca Towel/Universidade da Califórnia/Estados Unidos

Figura 100 Biblioteca Darwin College Study Centre Cambridge, Inglaterra $\quad 148$

Figura 101 Sistema Estrutural Biblioteca Richmond Hill/Toronto/Canadá $\quad 150$

Figura 102 Sistema Estrutural Biblioteca Richmond Hill/Toronto/Canadá $\quad 150$

Figura 103 Busca de Informação Biblioteca Rotch/MIT/Massachusetts 151

Figura 104 Sala de Leitura Biblioteca em Múrcia/Espanha 152

Figura 105 Sala de Leitura Biblioteca Universidade Oviedo/Espanha 152

Figura 106 Devolução/Livros Biblioteca Centro Universitário Otávio Bastos/Brasil

Figura 107 Planta/Biblioteca/Universidade Wilfrid Laurier/Canadá 155

Figura 108 Iluminação 162

Figura 109 Iluminação Bibl. Medicina/Universidade de Yale 162

Figura 110 Implantação Biblioteca/Universidade de Valência

Figura 111 Implantação Biblioteca/Universidade de Washington 168

Figura 112 Implantação Biblioteca/Universidade da Virgínia 171

Figura 113 Implantação Biblioteca Universidade de Valência/Espanha 171

Figura 114 Implantação Biblioteca Universidade de Ontário/Canadá 171

Figura 115 Unidades Universitárias/UNESP/Estado de São Paulo 189

Figura 116 Faculdade de Filosofia, Ciências e Letras, 1959 - Marília 195

Figura 117 Faculdade de Filosofia, Ciências e Letras, 1959 - Marília 195

Figura 118 Biblioteca do Campus/Unesp - Marília, anos 60

Figura 119 Implantação Biblioteca - Campus/Unesp - Marília 198

Figura 120 Entrada Principal da Biblioteca do Campus/Unesp - Marília 199

Figura 121 Entrada Principal da Biblioteca do Campus/Unesp - Marília 199

Figura 122 Entrada Secundária da Biblioteca do Campus/ Unesp - Marília 199

Figura 123 Entrada Secundária da Biblioteca do Campus/ Unesp - Marília 199

Figura 124 Entrada da Biblioteca/Unesp - Marília/Detalhe do corrimão e rampa 200

Figura 125 Partido arquitetônico da biblioteca: elementos vazados e dimensionamento modular 201

Figura 126 Partido arquitetônico da biblioteca: elementos vazados e dimensionamento modular 201

Figura 127 Partido arquitetônico da biblioteca: elementos vazados e dimensionamento modular 201

Figura 128 Pavimento térreo/Biblioteca Unesp/Marília 202

Figura 129 Pavimento inferior/Biblioteca Unesp/Marília 203

$\begin{array}{ll}\text { Figura } 130 \text { Recepção da Biblioteca } & 204\end{array}$

Figura 131 Guarda-Volumes da Biblioteca 204

Figura 132 Exposição da Biblioteca 204

Figura 133 Planta Empréstimo e Devolução/Biblioteca Unesp/Marília 205

Figura 134 Vista Externa Balcão de Devolução 205

Figura 135 Empréstimo e Controle 205

Figuras 136/137 Vista Interna Balcão de Devolução,Empréstimo e Controle 206

$\begin{array}{ll}\text { Figuras 138/139 Portal de controle } & 206\end{array}$

Figura 140 Hall Principal 208

Figura 141 Hall principal: consulta base de dados e atendimento
pesquisa bibliográfica 
Figura 142 Hall principal: consulta base de dados e atendimento pesquisa bibliográfica 208

Figura 143/144 Hall principal: estar e consulta manual/acervo 208

Figura 145 Planta Área de Leitura e Acervo/Biblioteca Unesp/Marília 209

Figuras 146/147/148 Acesso escada e áreas de leitura 210

Figuras 149/150/151/152 Área do acervo e leitura 210

Figura 153 Planta Pavimento Inferior/Biblioteca Unesp/Marília 212

Figura 154 Planta Área Administrativa - Biblioteca Unesp/Marília 214

Figuras 155/156/157 Área administrativa e serviços técnicos 215

Figuras 158/159 Sala da Direção e STATI - Seção Técnica de Aquisição e Tratamento da Informação

Figura 160 Planta Sanitários - Biblioteca Unesp/Marília

Figura 161 Sala Pesquisa Internet - Biblioteca Unesp/Marília

Figura 162 Planta Sala Pesquisa Internet - Biblioteca Unesp/Marília 218

Figura 163 Implantação - Centro Universitário Senac/Santa Amaro 221

Figura 164 Ilustração - Centro Universitário Senac/Santo Amaro 222

Figura 165 Bloco Acadêmico/Senac Santo Amaro 223

Figuras 166/167 Forro metálico ondulado - Biblioteca Senac/ Santo Amaro 224

Figuras 168/169 Vistas Externas: caixilharia recuada e acabamento texturizado / Biblioteca Senac/ Santo Amaro 224

Figura 170 Corte esquemático/ Biblioteca Senac/ Santo Amaro 225

Figuras 171/172 Vista átrio central e entrada lateral/Biblioteca Senac 225

Figura 173 Pavimento térreo/ Biblioteca Senac/ Santo Amaro 227

Figuras 174/175 Entrada principal/ Biblioteca Senac/ Santo Amaro 228

Figura 176 Pavimento térreo - Entrada Principal/
Biblioteca Senac/ Santo Amaro

Figura 177 Hall de Entrada e Sensor de Segurança- Biblioteca Senac/ Santo Amaro 230

Figura 178 Empréstimo/Devolução - Biblioteca Senac/ Santo Amaro 230

Figura 179 Guarda-Volumes- Biblioteca Senac/ Santo Amaro

Figuras 180/181/182

Sistema de Comunicação nas Estantes e Espaço para

Exposição/ Biblioteca Senac/ Santo Amaro

Figura 183 Área de Descanso e Lazer/ Biblioteca Senac/ Santo Amaro 231

Figura 183 Área de Descanso e Lazer/ Biblioteca Senac/ Santo Amaro 232

Figura 184 Janela fixa entre o Guarda-Volumes e a Sala de Fotocopias

Biblioteca Senac/ Santo Amaro

Figuras 185/186 Acervo pav. Térreo - Estantes - Biblioteca

Senac/ Santo Amaro

Figura 187 Pavimento térreo - Entrada Principal/ Biblioteca Senac/

Santo Amaro

235

Figuras 188/189 Acervo pav. Térreo - Estantes - Biblioteca

Senac/ Santo Amaro 236

Figura 190 Primeiro Pavimento-Biblioteca Senac Santo Amaro 237

Figuras 191/192 Mesas de Leitura e Pesquisa-Biblioteca Senac Amaro 238

Figuras 193 Primeiro Pavimento - Biblioteca Senac/ Santo Amaro 238 
Figuras 194/195 Salas de Estudo/Pesquisa Individual - Biblioteca

Senac/ Santo Amaro

Figura 196 Primeiro Pavimento- Biblioteca Senac/ Santo Amaro

Figuras 197/198 Sala de Atendimento à Pessoas Portadoras de Necessidades Visuais Biblioteca Senac/ Santo Amaro

Figuras 199/200/201 Acervo de Moda/ Biblioteca Senac/ Santo Amaro 241

Figuras 202/203 Acervo de Moda/Biblioteca Senac/ Santo Amaro 241

Figura 204 Primeiro Pavimento-Biblioteca Senac/ Santo Amaro 242

Figura 205 Sala de Atividades Manuais do Curso de Design - Biblioteca

Senac/ Santo Amaro

Figura 206 Primeiro Pavimento-Biblioteca Senac/ Santo Amaro

Figura 207 Segundo Pavimento-Biblioteca Senac/ Santo Amaro

Figura 208 Segundo Pavimento Administração -Biblioteca

Senac/Santo Amaro

Figuras 209/210 Setor técnico-administrativo - Biblioteca

Senac/ Santo Amaro

Figuras 211/212 Brises Metálicos e Iluminação Zenital - Segundo

Pavimento Biblioteca Senac/ Santo Amaro

Figuras 213/214/215/216 Acervo, consulta terminais e sala individual de pesquisa - Segundo Pavimento-Biblioteca Senac/ Santo Amaro

Figura 217 Cadastro do Objeto de Estudo

Figura 218 Sexo/Biblioteca Unesp/Marília

Figura 219 Sexo/Biblioteca Senac/Santo Amaro 275

Figura 220 Faixa Etária - Estudos de Caso 376

Figura 221 Escolaridade - Biblioteca Senac/Santo Amaro 277

$\begin{array}{ll}\text { Figura } 222 \text { Escolaridade - Biblioteca Unesp/Marília } & 277\end{array}$

Figura 223 Referências técnicas adotadas nos estudos de caso 278

Figura 224 Nível de Satisfação: adequação do tipo de mobiliário Biblioteca Senac

Figura 225 Nível de Satisfação: adequação do tipo de mobiliário

- Biblioteca Unesp/Marília

Figura 226 Tipologia do mobiliário - Estudos de caso 280

Figura 227 Cadeiras - Modelo 01 - Biblioteca Senac/Santo Amaro 282

Figura 228 Cadeiras - Modelo 02 - Biblioteca Senac/Santo Amaro 282

Figura 229 Cadeiras - Modelo 03 - Biblioteca Senac/Santo Amaro 283

Figura 230 Cadeiras - Modelo 04 - Biblioteca Senac/Santo Amaro 283

Figura 231 Layout Cadeiras/Modelo 03 e 04 / Biblioteca Senac/Santo Amaro 285

Figura 232 Cadeiras - Biblioteca Unesp/Marília 287

Figura 233 Layout Cadeiras/Modelo 05 e 06 / Biblioteca Unesp/Marília 288

Figura 234 Cadeiras - Modelo 05 - Biblioteca Unesp/Marília 288

Figura 235 Cadeiras - Modelo 06 - Biblioteca Unesp/Marília 289

Figura 236 Mesas - Modelo 07 - Biblioteca Senac/Santo Amaro 291

Figura 237 Mesas - Modelo 08 - Biblioteca Senac/Santo Amaro 292

Figura 238 Mesas - Modelo 09 - Biblioteca Senac/Santo Amaro 292

Figura 239 Mesas - Modelo 10 - Biblioteca Senac/Santo Amaro 292

Figura 240 Mesas - Modelo 11 - Biblioteca Senac/Santo Amaro 293 
Figura 241 Mesas - Modelo 12 - Biblioteca Senac/Santo Amaro 293

Figura 242 Modelos de mesas - Biblioteca Unesp/Marília 294

Figura 243 Mesas - Modelo 13 - Biblioteca Unesp/Marília 294

Figura 244 Mesas - Modelo 14 - Biblioteca Unesp/Marília 295

Figura 245 Mesas - Modelo 15 - Biblioteca Unesp/Marília 295

Figura 246 Mesas - Modelo 16 - Biblioteca Unesp/Marília 295

Figura 247 Mesas - Modelo 17 - Biblioteca Unesp/Marília 296

Figura 248 Mesas - Modelo 18 - Biblioteca Unesp/Marília 296

Figura 249 Nível de Satisfação: adequação tipo de mobiliário: Biblioteca Unesp/Marília 297

Figura 250 Área de Leitura de Jornais- Mesas (Modelo 15) - Biblioteca Unesp/Marília 298

Figura 251 Área do Acervo Bibliográfico- Mesas (Modelo 14 e Modelo 16) - Biblioteca Unesp/Marília 298

Figura 252 Área do Pavimento Inferior - Mesas (Modelo 16) - Biblioteca Unesp/Marília

Figura 253 Área Administrativa - Biblioteca Unesp/Marília

Figura 254 Nível de Satisfação: altura e disposição dos equipamentos de informática (comput./impressora ) no posto de trabalho Biblioteca Senac/Santo Amaro e Biblioteca Unesp/Marília 302

Figuras 255/256 Área consulta base de dados - Biblioteca Unesp/Marília 305

Figura 257Nível de Satisfação professores: dimensões dos arquivos, armários e estantes de trabalho Biblioteca Senac/Santo Amaro e Biblioteca Unesp/Marília

Figura 258 Estantes - Modelo 01 - Biblioteca Senac/Santo Amaro 310

Figura 259 Estantes - Modelo 01 - Biblioteca Senac/Santo Amaro 310

Figura 260 Área do Pavimento Térreo - Estantes (Modelo 01)
- Biblioteca Senac/Santo Amaro

Figura 261 Estantes - Modelo 02 - Biblioteca Senac/Santo Amaro 313

Figura 262 Área do Segundo Pavimento - Estantes (Modelo 02) - Biblioteca Senac/Santo Amaro 313

Figura 263 Estantes - Modelo 03 - Biblioteca Unesp/Marília 317

Figura 264 Área Pavimento Inferior - Estantes (Modelo 03) - Biblioteca Unesp/Marília

Figura 265 Áreas de armazenamento - Segundo Pavimento - Biblioteca Senac/Santo Amaro

Figura 266 Áreas de armazenamento / Pavimento térreo / Biblioteca Unesp/Marília

Figura 267 Áreas de armazenamento - Circulação - Biblioteca Unesp/Marília

Figura 268 Nível de Satisfação da Biblioteca Senac/Santo Amaro: privacidade visual no posto de trabalho

Figura 269 Layout demarcado da circulação primária e secundária no pavimento térreo da Biblioteca Senac/Santo Amaro

Figura 270 Layout demarcado da circulação primária e secundária no primeiro pavimento da Biblioteca Senac/Santo Amaro 
Figura 271 Layout demarcado da circulação primária e secundária no segundo pavimento da Biblioteca Senac/Santo Amaro

Figura 272 Exs. dos esquemas de circulação da Biblioteca Senac/Santo Amaro

Figura 273 Layout demarcado da circulação primária e secundária no segundo pavimento da Biblioteca Unesp/Marília

Figura 274 Exs. dos esquemas de circulação da Biblioteca Senac/Santo Amaro

Figura 275 Nível de Satisfação alunos da Biblioteca Unesp/Marília: acesso e adaptação do deficiente físico

Figura 276 Detalhe de circulação e foto da escada entre o Pav.Térreo e Pav.Superior Biblioteca Unesp/Marília

Figura 277 Sinalização tátil de alerta nas escadas recomendado pela norma 357

Figura 278 Empunhadura de corrimão recomendado pela norma 357

Figura 279 Sanitários Biblioteca Unesp/Marília 358

Figura 280 Área para manobra de cadeiras de rodas com deslocamento recomendado pela norma

359

$\begin{array}{lll}\text { Figura 281 Dimensionamento mínimo de estantes em bibliotecas } & 359 \\ \text { Figura 282 Corredor de estantes Biblioteca Unesp/Marília } & 360\end{array}$

Figura 283 Dimensionamento mínimo das mesas de trabalho recomendado pela norma

Figura 284 Dimensionamento das mesas de trabalho Biblioteca Unesp/Marília

Figura 285 Dimensionamento mínimo terminais de consulta

Figura 286 Dimensionamento consulta em bases de dados Biblioteca Unesp

Figura 287 Dimensionamento setor administrativo Biblioteca Unesp/Marília

Figura 288 Dimensionamento mínimo terminais de consulta 363

Figura 289 Balcão de empréstimo e devolução Biblioteca Unesp/Marília

Figura 290 Bebedouro recomendado pela norma

Figura 291 Rampa de acesso e barros de apoio entrada principal da Biblioteca Unesp/Marília

Figura 292 Nível de Satisfação alunos da Biblioteca Senac/Santo Amaro: acesso e adaptação do deficiente físico

Figura 293 Circulação em torno do elevador da Biblioteca Senac/Santo Amaro enquadrada na NBR - 9050/2004

Figura 294 Acessibilidade no balcão de atendimento da Biblioteca Senac 368

Figura 295 Corte esquemático do Balcão de atendimento/ Biblioteca Senac

Figura 296 Acessibilidade no setor administrativo da Biblioteca Senac 369

Figura 297 Mesas de pesquisa on-line Biblioteca Senac/Santo Amaro: condições de acessibilidade

Figura 298 Mesas de pesquisa e leitura Biblioteca Senac/Santo Amaro: condições de acessibilidade

Figura 299 Mesas de pesquisa/leitura e pesquisa on-line Biblioteca Senac/Santo Amaro: condições de acessibilidade

Figura 300 Elevação estantes Modelo 01 e 02 Biblioteca Senac/Santo Amaro: condições de acessibilidade 
Figura 301 Plantas estantes Modelo 01 e 02 Biblioteca

Senac/Santo Amaro: condições de acessibilidade 372

Figura 302 Plantas estantes Modelo 01 e 02 Biblioteca

Senac/Santo Amaro: condições de acessibilidade $\quad 372$

Figura 303 Sanitários na Biblioteca Senac: condições de acessibilidade $\quad 374$

Figura 304 Área de descanso e encontros informais Biblioteca Senac 375

Figura 305 Nível de Satisfação alunos da Biblioteca Senac/Santo

Amaro áreas de descanso e encontros informais 376

Figura 306 Áreas de descanso e encontros informais Biblioteca Unesp/Marília

Figura 307 Nível de Satisfação alunos da Biblioteca

Unesp/Marília: áreas de descanso e encontros informais $\quad 378$

Figura 308 Detalhes - rotas de fuga - Pavimento térreo

Biblioteca Senac

381

Figura 309 Rotas de fuga - Pavimento térreo Biblioteca Senac/Santo Amaro

381

Figura 310 Nível de Satisfação funcionários da Biblioteca

Senac/Santo Amaro: saídas de emergência e segurança contra incêndio

382

Figura 311 Rotas de fuga - Pavimento térreo e superior Biblioteca Unesp/Marília

Figura 312 Rotas de fuga - Pavimento inferior Biblioteca Unesp/Marília

Figura 313 Nível de Satisfação funcionários Biblioteca

Unesp/Marília: segurança contra incêndio e saídas

de emergência

Figuras 314/315 Área de armazenamento: disposição dos

livros nas Biblioteca Senac/Santo Amaro

Figuras 316/ 317 Documentos encadernados Biblioteca Senac/Santo Amaro

Figuras 318/319 Área de armazenamento Modateca Biblioteca Senac 388

Figuras 320/321 Armazenamento de folhetos, álbuns e fotografias

Biblioteca Senac/Santo Amaro

Figuras 322/323 Áreas de armazenamento Biblioteca

Senac/Santo Amaro

Figuras 324/ 325 Áreas de armazenamento e o controle de insolação Biblioteca Senac/Santo Amaro

Figura 326 Áreas de armazenamento Biblioteca Senac/Santo Amaro

Figura 327 Nível de Satisfação alunos Biblioteca Senac/Santo Amaro: espaço para armazenamento no acervo

Figura 328 Mapoteca Biblioteca Unesp/Marília

392

Figura 329 Áreas de armazenamento Biblioteca Unesp/Marília 393

Figura 330 Nível de Satisfação Biblioteca Unesp/Marília: tamanho e quantidade de sanitários

Figura 331 Sanitários Biblioteca Unesp/Marília

Figura 332 Nível de Satisfação alunos Biblioteca Senac/Santo

Amaro: tamanho e quantidade dos sanitários

Figura 333 Nível de satisfação funcionários Biblioteca

Senac/Santo Amaro: sinalização interna 
Figura 334 Nível de Funcionários alunos Biblioteca Unesp: sinalização interna

Figuras 335/ 336 Sistema de ar-condicionado Biblioteca

Senac/Santo Amaro

405

Figura 337 Brises e elementos vazados Biblioteca Unesp/Marília 407

Figura 338 Brises metálicos Biblioteca Senac/Santo Amaro 408

Figura 339 Sistema de ar-condicionado Biblioteca

Senac/Santo Amaro

Figura 340 Nível satisfação professores Biblioteca Unesp/Marília: ar-condic.

Figura 341 Sistema de ar-condicionado Biblioteca Senac/Santo Amaro

Figura 342 Iluminação natural Biblioteca Unesp/Marília

Figura 343 Vista interna do acervo e mesas de leitura/pesquisa da Biblioteca Unesp/Marília: materiais de acabamento reduzem os níveis de iluminamento no ambiente

Figura 344 Iluminação zenital Biblioteca Senac/Santo Amaro

Figura 345 Iluminação artificial Biblioteca Senac/Santo Amaro

Figura 346 Iluminação artificial acervo, setor de leitura e pesquisa Biblioteca Unesp/Marília

Figura 347 Iluminação artificial setor administrativo Biblioteca Unesp/Marília

Figura 348 Ambientes do primeiro pavimento Bbilioteca

Senac/Santo Amaro: tecnologias de informação e comunicação

Figura 349 Espaço Braille Biblioteca Senac: tecnologias de informação e comunicação

Figura 350 "Ilha de atendimento" Biblioteca Senac/Santo Amaro: tecnologias de informação e comunicação

Figura 351 Hall de entrada balcão de atendimento e serviço de Encomendas do material bibliográfico /Biblioteca Unesp/Marília: tecnologias e informação e comunicação

Figura 352 Sala de internet /BibliotecaUnesp/Marília: tecnologias e informação e comunicação

Figura 353 Sala de internet /BibliotecaUnesp/Marília: tecnologias e informação e comunicação

Figura 354 Setor administrativo /BibliotecaUnesp/Marília: tecnologias e informação e comunicação 


\section{LISTA DE GRÁFICOS}

Gráfico 01 Nível de Satisfação dos Alunos Biblioteca Senac/Santo Amaro: características das cadeiras

Gráfico 02 Nível de Satisfação dos Professores Biblioteca

Senac/Santo Amaro: características das cadeiras

Gráfico 03 Nível de Satisfação dos Funcionários Biblioteca

Senac/Santo Amaro: características das cadeiras

Gráfico 04 Nível de Satisfação: adequação do tipo de mobiliário: alunos - Biblioteca Unesp/Marília

Gráfico 05 Nível de Satisfação: adequação do tipo de mobiliário: professores - Biblioteca Unesp/Marília 286

Gráfico 06 Nível de Satisfação: adequação do tipo de mobiliário: funcionários - Biblioteca Unesp/Marília 287

Gráfico 07 Nível de Satisfação: adequação tipo de mobiliário: alunos - Biblioteca Senac/Santo Amaro

Gráfico 08 Nível de Satisfação: adequação tipo de mobiliário: professores - Biblioteca Senac/Santo Amaro

Gráfico 09 Nível de Satisfação: adequação tipo de mobiliário: funcionários - Biblioteca Senac/Santo Amaro

Gráfico 10 Nível de Satisfação alunos: altura e disposição dos equipamentos de informática (comput./impressora) no posto de trabalho Biblioteca Unesp/Marília

Gráfico 11 Nível de Satisfação funcionários: altura e disposição dos equipamentos de informática (comput./impressora) no posto de trabalho Biblioteca Unesp/Marília

Gráfico 12 Nível de Satisfação professores: altura e disposição dos equipamentos de informática (comput./impressora) no posto de trabalho Biblioteca Unesp/Marília

Gráfico 13 Nível de Satisfação funcionários: espaço de armazenamento - Biblioteca Senac/Santo Amaro

Gráfico 14 Nível de Satisfação alunos: estado de conservação do mobiliário - Biblioteca Senac/Santo Amaro e Biblioteca Unesp/Marília

Gráfico 15 Nível de Satisfação da Biblioteca Unesp/Marília: privacidade visual no posto de trabalho

Gráfico 16 Nível de Satisfação alunos da Biblioteca Senac/Santo Amaro largura e à localização das escadas e corredores

Gráfico 17 Nível de Satisfação funcionários da Biblioteca Senac/Santo Amaro largura e à localização das escadas e corredores

Gráfico 18 Nível de Satisfação professores da Biblioteca Senac/Santo Amaro largura e à localização das escadas e corredores

Gráfico 19 Nível de Satisfação alunos da Biblioteca Unesp/Marília: largura e à localização das escadas e corredores

Gráfico 20 Nível de Satisfação Professores da Biblioteca Unesp/Marília: largura e à localização das 
escadas e corredores

Gráfico 21 Nível de Satisfação funcionários da Biblioteca

Unesp/Marília: largura e à localização das

escadas e corredores

353

Gráfico 22 Nível de conforto ambiental funcionários

Biblioteca Unesp/Marília

409

Gráfico 23 Nível de conforto ambiental alunos Biblioteca

Unesp/Marília

409

Gráfico 24 Nível de conforto ambiental professores

Biblioteca Unesp/Marília

409

Gráfico 25 Nível satisfação professores Biblioteca Senac/Santo Amaro:

ar-condicionado no local de trabalho

412

Gráfico 26 Nível satisfação alunos Biblioteca Senac/Santo Amaro:

ar-condicionado no local de trabalho

412

Gráfico 27 Nível satisfação funcionários Biblioteca

Senac/Santo Amaro: ar-condicionado no local de trabalho

412

Gráfico 28 Nível satisfação funcionários Biblioteca

Senac/Santo Amaro: tecnologia da informação e comunicação

426

Gráfico 29 Nível satisfação alunos Biblioteca Senac/Santo

Amaro: tecnologia da informação e comunicação

426

Gráfico 30 Nível satisfação professores Biblioteca Senac/Santo

Amaro: tecnologia da informação e comunicação

Gráfico 31 Nível satisfação professores Biblioteca

Unesp/Marília: tecnologia da informação e comunicação

Gráfico 32 Nível satisfação alunos Biblioteca Unesp/Marília: tecnologia da informação e comunicação

Gráfico 33 Nível satisfação funcionários Biblioteca

Unesp/Marília: tecnologia da informação e comunicação

Gráfico 34 Avaliação técnica e dos usuários das áreas do Mapa de Descobertas - Biblioteca Unesp/Marília

Gráfico 35 Avaliação técnica e dos usuários das áreas do Mapa de Descobertas - Biblioteca Unesp/Marília 


\section{LISTA DE QUADROS}

Quadro 01 Biblioteca Regional Technical College 63

Quadro 02 Biblioteca Darwin College Study Centre 67

$\begin{array}{lll}\text { Quadro } 03 & \text { Biblioteca Cranfield } & 71\end{array}$

$\begin{array}{lll}\text { Quadro } 04 & \text { Biblioteca de Direito Squire } & 74\end{array}$

$\begin{array}{lll}\text { Quadro } 05 & \text { Biblioteca Nacional/Universitária Gottingen } & 78\end{array}$

$\begin{array}{lll}\text { Quadro } 06 & \text { Biblioteca Uned } & 81\end{array}$

Quadro 07 Biblioteca Learning Resouces Centre 84

Quadro 08 Biblioteca John J Ross, Willian Blakelly 87

Quadro 09 Função do Setor Referencial das bibliotecas universitárias $\quad 90$

Quadro 10 Função do Setor Referencial das bibliotecas universitárias 90

Quadro 11 Biblioteca do Instituto de Economia da

Universidade Estadual de Campinas $\quad 124$

Quadro 12 Biblioteca do Centro Universitário Positivo - UNICENP 125

Quadro 13 Biblioteca da Pós-Graduação da FAUUSP - Maranhão 131

Quadro 14 Modelos de estantes - Biblioteca Senac/Santo Amaro 282

Quadro 15 Modelos de mesas- Biblioteca Senac/Santo Amaro 291

Quadro 16 Modelos de estantes - Biblioteca Senac/Santo Amaro 309

Quadro 17 Síntese da avaliação de satisfação nas áreas do Mapa de

Descoberta pavimento térreo - Biblioteca Unesp/Marília 451

Quadro 18 Síntese da avaliação de satisfação nas áreas do Mapa de

Descoberta pavimento térreo - Biblioteca Unesp/Marília 452

Quadro 19 Síntese - avaliação de satisfação nas áreas do

Mapa de Descoberta pavimento inferior

- Biblioteca Unesp/Marília 453

Quadro 20 Síntese - avaliação de satisfação nas áreas do

Mapa de Descoberta pavimento inferior

- Biblioteca Unesp/Marília 454

Quadro 21 Recomendações - Biblioteca Unesp/Marília 456

Quadro 22 Síntese - avaliação de satisfação nas áreas

do Mapa de Descoberta Pavimento térreo

- Biblioteca Senac/Santo Amaro

Quadro 23 Síntese - avaliação de satisfação nas áreas

do Mapa de Descoberta Pavimento térreo

- Biblioteca Senac/Santo Amaro

Quadro 24 Síntese - avaliação de satisfação nas áreas

do Mapa de Descoberta Primeiro pavimento

- Biblioteca Senac/Santo Amaro

Quadro 25 Síntese - avaliação de satisfação nas áreas

do Mapa de Descoberta Primeiro pavimento

- Biblioteca Senac/Santo Amaro

Quadro 26 Síntese - avaliação de satisfação nas áreas

do Mapa de Descoberta Segundo pavimento

- Biblioteca Senac/Santo Amaro

Quadro 27 Síntese - avaliação de satisfação nas áreas do

Mapa de Descoberta Segundo pavimento

- Biblioteca Senac/Santo Amaro

Quadro 28 Recomendações - Biblioteca Senac/Santo Amaro 


\section{LISTA DE TABELAS}

$\begin{array}{ll}\text { Tabela } 01 \text { Etapas nos serviços informacionais } & 138\end{array}$

Tabela 02 Amostragens - Biblioteca Senac/ Santo Amaro 263

Tabela 03 Amostragens - Biblioteca Unesp/Marília 264

Tabela 04 Mesas fixas: dimensões gerais comparativas - Biblioteca Unesp 300

Tabela 05 Medidas para mesas de informática: dimensões comparativas - Biblioteca Senac/Santo Amaro 303

Tabela 06 Medidas para mesas de informática: dimensões comparativas - Biblioteca Unesp - área destinada à consulta de bases de dados

Tabela 07 Áreas/percentuais: edifício e estantes - Biblioteca Senac/Santo Amaro

Tabela 08 Percentual de ocupação e crescimento das estantes - Biblioteca Senac/Santo Amaro

Tabela 09 Percentual de ocupação e crescimento das estantes - Biblioteca Unesp/Marília $\quad 318$

Tabela 10 Áreas/percentuais: edifício e estantes - Biblioteca Unesp/Marília 319

Tabela 11 Modelos e dimensões dos armários Biblioteca Senac e Biblioteca Unesp $\quad 321$

Tabela 12 Áreas/percentuais: edifício e estantes - Biblioteca Senac 324

Tabela 13 Armários e arquivos deslizantes: dimensões 325

Tabela 14 Áreas de arquivamento - Biblioteca Unesp/Marília 332

Tabela 15 Tipologias de organização espacial do mobiliário e estações de trabalho - Biblioteca Senac/Santo Amaro

Tabela 16 Tipologias de organização espacial do mobiliário e estações de trabalho - Biblioteca Unesp/Marília

Tabela 17 Tipos de sinalização interna/Biblioteca Senac/Santo Amaro e Biblioteca Unesp/Marília

$\begin{array}{lll}\text { Tabela } 18 & \text { Tipos de sinalização interna/Biblioteca Senac/Santo Amaro } & 399 \\ \text { Tabela } 19 & \text { Tipos de sinalização interna/Biblioteca Senac/Santo Amaro } & 402\end{array}$

Tabela 20 Áreas destinadas à Tecnologia da Informação - Biblioteca Senac/Santo Amaro

Tabela 21 Áreas destinadas à Tecnologia da Informação

- Biblioteca Senac/Santo Amaro

Tabela 22 Áreas destinadas à Tecnologia da Informação - Biblioteca

Senac/Santo Amaro

Tabela 23 Áreas destinadas à Tecnologia da Informação

- Biblioteca Unesp/Marília

Tabela 24 Áreas destinadas à Tecnologia da Informação

- Biblioteca Unesp/Marília 


\section{LISTA DE ABREVIATURAS}

ACOB

AENOR

ALA

ANPUH

ANSI

APO

BSPL

CAPES

CBPA

CEDATE

CEDHUM

CEES

CESESP

CNPQ

CGB

DIN

FAPESP

HEDQF

IES

MEC

NCEF

PNBU

PREMESU

PROBE

RIBA

SCONUL

SENAC

SESU

SIBI

STATI

UFRJ
Advisory Committee on Buildings

Asociación Española de Normalización y Certificación

American Library Association

Associação Nacional dos Professores Universitários de História

American National Standards Institute

Avaliação Pós-Ocupação

British Standards Publishing

Coordenação de Aperfeiçoamento de Pessoal de Nível Superior

Conservação Preventiva em Bibliotecas e Arquivos

Centro de Desenvolvimento e Apoio Técnico à Educação

Centro de Documentação Histórica e Universitária de Marília

Centro de Estudos de Educação e Saúde

Coordenadoria do Ensino Superior do Estado de São Paulo

Conselho Nacional de Desenvolvimento Científico e Tecnológico

Coordenadoria Geral de Bibliotecas

Deutsches Institut fur Normung

Fundação de Amparo à Pesquisa do Estado de São Paulo

Higher Education Design Quality Forum

Instituições de Educação Superior

Ministério da Educação e Cultura

National Clearinghouse for Educational Facilities

Programa Nacional de Bibliotecas Universitárias

Programa de Expansão e Melhoramento das Instalações do

Ensino Superior

Post-Occupancy Review of Buildings and Their Engineering

Royal Institute of British Architects.

Society of College, National \& Universitym Libraries

Serviço Nacional de Aprendizagem Comercial

Secretaria de Ensino Superior

Sistema Integrado de Bibliotecas

Seção Técnica de Aquisição e Tratamento da Informação

Universidade Federal do Rio de Janeiro 


$\begin{array}{ll}\text { UNATI } & \text { Universidade Aberta à Terceira Idade } \\ \text { UNB } & \text { Universidade de Brasília; } \\ \text { UNESP } & \text { Universidade Estadual Paulista } \\ \text { UNIREDE } & \text { Universidade Virtual Pública do Brasil } \\ \text { UNIRIO } & \text { Universidade do Rio de Janeiro }\end{array}$




\section{RESUMO}

A presente tese objetiva identificar quais as diretrizes projetuais podem ser tomadas para os futuros edifícios de bibliotecas universitárias no âmbito nacional, utilizando como instrumento de apoio a avaliação de desempemho do ambiente construído desses ambientes. Para tanto, em uma primeira fase, buscou-se estudar a problemática por meio de análises comparativas de exemplos internacionais, nacionais e estudos de caso, identificando suas intervenções, suas potencialidades e suas espacialidades. Na segunda fase, a proposta da avaliação teve como foco, dois estudos de caso, a saber, dois edifícios de bibliotecas universitárias com características e componentes organizacionais distintos: o primeiro caso, uma biblioteca central de uma instituição privada e, o segundo caso, uma biblioteca central de uma universidade pública. Ou seja, a pesquisa se inseriu nos procedimentos e métodos da Avaliação PósOcupação (APO), realizando análises de desempenho físico (medições, vistorias técnicas) e aferição de satisfação dos usuários dos estudos de caso. As bases teóricas da pesquisa abordaram questões relativas à linguagem arquitetônica e a ambientação física dos edifícios de bibliotecas universitárias, tratando dos elementos relativos às concepções e funções desses edifícios, bem como, as principais operações dos serviços informacionais de localização, de recuperação, de comunicação e de devolução da informação. Foram também apresentadas as contribuições da Avaliação Pós-Ocupação no contexto das bibliotecas universitárias, principalmente no contexto internacional onde os procedimentos metodológicos são mais presentes e consistentes, voltados para o estabelecimento de indicadores de desempenho e diretrizes mínimas em intervenções projetuais. Por fim foi possível criar uma série de diretrizes para futuros projetos, neste caso, de bibliotecas universitárias no contexto nacional, direcionados à construção, operação e manutenção destes ambientes construídos Os resultados da pesquisa demonstram que a utilização de avaliações sistêmicas (estudos de caso) podem coloborar significativamente na instrumentação necessária para realimentação no processo de produção e uso de futuros ambientes de bibliotecas universitárias.

Palavras chave: Avaliação Pós-Ocupação; Arquitetura de Bibliotecas Universitárias; Diretrizes Projetuais. 


\begin{abstract}
The objective of the present thesis is to identify which projectual guidelines may be taken for future university library buildings at national level, using the evaluation of performance of the ambience built in these environments as an instrument of support. To achieve this, in a first phase, the problems were studied by means of comparative analyses of international and national examples and case studies identifying its interventions, potentialities and spatialities. In the second phase, the purpose of the evaluation was to focus on two case studies, namely two university library buildings with distinct organizational characteristics and components: the first case, a central library of a private institution and, the second case, a central library of a public university. In other words, the study was inserted in the procedures and methods of Post-Occupation Evaluation (POE), conducting analyses of physical performance (measurements, technical inspections) and gauging satisfaction of the users in the case studies. The theoretical bases of the study address questions relative to the architectural language and the physical environment of the university library buildings, treating the elements relative to the conceptions and functions of these buildings, such as the principle operations of the informational services of localization, recuperation, communication and devolution of information. The contributions of the PostOccupation Evaluation in the context of the university libraries also were presented, principally in the international context where the methodological proceedings are more present and consistent, directed to the establishment of performance indicators and minimum guidelines in intervention projects. In the end it was possible to create a series of guidelines for future projects, in this case, university libraries in the national context, directed at the construction, operation and maintenance of these built environments. The results of the research demonstrate that the use of systematic evaluations (case studies) can significantly collaborate in the instrumentation necessary for feedback in the production process and use of future environments of university libraries.
\end{abstract}

Key words: Post-Occupancy Evaluation; Architecture of University Libraries Projectual Guidelines 


\section{SUMÁRIO}

DEDICATÓRIA $\quad 4$

AGRADECIMENTOS

LISTA DE FIGURAS $\quad 7$

LISTA DE GRÁFICOS

LISTA DE QUADROS $\quad 18$

LISTA DE TABELAS 19

LISTA DE ABREVIATURAS $\quad 20$

$\begin{array}{ll}\text { RESUMO } & 22\end{array}$

$\begin{array}{ll}\text { ABSTRACT } & 23\end{array}$

CAPÍTULO 1 - INTRODUÇÃO 28

1.1 Apresentação do Objeto de Pesquisa e Objetivos 28

1.2 Estruturação da Hipótese 33

1.3 A Organização da Tese 36

CAPÍTULO 2 - A BIBLIOTECA UNIVERSITÁRIA 42

2.1 Definição e Conceito da Biblioteca Universitária 42

$\begin{array}{ll}2.2 \text { Objetivos } & 42 \\ 2.3 & 43\end{array}$

2.3 A Biblioteca Universitária e a Universidade 43

2.4 A Estrutura da Biblioteca Universitária $\quad 45$

2.5 Funções 46

2.6 Serviços Oferecidos 46

2.7 Equipamentos 47

2.8 Ambientação Física 47

CAPÍTULO 3 - O CONTEXTO DA ARQUITETURA 50

3.1 Aspectos Históricos da Arquitetura de Bibliotecas $\quad 50$

3.2 Contexto das Bibliotecas Universitárias Internacionais $\quad 60$

$\begin{array}{ll}3.2 .1 \text { Exemplos Internacionais } & 61\end{array}$

3.2.2 Aspectos Organizacionais $\quad 89$

3.2.3 Aspectos Arquitetônicos $\quad 93$

$\begin{array}{lr}\text { 3.3. A Realidade Brasileira } & 100\end{array}$

3.3.1 A Biblioteca Universitária Brasileira e o Ensino Superior 101

3.3.2 Formas de Organização 103

3.3.3 Fatores Macro-Ambientais 105

3.3.3.1 A Política Educacional 105

3.3.3.2 Novas Tecnologias Informacionais e Biblioteca Universitária 106

3.3.3.3 Serviços de Informações Oferecidos por outras Entidades 107

$\begin{array}{ll}\text { 3.3.3.4 Educação à Distância } & 108\end{array}$

$\begin{array}{ll}\text { 3.3.3.5 Perfil do Aluno/Usuário } & 108\end{array}$

$\begin{array}{ll}\text { 3.3.4 Modelos Funcionais e Estruturais } & 109\end{array}$

3.4 Arquitetura de Bibliotecas Universitárias: o Caso Brasileiro 111 


\section{CAPÍTULO 4 - LINGUAGEM ARQUITETÔNICA E AMBIENTAÇÃO} FÍSICA

4.1 Concepções de Funções Espaciais 138

$\begin{array}{ll}\text { 4.2 Tipos de Acervo } & 141\end{array}$

4.2.1 Acervo Aberto 141

4.2.2 Acervo Fechado 144

4.3 Localização da Informação no Acervo 144

4.4 Armazenamento 146

4.5 Busca e Recuperação da Informação 150

4.6 Concepção Espacial das Salas de Leitura e Pesquisa 152

4.7 Espaço e Devolução do Material Bibliográfico 154

4.8 Espaços e Serviços Relacionados aos Usuários 155

4.8.1 Consultas 156

4.8.2 Cópia das informações 156

4.8.3 Fontes Externas de Informação 157

4.8.4 Estabelecimentos de Livrarias 158

4.9 Setores Técnicos e Administrativos 158

4.9.1 Área Administrativa 158

4.9.2 Área Técnica 159

4.10 Serviços e Estrutura 159

\section{CAPÍTULO 5 - CONSIDERAÇÕES SOBRE O MÉTODO DE AVALIAÇÃO PÓS-OCUPAÇÃO (APO) 182}

5.1 Conceituação 182

5.2.Contribuição da APO 183

CAPÍTULO 6 - CARACTERIZAÇÃO DOS ESTUDOS DE CASO 192

6.1 Estudos de Caso $\quad 192$

6.2 Avaliações Quantitativa e Qualitativa 193

6.3 Descrição dos Edifícios Escolhidos 193

6.3.1 Histórico da UNESP - Universidade Estadual Paulista 193

$\begin{array}{ll}\text { 6.3.1.1 O Campus de Marília } & 194\end{array}$

6.3.1.2 Caracterização Geral do Edifício Biblioteca Unesp/Campus Marília 196

6.3.1.3 Caracterização Arquitetônica do Edifício 197

$\begin{array}{ll}\text { 6.3.2 O Senac } & 219\end{array}$

$\begin{array}{ll}\text { 6.3.2.1 O Senac/São Paulo } & 219\end{array}$

6.3.2.2 Centro Universitário Senac/São Paulo 220

6.3.2.3 Caracterização Arquitetônica da Biblioteca do

Centro Universitário Senac/São Paulo 223 


\section{CAPÍTULO 7 - PROCEDIMENTOS METODOLÓGICOS PARA APLICAÇÃO DA APO}

7.1 Métodos, Técnicas e Instrumentos

250

7.2 Informações e Memória dos Objetos de Estudo 251

7.3 Atualização e Cadastro do Objeto de Estudo 251

$\begin{array}{ll}7.4 \text { Ambientes Analisados } & 253\end{array}$

$\begin{array}{ll}7.5 \text { Vistorias técnicas (walkthrough) } & 255\end{array}$

$\begin{array}{ll}\text { 7.6 Registros fotográficos } & 257\end{array}$

$\begin{array}{ll}\text { 7.7 Contatos com os usuários } & 257\end{array}$

$\begin{array}{ll}7.8 \text { Grupos focais } & 258\end{array}$

$\begin{array}{ll}7.9 \text { Entrevistas } & 258\end{array}$

$\begin{array}{ll}7.10 \text { Questionários } & 259\end{array}$

7.11 Levantamento da População 261

7.12 Determinação da Amostra 262

7.13 Tabulação dos Dados $\quad 264$

7.14 Mapa de Descobertas 265

CAPÍTULO 8 - FATORES FUNCIONAIS ANALISADOS 266

8.1 Elementos Preliminares 266

$\begin{array}{ll}8.2 \text { Fatores Funcionais } & 267\end{array}$

8.2.1 Dimensionamentos mínimos 268

8.2.2 Armazenamento 268

$\begin{array}{ll}\text { 8.2.3 Flexibilidade } & 269\end{array}$

8.2.4 Circulações 269

$\begin{array}{ll}\text { 8.2.5 Acessibilidade } & 270\end{array}$

8.2.6 Comunicação Visual 271

$\begin{array}{ll}\text { 8.2.7 Ergonomia } & 271\end{array}$

8.2.8 Conforto Ambiental 272

8.2.9 Tecnologia da Informação $\quad 272$

CAPÍTULO 9 - RESULTADOS DA AVALIAÇÃO DOS FATORES

$\begin{array}{ll}\text { FUNCIONAIS } & 274\end{array}$

$\begin{array}{ll}\text { 9.1 Perfil dos Usuários } & 274\end{array}$

9.2. Aspectos Funcionais $\quad 277$

9.3 Áreas Destinadas ao Armazenamento de Uso Comum 327

9.4 Privacidade X Comunicação $\quad 335$

9.5 Largura e Localização das Escadas e Corredores 341

9.6 Acesso e Adaptação do Deficiente Físico 353

9.7 Espaços para Encontros e Contatos Informais 374

$\begin{array}{ll}9.8 \text { Segurança } & 378\end{array}$

9.9 Áreas Destinadas ao Armazenamento do Acervo 385

9.10 Quantidade e Tamanho dos Sanitários $\quad 393$

9.11 Sinalização Interna da Biblioteca 396

9.12 Análise do Conforto Ambiental 403

9.13 Tecnologia da Informação e Comunicação 425 


\section{CAPÍTULO 10 - DIAGNÓSTICO E RECOMENDAÇÕES DOS ESTUDOS DE CASO}

10.1 Considerações Preliminares 446

10.2 Desenvolvimento do Diagnóstico 446

10.3 Utilização do Mapa de Descobertas $\quad 447$

10.3.1 Critérios para Construção do Mapa de Descobertas 447

10.4 Quadro de Sínteses 448

10.5 Diagnóstico da Biblioteca da Unesp/Marília 449

10.6 Recomendações da Biblioteca da Unesp/Marília 455

10.7 Diagnóstico da Biblioteca do Senac/Santo Amaro 458

10.8 Recomendações da Biblioteca do Senac/Santo Amaro 465

CAPÍTULO 11 - CONSIDERAÇÕES FINAIS E RECOMENDAÇÕES 468

11.1 Quanto ao Contexto Internacional 469

11.2 Quanto ao Contexto Nacional 471

11.3 Quanto à Aplicação da APO 473

11.4 Considerações Finais e Diretrizes Gerais para

Bibliotecas Universitárias Brasileiras $\quad 480$

$\begin{array}{lr}\text { REFERENCIAS } & 502\end{array}$

$\begin{array}{lr}\text { ANEXOS } & 524\end{array}$ 


\section{CAPÍTULO 1 - INTRODUÇÃO}

\subsection{Apresentação do Objeto de Pesquisa e Objetivos}

A biblioteca universitária é uma agência social criada para atender as necessidades e as urgências da instituição à qual serve. Como tal é também um instrumento moldado e condicionado pela estrutura social, de acordo com os padrões e os valores culturais que regem essas instituições. Por outro lado, é o repositório e um meio de difusão das experiências culturais desenvolvidas nos níveis adaptativo, associativo e ideológico, que determinam aqueles valores. Sob todos esses aspectos, a importância da biblioteca universitária em todos os setores da sociedade, sempre foi reconhecida e compartilhada por todos, estabelecendo ponto de equilíbrio das ações que lhe são conferidas. Indubitavelmente, a biblioteca universitária vem formatando e protagonizando sua importante missão de ensino, pesquisa e extensão. Hoje, diferentemente do que era no passado, ela é capaz de disponibilizar informações para um maior número de usuários, em decorrência da introdução da informática e da celeridade dos meios eletrônicos na recuperação, tratamento e disseminação da informação, em todas as áreas do conhecimento.

Com essa revolução informacional, conduzida principalmente pela introdução das novas tecnologias informacionais e comunicacionais no âmbito das bibliotecas universitárias, novos meios de troca de informações, além do acesso irrestrito das organizações, pesquisadores e usuários, dentro ou fora das universidades, vêm contribuindo para a democratização do conhecimento, independente de qualquer formação do usuário. Estas mudanças tecnológicas têm alterado substancialmente a idéia e o perfil das bibliotecas universitárias e, conseqüentemente, novos conceitos, parâmetros e posições destas inovações tecnológicas ainda estão sendo estabelecidos.

A biblioteca universitária tem caminhado então, para transformar-se em um ponto de acesso facilitado por meio de redes de telecomunicações, principalmente pela internet, que se torna a grande agente de mudança da biblioteca automatizada do futuro. Hoje os acervos, além das publicações impressas, têm novo suporte - as publicações eletrônicas - equivalendo a mais um passo para uma nova etapa, ou seja, a biblioteca digital ou virtual. 


\section{A Biblioteca Universitária e a Arquitetura}

Ora, de que forma a arquitetura tem se relacionado com a questão da biblioteca universitária? Ou, voltando um pouco para a problemática desta tese, como o a arquitetura tem respondido a essa necessidade e avaliado os possíveis caminhos a serem percorridos no tocante aos projetos de bibliotecas universitárias?

Os acervos acumulados em muitos países, mesmo com o uso das ferramentas das novas tecnologias informacionais, continuam crescendo e necessitando maiores espaços para seu armazenamento e disponibilização ao usuário. Tanto é que as principais universidades, faculdades e centros de estudos têm realizado ao longo desses anos, um extraordinário avanço na experiência do planejamento e da construção de edifícios de bibliotecas universitárias. É justamente no âmbito internacional que a construção desses edifícios, que se dá graças ao apoio conjunto dos estados e das próprias universidades, destinando recursos não só para as obras civis, mas também para a aquisição de equipamento e de mobiliário. Esse apoio irrestrito do estado às questões relativas à biblioteca universitária, tem, como objetivo básico, a integração desse manancial de cultura e comunicação com a sociedade. A biblioteca passa a funcionar não só como um local de leitura, mas também com um local de eventos culturais, prestação de serviços e acesso à rede de informação e pesquisa.

Naturalmente, há consciência de que a realidade territorial é formada por uma série de extratos bastante complexos que constituem modelos espaciais diferenciados no âmbito econômico, geográfico, administrativo, social e outros, e que as realidades físicas devem ser organizadas entre si com um objetivo comum o que deve concretizar numa nova maneira de projetar cada unidade da biblioteca universitária. Daí a necessidade de se entender a prerrogativa do contexto espacial para nortear as decisões nos projetos de bibliotecas universitárias, ou seja, a idéia de aplicar soluções padronizadas e acabadas não deve acompanhar tais projetos. Isso é fundamental no entendimento da relação profunda entre a percepção urbana e o projeto de arquitetura, e mais particularmente neste estudo, dos projetos de bibliotecas universitárias.

Em relação à arquitetura de bibliotecas universitárias no contexto internacional, a complexidade, a amplitude e as possibilidades de intervenção dos diversos projetos desses edifícios tendem hoje a mapear variantes, elementos tipológicos, morfológicos e tecnológicos, baseados nas diversas experiências interdisciplinares da área da arquitetura. Hoje mais do que nunca, a especialização 
desses projetos tem sido capaz de explorar importantes desdobramentos e conquistas na racionalização da biblioteca, a ponto de propor uma nova forma na sistematização da arquitetura. Uma das explicações mais coerentes sobre esse fato, diz respeito à aceleração e à expansão das modificações do ambiente e da sociedade em todas as escalas. Isso obriga arquitetos a elaborarem instrumentos de projeção inovadores e recorrerem à ajuda de outras disciplinas para a concretização das novas propostas nos setores da ciência da informação, biblioteconomia, arquiviologia e arquitetura.

No âmbito da discussão da questão da arquitetura de bibliotecas universitárias no Brasil, tanto a nível conceitual, detectando problemas de forma científica e metodológica, ou, a nível prático, apontando soluções no planejamento físico desses espaços, as análises têm evidenciado a necessidade de subsídios realistas e confiáveis para a formulação dos projetos em relação ao desenvolvimento de suas atividades. Por outro lado, constata-se que poucos programas arquitetônicos têm sofrido transformação tão intensa quanto dos edifícios de bibliotecas universitárias brasileiros. Isso acontece porque os suportes tradicionais do livro vêm somando outros meios de comunicação e tem havido o desenvolvimento da idéia clássica de biblioteca, que se converter em um centro midiático e virtual, incorporando em seus processos e sistemas de comunicação diferentes formas de disseminação da informação.

Uma das experiências mais enriquecedoras nos projetos de bibliotecas universitárias brasileiras tem sido aceitar seu caráter plural e diversificado. Os programas arquitetônicos, então, vêm impondo às disciplinas projetuais ligadas à informação e à comunicação a dependência dos conteúdos culturais locais, inclusos nos processos de gestão, procedimentos, suportes distintos meios organizacionais. Em vista disso, o tema da biblioteca universitária brasileira vem, aos poucos, influenciando os processos de desenvolvimento de projetos e as pesquisas em arquitetura e urbanismo.

Ainda com ao relação ao tema, grandes desafios são apresentados aos profissionais da área da arquitetura envolvidos nos projetos de bibliotecas universitárias no Brasil, principalmente, quanto ao entendimento das políticas de desenvolvimento das coleções e das técnicas utilizadas por agentes ligados à área da ciência da informação e biblioteconomia para o tratamento dos documentos de seu acervo. A problemática abrange questões não só inerentes a um espaço físico que abrigue corretamente as clientelas, acervos e necessidades distintas de cada contexto da unidade de ensino superior, mas engloba também diretrizes que atendam às novas tecnologias informacionais de qualidade, evitando desperdício de tempo e oferecendo informações 
precisas e atualizadas. A biblioteca universitária é responsável, então, por parte importante da infraestrutura e formação da massa crítica da comunidade a quem se destina, tornando-se um organismo vivo e não apenas um depósito de documentos informacionais.

\section{O Problema Pesquisado}

Conforme se percebe, no contexto da maioria das universidades brasileiras, a biblioteca é considerada um serviço de apoio à docência e à investigação, constituído pelos principais suportes informacionais e comunicacionais. Tal definição e abrangência são perfeitamente compatíveis com os principais objetivos desse espaço instituional, que é promover o ajustamento orgânico de pessoas, acervo e edifícios com a intenção de assistir a comunidade universitária no processo de transformação da informação em conhecimento. A biblioteca universitária brasileira tem sido praticamente um espaço acadêmico comum único, não somente à classe docente, mas a toda comunidade de alunos, funcionários e sociedade em geral, razão pela qual exige, de forma enfática, um tratamento adequado ao planejamento físico de seus espaços.

É importante assinalar que, com o passar dos anos, houve evolução quanto à preocupação de uma política de atendimento às bibliotecas universitárias, principalmente nas áreas relacionadas à biblioteconomia e ciência da informação. A biblioteca universitária brasileira tem merecido, portanto, especial atenção de estudiosos, aqui e fora do Brasil. Enfocando aspectos importantes, discutindo suas funções, avaliando seu desempenho, propondo padrões para seu desenvolvimento, alguns trabalhos demonstram o grau de maturidade a que se chegou na análise da biblioteca universitária brasileira. Com esse objetivo, os estudos têm se concentrado nos setores de administração e planejamento com a utilização de novos instrumentos nas atividades organizacionais desses espaços.

Entretanto, apesar dos esforços contínuos no entendimento das operações e dos serviços de bibliotecas universitárias no Brasil, poucos exemplos têm se produzido na área da arquitetura que, efetivamente, do ponto de vista metodológico, contribuam com recomendações sobre seus problemas técnico-construtivos, funcionais e comportamentais. É justamente nesse ponto que se encaixa o problema básico desta tese: os poucos estudos sistemáticos voltados ao acompanhamento de projetos e modelos direcionados à construção de bibliotecas universitárias no Brasil, não tem sido 
instrumentos de interesse nos possíveis caminhos e respostas desses espaços edificados. Ou ainda, a dificuldade de aplicação de avaliações nesses edifícios, por parte dos agentes envolvidos no uso, manutenção e administração no caso das bibliotecas universitárias, tem refletido essa situação, valorizando principalmente as etapas de planejamento/programação, projeto e construção, esquecendo-se da avaliação sistêmica pós-ocupação, do ambiente construído.

É relevante entender que as avaliações e recomendações sobre os edifícios de bibliotecas universitárias têm como propósito situá-las no contexto do progressivo interesse dos serviços bibliotecários na sociedade e oferecer, também para a universidade, uma ferramenta de melhoria nas atividades desenvolvidas, correção de falhas e anulação das carências dos serviços. Há, entretanto, de se avaliar a situação desses ambientes na realidade atual, seus principais impactos em termos de usos, a satisfação de seus usuários e eventuais demandas existentes. Como em qualquer programa arquitetônico, a biblioteca universitária deve propiciar condições ambientais de qualidade, por meio com as quais ela possa desempenhar suas atividades no oferecimento de informação e conhecimento à sociedade.

Os objetivos da pesquisa

O trabalho proposto tem como objetivo principal realizar análises de desempenho físico (medições, vistorias técnicas) e aferição de satisfação dos usuários em ambientes de bibliotecas universitárias, a fim de detectar quais os principais elementos relacionados aos procedimentos para a gestão da qualidade do processo de projeto e elaboração de diretrizes para futuros projetos, ou seja, propor recomendações sobre questões funcionais e comportamentais.

A proposta da avaliação tem como foco dois estudos de caso, a saber, dois edifícios de bibliotecas universitárias com características e componentes organizacionais distintos: no primeiro caso, a biblioteca central de instituição privada e, no segundo a biblioteca central de uma universidade pública. Ou seja, a pesquisa se insere nos procedimentos e métodos da Avaliação Pós-Ocupação (APO) objetivando contribuir para a compreensão das bibliotecas universitárias, sob o ponto de vista funcional, oferecendo subsídios de avaliação desses espaços. 
Os objetivos específicos desta tese são:

- obtenção de resultados mais precisos e abrangentes no que se refere ao desempenho físico dos edifícios de bibliotecas universitárias e elaboração de diretrizes para futuros projetos, propondo recomendações sobre problemas construtivos, funcionais e comportamentais para bibliotecas universitárias;

- fornecer uma visão estruturada de conhecimentos e estudos referentes aos métodos e às técnicas da Avaliação Pós-Ocupação para desenvolvimento da pesquisa aplicada às bibliotecas universitárias;

- contribuir para o aprimoramento do processo de ensino superior no Brasil por meio de intervenções nas instalações físicas em bibliotecas universitárias;

- disponibilizar uma sistemática de APO como parte integrante da análise crítica dos processos e programas de implantação de bibliotecas universitárias no contexto brasileiro;

- fixar um programa de intervenção, de manutenção e de conscientização do público usuário, sobre a necessidade de alterações comportamentais relacionadas aos aspectos perceptivos do espaço de biblioteca universitária;

- produzir um modelo comparativo e avaliativo de duas realidades, a priori, contrastantes, uma APO em uma biblioteca universitária no contexto privado e outra avaliação em um edifício no âmbito público;

- utilizar o resultado destas avaliações sistemáticas (estudo de caso) para realimentar o ciclo do processo de projeto, produção, e uso de ambientes semelhantes, buscando otimizar o desenvolvimento de futuros projetos.

\subsection{Estruturação da Hipótese}

A estruturação da hipótese da tese baseia-se no fato de que, por meio da avaliação do ambiente construído de bibliotecas universitárias, é possível determinar futuros caminhos aos projetos arquitetônicos, propondo e recomendando diretrizes ligadas às questões funcionais e comportamentais desses edifícios. Fora isso, a avaliação funcional da biblioteca universitária permitiria traçar um plano de realinhamento e reposicionamento da operação de projeto, além de contemplar 
perspectivas futuras no fornecimento de serviços informacionais compatíveis com as necessidades de seus usuários.

Existem, ainda, perguntas relacionadas a esta tese que deverão ser esclarecidas, como por exemplo:

1. A utilização de avaliações sistêmicas (estudos de caso) é instrumento necessário para a realimentação do processo de produção e uso de futuros ambientes de bibliotecas universitárias?

2. A avaliação da qualidade é um antecedente que pode determinar a satisfação dos usuários em ambientes de bibliotecas universitárias?

3. A integração de equipes interdisciplinares das áreas de arquitetura, biblioteconomia e ciência da informação expressam importância no processo de gestão da qualidade do projeto, implementação e avaliação dos edifícios de bibliotecas universitárias?

\section{Delimitação da Pesquisa}

Como se apresentou anteriormente, a aplicação dos métodos de avaliação do ambiente construído tem sido fundamental na aferição das necessidades dos usuários por conseguinte, na detecção de problemas relacionados aos fatores construtivos, funcionais e comportamentais, que visam a realimentar o próprio estudo de caso bem como futuros projetos. Além disso, a compreensão da organização no âmbito em que se insere, analisando a evolução do seu desenvolvimento e o modo como esses aspectos influenciam o comportamento das pessoas no local de trabalho é condição obrigatória no processo avaliativo do ambiente. No caso das bibliotecas universitárias, foi urgente entender não só os principais contextos de inserção espacial destes edifícios, mas também analisar os agentes envolvidos na sua administração e sua manutenção.

No âmbito e conforme os objetivos da pesquisa, na qual se busca compreender os ambientes das bibliotecas universitárias, sob o ponto de vista funcional e da satisfação do usuário, para oferecer subsídios de avaliação, algumas delimitações básicas foram estabelecidas, sem necessariamente implicar o comprometimento da validade da sua aplicação. São, portanto, elementos delimitadores do trabalho: 
a)- a pesquisa tem como objetivo principal fornecer um roteiro com a conceituação e os procedimentos metodológicos pertinentes a uma APO em ambientes de bibliotecas universitárias, incluindo os principais descritores da fundamentação, proposição e utilização dos estudos de caso. Ou seja, a proposta do trabalho foi justamente formar uma base conceitual relevante ao tema, projetando e gerando elementos suficientemente claros nos resultados e diagnósticos dos casos estudados;

b)- o trabalho apresenta essencialmente cunho investigativo. Dessa maneira, buscou-se a identificação dos principais elementos de compreensão de ocupação das bibliotecas universitárias, sob o ponto de vista funcional e da satisfação do usuário, evidenciando o contexto político/financeiro brasileiro e sua influência sobre os dados a serem analisados;

c)- a proposta da avaliação teve como foco dois estudos de caso, a saber, dois edifícios de bibliotecas universitárias com características e componentes organizacionais distintos: o primeiro caso, biblioteca central de uma instituição privada e o segundo caso, biblioteca central de uma universidade pública. Na verdade, tem-se a proposta de produzir um modelo comparativo e avaliativo de duas realidades, a priori, contrastantes. Portanto, somente ao final da pesquisa essa tese pode ser comprovada ou não.

Os Objetos do Estudo de Caso

Como foi apresentado anteriormente, o universo desta investigação foi composto por dois edifícios de bibliotecas universitárias, sendo a (1) Biblioteca Central do Centro Universitário Senac/Santo Amaro, na cidade de São Paulo (SP) e a (2) Biblioteca Central da UNESP - Universidade Estadual Paulista do campus da cidade de Marília (SP). De forma sucinta, os prédios apresentam as seguintes características:

(1) - A Biblioteca Central do Centro Universitário Senac/Santo Amaro, na cidade de São Paulo (SP), foi inaugurada em março de 2004 e o espaço abriga um acervo de 90 mil itens, entre livros, periódicos, mapas, CD-ROMs, CDs, DVDs e fitas VHS. Com 6 mil m2 de área construída, oferece apoio e informação aos cursos superiores de graduação (bacharelado e tecnologia), pós-graduação (lato e stricto 
sensu) e diversificados programas de extensão universitária.

(2) - A Biblioteca Central da Faculdade de Filosofia e Ciências - UNESP está localizada no Campus da cidade de Marília (SP) e iniciou suas atividades no dia $1^{\circ}$ de abril de 1959. Inaugurada em prédio próprio no Campus Universitário no dia 03 de novembro de 1980, engloba uma área de $1.745 \mathrm{~m}^{2}$, localizada no eixo norte/sul do Campus. Além disso, a biblioteca atende aos cursos de Arquivologia, Biblioteconomia, Ciências Sociais, Educação Especial, Filosofia, Fisioterapia, Fonoaudiologia, Pedagogia, Relações Internacionais e Terapia Ocupacional, além dos Programas de Pós Graduação nas áreas de Ciência da Informação, Ciências Sociais, Educação e Filosofia.A Biblioteca está vinculada administrativamente à Direção da Unidade e tecnicamente à Coordenadoria Geral de Bibliotecas - CGB sendo parte integrante da rede de Bibliotecas da UNESP.

\subsection{A Organização da Tese}

A tese está dividida em duas partes: a primeira, contida nos Capítulos 2 a 5, trata da fundamentação e proposição teóricas, tendo como objetivo responder às perguntas apresentadas nas páginas anteriores; a segunda compreende a utilização de estudos de caso como estratégia (Capítulos 6 a 9), de maneira que possam ser respondidas as perguntas relacionadas ao âmbito da pesquisa.

O Capítulo 2, que tem como título "A Biblioteca Universitária”, visa ao aprofundamento das questões relativas à definição e à conceituação da biblioteca universitária, revelando seus principais fundamentos e valores. O capítulo ainda aborda os fatores denominados macro-ambientais que, de uma certa forma, influenciam e exigem certas mudanças na estrutura organizacional das bibliotecas universitárias. Em relação às funções principais da biblioteca universitária, destacar-se-ão os procedimentos de organização das coleções (da seleção, coleta, representação descritiva e temática à armazenagem), da disseminação e orientação da informação e do controle operacional das atividades administrativas.

A segunda parte trata especificamente dos serviços oferecidos pelas bibliotecas universitárias aos usuários, principalmente, nos níveis educacional, social e cultural. A questão dos recursos humanos também faz parte deste item, evidenciando a seleção e o treinamento do pessoal para a adequação de desempenho às exigências 
específicas dos seus públicos, dos produtos e serviços projetados. Finalizando a questão da organização da biblioteca universitária, serão apresentados sucintamente os elementos básicos dos equipamentos e da ambientação física, um dos pontos fortes de seu planejamento e operação.

O Capítulo 3, "O Contexto da Arquitetura de Bibliotecas Universitárias", apresenta inicialmente a caracterização histórica da arquitetura de bibliotecas ao longo da história da humanidade, ressaltando principalmente os conceitos relacionados ao espaço e seus efeitos no contexto da sociedade. No âmbito internacional, serão analisados dois importantes aspectos relacionados às bibliotecas universitárias: o primeiro, as aproximações relativas aos elementos organizacionais, identificados como dois setores - referencial e cultural das atividades desenvolvidas nesses edifícios; e o segundo, as aproximações arquitetônicas, evidenciando os partidos e os principais programas arquitetônicos presentes nas tendências mundiais de bibliotecas universitárias. Como forma de exemplificar tais análises, treze projetos de bibliotecas universitárias internacionais focando: descrição técnica, através de figuras e desenhos de plantas, caracterização arquitetônica das bibliotecas escolhidas, tipos de implantação, descrição dos ambientes e perfil dos usuários.

Em relação ao contexto brasileiro das bibliotecas universitárias, como forma de enriquecer a problemática da tese, serão feitas reflexões a respeito de suas principais características e desenvolvimento, sua tradição cultural e seus problemas e, além disso, o papel fundamental do ensino superior no processo de formação da biblioteca universitária. Aprofundando um pouco mais essa questão, tratar-se-á dos fatores macro-ambientais, decisivos na organização das bibliotecas universitárias brasileiras e que influenciam nos destinos da estrutura organizacional das mesmas.

Finalizando o Capítulo 3, far-se-á a análise propriamente dita da arquitetura de bibliotecas universitárias na realidade brasileira, entendendo o caráter plural e diversificado que os programas arquitetônicos vêm impondo às disciplinas projetuais ligadas à informação e comunicação e, por conseguinte, a dependência dos conteúdos culturais locais, inclusos nos processos de gestão, procedimentos, suportes e os distintos meios organizacionais. Como no caso das bibliotecas universitárias internacionais, aqui também serão descritos seis exemplos tentando resgatar e vislumbrar avanços conseguidos na área de construção de bibliotecas universitárias brasileiras. 
O tema proposto para o Capítulo 4 é "Linguagem Arquitetônica e a Ambientação Física dos Edifícios de Bibliotecas Universitárias" trata-se das questões relativas às concepções e funções arquitetônicas das bibliotecas universitárias e explicitam-se no contexto arquitetônico das bibliotecas universitárias, as principais operações dos serviços informacionais: localização, recuperação, comunicação e devolução da informação. Ainda no início deste capítulo, aborda-se a questão do tipo de acervo fechado ou aberto, item diretamente ligado à planificação e ao desenho dos locais destinados, tanto para a leitura como para os ambientes destinados ao armazenamento dos livros.

Várias operações essenciais direcionadas às atividades desenvolvidas no seio da biblioteca universitária dão suporte à busca, localização, armazenamento e recuperação da informação e, em certa medida, necessitam de um apurado processo de planejamento espacial, principalmente, na sua concepção arquitetônica e na locação dos seus serviços. Esses tópicos são tratados neste capítulo, além do detalhamento dos principais serviços direcionados aos usuários como o controle, a consulta, a cópia de informações, as fontes de informação externa e o estabelecimento de livrarias. Fechando o capítulo, há destaque para as competências dos setores administrativos e técnicos, quanto à função que desempenham nas rotinas relativas ao controle dos departamentos e núcleos, e, também, na seleção, na análise e na indexação dos documentos.

No Capítulo 5, serão descritos os principais conceitos pertinentes à Avaliação Pós-Ocupação (APO) aplicados às questões relativas ao projeto, à construção e ao uso, além da análise dos elementos comportamentais dos usuários e, suas possíveis alterações e necessidades ao longo do tempo. Destaca-se também, a vertente histórica da APO, em decorrência da necessidade da avaliação do ambiente construído a partir do ponto de vista dos usuários e a combinação da avaliação técnica.

Em um segundo momento, serão apresentadas as contribuições da Avaliação Pós-Ocupação no contexto das bibliotecas universitárias, verificando, principalmente no Brasil, a existência de poucos estudos no gênero, particularmente aqueles que contam com procedimentos metodológicos claros e consistentes, voltados para o estabelecimento de indicadores de desempenho e diretrizes mínimas em intervenções projetuais de bibliotecas universitárias. $\mathrm{Na}$ realidade, os principais exemplos encontrados estarão inseridos na esfera internacional, em que a busca e a fundamentação teórica têm sido a tônica na avaliação sistemática de ambientes 
construídos de bibliotecas universitárias, principalmente, buscando na tomada de decisões quanto a alternativas de projetos nesses espaços, sempre seguindo abordagens e fases metodológicas semelhantes às aplicadas em pesquisas tipo a APO.

No Capítulo 6, o tema é voltado para a Caracterização dos Estudos de Caso com o objetivo de conceituar e evidenciar de que forma a utilização desses estudos, poderá contribuir, por meio de casos práticos e reais, a análise de desempenho físico dos ambientes de bibliotecas universitárias, a determinação de intervenções e melhorias nos objetos analisados. O capítulo ainda trata dos conceitos de avaliação quantitativa e qualitativa em relação à avaliação pós-ocupação, entendendo os edifícios analisados como um sistema ecologicamente integrado.

$\mathrm{Na}$ segunda parte, serão expostos os dados relativos às informações concernentes aos edifícios escolhidos, tanto da Biblioteca Central da Unesp/Campus de Marília, quanto da Biblioteca Central do Centro Universitário do Senac/Campus Santo Amaro em São Paulo. Essas explanações e análises traçam um quadro geral das edificações e de seus contextos, apresentando principalmente, suas características.

Os procedimentos metodológicos da avaliação pós-ocupação (APO), considerando o desempenho técnico dos edifícios eleitos, as informações e os levantamentos junto aos usuários, são discutidos no Capítulo 7. Trata-se-á da importância do levantamento detalhado dos dados e das informações referentes ao objeto de estudo, bem como da determinação da população e dos ambientes selecionados. Serão identificados os métodos e as técnicas trabalhados na pesquisa.

O Capítulo 8 destacam-se os fatores funcionais (dimensionamentos mínimos, armazenamento, flexibilidade, circulações, acessibilidade, comunicação visual, ergonomia e tecnologia da informação) com o objetivo de apresentar suas principais características, visto que cada um dos itens analisados servirá de base para toda a análise e conseqüente proposições e recomendações apresentadas no final do trabalho.

Os resultados da avaliação dos fatores funcionais serão apresentados no Capítulo 9 com o objetivo de interpretar os principais aspectos funcionais, tanto positivos como negativos do ambiente construído das referidas bibliotecas universitárias, os necessários ao longo do processo de análise, principalmente acerca da sua ocupação física, desempenho funcional, tipos de uso e percepção dos usuários em relação aos itens analisados. 
No Capítulo 10 serão apresentados os resultados do diagnóstico que foram consolidados por meio da análise e da avaliação de todo o conjunto de dados e informações coletados fruto do levantamento dos elementos funcionais e pelos usuários. $\mathrm{Na}$ análise, considerou-se todo e qualquer dado coletado desde o início da pesquisa, como as entrevistas efetuadas com pessoas-chave dos edifícios escolhidos, mapa de descobertas e pessoas envolvidas diretamente com a administração, encarregados, chefes de setores, entre outros.

Por fim, no Capítulo 11 há uma lista final de intervenções e as conclusões sobre o desempenho funcional das bibliotacs e junto aos usuários. Como a idéia básica é criar uma série de diretrizes para futuros projetos de bibliotecas universitárias, direcionados à construção, operação e manutenção destes ambientes construídos, estabelecem-se as correlações necessárias para a comprovação ou não da hipótese. 


\section{CAPÍTULO 2 - A BIBLIOTECA UNIVERSITÁRIA}

\subsection{Conceito da Biblioteca Universitária}

Por definição, a universidade tem caráter múltiplo, global e diversificado, sendo considerada uma instância privilegiada de criação/produção de saberes, formação de competências e de difusão da experiência cultural e científica da sociedade. A biblioteca universitária possibilita à universidade atender às necessidades de um grupo social ou da sociedade em geral, através da administração do seu acervo informacional e do exercício da sua função educativa, ao orientar os usuários na utilização da informação. Sua missão é prover, disseminar e transferir informação de forma a possibilitar a atuação plena da universidade na promoção do ensino, pesquisa e extensão, por meio da oferta de cursos de graduação e pós-graduação, produção e transferência de conhecimento e de tecnologia. Ela atua como ponto de apoio fundamental no setor informacional, com seus acervos quer centralizados ou descentralizados (bibliotecas setoriais) e está intimamente relacionada à finalidade da própria universidade ou da instituição superior. Portanto, as bibliotecas universitárias são espaços comunitários onde se compartilham saberes, em função da comunidade para a qual foram planejadas, isto é, para a demanda específica de usuários.

A biblioteca universitária é um importante órgão na promoção da aprendizagem, na medida em que permite o uso da informação organizada e a geração de novos conhecimentos, podendo ser vista, portanto, como uma organização inteligente para a organização do conhecimento. No entanto, os autores alertam que, para caracterizar-se como tal, deve gerenciar suas dimensões infra-estrutura, pessoas e tecnologia, na tentativa de captar, armazenar, gerar e compartilhar melhor o conhecimento.

\subsection{Objetivos}

Essencialmente, o objetivo geral de uma biblioteca universitária é promover o intercambio entre a informação e os usuários, direcionando suas atividades ao cumprimento dos objetivos da instituição. A biblioteca, para isso, deve organizar as coleções (seleção, coleta, representação descritiva e temática e armazenagem), 
disseminar a informação e orientar seu uso, controlar operacionalmente o sistema de informações (do planejamento à avaliação). Portanto, é possível entender, que as universidades e as bibliotecas são agências sociais organizadas com a missão de servir a sociedade enquanto instâncias criadoras do conhecimento e facilitadoras do acesso a este conhecimento.

Segundo a definição da American Library Asociation (ALA), a biblioteca universitária é aquela estabelecida, mantida e administrada por uma universidade para cumprir as necessidades de informação de seus estudantes e apoiar programas educativos de investigação e outros serviços. Portanto a biblioteca universitária é considerada o elemento fundamental nos programas educativos e científicos no desenvolvimento da universidade, ou seja, é o "coração da universidade", em que se dá a coleta, o processamento e a disseminação do conhecimento. Em resumo, é o comprometimento com os seus objetivos que a tornará essencial para a organização do conhecimento humano, participando e tornando-se um importante elemento no processo da inovação.

São objetivos técnicos-funcionais de uma biblioteca universitária:

- Organizar as coleções (desde a seleção, a coleta, a representação descritiva e a temática até a armazenagem);

- Disseminar a informação e orientar seu uso;

- Controlar operacionalmente as atividades administrativas, do planejamento à avaliação;

- Direcionar suas atividades ao cumprimento dos objetivos da instituição,

- Apoiar as necessidades de ensino, pesquisa e extensão e as de caráter administrativo a fim de propiciar condições para incrementar a produtividade científica e acadêmica.

\subsection{A Biblioteca Universitária e a Universidade}

Como se sabe, a relação entre a universidade e a biblioteca está estruturada para atender às necessidades da comunidade acadêmica e da sociedade em geral. Portanto, a biblioteca universitária já nasce subordinada a uma instituição de ensino superior, com a função específica de dar suporte às atividades desta instituição. Seu objetivo é contribuir decisivamente para o ensino, a pesquisa e a extensão, assumindo, assim, o papel social de prover a infra-estrutura documental e promover a 
disseminação da informação, em prol do desenvolvimento da educação, da ciência e da cultura.

Partindo deste pressuposto de que a essência básica da universidade é gerar conhecimento e que, para alcançar este objetivo, depende dos recursos informacionais, administrados pela biblioteca, pode-se dizer que deve haver perfeita sintonia entre a biblioteca e a universidade. Sendo assim, a biblioteca universitária tem papel fundamental na produção e disseminação do conhecimento na universidade, pois é em seu âmbito que o processo começa e termina. Ou seja, a comunidade acadêmica consulta a biblioteca para produzir conhecimento e, posteriormente transfere a sua produção, por meio de algum recurso de informação à biblioteca universitária.

Clarificando esta relação entre biblioteca e universidade, as instituições, de um modo geral, formam-se por conjuntos de pessoas ligadas umas às outras por objetivos organizacionais em comum, trabalhando do ponto de vista da organização, pela mesma "missão". Portanto, a biblioteca universitária, enquanto organização ligada a uma instituição maior, possui um conjunto de particularidades e traços próprios e definidos a partir da missão da própria universidade. Sua missão é garantir e proporcionar educação de qualidade e de alto nível através do ensino, da pesquisa e da extensão, apoiando-as na qualificação profissional, na formação de pesquisadores, no crescimento da pesquisa e nas atividades de extensão que ligam diretamente a instituição à comunidade.

Segundo Paula (1992) a biblioteca universitária deve contribuir para capacitação do estudante e para a formação contínua do professor, no sentido de tornálos 'usuários independentes da informação', conscientizando-os de que, usando corretamente os recursos informacionais e os princípios de pesquisa bibliográfica, poderão retornar ao sistema de informação para contribuir com novas produções de conhecimento, com apoio em normas documentais.

Ela vem executando sua notável missão, principalmente quando o usuário consegue acessar a informação de maneira autônoma informação. A biblioteca universitária se defronta com o grande desafio de ajustar-se aos padrões modernos, aprimorando suas condições de acesso à informação com o uso de tecnologias avançadas, tornando-se cada vez mais eletrônica, digital e virtual. Entretanto, vê-se que, mesmo com dificuldades financeiras a maioria das bibliotecas estão se modernizando e automatizando seu acervo para disponibilizá-lo ao usuário. 
Em nível nacional, o acervo das bibliotecas universitárias detém as maiores coleções em Ciência e Tecnologia do país. Mas, apesar da sua importância, as bibliotecas universitárias têm passado por uma série de crises, salvo algumas exceções, que vêm crescendo ao longo dos anos. Partindo dessa idéia, os acervos também enfrentam dificuldades, pois se apresentam em quantidade insuficiente para atender à demanda, com coleções incompletas e desatualizadas. Geralmente esse quadro é característico de universidades públicas, pois nas instituições privadas em virtude do controle do Ministério da Educação e Cultura (MEC) e da exigência da clientela, percebe-se uma realidade menos deficitária, uma vez que a preocupação com a manutenção e preservação de coleções que satisfaçam a demanda é uma meta constante. Para formar e desenvolver coleções de materiais informacionais das bibliotecas universitárias no cenário da globalização, quando a informação se multiplica em passo acelerado, surge uma dificuldade - como manter e desenvolver essas informações atualizadas e adequadas? O bibliotecário precisa redefinir e esquecer antigos paradigmas para estabelecer normas para seleção, aquisição e descarte de materiais, tendo como base novos critérios, previamente definidos, para a formação de um acervo ideal.

Finalmente, é evidente que, o desempenho das universidades beneficia a sociedade, principalmente porque essas instituições visam a formar e capacitar pessoas, a incentivar a produção, o registro do conhecimento, além de apoiar o desenvolvimento de pesquisas e as atividades de extensão, fortalecendo o país como um todo. Pela mesma razão, as bibliotecas universitárias, ao apoiarem as atividades de ensino, pesquisa e extensão das universidades, têm papel preponderante no desenvolvimento da sociedade, pois são mediadoras no processo de geração e produção do conhecimento.

\subsection{A estrutura da Biblioteca Universitária}

A estrutura da biblioteca universitária é afetada diretamente por alguns fatores importantes como, por exemplo, os serviços e produtos ofertados, o modelo gerencial adotado e a tecnologia utilizada para a organização dos trabalhos internos. Estes fatores, por sua vez, sofrem impacto e são, em grande medida, determinadas pela missão da organização e pelas tendências pessoais. Num contexto maior, as bibliotecas universitárias atendem fatores macro-ambientais que, de certa forma, influenciam e até exigem certas mudanças na estrutura organizacional. Portanto, um dos principais 
objetivos na análise do macro-ambiente é identificar questões atuais emergentes que sejam significativas para a organização e determinar prioridades para as bibliotecas universitárias.

Para a melhor compreensão dos elementos da biblioteca universitária, os principais componentes desse sistema são esclarecidos a seguir:

\subsection{As Funções}

São funções principais da biblioteca universitária: armazenar, preservar e processar o acervo documental de acordo com as necessidades e níveis de usuários, levando em conta as tendências atuais de informatização, ou mesmo, quando for o caso, na forma de organização tradicional. De qualquer modo, as bibliotecas universitárias têm um fluxo comum de organização, ressalvadas as peculiaridades de áreas de conhecimento, grau de especialização e técnicas, automatizadas ou não, de armazenagem e recuperação da informação.

\subsection{Serviços oferecidos}

Os serviços prestados pela biblioteca universitária estão sujeitos a um conjunto de variáveis, nos níveis educacional, social e cultural. Deve-se buscar a otimização do uso dos recursos disponíveis, por meio de atividades de capacitação dos usuários e sua orientação na busca e uso da informação, com cuidadosa comunicação visual e gráfica da biblioteca.

A questão dos recursos humanos para a biblioteca universitária pressupõe a seleção e treinamento de pessoal para a adequação de desempenho às exigências específicas dos seus públicos, dos produtos e serviços projetados. 


\subsection{Equipamentos}

A aquisição de equipamentos necessários a uma biblioteca universitária adquire maior importância quando se considera que são insumos fundamentais à infraestrutura de prestação de serviços informacionais.

\subsection{Ambientação Física}

Apesar de este tema ser tratado logo mais a seguir, vale ressaltar a ambientação interior deve ser projetada e mantida para oferecer condições adequadas à motivação e aumento de produtividade dos funcionários e dos usuários reais, ou para atrair usuários potenciais. Essa ambientação tem sido um dos pontos importantes que modernamente direcionam planejadores de bibliotecas.

No que diz respeito a espaço e instalações físicas, é preciso observar se são projetados, equipados e decorados adequadamente para atender às necessidades diversas dos usuários: permanência para estudo, reflexão, pesquisa e elaboração de trabalhos acadêmicos; atividades de leitura livre e atualização; debates, preparação de seminários, estudos em grupo, etc. A arquitetura interior, a adequação do mobiliário e sua padronização, as instalações elétricas, iluminação, segurança, acústica, ventilação, higiene, arranjo físico, etc, são aspectos que devem ser observados dentro de critérios já estabelecidos na literatura especializada. Deve-se cuidar para que o acesso às instalações físicas da biblioteca não dificulte o percurso dos usuários. De outro lado, o arranjo físico da biblioteca deve possibilitar ampliações, com entradas independentes e condições arquitetônicas que facilitem o acesso.

Um aspecto importante para qualquer tipo de biblioteca é oferecer livre acesso ao acervo, de modo a possibilitar maior independência para as buscas bibliográficas, bem como prover, ao usuário (aluno/docente), treinamento adequado para busca e localização de material.

Atenção especial deve recair em questões de comunicação visual, cuidando para que a sinalização da biblioteca seja adequada.É preciso diminuir deslocamentos desnecessários dos usuários para o encontro da informação. 
A instrução para o uso adequado de catálogos e recursos da biblioteca, instalação de quadros e murais, que visam a facilitar a comunicação de eventos, novas aquisições, regulamentos, etc, deve ser de interesse da instituição. 


\section{CAPÍTULO 3 - O CONTEXTO DA ARQUITETURA}

\subsection{Aspectos Históricos da Arquitetura de Bibliotecas}

Dos grandes espaços destinados às grandes bibliotecas da Antiguidade, como Pérgamo, Éfeso, Atenas e Alexandria, poucas referências restaram até o dia de hoje. A maioria dessas bibliotecas definia seus espaços como uma grande sala com nichos escavados nas paredes duplas onde eram guardados os rolos e pergaminhos dos livros. Importante destacar que, até o século XIV, o ambiente da biblioteca tinha seu significado atrelado ao próprio conceito etimológico da palavra "biblioteca", ou seja, significava depósito de livros.

Outro local bastante comum nesse período, em que os livros eram guardados em nichos das paredes, eram os mosteiros. Grandes quantidades de livros e manuscritos eram produzidas nestes locais, de forma que, aos poucos, novos espaços eram acrescentados a esses para confecção de novos documentos. Seguindo este mesmo conceito, outro tipo era uma espécie de gabinete disposto ao longo do claustro, onde os monges podiam escrever e ler.

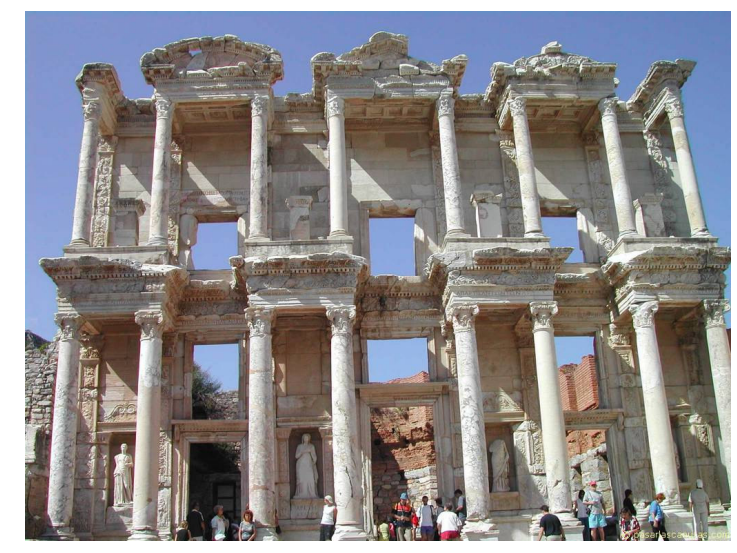

Figura 01 - Biblioteca de Éfeso

Fonte: www.coloredhome.com/

Como já foi descrito anteriormente, por volta do século XIII, com o surgimento das principais universidades na Europa, a biblioteca ganha um importante papel junto a essas instituições. Exemplo disso, a Biblioteca da Universidade de Sorbone ocupa um local especial no conjunto dos edifícios da instituição. Trata-se de um edifício isolado em que os livros não estão mais em armários, mas sim em átrios. 
Esse sistema previa conjuntos de dois a dois átrios e, geralmente, posicionava-se uma janela ao meio, ficando dispostos em fileiras de madeira. Vale destacar que esse desenho foi bastante aceito nos principais projetos de bibliotecas universitárias construídas por toda a Europa e, de certa forma, ditava exemplos de mobiliários e organização do espaço interno.

A grande desvantagem do sistema de átrio em bibliotecas residia no fato de ocupar um grande espaço de armazenamento dos documentos, o que foi contornado com o surgimento da imprensa e a crescente substituição do pergaminho pelo livro. Apesar das transformações acerca da impressão do livro e as formas de armazenamento espacial, as bibliotecas não tiveram grandes mudanças em suas disposições internas. Praticamente, os átrios e as estantes enfileiradas permaneceram com o mesmo desenho por muitos anos, introduzindo-se somente um novo desenho de nave central e nave lateral, de que são exemplo os exemplos a Biblioteca de São Marco, em Florença e a Biblioteca Malatestiana, em Cesena.

Um dos exemplos mais marcantes de bibliotecas no período renascentista, que espelham essa tipologia na construção do espaço é a Biblioteca Laurenziana (1523-1571), projetada por Michelangelo e encomendada pela família dos Médici ${ }^{1}$ de Florença. A biblioteca foi concebida dentro de um conceito volumétrico triplo, no qual se inserem um quadrado, um retângulo e um triângulo. Nesse processo construtivo, o primeiro elemento (quadrado) se apresenta como um espaço tenso, onde as aberturas de janelas inexistem e o espaço é intercalado com colunas duplas e pequenos nichos nas paredes. Uma grande escadaria, concebida como uma grande escultura de mármore e granito, conduz o usuário até ao pavimento superior. É importante destacar que, este segundo ambiente (retângulo) apresenta uma característica bastante calma e organizada, com uma seqüência rítmica de aberturas para o exterior, ressaltando bastante a iluminação natural do ambiente. Fica claro que a disposição racional das estantes de madeira, organizando todo o acervo de livros e documentos, evidencia a aplicação da geometria espacial do início do Renascimento. O terceiro bloco (triângulo), que não foi executado, projetava uma biblioteca de uso restrito e previa o armazenamento de obras raras (COSME, 2004).

\footnotetext{
${ }^{1}$ Importante família florentina do século XV que dominava as diversas atividades comerciais, artísticas e políticas.
} 

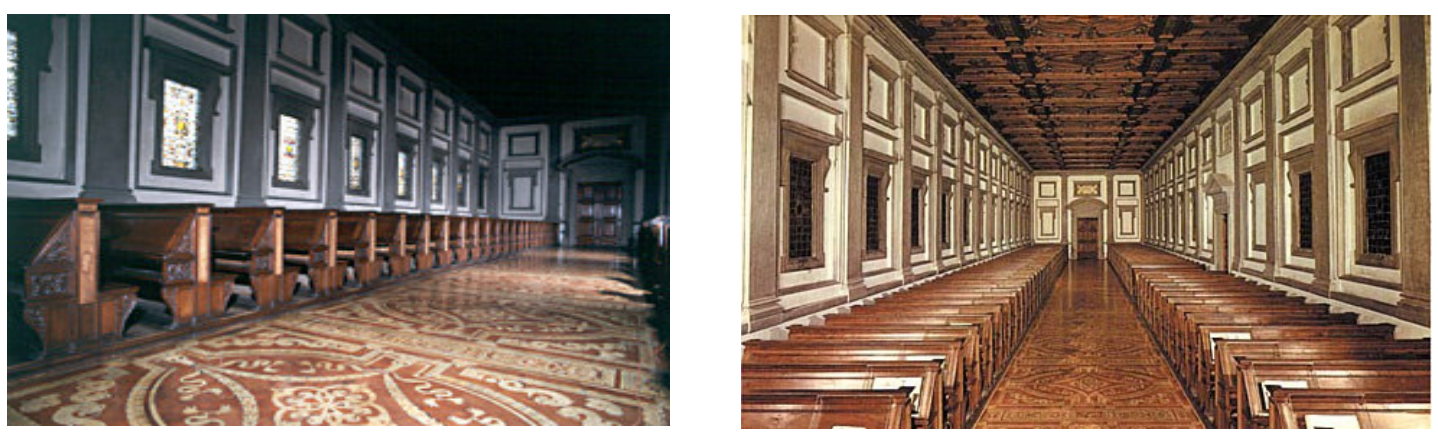

Figura 02 e 03 - Biblioteca Laurenziana-1523-1571

Fonte: www.comune.fi.it

O Humanismo foi predominante na incorporação de uma nova estrutura quantitativa e qualitativa na produção de livros, na medida em que retoma e incorpora os códigos dos clássicos greco-romanos. Junto a isso, um novo espírito de liberdade de expressão toma conta todos os setores da sociedade, entendendo o livro como elemento cultural imprescindível no desenvolvimento das áreas científicas e as bibliotecas como a personificação desse processo (COSME, 2004).

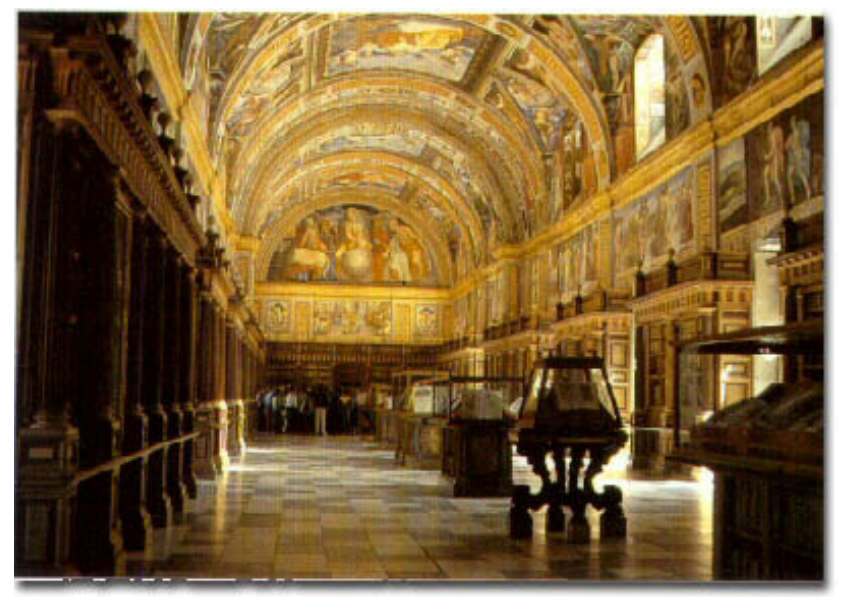

Figura 04 - Biblioteca do Escorial/Madri Fonte: www8.madrid.org

Com isso, os primeiros modelos de "bibliotecas-salão" são construídos, planificando a colocação dos livros em grande estantes enfileiradas ao longo das 
paredes. É interessante notar que o primeiro edifício que apresentou este tipo de modelo foi a Biblioteca do Escorial, em Madri, com um grande salão de leitura e um teto em forma de abóbada. Outra importante biblioteca que também segue o mesmo modelo é a Biblioteca Ambrosiana na cidade de Milão (1603-1609), edifício em que o acesso aos pavimentos superiores se dá por meio de escadas ou por uma grande galeria suspensa (COSME, 2004).

Pode-se constatar que, ao longo dos séculos XVII e XVIII, o sistema de estantes fixas nas paredes foi o tipo comum de armazenamento de livros em bibliotecas. Dentre os principais exemplos de espaços que vislumbraram esse modelo, destaca-se em Roma, a Biblioteca Vallicelliana do Oratório (1640-1642) projeto de Borromini e a Biblioteca Alexandrina (1661-1662). Todas essas bibliotecas apresentavam o mesmo modelo de estantes nas paredes e galeria superior e, representavam importantes centros de referência na área cultural e artística da Itália. Já na Áustria e Alemanha, apareceram as primeiras bibliotecas monásticas do período do barroco, locais com forte apego emocional, com esculturas, pinturas, jogo de luzes e espaços integrados, cujo espaço era tratado não só como um ambiente funcional de atividades ligadas à leitura e pesquisa, mas também como um espaço lúdico de formas inusitadas e cheias de vida.

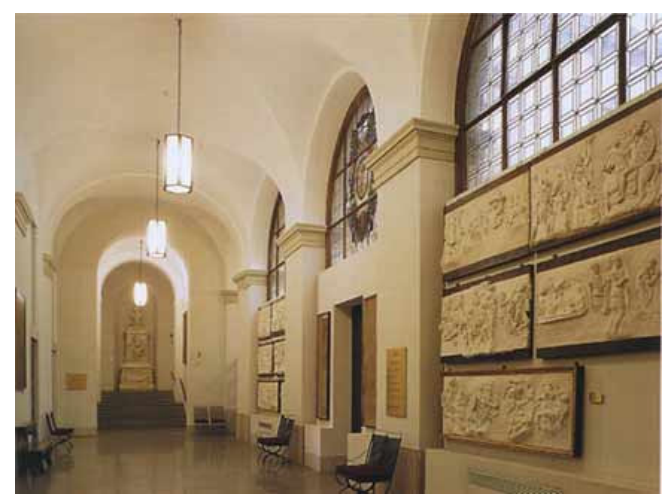

Figura 05 - Biblioteca Ambrosiana de Milão (1603-1609)

Fonte: www.comune.fi.it

Com o aumento considerável de livros publicados nos anos seguintes, e o grande afluxo de usuários nos espaços de bibliotecas, configara-se a separação institucional entre o Estado, a Universidade e a Igreja, fato que gera automaticamente, a busca incessante por espaços mais generosos e livres, com o objetivo de fortalecer o 
vínculo do usuário em relação ao espaço e melhor adaptação do livro no âmbito da biblioteca.

O principal modelo de edifício que traduziu essa necessidade foi o projeto de Etienne-Louis Boullée (1784) para a Biblioteca Real de Paris. Boullée consegue reunir elementos de qualidade na solução arquitetônica proposta, insistindo sempre na exaltação da escala, proporção e estética, não se importando com seus defeitos práticos ou funcionais e sim com seu caráter inspirativo. Boullée reforçou, então, a idéia do acesso livre dos leitores aos livros na biblioteca, entendendo o conhecimento e a informação como fonte geradora de desenvolvimento na sociedade. A biblioteca passa a ser considerada uma imensa basílica, iluminada zenitalmente, com a finalidade de conter todo patrimônio da humanidade reunido em um único espaço. $\mathrm{O}$ projeto da biblioteca consistiu em cobrir um imenso pátio interno em formato de abóbada, estabelecendo dimensões generosas (30 m x $100 \mathrm{~m}$ x $45 \mathrm{~m}$ ) e criando uma sucessão de andares nesta grande cobertura. Em termos volumétricos, o edifício é dividido em três áreas bem demarcadas: uma primeira zona, onde ficam instaladas as estantes dos livros e o acesso principal dos usuários; a segunda, uma área intermediária de colunas jônicas, servindo apenas para espaço de circulação; e a terceira, uma cobertura em forma de abóbada onde se encontra um grande recorte no teto, servindo para entrada de iluminação zenital.

Quanto à definição espacial dos ambientes internos, Boullée sistematizou as operações no interior da biblioteca, de forma organizada e racional, criando a separação documental do acervo em tipos de áreas de conhecimento e abrigando várias secções específicas destinadas aos livros, manuscritos e obras raras. A Biblioteca Real de Paris estabelece um marco importante na definição de um modelo de edifício bibliotecário, na medida em que resgata e valoriza o conceito espacial destinado ao usuário como estrutura funcional, articulada e integrada ao acervo documental da instituição. 


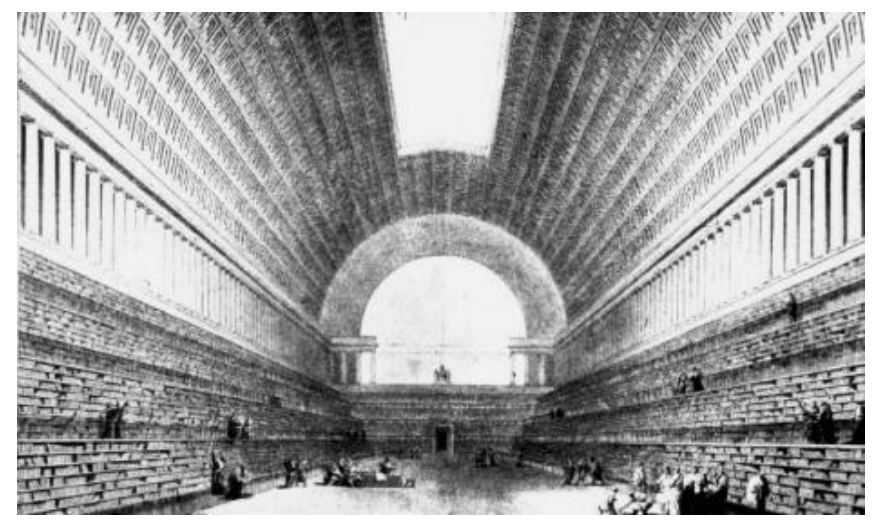

Figura 06 - Biblioteca Nacional da França/Etienne-Louis Boullée (1784)

Fonte: fr.wikipedia.org

No ano de 1816, o italiano Leopoldo della Santa registra os principais elementos presentes no planejamento de uma biblioteca, reforçando a idéia da divisão tripartida na organização espacial, ou seja, estipula a separação dos espaços de armazenagem, leitura, consulta e administração. Dessa maneira, o espaço central da biblioteca ficaria destinado às salas de leitura, dentro de uma planificação retangular espacial e as estantes destinadas aos livros estariam dispostas transversalmente em relação ao comprimento da sala. A grande vantagem desse sistema residia no fato de funcionar não somente no plano horizontal, mas também no conjunto vertical da edificação.

Como exemplo disso, no ano de 1843, é projetada por Henri Labrouste a Biblioteca de Sainte-Genevieve, utilizando-se a divisão tripartida do espaço. No andar superior se encontra a biblioteca em si, definida principalmente, por dois grandes espaços destinados à leitura e pesquisa. $\mathrm{O}$ grande destaque deste ambiente é a perfeita interação que se estabelece os espaços separados somente pelo desnível do piso e disposição inteligente do mobiliário. Os locais de leitura posicionam-se um pouco acima das estantes dos livros, objetivando a não interferência do campo visual interno e a adequada distribuição da luz natural no ambiente. Mesmo em relação à iluminação, existe uma medida estabelecida entre o espaço interno e externo do edifício, proporcionada estrategicamente pelas aberturas que estão acima das estantes nas paredes laterais. Já no térreo, onde está localizado o principal ponto de acesso à biblioteca, o espaço contempla uma grande superfície retangular, recortada por elementos vazados e onde se localizam as áreas administrativas, salas de depósito e salas de livros raros. 
Labrouste consegue aplicar o conceito da linguagem arquitetônica vinculada aos desígnios da revolução industrial, refletida principalmente na racionalização da construção. Em função disso, o grande destaque do edifício seu sistema estrutural, composto por arcos construídos em ferro, formando um importante conjunto de extrema leveza e beleza espacial. A Biblioteca de Sainte-Genevieve foi o primeiro edifício público que utilizou o ferro fundido e aço, não só no sistema estrutural como também nas colunas internas, nos travamentos e na cobertura. Labrouste consegue provar como a estrutura de ferro se auto equilibra, descarregando poucos esforços nas paredes externas, fato que inaugura uma importante fase na construção de edifícios públicos, mediante o desenvolvimento dos conhecimentos relativos aos processos de fabricação de novos materiais, como o ferro e vidro, sugerindo uma nova maneira de produzir o espaço arquitetônico (COSME, 2004).
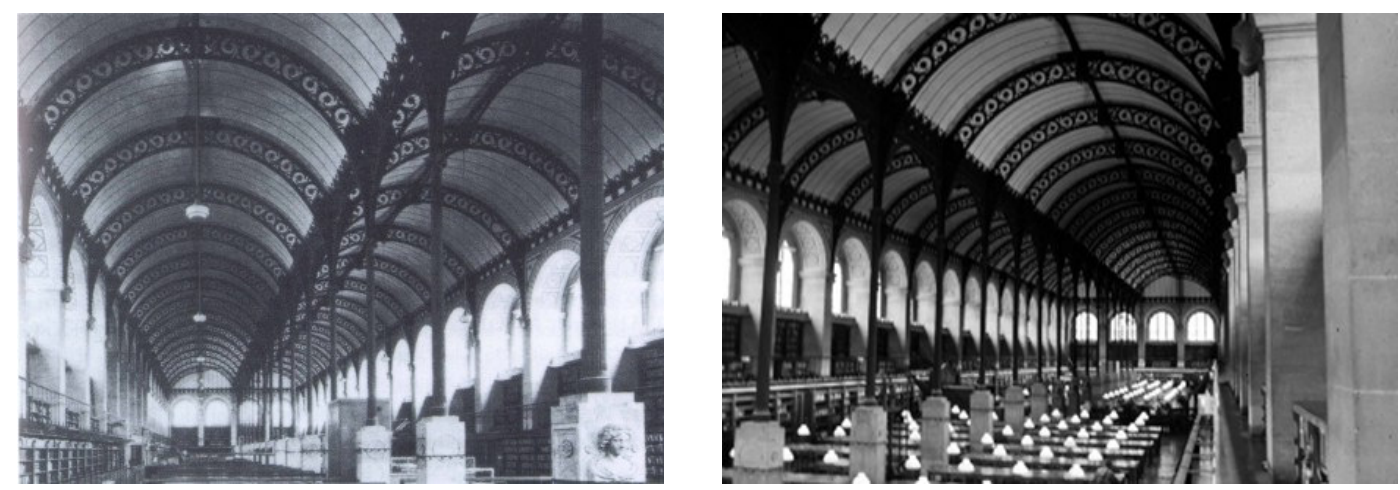

Figuras 07 e 08 - Biblioteca de Sainte-Genevieve

Fonte: www.comune.fi.it

No ano de 1865, Labrouste é convidado para executar o novo projeto Biblioteca Nacional de Paris, em função da experiência adquirida nos trabalhos anteriores. Nesse desenho, o arquiteto estabelece a clara separação entre a área de armazenamento e zona de leitura, dando tratamento diferenciado aos elementos arquitetônicos. O projeto também contempla uma profunda preocupação com a questão do armazenamento de livros, preservando a necessidade de separar os ambientes de leitura da área de depósito de livros. Neste caso, o depósito é construído de ferro e utiliza uma planificação bastante racional e sem ornamentos, cuja principal preocupação é estabelecer uma linguagem arquitetônica despojada e limpa. O projeto se estrutura em quatro pavimentos e um sub-solo.Outro ponto forte é a utilização de uma cobertura de 
vidro e de lajes em forma de grelha. Essas alternativas projetuais tinham o objetivo de introduzir as novas tecnologias construtivas provindas do processo da Revolução Industrial. Além disso, havia uma eficiente comunicação interna executada por meio de passarelas metálicas que cruzam as principais salas da biblioteca.
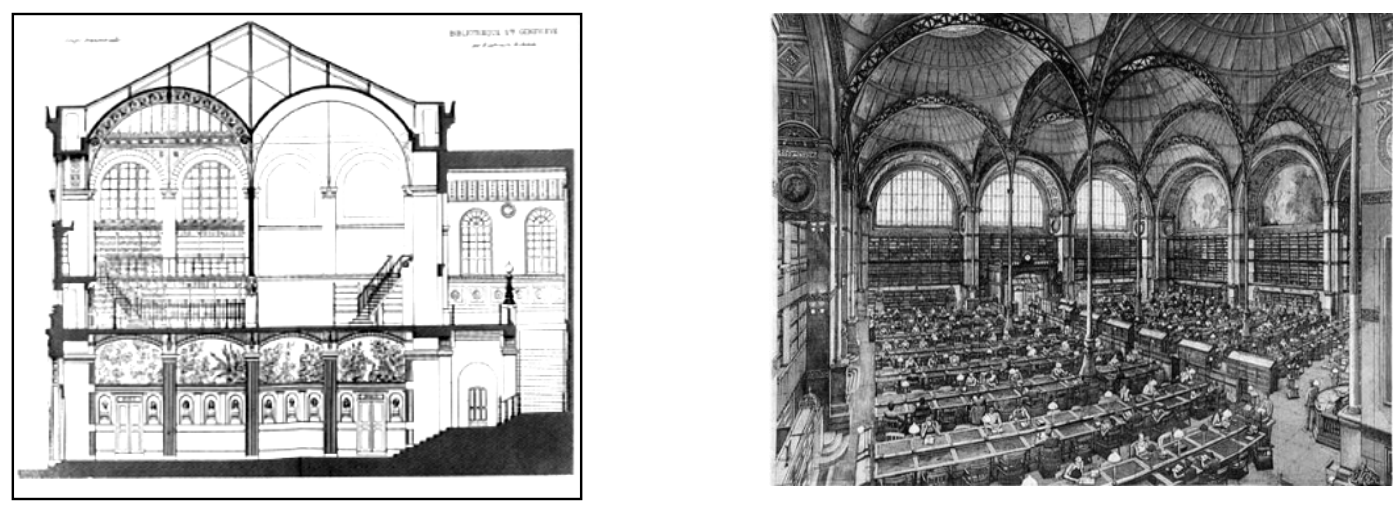

Figuras 09 e 10 - Biblioteca de Sainte-Genevieve

Fonte: www. soa.syr.edu

Durante o mesmo período, as primeiras bibliotecas públicas, com acesso livre às estantes dos livros, começaram a surgir no Estados Unidos. A principal característica desses edifícios é a da auto-educação do indivíduo, principalmente em função da evangelização da igreja protestante que considera o processo educativo como instrumento para o desenvolvimento da sociedade.

Outros importantes exemplos de edifícios de bibliotecas, enquadrados no neoclassicismo americano, são a Biblioteca Pública de Boston (1888-1892) projetada por Mckim, Mead \& White e inspirada na Biblioteca de Sainte-Geneviève de Paris. Mais recentemente, entre os anos de 1967 e 1971, o edifico ganhou um anexo projetado por Philip Johnson, formando um imenso conjunto compacto, contrastando com edifício antigo existente. Outro grande exemplo americano desse período é a Biblioteca do Congresso em Washington, projetada e construída dentro dos parâmetros defendidos por Thomas Jefferson, que preconizava que todo assunto é importante para a formação completa de cada cidadão. Hoje, a biblioteca possui o maior acervo de documentos históricos do mundo. São mais de 115 milhões de itens em 460 idiomas diferentes, incluindo caricaturas, pôsteres, partituras, instrumentos musicais, jornais, fotos, etc. 

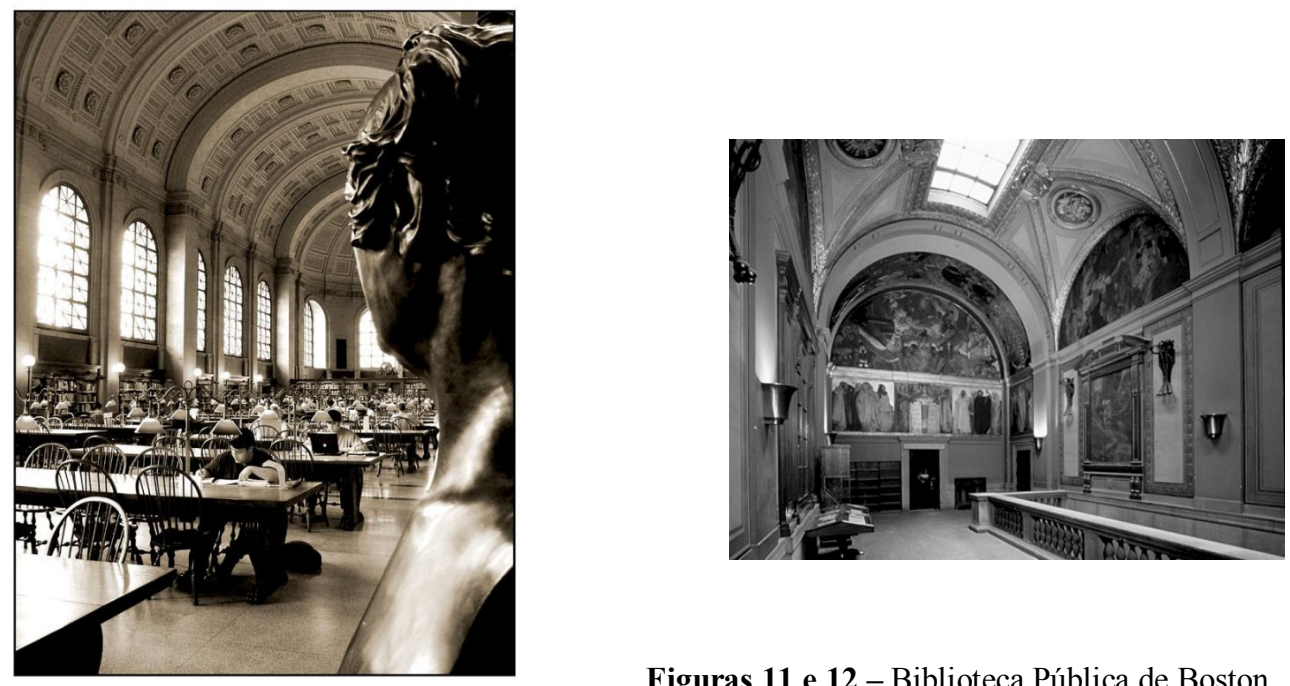

Figuras 11 e 12 - Biblioteca Pública de Boston Fonte: www.jillianmyers.com

No começo do século XX, mais precisamente no inicio dos anos vinte, o arquiteto dinamarquês Erik Gunnar Asplund iniciou os estudos para o projeto da Biblioteca Municipal de Estocolmo. Asplund teve como fonte de inspiração as idéias de Boullée, ressaltando os elementos de dignidade do espaço e enfatizando seu sentido sublime para o conhecimento. O edifício agrega uma cúpula central sobre a sala principal de leitura, permitindo que, por uma grande abertura no teto, entre iluminação natural. Esse local é circundado por salas de leitura e pátios com clarabóias, criando um interessante resultado de cheios e vazios entre as salas. $\mathrm{O}$ arquiteto escolheu posicionar as salas de estudo, que estão em volta da sala central, com mesas próximas às aberturas para receberem iluminação natural.
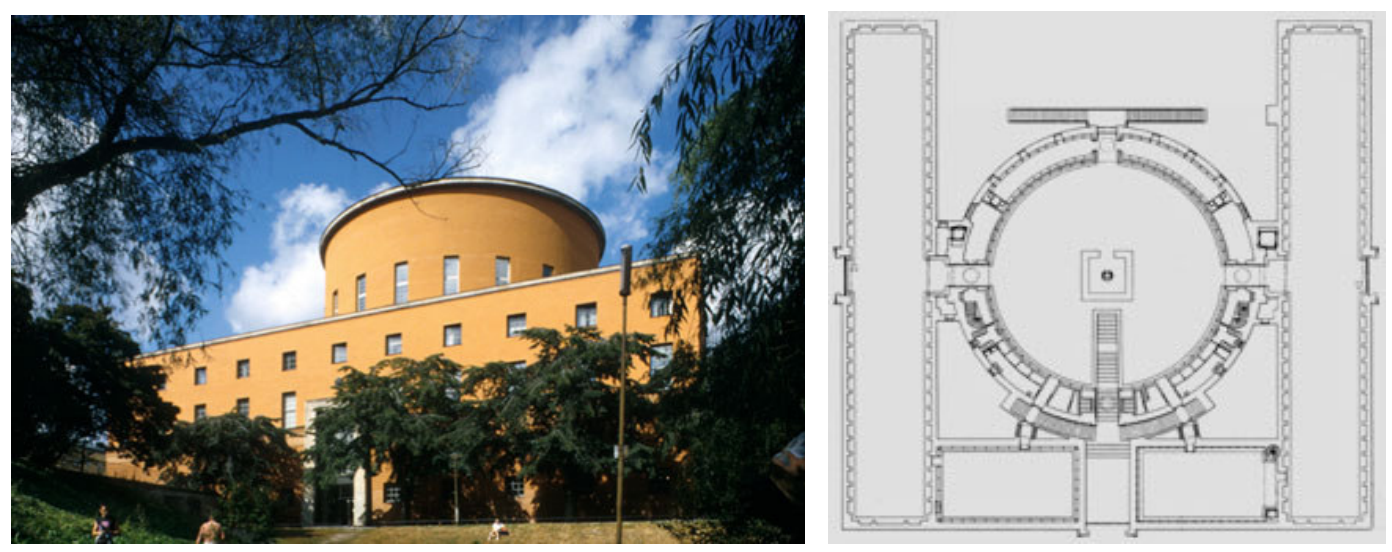

Figuras 13 e 14 - Biblioteca Municipal de Estocolmo/Vista Externa/Planta

Fonte: www.comune.fi.it 
Nos anos seguintes, os espaços das bibliotecas passaram por profundas transformações nas questões programática-espaciais, para atender às novas demandas do crescente aumento de livros e coleções, com novos modelos de armazenamento, conservação, transporte, acesso e manuseio.

Como exemplo importante da dimensão da biblioteca no âmbito comunitário inserido na sociedade, a Finlândia se destaca com os projetos do arquiteto Alvar Aalto para a Biblioteca Municipal de Viipuri e a Biblioteca Pública de Seinäjoki. Em Viipuri, o edifício resgata a dimensão humana para os espaços de leitura e consulta, criando um espaço qualificado e integrado. $O$ arquiteto fixa a localização de um auditório e uma biblioteca infantil no piso térreo, demonstrando o caráter socializante da informação em relação à comunidade. Já no nível inferior, os espaços dedicados ao atendimento, aos serviços infantis e ao conjunto do acervo da biblioteca são interligados por meio de um grande mezanino com a secção de empréstimos de livros. O projeto de Alvar Aalto prima pelo cuidadoso trabalho de iluminação zenital nas salas de leitura, por meio da instalação de um conjunto de 57 lanternis cilíndricos e cônicos, que funcionam como clarabóias. Por meio de um preciso cálculo de abertura desses lanternis, a iluminação acontece de forma indireta e uniforme, garantindo durante o ano inteiro o controle correto da luz nas salas de leitura.
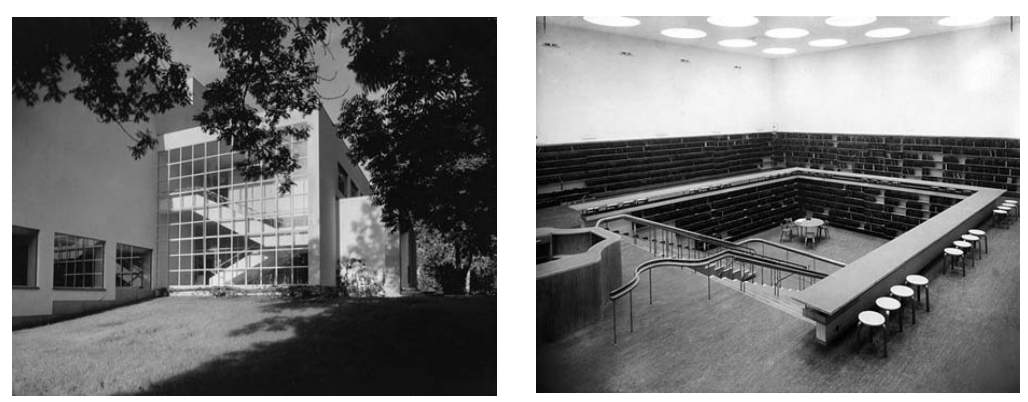

Figuras 15 e 16 - Biblioteca Municipal de Viipuri/Vista Interna Fonte: www.alvaraalto.fi
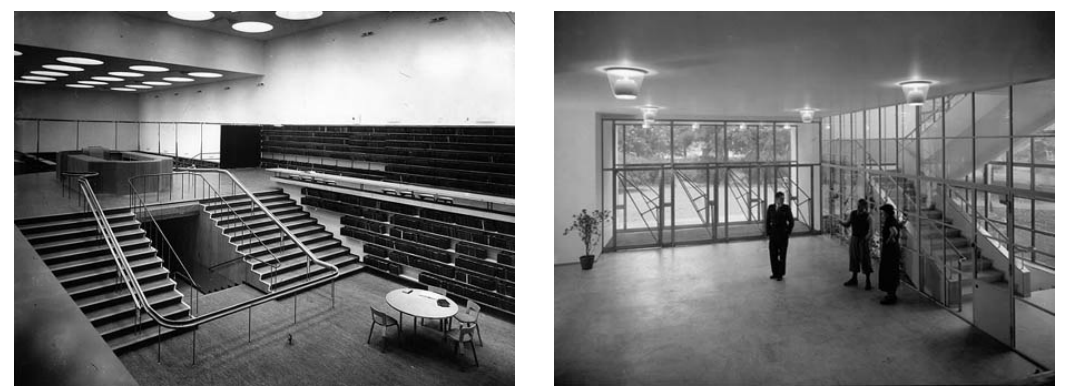

Figuras 17 e 18 - Biblioteca Municipal de Viipuri/Vista Interna Fonte: www.alvaraalto.fi 
Outro importante exemplo é a Biblioteca Pública de Seinäjoki, onde Alvar Aalto projetou entre os anos de 1960 e 1963. A principal característica deste projeto está vinculada as suas formas assimétricas que abrigando os principais ambientes, formando uma imponente composição arquitetônica.
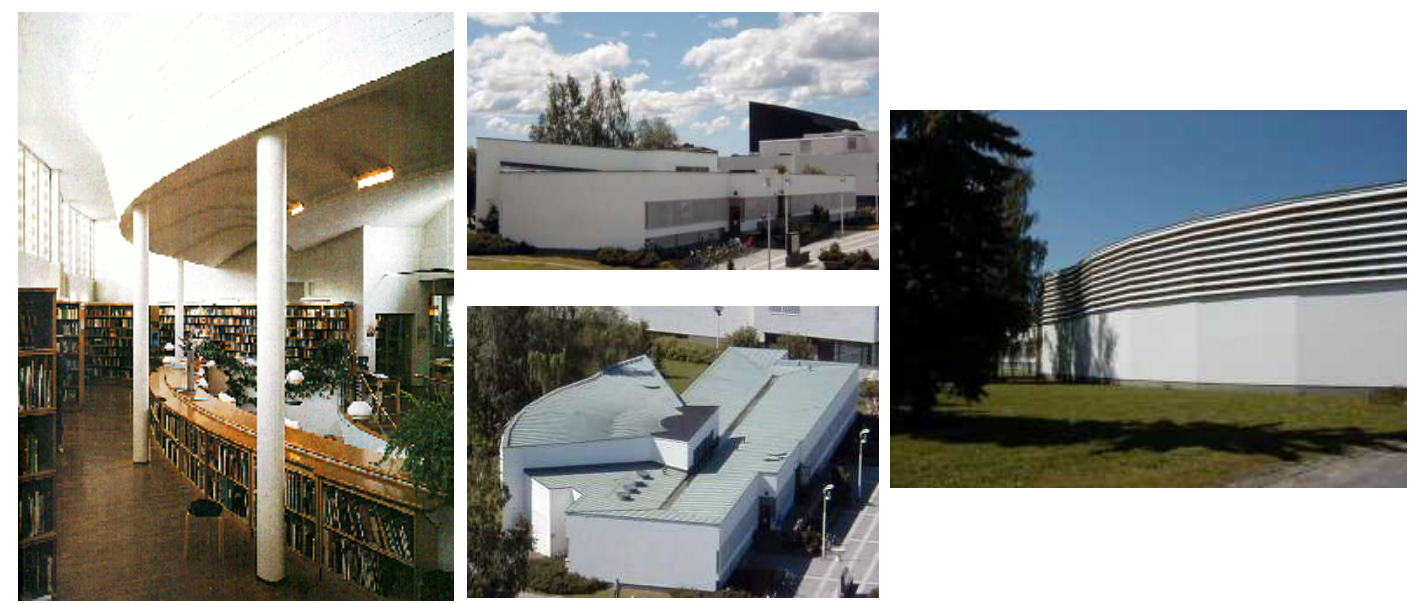

Figuras 19, 20, 21 e 22 - Biblioteca Pública de Seinäjoki/Vistas

Fonte: www.vitruvius.ch

O principal volume lembra o desenho de um leque que abriga as salas de leitura e empréstimo, anexadas a outro volume destinado a uma secção infantil, secção de referências, sala de conferências e áreas administrativas. No nível abaixo está localizado todo o acervo da biblioteca e uma área destinada a uma biblioteca circulante, que atende a toda a comunidade rural da cidade. Aalto concebe um espaço adequado às questões técnicas de conforto do usuário em relação à biblioteca, principalmente no volume principal do edifício, onde estão as salas de leitura, instalando quebra-sóis horizontais externos para proteção da incidência de radiação solar.

\subsection{Contextos das Bibliotecas Universitárias Internacionais}

Conforme apresentado neste trabalho, as bibliotecas universitárias, no contexto internacional, têm objetivado, ao longo do seu processo de atuação, transmitir ao público a importância das atividades que ocorrem em seu interior, bem como da concepção, desenho e funcionalidade da sua arquitetura, sua ambientação e sua sinalização. De certo modo, as análises espaciais apresentadas nesse trabalho visaram a contemplar as manifestações dos conceitos espaciais da biblioteca, determinando a 
circulação em seu espaço, influenciando e manipulando o deslocamento do usuário e revelando como a dinâmica do espaço afeta a utilização de seu ambiente, o que se dá pelo olhar interpretativo daqueles que a freqüentam. Assim, a arquitetura das bibliotecas universitárias articula formas interativas e subjetivas, manifestadas pela sua localização no tecido urbano, pela materialidade da cor, textura, transparência, opacidade, geometricidade e pela funcionalidade.

É importante salientar que, na análise dos espaços de bibliotecas universitárias internacionais, os critérios de escolha dos exemplos aqui apresentados focaram as tendências mundiais de construção destes edifícios, destacando basicamente, duas abordagens consideradas representativas do universo anteriormente descrito: o primeiro aspecto discute a atividade mediadora entre a informação e a comunidade universitária da biblioteca, considerada função básica na qualidade dos serviços bibliográficos; e o segundo aspecto refere-se à análise dos projetos em termos arquitetônicos, visando a compreender a finalidade principal desses espaços e as atividades relacionadas ao ambiente informacional das bibliotecas.

\subsubsection{Exemplos Internacionais}

Este item analisa as bibliotecas universitárias no âmbito internacional e considera não apenas os elementos correspondentes aos aspectos arquitetônicos, mas a caracterização organizacional presente nestes edifícios, com base em duas linhas investigativas: a primeira, uma descrição técnica, por meio de figuras e desenhos de plantas, evidenciando as principais informações quanto às suas características arquitetônicas, técnicas construtivas, tipos de implantação, descrição dos ambientes e perfil dos usuários; a segunda, uma análise de forma interpretativa, descreve não só os conceitos de partido e programa arquitetônico dos espaços, mas as tendências organizacionais das bibliotecas.

Considerando o universo das bibliotecas universitárias internacionais, convém indicar os principais critérios escolhidos para a análise dessas bibliotecas no contexto deste trabalho. São eles:

- $\quad$ Projetos de bibliotecas implantadas em universidades com tradição comprovada;

- $\quad$ Significativa adequação ambiental-espacial;

- $\quad$ Criatividade na proposição de tecnologias e técnicas construtivas; 
- $\quad$ Projetos com expressão arquitetônica relevante;

- Projetos que contemplem a introdução de novas tecnologias informacionais e comunicacionais na definição de seus espaços.

Dessa maneira, o estudo das edificações de bibliotecas universitárias apresentadas a seguir mostra suas necessidades, suas percepções ambientais e o papel desses espaços desempenham em nossa sociedade: 
Quadro 01 - Biblioteca Regional Technical College

\begin{tabular}{|l|l|l|l|}
\hline \multicolumn{1}{|c|}{ Projeto } & \multicolumn{3}{|c|}{ Biblioteca Regional Technical College } \\
\hline \multicolumn{1}{|c|}{ Local } & Cork, Irlanda & \multicolumn{1}{|c|}{$\begin{array}{l}\text { Ano de } \\
\text { construção }\end{array}$} & 1994 \\
\hline $\begin{array}{l}\text { Área } \\
\text { construída }\end{array}$ & $2.672 \mathrm{~m}^{2}$ & Arquitetos & Blacam \& Meagher Arquitetos Associados \\
\hline
\end{tabular}

Localizado na cidade de Cork, Irlanda, faz parte de um importante projeto de revitalização das principais construções existentes no campus da universidade e inclui em seu plano diretor várias fases e etapas no processo de recuperação de suas edificações. A biblioteca se encaixa nestas duas vertentes: recupera um importante espaço existente e projeta para o futuro um conjunto de prédios que abrigarão importante centro de informações e comunicações para o campus universitário. As novas instalações prevêem um grande auditório de conferências para apresentações e palestras. A biblioteca, então, materializa a primeira fase desse processo de requalificação do espaço no campus do RTC (TOH, 1999).

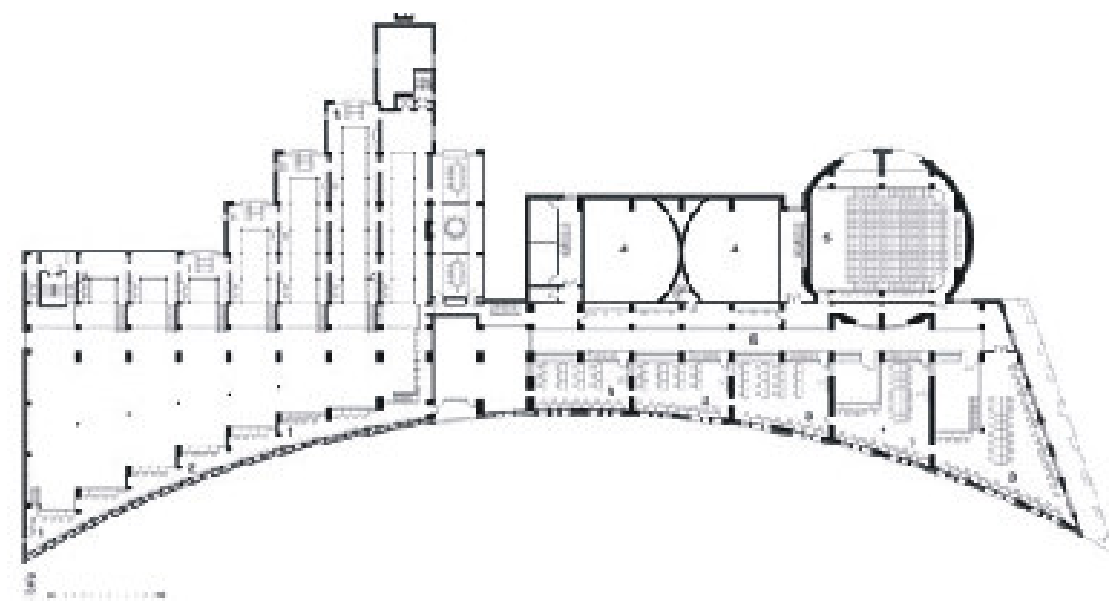

Figura 23 - Planta/Bibliot. Regional Technical College

Fonte: www.deblacamandmeagher.com. 


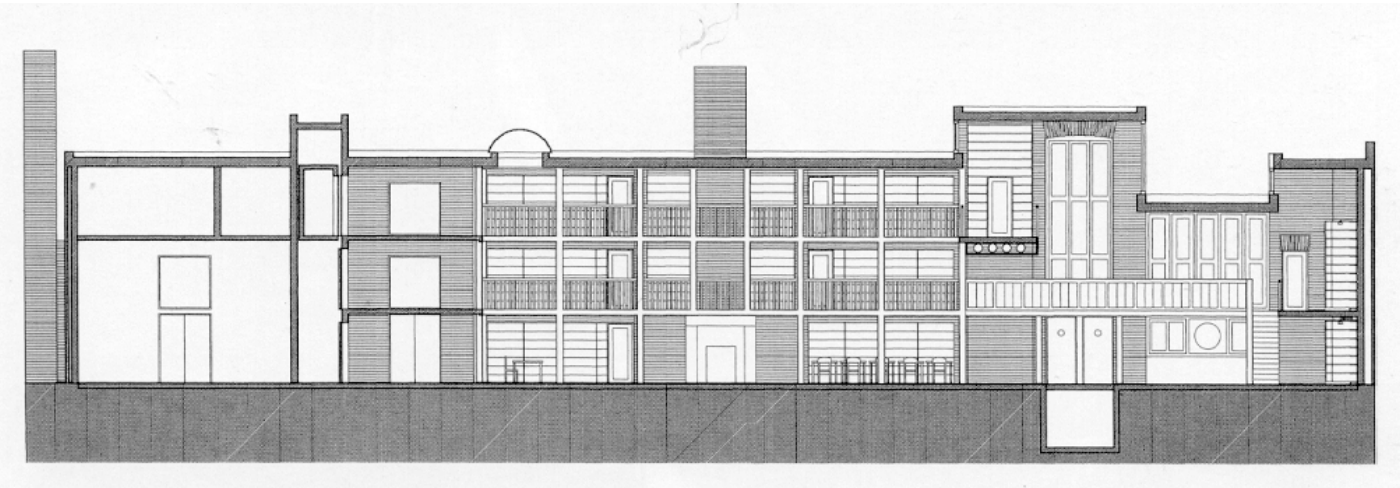

Figura 24 - Corte Esquemático/Biblioteca Regional Technical College Fonte: www.deblacamandmeagher.com.

O partido arquitetônico adotado para o projeto da biblioteca estabelece dois elementos fundamentais como base: primeiro, a valorização da fachada com a utilização do tijolo vermelho, provavelmente influência das Bibliotecas de Louis Kahn e de Phillips Exeter, como declaram os próprios autores do projeto; e segundo, a predominância de pequenas aberturas de janelas, que se voltam para o exterior, destacando ainda mais o aspecto sólido e volumétrico da biblioteca. Essa rigidez é quebrada somente por uma grande parede curva que se posiciona na fachada principal da edificação, ou seja, bem em frente à rua de acesso à entrada da biblioteca.

Como forma de referenciar e destacar o acesso ao edifício, o hall de entrada principal apresenta pé-direito triplo, justamente para propiciar a ventilação natural do ambiente, provinda do eixo leste-oeste e assegurar um microclima agradável a todos os espaços que lhe ficam circunvizinhos ao hall de entrada. Além de cumprir a função de atendimento e recepção dos usuários da biblioteca, o espaço garante um grande ponto de encontro e convívio entre as pessoas que acessam as dependências do edifício ou mesmo circulam nesse eixo de ligação. Dando continuidade a este espaço de entrada, o projeto também explora uma grande clarabóia localizada no eixo central do espaço da biblioteca, criando um enriquecedor trabalho de luz natural no interior das salas laterais (TOH, 1999).

A iluminação natural e a qualidade dos espaços destinados aos usuários/leitores tiveram especial cuidado no processo de planejamento do projeto da biblioteca. Todas as áreas definidas como espaços de leitura ou pesquisa foram alocadas estrategicamente de tal forma que as aberturas de janelas permitem entrada de luz suficiente e adequada nas mesas de trabalho. Desta forma, é possível ter um ambiente com luz controlada, além de prover conforto visual e térmico aos consulentes e aos 
funcionários da biblioteca. Outra vantagem da qualidade espacial desses ambientes esta principalmente na privacidade, nas dimensões e no aspecto organizacional do mobiliário.

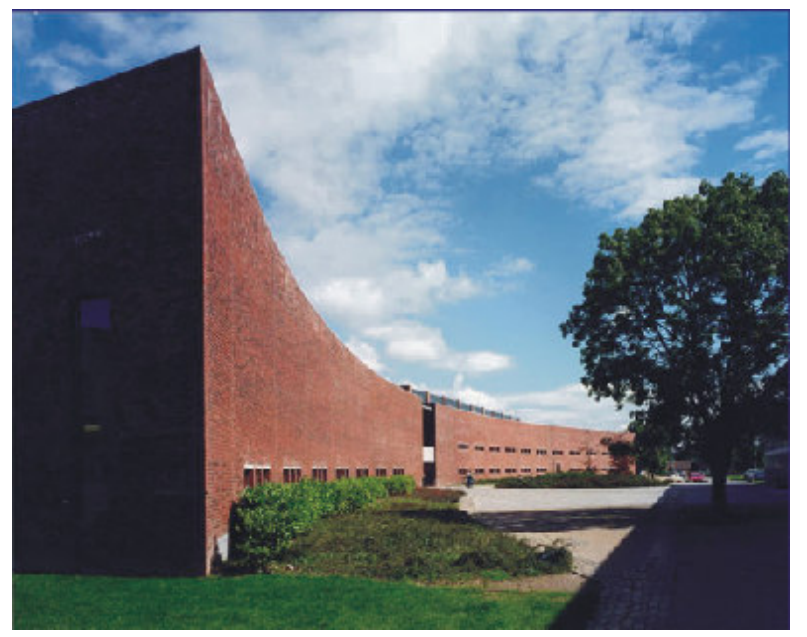

Figura 25 - Vista Externa da Biblioteca Regional Technical College Fonte: www.deblacamandmeagher.com.
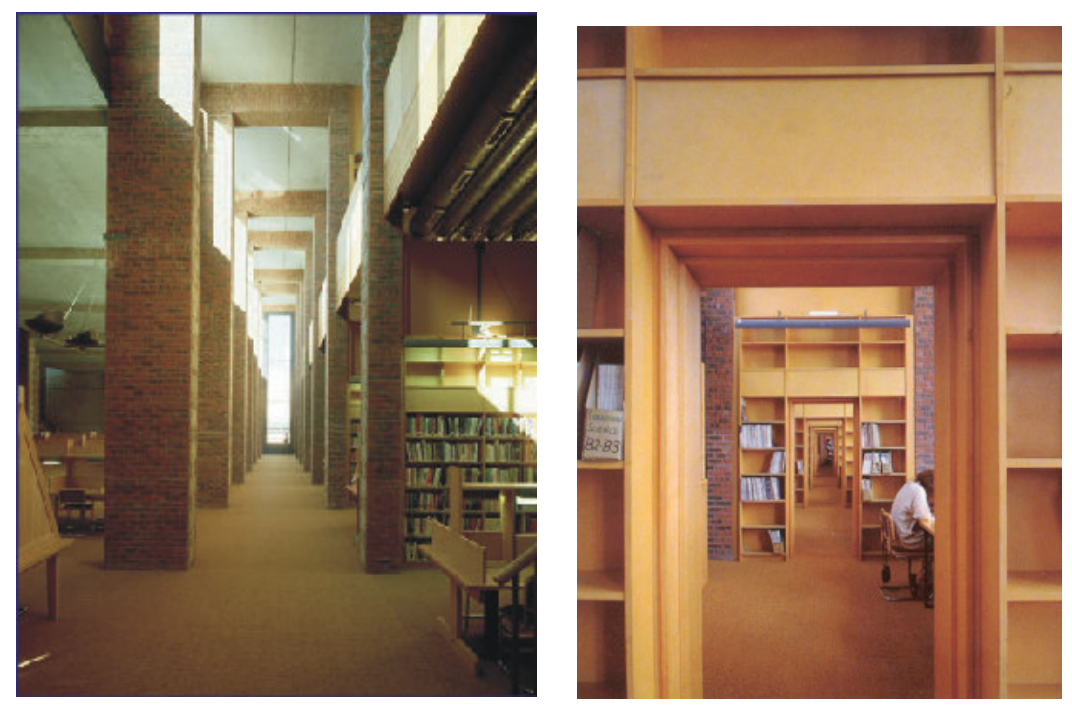

Figuras 26 e 27 - Vista Interna da Biblioteca Regional Technical College Fonte: www.deblacamandmeagher.com.

Outro ponto forte do projeto é o desenho dos móveis, efetivado pelos arquitetos. A equipe definiu a utilização de fibras naturais de madeira em seus revestimentos, como forma de garantir, ao ambiente interno, um aspecto intimista e familiar Provavelmente, em decorrência desta ambientação da biblioteca, a percepção 
do usuário é motivada a reconhecer no espaço, qualidades para o desenvolvimento de suas atividades de pesquisa e leitura. 
Quadro 02 - Biblioteca Darwin College Study Centre

\begin{tabular}{|l|l|l|l|}
\hline \multicolumn{1}{|c|}{ Projeto } & \multicolumn{3}{c|}{ Biblioteca Darwin College Study Centre } \\
\hline \multicolumn{1}{|c|}{ Local } & Cambridge, Inglaterra & $\begin{array}{l}\text { Ano de } \\
\text { construção }\end{array}$ & 1994 \\
\hline $\begin{array}{l}\text { Área } \\
\text { construída }\end{array}$ & $600 \mathrm{~m}^{2}$ & Arquitetos & \multicolumn{3}{|c|}{ Jeremy Dixon e Edward Jones } \\
\hline
\end{tabular}

A finalidade desta biblioteca é prover os estudos dos alunos de pósgraduação de mestrado e doutorado nas áreas de ciências e educação do Darwin College, pertencente à Universidade de Cambridge. O projeto arquitetônico estabelece em suas diretrizes básicas, espaços agradáveis e prazerosos.

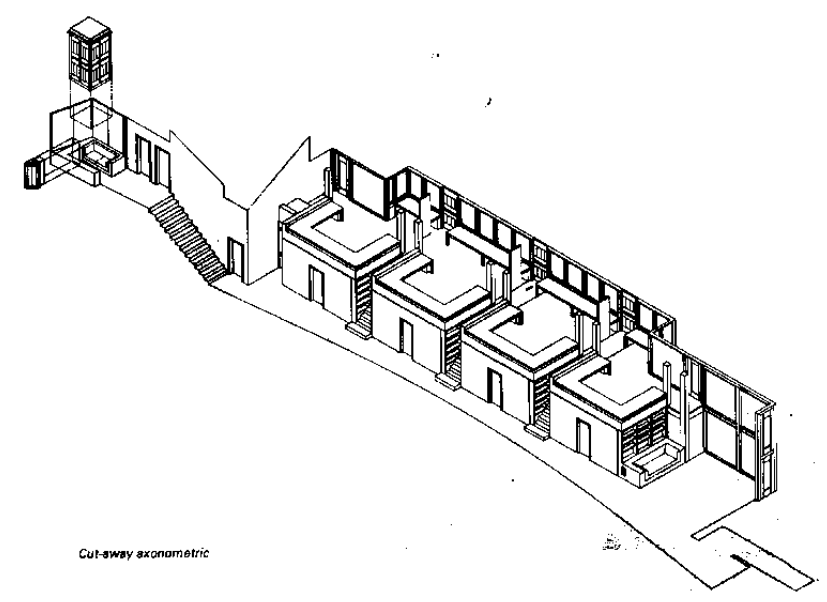

Figura 28 - Vista Axonométrica Interna/ Biblioteca Darwin College Study Centre Fonte: KITO, 1995

O primeiro ponto marcante do projeto estabelece uma relação estreita entre o meio-ambiente e sua forma de implantação. O edifício é orientado frontalmente em relação ao principal elemento natural que corta a campus da faculdade: o Rio Cam. Este recurso possibilita que todas as aberturas de janelas se voltem e acompanhem o leito principal do rio. Além de permitir que o pavimento das salas da biblioteca projetase em balanço em forma de um grande deck de madeira, reforçando ainda mais a estreita ligação entre o rio e o edifício (KITO, 1995).

Em termos volumétricos, a biblioteca se aproxima da forma de um retângulo e distribui-se em três níveis diferentes ao longo do terreno. Este conceito concretiza a edificação em uma dimensão reduzida e uma escala humana equilibrada, se comparada com os outros edifícios do complexo do campus universitário. Essa solução 
projetual simples é constatada também no projeto de coberturas da biblioteca, onde duas águas simples de telhas cerâmicas projetam-se na direção dos blocos.

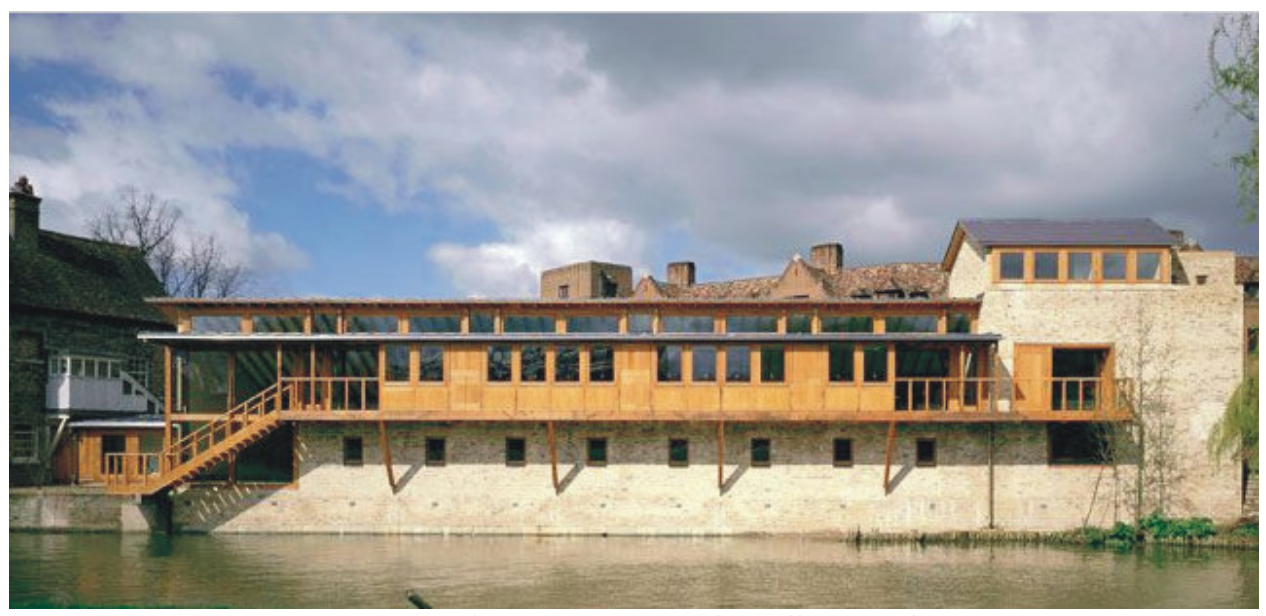

Figura 29 - Vista Externa, Darwin College Study Centre

Fonte: KITO, 1995

Como forma de possibilitar acesso rápido e tranqüilo do usuário até o prédio, uma grande parede curva emerge da rua em direção à entrada principal, recriando uma alternativa de espaço público antes inexplorável e inexistente. Novas formas e materiais enriquecem a linguagem simples dessa arquitetura, valorizando tanto o espaço interno quanto os elementos externos da edificação.

Externamente, o edifício é construído em alvenaria e revestido em pedra especial inglesa.Uma junta de cal foi aplicada ao rejunte das paredes, com o objetivo de evitar problemas sérios de umidade e infiltração. Com isso, a biblioteca traz um forte traço vernacular, principalmente, no tratamento de suas superfícies externas e na compatibilização com a cultura local inglesa. O telhado recebeu estrutura de madeira especial de vários tamanhos e formas, de acordo com as necessidades requeridas dos esforços. Tecnicamente, a preocupação era evitar o alto acúmulo de umidade nas peças e nos encaixes de madeira, principalmente nos meses de inverno, em que as temperaturas atingem níveis baixíssimos. Para garantir que não acontecessem prejuízos em termos estruturais da edificação, a equipe de projetistas elaborou dois procedimentos básicos na estrutura do telhado. Além de providenciar a impermeabilização da madeira, a primeira solução encontrada foi a fixação, ao longo do telhado, de elementos de aço inoxidável na junção de todas as peças de encaixe. Mesmo com a dilatação normal da 
madeira, a estrutura não está comprometida com as variações de umidade e temperatura. A segunda solução foi revestir as peças de madeira com uma camada dupla de madeira compensada naval para facilitar a estabilização lateral. Com todos esses procedimentos preventivos em relação à instalação do telhado da biblioteca, os arquitetos puderam tirar melhor partido das possibilidades da madeira e suas aplicações (KITO, 1995).
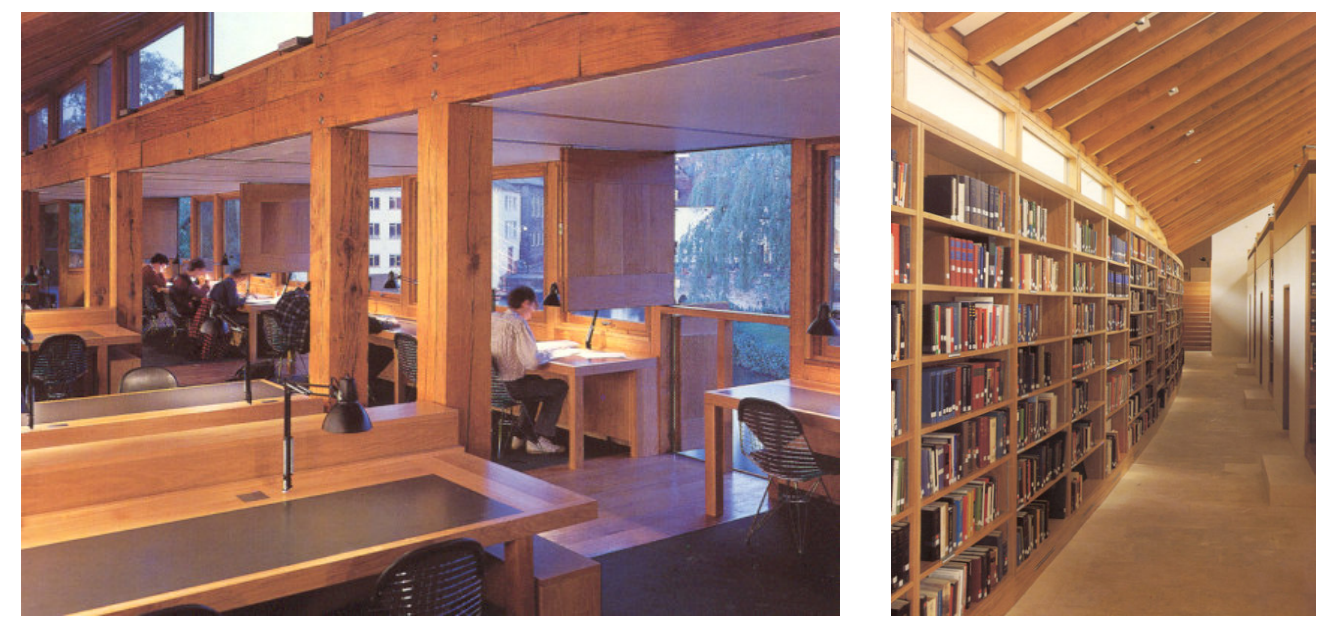

Figuras 30 e 31 - Sala de leitura e pesquisa e Prateleiras de livros, Darwin College Study Centre Fonte: KITO,1995

Internamente, a biblioteca é toda concebida também em madeira, tanto na mobília quanto no sistema estrutural. Revestimentos, portas, janelas e mobiliário são feitos de belíssimas peças de carvalho, fornecendo ao ambiente uma forte carga dramática na aplicação das texturas da madeira. Esse conjunto se completa, principalmente, no aspecto dominante da geometria do telhado, ou seja, todo o forro acompanha o desenho inclinado da estrutura de madeira, permitindo que os espaços das salas recebam iluminação proveniente das janelas localizadas na parte superior do teto. Outro fator que se destaca é a preocupação com o conforto ambiental nos espaços da biblioteca. A orientação do edifício foi definida em função da menor incidência de raios solares projetados nas aberturas de janelas. Isso se justifica, principalmente, no controle das temperaturas internas das salas e também, nos cuidados relativos à preservação das coleções de livros, periódicos e material bibliográfico. Como resultado disso, as aberturas das janelas não acontecem para o lado da rua, onde o ruído e o barulho se concentram, mas em direção à lateral do Rio Cam (KITO, 1995). 
Conclui-se que o objetivo principal do projeto, é de formar uma interativa simbiose entre arquitetura e meio natural, concretiza-se não só o edifício da biblioteca, mas em todo conjunto arquitetônico do campus da faculdade. 
Quadro 03 - Biblioteca Cranfield

\begin{tabular}{|l|l|l|l|l|}
\hline \multicolumn{1}{|c|}{ Projeto } & \multicolumn{3}{|c|}{ Biblioteca da Universidade de Cranfield } \\
\hline \multicolumn{1}{|c|}{ Local } & Bedfordshire, Inglaterra & $\begin{array}{l}\text { Ano de } \\
\text { construção }\end{array}$ & 1992 \\
\hline $\begin{array}{l}\text { Área } \\
\text { construída }\end{array}$ & $2.800 \mathrm{~m}^{2}$ & Arquiteto & Norman Foster \\
\hline
\end{tabular}

O Instituto de Tecnologia de Cranfield foi fundado no ano de 1946 e, já nesta data, reunia a elite educacional na área da engenharia aeronáutica da Inglaterra. Por muitos anos, esta instituição foi reconhecida como a principal fomentadora das ações efetivas de pesquisa e educação voltadas aos avanços aeronáuticos no país e em âmbito internacional. Essa estratégia de consolidar a faculdade como centro referencial de pesquisa se concretiza com o aperfeiçoamento e o aumento dos estudos de PósGraduação e, principalmente, com a possibilidade de expansão de três novos campus projetada. Portanto, o novo edifício da biblioteca faz parte deste grande plano de ação de inserção de novos espaços e construções na Universidade de Cranfield.
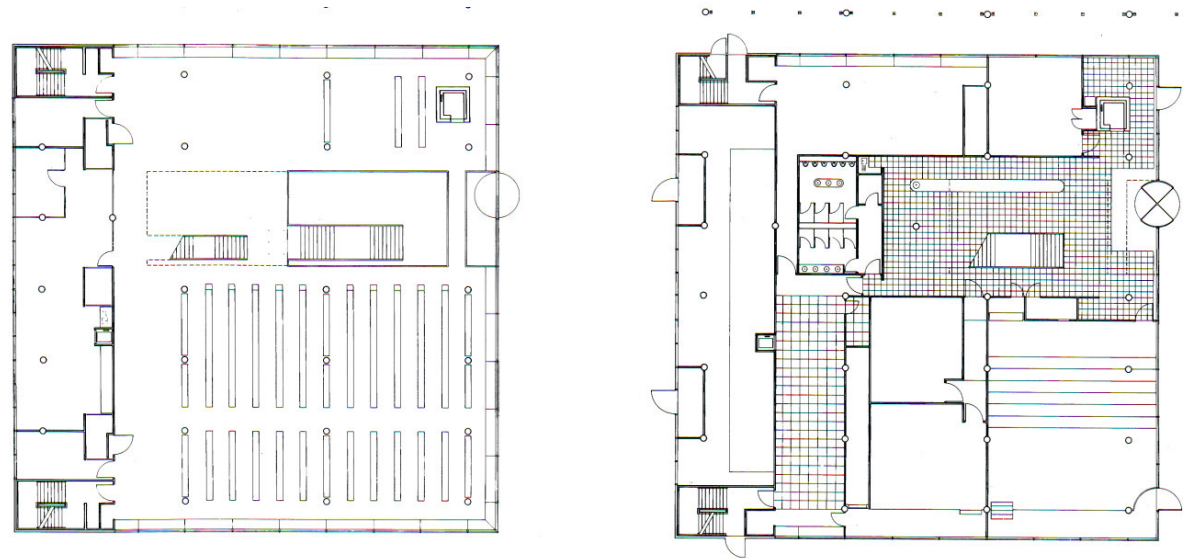

Figuras 32 e 33 - Planta Térreo e Pavimento Superior/Biblioteca Cranfield Fonte: BRAWNE, 1997

Um dos principais diferenciais do projeto reside no fato de que a nova biblioteca agrega informação não só na área de engenharia aeronáutica, mas também reúne pesquisa voltada à área de administração, ou seja, duas áreas de conhecimento inseridas em um mesmo edifício. Essa integração é representada simbolicamente pela implantação do edifício bem ao centro do campus de Cranfield, entre as faculdades de administração e engenharia aeronáutica (BRAWNE, 1997). 

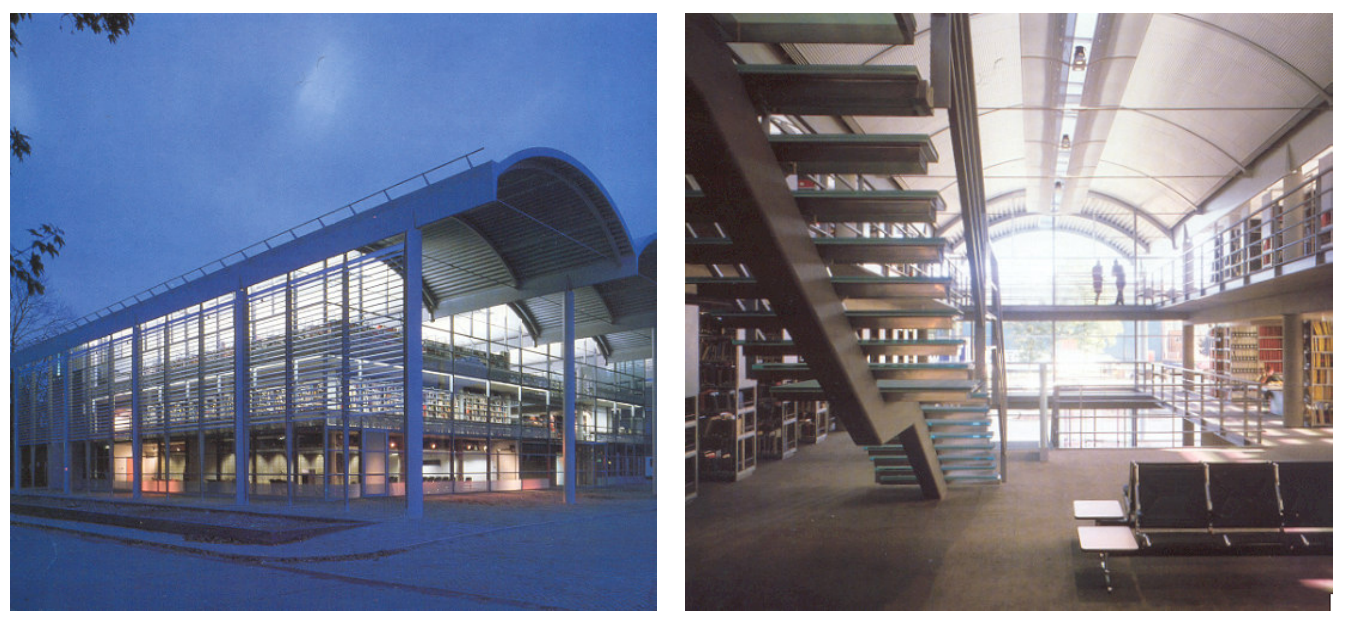

Figuras 34 e 35 - Fachada principal Biblioteca Cranfiel/ Vista Interior Biblioteca Cranfield Fonte: BRAWNE, 1997

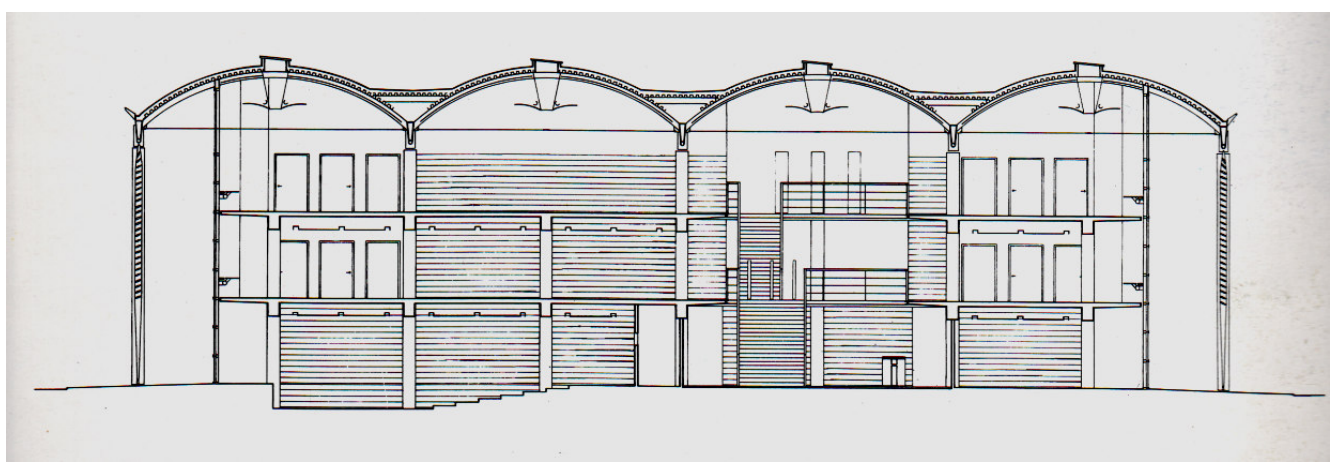

Figura 36 - Corte/Biblioteca Cranfield Fonte: BRAWNE, 1997

O edificio da Biblioteca de Cranfield é construído em estrutura metálica aparente e remete à linguagem da arquitetura aeronáutica, ou seja, faz alusão aos grandes galpões e hangares de aeroportos. Isso fica mais claro, principalmente, pela divisão da construção em quatro grandes blocos e pela conformação da cobertura do telhado em forma curvilínea. Essa linguagem de "galpão" é finalizada com grandes aberturas no telhado, em forma de shed, que permitem adequar a entrada de luz natural no interior do edifício e controlar a ventilação em todos os ambientes instalados no pavimento superior. O projeto também estabelece um grande espaço de circulação interno, uma espécie de átrio central, iluminado pela abertura zenital. Na intenção do arquiteto transparece a idéia de estimular o ponto de encontro das pessoas, ligando todo 
o conjunto de salas e ambientes a esse grande espaço. Mesmo com toda essa integração, os locais destinados à leitura e à pesquisa estão inteiramente preservados, quesito essencial para que tais atividades possam ocorrer simultaneamente sem interferências sonoras. Essa integração é completada pela da fixação de grandes panos de vidro, voltados tanto às áreas externas como aos espaços internos (BRAWNE, 1997).

No desenho dos espaços interiores, a equipe de Norman Foster elaborou todo o projeto de mobiliário e design da biblioteca de Cranfield. Entre os principais elementos que nortearam a idéia, o estabelecimento das estações de trabalho trouxe flexibilidade na montagem espacial das salas. Com esse conceito, foi possível trabalhar com a idéia de liberdade e agilidade na criação e na alteração do layout, tão necessário em espaços abertos como os dessa biblioteca.Desta forma, todas as ações desempenhadas pelos funcionários e usuários desenvolvem o conceito de funcionalidade e ergonomia.

A aplicação do aço permitiu agilidade e precisão de detalhes arquitetônicos que, por sua diversidade e riqueza, exigiram emprego de grande variedade de perfis metálicos e elementos estruturais. A combinação desses elementos, além de cumprir rigorosamente os prazos de entrega, conferiu ao projeto da biblioteca simplicidade, harmonia e transparência, convertendo a obra na grande atração do campus na universidade. 
Quadro 04 - Biblioteca de Direito Squire

\begin{tabular}{|c|l|l|l|l|}
\hline \multicolumn{1}{|c|}{ Projeto } & \multicolumn{3}{l|}{$\begin{array}{l}\text { Biblioteca de Direito Squire da Universidade de } \\
\text { Cambridge }\end{array}$} \\
\hline \multicolumn{1}{|l|}{ Local } & \multicolumn{2}{|l|}{ Cambridge, Inglaterra } & $\begin{array}{l}\text { Ano de } \\
\text { construção }\end{array}$ & 1995 \\
\hline $\begin{array}{l}\text { Area } \\
\text { construída }\end{array}$ & $9.000 \mathrm{~m}^{2}$ & Arquiteto & Norman Foster \\
\hline
\end{tabular}

Em Cambridge, o ensino do direito sempre teve papel de destaque ao longo de vários anos de atividades. Com uma forte orientação nas áreas de pesquisa, ensino e extensão, a faculdade recebe todo ano alunos não só da Inglaterra e da Europa, mas também de todos os países do mundo. Mais recentemente, a Universidade propôs um plano de ação de expansão do ensino de Direito em toda a Grã-Bretanha, com a inclusão de mais de oito mil alunos de graduação e dois mil alunos de Pós-Graduação, prevendo-se a construção de novas unidades e edificações (SLYCK \& AYRES, 1995).

No rol das disciplinas oferecidas, a faculdade prioriza algumas especialidades como, por exemplo, Direito Inglês, Leis Internacionais, Filosofia Legal e Criminologia. Nos centros de pesquisa, três se destacam dentro da faculdade: O Instituto Wolfson de Criminologia, o Centro de Pesquisa Internacional de Direito e o Centro Europeu de Estudos do Direito.

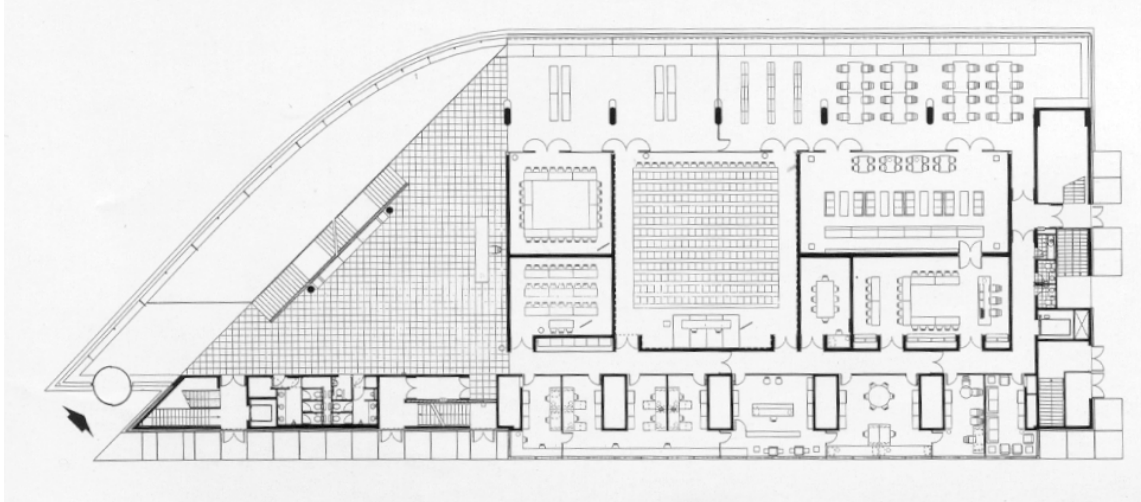

Figura 37 - Planta Pavimento Térreo/ Biblioteca de Direito Squire Fonte: www.fosterandpartners.com

No ano de 1990, a faculdade iniciou o processo de construção das novas unidades dos cursos de Direito e do Instituto de Criminologia numa área não muito grande, um terreno privilegiado do campus da universidade. Fazendo parte do complexo 
de construção da Faculdade de Direito, a biblioteca ganhou destaque, acomodando um centro de pesquisa e um grande acervo para alunos de graduação e pós-graduação.

Norman Foster trabalha o conceito de um edifício em estrutura metálica, explorando a dramaticidade dos ângulos irregulares, tanto no desenho da planta como na exterioridade das fachadas. O partido arquitetônico também tenta sair do modelo tradicional dos outros edifícios do campus universitário, em que a regularidade e monotonia fazem a sua principal marca. $\mathrm{O}$ arquiteto propõe algumas soluções bastante inovadoras como, por exemplo, utilizar alguns espaços enterrados (sub-solo) com atividades de grande concentração, que são as salas com mesas para leitura, salas de pesquisa e as salas administrativas. Já o pavimento térreo abriga atividades com grande concentração de pessoas: o auditório, o acervo de livros e as salas de pesquisa, e logicamente, a entrada principal da biblioteca, que todo o contexto do edifício (SLYCK \& AYRES, 1995).

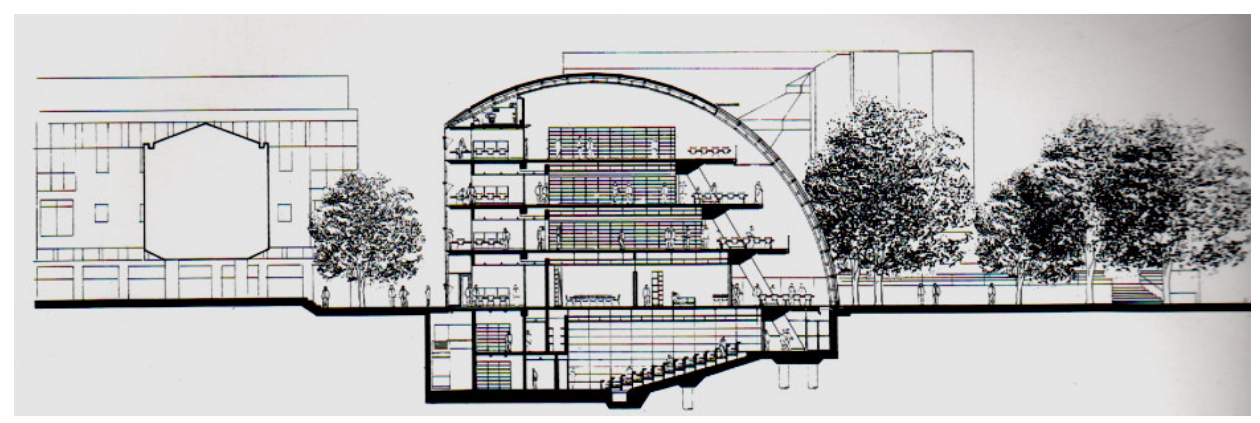

Figura 38 - Corte/Biblioteca de Direito Squire

Fonte: www.fosterandpartners.com

A luz natural é usada como efeito dramático em toda biblioteca. Este efeito é conseguido, uma grande fachada de vidro curva instalada em uma das faces que engloba todos os pavimentos. As áreas principais de estudo e pesquisa estão neste local, propiciando uma agradável visão aos usuários já que todos os jardins estão localizados nesta fachada. Outra função desse espaço é formar um microclima que se estende por a toda biblioteca, facilitando o conforto, a visibilidade e a integração dos planos dos ambientes.Os elementos das caixas de escada e de elevadores são executados em concreto armado, entretanto, todo o restante do edifício é executado em estrutura metálica com fechamento de vidro temperado. $\mathrm{O}$ desenho da estrutura metálica recebeu um formato triangular criado a partir de uma retícula modulada, proporcionando 
importante eficiência estrutural. Um fato que permitiu sua instalação rápida foi a modulação das peças metálicas e a pré-fabricação das mesmas.
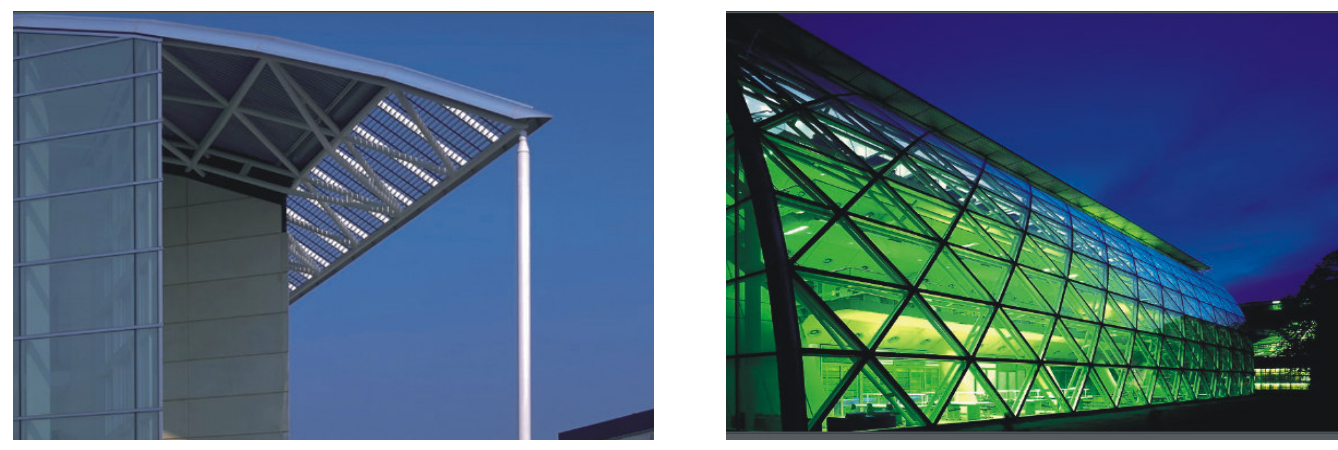

Figuras 39 e 40 - Vista Externa/Biblioteca de Direito Squire

Fonte: www.fosterandpartners.com
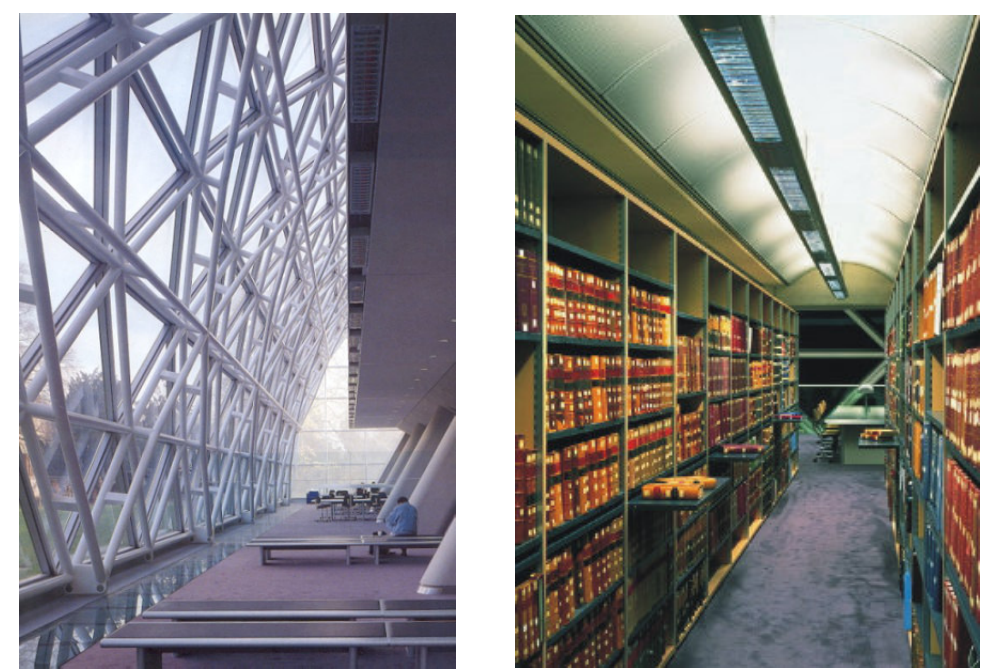

Figuras 41 e 42 - Vista Interna/Biblioteca de Direito Squire

Fonte: www.fosterandpartners.com

Como já foi dito anteriormente, a fachada norte recebeu uma "pele" de vidro curvo, com inclinações médias de 45 graus. Esta inclinação se deve principalmente aos valores mínimos calculados de entrada de luz natural nesses ambientes. Já na fachada sul do edifício, foi projetado um grande pano de vidro vertical, para compensar a falta de luz nesta orientação. Este sistema permite a abertura natural 
das janelas resolvendo principalmente o problema de ventilação natural (SLYCK \& AYRES, 1995).

A faculdade exigiu um edifício energeticamente eficiente e assim, o projeto analisou várias possibilidades de aproveitamento dos elementos naturais. Externamente, foram instaladas várias placas metálicas que captam a energia solar e são utilizadas no funcionamento diário da biblioteca. Agregados a esse pensamento de eficiência energética, o edifício conta com dois sistemas de ventilação: um natural e outro artificial. O segundo sistema é utilizado principalmente nos espaços fechados do auditório e salas do sub-solo. Com esse sistema de aproveitamento da ventilação e luz natural, foi possível minimizar os custos de manutenção do edifício. 
Quadro 05 - Biblioteca Nacional/Universitária Gottingen

\begin{tabular}{|c|c|c|c|c|}
\hline Projeto & \multicolumn{4}{|c|}{ Biblioteca Nacional/Universitária de Gottingen } \\
\hline Local & \multicolumn{2}{|c|}{ Gottingen, Alemanha } & $\begin{array}{l}\text { Ano de } \\
\text { construção }\end{array}$ & 1993 \\
\hline $\begin{array}{l}\text { Área } \\
\text { construída }\end{array}$ & $23.342 \mathrm{~m}^{2}$ & Arquiteto & Eckhard Gerber & \\
\hline
\end{tabular}

Com um acervo de quase meio milhão de livros e mais de vinte áreas de especialidades, a Biblioteca Nacional e Universitária de Gottingen é considerada a quinta maior biblioteca da Alemanha. Situada no centro da cidade, ela fica perto do Centro de Ciências Humanas da Universidade Georg August. Em termos de localização, a biblioteca se situa entre o Centro de Ciências Humanas da universidade e o centro da cidade, estando em posição de destaque em relação ao campus universitário. O edifício está divido em quatro grandes áreas: uma zona pública, destinada à pesquisa; uma área administrativa; uma área de armazenamento e serviços técnicos e área de estacionamento. A área pública e administrativa estão localizadas nos quatro primeiros pavimentos, enquanto o armazenamento e estacionamento no sub-solo do edifício. (LANG, 2001).

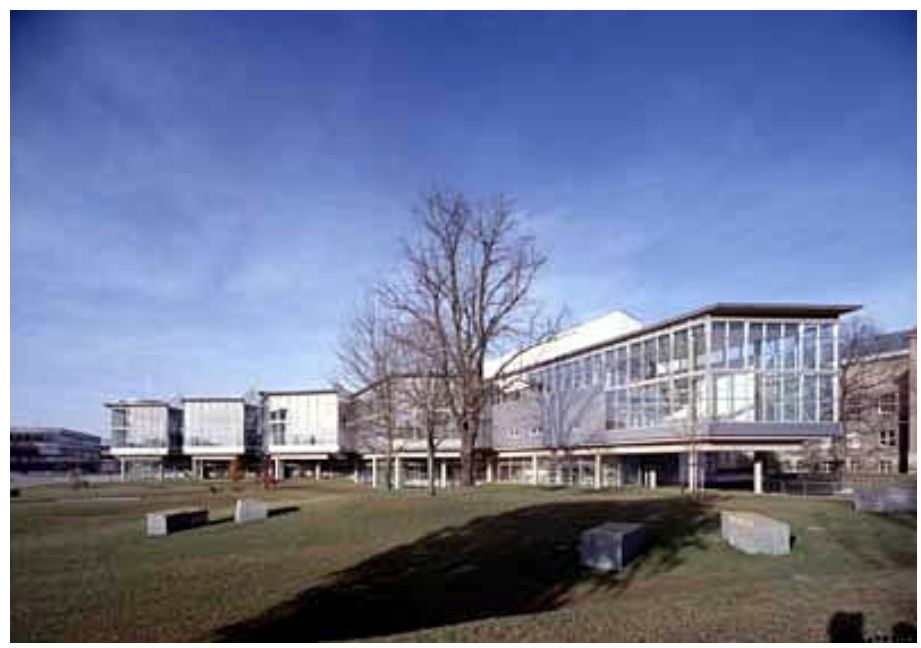

Figura 43 - Fachada Principal Biblioteca Nacional/Universitária Gottingen Fonte: www.gerberarchitekten.de 
$\mathrm{O}$ edifício é executado em estrutura metálica e concreto armado. O resultado é bastante simples e contido, principalmente na aparência dos materiais e cores. A estrutura aparente de concreto, com ênfase nos pilares, reforça este lado singelo dos materiais. Ao contrário do exterior, em que a estrutura de aço traz um componente brilhante e colorido, graças aos elementos presentes em contato com a luz solar. Vale lembrar que a escolha de materiais como o aço, vidro e concreto aparente reflete uma linguagem contemporânea da construção, ou seja, manifesta o conceito de apropriação na utilização de materiais que incorporam o conceito das novas tecnologias na construção. Essa mesma idéia é encontrada na solução do telhado da biblioteca, com um material metálico de alta tecnologia (LANG, 2001).

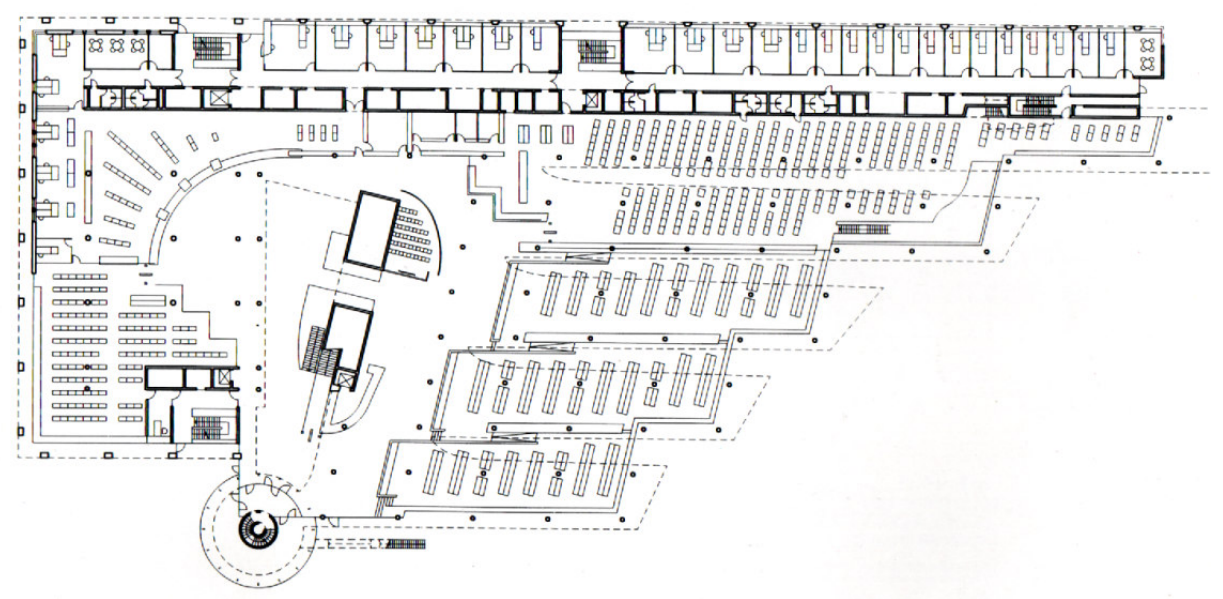

Figura 44 - Planta Térro/ Biblioteca Nacional/Universitária Gottingen Fonte: www.gerberarchitekten.de
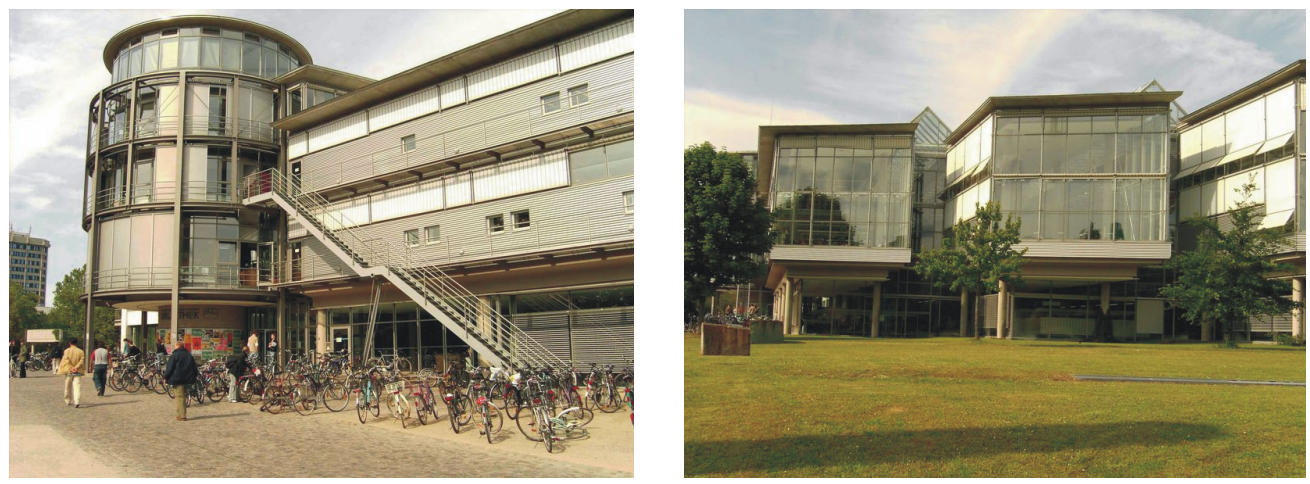

Figuras 45 e 46 - Vista Externa/ Biblioteca Nacional/Universitária Gottingen Fonte: www.gerberarchitekten.de 
Um elemento prismático de vidro marca a entrada principal da biblioteca, propiciando que o hall receba uma grande quantidade de luz natural. A transparência e a escala desse elemento prismático ajudam na orientação e no acesso dos usuários aos ambientes de pesquisa, leitura e busca no acervo de livros. O teto suspenso é branco e os elementos metálicos que o sustentam são coloridos, provocando um contraste bastante interessante. Assim, os elementos referenciais que orientam o acesso dos usuários aos espaços da biblioteca são elevados ao seu grau máximo de dramaticidade, utilizando-se para isso, cores e materiais não convencionais.
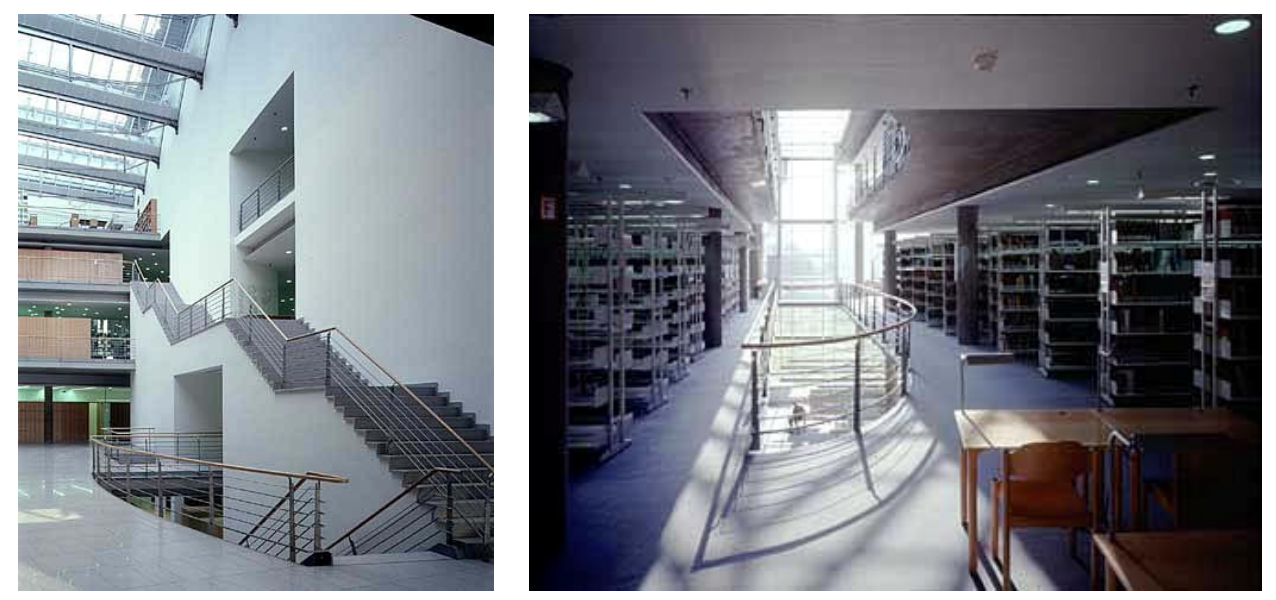

Figuras 47 e 48 - Vista Interna/ Biblioteca Nacional/Universitária Gottingen Fonte: www.gerberarchitekten.de

O setor administrativo está disposto uniformemente nos quatros níveis e os serviços ao público, no terceiro pavimento. Todas as áreas que prevêem o atendimento direto ao usuário, como consulta ao acervo e pesquisa de material bibliográfico, estão localizadas em um local de bastante iluminação natural. Com isso, o ambiente se torna bastante agradável para qualquer atividade desenvolvida na biblioteca. As áreas que se localizam na face norte do edifício são usadas para atividades que exigem concentração, como leitura e pesquisa (LANG, 2001). 
Quadro 06 - Biblioteca Uned

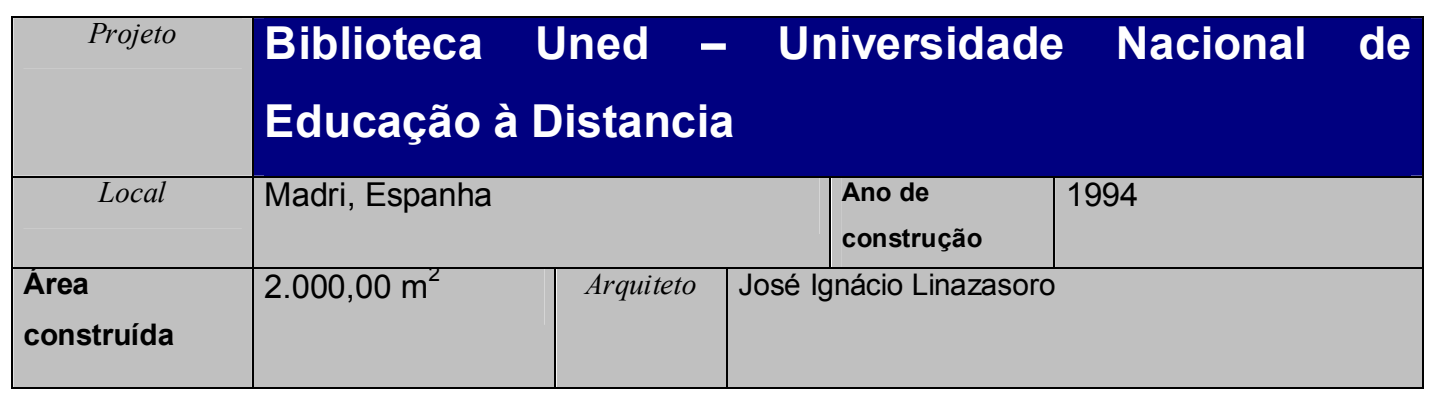

A Universidade Nacional de Educação à Distancia - Uned - localizada na Espanha, é uma das instituições superiores pioneiras neste tipo de ensino a distancia praticado não só na Europa, mas em todo o resto do mundo. O projeto da biblioteca pertence ao campus da Uned e localiza-se ao lado do Rio Manzanares na cidade de Madri.

Como conseqüência do programa e considerando as características do terreno, o arquiteto optou por uma solução estrutural modular racional e simplificada. Essa modularidade por ser notada na distribuição interna dos pilares, que se alinham numa interessante seqüência rítmica, repetida em todos os sete pavimentos do edifício. Por outro lado, como contraponto a essa racionalidade, a biblioteca é revestida de tijolo cerâmico ao longo de todas as fachadas, reservando, somente ao lado Oeste, pequenas aberturas de janelas que quebram o aspecto severo da volumetria do conjunto. Com isso, consegue-se um surpreendente contraste entre o espaço externo e o interno, mais introspectivo nas salas de pesquisa da Biblioteca (BRAWNE, 1997).

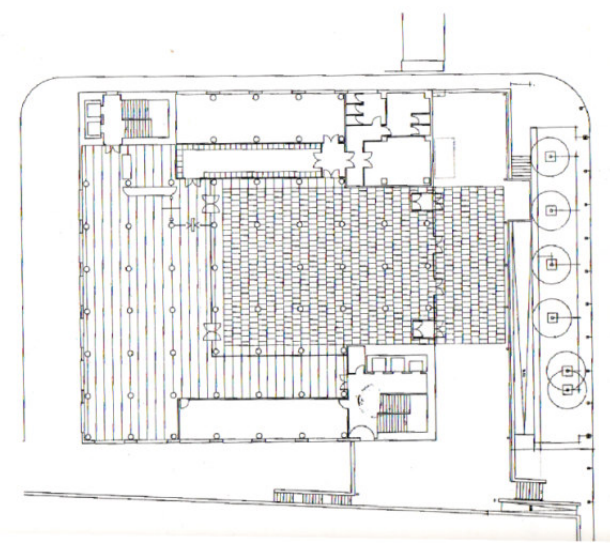

Figura 49 - Planta/Biblioteca Uned Fonte: BRAWNE, 1997 
Ao entrar no edifício, o usuário se depara com um hall de dimensões bastante generosas, reforçando elementos de visibilidade, imponência e luminosidade. Ao mesmo tempo em que o partido arquitetônico trabalha esses conceitos de monumentalidade, o hall de entrada tem um resultado formal bastante acolhedor, dado principalmente ao revestimento de madeira aplicado às paredes (BRAWNE, 1997). Todo o controle de entrada de pessoas, empréstimo de livros e informações é executado nesse espaço. Bem ao centro da biblioteca, um grande conjunto de elementos prismáticos filtra a entrada da luz natural até o interior de todos os pavimentos do edifício. Esses elementos também têm a função de permitir a entrada de ventilação natural ao longo de todos os espaços que estão em torno deste átrio central. Como foi mostrado anteriormente, o arquiteto também optou por utilizar forro de madeira em toda a cobertura do átrio, criando assim um interessante ambiente de cores e texturas de atmosfera aconchegante. Nesse mesmo raciocínio, o projeto contempla o conjunto de mobiliários e prateleiras com revestimentos de madeira. A circulação lateral da biblioteca é feita facilmente por um conjunto de dois blocos de escadas e elevadores que estão alocados nas laterais opostas do edifício. Esse mecanismo facilita o acesso a todos os pavimentos e espaços do edifício, já que desvia e direciona todo o fluxo de serviço da biblioteca para essa área.
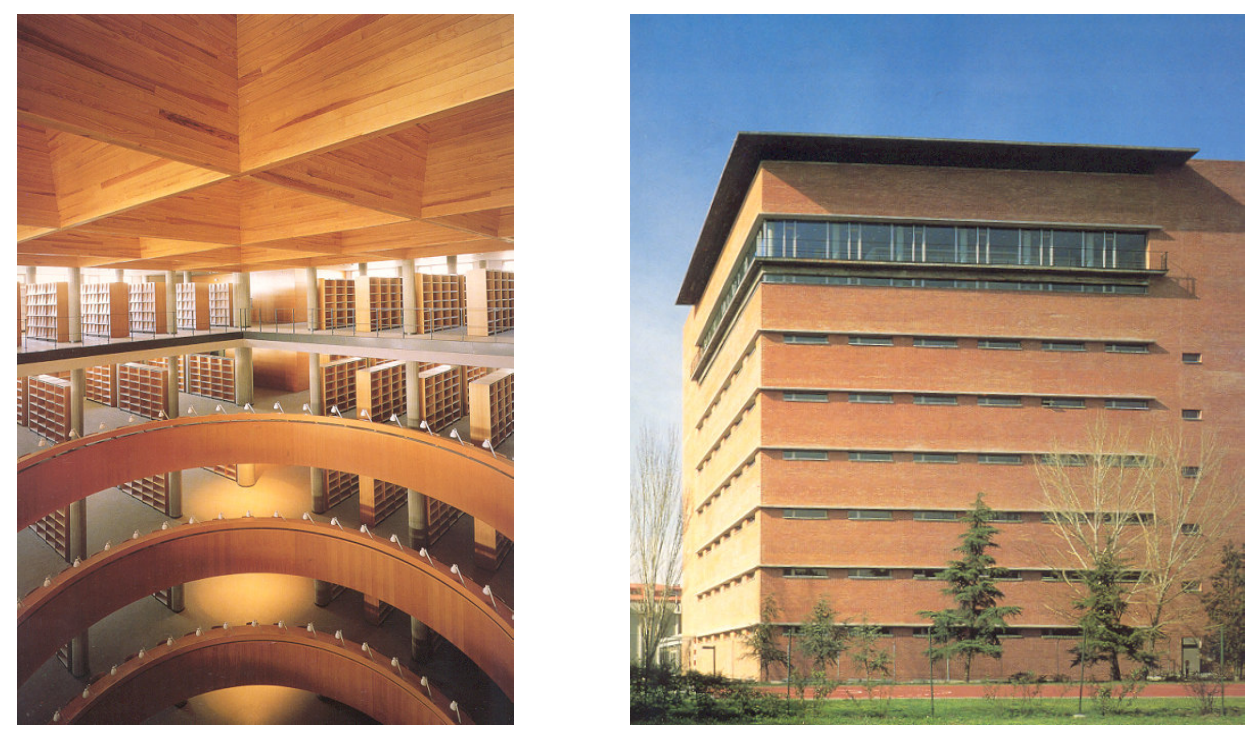

Figuras 50 e 51 - Vista Interna e Externa/ Biblioteca Uned Fonte: BRAWNE, 1997

O projeto da biblioteca da Uned consegue reunir e resolver alguns importantes elementos no âmbito da arquitetura de bibliotecas: explora a expressão da 
luz natural como elemento capaz de valorizar os espaços naturais em todas as suas potencialidades; requalifica o espaço pela reorganização geométrica do círculo e do quadrado instalados entre os pavimentos da edificação; e, finalmente, consegue dar uma resposta coerente para a utilização da modulação dos elementos estruturais, estabelecendo relação positiva entre a funcionalidade espacial das salas da biblioteca e a rígida formalidade da edificação (BRAWNE, 1997). 
Quadro 07 - Biblioteca Learning Resouces Centre

\begin{tabular}{|c|c|c|c|c|}
\hline Projeto & \multicolumn{2}{|c|}{$\begin{array}{l}\text { Biblioteca Learning } \\
\text { Valley University }\end{array}$} & Resouces & ntre - Thames \\
\hline Local & Slough, Inglaterra & & $\begin{array}{l}\text { Ano de } \\
\text { construção }\end{array}$ & 1994 \\
\hline $\begin{array}{l}\text { Area } \\
\text { construída }\end{array}$ & $3.500,00 \mathrm{~m}^{2}$ & Arquiteto & Richard Rogers & \\
\hline
\end{tabular}

A biblioteca do Learning Resouces Centre está localizada no campus da Universidade de Thames Valley, em Stough, Inglaterra, e destaca-se no conjunto das edificações do campus universitário como um projeto inovador e diferenciado em relação aos outros edifícios existentes. Para o projeto do edifício da nova biblioteca do Learning Resouces, o arquiteto Richard Rogers procurou estabelecer harmonia com os prédios vizinhos e com o entorno, rico em histórias e simbolismos. Partindo desse princípio, procurou-se identificar uma área que pudesse conter as condições mínimas de paisagismo e infra-estrutura, incluindo áreas de estacionamento, acessos de veículos e pessoas e possibilidades de aumento na área de construção. Esses condicionantes exigiram da arquitetura uma resposta criativa, audaciosa e uma escala relativamente reduzida.
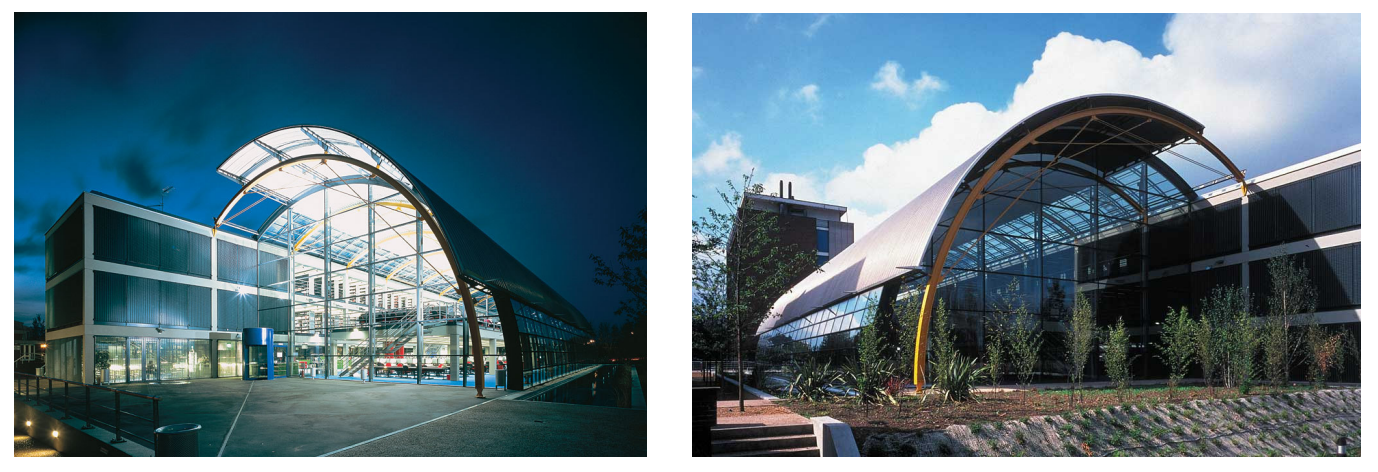

Figuras 52 e 53 - Vista Externa/Biblioteca Learning Resouces Centre

Fonte: www.rsh-p.com

Em termos formais, o partido arquitetônico tem uma linguagem bastante simples e equilibrada, dividindo o conjunto dos volumes em dois grandes blocos. $\mathrm{O}$ primeiro, um grande volume retangular de concreto de três pavimentos, abrigando o centro de bases de dados e salas administrativas, e o segundo bloco, uma grande 
cobertura metálica curvada destinada ás áreas de pesquisa e leitura da biblioteca. $\mathrm{O}$ acesso principal dos usuários, que leva ao balcão de atendimento e recepção, passa necessariamente por essa grande cobertura curva e leva o visitante a contemplar um magnífico jogo espacial de volumes, cores e formas. Na visão do arquiteto, como todo o produto principal da biblioteca é a informação e o conhecimento, esses elementos devem receber atenção especial em relação a sua apresentação, seu formato e sua disponibilidade informacional no contexto do espaço. Ou seja, como acontece no interior dessa grande cobertura curva, o acesso ao acervo deve ser livre, ou seja, não deve conter barreiras físicas (BROWN, 2002).

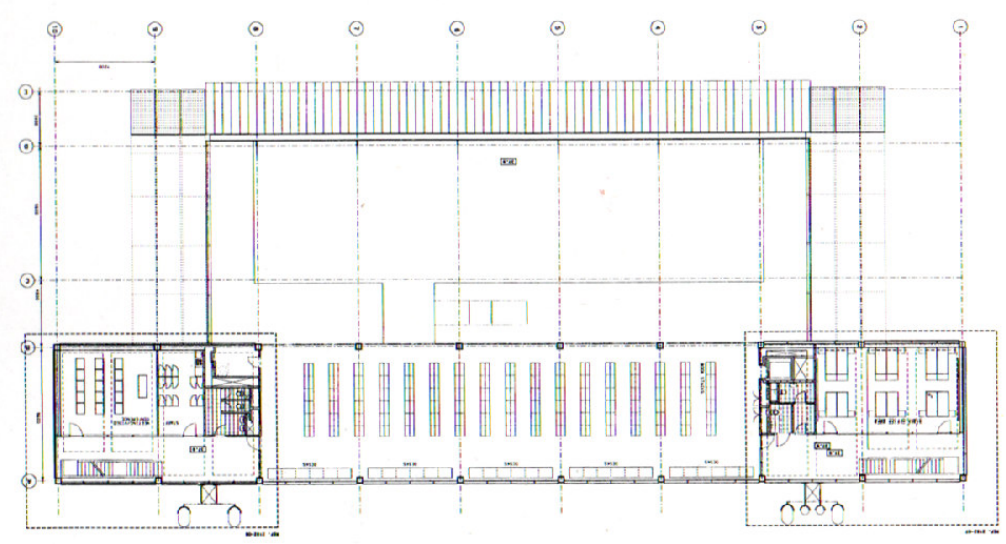

Figura 54 - Planta/Biblioteca Learning Resouces Centre

Fonte: www.rsh-p.com

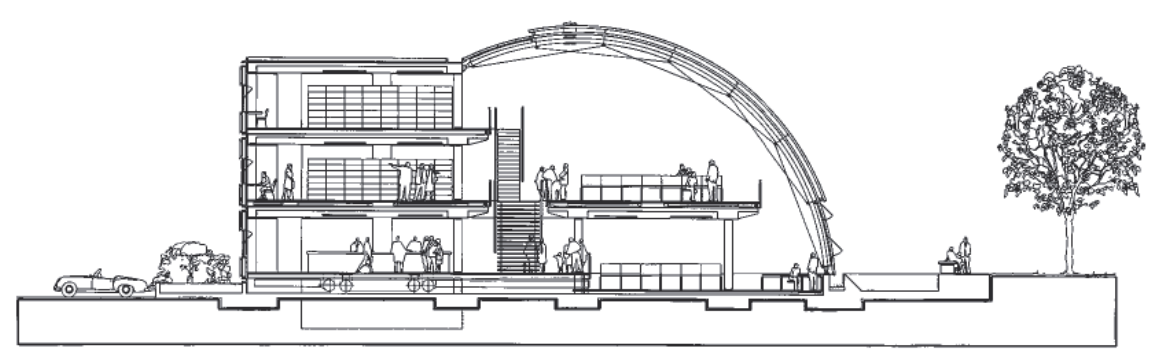

Figura 55 - Corte/Biblioteca Learning Resouces Centre

Fonte: www.rsh-p.com 

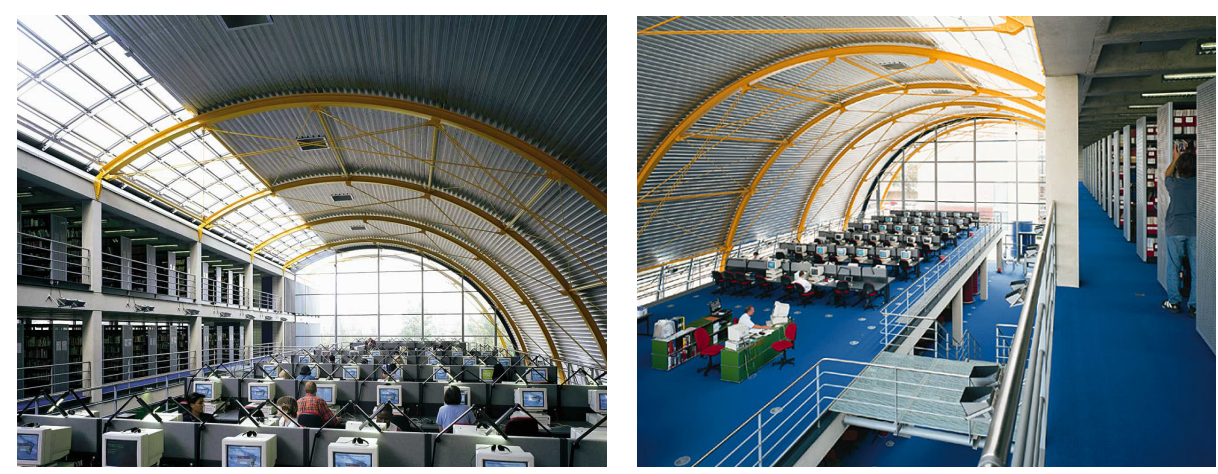

Figuras 56 e 57 - Vista Interna/Biblioteca Learning Resouces Centre

Fonte: www.rsh-p.com

Como o ambiente da biblioteca necessita de boas condições térmicas para que o usuário possa sentir-se disposto a desenvolver suas atividades, o edifício foi especialmente projetado para receber ventilação natural em todos os seus espaços, respondendo ao objetivo principal de minimizar as condições de desconforto ambiental. Nesse caso, a temperatura e a umidade do ar são controladas, principalmente, nas áreas reservadas ao acervo de livros e materiais técnico, e nas salas destinadas a receber um número grande de pessoas, como as salas de pesquisa, leitura e consulta às bases de dados da internet. A biblioteca também conta com um sistema mecânico auxiliar de ventilação em casos de grande necessidade.

Richard Rogers tem o mérito de evidenciar um importante contraste na escolha do tipo de sistema construtivo utilizado na biblioteca. De um lado, o bloco retangular bastante rígido e racional, utiliza o sistema tradicional de concreto armado e, de outro lado, uma cobertura com um desenho curvo, expressando liberdade, é construído em estrutura metálica transparente. Este dualismo constitui um importante componente qualitativo e estético que passou fazer parte do conjunto da paisagem espacial do campus universitário. Portanto, é possível afirmar que o projeto procura sublinhar as diferentes partes do complexo de edificações existentes do campus, tentando mais separar do que unir as distintas linguagens arquitetônicas (BROWN, 2002). 
Quadro 08 - Biblioteca John J Ross, Willian Blakelly

\begin{tabular}{|c|c|c|c|c|c|c|}
\hline Projeto & $\begin{array}{l}\text { Bibliotec } \\
\text { Universic }\end{array}$ & $\begin{array}{l}\text { Ohn } \\
\text { Estad }\end{array}$ & & $\begin{array}{l}\text { Ross, WH } \\
\text { o Arizona }\end{array}$ & an & Blakelly \\
\hline Local & Tempe, Estac & & & $\begin{array}{l}\text { Ano de } \\
\text { construção }\end{array}$ & 1993 & \\
\hline $\begin{array}{l}\text { Area } \\
\text { construída }\end{array}$ & $7.875,00 \mathrm{~m}^{2}$ & Arquiteto & & yin, Elam \& Bray & & \\
\hline
\end{tabular}

A Biblioteca da Arizona State University é uma das mais respeitadas na área do Direito, contando com um acervo de mais de 3.200.000 volumes em suas estantes. A coleção inclui ainda uma vasta seleção de estudos de casos anglo-saxônicos, bem como acordos legais, periódicos, enciclopédias, sumários, citações e materiais administrativos. O acer'vo cresceu muito principalmente na área do Direito Internacional nestes últimos anos (WARD, 1994).

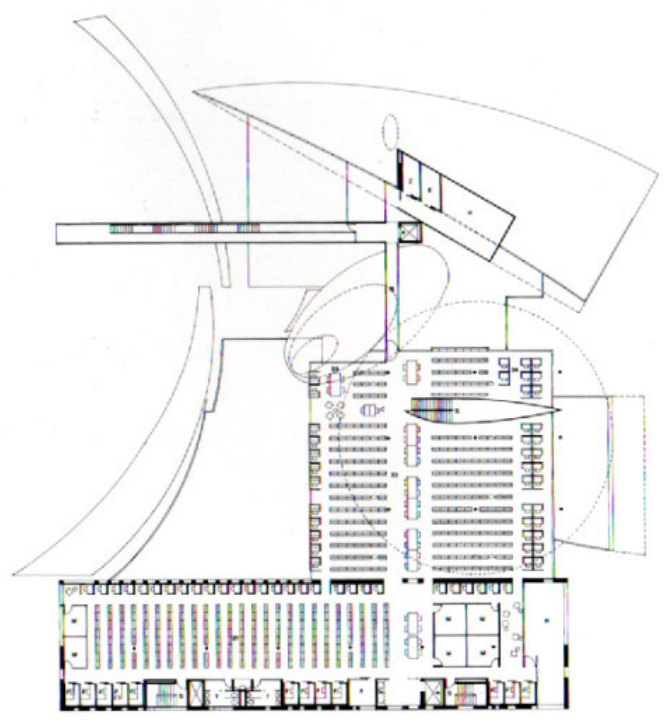

Figura 58 - Planta/Biblioteca John J Ross, Willian Blakelly

Fonte: www.msmearch.com

O local onde a Biblioteca está instalada está próximo a uma encosta do campus da Arizona State University e possui um entorno bastante interessante. A multiplicidade do contexto, contida na vegetação, no desenho sinuoso da encosta e na posição estratégica dos outros edifícios, direciona o partido do projeto. As formas 
geométricas dinâmicas da nova da Biblioteca de Direito refletem a idéia de estabelecer contrastes e movimentos em relação aos prédios existentes, estabelecendo-se uma relação dinâmica entre formas, espaços, cores e texturas.
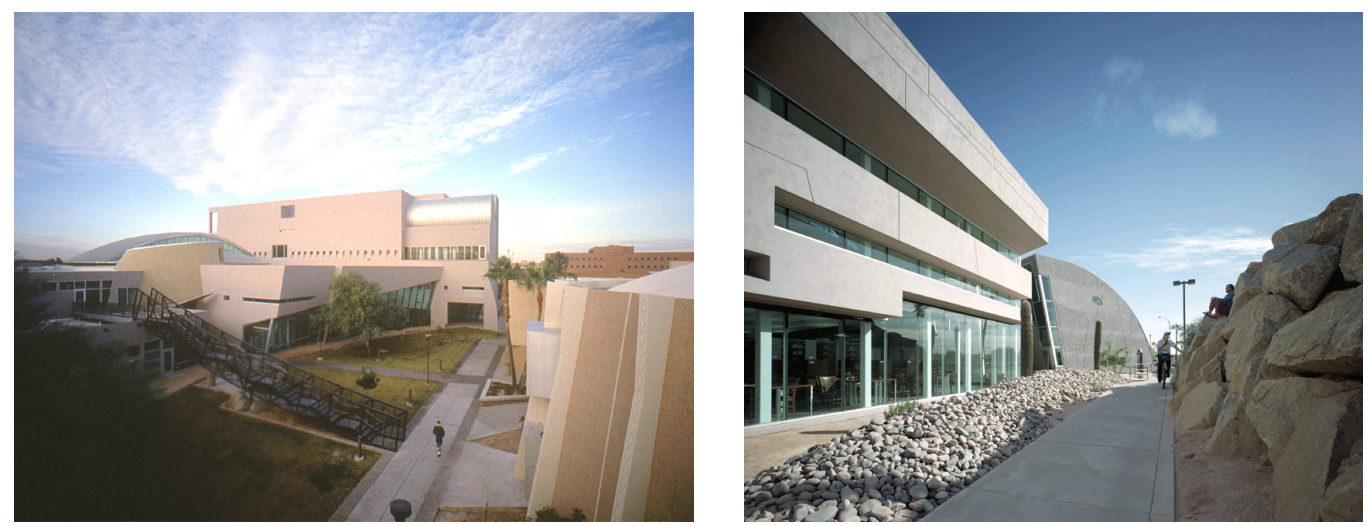

Figuras 59 e 60 - Vista Externa/Biblioteca John J Ross, Willian Blakelly

Fonte: www.msmearch.com
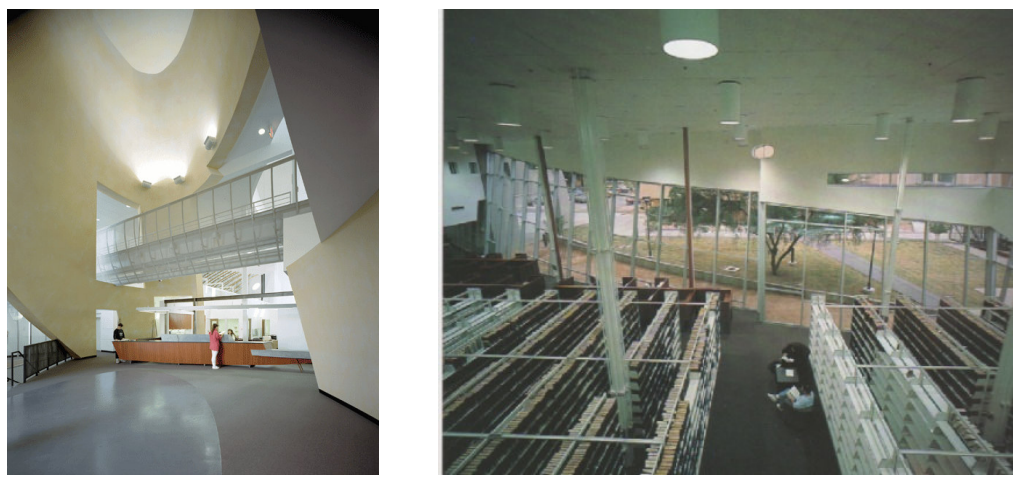

Figuras 61 e 62 - Vista Interna/Biblioteca John J Ross, Willian Blakelly

Fonte: www.msmearch.com

A praça, que está entre a biblioteca e os outros edifícios do conjunto da Faculdade de Direito, funciona como um "oásis no deserto", principalmente na sua função de ponto de encontro e pólo de atração para as atividades sociais.

Em termos espaciais, o prédio da biblioteca é todo esquematizado para valorizar cada elemento volumétrico com suas respectivas funções, ou seja, serviços técnicos, circulações, salas de leitura e pesquisa e acervo da biblioteca possuem fácil 
identificação volumétrica. Esse jogo de formas que se articulam a todo instante, cria um ambiente rico e heterogêneo na dinâmica do espaço.

Por meio do acesso lateral da biblioteca é possível chegar ao acervo principal e nas salas de pesquisa e leitura. Nesta área também está localizado um espaço para mais de 30 terminais de computadores que dão acesso às principais bases de dados bibliográficos da área do Direito, e, ainda, Podemos ter ainda o acesso às salas de reuniões, de micro-filmagem e de estudo.

Ward (1994) conclui que a estrutura do edifício é feita em aço e as fundações, em concreto armado. Suas fachadas alternam placas de revestimento de alumínio, elementos metálicos e vidros temperados, concedendo-lhe um aspecto bastante contemporâneo e futurista

\subsubsection{Aspectos Organizacionais}

Como se viu anteriormente, as bibliotecas universitárias internacionais estudadas, independente da área de conhecimento científico atendido, destinam-se a fornecer aos usuários dois grandes setores - referencial e cultural (LEMOS \& MACEDO, 2001), funcionando como elementos balizadores das atividades desenvolvidas, em relação aos dois quesitos básicos:

- Primeiro, os edifícios de bibliotecas têm sido capazes de garantir a crescente necessidade de disponibilização e centralização da informação, permitindo que ela chegue rápida, confiável e eficaz àqueles que dela necessitam. Enfatiza-se que a presença da informação, em todos os setores da sociedade, tem sido registrada e apresentada como uma realidade concreta e necessária (GREEN, 1993; BERNHARD, \& BRETON, 1994; CARVALHO, 1998; ALPHEN, F, 1998; CUNHA, 2007).

- $\quad$ Segundo, as principais bibliotecas universitárias têm construído espaços de socialização no contexto de interações/inter-relações pessoais, ambientais, informacionais, culturais e comunicações. Dessa forma, os usuários têm acesso permitido à informação e à cultura, possibilitandolhes a apropriação da instituição biblioteca, seus produtos e serviços como um todo. Para tanto, a diversidade cultural, em seus variados 
aspectos sócio-econômicos, geográficos, de faixa etária, de linguagem e de mídias tem norteado a construção não só física, mas também a organização das ações cotidianas da biblioteca universitária (TOH, 1995; COOKE, 2001; GOMES, 2001; RIBENBOIM, 2001).

Diante desses elementos, é possível reconhecer e esboçar dois esquemas de atividades presentes nas bibliotecas universitárias analisadas:

Quadro 09 - Função do Setor Referencial das bibliotecas universitárias

Atividades referenciais: fornecem informação referencial organizada e sistematizada a usuários pessoais ou institucionais, altamente especializados nas áreas atendidas; proporciona assistência direta a esses usuários, a fim de responder questões informacionais relevantes para o avanço das áreas do conhecimento (CARVALHO, 1998).

\begin{tabular}{|l|l|}
\hline \multicolumn{2}{|c|}{ Função } \\
\hline \\
Reduzem os obstáculos ao acesso às informações existentes nas áreas de \\
conhecimento. \\
Reúnem de forma estratégica, informações necessárias nas diversas áreas \\
do conhecimento. \\
$\begin{array}{l}\text { Realizam um amplo e apurado processo de disseminação seletiva da } \\
\text { informação no âmbito da pesquisa nas diversas áreas do conhecimento. }\end{array}$ \\
\hline
\end{tabular}

Quadro 10 - Função do Setor Referencial das bibliotecas universitárias

Atividades culturais: Este item deve ser entendido como um suporte que facilita, promove e dá continuidade às atividades culturais e informacionais das diversas áreas do conhecimento (COOKE, 2001).

\begin{tabular}{|c|}
\hline Função \\
\hline Promovem e incentivam a disposição de atividades culturais. \\
\hline $\begin{array}{l}\text { Mantêm contato com entidades e órgãos afins, colaborando no intercâmbio } \\
\text { cultural e geração de produtos e serviços informacionais para o grande público. }\end{array}$ \\
\hline $\begin{array}{l}\text { Proporcionam a disponibilidade de espaços e áreas para atividades } \\
\text { culturais, com intuito de divulgar, preservar e desenvolver a cultura. }\end{array}$ \\
\hline
\end{tabular}

Os setores referenciais das bibliotecas universitárias estudadas têm disponibilizado informação primária, estratégica, a um público-alvo específico; e, por outro lado, o setor cultural destes edifícios tem funcionado como pólo gerador de 
atividades culturais e criativas no ambiente informacional das universidades. Enquanto o setor referencial agrega um público especializado nas áreas de conhecimento específico, o setor cultural tem promovido uma gama de atividades culturais, no âmbito da informação, para um grupo de usuários bem mais amplo e diversificado, tanto de comunidades locais universitárias quanto de áreas correlatas e do público em geral. Esta divisão técnica dos setores, entretanto, não tem invalidado o caráter qualitativo dos serviços oferecidos, facilidades informacionais oferecidas pelas atividades de disseminar informação nas áreas de conhecimento atendidas, seja pelo serviço de referência ou pelas atividades culturais planejadas, configuram a preocupação primeira no atendimento ao usuário.

Ficou também comprovado que as bibliotecas universitárias que demandam grandes investimentos físico-financeiros em espaços destinados a receber informações e dados referenciais "on line", com equipamentos computacionais de última geração e ambientes arquitetônicos devidamente adaptados às novas tecnologias informacionais, representam interface entre a informação disponibilizada e o usuário especializado. Tal quadro mostra a importância desses serviços, enquanto elementos fundamentais na prestação de serviços ao público da biblioteca universitária. Em relação a isso, cabe listar uma série de vantagens no envolvimento entre a relação equilibrada dos espaços das bibliotecas universitárias analisadas e a informação referencial (BAZILLIO; RICHARD; CONNIE, 2001).

a. Suprem as demandas e as necessidades inerentes à pesquisa e à informação de pesquisadores universitários, no que diz respeito ao suporte e ao conteúdo informacional adequado ao usuário;

b. Provêm eficazmente o público-alvo com serviços de informação e de apoio à pesquisa;

c. Disponibilizam dados, informações e produtos informacionais atualizados;

d. Fomentam a divulgação e a transferência de conhecimentos;

e. Promovem o contínuo intercâmbio com outras entidades de pesquisa, ensino e tecnologia das áreas de conhecimento;

f. Coletam dados sobre fontes de informação científica e tecnológica em todas as áreas do conhecimento, tornando-os disponíveis a pessoas e 
instituições que deles necessitem para desempenhar sua competência científica e tecnológica.

g. Implantam serviços e geram produtos informacionais, promovendo a disseminação seletiva da informação para o público-alvo.

Quanto aos aspectos relacionados ao oferecimento de atividades culturais, vislumbrados nas bibliotecas universitárias analisadas, constatou-se importante tendência mundial em disponibilizar em serviços, principalmente em grandes centros universitários localizados nas grandes cidades e capitais. Apesar de a análise espacial e arquitetônica ser tratada apenas nos próximos tópicos, cabe lembrar que os espaços direcionados ao desenvolvimento das atividades culturais nas bibliotecas analisadas, geralmente priorizam facilidade de acesso ao público e formatam ambientes abertos e fluidos, em que as divisões espaciais se dão por elementos flexíveis ou mesmo pelo próprio mobiliário das salas (COOKE, 2001).

Em relação a esses serviços, verifica-se que:

1. Reforçam as atividades culturais produzidas nas universidades como instrumentos de integração entre as diversas áreas do conhecimento científico e a sociedade;

2. Contribuem para o fortalecimento da identidade cultural das unidades universitárias pelo estímulo e a divulgação de diferentes formas de expressão artística local, regional, nacional e internacional;

3. Oferecem espaço para a difusão das manifestações culturais relacionadas, cooperando na formação ampla dos usuários das universidades, propiciando-lhes uma melhor qualidade de vida por meio da informação e do conhecimento;

4. Democratizam o acesso à informação e à cultura e dão apoio às produções experimentais correlatas, fora do circuito comercial.

5. E, finalmente, em alguns casos, foi verificado que os setores culturais das bibliotecas universitárias analisadas realizam parcerias com empresas e/ou instituições públicas e privadas para o desenvolvimento e a implementação de projetos nas áreas de cultura, ciência, tecnologia, educação, cultura e marketing, sejam de âmbito interno ou de extensão. 


\subsubsection{Aspectos Arquitetônicos}

A segunda aproximação refere-se à análise dos projetos das bibliotecas

universitárias internacionais em termos arquitetônicos, visando a compreender a finalidade principal desses espaços e as atividades relacionadas ao ambiente espacial. Vale destacar que as mudanças ocorridas no âmbito das universidades provocaram possíveis reflexos em suas bibliotecas, pois se considera que estes edifícios devem estar inseridos em um contexto maior (WEHRPLOTZ, CANDIDO, BONO, 2001; MORIS, 2006).

Pelos resultados analisados em relação às diretrizes arquitetônicas dos edifícios de bibliotecas universitárias no contexto internacional, foram obtidos os seguintes tópicos de análise:

\section{- Quanto ao partido arquitetônico}

$\mathrm{Na}$ maioria dos casos analisados, o partido arquitetônico adotado apresenta a informação como elemento gerador dos espaços e dos ambientes utilizados, ou seja, o local estava apto a desenvolver as funções estratégicas de disseminação da informação (referenciais ou culturais). O desdobramento dos elementos geradores espaciais, presentes na delimitação dos ambientes, reforça o sentido da versatilidade da ocupação dos espaços. Ou seja, alia a definição espacial do ambiente ao caráter fundamental de transformação social da informação. Nesta visão, os espaços obedecem principalmente a uma visão de movimento e rotação das formas, tanto nas áreas bidimensionais da planta baixa como no repertório tridimensional dos volumes. A metáfora da informação, apresentada como interativa e transformadora no âmbito da sociedade, é reforçada pela fluidez dos espaços propostos e pela estruturação dos significados da intervenção arquitetônica. É justamente nestes espaços que se apresentam as atividades principais ligadas ao contexto dos produtos informacionais e culturais dos edifícios das bibliotecas universitárias. As zonas e os ambientes onde são desenvolvidas as atividades programadas geralmente permeiam a idéia de "não parede", possibilitando de transparência e flexibilidade em todo o contexto espacial. Por esta razão, todas as ações concentradas de atendimento ao público, que englobem o fornecimento e a prestação de serviço de informação, ficam vinculadas a estes grandes espaços. Ou seja, a definição dos projetos dessas bibliotecas parte da constatação de que 
a transparência dos elementos construtivos, a fluidez do espaço e a fixação de volumes dinâmicos, atrelados sempre a uma metáfora de um vocabulário informacional espacial, garantem o significado formal do partido arquitetônico.

Outro importante elemento estudado em relação ao partido arquitetônico presente em muitas das bibliotecas universitárias analisadas relaciona-se ao significado lúdico da disposição das grandes aberturas de janelas e nos panos de vidro presentes nos edifícios. Além de fazer cumprir a função de iluminação e ventilação dos espaços, este sistema permite estabelecer uma relação entre o espaço interno e o espaço externo das bibliotecas. Este simbolismo ganha explicação no contexto do partido arquitetônico, quando se compreende a informação como elemento gerador de transformação da sociedade; portanto, sob a ótica, o edifício simboliza o intercâmbio e a penetração que a informação deve desempenhar no âmbito da sociedade e, principalmente, seu significado junto às áreas do conhecimento científico. Desta forma, a transparência e os vãos nas grandes áreas de janelas formalizam este significado e materializam-no em forma de construção.

A preocupação de se manter uma característica permeável no projeto arquitetônico, reforçando os vínculos entre informação e cultura no contexto e nos locais onde se inserem, marca os principais caminhos do partido arquitetônico das bibliotecas universitárias estudadas. A leitura dessas diretrizes é conseguida a partir da universalidade das formas arquitetônicas primárias (cubos, retângulos, pirâmides), a ortogonalidade dos planos geométricos e a utilização de elementos visuais de fácil apreensão por parte do usuário. Desta maneira, o conjunto dos edifícios permite uma completa integração entre forma e função, ou seja, estabelece a função essencial de disseminar a informação, moldada dentro de uma forma específica para tal função.

\section{- Quanto ao programa arquitetônico}

Observou-se que no caso das bibliotecas universitárias internacionais, o grau de complexidade da definição do programa arquitetônico dos espaços direciona-se em dois sentidos básicos:

1. Espaços destinados às informações referenciais e mais específicas, proporcionando consultas, em local adequado, próprio e devidamente equipado para o ato da leitura, o estudo e a pesquisa; 
2. Locais direcionados a promover atividades culturais e disseminação do conhecimento das áreas específicas.

Esses indicadores aqui apresentados reforçam a vocação intrínseca desses dois grandes setores abrigados nas bibliotecas universitárias analisadas: setores referenciais, que disponibilizam informação primária, estratégica, confiável e precisa às áreas atendidas e os setores culturais, que promovem um leque de atividades culturais, no âmbito da informação, a um grupo de usuários bem mais amplo e diversificado, principalmente ao público em geral. Em vista disso, o programa arquitetônico desses edifícios parte da premissa de poder trabalhar prioritariamente os dois setores em que espaço e função se articulam com os setores técnicos e administrativos. Essa estruturação setorial colabora decisivamente na distribuição dos elementos do programa e no agrupamento das atividades desenvolvidas.

O programa arquitetônico dos espaços foi balizado por alguns elementos básicos: primeiramente, definiu-se o posicionamento dos ambientes dos setores culturais por razões óbvias, próximos às áreas de grande fluxo de usuários e visitantes, sendo sempre organizados de maneira nítida e aberta. Essa estratégia é encontrada também nos setores administrativos e de serviços, formalizando a importância logística de apoio e suporte aos outros setores da biblioteca universitária. Evidentemente que esses espaços se integram aos setores culturais de forma mais restritiva, estabelecendo por vezes separação física, ou mesmo utilizando o conceito de conexão por halls, pátios internos, áreas de convívio, escadas, divisórias, etc.

Os setores referenciais, definidos nas bibliotecas universitárias como espaços de atendimento às classes de usuários mais especializadas, ganharam localizações mais especiais. Essa decisão se deve principalmente à priorização de uma zona mais restrita ao grande público, garantindo ao usuário destes setores maior privacidade nas ações ali executadas. De qualquer forma, a privacidade dos setores permite ao usuário uma atuação tranqüila e satisfatória na busca e na manipulação de informação específica. Entretanto, mesmo tendo essa tipologia "fechada", a integração com os outros setores descritos anteriormente, tanto dos fluxos de visitantes e usuários normais quanto de funcionários, fica extremamente facilitada (CARVALHO, 1998). 
- Quanto à descrição espacial dos ambientes analisados

Destacam-se, neste item, as pertinentes considerações à descrição espacial dos principais ambientes das bibliotecas universitárias analisadas, obtidas pelo mapeamento das condições em que foram definidas as prioridades de atendimento aos usuários, suas necessidades e seus usos mais previsíveis.

No caso dos ambientes ligados às atividades culturais, o processo de apropriação espacial se dá de forma direta, envolvendo elementos lúdicos em todos os ambientes projetados. Esse sistema interativo entre o usuário e o espaço reforça a presença de elementos volumétrico-espaciais com o objetivo de afetar diretamente os sentidos do tato, do olfato e da visão do visitante, lançando mão das novas tecnologias de comunicação e computação. A proposta é criar um espaço cenográfico e lúdico, em que o usuário não somente "visite" os acervos e as atividades culturais, mas também "participe" dos ambientes, envolvido em uma "aura" cultural. Essa visão interativa e participativa, direcionada aos espaços dos setores culturais, ressalta o significado estratégico que a informação pode desempenhar nas várias áreas do conhecimento científico da biblioteca universitária (COOKE, 2001).

Dos exemplos analisados, principalmente dos edifícios com grandes dimensões espaciais, o posicionamento do hall de entrada desempenha papel fundamental no contexto da biblioteca.Geralmente ele prioriza boa acessibilidade aos espaços, com grandes panos de vidros e estabelece a não existência de barreiras visuais e arquitetônicas, dando a sensação de amplitude. O principal objetivo é proporcionar ao usuário um processo positivo de interação espacial, que se inicia neste ponto de entrada e se estende a todos os espaços da biblioteca. Além disso, em quase todos os casos, o hall de entrada sempre conta com um sistema de comunicação visual eficiente, relativo às atividades programadas e desenvolvidas, divulgadas por painéis e banners, além dos serviços oferecidos. Além de ser ponto de entrada, estes espaços estabelecem a intercomunicação com os outros ambientes, trazendo ao usuário habitual a facilidade de reconhecimento da localização e de orientação espacial.

Um fato bastante relevante na análise dos setores culturais das bibliotecas universitárias é sua presença marcante nos programas arquitetônicos de auditórios e salas multiuso. Esses ambientes são destinados a facilitar a reunião de um grande número de pessoas em atividades como, por exemplo, palestras, convenções, apresentações teatrais e musicais. Esta característica dota o edifício de um importante 
significado, o de ser pólo de transmissão e discussão das idéias, por meio das atividades desenvolvidas.

Como foi apresentado anteriormente, o setor referencial das bibliotecas universitárias estudadas destina suas atividades ao fornecimento de informação atual, estratégica e precisa nas áreas de conhecimento atendidas pelas universidades. Essas características foram decisivas na escolha do posicionamento espacial dos setores referenciais e na sua ligação com o restante do projeto dos edifícios. Neste caso, em termos arquitetônicos, as atividades desenvolvidas nesta zona devem acompanhar quesitos importantes de funcionalidade, flexibilidade e privacidade.

Diferentemente dos setores culturais, a preocupação básica na formação espacial dos setores referenciais foi conceber um modelo de salas que responda satisfatoriamente às exigências de ordem técnica, tanto na produção de informação referencial quanto no processo racional de ocupação espacial do futuro usuário. Diante disso, os ambientes dos setores referenciais têm características e funções que cumprem, adequadamente, todos os objetivos propostos:

- Isolamento acústico das salas, para que o ruído desnecessário não interfira nas atividades desenvolvidas;

- Espaços convidativos e acolhedores, para que o tempo de permanência do usuário operacional e do usuário final seja proveitoso e não estressante;

- Excelente infra-estrutura e recursos (equipamentos e materiais) que garantam a execução das funções programadas;

- Privacidade funcional em todos os ambientes dos setores referenciais.

Em relação à linguagem do espaço interno das salas que contemplam os acervos dos setores referenciais das bibliotecas universitários vários elementos são contemplados:

- Distribuição espacial do ambiente e posicionamento dos equipamentos tecnológicos: Por uma estratégia harmonizadora, o arranjo espacial, principalmente no que se refere às funções, é feito por meio de "estações de trabalho", nas quais cada atividade programada se relaciona com outros. A concepção desta idéia é semelhante àquela utilizada em escritórios de trabalho 
corporativo, nos casos em que inexiste divisória piso-teto e o ambiente é divido apenas por móveis baixos e articulados. Computadores e equipamentos informáticos são dispostos no sentido de procurar a facilidade de reconfiguração das "estações de trabalho" e uma nova personalização do espaço (CONNIE, 2001; ORCIUOLI, 2006).

- Conforto mobiliário: este item está ligado à tecnologia e à produtividade. A preocupação com a ergonomia tornou-se fator imprescindível nas atividades desenvolvidas. Assim, as cadeiras são providas de ajustes da altura de braços, altura, profundidade de assento e inclinação de encosto. Neste aspecto, as mesas e os porta-teclados são passíveis também de ajustes, considerando a melhor adaptação possível a cada usuário. O mobiliário também respeitou soluções e especificações técnicas indicadas quanto à durabilidade e à segurança dos materiais empregados (GRAHAM, 2006).

- Conforto ambiental: foi comprovado que, nesses espaços, o bem-estar não está associado apenas ao aspecto físico, mas, evidentemente às questões acústicas e visuais. Conforto acústico e visual fazem parte dos elementos presentes em todos os ambientes pertencentes aos setores referenciais. Iluminação: A iluminação desempenha papel fundamental na concepção arquitetônica das salas. Em quase todos os casos analisados, nota-se a preocupação na adequada utilização dos itens pertinentes à iluminação (artificial e natural) dos espaços como, direcionamento, design, performance e consumo (MAMBRINI, 2001; DEAN, 2004).

- Ventilação: A ventilação natural também é outro quesito utilizado como recurso mais eficiente para amenizar o estresse térmico gerado pelo excesso de calor e umidade dos ambientes salas. As formações de ilhas de calor e acúmulo de poluição poderão ser melhor por ventilação natural.

Outros importantes espaços, instalados nos setores referenciais, são as salas de informática destinadas às atividades das informações referenciais das bibliotecas universitárias. As salas formam importante espaço de geração de produtos informacionais que dependem do apoio de meios informáticos, além de serem 
responsáveis pela gestão e implementação da informação disponibilizada nos acervos dos setores referenciais. Os ambientes de informática contam com um conjunto de computadores, impressoras, acessórios e softwares que permitem às equipes responsáveis pelos setores desenvolvimento de projetos de trabalho no âmbito da sistematização, padronização e divulgação da informação referencial nas áreas de conhecimento atendidas. primeira instância (GASCUEL, 1993; PUACZ \& BRADFIELD, 2000).

Com as análises efetuadas, verifica-se que a construção do espaço das bibliotecas universitárias parte primeiramente da observação que só pode ser apreendida e relacionada como espaço de informação e de conhecimento, independente das variáveis que possa apresentar. A biblioteca implica num espaço significante que, ao ser articulado com o seu significado, estabelece uma relação de uso que lhe é própria.

Conforme analisa Barbalho (2006, p.40):

\footnotetext{
"O edifício da biblioteca é uma manifestação de linguagem para contemplação dos transeuntes. Sob o olhar do usuário, essa imagem comunica sua função, seus significados plásticos e icônicos, afirmando sua presença no contexto onde se insere, provocando ou não os passantes e despertando, no público, sentidos que variam de acordo com a aparência geral do objeto"
}

Nesta análise, o edifício da biblioteca universitária é constituído de valores que são simbolicamente compostos por duas dimensões. A primeira é a de contribuir para o desenvolvimento do cidadão/universidade - valor de base -, e a segunda é a de proteção aos bens culturais e arquitetônicos que estão sob sua guarda, facilitada pela utilização de seu espaço e a acessibilidade ao conhecimento - valor de uso. Portanto, esses prédios não são elementos neutros, influenciam sobremaneira o universo urbano, a imagem da cidade e, conseqüentemente, a própria imagem da universidade.

Atualmente, na área da arquitetura, a idéia de biblioteca universitária agrega o conceito de espaço-facilitador, principalmente pela forma como se apresentam ou como se organizam o conteúdo, a forma, a composição e o equilíbrio dos elementos da informação. Algumas recomendações são formuladas em relação aos edifícios de bibliotecas, de forma a responder às exigências de compatibilidade, adaptabilidade, 
acessibilidade e ambiência arquitetônica compatível (MALINCONICO, 1992; HAYCOCK, 1992; GREEN, 1993). Nesse caminho, a biblioteca é então apresentada como um código que deve ser apreendido pelo usuário, ou seja, ao dominar esse código, ele passa a ter reais condições de uso e de interpretações dos mais variados significados produzidos pelo espaço

Dessa forma, por meio do dispositivo que instala, no conjunto arquitetônico, a praça - espaço público disposto para o descanso, o relaxamento e o lazer do transeunte -, a biblioteca quer ser vista, admirada, contemplada pelo olhar de seu usuário. Os regimes de presença da biblioteca no espaço urbano a dispõe para contemplação do transeunte e a colocam como um convite para a entrada no seu fascinante mundo real e imaginário ou como uma muralha posta para a defesa do patrimônio que guarda.

Assim, a necessidade de subsídios realistas para a formatação de projetos de bibliotecas universitárias continua sendo a necessidade prioritária: informações confiáveis sobre os planos de desenvolvimento de atividades universitárias, aumento de matrículas, pesquisa, assim como definições quanto a questões de planejamento físico das organizações existentes. Avaliar a própria experiência e vislumbrar problemas de forma científica já faz parte da própria solução que aponta para a melhoria da atividade de planejamento físico de bibliotecas universitárias.

\subsection{A Realidade Brasileira}

Nesses últimos anos, a análise das bibliotecas universitárias brasileiras tem experimentado especial atenção em estudos e análises da comunidade científica. Essas pesquisas têm concentrado suas atividades na avaliação das funções desempenhadas, na atenção aos aspectos organizacionais e, em última análise, tem proposto padrões para seu desenvolvimento. A partir do estudo de Tarapanoff (1981) sobre bibliotecas universitárias, que as considera fator preponderante nos processos de interação sócio-econômico, a biblioteca universitária, no contexto brasileiro, é parte integrante da sociedade, refletindo suas características, o seu grau de desenvolvimento, sua tradição cultural e seus problemas.

Cabe lembrar que a biblioteca universitária é uma organização que tem como missão suprir as necessidades informacionais da comunidade em que esta inserida quanto ao desempenho de suas atividades de ensino, pesquisa e extensão e para tanto 
deverá ter um acervo heterogêneo, com nível intelectual compatível com as necessidades da clientela a quem se destina.

\subsubsection{A Biblioteca Universitária Brasileira e o Ensino Superior}

Na discussão do papel da biblioteca universitária, é impossível deixar de lado o contexto do ensino superior no Brasil. As universidades brasileiras têm concentrado o maior número de pesquisas e avanços nas novas tecnologias desenvolvidas no país. Como afirma Ferreira (1980), a universidade deve acompanhar esse processo de desenvolvimento da sociedade, preparando a mão-de-obra especializada, não só no presente, mas também com vistas ao futuro próximo.

As bibliotecas universitárias são conceituadas tradicionalmente como "Bibliotecas de Instituições de Ensino Superior (IES), destinadas a suprir as necessidades informacionais da comunidade acadêmica, no desempenho de suas atividades de ensino, pesquisa e extensão" (CARVALHO, 1981, p.1). Essa visão limitada ao aspecto técnico e aos usuários pode ter conseqüências sérias, principalmente porque, numa visão sistêmica (HERSEY \& BLANCHAR, 1986), esses dois aspectos estão diretamente relacionados aos aspectos sociais e humanos. As bibliotecas universitárias, então, devem ter seus objetivos direcionados em conformidade com os da universidade à qual está vinculada, uma vez que é parte desse sistema de cujo ambiente recebe influências sociais, culturais, políticas e econômicas, que são determinantes para o seu funcionamento. Além disso, é considerada um segmento de vital importância na estrutura da Instituição, visto o seu caráter de promover o acesso e a disseminação da informação para que os objetivos da universidade sejam plenamente atingidos.

Nota-se que existe uma relação bastante forte entre os padrões de ensino e pesquisa praticados pela universidade e as condições de funcionamento das bibliotecas universitárias: quanto mais a universidade melhora sua atuação nestas áreas, mais a biblioteca é pressionada a dar melhores condições de uso e eficácia nas atividades desenvolvidas; e estas, por sua vez, funcionando adequadamente, dão melhores condições de apoio aos programas educacionais da própria universidade. Esse círculo de retroalimentação, da qual depende não somente a qualidade e continuidade dos serviços oferecidos, bem como a qualidade do próprio ensino superior, ressalta o papel importante da biblioteca universitária. Portanto, a ampliação das finalidades do ensino 
superior no Brasil, implicará novos conceitos dos serviços bibliotecários no suporte ao ensino, pesquisa, pós-graduação e extensão universitária.

Nesse processo de melhoria da relação entre a biblioteca e o ensino superior no Brasil, alguns exemplos têm sido executados, considerando a educação como um sistema e a biblioteca, um de seus subsistemas fundamentais. Até então o ensino superior atribuía pouco valor à pesquisa, como recurso de preparação intelectual e como instrumento de avaliação positiva, ou de produção original do saber (FERREIRA, 1980). Na realidade, essa transformação iminente deve passar por uma organização adequada, com delimitação de funções, sistema hierárquico e definição de padrões/modelo para as bibliotecas.

Fugita (2006, p.14) lembra que a biblioteca universitária deve estar inserida dentro do contexto mais amplo da universidade e não pode estar desvinculada do meio-ambiente acadêmico e sua cultura. Conforme a autora destaca:

\footnotetext{
"...A universidade atua como organismo gerador, transmissor e receptor de conhecimentos e a biblioteca universitária torna-se consciente de sua função intermediadora realizando os processos documentários e preservando a informação para sua próxima transformação em conhecimento em uma espiral de evolução científica e tecnológica."
}

Das três funções básicas da biblioteca universitária provém a dinâmica social que, em um movimento circular, alimenta os insumos para sua própria continuidade, são elas (FUGITA, 2006):

- Armazenamento do conhecimento: desenvolvimento de coleções, memória da produção científica e tecnológica, preservação e conservação;

- Organização do conhecimento: qualidade de tratamento temático e descritivo que favoreça o intercâmbio de registros entre bibliotecas e sua recuperação;

- Acesso ao conhecimento: a exigência de informação transcende o valor, o lugar e a forma e necessita de acesso. Por isso deve-se pensar não só em fornecer a informação, mas possibilitar o acesso simultâneo de todos. 


\subsubsection{Formas de Organização}

Como nos revela Etzioni (1980), organização, no sentido de empresa ou entidade, é uma unidade planejada e intencionalmente estruturada com o propósito de atingir objetivos específicos. Assim, o tipo de organização existente e o ambiente na qual ela se insere são fatores preponderante para que os objetivos estipulados sejam atingidos. Ou seja, a forma de organização administrativa de uma biblioteca universitária é fator chave para que os serviços bibliotecários sejam eficientes e satisfaçam às necessidades e exigências dos usuários.

A organização de uma biblioteca universitária é basicamente composta por sua estrutura, pessoas e elementos tecnológicos que, de uma certa forma, representam o sistema interno desta organização. Somados a esses componentes, os fatores arquitetônicos estruturais do espaço da biblioteca universitária e o partido espacial adotado, estão intimamente atrelados à configuração organizacional da biblioteca. Além disso, por os indivíduos serem constituídos de valores, competências, cnhecimento, necessidades e objetivos, isso torna o ambiente de trabalho dinâmico e único. Portanto, a estrutura formal da biblioteca é fundamental para que o trabalho individual e em grupo seja eficazmente coordenado nas principais atividades desenvolvidas.

Como coloca Ferreira (1980), centralizar ou descentralizar bibliotecas universitárias no Brasil sempre deu margem a muitas discussões e o assunto continua sendo apresentado sem que se tenha conseguido chegar a um acordo. No âmbito dessa discussão, a corrente daqueles que apontam vantagens na adoção do sistema de centralização em bibliotecas universitárias apresenta:

- A oportunidade de haver uma biblioteca completa, sobre os mais variados títulos e assuntos, gera grande inter-relacionamento entre as ciências e leva o usuário a pesquisar assuntos afins, sem locomover-se de uma para outra biblioteca;

- $\quad$ A melhoria de qualidade dos serviços, com menor custo, evita duplicação desnecessária de todo tipo de material bibliográfico;

- $\quad$ O emprego racional dos recursos financeiros disponíveis na aquisição de novos títulos; 
- $\quad$ A utilização mais racional do pessoal técnico e diminuição do pessoal de outras categorias;

- A possibilidade de equipar melhor a biblioteca central já que a multiciplidade de bibliotecas dá origem ao rateamento dos custos de manutenção.

Essa corrente declara que o temp gasto pelo usuário/leitor de sua unidade até a biblioteca central pode ser amplamente compensado, pois ali ele terá a possibilidade de fazer uma ampla pesquisa e estabelecer contato com inúmeros estudiosos afins na troca de experiências enriquecedoras.

Já os defensores da descentralização apresentam como principais vantagens desse sistema:

- A necessidade de o material bibliográfico estar localizado próximo aos leitores e usuários, sem que os mesmos precisem locomover-se de sua unidade de ensino para a biblioteca central;

- A maior rapidez na aquisição do material bibliográfico solicitado por alunos e professores.

Ferreira (1980) destaca que a posição intermediária entre esses dois sistemas é o de centralização parcial, em que apenas o acervo é descentralizado, sendo o processamento técnico executado pela biblioteca central. Nessa situação, os documentos estarão junto aos leitores, mas o órgão central tem possibilidade de exercer controle, senão na aquisição, pelo menos padronizando o tratamento das publicações e registrando o acervo bibliográfico de toda a universidade.

De qualquer maneira, a adoção deste ou aquele sistema e, acima de tudo, a mudança de um para outro sistema não é uma operação tão simples quanto se possa imaginar à primeira vista, pois as estruturas organizacionais das universidades são bastante complexas, com uma série de fatores e variáveis que afetam a escolha do sistema. Em suma, toda decisão deve ser tomada baseada na própria realidade de cada universidade, não existindo solução única que se molde a todos os casos. Em relação a isso, Ferreira (1980) recomenda que o tipo de estrutura a ser adotado deve seguir um amplo processo de planejamento da equipe da biblioteca universitária, levando-se em 
conta, como peça fundamental desse processo, o projeto de arquitetura. E ele conclui que é imprescindível que se pense em sua estrutura organizacional, o que não impede que essa mesma estrutura venha a ser modificada mais tarde por força dos próprios objetivos da biblioteca, revistos para se adequar a novas necessidades surgidas. Como exemplo das ações citadas anteriormente, algumas bibliotecas universitárias no Brasil, pertencentes às faculdades, escolas e cursos correlatos, reuniram-se numa só biblioteca para servir a um determinado centro ou setor, na acepção que os mesmos possuem hoje, de órgãos coordenadores de unidades universitárias de uma mesma área de conhecimento. Dessa forma há melhora da qualidade dos serviços e do acervo por conta de uma melhor administração.

Como foram expostas anteriormente, as formas de organização da biblioteca universitária brasileira remetem aos aspectos de centralização ou descentralização e sempre foram uma discussão bastante presente nas áreas da biblioteconomia e ciência da informação. Porém, em nosso caso, mais importante é discorrer sobre os tipos de estruturas nas quais a biblioteca universitária do Brasil se instala e de que forma essas discussões cooperam e interferem nas decisões dos projetos arquitetônicos das bibliotecas universitárias brasileiras.

\subsubsection{Fatores Macro-Ambienteais}

Oliveira (2006) demonstra que, sob um olhar mais prático, a estrutura da biblioteca universitária é afetada, em um primeiro momento, pelos serviços e produtos oferecidos, pelo modelo gerencial adotado e pela tecnologia utilizada pela organização para desenvolver os trabalhos internos. Estes, por sua vez, sofrem um impacto e são, em grande medida, determinados pela missão da organização e pelas tendências relativas às pessoas. Nessa dimensão, os fatores macro-ambientais são decisivos na organização das bibliotecas universitárias brasileiras, influenciando sobremaneira os destinos da estrutura organizacional. Os fatores apresentados a seguir não esgotam a discussão, apenas apontam para algumas possibilidades.

\subsubsection{A Política Educacional}

A política educacional praticada no país, principalmente nesses últimos trinta anos, tem afetado os rumos da universidade e tem alterado a estrutura da 
biblioteca universitária. Vários elementos dessa política podem ser citados: a desmistificação da erudição, resultado direto do incentivo e "endeusamento" das especializações, o desnível de prestígio entre ensino e pesquisa e o futuro do financiamento para pesquisa, isso tudo tem gerado incertezas em todos os âmbitos da universidade. Assim, paira no ar uma indefinição sobre o futuro das IES e ainda não se sabe muito bem qual o caminho mais adequado a seguir em termos de estratégias para preparar as pessoas para a vida profissional.

Outra questão que se coloca são os recursos financeiros absorvidos pelas universidades. Geralmente os recursos são conseguidos e liberados para aquelas instituições que possuem relacionamento mais estreito com a indústria e, como a biblioteca universitária só "absorve" despesas e não gera recursos, ela certamente se encontra em nítida desvantagem. Como lembra Cunha (2000), ao refletir sobre o futuro da universidade brasileira, a falta de uma definição clara sobre o futuro das IES e uma política educacional indefinida e confusa influenciam a decisão quanto à estrutura da biblioteca universitária brasileira.

\subsubsection{Novas Tecnologias Informacionais}

Com o advento das novas tecnologias informacionais em todos os âmbitos da sociedade brasileira, intensificou-se o uso da "coleção eletrônica", fora da biblioteca universitária, restringindo sua utilização em residências ou outros locais diferentes do meio acadêmico. Outrora alunos, pesquisadores e professores e mesmo a comunidade local se voltavam para a biblioteca universitária para satisfazer suas necessidades de informação, eles agora se dirigem aos seus micros computadores - em casa ou no trabalho - para executarem pesquisas ou buscarem informação. Alunos têm buscado apoio nos recursos telamáticos para enriquecer suas experiências mesmo fora das salas de aulas, pelo intercâmbio com outros alunos de outras universidades, inclusive fora do país. Isso acontece pela falta de equipamentos computacionais mais avançados no interior das bibliotecas universitárias, com mais recursos e softwares de última geração. Além disso, muitas bibliotecas restringem o uso dos equipamentos, não permitindo acesso a e-mail, processamento de texto ou programação.

Estudos têm revelado que, no meio acadêmico, os alunos têm utilizado somente ferramenta de busca populares na Web, ou seja, instrumentos de busca que indexam apenas a informação de "superfície" da Web. Por outro lado, de acordo com 
Bergman (2000), a Web "profunda" (Deep Web) é 500 vezes maior e cresce a um ritmo muito mais veloz que a Web de "superfície". É possível com ela pesquisar informação em todas as áreas científicas, chegando a ser de 1.000 a 2.000 vezes melhor em qualidade que a Web de "superfície". Segundo o autor, apenas 0,03\% dos alunos em graduação utilizam as possibilidades da rede mundial, ignorando completamente os livros, periódicos, base de dados, recursos digitais full-text e outros recursos informacionais oferecidos pela biblioteca universitária.

Uma das formas para reverter esse quadro no âmbito das bibliotecas universitárias brasileiras, seria aplicar o ensino e a instrução aos alunos, com ênfase na utilização eficaz de todos os recursos disponíveis on-line. Além disso, as implicações destas funções para o gerenciamento organizacional devem ser analisadas em relação ao treinamento de pessoal, à readequação do espaço físico e equipamentos e a uma nova perspectiva administrativa.

\subsubsection{Serviços de Informações Oferecidos por outras Entidades}

Outro fator macro-ambiental preponderante nos elementos de influência no espaço das bibliotecas universitárias brasileiras tem sido os novos produtos e serviços informacionais presentes em diversas entidades e organizações, concorrendo diretamente com as bibliotecas. É possível encontrar verdadeiros catálogos/base de dados de livros e periódicos em livrarias espalhadas pelo país. Embora muitas bibliotecas universitárias ofereçam catálogos on-line de seu acervo, o serviço ainda exige uma estrutura mais adequada de suporte e disponibilização das bases de dados, configurando um quadro ainda em desenvolvimento. Além do fator disponibilidade, existe o elemento de ambientação física desses locais que atraem o público, afastando-o da biblioteca universitária tradicional. Em contraste, as bibliotecas restringem sua atuação e a mobilidade dos usuários, tanto em nível macro (serviços oferecidos) quanto micro (formas de utilizar os serviços e equipamentos).

Dessa maneira, estudos sistemáticos (quantitativos e qualitativos) destes serviços e recursos informacionais precisam ser implementados no sentido de compreender seus impactos no uso da biblioteca universitária e nos usuários que ela almeja servir. As pesquisas devem ser direcionadas à compreensão de questões como, por exemplo, se os usuários estão usando estes serviços, como os bibliotecários podem orientá-los, direcioná-los, guiá-los aos melhores provedores e instruí-los a, de forma 
crítica, recuperar as informações desejadas. Esta decisão e providências afetarão a estrutura da biblioteca. (OLIVEIRA, 2006).

\subsubsection{Educação à Distância}

O Brasil, por meio do MEC e iniciativas das instituições privadas de ensino, vem se preparando para, cada vez mais, aplicar as tecnologias da informação e comunicação disponíveis ao processo de ensino-aprendizagem. Um dos exemplos disso foi o programa criado no Brasil e denominado UNIREDE, com objetivo de disseminar conhecimentos, informações e educação a distância por meio da Internet. Dessa rede, fazem parte trinta e três universidades federais e em estaduais com a pretensão de atender as necessidades tanto nos níveis de graduação, pós, extensão e educação continuada. (CUNHA, 2000). Como ressalta Oliveira (2006), a biblioteca universitária terá que se adaptar aos impactos causados por esta "nova" modalidade de ensino/aprendizagem, pois provavelmente o número de usuários virtuais aumentará, demandando novas estratégias organizacionais.

\subsubsection{Perfil do Aluno/Usuário}

Cada vez mais, o mercado de trabalho brasileiro exige mão-de-obra mais especializada e o resultado disso tem sido a necessidade de maior treinamento em nível superior. Na verdade, mais e mais alunos buscam uma educação que faça frente a esta exigência das empresas e instituições da sociedade. Com isso, as universidades têm se deparado com um cenário bastante diverso e heterogêneo, principalmente, no que diz respeito à composição dos alunos no ambiente universitário, tanto nos cursos de graduação quanto nos programas de pós-graduação.

Outro aspecto interessante é maior demanda de alunos de idade mais avançada, os chamados alunos da terceira idade. Muitas dessas pessoas estão vendo no ensino superior uma forma de crescimento pessoal e uma excelente maneira de aproveitar seu tempo de aposentadoria. A biblioteca universitária brasileira deve levar em consideração estas mudanças e tendências ao desenvolver sua oferta, o que implicará transformações na estrutura das bibliotecas. 


\subsubsection{Modelos Funcionais e Estruturais}

Em relação ao modelo adotado para a universidade brasileira e para suas bibliotecas, pode se citar o Programa Nacional de Bibliotecas Universitárias - PNBU no ano de 1987. Com esse modelo, as bibliotecas se estruturam e reestruturaram, chegando atualmente a ter condições de desenvolver propostas de modernização com maior maturidade.

Mercadante (1990) menciona que, desde a sua formação, o PNBU vinha recebendo solicitações sobre a forma mais adequada de se estruturarem as bibliotecas universitárias, com o objetivo de promover a melhoria dos serviços prestados aos usuários. Esse processo de mudança tinha como função orientar os modelos organizacionais e os níveis de centralização e descentralização das bibliotecas universitárias. Mesmo não atingindo todas as metas estipuladas, uma série de recomendações foi enviada às universidades, proporcionando um importante debate entre os componentes das administrações das bibliotecas envolvidas. A partir de então, o modelo sistêmico foi assim sugerido como uma proposta mais interessante e eficiente nas atividades desenvolvidas pelo órgão, assim como instalar um canal mais aberto de diálogo entre o Ministério da Educação (MEC), pela Secretaria de Ensino Superior (SESU) e com o Diretor do Sistema de Bibliotecas o qual, por recomendação do próprio MEC, deveria estar subordinado diretamente ao reitor da universidade.

Dodebei (2006), em seu estudo a respeito dos modelos de organização das bibliotecas universitária brasileiras, explica que a preocupação da adoção do modelo sistêmico para as bibliotecas universitárias brasileiras tem sua justificativa. Nas estruturas existentes nas universidades durante as décadas de 70 e 80 , vinham se desenvolvendo a partir do modelo de especialização do conhecimento, criando cursos e programas voltados para áreas e temas particulares do saber, o que gerava a demanda de atendimento bibliográfico também especializado. De qualquer maneira, como afirma Dodebei (2006, p.75):

\footnotetext{
“Assim, não há como afirmar a priori que o modelo centralizado é melhor que o descentralizado ou ao contrário, uma vez que não só as características das universidades são diferentes como, principalmente, as características particulares de cada uma delas podem mudar, dado o caráter dinâmico da evolução social."
} 
Dentre os exemplos encontrados em bibliotecas universitárias, prioritariamente no final da década de 90, há as mais variadas estruturas organizacionais: as centrais únicas, como é o caso, da UNB - Universidade de Brasília; as centrais setorializadas, a Biblioteca da Universidade Gama Filho; descentralizadas com coordenação central, como é o caso da Universidade do Rio de Janeiro (Uni-Rio), entre outras.

Analisando a maioria dos exemplos de bibliotecas no Brasil, à exceção da biblioteca central única, todas as demais estruturas adotaram total ou parcialmente o modelo sistêmico. Em alguns casos, como o da Universidade Federal do Rio de Janeiro (UFRJ), foi criodo um sistema independente acima das bibliotecas, o SIBI, mesmo tendo a figura da biblioteca central com a função de coordenar e gerenciar todas as bibliotecas da universidade.

De que forma o sistema sistêmico pode ser definido no contexto brasileiro? Como uma alternativa para resolver a dicotomia dos modelos centralizado/descentralizado, pois esses modelos de estruturas verticalizadas não respondiam mais às necessidades e funções das bibliotecas modernas. Nessa discussão, dois fatores antagônicos foram considerados básicos na aplicação dos modelos em bibliotecas universitárias brasileiras: a especialização e a interdisciplinaridade. De fato, tais fatores foram considerados eixos coordenados, ressaltando a interseção de vantagens e desvantagens. Obteve-se um produto que atendia às especificidades de cada biblioteca e, ao mesmo tempo, permitia a sua comunicação globalizada.

Como reflexo prático na definição dos espaços arquitetônicos da biblioteca universitária, pode-se citar o caso do "Ciclo da Informação", que começa e termina na biblioteca. Nessa situação, a produção do conhecimento e da informação deixa seu sentido vertical de especialização, para se conduzir mais no caminho da horizontalidade das abordagens transdisciplinares, ou seja, não mais são classificados em categorias fixas e imutáveis, mas sim produzidos em produtos informacionais abundantes, abertos e intercambiáveis. Como resultado disso, a biblioteca universitária começou a espelhar soluções espaciais abertas e flexíveis, conferindo liberdade ao layout das salas e trabalhando com uma linguagem simples, leve e espaçosa.

Quanto aos formatos de editoração do material bibliográfico, as informações produzidas ganharam suportes variados como os textuais, visuais, sonoros e tridimensionais. Com o avanço das tecnologias informacionais e comunicacionais, os 
suportes digitais conquistaram espaço cativo nas bibliotecas, disseminando a informação de forma rápida e com baixo custo. Apesar de haver pouco estudo na área da arquitetura, conceituando a convergência e aplicação das novas tecnologias da informação e comunicação, principalmente nos edifícios de bibliotecas universitárias, esses locais sentiram os efeitos diretos e indiretos dos novos parâmetros telemáticos na arquitetura, respondendo com soluções ainda desprovidas de estudos consistentes e comprovativos no âmbito funcional.

Portanto, como afirma Dodebei (2006), a biblioteca universitária brasileira deve permitir "um modelo que possa garantir o papel de produtor da informação por parte da universidade e de disseminador de informações por parte da biblioteca deve considerar uma estrutura matricial que agregue as vantagens da descentralização (especialização) e as vantagens da centralização a um menor custo em recursos humanos, em recursos físicos e materiais e em recursos tecnológicos". Independentemente das especificidades das formas de estruturas de cada universidade, o planejamento arquitetônico de bibliotecas deve ser sensível às necessidades das atividades universitárias, ao crescimento de matrículas, às pesquisas desenvolvidas por alunos e professores, assim como definições quanto a questões de planejamento físico dos campi e dos organogramas institucionais

\subsection{Arquitetura de Bibliotecas Universitárias: Caso Brasileiro}

\subsubsection{Contexto Arquitetônico}

Até agora, demonstraram-se os principais elementos funcionais, organizacionais e administrativos das bibliotecas universitárias brasileiras, traçando um panorama atualizado dos vários modelos adotados por essas instituições. Na segunda parte desse estudo, pretende-se contribuir com a análise propriamente dita da arquitetura de bibliotecas universitárias, tendo em vista a crescente urgência de estudos nessa área, sobre a melhoria das condições de ordenação e organização desses espaços no Brasil.

A problemática espacial dos edifícios de bibliotecas, principalmente daqueles destinados às universidades, sempre foi um assunto deixado de lado na área da arquitetura. A compreensão dos estudos comportamentais do ambiente construído, os fatores do espaço arquitetônico e os reflexos no plano urbanístico dessas edificações, quase nunca ganharam lugar de destaque em pesquisas e análises desenvolvidas. Além 
disso, bibliotecários e cientistas da informação procuram evidenciar uma certa distância na tomada de decisões do planejamento físico e definição do partido arquitetônico das bibliotecas.

Um dos principais estudos a respeito da construção de bibliotecas universitárias no Brasil é documento apresentado por Miranda (1998), uma investigação reveladora dos tópicos relacionados ao desenvolvimento, construção e planejamento de bibliotecas universitárias. De primeiro momento, o estudo retrata que as bibliotecas universitárias que foram construídas na última década como, por exemplo, as bibliotecas da Universidade Federal de Uberlândia, da Universidade Católica de Curitiba, da Universidade Católica de Brasília, da Universidade Metodista de Piracicaba, são oriundas de instituições da iniciativa privada, ou, em outros casos, de universidades públicas que receberam verbas extras. Os programas de verbas universitárias, existentes nos anos 70 e 80, com financiamento de agências internacionais de desenvolvimento e que formavam a base financeira de tais projetos, acabaram se extinguindo. Programas como o PREMESU, depois CEDATE, com recursos do Banco Mundial durante uma mais de uma década, permitiram em grande medida a construção de edifícios na maioria das universidades federais: Universidade de Brasília, Universidade Federal de Goiás, Universidade de Alagoas, Universidade Federal do Amazonas, Universidade Federal do Espírito Santo, e muitas outras. Hoje, praticamente nenhuma linha de financiamento de construções de novas unidades está disponível, com exceção de algumas para obras menores com o apoio da FAPESP, em São Paulo.

\footnotetext{
Miranda (1998) insere em seu relato, uma pesquisa intitulada “Aclimatação ambiental dos prédios de Bibliotecas Centrais Universitárias: especificações de construção seguidas após a Reforma", desenvolvida por Augustinho (1987) no curso de mestrado de ciência da informação da Universidade de Brasília. A hipótese geral da pesquisa sugere que os edifícios de bibliotecas centrais construídos no período não consideraram meio ambiente como variável decisiva nas especificações gerais para as construções. A premissa da pesquisa traz três pontos básicos de análise:
}

- a estrutura administrativa (se centralizada ou descentralizada em relação à concepção dos sistemas).

- a estrutura física ( se os prédios eram monolíticos - isto é, bibliotecas centrais únicas - ou se setoriais). 
- os materiais de construção utilizados (madeira, vidro, metal, concreto, alvenaria, tipo de cobertura)

As bibliotecas universitárias analisadas no estudo são:

Região Norte:

- Fundação Universidade Federal do Acre

- Universidade Federal do Pará

Região Sul:

- Universidade Federal de Santa Catarina

- Fundação Universidade Federal de Pelotas

Região Nordeste:

- Universidade Federal da Paraíba

- Universidade Federal do Ceará

Região Sudeste:

- Universidade Federal de Minas Gerais

- Universidade Federal do Espírito Santo

Região Centro-Oeste:

- Fundação Universidade de Brasília

- Fundação Universidade Federal de Mato Grosso
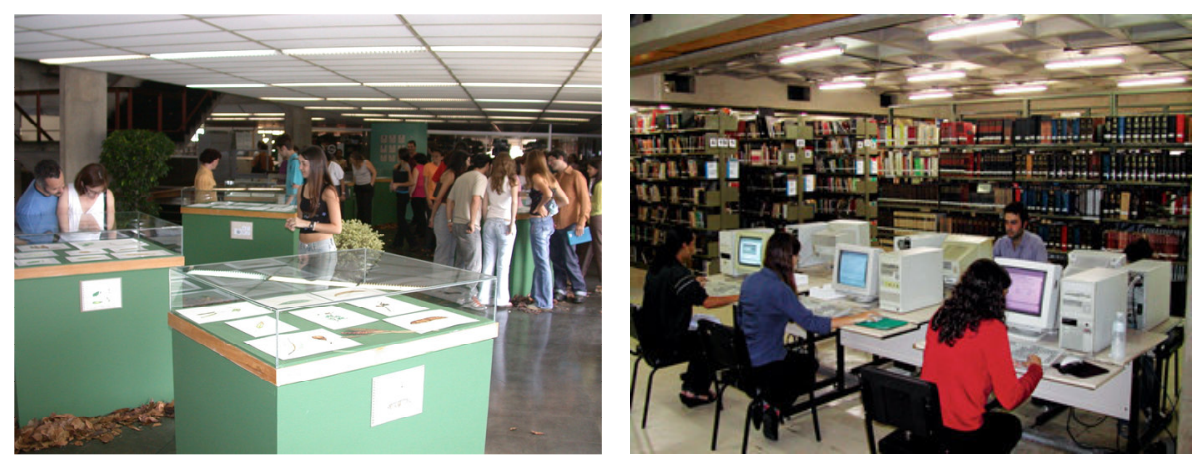

Figuras 63 e 64 - Biblioteca Central Universidade Federal de Minas Gerais Fonte: www. ufmg.br 

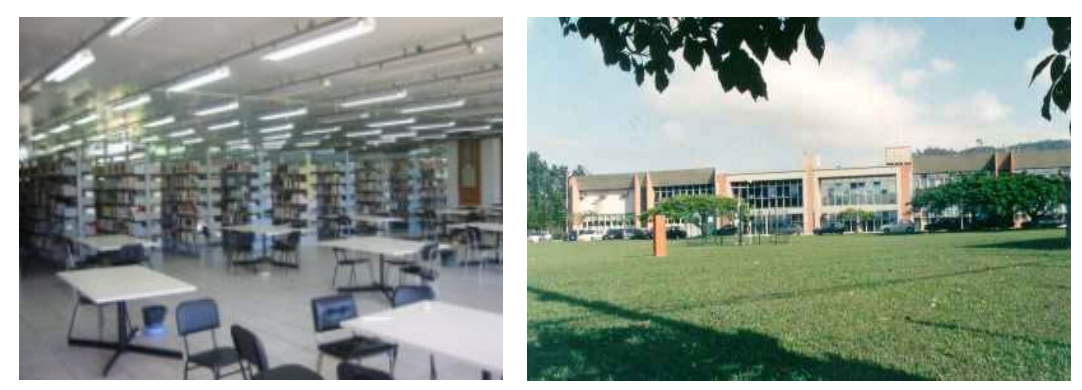

Figuras 65 e 66 - Biblioteca Setorial de Ciências/ UFSC

Fonte: www. ufsc.br

$\mathrm{O}$ estudo apontou que as equipes multidisciplinares que participaram do projeto arquitetônico dos edifícios compreendiam arquitetos, engenheiros civis, bibliotecários, paisagistas, pessoal administrativo e representante de docentes. Sem dúvida nenhuma a organização de tais equipes representou grande avanço na experiência do planejamento de edifícios de bibliotecas universitárias. O fator negativo constatado foi que somente em $20 \%$ das equipes havia técnicos especializados nos quesitos de conforto ambiental (umidade e temperatura) e fatores relacionados ao entorno das edificações (urbanismo). Outro dado relevante diz respeito à participação de arquitetos responsáveis pelos projetos, pois nem sempre eles eram da região, ou seja, sem a experiência relativa ao clima, aos hábitos, a variações de iluminação e das características do local.

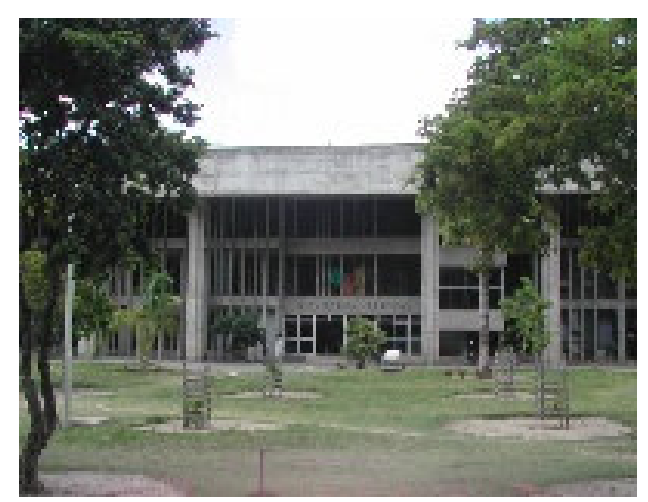

Figura 67 - Biblioteca Central/ UFPB

Fonte: www. ufpb.br 


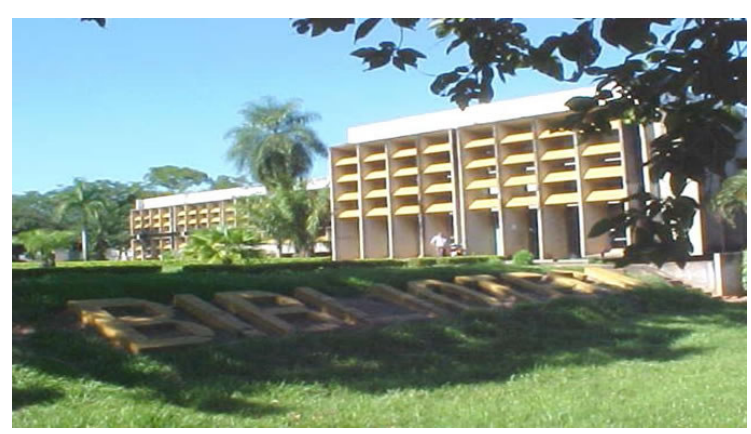

Figura 68 - Biblioteca Central/ UFMT

Fonte: www. ufmt.br

Outra questão levantada e estudada foi a ventilação natural, tão importante e determinante nas questões relacionadas ao conforto ambiental de uma biblioteca. Constatou-se que muitos edifícios foram previamente projetados para receberem sistema de ar-condicionado e, por algum motivo administrativo, acabaram ficando sem esse conforto, valendo-se de ventiladores insuficientes e inadequados para sua operação. Em relação a isso Miranda (1998, p. 27) diz que:

“...70\% dos casos encontraram condições satisfatórias para captar ventilação natural, embora nem todas as regiões do país sejam tão generosas neste quesito, exigindo a utilização de meios mecânicos para tornar o ambiente interno arejado, além de soluções de partido arquitetônico mais criativos com jardins internos e outras idéias mais inventivas (portas, janelas, espaços livres, jardins externos, clarabóias, etc). Dentre os problemas resultantes estão a ventilação direta forte no interior, falta de ventilação em certas áreas, acúmulo de ar saturado, etc.”

O uso da luz natural foi outra questão estudada. Nesse aspecto, algumas soluções construtivas foram utilizadas para resolver os problemas de incidência solar como grandes aberturas de janelas, clarabóias no teto, paredes pintadas com cores claras, pisos claros, etc. Por outro lado, essas medidas projetuais tomadas sem uma prévia análise dos fatores locais, ajudaram a aumentar a incidência da luz natural nos ambientes e esse excesso criou problemas de conservação de materiais de construção, desconforto ambiental e destruição das coleções do patrimônio bibliográfico. 

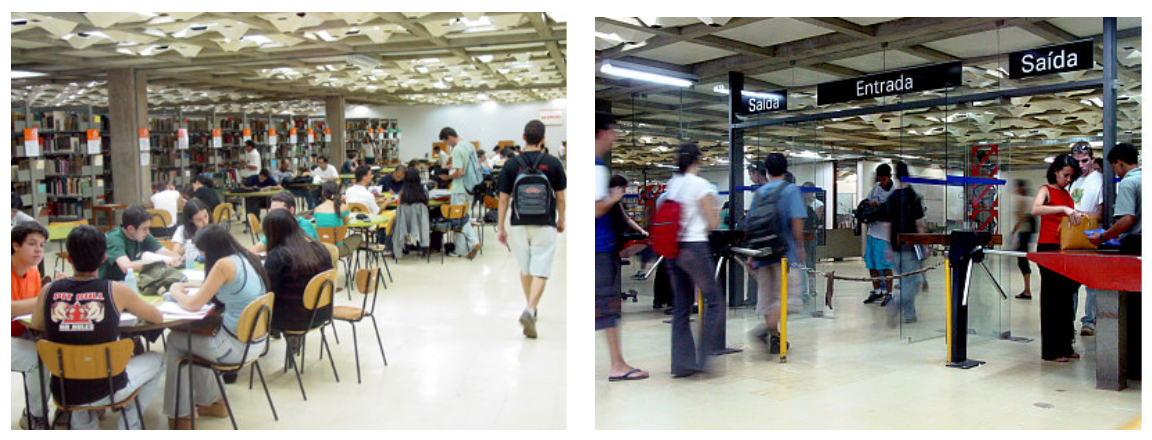

Figuras 69 e 70 - Biblioteca Central/ Unb

Fonte: www. unb.br

A segunda pesquisa apresentada por Miranda (1998) compreende a análise de dados de 401 bibliotecas universitárias brasileiras ano de 1993, empreendida por José Galbinski e Antonio Miranda, respectivamente arquiteto e bibliotecário, ambos da Universidade de Brasília. O estudo foi patrocinado pelo CNPq e do MEC/CAPES e encomendado pelo II Simpósio Nacional sobre Arquitetura de Bibliotecas Universitárias. $\mathrm{O}$ estudo, em sua primeira parte, elucida questões relativas à equipe de planejamento do edifício da biblioteca, pela análise dos elementos a serem executados como: linguagem arquitetônica, estrutura administrativa, definição da tipologia funcional, escolha do local, uso de equipamentos mecânicos, programa de atividades e avaliação de projetos.

O trabalho tem como cerne central a convicção de que o planejamento prévio das estruturas sistêmicas da biblioteca universitária deve direcionar $o$ planejamento arquitetônico, modelando o uso do espaço físico e permitindo que a flexibilidade seja capaz de ajustar-se a uma cultura em desenvolvimento e a mudanças estruturais. A pesquisa envolveu todos os tipos de bibliotecas existentes, desde as setoriais até as centrais únicas e chegou a resultados que ainda espelham a difícil realidade do setor.

Quanto ao diagnóstico da pesquisa, os resultados a seguir, apresentam os principais itens analisados: 


\section{- $\quad$ Centralização X descentralização}

Pelos índices de rendimento, as bibliotecas centrais apresentaram uma certa vantagem sobre as setoriais. Nesta situação, os valores relacionados à taxa de ocupação dos postos de leitura é 20,5\% maior nas bibliotecas centrais. Deve-se levar em consideração que essa taxa tem efeitos positivos na diminuição da área total do prédio com reflexos na diminuição dos custos. A taxa de oferta de livros por posto de leitura é $34 \%$ maior nas bibliotecas centrais, bem como a relação livro/leitor é aproximadamente $11 \%$ maior nas centrais.

- $\quad$ Dimensionamentos e Condições ambientais.

$\mathrm{O}$ estudo traz à luz os elementos do dimensionamento das bibliotecas setoriais e as diversas áreas, por ambientes, nas bibliotecas. A conclusão que se teve pelos resultados, foi que existe uma fraca influência nas áreas desses ambientes causada pelo tamanho da coleção bibliográfica. Nesta análise, um fato importante chamou a atenção dos pesquisadores: as dimensões do espaço físico das bibliotecas não guardam uma relação necessária com o volume do acervo, ou seja, as bibliotecas relativamente grandes contemplam às vezes acervos modestíssimos e muitas bibliotecas com espaços mínimos contêm estoques abarrotados.

\section{- $\quad$ Condições de conforto ambiental}

Em relação às condições de conforto ambiental, as bibliotecas setoriais apresentaram desconforto ao usuário na ordem de $53 \%$. Os valores extremos ocorrem com "desconforto térmico" e "insuficiência da aeração" em 79\% e 78\% dos casos. No tocante à "perturbação sonora", $61 \%$ dos usuários declaram descontentes com este item. Um outro problema detectado foi a deficiência de iluminação artificial que decorre de uma certa rigidez das instalações elétricas que não se adaptam as modificações na disposição do mobiliário e estantes de livros. 
- $\quad$ Planta fisica

As respostas aos questionários revelaram que o dimensionamento de ambientes de todas as bibliotecas é considerado exíguo e pequeno. Isso também é preocupante, pois, entre $50 \%$ a $58 \%$ das bibliotecas têm relacionamentos inadequados entre suas várias funções; em outras palavras, todos estão instalados, mas alguns em péssimas condições.

\section{- $\quad$ Manutenção}

Os maiores problemas encontrados nesta área foram os de infiltrações na cobertura, fato constatado em mais de $24 \%$ das bibliotecas universitárias, o que reclama especificações mais acuradas e maiores cuidados de detalhamento arquitetônico. $\mathrm{Na}$ grande parte dos casos, os pisos predominantes são os tacos e madeiras (29\%) e do tipo vinílico (27\%), que são relativamente econômicos, mas não são isentos de problemas de conservação, criando problemas em 31\% das bibliotecas pesquisadas. Nas escadas, sanitários e saguões aparecem os piores desgastes, principalmente porque estão sujeitos a um tráfego muito grande.No caso das madeiras, os problemas são o descolamento dos tacos e uso de madeiras não completamente secas que acabam deformando-se.

\section{- $\quad$ Segurança e outros problemas}

Refere-se a questões relacionadas, principalmente, com a existência de guarda-volumes, revista de usuários na saída, existência de vigias nos prédios e a proteção contra roubo nas janelas. Verificou-se que a revista de usuários é efetuada em somente $17 \%$ das bibliotecas universitárias brasileiras, e que somente agora seus responsáveis começaram a instalar os sistemas modernos de detecção, códigos de barra e de outros mecanismos de prevenção ao furto.

\subsubsection{Exemplos Nacionais de Arquitetura}

Cunha (2007) destaca que poucos programas arquitetônicos têm sofrido uma transformação tão intensa quanto os edifícios de bibliotecas universitárias no Brasil. Não somente porque os suportes tradicionais do livro vêm somando outros meios 
de comunicação e informação, mas também tem havido um desenvolvimento na idéia clássica de biblioteca para converter-se em um centro midiático, incorporando em seus processos e sistemas de comunicação, diferentes formas de disseminação da informação. Negar ao projeto de arquitetura esta realidade já bastante consolidada é desmerecer todo um processo desenvolvido ao longo de vários anos, no reconhecimento de dados essenciais da cultura contemporânea, como experiência real, autêntica e merecedora de crédito.

Uma das experiências mais ricas nos projetos de bibliotecas universitárias brasileiras tem sido aceitar o caráter plural e diversificado que os programas arquitetônicos vêm impondo às disciplinas projetuais ligadas à informação e comunicação e, por conseguinte, à dependência dos conteúdos culturais locais, inclusos nos processos de gestão, procedimentos, suportes e os distintos meios organizacionais. Em vista disso, o tema da biblioteca universitária brasileira vem aos poucos ocupando um importante papel nos processos de desenvolvimento de projetos e nas pesquisas em arquitetura e urbanismo. Assim, melhorar e discutir a qualidade desses edifícios para um futuro desejado é também, necessariamente, aceitar e pôr em prática a sistematização de seu conhecimento.

Dessa maneira, este item tem por objetivo trazer à luz os principais elementos essenciais da arquitetura de bibliotecas universitárias brasileiras, tendo como suporte, a leitura interpretativa dos três edifícios. Evidentemente, não se trata de esgotar o assunto ou mesmo estabelecer uma "camisa de força" ao longo desse processo de análise; o estudo procura desencadear uma proposta de aprofundamento das questões relacionadas aos caminhos projetuais dos edifícios em questão. Vale a pena destacar que, por se tratar de uma análise prospectiva, não se teve o objetivo de demonstrar perguntas e respostas para toda a problematização da arquitetura da biblioteca universitária brasileira. Acima de tudo, procurou-se estabelecer um instrumento de auxílio na reflexão do tema na área da arquitetura.

Hoje em dia, em termos brasileiros, temos o grande desafio é manter qualidade de comunicação adequada, entre o leitor e livro, dirigida à escala humana em volta à organização de quantidades de publicações atualizadas (DODEBEI, 2006). Desta forma, a compreensão do desenvolvimento de intervenções arquitetônicas dos edifícios de bibliotecas universitárias em cidades brasileiras coloca em discussão novas formas de atuação no espaço urbano. Consta-se hoje um processo de redefinição - ainda inconcluso - de novas alternativas de programas, necessidades e realidades no contexto 
dos edifícios de bibliotecas estudados. Na atenção a outros paradigmas, é fato inegável que essas transformações, na concepção contemporânea de espaço em bibliotecas universitárias, são fundamentais para o entendimento de novos fenômenos sociais, técnicos, lógicos, metodológicos, urbanísticos, políticos e mercadológicos que regem uma nova arquitetura desses edifícios. Assim, pensar a produção arquitetônica dos edifícios de bibliotecas no âmbito universitário, exige hoje outros olhares sobre as questões que envolvem o espaço contemporâneo, um espaço incapaz de abster-se ao progressivo confronto entre as tradicionais definições de cidade, paisagem e território. Conseqüentemente, construir esses espaços nos incita, como parâmetro indispensável, a um inevitável embate com estas novas percepções desenvolvidas pelo homem, cidade e metrópole.

A variedade e a complexidade de diferenças econômicas, culturais e sociais presentes no país exigem um projeto de arquitetura de bibliotecas universitárias baseado não apenas em volumes, implantações e forma, mas em estratégias apuradas de entrono - intervenções que possam agir por complementaridade ao existente.Idéias que, disseminadas numa região, constituam uma rede de espaços que evoquem um novo uso da disseminação da informação. Dessa maneira, a biblioteca universitária no Brasil deve resgatar esse caráter abrangente e dinâmico da sociedade, oferecendo a possibilidade de leitura sob as mais diversas formas, algumas já presentes, outras vindouras, ainda não exploradas, e até mesmo tentar resgatar práticas mais antigas, hoje não tão freqüentes como a leitura oralizada e pública. Deve oferecer também a oportunidade de acesso e leitura adequados, diferencialmente a cada suporte em sua forma de emissão do material registrado, que pode ser texto, imagem, ou som, ou os três combinados. As novas tecnologias poderiam servir como auxílio à complementação de práticas individuais de leitura ou como fomento de práticas coletivas (KRZYZANOWSKI, 1998 RIBENBOIM, 2001; FUGITA, 2006).

\section{Critérios das Análises}

Os exemplos a seguir apresentados resgatam e alguns avanços conseguidos nessa área de construção de bibliotecas universitárias brasileiras. É importante, porém, explicar que os critérios de análise de tais edifícios estão baseados nas várias tendências arquitetônicas empregadas à realidade brasileira. É importante destacar que quando se fala de tendências, os arquitetos não têm dado fórmulas ou 
formas prontas, mas sim apontando em comum a garantia da diversidade no caso brasileiro, diversidade que remete logo à coerência das soluções em espaços de bibliotecas universitárias. Na verdade, o que se tem são grandes diversidades regionais não redutíveis exclusivamente a questões econômicas, mas sim de diferenças de ordem geográfica, como clima, materiais disponíveis e adequados, mão-de-obra, fatores que moldam facilidades ou dificuldades para implantação ou disseminação de tecnologias. Por fim, tem-se as características culturais, interagindo com todo esse complexo e propiciando determinadas propostas construtivas.

Assim, pode-se considerar que os exemplos analisados se enquadram entre as tendências de futuro de arquitetura de bibliotecas universitárias que se preocupam em trabalhar a favor da realidade em que se inserem, com o compromisso de serem coerentes com seus contextos e inseridas na realidade brasileira. Pode-se adiantar que essa coerência projetual está muito voltada para as potencialidades e possibilidades naturais e culturais da sociedade brasileira, construindo uma arquitetura atrelada à realidade dos contextos de contrastes locais e regionais (DINIZ, 2001; CUNHA, 2007).

Outro critério estipulado nesta análise diz respeito à aplicação das novas tecnologias informacionais nos espaços destes edifícios. Com o crescente direcionamento das unidades universitárias para o conhecimento, é natural que as bibliotecas sejam grandemente afetadas pelos rápidos progressos na tecnologia da informação, notadamente computadores, telecomunicações e redes (CUNHA, 2007). Essa tecnologia é um direcionador importante de mudança no conceito espacial das bibliotecas universitárias, afetando as atividades acadêmicas e reforçando a urgente necessidade de sua aplicação. Os projetos escolhidos para este estudo procuram reforçar os dois desafios básicos dessa tendência no planejamento do espaço físico: o primeiro é materializado em razão de muitos edifícios aqui apresentados não teriam sido previamente projetados para dar suporte a sistemas que utilizam meios comunicacionais e elétricos requeridos para apoiar os suportes informacionais. E segundo, outros casos em que os espaços são concebidos para absorverem as novas tecnologias e serem utilizados por um longo período sem modificações espaciais.

Assim sendo, os critérios das análises seguiram um plano de ação bastante definido, acompanhando respectivamente os seis casos apresentados neste capítulo, ou seja, cada projeto de biblioteca universitária analisada propõe três critérios básicos que ficam assim subdividos: 
1. Bibliotecas Universitárias Públicas - Setorizadas de Pequeno Porte: são edifícios que apostam em obras autônomas e inovadoras, incorporando novas soluções e experimentações no âmbito das decisões de projeto. Mesmo partindo de um universo econômico bastante restritivo, como é o caso das universidades públicas, esses espaços expressam contribuições positivas empreendidas nesses projetos. Apesar da tecnologia simples, materiais tradicionais locais e programas arquitetônicos modestos, as bibliotecas universitárias que caminham nesta direção, manifestam alternativas concretas na produção da arquitetura brasileira contemporânea. Para essa vertente, foi escolhida a Biblioteca do Instituto de Economia da Universidade Estadual de

\section{Campinas.}

2. Bibliotecas Universitárias Privadas de Grande Porte: esses edifícios expressam a força das instituições privadas universitárias na realidade brasileira, estipulando generosos programas arquitetônicos para as bibliotecas e propostas de uma arquitetura de "impacto" e "espetáculo" no âmbito espacial. Geralmente os partidos arquitetônicos se estruturam em conceitos e formas marcantes, tanto nas definições volumétricas compositivas quanto nos conceitos aplicados à funcionalidade, tecnologia e inovação organizacional. Outro traço marcante destes espaços são os recursos associados à monumentalidade e à identidade estética, elencando pontos referenciais e visuais do campus universitário. E finalmente, essas bibliotecas dispõem de grandes somas financeiras para o planejamento e a construção das edificações, revertendo em projetos de maiores intervenções. Nessa análise, foi escolhida a Biblioteca do Centro Universitário Positivo - UNICENP de Curitiba.

3. Revitalizações destinadas às Bibliotecas Universitárias: para atender às crescentes necessidades de novos espaços de bibliotecas universitárias, muitas instituições de ensino superior no Brasil têm procurado executar projetos de revitalizações e adaptações em suas próprias sedes, reaproveitando e incorporando estruturas locais existentes. Nessas intervenções, os fatores associados à compatibilização dos novos programas de necessidades das bibliotecas universitárias aos espaços já construídos têm sido o grande desafio de arquitetos e planejadores que atuam nessa área. Em função do grau de dificuldade destes projetos arquitetônicos, principalmente no que se refere a sua readaptação a um novo uso e a sua reintegração, muitos exemplos não têm respondido satisfatoriamente aos processos de revitalizações. 
Contudo, o projeto aqui descrito, a Biblioteca de Pós-Graduação da FAUUSP -

Maranhã, de São Paulo, trouxe parâmetros relevantes no contexto da arquitetura de bibliotecas universitárias.

No caso da arquitetura das bibliotecas universitárias, é importante destacar as enormes possibilidades do futuro desses espaços no Brasil e entender o grande desafio de responder adequadamente às necessidades de uma clientela em mudança, no reordenamento dos processos construtivos e no questionamento das premissas existentes. 
Quadro 11 -Biblioteca do Instituto de Economia da Universidade Estadual de Campinas

\begin{tabular}{|l|l|l|l|}
\hline \multicolumn{1}{|c|}{ Projeto } & \multicolumn{3}{|c|}{$\begin{array}{l}\text { Biblioteca do Instituto de Economia da Universidade } \\
\text { Estadual de Campinas }\end{array}$} \\
\hline \multicolumn{1}{|l|}{ Local } & Campinas-SP & \multicolumn{3}{|l|}{$\begin{array}{l}\text { Ano de } \\
\text { construção }\end{array}$} & 2001 \\
\hline $\begin{array}{l}\text { Area } \\
\text { construída }\end{array}$ & $863 \mathrm{~m}^{2}$ & Arquitetos & $\begin{array}{l}\text { Escritório Bloch Só Arquitetura e Urbanismo - Luiz } \\
\text { Laurent Bloch e Heloísa Lima Herkenhoff. }\end{array}$ \\
& & & \\
\hline
\end{tabular}

A Biblioteca do Instituto de Economia da Universidade Estadual de Campinas - UNICAMP - caracteriza-se por ser uma construção simples (no formato de um retângulo), e apresentar um espaço muito funcional, além de se constituir como uma espécie de anexo do CEDOC - Centro de Documentação, também pertencente a essa universidade. Podem ser destacados outros atributos que marcam a construção dessa biblioteca, tais como sutilezas no desenho interno e externo da construção; adaptação à topografia, permitindo o aproveitamento da iluminação e ventilação naturais; apresenta a mesma linha de continuidade com os demais prédios e, além disso, apresenta uma rampa de acesso ao CEDOC (MELENDEZ, 2003).

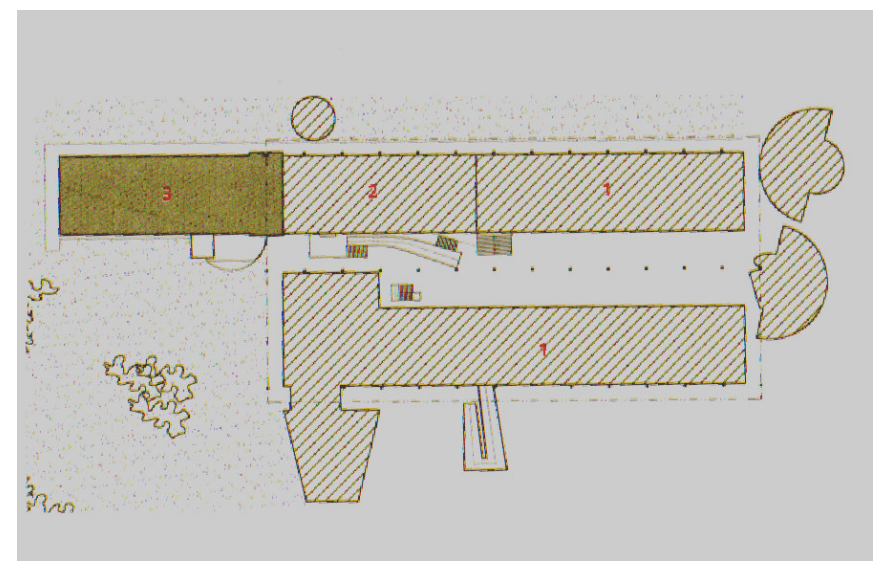

Figura 71 - Implantação Biblioteca do Instituto de Economia da Universidade Estadual de Campinas Fonte:www. arcoweb.com.br

Como primeiro elemento analítico desse edifício, identifica-se um comparativo à posição humanista de Alvar Aalto, com sua maneira de construir os novos espaços arquitetônicos, levando em conta os elementos geradores do entorno, mas sempre dentro de um processo de contínuo questionamento em busca de uma 
linguagem própria e de novos sentidos. À primeira vista, o espaço da biblioteca é demarcado com este forte legado, respondendo ao contexto de seu partido, o despojamento e a simplicidade das soluções encontradas. Assim, dentro das limitações orçamentárias impostas, o projeto abre mão dos recursos sofisticados e dos grandes gestos construtivos, fazendo de sua simplicidade e do seu minimalismo sua principal marca.

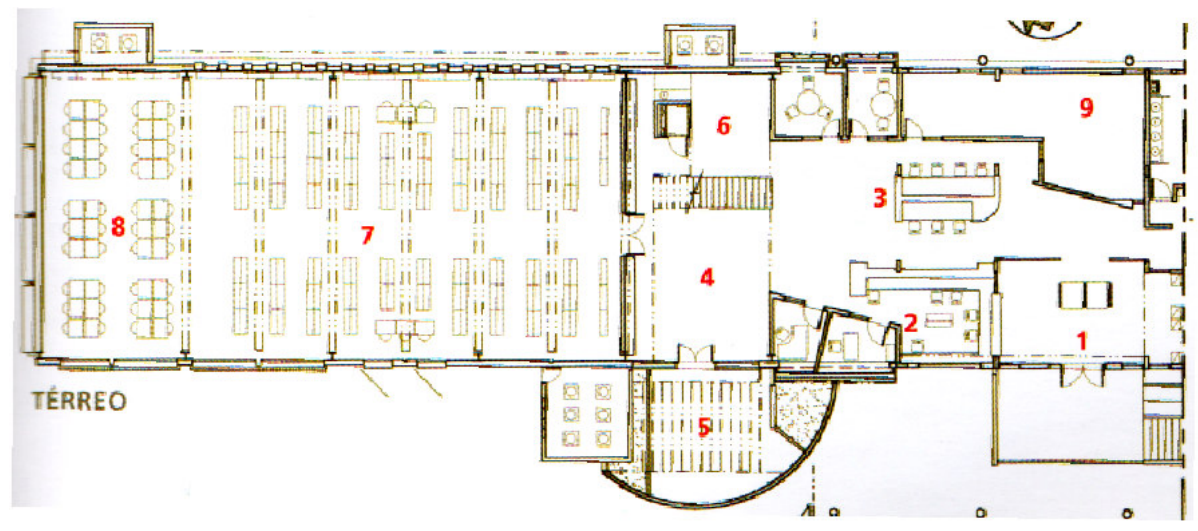

Figura 72 - Pavimento Térreo/Biblioteca

Fonte:www. arcoweb.com.br

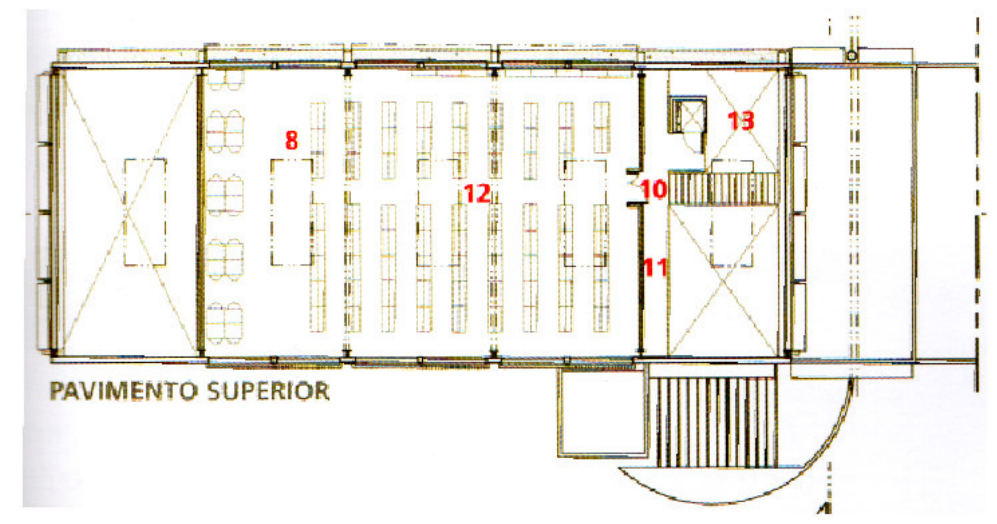

Figura 73 - Pavimento Superior/Biblioteca

Fonte:www. arcoweb.com.br

O projeto exprime, como na maioria dos exemplos apresentados de bibliotecas universitárias brasileiras, a grande preocupação para a solução dos problemas relacionados ao conforto ambiental, com a utilização de brises de proteção na fachada e revestimentos específicos e forros termoacústicos (Figura 81). Esse raciocínio é explicado, provavelmente, pelo aprofundamento projetual positivo que os edifícios de bibliotecas tem percorrido ao longo dos últimos anos no Brasil 


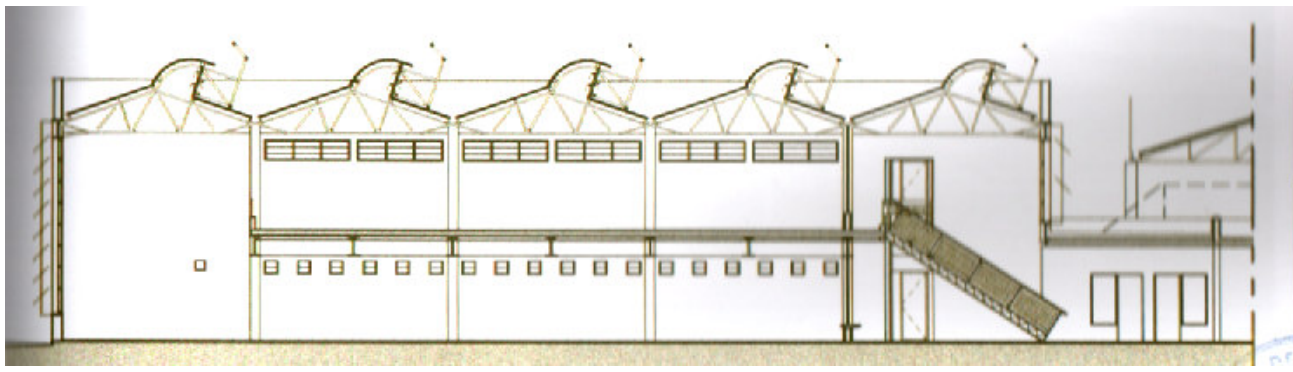

Figura 74 - Corte esquemático/ Biblioteca do Instituto de Economia da Universidade Estadual de Campinas

Fonte:www. arcoweb.com.br
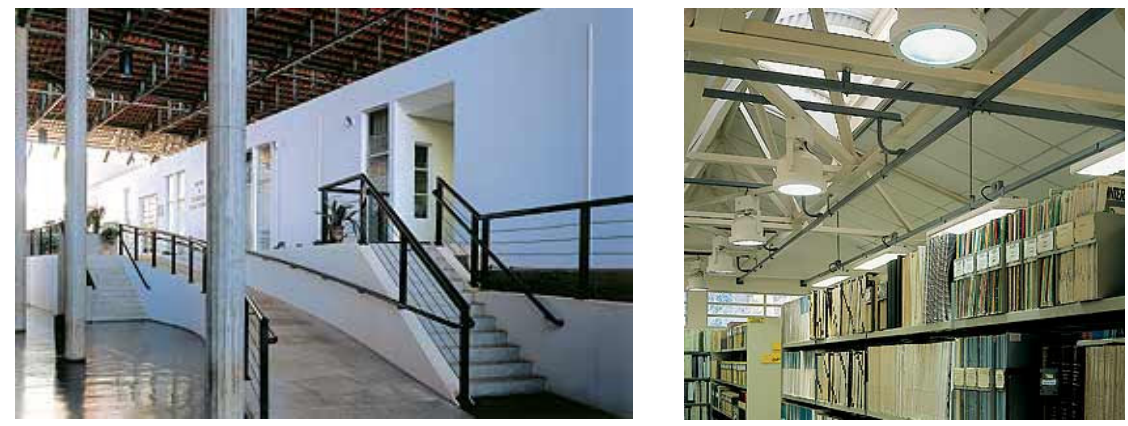

Figuras 75 e 76 - Entrada Lateral/Vista Interna/Estantes

Fonte:www. arcoweb.com.br

Em relação à definição dos espaços internos, o partido procura enfatizar a organização participativa na biblioteca, de modo que os usuários possam controlar visualmente o que acontece em todo o prédio (Figura 82), por parâmetros próprios de cores, formas e texturas. Esses elementos compositivos no espaço reforçam a qualidade inerente do tema arquitetônico do edifício a correta integração entre a informação disponibilizada e do usuário da universidade
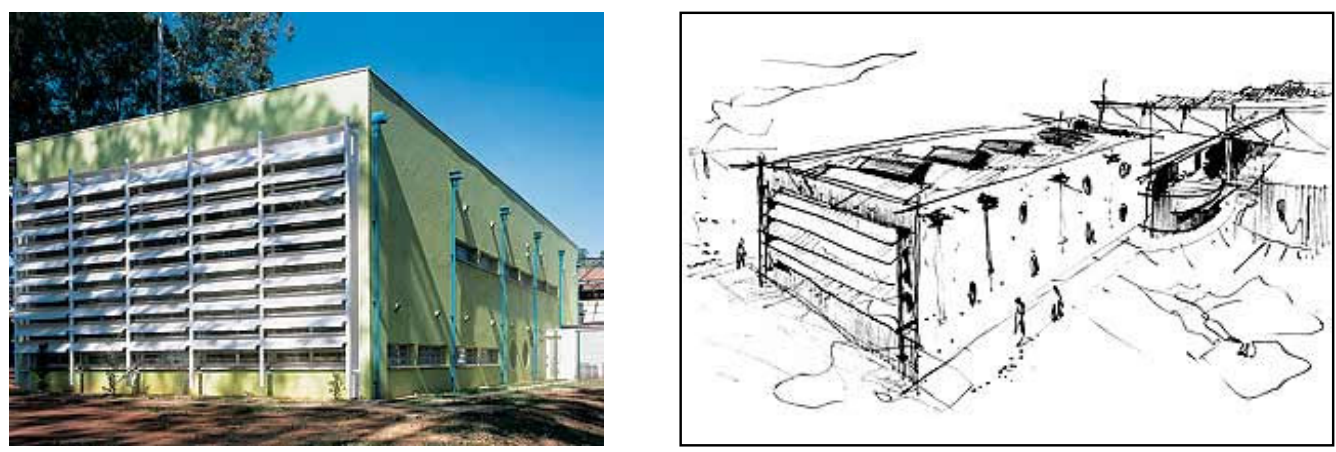

Figuras 77 e 78 - Vista Externa

Fonte:www. arcoweb.com.br 
Quanto aos materiais, tanto internamente como externamente, na biblioteca prevalece à utilização da idéia do mais prático, talvez, por ser tratar de um edifício inserido no contexto da área pública e por se saber que não existe a tradição de manutenção preventiva neste tipo de edificação. Portanto, a escolha dos materiais estabelece o critério de economia e durabilidade, facilitando as atividades de limpeza e conservação. Esse mesmo conceito é aplicado na cobertura de telha metálica (Figura 81), que recebeu tinta especial para diminuir a carga térmica e acústica e, nas paredes internas, tinta acrílica com verniz facilmente lavável. Dessa maneira, sem a proposta de sofisticação dos espaços e das soluções, o projeto acima de tudo, responde às aspirações do usuário, com soluções possíveis e concretas (MELENDEZ, 2003).
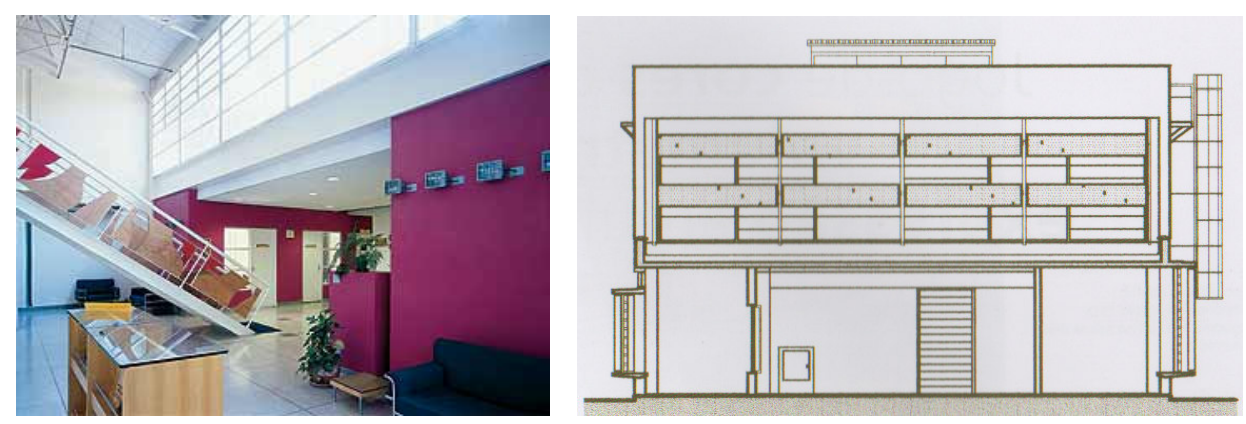

Figuras 79 e 80 - A escada metálica/Corte Esquemático/Biblioteca Fonte:www. arcoweb.com.br
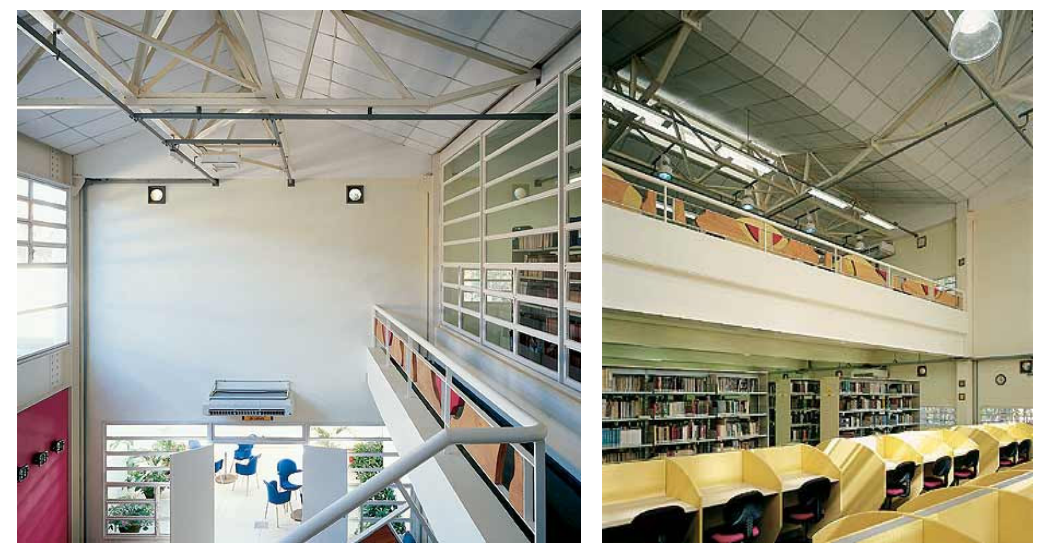

Figuras 81 e 82 - Vista Interna /Acervo e Leitura Fonte:www. arcoweb.com.br 
Quadro 12 - Biblioteca do Centro Universitário Positivo - UNICENP

\begin{tabular}{|c|c|c|c|c|c|}
\hline Projeto & $\begin{array}{l}\text { Biblioteca } \\
\text { UNICENP }\end{array}$ & do Cer & tro & Univer & ário Positivo \\
\hline Local & Curitiba-PR & & & $\begin{array}{l}\text { Ano de } \\
\text { construção }\end{array}$ & 2002 \\
\hline $\begin{array}{l}\text { Área } \\
\text { construída }\end{array}$ & $6.300 \mathrm{~m}^{2}$ & Arquitetos & \multicolumn{3}{|c|}{ Escritório Manoel Coelho Arquitetura e Design } \\
\hline
\end{tabular}

Outro exemplo, vem da Biblioteca da UNICENP - Universidade do

Positivo, em Curitiba - PR, edificada com o objetivo de ser uma construção com um destacado visual estético (Figura 83) e explorar com habilidade os diferentes recursos de composição arquitetônica. Uma leitura mais atenta da obra pode trazer algumas questões interessantes, não só nos aspectos relacionados ao modelo organizacional da informação, mas também nas respostas direcionadas à área da arquitetura.

O edifício da biblioteca apresenta um formato trapezoidal e o partido existente nas laterais e fachada de todo o prédio foi criado com o intuito de estimular a contemplação e o devaneio. Isso é possível pelo fato de a biblioteca estar cercada de intensa vegetação local, recomposta para proporcionar um ambiente mais agradável.
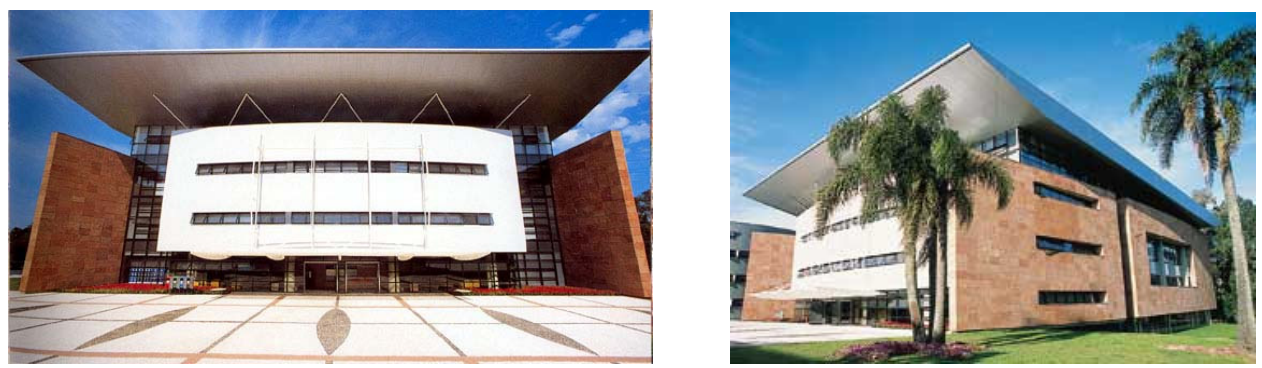

Figuras 83 e 84 - Visão da fachada lateral, rasgos evidenciam sobreposição de planos Fonte: biblioteca.unicenp.edu.br

As primeiras aproximações em relação a este edifício dão conta de temas bastante presentes na arquitetura contemporânea brasileira, principalmente em espaços de grande visibilidade como esse: "a obra como evento", "continuidade espacial" e "singularidade espacial". Entretanto, não resultam desses desdobramentos a incoerência e o desmerecimento da obra arquitetônica em si. Encarar a arquitetura como "evento" significa aproximar-se do conceito de arquitetura como resposta específica, 
circunstancial e expressão particularizada. A biblioteca analisada procura exatamente percorrer esse caminho, recorrendo às formas inusitadas de composição e estabelecendo uma relação única nos próprios parâmetros de implantação em relação ao campus universitário (GALBINSKI, 1993). Essa mesma preocupação é verificada no conceito do "espaço negativo", conseguido por meio de elementos contrastantes de composição em fachadas, como cheios e vazios e claros e escuros (Figura 84). Nesse caso, a idéia dos contrastes é levada até as últimas conseqüências, principalmente no prolongamento da cobertura que parece flutuar e incorporar um certo ar de desafio em relação às forças estruturais da edificação (Figura 84).

A tendência do partido arquitetônico da biblioteca é desmembrar e recompor formas, além de atender às exigências programáticas de vãos, janelas e aberturas. Por meio da decomposição de formas obtém-se justamente a "continuidade espacial" referida anteriormente, pela interpenetração dos espaços e a supressão de qualquer hierarquia de planos. Explicam-se, assim, os grandes vãos de janelas, o pédireito valorizado e o tratamento monumental dos espaços interiores (WEHRPLOTZ; CANDIDO; BONO, 2001). Vale lembrar ainda que, a biblioteca exteriormente mantém um forte aspecto de horizontalidade, privilegiando a ordenamento racional e equilibrado (Figura 84).

Já os interiores apresentam fluxos claros, espaços integrados, sinalização precisa e um mobiliário que compõe um ar de sobriedade e praticidade. De acordo com Melendez (2003c, p. 66), “[...] A imagem dos interiores de um transatlântico é evocada por Coelho para descrever o que tinha em mente ao desenhar o espaço interno".
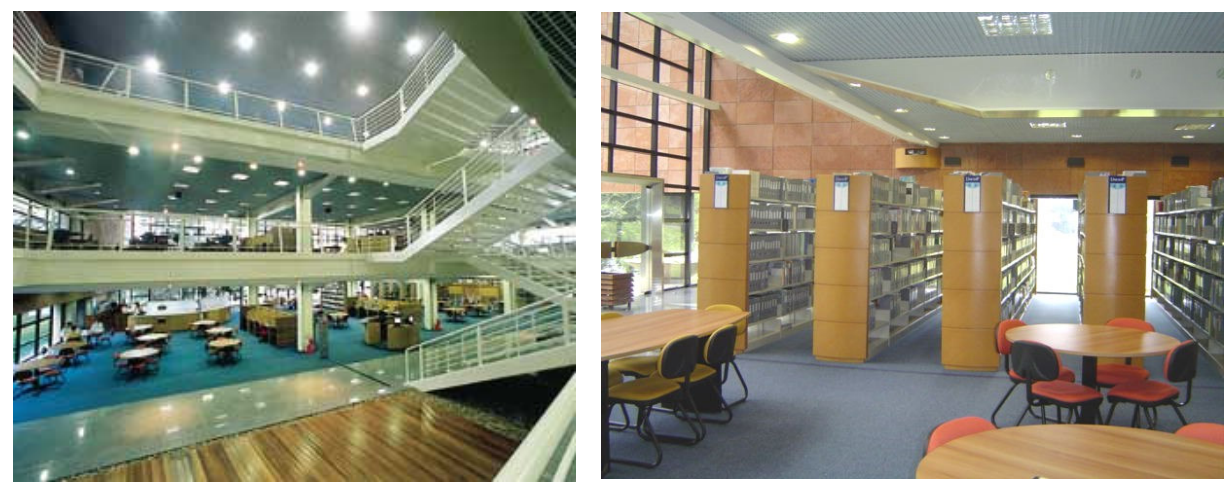

Figuras 85 e 86 - Vista Interna da biblioteca Fonte: biblioteca.unicenp.edu.br 

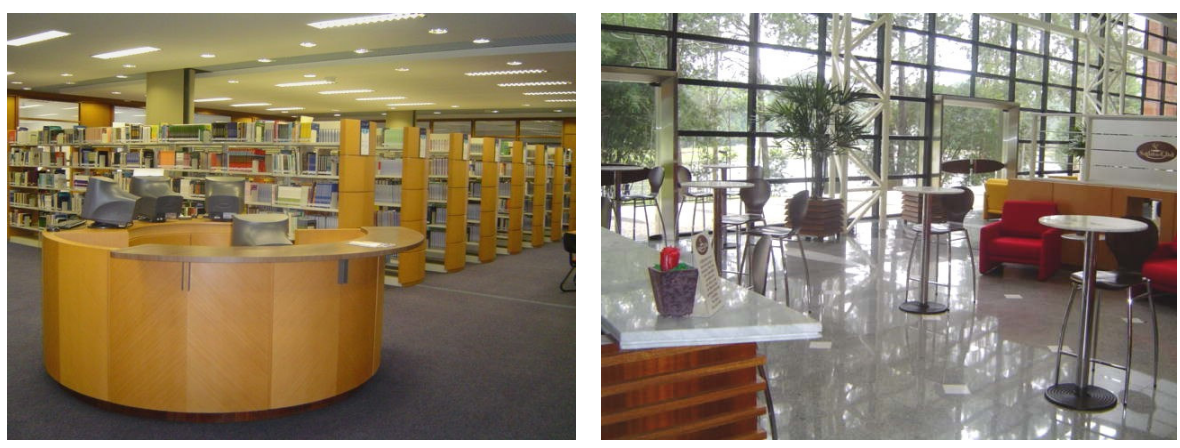

Figuras 87 e 88 - Vista Interna da biblioteca

Fonte: http://biblioteca.unicenp.edu.br

A preocupação em evidenciar cada parte do edifício da biblioteca em relação à sua destinação de uso permeia as soluções arquitetônicas dos espaços. $\mathrm{O}$ edifício está demarcado na horizontal por quatro andares de planta livre e na vertical, por um grande átrio central (Figura 85), definido como uma área de ponto de encontro dos usuários. A partir da definição desse sistema ordenador, o edifício estabelece uma relação equilibrada dos cheios e vazios, além de fixar que as formas livres desempenham a função do programa, diferenciando-as e estabelecendo a contrapartida desse sistema. Mais uma vez a temática de trabalhar a informação como pólo gerador das atividades desenvolvidas no espaço da biblioteca, é conseguida a partir da adequação de um ambiente cultural fértil. Assim, sem procurar criar uma arquitetura desprendida de seu contexto e vizinhança próxima, a biblioteca produz um espaço que assume francamente um compromisso social na consolidação do tecido urbano do campus sem retirar o seu caráter particular de biblioteca universitária. 


\begin{tabular}{|l|l|l|l|l|}
\hline \multicolumn{1}{|c|}{ Projeto } & \multicolumn{1}{|c|}{ Biblioteca da Pós-Graduação da FAUUSP- Maranhão } \\
\hline \multicolumn{1}{|c|}{ Local } & \multicolumn{2}{|c|}{$\begin{array}{l}\text { São Paulo-SP } \\
\text { Ano de } \\
\text { construção }\end{array}$} & 2002 \\
\hline $\begin{array}{l}\text { Area } \\
\text { construída }\end{array}$ & $250 \mathrm{~m}^{2}$ & Arquitetos & $\begin{array}{l}\text { Escritório Piratininga Arquitetos associados - José } \\
\text { Armênio de Brito Cruz. }\end{array}$ \\
\hline
\end{tabular}

As novas instalações da Biblioteca de Pós-Graduação da FAU - USP, na Rua Maranhão, bairro de Higienópolis em São Paulo, são parte do importante casarão centenário da família Penteado. Nesse projeto foram restaurados e recuperados seus ambientes internos, pinturas e murais. Além disso, o projeto da biblioteca é um referencial para a recuperação do restante do prédio.

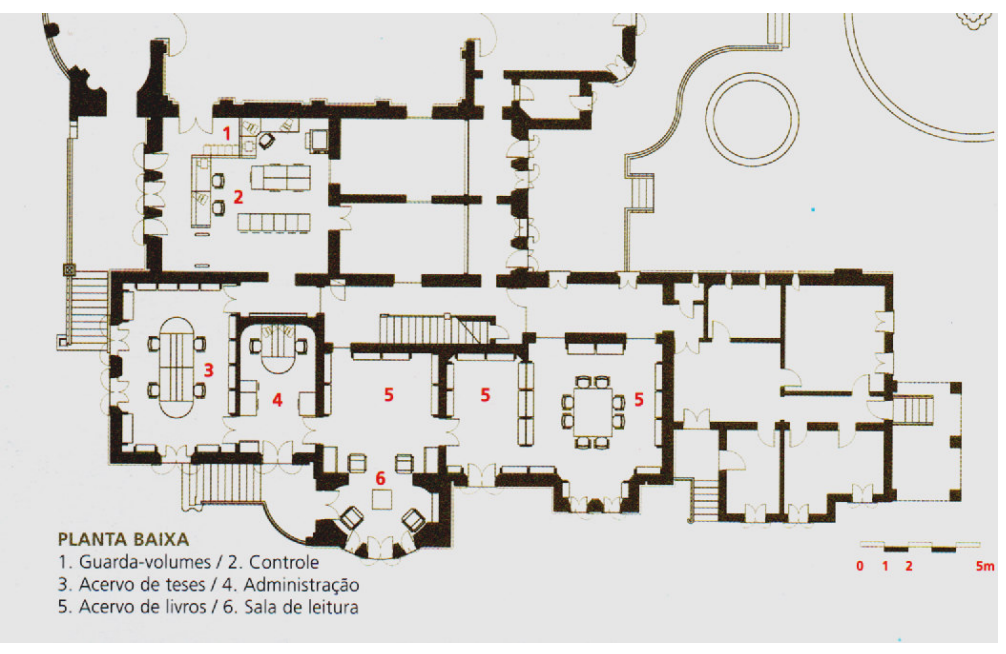

Figura 89 - Planta Biblioteca FAU-Maranhão

Fonte: www.revistaau.com.br

Em relação a este projeto, é importante, antes de tudo, discutir de forma sucinta a questão da preservação dos monumentos tombados, pois envolvem soluções não exclusivamente técnicas, de projeto ou restauro, mas também elementos vinculados à cultura e estéticos. $\mathrm{Na}$ verdade, essas intervenções se moldam por um rigoroso equilíbrio entre o atendimento às novas necessidades funcionais e o respeito aos valores do monumento, ressaltando inclusive sua relação com o contexto cultural, social e urbano. Nos casos específicos de restauros e recuperações, como é neste caso, algumas 
características são intrínsecas ao projeto e quem comanda todo o processo é próprio monumento a ser restaurado, ou seja, a partir de elementos concretos, impregnados de valores e significados, instala-se o processo de reapropriação, visto que, o monumento e sua arquitetura são itens preexistentes nesse caminho e devem ser preservados (MENEGUELLO, 2006). Nesse ponto, insere-se o caso da Biblioteca de Pós-Graduação da FAU - USP, podendo-se avaliar melhor como surgem essas dificuldades, como são equacionadas e como são tratadas as soluções arquitetônicas.
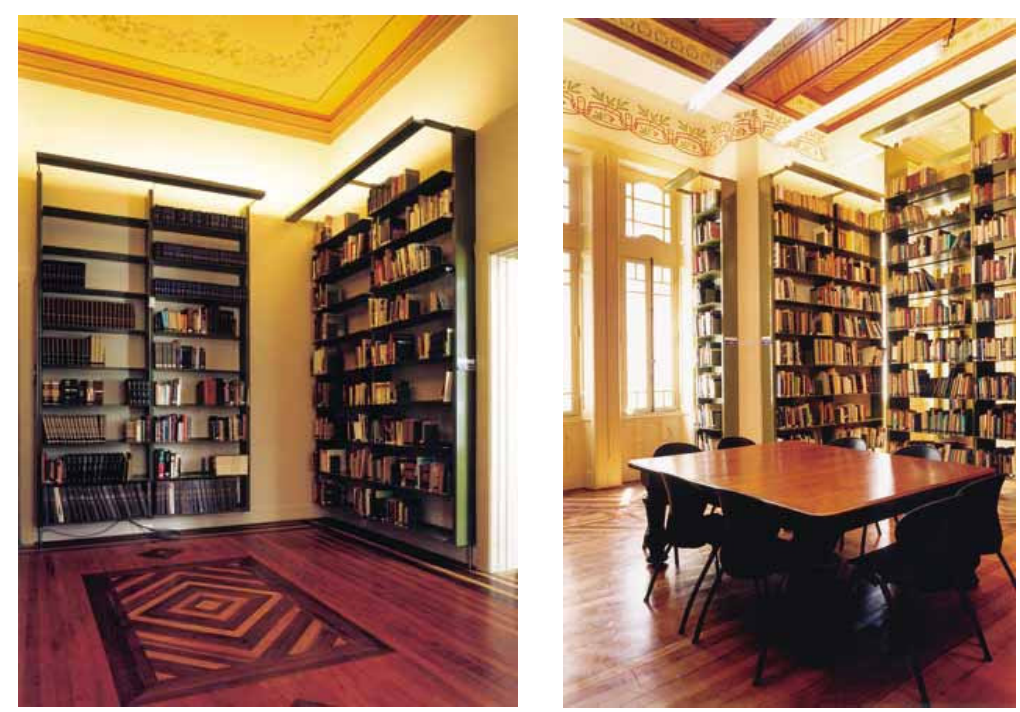

Figuras 90 e 91 - Fixação das prateleiras nas paredes / Biblioteca FAU-Maranhão Fonte: www.revistaau.com.br/
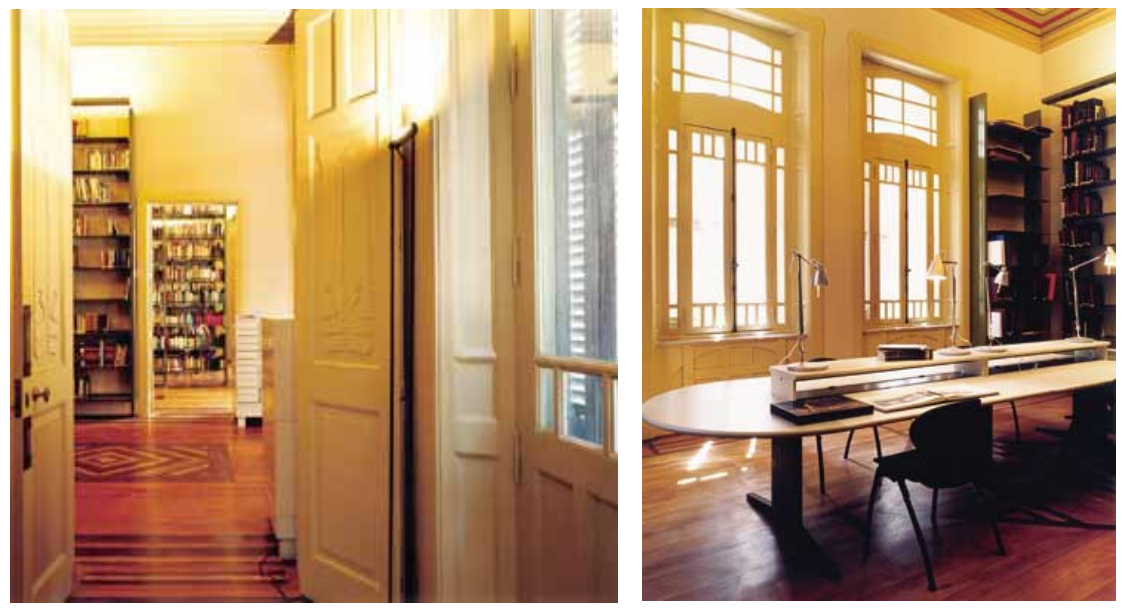

Figuras 92 e 93 - Vista Interna/ Biblioteca FAU-Maranhão

Fonte: www.revistaau.com.br 


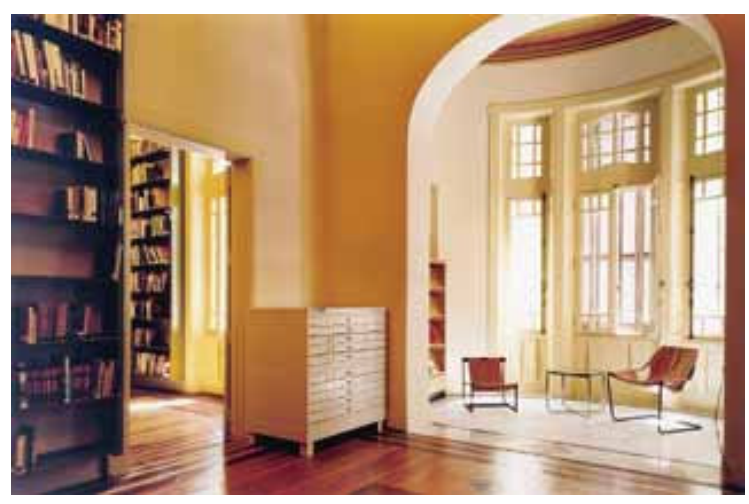

Figura 94 - Vista Interna/ Biblioteca FAU-Maranhão

Fonte: www.revistaau.com.br

O primeiro problema encontrado neste projeto foi resolver a importante relação que se estabelece entre o edifício histórico e seu novo uso - uma biblioteca de pós-graduação nas áreas da arquitetura e urbanismo. Para essa intervenção é preciso entender primeiramente que esse edifício da biblioteca nasce dentro de uma nova lógica de valores, significados e usos. Tratando-se da operação mais delicada de todo o processo de restauração e requalificação do monumento, porque deveriam conviver, no mesmo território, a marca do desenho contemporâneo e os valores impregnados do prédio histórico em questão. Ou seja, novo e velho estabeleceriam uma nova relação de fruição no espaço, sem detrimento das qualidades específicas do edifício restaurado e dos equipamentos modernos a serem introduzidos (MOURA, 2003).

Tendo esses elementos como balizadores do partido arquitetônico adotado, destacandom-se algumas ações concretas no sentido para viabilizar a preservação do prédio histórico e a instalação do novo espaço de biblioteca. $O$ meticuloso trabalho de resgate dos principais elementos históricos da edificação da Vila Penteado, presentes nos desenhos decorativos no teto e nos imponentes pisos de madeira das salas, foi uma das principais premissas que nortearam o projeto de restauro do espaço. Além disso, era imprescindível a instalação harmoniosa das prateleiras dos livros (Figura 90), sem que houvesse prejuízo tanto nas cargas direcionadas diretamente nas fundações quanto no aspecto de interferência visual dos elementos restaurados. Dessa forma, foram projetadas estantes especiais de aço delgado, fixadas diretamente nas paredes de alvenaria e liberadas dos assoalhos de madeira.

A presença da luz teve papel fundamental no caráter na valorização dos elementos restaurados e revitalizados do edifício, bem como no destaque dos novos espaços projetados da biblioteca. $\mathrm{Na}$ parte superior das estantes foram instaladas 
luminárias especiais que, direcionadas sobre o forro, destacam a pintura restaurada e iluminam o ambiente de forma indireta. Além disso, todas as mesas de estudo e pesquisa contemplam luminárias direcionadas que auxiliam no trabalho diário de usuários e estudantes. A luz natural do ambiente, proveniente de imensos janelões (Figura 93), posiciona-se estrategicamente no alinhamento central das paredes das salas e cria uma interessante atmosfera de nuances, cores e matizes ao longo dos ambientes. $\mathrm{Na}$ verdade, todas essas janelas foram preservadas e incorporadas ao novo layout dos espaços da biblioteca, propondo-se, inclusive, o fechamento de um alpendre lateral existente, para a instalação de uma pequena saleta de jornais e periódicos (Figura 94).

Tais intervenções foram possíveis, pela perfeita consonância com o vocabulário arquitetônico do prédio histórico e a proposta da nova biblioteca. Realmente, o grande desafio foi dotar o edifício de um novo semblante, adaptando-o a um outro propósito que se sobrepunha às funções precedentes. Agora, pelo contrário, buscou-se a reabilitação ou revalorização das marcas deixadas pelas diferenças históricas e sucessivas de intervenções. Acima de tudo, o projeto dessa biblioteca tem o mérito de moldar um novo organismo, constituído de novos espaços e elementos arquitetônicos remanescentes ou recapturados. A sua forma está definida pela aglutinação de valores persistentes e significados especiais relacionados com sua história e, além disso, atende às necessidades funcionais de um novo uso e um novo espaço arquitetural (MOURA, 2003).

No caso do Brasil, pode-se concluir que, apesar do salto qualitativo nos últimos anos nos espaços de bibliotecas universitárias, quando analisadas sob o olhar crítico de suas intervenções e sua espacialidades, ainda há apresenta problemas relacionados à formulação de um método projetivo coerente para a produção desses espaços, ou seja, uma metodologia projetual que realmente atenda as variantes tipológicas, morfológicas e tecnológicas (MIRANDA, 1998). Este problema suscita outro mais amplo e geral: a falta de um acompanhamento analítico e constante, por parte da arquitetura, de instrumentos que permitam controlar as diversas fases de seleção, utilização e análise das experiências de projetos de bibliotecas universitárias. A complexidade deste objetivo, a amplitude e as possibilidades de intervenção representam o grande desafio de uma pesquisa realmente científica em arquitetura que responda claramente nos anseios das diversas disciplinas envolvidas nesse campo de trabalho. 
Diante disso, surgem algumas questões : quais os desafios e caminhos a seguir, a fim de garantir coerência nos espaços definidos como bibliotecas universitárias? Ou, mais que isso, como a arquitetura pode oferecer melhores possibilidades de ocupação para esses espaços, por meio do estabelecimento de padrões, diretrizes e métodos de aferimento de confiabilidade?

De fato, ainda que os resultados positivos venham sendo contabilizados no planejamento dos espaços de bibliotecas universitárias no Brasil, principalmente entendendo os aspectos de armazenamento de coleções, acesso, uso, fluxos e serviços, há necessidade de uma série de cuidados e procedimentos serem tomados nas definições de partidos e projetos arquitetônicos relacionados à temática apresentada. São eles:

a) Planejamento e adequação das instalações físicas - Em geral, as bibliotecas universitárias brasileiras convivem com problemas derivados da necessidade de instalações e espaços físicos insuficientes para armazenar seus acervos quanto para prover serviços aos seus usuários. Em todos os âmbitos da discussão dessa problemática, a questão ficou centrada na preocupação de acomodar o crescente aumento de coleções na biblioteca. Dessa maneira, administradores e diretores voltaram a resgatar o papel imprescindível do planejamento arquitetônico desses locais, como forma de garantir e adaptar às novas e constantes demandas dos programas informacionais. (AUGOSTINHO, 1987; MIRANDA, 1998; FIALHO, 2000). Por outro lado, com os impactos sentidos por meio dos suportes digitais e os novos meios tecnológicos comunicacionais, a biblioteca universitária tradicional se viu diante de um ambiente de rápida mudança, tendo que repensar como ela deveria coexistir em um espaço conectado a uma ampla variedade de recursos informacionais (CUNHA, 2007). Para isso, novas abordagens e necessidades se colocam frente à aquisição de equipamentos computacionais, instalação de cabeamento em fibra ótica, redes locais e outras tecnologias da informação que começam a fazer parte da moderna biblioteca universitária brasileira. Ainda, o planejamento dos espaços passa necessariamente a adequar os locais liberados com o abandono parcial ou total dos catálogos tradicionais de fichas para abrigar os terminais necessários ao catálogo informatizado; deve, portanto, prover pontos de acesso no qual o 
próprio usuário ligará o seu equipamento portátil, a fim de utilizar o sistema da biblioteca para acessar a informação (DODEBEI, 2006).

b) Adaptações ao espaço arquitetônico: Apesar de existirem, no Brasil, bons prédios de bibliotecas universitárias projetados especificamente para seu funcionamento, muitas ainda estão instaladas em edifícios que não foram construídos para este fim. Dessa forma, tanto em prédios próprios, quanto em espaços adaptados, o estudo do interior das bibliotecas exigirá atenção bastante especial. Quando instalada em prédios adaptados, a questão do planejamento arquitetônico deve se voltar aos limites vinculados à estrutura existente, prioritariamente aos quesitos relacionados às área de acesso (escadas, elevadores, portas), áreas com infra-estrutura hidráulica (sanitários, cozinhas), iluminação natural (janelas, vitrôs) e carga de peso que a estrutura suporta. Essa análise é vital, porque, em função dela, direcionam-se ações e planos de adaptações em espaços já existentes (RIBENBOIM, 2001).

c) Análise dos aspectos perceptivos: O estudo do espaço perceptivo tem-se mostrado bastante útil nas aplicações do planejamento arquitetônico dos edifícios de bibliotecas, na medida em que fornece subsídios concretos de territorialidade, privacidade, identidade e ambiência. A leitura de espacializações presente nos ambientes das bibliotecas deve ser basicamente um procedimento no qual são considerados todos os registros a respeito do espaço arquitetural em estudo (fotos, mapas, plantas, desenhos, entrevistas), observando-se a presença de conflitos entre as formas sociais e os elementos espaciais ausentes ou inadequados, que afetam a apropriação do espaço. Esses conflitos devem ser descritos exaustivamente e isso é uma característica importante do método aplicado, nos termos de uma abordagem fenomenológica, o marco teórico para a técnica de leituras de espacializações (MOORE, 1984).

d) Análise do crescimento do número de usuários: Pelos dados estatísticos, os serviços fornecidos pelas universidades brasileiras continuam a crescer numa velocidade assustadora; por conseguinte, o número de alunos que irá passar nos espaços das bibliotecas destas unidades continuará a aumentar na mesma proporção. Portanto, é bastante prudente que os edifícios destinados às bibliotecas universitárias estejam previamente qualificados no tocante à provisão de informação dentro dos programas do ensino superior no Brasil (RUSSO, 1998; LEMOS \& MACEDO, 2001; OLIVEIRA, 2006). 
e) Conhecimento da organização do acervo informacional: $\mathrm{O}$ conhecimento apurado de todo o processo técnico informacional, que acontece no ambiente da biblioteca universitária e se faz desde a chegada do material bibliográfico, catalogação, indexação e disseminação da informação, deve ser parte integrante e conhecida de toda a equipe responsável do projeto arquitetônico deste edifício. Principalmente agora, quando se discute a inclusão da informação digital, com a utilização de textos completos de periódicos, imagens digitais, dados numéricos e multimídia, esse setor é desafiado a prover novas estruturais informacionais e arranjos espaciais bem diferentes daqueles tradicionalmente arrolados pelo controle bibliográfico (GALBINSKI, 1993).

f) Novas infra-estruturas: Hoje em dia, as bibliotecas universitárias possuem importante papel na formação de alianças, atuando como parceiras de empresas e pesquisadores. A elas cabem o apoio e o suporte informacional, de localização, seleção, tratamento e disponibilidade da informação que será vital em uma dada pesquisa e a fazem uso de cooperação e troca de informações, as bibliotecas, também parceiras, poderão agilizar o trabalho dos pesquisadores, influenciando nas decisões referentes à estratégia e à alocação de capital e investimentos no universo da pesquisa. Dessa maneira, o espaço físico das bibliotecas universitárias deve ser propício a atender às novas infra-estruturas de apoio a esses serviços de cooperação em todos os setores da sociedade da informação (CUNHA, 2007). 


\section{CAPÍTULO 4 - LINGUAGEM ARQUITETÔNICA E AMBIENTAÇÃO FÍSICA}

\subsection{Concepções e Funções Espaciais}

A biblioteca sempre desempenhou sua função de forma clara e definida, a despeito das recentes inovações tecnológicas presentes em nosso dia-a-dia. Sob esta ótica, o armazenamento, o tratamento e a disseminação de informação trazem no contexto da sociedade, sua verdadeira função de utilidade e processo transformador. Até agora, a grande massa de conteúdo informacional estava contida, principalmente, nos suportes tradicionais impressos como os livros, as revistas, os folhetos ou os periódicos. Entretanto, as profundas mudanças nos métodos de armazenamento e recuperação de informação, dadas principalmente pelas novas tecnologias informacionais, têm modificado esse processo radicalmente.

Mesmo diante deste quadro de alterações no contexto das bibliotecas, as quatro operações básicas presentes nos serviços informacionais estarão sempre funcionando independente dos meios utilizados para produzir o armazenamento da informação no espaço da biblioteca. Essas quatro operações são:

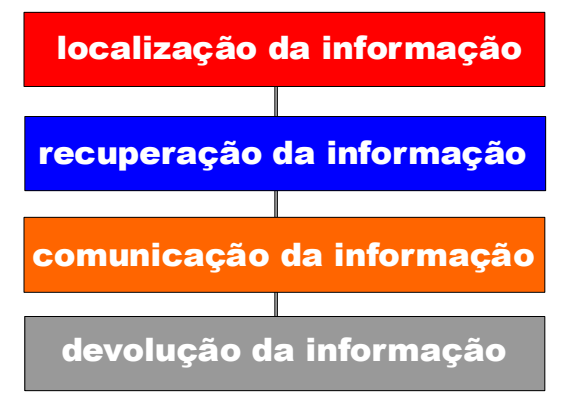

Tabela 01 - Etapas nos serviços informacionais

Este ciclo funciona independente das dimensões consideradas da biblioteca, e, via de regra, pode ser determinado em função dos elementos geradores da complexidade espacial e das dimensões em que a informação será depositada. No entendimento deste ciclo, a localização, a recuperação, a comunicação e a devolução forma uma seqüência de operações que interfere em grande medida no processo criativo de um projeto de biblioteca. Isso porque, se os dados informacionais que estiverem contidos nos livros forem catalogados de forma errada, o resultado final arquitetônico 
da biblioteca provavelmente será completamente diferenciado daquele projeto inicial. Nesta interface, o mais importante para o projeto do edifício é que ele seja produto natural desse ciclo, gerando espaços completamente comprometidos com sua função.

No caso das bibliotecas universitárias de pequeno porte, o projeto do espaço e suas relações entre si também depende da importância relativa que elas assinalam no contexto do edifício. Essa importância relativa pode variar em função do tipo de informação que a biblioteca necessita ter em seu acervo, ou seja, em que área do conhecimento científico a biblioteca trabalha. Pode-se dizer que esse fato é a marca distintiva de cada tipo de edifício entre os que desempenham o serviço de biblioteca universitária. Essa diferença ou escalonamento de importância, dentro do ciclo de uso, tem suas repercussões na organização arquitetônica do edifício.

Diante desses fatos, é possível extrair algumas lições importantes no planejamento e na construção das pequenas bibliotecas universitárias:

1. Bibliotecas que tratam temáticas como, por exemplo, ficção e formas literárias, podem pensar a localização do seu acervo de maneira livre e aberta. O livro deve ser encontrado de forma rápida e precisa, permitindo que o usuário faça sua busca entre seus favoritos e, principalmente, elegendo suas novidades. Na maioria dos casos, o leitor pode localizar a informação sem recorrer ao catálogo.

2. A recuperação da informação deve ser executada também pelo usuário, imediatamente após a sua localização; ambas as operações devem acontecer quase que simultaneamente. Alguma comunicação inicial do tipo de uma toma de mostra pode acontecer tão logo foi pego o livro, mas a massa maior da comunicação só deve ter lugar fora da biblioteca ou em sua casa. A devolução do livro para ser arquivado deve ser feita somente a uma pessoa responsável da biblioteca.

Uma biblioteca universitária de pequeno porte deve ser parte integrante dos serviços de uma comunidade acadêmica e, portanto, suas expectativas e anseios devem ser vislumbrados a todo o momento e em todos os níveis. O espaço da biblioteca deve permitir facilidade de acesso aos acervos e às coleções, bem como o acesso às salas destinadas à leitura e pesquisa. O desenho espacial deve, então, ser capaz de satisfazer os gostos dos leitores habituais, mas também daquele que não está habituado a ir até ela. Portanto, tal situação não deve ser incompatível com a indispensável 
necessidade de tranqüilidade e silêncio dos usuários, mas deve permitir a possibilidade de novas ampliações.

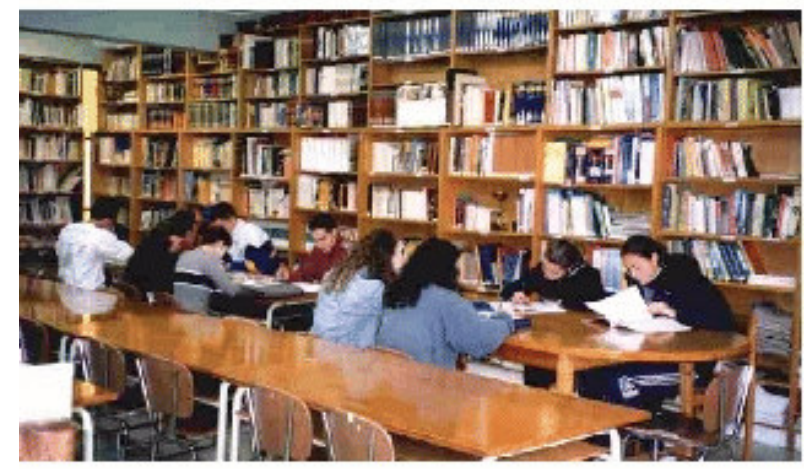

Figura 95 - Biblioteca Universitária de Pequeno Porte/Colômbia Fonte: www.radioventisqueros.cl/

Outro aspecto importante na definição das diretrizes projetuais de uma biblioteca universitária de pequeno porte leva em conta o grau de comprometimento que ela desempenha junto à comunidade acadêmica. Geralmente, se o projeto proposto tem como razão responder satisfatoriamente aos anseios pertinentes dos usuários, determinando um espaço agradável e prazeroso para utilização de suas tarefas, os quesitos de implantação e grau de acessibilidade se tornam indispensáveis. Dentro desta idéia, as bibliotecas universitárias podem ser transformadas em pontos de encontro, não só dos alunos, mas também de toda a comunidade. Em função disso, devem ser previstos nesses projetos ambientes aptos e preparados para o desenvolvimento de tais atividades, como por exemplo, praças, auditórios, salas multiuso, etc.

Uma das principais características na definição e implementação de um projeto arquitetônico de biblioteca universitária consiste no planejamento prévio de três elementos padrões para instalações desses espaços. O primeiro diz respeito às áreas de armazenamento da coleção (acervo); segundo, ao local destinado ao trabalho dos funcionários; e, em último lugar, o local de leitura para os usuários. O planejamento arquitetônico destes espaços, sempre que possível, deve ser um trabalho conjunto entre o bibliotecário da instituição, assessorado pela sua equipe de trabalho e um arquiteto. $\mathrm{O}$ bibliotecário deve fixar para o arquiteto as funções básicas da biblioteca, por gráficos, diagramas, organogramas e fluxogramas, demonstrando como as funções são realizadas, a quantidade de usuários, faixa etária, a maneira de utilização da biblioteca e seus ambientes, considerando as relações e integração dos serviços e setores, demonstrando 
como a biblioteca organiza seu expediente, seus serviços e pessoal para desempenhar suas funções e o número médio de funcionários disponíveis. Vale lembrar que o conhecimento da rotina dos serviços possibilitará ao arquiteto a compreensão, que o orientará na disposição das áreas para chegar à previsão de espaços necessários, sempre considerando os usuários, inclusive os portadores de deficiências físicas, equipamentos e exigências ambientais. Em suma, o arquiteto deve participar de todas as etapas do processo de distribuição dos espaços, trabalhando de forma integrada com o bibliotecário para que o projeto final resulte na elaboração de uma biblioteca adequada às finalidades propostas.

\subsection{Tipos de Acervo}

A distinção entre a utilização dos acessos abertos ou fechados em bibliotecas universitárias foi um tema amplamente debatido entre bibliotecários e arquitetos em um passado recente, pois formatava a importância para o desempenho do edifício da biblioteca. É importante ressaltar que a decisão acerca do uso do acervo fechado ou aberto, em bibliotecas universitárias, tem repercussão direta no planejamento e no desenho dos locais destinados, tanto para a leitura como para os ambientes destinados ao armazenamento dos livros.

A seguir, apresenta-se os dois tipos existentes de acervos, exemplificando suas vantagens e desvantagens no contexto da biblioteca universitária:

\subsubsection{Acervo Aberto}

Já no desenho dos espaços abertos, os usuários têm livre acesso às prateleiras e podem retirar o livro que desejam para fazer a leitura ou consulta, de modo que os locais de arquivos e comunicações devem estar agrupados perto um dos outros. A eleição entre esses sistemas, no projeto de uma biblioteca universitária, vai depender em grande parte do tamanho do acervo e do espaço disponível a ele. É preciso entender que quanto maior for a quantidade de livros no acervo, maior será a dificuldade de armazenamento de novos títulos e, provavelmente, maior o tempo gasto pelo bibliotecário em seu arquivamento. Nos casos em que onde uma extensa coleção de livros atende um número restrito de leitores, a relação desigual entre os locais de armazenamento de livros e os destinados aos leitores estará bastante evidente. O ideal 
nessas situações é que haja um certo equilíbrio entre os acervos disponibilizados na biblioteca e o número estimado de usuários que freqüentam o local.
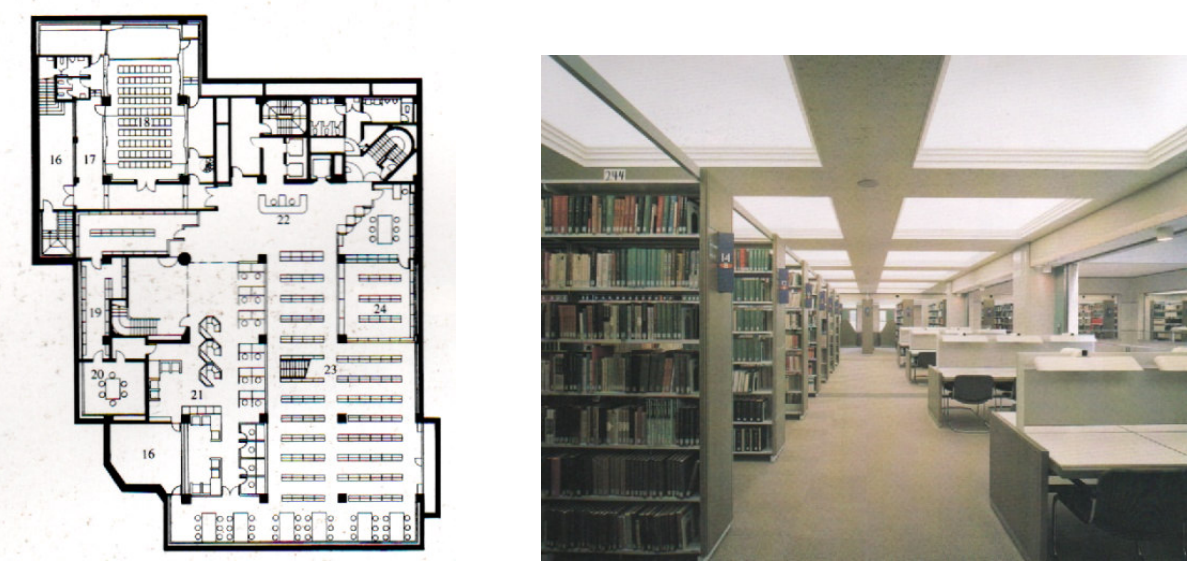

Figuras 96 e 97 - Biblioteca da Universidade de Seijo/Japão Fonte: KITO, 1995 p.128.

Quanto aos espaços destinados às consultas de catálogos e fichas bibliográficas, a maioria das bibliotecas universitárias dispõe de ambientes de consulta geralmente posicionados no hall de entrada principal, nas áreas centrais do edifício. Essa estratégia se explica porque, em parte, esse espaço será o primeiro local avistado pelo usuário que adentra à biblioteca e, evidentemente, os principais títulos do acervo estarão disponíveis para serem consultados. O próximo passo será a busca do material de consulta, executado pelo próprio pessoal da biblioteca ou mesmo pelo usuário e, nestas circunstâncias, essa ação dependerá do tipo de acervo que a biblioteca tenha estipulado, aberto ou fechado.

Outro aspecto importante no desenho do acesso aberto destinado às bibliotecas universitárias consiste na compatibilização que deve existir entre os ambientes destinados à leitura e pesquisa e as áreas de circulação de pessoas que estão adjacentes a estas salas. Se essa separação não for bem equacionada, um grande foco de conflito pode existir em função daquelas pessoas que querem preservar o silêncio e os outros usuários que necessitam recorrer aos livros das estantes. Essa contradição de usos é mais fácil de resolver quando os livros estão perto dos leitores e quando as prateleiras são proporcionais com uma boa proteção em relação aos usuários. A organização espacial resulta de um sistema de acessos abertos especialmente adequados à maneira 
como uma biblioteca de investigação pode ser usada com eficiência. Vale lembrar que esta relação estabelecida entre o usuário e o local ocupado pelo acervo de livros deve resultar numa solução apropriada, particularmente, no conforto lumínico dos espaços, nos elementos de distribuição do mobiliário e nas soluções de rotas de circulação pelo interior do edifício. Isto significa dizer que a decisão a respeito da maneira com que o sistema aberto deva ser projetado e utilizado, varia conforme o tipo da biblioteca.

Hoje em dia, com utilização do sistema aberto em bibliotecas universitárias, é possível planejar corredores mais estreitos, empregando largura mínima de $90 \mathrm{~cm}$, especialmente quando o número de pessoas que fazem uso da biblioteca é reduzido. Dessa maneira, a capacidade de armazenamento do acervo pode chegar em até $15 \%$, referendando a idéia de melhor aproveitamento dos espaços e ganhos no gerenciamento das atividades desenvolvidas no âmbito da biblioteca.

Portanto, o ideal é que o local para consultas do material bibliográfico esteja o mais próximo possível; em outras palavras, mesas e cadeiras deve estar agrupadas junto às estantes ou inclusas em grupos. Esta disposição é bastante comum, especialmente nas bibliotecas universitárias americanas e nas novas bibliotecas da Inglaterra. A idéia é que o usuário examine o material sem a necessidade de ter um trabalho árduo e penoso de buscar uma ficha ou marcar em um disco numerado o código correspondente ao livro que solicita.

Outro ponto crítico na definição do sistema de acesso ao acervo de uma biblioteca universitária é o aumento considerável de material bibliográfico presente no acervo. Estudos recentes demonstram que, em bibliotecas universitárias de médio e grande portes, o aumento da coleção bibliográfica tem girado em torno de $50 \%$ ou até $85 \%$ de sua plena capacidade em pouco mais de 13 anos. Em face desses números, é conveniente que, mesmo durante a fase do projeto, todas as possibilidades e hipóteses que envolvam as atividades de planejamento e aquisição do material bibliográfico passem por um minucioso cálculo de suas atividades, permitindo que os espaços destinados a este acervo tenham uma margem de 50\% pelo menos de sua capacidade. Essa estratégia garante ao planejamento arquitetônico da biblioteca uma visão organizada e sistêmica do processo de estruturação dos espaços que deverão sofrer aumento no contexto da capacidade de armazenamento. É evidente que o entendimento entre o planejamento arquitetônico dos espaços de uma biblioteca universitária e o aumento diário do acervo bibliográfico produzido por ela devem passar necessariamente pelo grau de flexibilidade para futuras ampliações. 


\subsubsection{Acervo Fechado}

A respeito dos acessos fechados, o armazenamento de livros está em uma área separada dos locais de leitura e o pessoal que trabalha na biblioteca fica encarregado a levar o livro até os locais de leitura e pesquisa. Nessa operação, alguns equipamentos mecânicos podem auxiliar na operação de busca e reposição dos livros que estão dispostos nas prateleiras. O sistema fechado permite desenhar compartimentos pré-definidos ou locais previamente estipulados; no acervo aberto, a distribuição é entrelaçada com as classes de locais temáticas, permitindo uma maior flexibilidade na distribuição das estantes Uma das principais vantagens da adoção do sistema fechado corresponde na possibilidade de se planejar um espaço arquitetônico mais adequado aos interesses da própria biblioteca, principalmente no que diz respeito aos métodos de armazenamento dos livros e à disposição das estantes. Nestes casos, o funcionário da biblioteca terá maior liberdade na sua própria circulação, no encaminhamento do material circulante e no serviço de apoio ao usuário.

\subsection{Localização da Informação no Acervo}

Dois aspectos importantes compõem as atividades relacionadas à localização da informação no espaço de uma biblioteca universitária: o primeiro referese ao descobrimento do manancial em que provavelmente estará contida a informação; o segundo corresponde à localização desse material no arquivo da biblioteca, de maneira que se possa fazer sua extração e entrega ao próprio usuário. O primeiro aspecto denota inevitavelmente, uma questão de organização espacial e traz conseqüências diretas na concepção arquitetônica da biblioteca. Cabe observar que, no processo de localização da informação, existe uma considerável diferença entre fazer a busca manualmente ou executar esta operação eletronicamente. A busca manual tem lugar no índice bibliográfico ou no arquivo de catálogos impressos encadernados em forma de livro. Neste caso, a busca tem lugar em um local específico, próprio para as atividades de consulta e encaminhamento das informações requeridas. É importante frisar que as dimensões deste local estão diretamente relacionadas com o volume da coleção da biblioteca e seu complexo e a quantidade de referências que se solicitem. No caso da busca eletrônica, terminais de computadores ficam disponíveis aos usuários e conectados às bases de dados do acervo da biblioteca. Esses terminais não estão 
necessariamente agrupados no mesmo local de consulta manual, mas podem ser distribuídos por todos os ambientes da biblioteca, de forma a auxiliar os usuários na informação requerida.

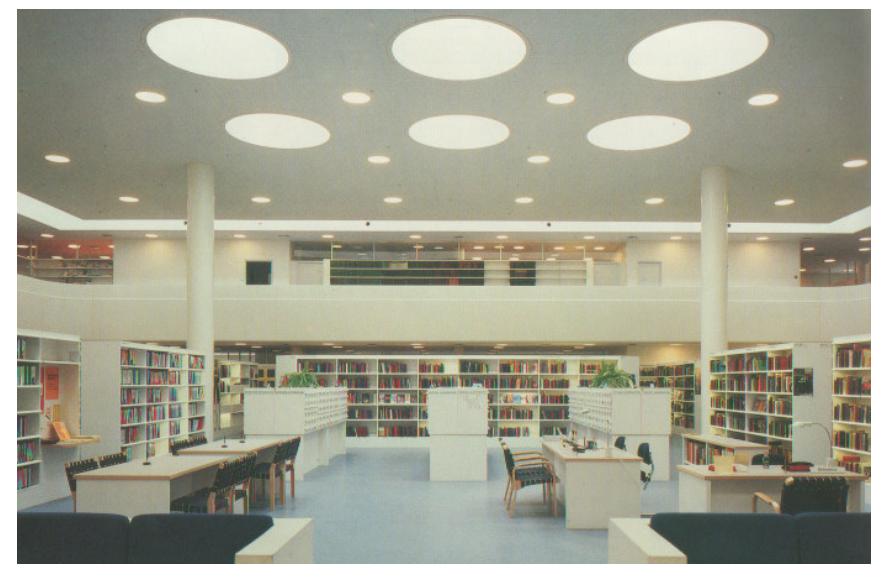

Figura 98 - Acervo da Biblioteca Pública de Gentofte/Conpenhage/Dinamarca Fonte: BRAWNE, 1997 p. 128.

Cumprida a identificação da fonte de informação, o próximo passo é localizar o volume correspondente às prateleiras da biblioteca. Normalmente, o registro que aparece na figura do catálogo, contém a descrição do livro e a fonte de informação bibliográfica desejada.Essa referência - relativa à localização que deve ocupar nas prateleiras - determina também o sistema de classificação de informação do conteúdo do livro, a ordem de aquisição ou chegada à biblioteca e a ordem alfabética dos grupos temáticos (novelas, viagens, dicionários, etc). A tradução deste código abstrato, convertendo-se numa explicação clara e precisa para o usuário, deve nortear o percurso das pessoas nos corredores, estantes e livros, de tal forma que haja facilidade no encontro da informação.

É importante não esquecer que grande parte da rapidez e eficácia com que se localiza uma informação no ambiente da biblioteca, depende de aspectos não relacionados à arquitetura. Qualquer medida que se tome para acelerar o processo de chegada ao livro, tal como os meios mecânicos e eletrônicos, deve ser acompanhada por um método igualmente efetivo de localização das informações. O principal problema, neste caso, não é buscar efetivamente uma ficha no catálogo, mas sim, descobrir em que ficha ou inscrição no catálogo deve estar contida a informação desejada. Num processo desta espécie, envolvendo uma massa enorme de informações e dados, é recomendável que seja aplicado um sistema de processamento de dados computacional. Naturalmente 
esse processo tem sido incorporado em quase todas as bibliotecas universitárias, sejam elas de pequeno, médio e grande portes.

\subsection{Armazenamento}

A conexão que existe entre essas operações de arquivamento e recuperação da informação em uma biblioteca é colocada de forma direta e evidente. Um dado ou uma informação não pode ser viabilizados, sem ter passado por um processo de armazenamento no ciclo essencial da disseminação da informação. Nem tampouco, inversamente a essa situação, é possível arquivar uma quantidade enorme de informação, de tal forma que, a comunicação da mesma não seja feita sem a intervenção das operações de busca e recuperação da informação.

Por sua vez, a aplicação do método de busca e recuperação depende das dimensões da coleção: uma biblioteca universitária de pequeno porte não tem grandes dificuldades para realizar as operações de busca e recuperação da informação, mesmo tendo um acervo aberto e acessível a sua comunidade; já uma biblioteca de grande porte, que organiza suas coleções em função da ordem de entrada e tamanho, necessitará dispor de um pessoal especializado somente para desenvolver tais atividades, além de meios computacionais adequados à tarefa de busca e recuperação da informação. Portanto, o problema da recuperação dos dados é diretamente proporcional às dimensões e complexidade das coleções.

A organização e a disposição espacial das coleções no âmbito da biblioteca universitária dependem, na maioria dos casos, da maneira com que o usuário executa essa busca e recuperação de informação. O sistema de armazenamento das coleções, que se desenvolve no ambiente da biblioteca, deve acompanhar importantes regras antropométricas, como por exemplo, livros que devem estar ao alcance das mãos, prateleiras devidamente adequadas às cargas dos livros e dimensões das estantes suficientemente amplas para circulação de pessoas. Com base nesses princípios de funcionalidade espacial, algumas diretrizes projetuais devem observadas nos locais de armazenamento:

- A dimensão crítica da estante, no sentido vertical, não deve ultrapassar 1,93 m do solo. Isso permite a instalação de pelo menos seis estantes espaçadas por igual e a facilidade na extração ou devolução dos livros (NBR - 12743); 
- O número de livros que podem ser arquivados nesse sistema dependerá da espessura dos volumes; as revistas permitem arquivar de uma média de 25 volumes por metro linear; os livros de história, arquitetura, literatura e artes, pelo menos 23 tomos; de ciência e tecnologia, uns 20 tomos; os de medicina, documentos públicos e a maioria dos periódicos encadernados na média de 17 tomos e os livros ligados à área do Direito e jurisprudência, 13 livros por metro linear (NBR - 12743);

- As prateleiras devem ser construídas em secções horizontais de $91 \mathrm{~cm}$ e a capacidade de cada uma dessas secções com altura de sete estantes pode armazenar uma quantidade total de 412 volumes. Esses valores são utilizados para os cálculos que acompanham os diagramas de um projeto de armazenamento de coleções de uma biblioteca. As estantes também acompanham um padrão de comprimento; neste caso, pode ser de 140 tomos (NBR - 12743 e NBR - 11678);

- A dimensão horizontal crítica é do espaçamento mínimo entre as estantes postas frente a frente com uma passagem entre elas. Essa passagem tem de permitir a circulação de pelo menos uma pessoa e de um carrinho para retirada de livros das estantes de ambos os lados. Como a média de pessoas que utilizam essa passagem vem crescendo a cada dia que passa, é indispensável que seja previsto espaço livre entre as estantes de forma confortável e segura;

- A profundidade da estante também é um item importante no alcance dos livros nas prateleiras e deve girar em torno de $20 \mathrm{~cm}$ para que possa alojar pelo menos $90 \%$ dos livros (NBR - 10518). 


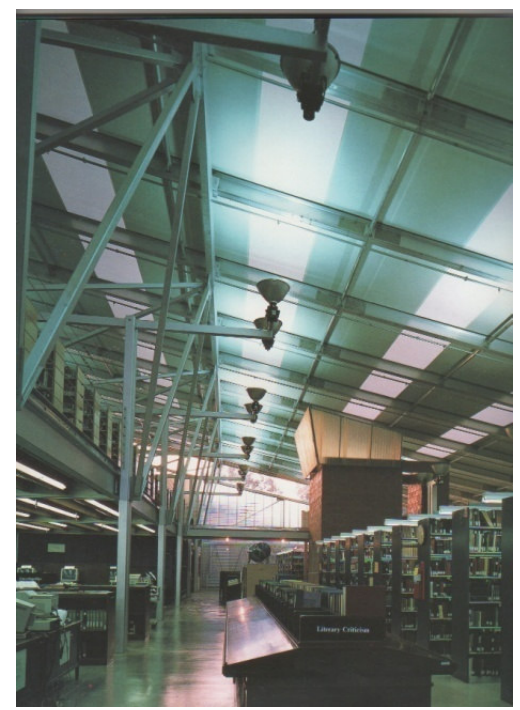

Figura 99 - Estantes da Biblioteca Towel/Universidade da Califórnia/Estados Unidos Fonte: BRAWNE, 1997

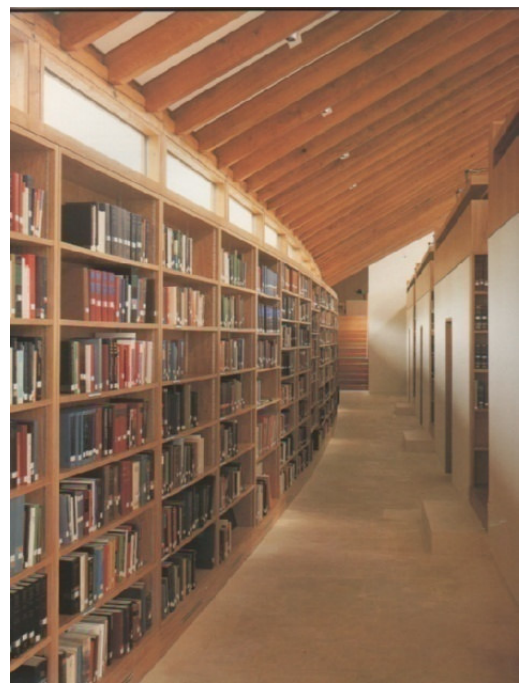

Figura 100 - Biblioteca Darwin College Study Centre Cambridge, Inglaterra Fonte: BRAWNE, 1997

Outro fator que vem colaborar na organização e disposição espacial das coleções da biblioteca diz respeito ao sistema estrutural escolhido para o desenho arquitetônico do edifício. Geralmente, dependendo do tipo de sistema empregado, o espaço destinado ao layout das estantes pode ganhar maior flexibilidade na operacionalização e no funcionamento do material bibliográfico armazenado. $\mathrm{O}$ contrário também é verdadeiro. Quando o sistema estrutural concebido para a biblioteca 
não corresponde às expectativas funcionais de flexibilizações, rearranjos e alterações espaciais, todo o planejamento das áreas de armazenamento ou arquivamento acaba sendo prejudicado. Esse problema pode ser evitado, em parte, permitindo que a equipe de bibliotecários, engenheiros e arquitetos responsáveis pelo projeto da biblioteca estabeleçam um dialogo intenso de entendimento nos vários níveis de desenvolvimento do desenho do edifício.

O nível da capacidade de carga estrutural de cada pavimento da biblioteca depende, naturalmente, dos espaços ocupados pelas estantes e componentes destinados ao armazenamento das coleções. Se for um espaço generoso, destinado principalmente às grandes coleções, é preferível que se considere o volume total disponível, já que a espessura dos pisos pode afetar a capacidade de armazenamento. Esse exemplo se aplica, principalmente, aos sistemas de arquivamento compacto, em que a carga sobre cada pavimento aumenta em uma proporção bastante considerável. Hoje em dia, com a utilização dos sistemas tradicionais de arquivamento, utilizando o padrão de módulos estantes de 1,35 m, $20 \mathrm{~cm}$ de profundidade, $30 \%$ dos corredores dedicados ao armazenamento e $70 \%$ para as circulações, os sistemas de arquivamento compacto constituem uma tentativa de aproveitar, com maior eficácia, a relação entre circulação e armazenamento no ambiente da biblioteca (NBR - 9578 e NBR - 1141).

Outras alternativas têm sido sugeridas para minimizar os problemas decorrentes do armazenamento das coleções existentes nos espaços de bibliotecas universitárias. Entre elas, destacam-se os modelos que incorporam secções suspensas e fixas nas estantes já existentes, formando uma espécie de portal entre as prateleiras. Outro método bastante utilizado e, provavelmente, um dos mais eficazes no uso de armazenamento de material bibliográfico, prevê estantes estreitas e unidas por varias secções que correm lateralmente, a fim de abrir um corredor de acesso.Tais estantes são suportadas por carrinhos fixos no solo, ou às vezes, suspensas lateralmente, permitindo que sejam deslizadas com a mão ou mesmo mecanicamente. 

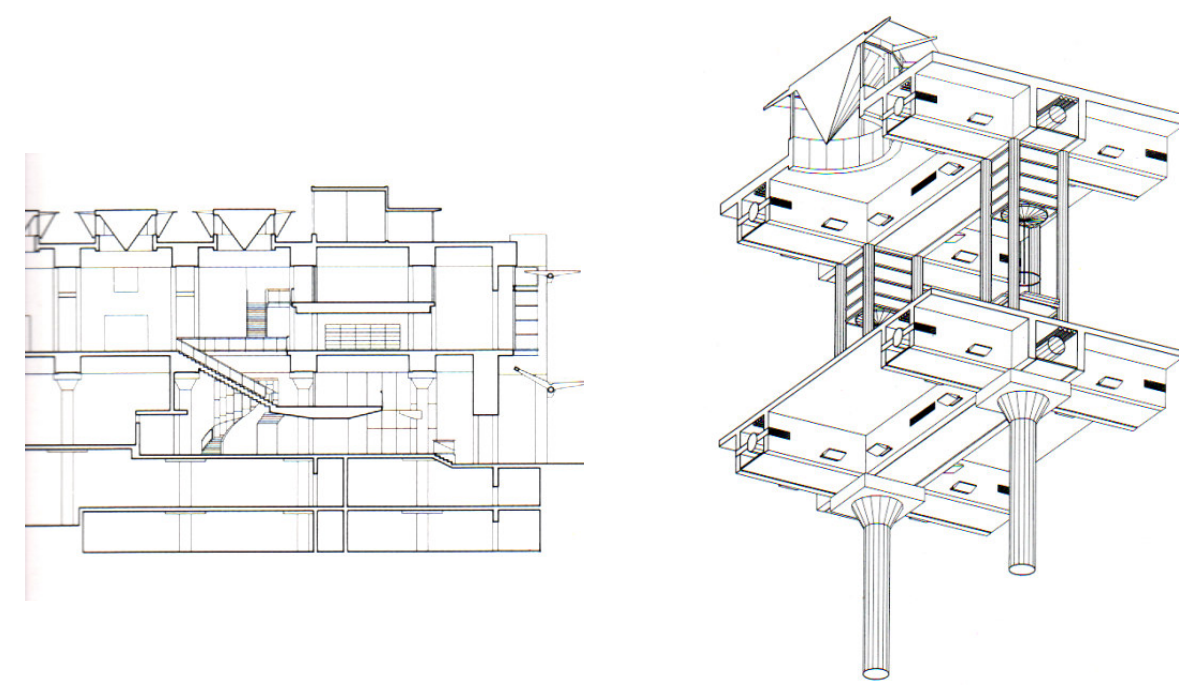

Figuras 101 e 102 - Sistema Estrutural Biblioteca Richmond Hill/Toronto/Canadá Fonte: www.richhill.org.

\subsection{Busca e Recuperação da Informação}

A decisão acerca do método de utilização da busca e recuperação da informação determinará uma parte considerável na organização arquitetônica do edifício da biblioteca. Nesse contexto, dois métodos são utilizados para execução da função: se o documento desejado ou qualquer outra fonte de informação, necessita ser buscado e recorrido no ambiente da biblioteca pelo usuário, o espaço ocupado pelas estantes deve ser planejado de tal maneira que, as linhas principais de circulação e os locais de leitura estejam estrategicamente bem posicionados; a experiência tem provado que, a boa articulação do resgate, recuperação e organização das fontes documentais de maneira ordenada no espaço arquitetônico, trazem benefícios pertinentes no contexto da biblioteca universitária; outro método de busca e recuperação da informação envolve o próprio pessoal da biblioteca, auxiliado por meios mecânicos no âmbito dos locais de armazenamento e leitura.

Em decorrência desses dois métodos, as formas de edifícios de

bibliotecas ganham diferentes interpretações no contexto de suas propostas e no resultado dos partidos arquitetônicos adotados. Evidentemente, existem certas classes de bibliotecas universitárias (grandes ou pequenas) em que o acesso às coleções especiais se mantém fechado ao público, sobretudo, nas grandes coleções nacionais e bibliotecas de pesquisa. Nestes casos, a própria biblioteca pode enviar os documentos pelo correio ou mesmo disponibilizar todas as informações textuais, visuais e sonoras relevantes em bases de dados por meio das redes digitais ou catálogos eletrônicos da biblioteca. 


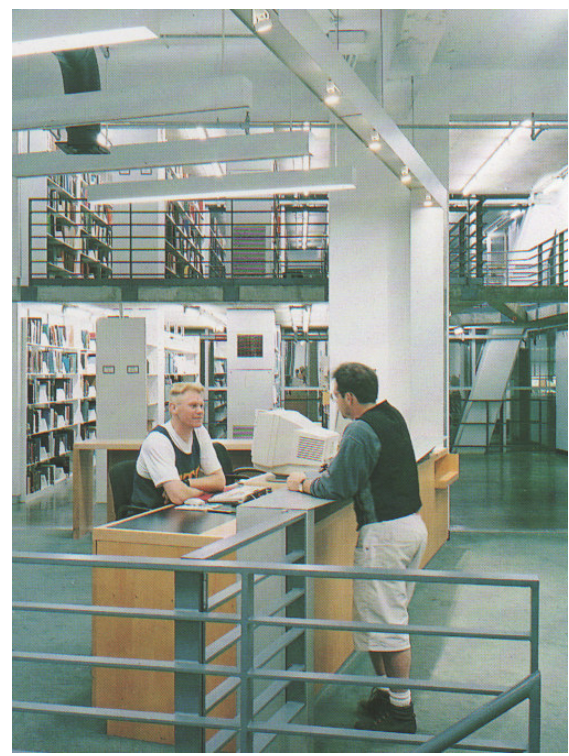

Figura 103 - Busca de Informação Biblioteca Rotch/MIT/Massachusetts Fonte: www. web.mit.edu

Existe uma relação crítica entre a busca e recuperação da informação em uma biblioteca em que o acesso ao público é restrito. Assim, a influência do método de armazenamento empregado fixará a capacidade com que um determinado local consegue disponibilizar este tipo de serviço. Vale lembrar ainda que o rendimento e a satisfação desse tipo de serviço estão vinculados diretamente com o tempo transcorrido da operação, desde a solicitação da informação até a sua entrega. Diante disso, o planejamento arquitetônico desses espaços deve proporcionar agilidade e velocidade nas operações que envolvam tanto usuários e o pessoal da biblioteca quanto sistemas digitais de armazenamento.

Pode-se concluir que a decisão acerca do acesso aos serviços de busca e recuperação da informação no ambiente da biblioteca será baseado no modelo arquitetônico adotado e no desenho administrativo da instituição, e pode, eventualmente, passar do modelo aberto para o método fechado. Em situações em que a busca e recuperação devam ser realizadas pelo usuário, o problema arquitetônico é relativamente sensível, pois sugere a criação de um ambiente dentro do próprio espaço de armazenamento do acervo. Portanto, o grande desafio é formatar um conjunto arquitetônico coeso e integrado com a totalidade dos outros espaços da biblioteca. 


\subsection{Concepção Espacial das Salas de Leitura e Pesquisa}

A comunicação é a função básica do edifício da biblioteca que, nesta perspectiva, converge e direciona todas as demais atividades relacionadas a ela. Em função desse processo comunicativo, a constituição de uma forte relação entre a fonte da informação e o usuário, no ambiente da biblioteca, pode ser sentida na tradição arquitetônica que concede às salas de leitura e pesquisa uma situação hierarquicamente dominante. Normalmente, esses espaços expressam um forte sentido monumental se comparado aos outros espaços da biblioteca. Como exemplo disso, verifica-se a imposição de um pé-direito elevado, a predominância da continuidade espacial e a utilização dos materiais que expressam luxo e riqueza. Em decorrência desses fatos, a característica na concepção arquitetônica dos espaços destinados à leitura e pesquisa, na ambiência espacial da biblioteca, vem atrelada o conceito de flexibilidade espacial, principalmente, verificado nas separações destas áreas pelo emprego do mobiliário existente como estantes, mesas e cadeiras. De uma certa forma, a própria relação entre informação-usuário é reforçada na medida em que coloca o leitor junto a uma atmosfera apropriada à leitura, pesquisa e transmissão de conhecimento.

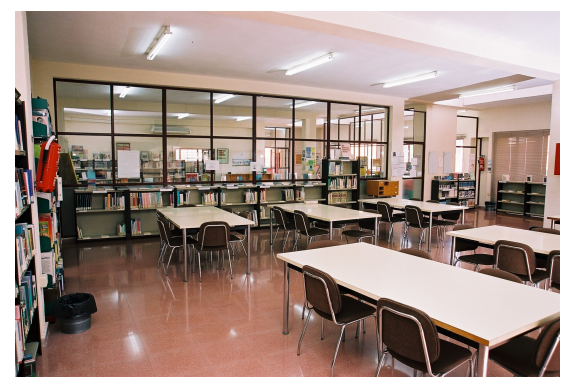

Figura 104 - Sala de Leitura Biblioteca em Múrcia/Espanha

Fonte: www.rmbm.org

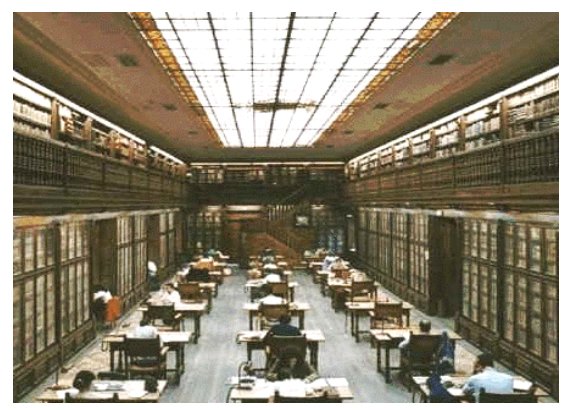

Figura 105 - Sala de Leitura Biblioteca Universidade Oviedo/Espanha

Fonte: www. buo.uniovi.es 
Outro setor extremamente importante na concepção dos espaços de leitura e pesquisa é definido pelas cabines ou pequenas salas de estudos planificadas ao longo do espaço da biblioteca. Para esses locais, onde o estudo deve ser mais intenso e reflexivo, a sensação de intimidade e reclusão pode cooperar nas atividades desenvolvidas. Historicamente, as antigas bibliotecas se serviram de numerosas construções engenhosas que suportavam os grandes e pesados manuscritos, proporcionando algum espaço lateral para suas atividades. Quando enfim, os livros foram ficando mais leves e práticos, tais disposições foram sendo abandonadas e, mais recentemente, voltou-se a considerar o ambiente ao redor do leitor. Uma das explicações seria que a leitura de micro-produções requer disposições que facilitem o estudo individual, e que esta tarefa se realize em um local pequeno e protegido, onde a imagem projetada não receba excesso de luz.

Boa parte do desenho e da qualidade ambiental desses espaços está relacionada com a iluminação e com o conforto sonoro destas salas e, ambos acabam influenciando a dinâmica do todo o conjunto da biblioteca. Nesses casos, é importante que haja algumas recomendações relativas ao equilíbrio, ao funcionamento e ao ordenamento espacial desses ambientes:

- Preservação e equilíbrio dos níveis de luminosidade, principalmente nas áreas internas da biblioteca envolvendo as superfícies de paredes, mobiliários e contornos imediatos.

- Controle da luz natural e artificial nos ambientes destinados à leitura e pesquisa, de forma a garantir qualidade nos aspectos de visualização, ofuscamento e distribuição adequada na iluminação nos vários ambientes adjacentes.

- Controle do volume sonoro nos locais de leitura, visando o conforto acústico e à absorção do som junto a sua origem (pode-se admitir a separação dos locais ruidosos daqueles em que se requer silêncio e a utilização de materiais acústicos absorventes).

- Utilização do conceito de distribuição flexível do espaço, por meio da implantação de divisórias, fechamentos removíveis e espaços entrelaçados.

Quanto mais haja preocupação de resolver os problemas relacionados aos espaços destinados ao estudo individual, à pesquisa e à leitura, tanto mais flexível será o 
espaço da biblioteca em absorver às mudanças tecnológicas que, inevitavelmente, irão se relacionar com sua função primordial: a comunicação do usuário com a fonte de informação.

\subsection{Espaço e Devolução do Material Bibliográfico}

A devolução do material bibliográfico aparece como um dos principais pontos críticos dos espaços de bibliotecas universitárias, pois envolve, no processo, diversos fatores, como, por exemplo, o transporte do material, o tipo de usuário, as características espaciais do edifício, o tipo de equipamento, etc. Mesmo diante desses desafios, faz-se necessário manter um trabalho coordenado, capaz de formular uma política de planejamento arquitetônico e administrativo no ambiente da biblioteca.

Uma das formas para tentar minimizar a problemática da operação de devolução de documentos, sem que haja grande acúmulo de atividades, é executar a ação em várias etapas. Para isso, sistemas mecânicos de transporte se dedicam às tarefas de devolução, sem ao tanto, prejudicar o transporte dos livros que saem das estantes e vão para as mãos dos leitores nas salas de leitura. Entretanto, qualquer interferência que surja em relação ao desaparecimento do material, anularia toda a margem de benefício que possa existir no uso de um sistema mecânico. Como já foi dito, a devolução de documentos que envolvam várias etapas pode ser feita tanto por monta-cargas que transportam verticalmente, quantos por carrinhos que são capazes de subir rampas. Nesse sentido, o projeto arquitetônico deve prever, antecipadamente, local destinado à instalação de monta-cargas ou elevador, bem como, rampas de acesso com a devida inclinação requerida.

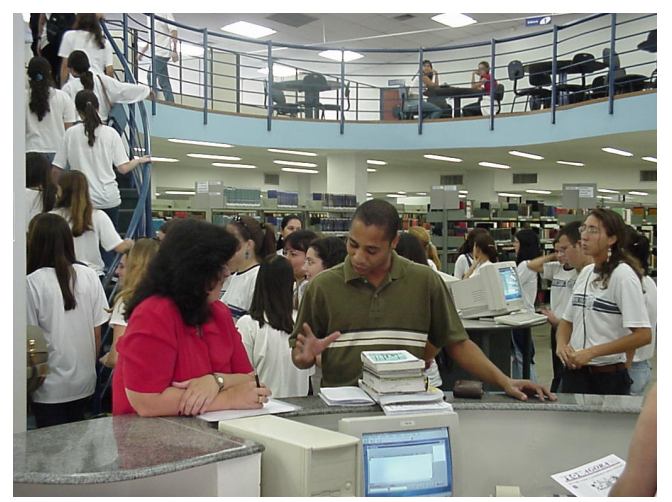

Figura 106 - Devolução/Livros Biblioteca Centro Universitário Otávio Bastos/Brasil 
A experiência tem mostrado que o êxito no planejamento, organização e implantação do processo de devolução do material bibliográfico em uma biblioteca universitária é experimentado quando o livro volta a ficar na estante na correta posição.

\subsection{Espaços e Serviços Relacionados aos Usuários}

A função do serviço de controle, que geralmente é realizada pelo próprio pessoal da biblioteca, tem a característica principal de verificar e catalogar entrada e saída de todo material bibliográfico circulante na biblioteca. Essa tarefa hoje é bastante simplificada pelo uso de sistemas digitais de computação, que armazenam e disponibilizam um número enorme de informações em um tempo bastante curto. Em termos espaciais, o trabalho é levado a cabo em uma mesa de controle individual ou mesmo em secções separadas e desenhadas em função do próprio tamanho da biblioteca, onde são registradas as informações de entrada e saída de material. Desta forma, é importante que o espaço tenha boa visibilidade e esteja posicionado de forma estratégia em relação ao usuário. A grande vantagem desse sistema reside no fato de acelerar o movimento do serviço e proporcionar relatórios diários de acompanhamento do fluxo de informação, com cópias dos prazos de vencimento.

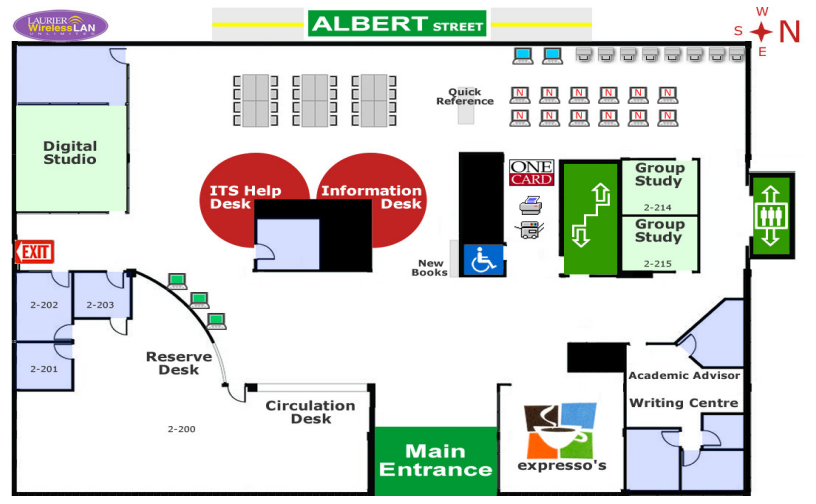

Figura 107 - Planta/Biblioteca/Universidade Wilfrid Laurier/Canadá Fonte: www.library.wlu.ca/

Portanto, se a biblioteca tem um número razoável de usuários, é bastante recomendável fazer a separação do setor de controle do de ajuda prestada aos leitores. Em tais casos, é conveniente, no projeto arquitetônico da biblioteca, separar um local 
exclusivo às atividades de controle, reservando aos bibliotecários mais experientes a tarefa de ajuda e participação aos usuários da biblioteca.

\subsubsection{Consultas}

O setor de consultas abrange a classe de serviços destinados a atender aos usuários e leitores, dando ênfase no recebimento e análise das solicitações de serviço, detalhando as necessidades de cada usuário, especificando cada tipo de pesquisa ou de material bibliográfico necessário e adequando àquele usuário nas secções de leitura e pesquisa.

Isto implica o desenvolvimento de espaços que agreguem o conceito de facilidade na acessibilidade entre o usuário e o pessoal da biblioteca. Desta forma, parece conveniente prever também salas preparadas com tratamento acústico, evitando que o trabalho executado nestes locais prejudique o restante da biblioteca. Mesmo assim, é importante situar o pessoal da biblioteca que atua no setor de consultas perto dos itinerários naturais de circulação e junto àqueles locais onde provavelmente surjam dificuldades: local do arquivo e consulta e as secções de referências.

Com o advento da Internet e novas modalidades de acesso a distância, em curso nas universidades, as bibliotecas estão sendo pressionadas a servir de suporte aos usuários presenciais e àqueles fisicamente distantes. Por conseguinte, há uma demanda por serviços e produtos para usuários remotos e as bibliotecas e seus recursos bibliográficos têm sido solicitados por um número crescente de usuários com as mais variadas questões. Neste contexto, o foco da biblioteca orientada ao usuário remoto deve considerar espaços arquitetônicos que incorporem questões como flexibilidade e adaptabilidade às novas mídias e ao perfil do novo usuário, educação no acesso a recursos on line, cooperação, rapidez e eficiência das coleções.

\subsubsection{Cópia das informações}

Em muitos casos, os usuários necessitam possuir uma reprodução pessoal de alguma informação ou fonte encontrada na própria biblioteca ou mesmo a obtenção de cópias de documentos não existentes no próprio local, mas locadas em instituições do Brasil e exterior Para satisfazer essas condições, as bibliotecas têm instalado máquinas copiadoras em um pequeno local separado onde pode ser organizado 
um serviço de cópia. Como os usuários podem ter que esperar um tempo considerável, é conveniente que haja uma sala de espera específica.

\subsubsection{Fontes Externas de Informação}

Nenhuma biblioteca universitária, por maior que ela seja, nunca pode chegar a possuir todas as fontes de informação. A melhor forma para solucionar este problema tem sido mediante um sistema de empréstimos mútuo entre bibliotecas, na qual o livro pode ser pedido a outra biblioteca. $\mathrm{O}$ empréstimo interbibliotecário é uma operação cooperativa que permite aos usuários terem acesso a um máximo possível de informação documental. Não se trata de um substituto do processo de desenvolvimento do acervo de uma biblioteca para atender as necessidades de seus usuários, mas um serviço de apoio para ampliar o acervo quando falha no atendimento da demanda em situações específicas.

A comutação bibliográfica é, portanto, um sistema operacional mediante a qual, por procedimentos reprográficos de qualquer índole (cópias tipo xerox, microfilmes, microfichas, etc.), os usuários de uma biblioteca, centro de documentação ou banco de dados têm acesso ao acervo de outra instituição similar participante de uma mesma rede. Este processo interbibliotecário é regido por normas específicas de prestação de serviços, de forma regular e responsáveis. As bibliotecas vêm observando uma demanda crescente neste tipo de serviço por parte de um número considerável de usuários.

Atualmente, a biblioteca universitária trabalha com uma nova perspectiva, utilizando os meios digitais e eletrônicos, tirando proveito do seu potencial. Hoje, ela pensa digitalmente e, ao pensar dessa forma, usa essa tecnologia como vantagem competitiva, aplica as informações coletadas com sua clientela em suas ações, entendendo que a internet muda a economia e reescreve as leis de oferta e da procura, além de cultivar uma constante postura de renovação. Contudo, mergulhar profundamente nesse processo é operacionalizar também projetos arquitetônicos que contemplem perspectivas de futuro, criando espaço promissor no fornecimento de serviços informacionais compatíveis com as necessidades dos seus clientes mais exigentes. Este é, portanto, o momento certo para a biblioteca universitária se posicionar frente às novas tecnologias, seus desafios e seus impactos junto ao âmbito do espaço 
construído e assim, encontrar caminhos para que atinja a maturidade dentro da chamada nova era da informação.

\subsubsection{Esbelecimentos de Livrarias}

O empréstimo e a venda de livros não devem ser considerados como componentes comerciais, mas como atividades complementares das bibliotecas universitárias. Efetivamente, estudos realizados sobre esse tema apontam que os estabelecimentos de livros não sofreram prejuízo algum pela proximidade das bibliotecas universitárias. É útil que, em alguns casos, a existência de livrarias vinculas às bibliotecas que possam vender material que não estão disponíveis para empréstimo nas bibliotecas. No interior de uma universidade, um estabelecimento de livraria desempenhará uma função análoga sem ser necessário, portanto, que haja a urgência de construir um edifício à parte da biblioteca.

\subsection{Setores Técnicos e Administrativos}

\subsection{1 Área Administrativa}

Toda biblioteca, mesmo que seja de tamanho reduzido e pequeno, deverá ter em sua planificação arquitetônica, uma área destinada aos serviços de administração. Para isso, o projeto deverá contemplar critérios básicos para o seu funcionamento, como, por exemplo, flexibilidade espacial, interconexão com as áreas do acervo e desenho funcional dos espaços. Em uma grande biblioteca universitária, esse local representará um espaço de considerável tamanho e importância, já que vários serviços ligados à administração geral da biblioteca deverão ser analisados. No que se refere ao uso desses espaços, convém lembrar que, geralmente, os bibliotecários desempenham dupla função no âmbito da biblioteca; não só desempenham função administrativa nas rotinas relativas ao controle dos departamentos e núcleos, mas também são responsáveis, em geral, pela seleção, análise e indexação dos documentos. Isto significa dizer que uma quantidade considerável de operações, procedimentos e informações passam por estes locais. Portanto, o projeto arquitetônico da biblioteca deve prever a separação dos locais administrativos e a acessibilidade aos outros locais deve ser desenhada de maneira clara e direta. 


\subsection{2 Área Técnica}

A maioria das bibliotecas necessita de uma área de trabalho denominada Secção Técnica, destinada ao trabalho bibliotecário de recebimento, registro e controle de documentos. Nesse caminho, o planejamento arquitetônico dessas áreas deve ser encarado como uma linha de produção industrial, ou seja, incorpora a idéia de uma progressão linear ou uma sucessão de operações a fim de garantir agilidade, flexibilidade e profissionalismo, desde a entrada até a saída do documento na biblioteca.

No início do processo, geralmente o material bibliográfico chega em caixas embaladas e, na seqüência, ele é descarregado e desembalado em um espaço próprio de expedições. Em seguida, esse material passa por um local de registro, onde se comprova a nota do pedido, inscrição e classificação dos documentos. Todas essas operações ocupam bastante espaço e deve ser reservado no projeto da biblioteca, uma boa percentagem para acomodação destas atividades. Por exemplo, deve-se calcular pelo menos $11,00 \mathrm{~m} 2$ por pessoa (NBR - 10518) e é importante que as área de trabalho sejam analisadas com profundidade pela equipe técnica, antes de serem adotadas como critérios espaciais.

É obvio que, nesses locais ou espaços projetados para a manipulação de material impresso, a operação com um sistema interligado de computadores seja matéria imprescindível no desenvolvimento das atividades planejadas, visto que, normalmente, as bibliotecas na atualidade já incorporaram as demandas das novas tecnologias informacionais no ambiente do espaço construído.

\subsection{Serviços e Estrutura}

\section{Elementos de Conforto Ambiental}

Quanto às condições de uso exigidas no ambiente da biblioteca, principalmente naqueles que se referem às necessidades aplicadas aos usuários e acervo documental, não existe muita variação nos quesitos de temperatura, umidade relativa e movimentação de ar. Em relação ao livro, o controle mais importante é a avaliação da umidade relativa do ar: o excesso de umidade pode produzir a formação de mofo nas páginas; contrário a isso, o excesso de tempo seco pode quebrar as páginas e danificar algumas encadernações. Isso é facilmente verificado em encadernações de pele animal, 
cuja composição é feita de resíduo ácido. Na verdade, pesquisas científicas têm provado que a vida útil dos atuais livros pode duplicar-se, mantendo a umidade relativa do ar na taxa de 50\%. Esse modelo também é aplicado na relação entre o conforto ambiental e a conservação dos livros: os documentos expostos a uma temperatura ambiente entre 20,6 C e a umidade relativa entre $45 \%$ a $55 \%$ conseguem ter maior êxito no seu tempo de duração.

Outro item bastante relevante no suporte instrumental e técnico do espaço construído diz respeito à ventilação natural. Existem estratégias de concepção e construção dos edifícios de bibliotecas por meio das quais é possível melhorar o comportamento e a eficiência energética dos mesmos. As estratégias que têm atenção às condições climáticas do local e à sua interação com o clima, proporcionando a adequação do edifício ao clima, designa-se geralmente por estratégias bioclimáticas. São no fundo regras gerais que se destinam a orientar a concepção do edifício de biblioteca tirando partido das condições climáticas de cada local. Em termos espaciais, as bibliotecas têm utilizado o modelo quadrático de planta, evitando assim, grandes desperdícios de áreas de circulação e melhorando o fluxo de ventilação natural. No Inverno, quando a temperatura exterior apresenta praticamente sempre valores abaixo das condições de conforto, interessa limitar as infiltrações. No entanto, a renovação do ar interior é uma medida necessária à manutenção das condições de salubridade interior do edifício de biblioteca, par assegurar seu mínimo recomendável por um sistema de ventilação natural.

Quanto à ventilação mecânica, a principal vantagem da aplicação deste mecanismo no interior do espaço da biblioteca, é a renovação diária de ar pelo sistema de filtração. Os filtros são capazes de reter as partículas que trazem malefício ao ambiente e contribuem na conservação das coleções e documentos da biblioteca. A grande desvantagem deste sistema mecânico reside no fato de produzir algum tipo de ruído, incomodando consideravelmente o conforto auditivo do usuário.

Outro sistema mecânico bastante utilizado nos espaços de bibliotecas universitárias ultimamente é o ar condicionado. O sistema é um recurso complementar que, quando bem planejado, ajuda a garantir o bem-estar com custos reduzidos de operação e manutenção. Dessa forma, é possível adotar opções mais eficientes, reduzindo as interferências com outros sistemas, prevendo necessidades elétricas e escolhendo equipamentos que garantam a melhor relação custo/benefício para cada projeto de biblioteca. É importante destacar que qualquer relação entre a capacidade do 
sistema e a área a ser atendida pela biblioteca serve exclusivamente como referência inicial, uma vez que a especificação correta depende da configuração física do espaço e de sua carga térmica, dado que varia em função da incidência solar e do calor gerado por pessoas e equipamentos.

Portanto, mesmo utilizando os sistemas mecânicos, conciliar o conforto ambiental e a eficiência energética em uma biblioteca universitária é um dos principais desafios para o projeto arquitetônico. Brises, fachadas ventiladas ou ventilação cruzada são alguns dos recursos que a própria arquitetura deve usar para minimizar a carga térmica no interior do edifício. Nesse contexto, a arquitetura tem grande responsabilidade: a de produzir construções sustentáveis, tanto em médio quanto em longo prazo. A elaboração de projetos arquitetônicos deve apontar soluções energeticamente eficientes e adaptadas ao clima local, tanto em construções novas quanto em adaptações nos edifícios já existentes. Se esses objetivos forem alcançados, visando sempre ao conforto do usuário, haverá também a conseqüente redução na carga de refrigeração por ar condicionado da biblioteca universitária.

\section{Instalações Elétricas}

Para se chegar a uma instalação segura e eficiente no ambiente da biblioteca, o primeiro passo é o projeto elétrico. Nele serão definidos os pontos de luz e eletricidade da edificação, de acordo com as necessidades de cada ambiente e os aparelhos eletrônicos a serem instalados. Nessa fase, é previsto o uso dos equipamentos de maior carga elétrica e a implantação dos sistemas de computador, telefonia, segurança e até mesmo uma iluminação diferenciada, feitas a partir de lâmpadas dicróicas e fluorescentes. Com base nessas informações, o projetista determinará o porte da instalação, estabelecendo circuitos, apontando a intensidade da corrente (amperagem) necessária e especificando os materiais elétricos que serão adquiridos. Tal especificação deve ser seguida rigorosamente, sob pena de todo o investimento na obra ser comprometido por um conjunto elétrico inadequado. O projeto elétrico totaliza entre $5 \%$ e $10 \%$ do custo total da obra, sem considerar peças de acabamento, como espelhos de tomadas, lâmpadas ou luminárias. 


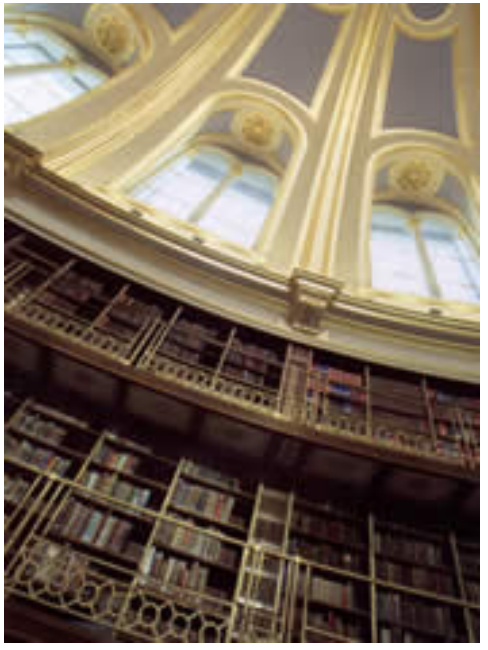

Figura 109 - Iluminação Bibl. Medicina/Universidade de Yale

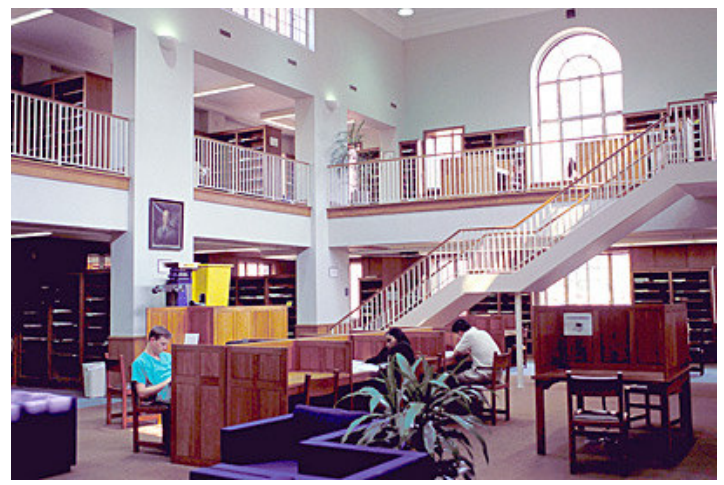

Figura 108 - Iluminação Fonte: www.thebritishmuseum.ac.uk

Fonte: info.med.yale.edu

Para aumentar a eficiência energética e a qualidade dos ambientes de uma biblioteca, deve-se pensar na complementaridade entre a luz natural e artificial. $\mathrm{O}$ arquiteto precisa considerar a integração entre os dois tipos de fonte de luz e, para isso, é fundamental o conhecimento básico tanto da luz natural quanto dos tipos de equipamentos de iluminação a serem utilizados nos espaços projetados. No projeto de iluminação, uma de suas principais decisões é a definição dos sistemas artificial e natural. Cada componente desses sistemas (lâmpadas, luminárias, reatores, sistemas de controle, janela...) tem desempenho e qualidade diferentes, que depende do tipo de tecnologia empregada em sua fabricação. A eficiência do sistema de iluminação artificial adotado no projeto depende do desempenho particular de todos os elementos envolvido como da integração feita como sistema de iluminação natural

As cargas elétricas devem ser calculadas baseadas nos níveis de iluminação compreendidos entre 320 e 430 lux nos locais de leitura e 53 e 107 lux nos planos verticais das estantes (NBR - 14539 e NBR - 15215). Como esses espaços são intercambiáveis, as médias estipuladas para todos os locais adjacentes devem girar em torno de 320 lux. Fora isso, pode acontecer a necessidade de instalação de luminárias compactas e direcionadas, principalmente para suprir a falta de iluminação em locais bastante defasados. Portanto, a rede elétrica tem que ser capaz de suportar tais cargas, de tal maneira que as conexões fiquem embutidas junto ao teto, chão e parede; isso é importante para prevenir futuras mudanças na disposição espacial. 
A luz artificial pode ser necessária nas áreas de leitura durante o dia, especialmente onde a superfície de janela foi reduzida em função da radiação solar incidente. A dificuldade está em encontrar o equilíbrio entre a quantidade de luz e de calor transmitidos para dentro do ambiente e a quantidade de luz refletida internamente. Nesse caso, vale lembrar: se a quantidade de luz direta transmitida for diminuída, haverá um escurecimento do interior da biblioteca, com efeitos negativos sobre a visão e a exigência de mais energia para iluminação artificial. Em resumo, no projeto de construção de uma biblioteca, fica clara a utilização de iluminação natural e artificial: a primeira transmite uma atmosfera psicológica no espaço interno, e a segunda é aquela utilizada por funcionários e usuários da biblioteca nos espaços de estudo e serviços. Portanto, um projeto de iluminação deve ser feito levando em consideração as dimensões do ambiente da biblioteca universitária, bem como sua função, a idade média dos usuários (o nível de iluminação será maior quanto maior for a idade destes ocupantes) e a quantidade de horas que estas pessoas ficarão expostas à iluminação artificial. A distribuição uniforme das luminárias é um fator importante. Quando o fluxo luminoso de fonte de alta luminosidade incide diretamente nos olhos, causa uma sensação de mal estar. Deve-se evitar fontes de luz de grande potência no ângulo de visão das pessoas (pode-se solucionar este problema elevando a luminária ou colocando colméias e grades nas mesmas). A melhor situação é escolher os aparelhos de iluminação e o tipo de lâmpada que deva ser empregada, para que o ambiente não tenha suas cores deformadas e a decoração prejudicada. Nesse sentido, a iluminação de cada ambiente deve ser principalmente projetada de acordo com sua função, valorizando sempre o conforto visual.

\section{Sistema Estrutural}

A importância do conhecimento das possibilidades estruturais, na concepção arquitetônica de uma biblioteca universitária, consiste na prévia análise das interferências das dimensões estruturais do partido, visando a determinar a maneira correta no projeto arquitetônico. Além disso, o aproveitamento da estrutura como linguagem estética da arquitetura só é possível com um projeto arquitetônico que demonstre a estrutura o mais fiel possível em relação ao resultado de sua execução, contemplando soluções tecnológicas disponíveis para a sua concretização. Portanto, sob esse aspecto, o trabalho conjunto de engenheiros de cálculo estrutural e arquitetos, no 
desenvolvimento do projeto arquitetônico da biblioteca, garante resultados extremamente favoráveis no âmbito das soluções encontradas.

O primeiro aspecto importante na concepção estrutural do edifício de biblioteca diz respeito aos cálculos das sobrecargas das lajes dos pavimentos que são submetidos em função do peso das estantes. Geralmente, estantes que tem 2,28 m de altura e estão com sua carga máxima de armazenamento propiciam um peso final em torno de $680 \mathrm{~kg} / \mathrm{m} 2$ (NBR - 14322, NBR - 6120, NBR - 5710 e NBR - 6122). É importante fixar que o máximo de aproveitamento da densidade das estantes não pode ser excluído, principalmente quando se fala em projetos de bibliotecas universitárias. É necessário, portanto, que o projeto do calculo estrutural contemple variações e adaptações nos espaços de bibliotecas, em função principal das cargas adicionais advindas dos rearranjos espaciais de estantes, equipamentos e mobiliários. Isso também é válido quando se utiliza o espaço compacto para armazenamento em estantes. Neste caso, parece bastante prudente ter a precaução já na fase do projeto arquitetônico.

Geralmente, a busca por grandes espaços de bibliotecas está inserida em uma das mais importantes tendências que vêm orientando a evolução destes espaços, ou seja, a procura por maior flexibilidade espacial. Havendo a necessidade de criar grandes vãos em pisos e possibilitar espaços com o mínimo de pilares ou outros elementos verticais, torna-se necessária à concepção de sistemas suficientemente rígidos à flexão, aplicando-se materiais como o aço e o concreto protendido. Esses aspectos visam à otimização das seções das peças estruturais, obtendo-se, por conseguinte, soluções as mais leves possíveis. O mesmo pensamento também é aplicado ao concreto de alto desempenho, com elevada resistência à compressão, que possibilita a aplicação em seções mais esbeltas que concretos menos resistentes, vencendo maiores vãos e aumentando a área útil das edificações.

\section{Sistema de Proteção Contra Incêndios}

O projeto de proteção contra incêndios em uma biblioteca deve nascer juntamente com o projeto de arquitetura, levam-se em conta as distâncias para serem alcançadas as saídas, as escadas (largura, dimensionamento dos degraus, controle de fumaça, corrimãos, resistência ao fogo etc), a combustibilidade e a resistência ao fogo das estruturas e materiais de acabamento, a vedação de aberturas entre pavimentos adjacentes, as barreiras para evitar propagação de um compartimento a outro, o controle 
da carga de incêndio e a localização dos demais sistemas contra incêndios. Um bom projeto deve contar com proteção passiva (contenção da propagação vertical e horizontal), ativa (equipamentos de combate), sistemas de alarme, pessoal treinado e principalmente saídas de emergência com iluminação de segurança adequada. É muito importante a limitação da carga de materiais combustíveis no interior da edificação.

O planejamento dos elementos de proteção contra incêndios em espaços de bibliotecas visa a integrar, de forma preventiva, as ações de combate aos problemas voltados nessa área de atuação, como por exemplo:

- Instalação de um adequado sistema de detecção de incêndio e sinalização;

- Presença obrigatória de extintores de incêndio. A distância máxima de deslocamento estipulado pela norma;

- Compartimentalização da biblioteca e instalação de paredes e portas corta-fogo; a compartimentalização possui o objetivo de, por meio das portas e paredes corta-fogo, confinar um incêndio à sala ou conjunto de salas onde se originou, ou mesmo retardar seu progresso de um espaço para outro;

- Eliminação de condições para correntes de ar verticais; com esse tipo de corrente de ar fica facilitada a propagação do incêndio por entre os andares;

- Utilização mínima de materiais combustíveis em acabamentos e equipamentos internos; mobílias, tais como escrivaninhas, mesas e cadeiras devem ser incombustíveis ou de madeira tratada com retardadores de fogo. Tecidos e cortinas devem ser à prova de chamas;

- Presença de saídas de emergência e/ou escadas de emergência; devem conter as seguintes exigências: ser construída de material resistente a fogo, o piso deve ser revestido com materiais incombustíveis e antiderrapantes, deve atender a todos os pavimentos, inclusive sub-solo, deve ser sinalizada e bem iluminada.

No edifício da biblioteca, a principal preocupação em relação à prevenção de incêndios deve ser voltada para o caso específico do papel. As áreas onde ficam localizadas as estantes podem permanecer longos períodos sem ser visitadas e, portanto, a possibilidade de que se inicie um incêndio nestes locais, causado por um curto-circuito ou uma outra razão é muito grande. Em casos onde a probabilidade de incêndio é alta e o material armazenado tenha grande valor cultural e econômico, é 
aconselhável a instalação de equipamentos de detecção automática de fogo, baseados na presença de fumaça no ar. No caso da utilização de extintores à base de água, não parece ser a opção mais indicada, justamente porque, os livros podem danificar-se com a presença da água e deixar a situação mais agravante.

A inclusão de medidas de prevenção e de extinção do incêndio em bibliotecas e, principalmente, de meios que permitam a rápida evacuação desses ambientes em chamas, deve ser conscientemente analisada pelo projetista e a equipe de administração da biblioteca, levando em consideração as condições específicas da obra, tais como: porte da biblioteca, número de usuários e tipo de utilização, além das exigências do poder público e as recomendações das normas técnicas para o projeto e a especificação de equipamentos. A segurança das estruturas em incêndio também podem ser analisadas por intermédio de métodos de avaliação de risco de ocorrência e propagação de incêndio. Os próprios meios utilizados para a segurança do material bibliográfico, associados às características geométricas e de ocupação da edificação, podem ser suficientes para extinguir o incêndio ou minimizar a ação térmica na estrutura.

\section{Disposição e Implantação do Edifício de Biblioteca Universitária}

O local destinado à implantação de um edifício de biblioteca universitária deve ter certas características físicas compatíveis com o uso desse local, principalmente, relacionado ao fornecimento de informação a um tipo de clientela específica. Portanto, o terreno escolhido deve ter características que satisfaçam o objetivo peculiar do tema da biblioteca e esteja completamente adequado às exigências estabelecidas no projeto. Freqüentemente, as decisões a acerca da implantação e localização de edifícios de bibliotecas universitárias são tomadas por comissões de bibliotecários muito antes de haver contato com um arquiteto. Nesse caso, pode ocorrer que a escolha não corresponda às exigências pré-estabelecidas no partido arquitetônico da biblioteca, gerando implantações extremamente difíceis e complicadas. É exatamente nesse período em que se deve ter em mente, o apoio de uma acessoria de projetistas e arquitetos na definição e orientação da implantação do edifício. 


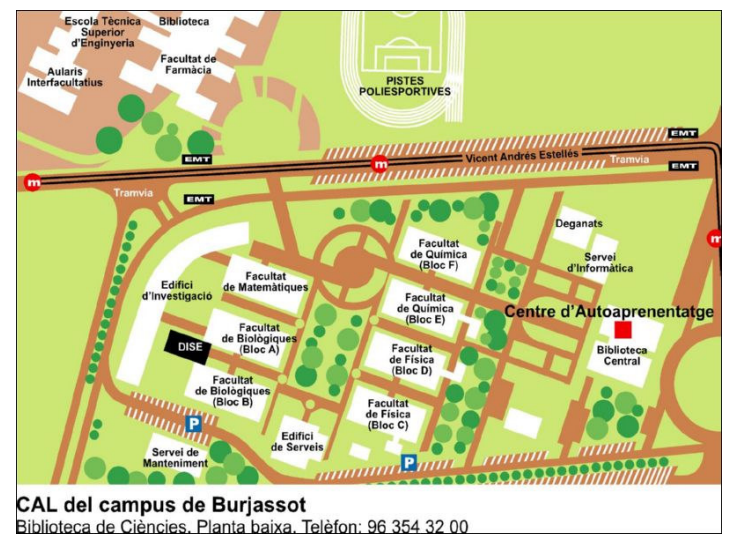

Figura 110 - Implantação Biblioteca/Universidade de Valência

Fonte: www. uv.es

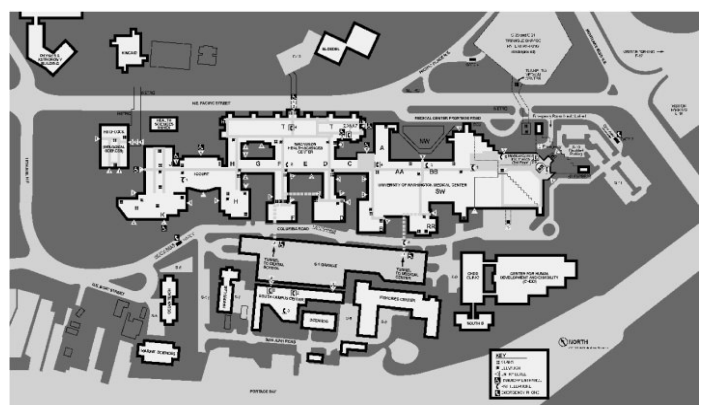

Figura 111 - Implantação Biblioteca/Universidade de Washington

Fonte: www. washington.edu

Alguns aspectos técnicos devem ser observados na escolha do terreno para implantação de um edifício de biblioteca universitária, constituindo-se os critérios de seleção. São eles:

- O relevo

- A área

- A localização

- O tipo de entorno e urbanização

- A orientação quanto ao sol e ventos dominantes

- Os serviços de infra-estrutura (água, energia, rede de esgoto, águas pluviais, etc.)

- Legislação pertinente

- $\mathrm{O}$ custo

- As vias de acesso e sistemas viários 
Esses aspectos técnicos devem ser analisados, em um todo ou em parte, dependendo do objetivo apresentado pelo partido arquitetônico. Há outros aspectos que eventualmente podem ser somados a esses já discriminados, se forem julgados significativos para a escolha, como por exemplo: a cobertura vegetal existente, o tipo de solo, o formato do terreno, etc.

\section{Características do Terreno}

\section{A - Forma e dimensão}

A forma e a dimensão do terreno escolhido são duas importantes vertentes a serem levadas em conta na elaboração do partido arquitetônico da biblioteca É relevante analisar o quanto de influência nas idéias do partido essas variáveis poderão exercer e isso. O projetista ou o arquiteto deve estar preparado para perceber o nível de influência dessas variáveis e saber usá-lo corretamente nas decisões de projeto. Verificando sob esse aspecto, essas variáveis tanto podem ser de natureza restritiva ou condicionante no que se refere às idéias do partido do projeto, especialmente à forma planimétrica da disposição do edifício, quanto pode deixar de influir sem ter validade nenhuma, nessas decisões de projeto. Como exemplo disso, alguns projetos de bibliotecas revelam que a forma de ocupação do terreno pelo edifício está restrita, condicionada à forma do terreno.

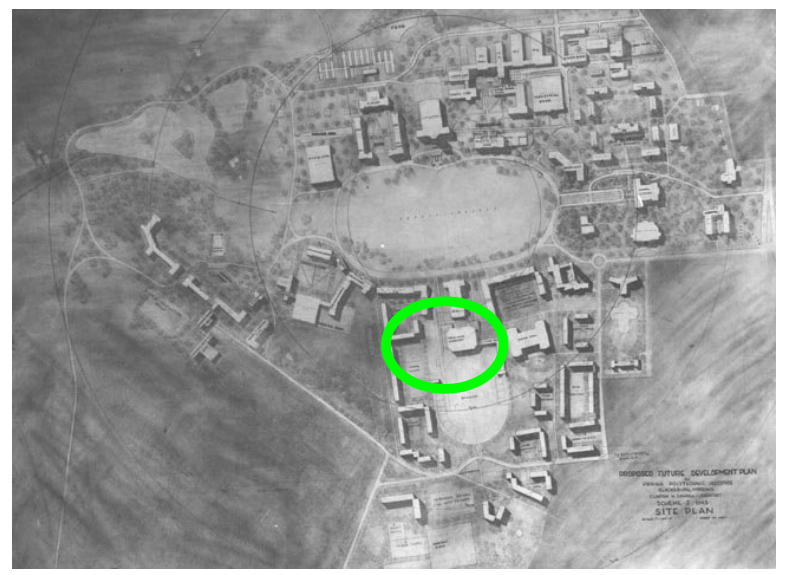

Figura 112 - Implantação Biblioteca/Universidade da Virgínia Fonte: info.med.yale.edu 
Quando o lote tem grandes proporções, provavelmente haverá condições suficientes para distribuir-se a construção sobre o terreno, sem restrições ou condicionantes de forma e dimensão, ou seja, a ocupação do terreno pelo edifício da biblioteca passa a ter uma situação tranqüila quanro a essas variáveis, que não exercem considerável influência na forma planimétrica. A grande vantagem dessa situação é que as decisões formais do projeto ficam para ser tomadas na etapa seguinte da síntese.

Outras abordagens podem ser dadas em relação as variáveis do formato do terreno, como por exemplo, a função exercida do fator altimétrico do lote. Quando uma situação dessa acontece, em que um terreno apresenta dimensões reduzidas e cuja ocupação máxima só pode ser de metade da área do lote, o partido arquitetônico é naturalmente induzido a uma solução verticalizada. Nesse caso existe uma influência restritiva para a solução do projeto e há apenas um caminho volumétrico do edifício, em função do dimensionamento do terreno e o pré-dimensionamento da biblioteca. É importante ressaltar que o projetista já deve contar com esta decisão de projeto antes mesmo de partir para a etapa da síntese, na qual define os principais quesitos do partido. Portanto, a análise da forma e da dimensão do terreno é peça fundamental no processo de decisão e desenho do projeto de uma biblioteca.

\section{$B$ - Conformação do relevo}

A definição de relevo pode ser dada como o conjunto de todos os acidentes geográficos que dão o formato a montanha, ao solo, ao vale, à planície, etc. e, nesse sentido, cada terreno tem determinadas características físicas que provem da conformação do relevo. Cabe ao arquiteto entender e analisar essa conformação, com o objetivo de captar o grau de influência que ela poderá exercer na solução do projeto de arquitetura. Toda essa consideração pode ser explicada pelo fato de existir uma forte relação entre a conformação do lote e a idéia do projeto de arquitetura. Desta forma, numa visão geral, a influência dessa variável física tanto pode ser sentida de uma forma impositiva e direta, impedindo alternativas concretas de implantação, quanto pode inexistir qualquer tipo de restrição projetual para o projeto da biblioteca universitária.

Sob o ângulo das características topográficas, os terrenos podem ser classificados em dois tipos básicos: plano e inclinado. Em face dessas duas linhas de característica de terreno, uma enorme variedade de conformações e situações topográficas se apresenta, exigindo a devida observação de alternativas de ocupação de 
um espaço dedicado à biblioteca. No processo avaliativo desses elementos físicos, todos os componentes servirão de base para as decisões de projeto a serem tomadas posteriormente na segunda etapa da adoção do partido arquitetônico. Entendendo esses dois tipos topográficos básicos como fatores determinantes, o projeto pode se encaminhar por duas vertentes: primeira, acomodar a implantação do edifício à conformação do relevo, respeitando suas características originais e vinculando as decisões de projeto em função dos desníveis do lote; segunda, acomodar o terreno à forma projetada de disposição do terreno. Cada caso analisado é uma situação diferente e requer um juízo que varia conforme o grau de influência a atribuir a cada variável do projeto, vinculada à decisão que diz respeito à conformação do relevo. Isso significa relatar que, seja o terreno inclinado ou plano, tenha a inclinação e a direção que tiver, sempre haverá uma ou mais formas de adaptar a ocupação de um edifico de biblioteca. Cabe ao projetista, então, escolher qual a alternativa que melhor se adapte às condicionantes do projeto da biblioteca.

\section{C - Orientação solar}

Este item relaciona-se à influência que a orientação solar poderá exercer no edifício de biblioteca projetado para balizar a forma de orienta-lo no terreno escolhido e conseguir o melhor proveito possível das condições naturais de conforto ambiental. É importante frisar que a influência da radiação solar provém basicamente do excesso de iluminação no ambiente construído e o efeito da insolação, principalmente, do efeito do calor sobre as paredes da edificação. 


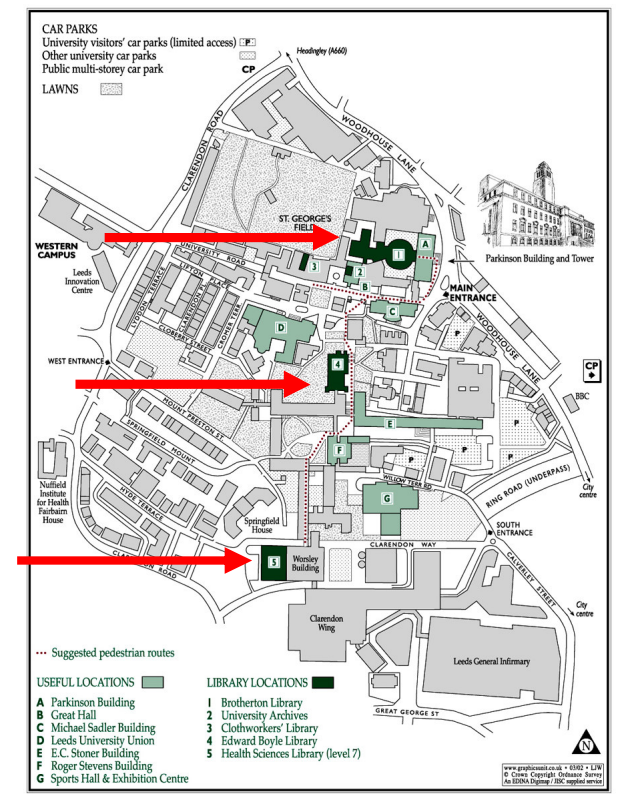

Figura 113 - Implantação Biblioteca Universidade de Valência/Espanha Fonte:www. leeds.ac.uk

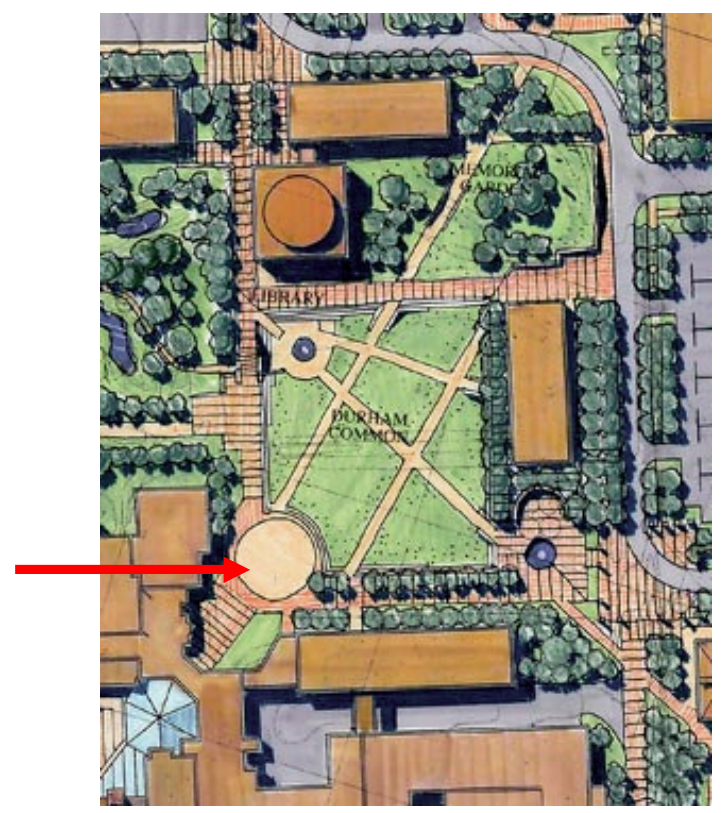

Figura 114 - Implantação Biblioteca Universidade de Ontário/Canadá Fonte: www.bradjohnson.ca

Nos últimos anos, a preocupação com as questões relacionadas ao conforto ambiental e à eficiência energética das edificações tem sido um dos principais desafios para a área da arquitetura. Numa região tropical, como é o caso do Brasil, na 
qual a incidência de radiação solar é muito grande, a preocupação é reduzir o desconforto provocado pelo excesso de iluminação natural e da insolação do edifício. Em relação aos espaços de bibliotecas, essa questão não acontece diferente: o ambiente da biblioteca necessita de conforto ambiental para que o usuário possa sentir-se disposto a desenvolver suas atividades e a influência do sol precisa ser controlada, pois afeta o acervo e o usuário.

As considerações a respeito da iluminação natural no edifício e o controle do excesso de radiação solar têm relação direta com a orientação quanto ao sol e à interna dos elementos do programa arquitetônico. É importante registrar que a questão do iluminamento pode ser controlada e minimizada também pelas aberturas existentes no edifício, como, por exemplo, portas, janelas e vãos de aberturas. O projetista deve ter em mente que esse controle deve ser acompanhado de uma análise da influência da posição solar para obter as referências de orientação a serem adotadas no arranjo espacial do edifício no terreno e, conseqüentemente, nos elementos e setores estipulados pelo programa arquitetônico da biblioteca.

O primeiro passo é obter uma análise exata de como ocorrerá a insolação no edifício e precisar o grau de influência do sol sobre ele, a fim de avaliar possíveis procedimentos de implantação de edifício e controle de conforto ambiental. Este procedimento inclui o local onde se situa o terreno, as posições geográficas e uma descrição gráfica mediante conhecimentos de geometria descritiva.Desta forma, é possível construir uma análise técnica, precisa e correta, que permite fixar a orientação do edifício no terreno e colher condições ambientais favoráveis. É importante dizer que o diagrama solar registra, em curvas traçadas nele, as horas de exposição solar em que cada fachada do edifício e no interior dos espaços arquitetônicos em qualquer orientação que esteja o terreno e o edifício. Portanto, dessa maneira, as informações obtidas no gráfico permitem indicar a direção do raio solar, os ângulos horizontais e verticais que os raios formam com o local durante o dia e durante as estações do ano. Cabe ao arquiteto ou projetista, a partir do conhecimento obtido, decidir qual a maneira mais adequada de dispor o edifício, no terreno, as orientações que melhor convêm no sentido de atenuar os efeitos do desconforto excessivo da radiação solar.

Não basta somente aplicar corretamente os conceitos de análise da carta solar em relação à implantação de um edifício de biblioteca, mas também outros meios e procedimentos devem ser incorporados na melhoria das condições ambientais destes edifícios. Em relação a esses métodos, pode-se destacar: 
- Seleção correta do tipo de material de cobertura;

- $\quad$ Seleção correta do tipo de material de revestimento de paredes e pisos;

- $\quad$ Análise da orientação do edifício quanto aos ventos;

- $\quad$ Aplicação correta do revestimento paisagístico;

- Uso correto de elementos construtivos (tipo "brise-solei” e beirais) para contribuir na melhoria do conforto.

Em qualquer situação de elaboração de projeto arquitetônico de uma biblioteca universitária, deve-se aproveitar as vantagens oferecidas pelos condicionantes naturais para se obter o máximo de conforto ambiental no edifício e eliminar as desvantagens desses mesmos agentes. Esse processo compreende os efeitos da insolação na edificação e a sua repercussão na adoção do partido, nos aspectos concernentes à disposição do prédio e na distribuição dos setores e dos elementos do programa arquitetônico.

\section{D - Orientação quanto aos ventos}

Outro fator preponderante na definição de parâmetros de análise de implantação de edifícios de bibliotecas universitárias é, sem dúvida, a orientação de ventos no controle dos efeitos do clima para tornar confortável a utilização dos espaços. Esse elemento, na maioria das vezes, tem sido deixado de lado na composição de um programa ou partido arquitetônico, principalmente, no que se relaciona às bibliotecas e unidades de informação.

Alguns projetos têm considerado que a atuação dos ventos numa região de clima quente, como o tropical, pode ser aproveitada para atenuar o excesso de insolação e diminuir consideravelmente a temperatura da biblioteca, usando vantagens oferecidas por esse fator natural. A utilização da ação benéfica dos ventos estará influenciando os elementos principais do projeto arquitetônico, especialmente quanto à disposição do edificio em relação ao terreno e quanto à distribuição dos setores espaciais do programa de arquitetura. Esse método visa a reduzir as cargas excessivas de transferência térmica na edificação, cooperando na manutenção da qualidade espacial e formatando um projeto adequado às condições climáticas/ambientais. 
Os ventos são movimentos do ar na atmosfera e resultam das diferenças de temperatura e de pressão atmosférica. Os dados meteorológicos obtidos pela observação contínua da incidência dos ventos ao longo das horas do dia, nas estações do ano, executadas por décadas seguidas, permitem aquilatar suas freqüências, direções, atuações e estabelecer um quadro referencial para saber reconhecer o grau de influência deles no local escolhido e utilizá-lo com referencial de partido arquitetônico. A diminuição da excessiva radiação solar no interior do edifício da biblioteca depende da utilização da ventilação natural como forma de corrigir o desconforto do clima e obter a redução da temperatura nos elementos espaciais, ou seja, obedecer à influência desse agente natural na concepção do partido.

É claro que esse elemento induz a solução arquitetônica, mas não determina como ela deve ser. Isso pode ser comprovado nos casos em que as maiores fachadas da edificação são voltadas para as orientações, obtendo-se maiores vantagens dos ventos dominantes. Evidentemente que essa situação nem se configura de forma executável, porque basicamente depende de outras variáveis, como por exemplo, as formas e dimensões do terreno e suas disposições espaciais. Nesses casos, cabe ao projetista estabelecer que setores têm prioridade sobre os outros, em função da setorização do programa. Quanto a esses elementos, as prioridades para as melhores orientações devem ser direcionadas aos ambientes considerados de permanência prolongada como, as salas de leitura e áreas administrativas. As outras áreas como, hall, corredores, escadas e sanitários são considerados espaços não prioritários. Em suma, a melhor forma de aproveitar o efeito do direcionamento do vento no edifício da biblioteca é permitir que a ventilação atravesse o espaço de um lado ao outro, refazendo o efeito de "ventilação cruzada" e fazendo circular pelos ambientes arquitetônicos as trocas térmicas de temperatura. A concepção espacial deve conceber o posicionamento da entrada do ar renovado e a saída do ar quente sem grandes dificuldades.

Além de estudar cuidadosamente o direcionamento de ventos, aproveitando melhor os agentes naturais, outras medidas podem ser adotadas no sentido de minimizar as condições de conforto ambiental no espaço construído da biblioteca. Uma das medidas é permitir que haja maior superfície de exposição de fachadas aos ventos dominantes, combinando com maiores aberturas de janelas e criação de disposições alternativas espaciais. 


\section{E - Acessibilidade}

A influência da acessibilidade ao terreno onde está disposto o edifício da biblioteca fica fortemente ligada as vias de acesso e meios de ligação existentes ao terreno e depende do tipo de via, de uma qualidade, quantidade, extensão e disposição. E ainda, a acessibilidade está ligada às possibilidades de situar essas vias no terreno, decorrendo principalmente, da disposição da análise e interpretação da várias variáveis de ordem física e conceitual. Em relação a isso, vários condicionantes devem ser contemplados na análise da acessibilidade, visando a estabelecer a melhor relação possível entre o acesso e a utilização coerente do edifício.

Um dos principais componentes desse intercâmbio entre o acesso, terreno e edificação é, sem dúvida, a influência da classificação dos tipos de vias. Neste caso, cada tipo de rua corresponde a exigências diferentes para o acesso ao terreno. Por exemplo: a constituição das vias primárias, onde o tráfego de veículos é carregado, convém não serem usadas como acesso direto ao terreno onde vai se construir a biblioteca. Nestas situações, projeta-se uma via local para acesso ao terreno da via primária; já as vias secundárias podem ser utilizadas como acesso em determinadas ocasiões, sob condições de uso da via do lote estabelecido na legislação pertinente, objetivando ordenar o tráfego; e, em último caso, nas vias locais, em que o acesso ao terreno se apresenta sem restrições, de acordo com o projeto arquitetônico. Nesse mesmo pensamento, a extensão da via de acesso influencia sobremaneira as definições de acessibilidade do terreno, na medida em que determina o grau maior ou menor de possibilidade ou flexibilidade na posição em relação à implantação do acesso.

Diante dos elementos expostos, o arquiteto precisa ter critérios, priorizar as diversas possibilidades existentes e decidir sobre a melhor situação de dispor o acesso ou acessos para o projeto de uma biblioteca. Indubitavelmente, outros critérios podem ser usados em relação aos acessos ao edifício na fixação do projeto de arquitetura. Um desses elementos relaciona a natureza física ou o relevo do terreno: as condições topográficas do terreno também influenciam na disposição do acesso, levando em conta a diferença de cotas de níveis, acidentes geográficos e elementos naturais presentes no local. Outro fator envolvido discrimina a relação existente entre os outros edifícios presentes no campus universitário, que na maioria dos casos, apresentam seus acessos já previamente estabelecidos. Nessas circunstâncias, a decisão de conjugar as influências desses prédios, no que se refere aos seus acessos, decorre da 
opção por criar um ambiente harmonioso e completamente integrado. Portanto, a correta sincronização dos elementos envolvidos no projeto (características formais do terreno, programa de necessidades e partido arquitetônico) referente aos acessos ao edifício deve gerar uma solução adequada ao tema da biblioteca universitária.

\section{F - Relações com o entorno}

Por definição, o entorno é o ambiente físico, natural ou criado, existente à volta do terreno e, neste caso, pode ser tanto a paisagem circundante como o conjunto de construções vizinhas. No caso específico de projetos voltados às bibliotecas universitárias, o entorno se caracteriza pelas edificações presentes no campus universitário (salas de aulas, áreas administrativas, restaurantes, áreas de manutenção, etc.), que formam a estrutura espacial construída e todos os componentes da paisagem natural.

Os elementos do entorno são capazes de influenciar favorável ou desfavoravelmente a concepção do partido arquitetônico relacionado à escolha do terreno. Em virtude dessas decisões que estabelecem as relações entre o terreno e o entorno, o arquiteto deve, de forma clara, avaliar o grau de influência e os reflexos que podem trazer ao planejamento arquitetônico do edifico da biblioteca.

Alguns projetistas têm tirado partido correto dos impactos positivos que alguns cenários paisagísticos podem oferecer, como benefícios, ao planejamento de edifícios de bibliotecas e como eles são proveitosos em relação às vistas obtidas. Geralmente, o que se vê como resultado prático dessa interação são espaços traduzidos em conforto, agradabilidade e perfeita continuidade espacial entre o ambiente interno e externo. Em muitos casos, o entorno é tão importante que supera as condições de orientação quanto ao sol. Nessas situações, o importante é estabelecer um processo de conciliamento entre os fatores naturais do entorno e a idéia de implantação do projeto da biblioteca. Essas mesmas considerações são válidas para os aspectos tipológicos da arquitetura existente no contexto do espaço local, induzindo o projetista a relacioná-las com a tipologia do edifício a ser projetado.

Finalmente, os fatores relacionados com o entorno também podem influir desfavoravelmente nas relações com o local escolhido, pelo fato de os edifícios vizinhos limitarem ou bloquearem a visão do ambiente à volta, determinando as disposições e os 
elementos dos setores definidos pelo programa arquitetônico de modo a fixar a proteção a intimidade das funções exercidas na biblioteca.

\section{G - Modificações e ampliações}

São raros os edifícios que permanecem no mesmo estado em que foram projetados ou que seguem utilizando a mesma forma de quando foram ocupados. Obviamente, esse processo é explicado pelo fato de que a vida útil da maior parte dos edifícios tem um tempo bem maior do que a função desempenhada por ele. Esse mesmo raciocínio é aplicado no caso das bibliotecas e, mais especificamente em nosso estudo, em bibliotecas universitárias. Atualmente, o tema tem sido debatido por arquitetos e bibliotecários, na tentativa de rever quais os principais pontos conflitantes no processo de produção do espaço construído, principalmente diante de um novo cenário de transformações e alterações dado em função das novas tecnologias informacionais e comunicacionais.

Em arquitetura, alguns edifícios chegam a ser considerados inadequados quando as funções por eles desenvolvidas são modificadas e alteradas em relação ao tempo. No espaço da biblioteca esse fato também se verifica. Para citar um exemplo, pode-se aplicar o caso do sistema que matém as instalações de ar condicionado: de vez em quando ele necessitará passar por um processo de manutenção, chegando num determinado momento em que o custo desta manutenção será maior que a amortização de um novo sistema de ar condicionado, obrigando a aquisição de um novo sistema. Essa posição é agravada nos casos em que a biblioteca aumenta de tamanho, e a instalação de ar condicionado é incapaz de atender o aumento de carga, forçando que se modifique todo o sistema existente. Outro exemplo análogo, que interfere na funcionalidade espacial, acontece dentro da estrutura interna do edifício, relacionando a manutenção de coleção de livros raros com equipamentos auxiliares de controle de temperatura. Com o passar do tempo, esses equipamentos se tornam obsoletos e a necessidade de uma boa conservação dos livros e do ambiente torna necessária a introdução de novas ações no âmbito da aquisição de equipamentos e treinamento de pessoal. O mesmo pode ser dito em relação a um elemento específico da biblioteca universitária: o sistema de transporte de livros e documentos. Com o envelhecimento dos componentes mecânicos deste sistema, a capacidade e utilização acabam sendo prejudicadas, exigindo da administração, mudanças no processo de produção. Portanto, 
uma análise criteriosa permite estabelecer um padrão de hierarquia de quais elementos sofrerão adaptação ou modificação dentro do contexto do edifício da biblioteca universitária. Como resultado dessa ordenação, algumas necessidades poderão ser priorizadas de acordo com as decisões tomadas acerca de tais mudanças.

Os critérios estipulados na fase do partido arquitetônico podem fixar limites para sua futura ampliação, principalmente no que se refere à flexibilidade. Por exemplo, a capacidade para modificar um espaço ou local não depende somente da liberdade adotada pelo sistema estrutural. Pelo contrário, um complexo sistema de outros elementos construtivos, exerce um controle completo e impõe limites na sua capacidade de modificação. Dentre os principais elementos, destacam-se os sistemas elétricos e mecânicos que, dependendo de sua utilização e instalação, mostram elevada tendência de cair no envelhecimento e desuso ao longo dos anos. Em vista disso, o projetista deve descrever cuidadosamente um plano estratégico de ação, limitando ou flexibilizando as futuras demandas provenientes dos diversos setores da biblioteca. $\mathrm{Na}$ essência, o limite da variabilidade pode depender não somente das características atuais e potenciais da cada local, mas também da relação que pode existir entre elas.

Um dos principais problemas que se colocam em relação aos espaços de bibliotecas universitárias é a questão de sua magnitude, em virtude evidentemente do crescente aumento destes edifícios no contexto da sociedade. Uma corrente de discussão advoga a implantação de uma biblioteca central no ambiente universitário, justamente pela impossibilidade de parcelamento do conhecimento existente, sugerindo a necessidade de instalação de unidades de informação em um único espaço. Neste caso, o usuário tem condições de ter acesso à informação desejada de forma compartimentada e setorizada nas diversas áreas de conhecimento e previamente estabelecidos pela administração da biblioteca. A grande desvantagem apresentada por esse sistema reside no fato de se ter, na maioria dos casos, edifícios com grandes dimensões espaciais, resultado direto dos elementos que compõem um campus universitário. Uma solução possível,então, seria a criação de bibliotecas setorizadas, atendendo de forma específica a satisfação dos grupos específicos das faculdades e das unidades universitárias.

As circunstâncias relativas ao crescimento das bibliotecas universitárias têm sido alvo constante de estudos e pesquisas, tanto na área da ciência da informação, em biblioteconomia e também na área da arquitetura. Como padrão, nenhuma biblioteca pode funcionar com $100 \%$ de sua capacidade de utilização, estipulando-se que o material presente no acervo e os serviços oferecidos pela biblioteca girem em torno de 
$85 \%$ de sua capacidade. Vale lembrar que, em outros casos, os espaços são projetados para funcionar somente com $50 \%$ de sua capacidade total. Esses valores variam em função do planejamento estipulado pela equipe de bibliotecários e, inevitavelmente, devem ser acompanhados diretamente por um arquiteto na concepção do projeto arquitetônico do edifício da biblioteca.

Em outras situações, em que a biblioteca já está concluída e não existe condição para a execução de acréscimos, o problema de resolução para o aumento numérico do material bibliográfico pode ser resolvido por meio do rearranjo do espaço existente e da modificação dos métodos de armazenamento do acervo no sentido de aproveitar melhor o local disponível. Além disso, outras decisões podem ser tomadas acerca das novas aquisições que a biblioteca faz no âmbito do acervo, como, por exemplo, formular um método de arquivamento que possibilite sua compactação ou transformação em microcópias. Fora isso, algumas dessas aquisições podem ser recebidas das editoras já em formato reduzido de microcópias ou bases de dados digitais. Como resultado prático no espaço da biblioteca, vários espaços que antes eram ocupados com uma grande quantidade de documentos e informação, agora ganham novas possibilidades de ocupação espacial nos ambientes direcionados a esta função.

Há, todavia, outros tipos de mudanças que se configuram no ambiente da biblioteca e que estão relacionadas com as diferentes necessidades dos usuários. Ao longo do tempo, várias configurações espaciais necessitam ser adaptadas e modificadas em razão das novas exigências que se colocam no espaço da biblioteca como, por exemplo, salas multiuso, locais de exposição, salas de estudo fechadas, áreas de descanso, etc. Essa idéia, que agrega inúmeras possibilidades do desenho de layouts no espaço, deve ser prevista já no momento da confecção do partido arquitetônico, de forma a garantir o conceito da flexibilidade. Um exemplo típico deste procedimento pode ser tratado no planejamento de ampliação das estantes e suas diferentes formas de distribuição espacial e dimensionamento do acervo.

As demandas de variabilidade, em geral, sugerem que cada um desses espaços característicos sejam tão amplos como seja possível, posto que o número de permutações nos locais utilizáveis dentro de um número determinado será proporcional ao tamanho destes volumes. É evidente, por exemplo, que se estão considerando espaços de trabalhos iluminados lateralmente com luz natural, quanto maior seja o comprimento daquele espaço característico, maior será o número de subdivisões diferentes possíveis de tal zona. Uma das considerações de grande importância no 
projeto de uma biblioteca, supõe um espaço característico dessa classe seria, por exemplo, manter relação apropriada entre essa classe de locais na zona periférica e nos locais interiores com luz zenital ou luz artificial. 


\section{CAPÍTULO 5 - CONSIDERAÇÕES SOBRE O MÉTODO DE AVALIAÇÃO PÓS-OCUPAÇÃO (APO)}

\subsection{Conceituação}

A Avaliação Pós-Ocupação (APO) é um conjunto de métodos e técnicas que busca avaliar o desempenho de ambientes construídos ${ }^{1}$ e, a partir da verificação de erros e acertos do ambiente em uso, permite conhecer, diagnosticar e formular diretrizes para produção (projeto e construção) e consumo (uso, operação e manutenção), considerando essencial o ponto de vista dos usuários. Sua aplicação e importância encontram-se essencialmente baseados nos relatos daqueles que usam os espaços edificados (ZIMRING, 1987, 1989; PREISER et al., 1988; BECKER, 1989; ORNSTEIN \& ROMÉRO, 1992; REIS \& LAY, 1994 e 1995). É importante destacar que o que diferencia a APO de outros métodos e técnicas ${ }^{2}$ aplicados às questões relativas ao projeto, à construção e seu uso é que além de analisar a memória da produção da construção, submete à avaliação os elementos comportamentais dos usuários e suas possíveis alterações e necessidades ao longo do tempo.

Historicamente, a APO surge nos países desenvolvidos em decorrência da avaliação do ambiente construído a partir do ponto de vista dos usuários. Com a construção, em larga escala, de conjuntos habitacionais no período pós-guerra e, em decorrência da não satisfação às exigências dos moradores, não só das condições técnicas de produção e uso do edifício, mas também das expectativas comportamentais dos usuários do ambiente construído, surge a área de conhecimento APO, combinando a avaliação técnica e o ponto de vista do usuário. Principalmente, a partir dos EUA, estudos de casos e investigação científica, aos poucos começaram a ser praticadas nos demais países desenvolvidos, tais como Alemanha, Inglaterra, Escócia, Austrália, Nova Zelândia e Japão, tendo se consolidado do ponto de vista acadêmico, apesar de se configurar como atividade profissional de consultoria nestes países. Entretanto, a APO

\footnotetext{
${ }^{1} \mathrm{O}$ ambiente construído aqui considerado é definido no sentido mais amplo, podendo se remeter a micro e macroambientes, tais como o edifício, a cidade, o espaço público ou ainda a região. Portanto, qualquer ambiente construído ou conjunto de ambientes construídos pode passar por um processo de avaliação (ORNSTEIN, 1992).

${ }^{2}$ Wener apud Lay \& Reis (1994) ressalta a principal diferença entre as avaliações pós-construção e pósocupação. Nestes casos, as avaliações que objetivam garantir a satisfação dos usuários são consideradas avaliações pós-construção, tais como as avaliações com enfoque técnico nos edifícios. Por outro lado, as avaliações pós-ocupação utilizam o grau de satisfação dos usuários como critério de desempenho do ambiente construído.
} 
no Brasil é um campo relativamente novo para as áreas da arquitetura e engenharia, na medida em que existem, ainda e relativamente, poucas pesquisas voltadas para a fase de uso, operação e manutenção, o que de uma certa medida faz com que seja reduzida a vida útil destes ambientes construídos (ORNSTEIN \& ROMÉRO, 1992).

A adoção constante das técnicas metodológicas relacionadas à APO, por meio da aplicação comparativa em diversas pesquisas e estudos de casos semelhantes ou em um dado estudo de caso, de forma seqüencial e constante no tempo, parece ser o procedimento mais eficiente na busca para o melhor desenvolvimento de projetos futuros. Para isso, a tomada de decisões quanto a alternativas de projeto, bem como a aplicação de procedimentos metodológicos rigorosos, aferindo ambientes construídos, trabalhando não só com teorias projetuais, mas efetivamente atuando junto às populações usuárias, integram pesquisas cujos resultados se voltam à melhoria do ambiente construído (SANOFF, 1991; PREISER, 2001 e ROMÉRO \& ORNSTEIN, 2003).

\subsection{Contribuição da APO}

Mesmo considerando a urgente necessidade, no Brasil, de pesquisas no campo de APO voltadas ao acompanhamento de projetos e modelos direcionados à construção de bibliotecas universitárias, está longe de ser a APO realmente implementada e utilizada como instrumento de interesse na avaliação desses espaços edificados. No contexto brasileiro, verificam-se poucos estudos no gênero, particularmente aqueles que contam com procedimentos metodológicos claros e consistentes, voltados para o estabelecimento de indicadores de desempenho e diretrizes mínimas em intervenções projetuais de bibliotecas universitárias.

Constatam-se, nessas ultimas décadas, os seguidos avanços alcançados na concepção e execução de projetos de bibliotecas universitárias, tanto no âmbito nacional como internacional, principalmente na utilização de novas tecnologias construtivas, no emprego de grande aparato comunicacional, na tentativa de promoção, no conforto e segurança dos usuários no seu ambiente construído. Além disso, considerando-se a iminência da escassez de energia elétrica e os altos custos de manutenção, há uma preocupação constante com a atualização dos equipamentos e serviços, adotando-se mecanismos de alta tecnologia da informação, direcionando a minimização de custos, conservação de energia e bem estar do usuário. Fora isso, as 
unidades superiores educacionais, principalmente aquelas vinculadas às instituições privadas, destacam-se pela crescente preocupação com o valor estético dessas edificações, valorizando fachadas impactantes, destacando cores e materiais variados e composição volumétrica complexa.

Tais variáveis, de uma certa maneira, fazem parte de um conjunto de normas, diretrizes e parâmetros técnicos que, quando ajustados adequadamente, objetivam formatar o ambiente construído adustado às condições previstas de projeto e aos anseios de seus usuários. Entretanto, a produção e a operação do projeto, as condições de evolução da construção e dos equipamentos obrigam a avaliação constante dos resultados do processo de produção e uso desses ambientes, tanto no que se refere aos aspectos positivos quanto aos aspectos negativos.

$\mathrm{Na}$ esfera internacional, vários exemplos têm sido constatados na avaliação sistemática de ambientes construídos de bibliotecas universitárias, buscando a fundamentação científica tanto para a tomada de decisões como alternativas de projetos nesses espaços, sempre seguindo abordagens e fases metodológicas semelhantes em pesquisas aplicadas em APO.

Um dos principais exemplos dessa área é o NCEF -National Clearinghouse for Educational Facilities, localizado na cidade de Washington, EUA e criado em 1997. O centro tem como função básica fornecer informações e subsídios no planejamento, na construção e na melhoria dos espaços e equipamentos destinados às atividades escolares. Um dos setores atendidos pelo NCEF é o que se refere aos projetos de bibliotecas universitárias, disponibilizando um acervo completo de relatórios, pesquisas, livros, artigos de jornais e abordagens que exploram o planejamento, o projeto, a construção e a operação de bibliotecas universitárias. Dentre os trabalhos mais representativos vinculados ao NCEF, destacaM-se as pesquisas que abordam não somente os aspectos metodológicos (avaliações técnicas de desempenho e aferição de satisfação dos usuários), mas também os resultados das análises funcionais, recomendações técnicas e avaliações construtivas. Assim, os exemplos que se seguem, ressaltam a constante preocupação em implementar proposições e intervenções em ambientes construídos de bibliotecas universitárias. São eles:

\section{- $\quad$ O Libris Design vinculado ao The Institute of Museum and Library}

Services, apresenta uma série de estudos e pesquisas que têm como objetivo subsidiar a avaliação de desempenho de bibliotecas universitárias no contexto da gestão e do controle do ambiente construído desses edifícios. No estudo 
intitulado "Daylighting Design in Libraries", Dean (2005) aborda o uso da luz natural em bibliotecas universitárias, discutindo os princípios gerais do projeto de iluminação natural e recomendando quais são os níveis de clareamento satisfatório em ambientes direcionados a esses edifícios. A pesquisa ainda aborda, por meio de resultados de entrevistas com usuários, recomendações técnicas necessárias quanto ao aproveitamento da iluminação natural no conforto visual do ambiente construído, com especificações de aberturas de áreas de janelas, definição de cores e acabamentos de materiais. Outro estudo é o "Furniture for Libraries", apresentado por Graham (2005), que discute o projeto de mobiliário na biblioteca na seleção, obtenção e instalação desse item no ambiente construído. A coletânea também apresenta os resultados das percepções dos usuários e funcionários em relação à ergonomia e ao conforto do mobiliário nos espaços estudados. Mccomb (2005) produziu o "Library Security" e trata objetivamente dos sistemas de segurança em bibliotecas. O trabalho avalia os elementos de risco, a segurança patrimonial, a segurança das coleções bibliográficas, os controles de acessos, políticas de segurança e a avaliação dos usuários e funcionários no tocante à segurança da biblioteca. No final, o documento apresenta algumas recomendações necessárias aos procedimentos de segurança por meio de esquemas, plantas e desenhos. Salter (2005), em sua pesquisa denominada "Acoustics for Libraries", elucida as principais questões vinculadas à acústica em bibliotecas universitárias, discutindo padrões e limitações de ruído; acústica nos espaços de trabalho; controle de vibrações para os equipamentos mecânicos e monitoramento dos índices e valores aceitáveis de ruído no ambiente construído. Mais alguns trabalhos seguem a mesma linha de investigação e avaliação, como por exemplo, Moris (2005) que trabalha o tema de materiais de revestimentos para os interiores e Malman (2005), discute a aplicabilidade da iluminação artificial em bibliotecas universitárias.

- $\quad$ A ALA - American Library Association (2006), é outro órgão que vem cooperando nas atividades de avaliações e análises de bibliotecas universitárias no EUA, disponibilizando importantes padrões voltados ao planejamento e operação física desses edifícios. O relatório Standards for Libraries in Higher Education (2004) referenda a importância da aplicação da avaliação no âmbito da biblioteca universitária, a fim de promover ajustes aos 
objetivos propostos e potencializar a interação entre todos os atores envolvidos nas atividades cotidianas do ambiente construído. Além disso, a pesquisa enfatiza e recomenda a participação direta dos usuários nas decisões relativas aos projetos de remodelação de espaços e alterações de layouts em ambientes de bibliotecas universitárias.

- $\quad$ Dois autores, Lackneyl, J.A. \& Zajfen, P. (2005), trabalham o tema da avaliação pós-ocupação na Biblioteca da Universidade de Palm Desert, Califórnia, EUA. As análises envolveram os aspectos relativos à funcionalidade espacial, conforto ambiental, disposição do acervo bibliográfico e, principalmente, entrevistas e questionários aplicados aos usuários, investigando o nível de satisfação e as expectativas concernentes ao ambiente construído da biblioteca em questão. O estudo estabelece elementos importantes finais de análises e recomendações, formatando um importante documento de planejamento para a direção da universidade.

- $\quad$ O estudo de Silver, S. \& Nickel, L.T. (2002) descreve uma pesquisa realizada na Biblioteca da Universidade do Sul Flórida (USF), EUA, com a finalidade de avaliar o ambiente construído desse edifício em função das atividades e necessidades desenvolvidas pelos usuários. Foram aplicados questionários e entrevistas para coleta de dados no sentido de aferir o nível de satisfação dos usuários (funcionários, estudantes e visitantes). Logo a seguir, executou-se a tabulação dos dados com o objetivo de determinar quais os pontos positivos e negativos estavam relacionados com os elementos do desempenho do ambiente construído. Ao final, o trabalho apresenta uma descrição sucinta de procedimentos e técnicas adotados, com o intuito de promover recomendações e diretrizes técnicas ao ambiente avaliado.

- $\quad$ Sannwald (2001) enumera em sua pesquisa, uma completa lista de elementos de verificação projetual, por meio da avaliação e da análise do ambiente construído de projetos de bibliotecas universitárias, por intermédio da participação dos usuários. O autor denomina está metodologia como "lista de verificação", englobando, inclusive, a possibilidade de avaliação das novas formas do desenho espacial, decorrentes das redes de computadores como, por exemplo, internet, bancos de dados e intranet.

Um dos principais exemplos no contexto internacional, concernente à aplicação das metodologias da APO, vem sendo desenvolvido na Nova Zelândia. Nesse 
país, as avaliações e as análises sistemáticas dos ambientes construídos visam a criar procedimentos que estimulem o desenvolvimento de propostas que colaboram com o bem-estar do usuário. O conceito básico desses trabalhos é o uso destes ambientes construídos entendidos como forma de apropriação dos espaços na operação e na manutenção, ou seja, formata-se o estabelecimento de programas eficientes de manutenção (preventiva e corretiva) em todos os segmentos da construção civil, arquitetura, engenharia, etc.

Dois exemplos de Avaliação Pós-Ocupação em bibliotecas universitárias

- Biblioteca de Vauxhall e a Biblioteca da Faculdade Waitakere - contaram com o apoio do Ministério da Educação da Nova Zelândia no ano 2000, fornecendo verbas a todas as etapas do trabalho. A pesquisa focou, principalmente, a revisão de todo o projeto arquitetônico das bibliotecas, analisando o desempenho dos elementos positivos e negativos presentes no ambiente construído ou de qualquer de seus componentes, em relação à satisfação dos usuários. É importante destacar que, como todo processo de construção das unidades das universidades teve o apoio e o suporte do Ministério da Educação da Nova Zelândia, a APO, relacionada aos ambientes desses edifícios, já estava contemplada nos programas de realimentação de projetos de faculdades e bibliotecas universitárias. Outro ponto forte do projeto das bibliotecas, quando da época da construção, foi atribuída à participação efetiva dos futuros usuários, adiantando suas possíveis necessidades relacionadas ao ambiente construído. A APO contou com a aplicação de questionários, entrevistas, análises de vídeos, grupos focais e walkthrough sempre focando os extratos principais dos usuários das bibliotecas (alunos, funcionários, visitante, etc). Com a tabulação de todos os dados levantados nesta primeira fase, na qual os usuários apontaram por uma escala de valores, todos os pontos negativos e positivos pertinentes ao ambiente construído das bibliotecas, as equipes de avaliadores puderam ter em mãos os quesitos necessários para a análise e o diagnóstico. A etapa final gerou um rol de recomendações distribuídas em várias fases de aplicação, sendo: em curto prazo (ações imediatas), em médio prazo (no máximo de três anos) e em longo prazo (para futuros projetos). Desta maneira, toda a comunidade universitária, equipe técnica e agentes governamentais envolvidos no processo da APO das bibliotecas puderam ter uma visão real e atualizada das demandas oriundas deste ambiente construído.

$\mathrm{Na}$ Inglaterra, outro importante país no contexto da APO, surge, no ano de 1995, o PROBE - Post-Occupancy Review of Buildings and Their Engineering - 
uma organização independente que tem a função de fornecer informações e subsídios ao planejamento, à construção e à melhoria de ambientes construídos de edifícios públicos. O órgão ainda conta com um corpo de profissionais e de técnicos envolvidos em programas de capacitação ligados à área da avaliação pós-ocupação, além de disseminar normas, padrões e resultados através do jornal Building Services Journal e pela internet. Entre os temas e discussões desenvolvidos, destacam-se: projeto e construção de edifícios, satisfação dos usuários em ambientes construídos, conservação de energia, operação e gerência de projetos, análise de desempenho de edificações, etc. Uma das áreas atendidas pelo PROBE são os estudos direcionados aos ambientes construídos de ensino superior, incluindo a estruturação de grupos de pesquisas, congressos, simpósios e encontros com as principais universidades e faculdades inglesas ligadas à área de construção e tecnologia de edifícios de ensino superior.Além disso, um rol de entidades e organizações colaboram com os trabalhos de investigação, como o HEDQF - Higher Education Design Quality Forum e o RIBA - Royal Institute of British Architects.

Ao longo da década de 1990, a Inglaterra passou por um intenso processo de desenvolvimento de suas bibliotecas universitárias, incluindo um programa de ação com o objetivo de projetar e construir, a médio e longo prazo, mais de 100 edifícios em faculdades, universidades e institutos superiores isolados. Ao mesmo tempo em que o setor de ensino superior presenciou o aumento considerável na quantidade de alunos e a forte presença das bibliotecas universitárias, surgiu a necessidade imediata na busca do controle de qualidade da construção desses edifícios e a definição de critérios mais precisos de desempenho do ambiente construído. Foi, portanto, nesse contexto, que surgiram no ano de 1995 os primeiros trabalhos do PROBE direcionados à avaliação pós-ocupação em bibliotecas universitárias na Inglaterra. Mais especificamente, o primeiro estudo foi realizado na Biblioteca da Universidade Politécnica de Anglia e o segundo, na Biblioteca da Universidade de Birmingham. É importante destacar que todos os resultados apresentados pelo PROBE $^{3}$ vinculados a esses estudos de caso, reforçam não só as características técnicas, físicas e dimensionais intrínsecas, mas fundamentalmente os critérios de desempenho, visando ao atendimento das necessidades dos usuários.

Além disso, em relação ao $\mathrm{HEDQF}$, que promove também a investigação e a avaliação dos centros de ensino superior na Inglaterra, organizou em outubro de

\footnotetext{
${ }^{3}$ Documento disponível no Website do PROBE: http://www.usablebuildings.co.uk/Probe/ProbeIndex.html
} 
1995, um simpósio intitulado "The Development of Learning Resource Centres of the Future", com o objetivo de discutir a evolução dos sistemas de avaliações destas instituições no âmbito da qualidade dos serviços oferecidos. Apesar de ainda não estarem explícitos os termos específicos de "avaliação pós-ocupação do ambiente construído", os trabalhos apresentados no setor de projetos de bibliotecas universitárias trataram de questões relativas ao conforto e melhoria da funcionalidade e do armazenamento do acervo bibliográfico. Mais recentemente, em função do crescimento e do desenvolvimento das pesquisas direcionadas à avaliação dos ambientes de bibliotecas universitárias, o HEDQF consolidou um grupo de trabalho denominado Space Management Advisory Group, estabelecendo a importância de fixar normas e padrões referenciais do desempenho mínimo aceitável dos edifícios de bibliotecas universitárias.

Outro importante órgão inglês que reúne e congrega as bibliotecas universitárias do país é a SCONUL - Society of College, National \& Universitym Libraries. Essa entidade, fundada no ano de 1950, além de estabelecer um amplo programa de atividades de compartilhamento e desenvolvimento das instituições conveniadas, atua no suporte à aplicação dos métodos de APO nos edifícios das bibliotecas acadêmicas. Como forma de viabilizar e de sistematizar esse apoio às bibliotecas, a SCONUL formatou quatro sub-programas assim divididos:

1. ACOB - Advisory Committee on Buildings: esse programa tem a função de disseminar as informações vinculadas ao controle de qualidade do ambiente construído, sugestões de mobiliários e equipamentos e padrões de operação do espaço edificado. Fora isso, a comissão organiza eventos, seminários, visitas e conferencias relativos aos temas desenvolvidos.

2. SCONUL - Library Buiding Projects Database: o objetivo desse programa é disponibilizar uma base de dados relativa às informações dos edifícios de bibliotecas universitárias, fichas técnicas, quantidades de acervos, serviços disponíveis, dados arquitetônicos e, um completo e atualizado arquivo dos avanços conseguidos na área APO em bibliotecas universitárias.

3. SCONUL - Library Buiding Visits: esse programa tem a função de organizar um amplo rol de visitas e tours nas bibliotecas universitárias conveniadas, voltadas, principalmente, aos especialistas das áreas de biblioteconomia e arquitetura, aos diretores de outras bibliotecas universitárias nacionais e 
internacionais e, finalmente, aos grupos especiais de visitantes da comunidade em geral. É comum também haver, nos ambientes das próprias bibliotecas, encontros dirigidos e eventos relacionados ao contexto das bibliotecas acadêmicas.

4. SCONUL - Design Award: todo ano a SCONUL concede um título de reconhecimento de qualidade àquelas bibliotecas universitárias que se destacaram nas atividades e nos serviços de excelência de funcionamento, aplicação de novas tecnologias e satisfação dos usuários em relação à avaliação do ambiente construído. Além disso, outros quesitos são levados em conta como funcionalidade, adaptabilidade, acessibilidade, sustentabilidade, segurança, eficiência energética e flexibilidade espacial.

Com a introdução dos métodos e procedimentos da APO nos edifícios de bibliotecas universitária na Inglaterra, foi possível conscientizar os principais agentes envolvidos em seu uso, operação e manutenção, além de criar uma cultura associada ao feedback das operações do bem-estar e à produtividade dos usuários. Outro ponto relevante foi o desenvolvimento, por parte do PROBE, de manuais, diretrizes, padrões e normas para projetos futuros de ambientes construídos nas bibliotecas acadêmicas. 


\section{CAPÍTULO 6 - CARACTERIZAÇÃO DOS ESTUDOS DE CASO}

\subsection{Estudos de Caso}

Pretende-se adotar estudos de caso como estratégia de pesquisa, de forma que se possa responder, por meio de casos práticos e reais, às perguntas relacionadas ao arranjo espacial. Com base nas respostas obtidas será possível investigar a validade das proposições teóricas, cujas questões básicas são: (1) Após a realização de análise de desempenho físico dos ambientes de bibliotecas universitárias, é possível determinar intervenções e melhorias nos objetos analisados? (2) Como relacionar fatores ambientais na determinação da satisfação dos usuários em ambientes de bibliotecas universitárias?

Segundo relata Yin (2001), a utilização de estudos de caso é pertinente quando se utilizam questões de "como" e "porque", quando não se tem a exigência do controle sobre eventos comportamentais e quando o foco se concentra em fenômenos contemporâneos, cooperando, de maneira exemplar, para a compreensão dos fenômenos sociais complexos. Por outro lado, a fim de obter ajustes dessa definição ao campo da arquitetura (ANDRADE 2005, apud GROAT, L; WANG, D., 2002), sugere-se que seja feio um adendo, de modo que não somente fenômenos sejam investigados, mas também locais (ambientes físicos), tanto os contemporâneos quanto os históricos. Dessa maneira, os estudos de caso não são apropriados somente na fase exploratória de uma investigação, mas podem ser executados também como ferramenta para descrever (fase descritiva) ou testar propostas (fase exploratória).

Neste trabalho, os estudos de caso deverão ser utilizados para fins de avaliação de desempenho, cujos objetivos podem ser classificados como de natureza exploratória, na medida em que buscam explicar os vínculos causais entre o ambiente construído, suas relações físico-funcionais e o bem-estar do usuário. Tem também um caráter exploratório, na medida em que pretendem explorar a dinâmica que perpassa essas relações e, por último, uma abordagem descritiva dos contextos e das realidades dos casos escolhidos e analisados. 


\subsection{Avaliações Quantitativa e Qualitativa}

Foram utilizadas técnicas e procedimentos quantitativos e qualitativos para envolver dados representativos. De um lado, pretende-se estruturar as informações quantitativas relacionadas aos índices, perfil dos objetos escolhidos e dados que possam estabelecer comparações entre os resultados obtidos, quando possíveis. E por outro lado, a avaliação qualitativa que visa a trabalhar com os valores, hábitos, crenças, representações, atitudes e opiniões de usuários, podendo-se assim, executar uma abordagem interpretativa para compor o contexto no qual se insere o fenômeno estudado (ORNSTEIN \& ROMÉRO, 1992; MINAYO \& SANCHES, 1993; ANDRADE 2005). Portanto, os dois estudos de caso servirão de comprovação à hipótese da tese.

Objetiva-se tratar o ambiente físico das bibliotecas universitárias analisadas como um sistema ecologicamente integrado: o edifício com seus espaços, infra-estrutura e sistemas; os usuários que dele fazem uso com suas necessidades, valores e expectativas, compreendendo que cada fase desta relação se constituiu de elementos que podem ser aferidos quantitativamente (dimensões, área ocupadas, estruturas, etc) e experimentados qualitativamente (nível de satisfação quanto ao ambiente, qualidade da iluminação, qualidade acústica, etc), construindo-se um processo contínuo de avaliação de desempenho que se retroalimenta ao longo do ciclo produtivo da vida do edifício.

\subsection{Descrição dos Edifícios Escolhidos}

\subsubsection{Histórico da UNESP - Universidade Estadual Paulista}

A Universidade Estadual Paulista (UNESP) foi fundada no ano 1976, pela união de 14 institutos isolados de Ensino Superior do Estado de São Paulo, unidades universitárias criadas, em geral, entre fins da década de 1950 e meados da década de 1960, situadas em diferentes pontos do interior paulista. Os institutos isolados tiveram origens diferenciadas, de acordo com os momentos de sua criação, de conformidade com as aspirações de seus criadores e segundo os objetivos a serem cumpridos. Apesar dessa heterogeneidade, eles tiveram em comum o fato de serem

pioneiros na implantação do ensino superior público de qualidade no interior do Estado 
de São Paulo. Essas escolas estiveram sob a administração da Secretaria da Educação do Estado de São Paulo que, em fins de 1969, criou a Coordenadoria do Ensino Superior do Estado de São Paulo, a CESESP, encarregada do gerenciamento dos Institutos Isolados. Desde inícios de 1975, a idéia da criação da UNESP foi sendo gerida no interior da CESESP, a partir de estudos fundamentados na experiência dos institutos isolados. Desenhada no interior da CESESP, com o apoio do governo do Estado, a proposta de criação da universidade foi aprovada, em 15 de outubro de 1975, pelo Conselho Estadual de Educação. A futura universidade contaria com 1.700 docentes, $78 \%$ em regime de dedicação integral à docência e à pesquisa, 50\% com titulação de doutor, contando com aproximadamente 11.000 alunos.

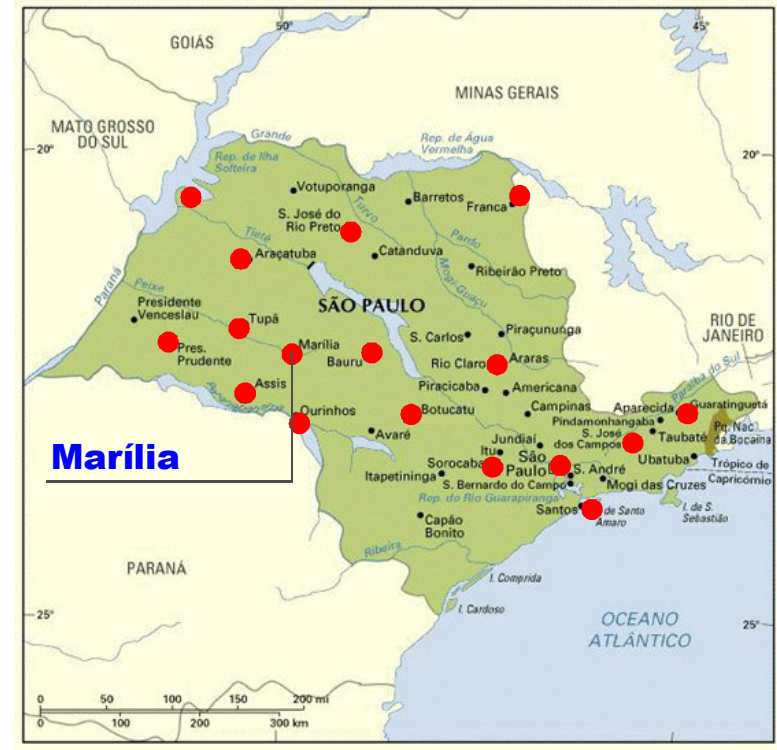

Campi Universitários

Figura 115 - Unidades Universitárias/UNESP/Estado de São Paulo Fonte: www.unesp.br

\subsubsection{O Campus de Marília}

Faculdade de Filosofia, Ciências e Letras Campus/Marília foi criada no contexto da política do governo de busca de solução para a procura de vagas para o ensino superior e a necessidade de formação de pessoal docente para o atendimento das escolas secundárias recém criadas. Para o atendimento a essa finalidade o governo do 
Estado de São Paulo propôs, então, a criação da várias escolas superiores, os Institutos Isolados de Ensino Superior. A solicitação era a de criação de escolas de alto nível e portadoras de uma linha renovadora de ação. Seu corpo docente poderia ser recrutado tanto no país, como no exterior e as condições de trabalho deveriam ser atraentes para garantir a consolidação de sua estrutura didática e administrativa. Seguindo esses princípios, criou-se uma Faculdade em Marília, há muito esperada e reivindicada pela população local.
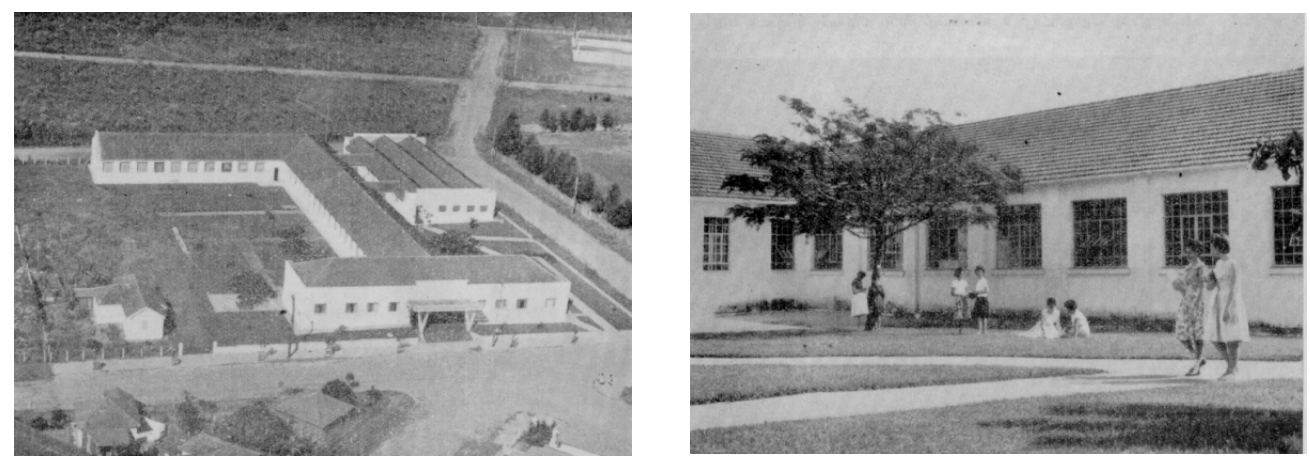

Figuras 116 e 117 - Faculdade de Filosofia, Ciências e Letras, 1959 - Marília Fonte: www.marilia.unesp.br

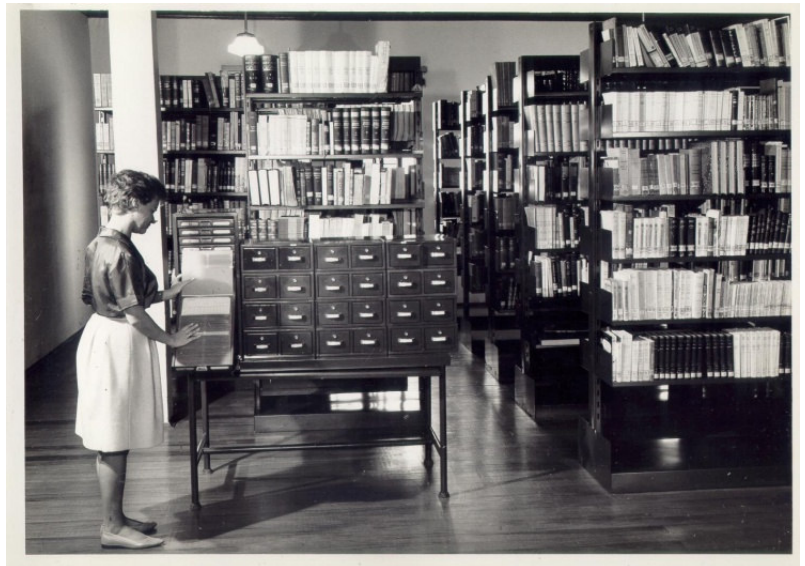

Figura 118- Biblioteca do Campus/Unesp - Marília, anos 60 Fonte: www.marilia.unesp.br

Faculdade de Filosofia e Ciências congrega em torno de 123 docentes, 137 funcionários técnico-administrativos, 1.659 alunos de graduação e 274 alunos de 
pós-graduação. Sua estrutura física está distribuída em dois locais diferentes, o Campus I e o Campus II, respectivamente localizados à Avenida Hygino Muzzi Filho, 737 e à Avenida Vicente Ferreira, 1278. No Campus I estão instaladas as estruturas administrativas, o Centro de Convivência Infantil, os laboratórios, as entidades representativas dos três segmentos, a Biblioteca, o Prédio de Atividades Didáticas, os Núcleos de Ensino e de Direitos Humanos, grupos de pesquisas, entre outros. A Biblioteca ocupa uma área de aproximadamente 2000 metros quadrados e possui um dos maiores acervos da região, hoje estimado em 74.636 títulos. É também no Campus I onde ocorre a maioria das atividades didáticas.

No Campus II funcionam o CEES - Centro de Estudos de Educação e Saúde (congregando a Clínica de Fonoaudiologia e o antigo Centro de Orientação Educacional), a UNATI (Universidade Aberta à Terceira Idade), a Unidade de Atendimento Médico, Odontológico e Social - UNAMOS, a Coordenadoria Geral de Bibliotecas - CGB, o Núcleo de Ciência e Cultura, o CEDHUM - Centro de Documentação Histórica e Universitária de Marília, o Museu Histórico e Pedagógico Embaixador Hélio Antonio Scarabôtolo, o CEICOMHU - Centro de Estudos Interdisciplinares da Comunicação Humana e outros setores ligados à área de extensão da Unidade.

\subsubsection{Caracterização Geral do Edifício Biblioteca Unesp/Campus Marília}

A Biblioteca da Faculdade de Filosofia e Ciências - UNESP Campus de Marília inicia suas atividades no dia $1^{\circ}$ de abril de 1959. Mais tarde inaugura prédio próprio no campus universitário no dia 03 de novembro de 1980, englobando uma área de $1.745 \mathrm{~m}^{2}$ e localizada no eixo norte/sul do Campus. Vinculada administrativamente à direção da unidade e tecnicamente à Coordenadoria Geral de Bibliotecas - $\mathrm{CGB}^{1}$ é parte integrante da rede de Bibliotecas da UNESP.

A biblioteca atende aos cursos de Arquivologia, Biblioteconomia, Ciências Sociais, Educação Especial, Filosofia, Fisioterapia, Fonoaudiologia, Pedagogia, Relações Internacionais e Terapia Ocupacional, além dos Programas de Pós Graduação nas áreas de Ciência da Informação, Ciências Sociais, Educação e Filosofia. Possui um acervo diversificado, atendendo não só ao campus universitário da UNESP,

\footnotetext{
${ }^{1}$ CGB gerencia o funcionamento sistêmico da rede de Bibliotecas da Unesp, aprimorando e promovendo a política informacional da Universidade.
} 
mas à comunidade local e regional. Atualmente conta com um acervo de 77.400 volumes de livros, 1.801 teses e dissertações, aproximadamente 2.329 títulos de periódicos nacionais e internacionais, além de mapas, slides e bases de dados.

\subsubsection{Caracterização Arquitetônica do Edifício}

Os itens seguintes descrevem as características mais importantes e relevantes dos aspectos arquitetônicos do edifício da Biblioteca da UNESP/Campus de Marília:

- Implantacão: as instalações administrativas e os blocos acadêmicos do Campus da UNESP de Marília são implantados em um terreno irregular, situado na região denominada de "Campus Universitário" da cidade e circunvizinhados por mais duas instituições privadas de ensino superior. Uma das suas principais características é a sua descrição no meio da paisagem de vegetação exuberante e espécies paisagísticas marcantes, estabelecendo uma relação equilibrada entre o volume construído e o conjunto paisagístico externo. Outro ponto marcante na implantação do campus é a distribuição bem separada de todos os blocos das edificações do campus universitário, estabelecendo uma leitura fragmentada dos elementos volumétricos. Além disso, alguns caminhos pavimentados fazem a ligação entre estes blocos e permitem uma variedade de possibilidades de acessos ao edifício da biblioteca. Uma das principais desvantagens é a fraca presença da comunicação visual indicativa dos edifícios, gerando grandes dificuldades na localização e na acessibilidade ao ambiente construído. O visitante que não tem conhecimento dos vários espaços do campus universitário e quer se dirigir até um dos edifícios, possivelmente passará por este problema de localização. 


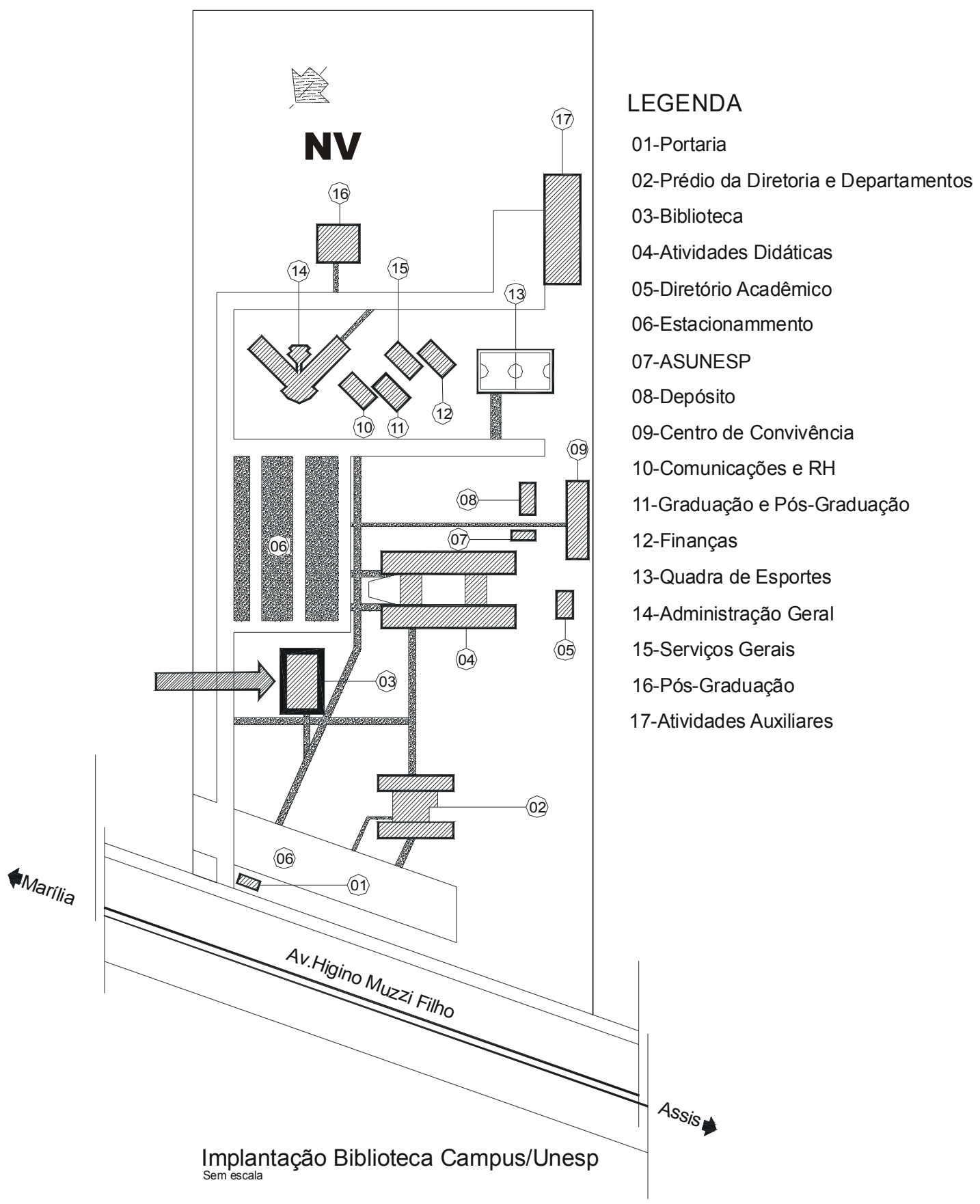

Figura 119 - Implantação Biblioteca - Campus/Unesp - Marília 

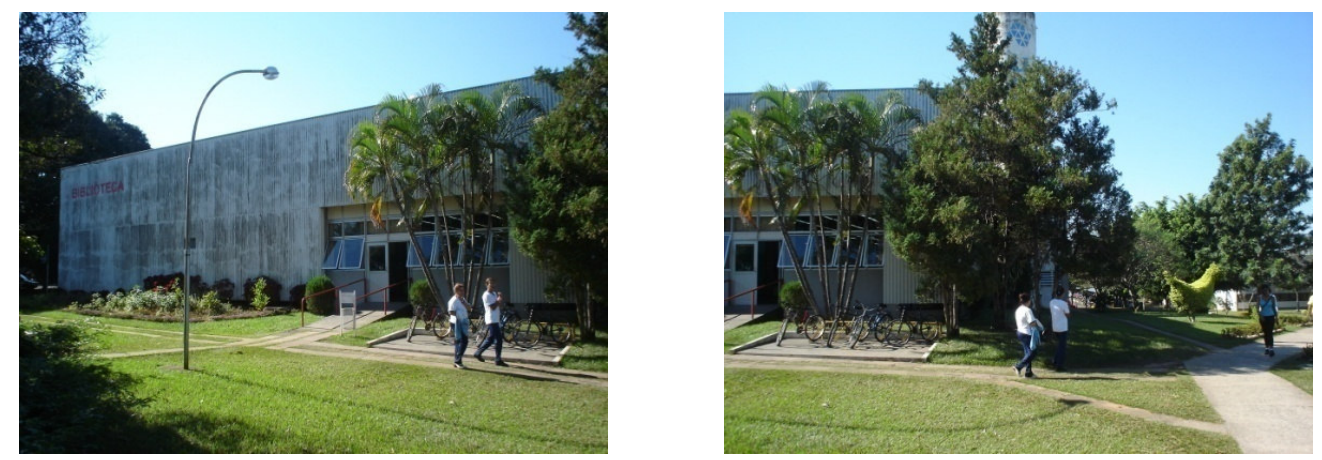

Figuras 120 e 121 - Entrada Principal da Biblioteca do Campus/Unesp - Marília
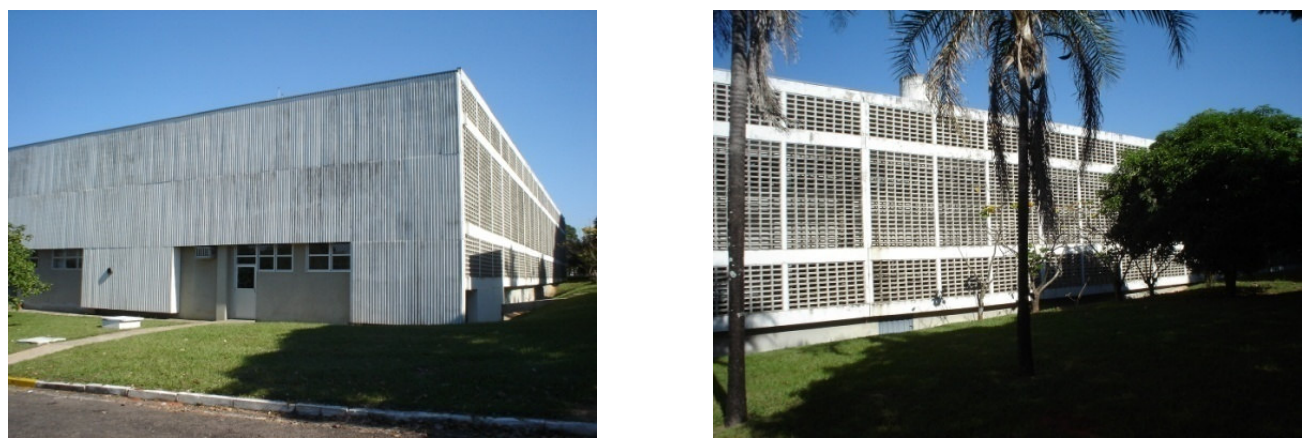

Figuras 122 e 123 - Entrada Secundária e Vista Lateral da Biblioteca do Campus/Unesp - Marília

- $\quad$ Condiç̃os de acessibilidade: apesar de a pesquisa não estabelecer seu foco diretamente neste item, as condições de acessibilidade ao edifício podem ser consideradas razoáveis, já que as calçadas de acesso e os elementos de pavimentação estão em bom estado de conservação. A dificuldade principal está justamente na acessibilidade para pessoas com dificuldade de locomoção, de um modo geral, não é considerada suficiente. Mesmo com medidas tomadas pela direção do campus universitário e pela própria coordenação da biblioteca, para melhorar as condições de acessibilidade, a biblioteca necessita fixar critérios e padrões para adequação da edificação ao uso público, de modo a garantir às pessoas portadoras de deficiência condições adequadas e seguras de locomoção. Com relação às condições de acessibilidade, a biblioteca apresenta faixa de pedestre com a guia rebaixada, rampa na calçada em frente à entrada principal do edifício e corrimão (Figura 124), porém, sem rebaixamento com rampa correspondente do outro lado da biblioteca, impedindo a continuidade de circulação do usuário de cadeira de rodas. 


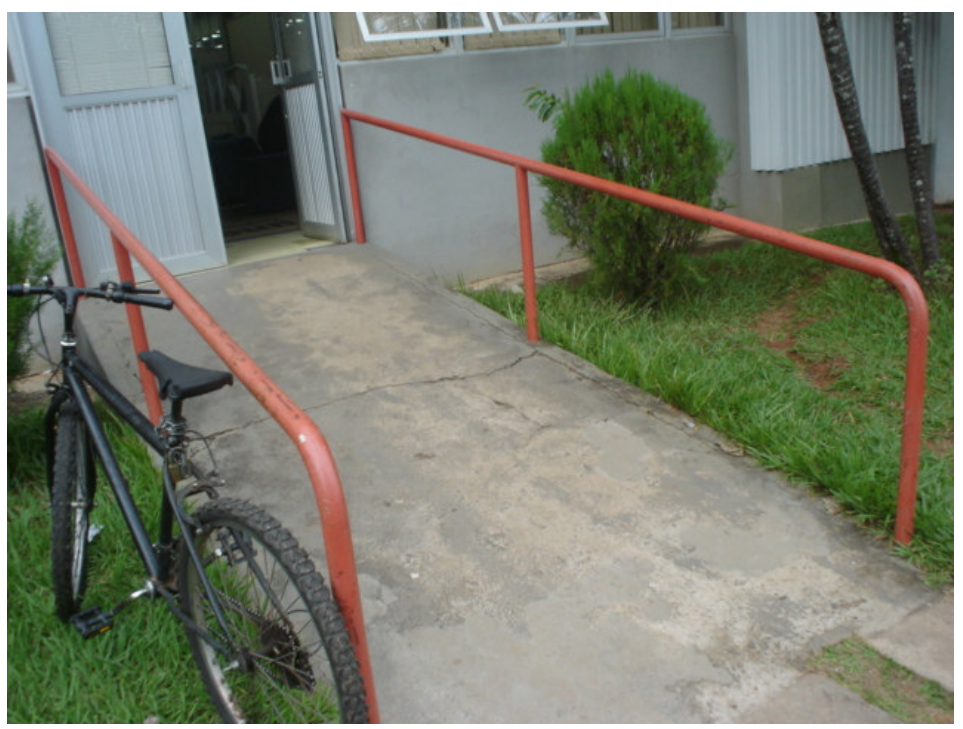

Figura 124 - Entrada da Biblioteca do Campus/Unesp - Marília/Detalhe do corrimão e rampa

- $\quad$ Sinalização externa: A sinalização externa da biblioteca é referente às indicações de acesso e entrada do edifício. Entretanto, a sinalização apresentada é insuficiente para indicar corretamente os acessos às pessoas portadoras de deficiência física (NBR 9050/2004), principalmente nas proximidades e nos outros caminhos e trajetos que conduzem até ao edifício.

- $\quad$ Partido arquitetônico da biblioteca: Assim como acontece em todo o conjunto construído dos blocos da unidade do campus, o prédio da biblioteca estudada segue padrões, normas e especificações adotados pela CGB - Coordenadoria Geral de Bibliotecas e Administração geral da UNESP. Ou seja, o partido arquitetônico do edifício da biblioteca tem, como idéia básica, estruturar uma certa "racionalidade construtiva" por meio de dimensionamentos modulares, utilização dos materiais construtivos baseado no concreto armado e alvenaria aparente e a simplicidade nas soluções volumétricas. A preocupação com a adequação dos fatores naturais do entorno e terreno levou à utilização de elementos vazados e brises horizontais ao longo das aberturas das janelas. Embora essa solução tenha trazido problemas de iluminação natural no interior do prédio, como se verá nas análises executadas, as condições de conforto ambiental estão razoavelmente coerentes com o partido arquitetônico adotado. É importante ainda ressaltar que este partido arquitetônico foi concebido em função de uma demanda de cursos de graduação oferecidos na época da execução do projeto, ou 
seja, a disponibilidade espacial dos ambientes da biblioteca apresenta hoje considerável defasagem com relação ao acervo que está em crescente aumento.
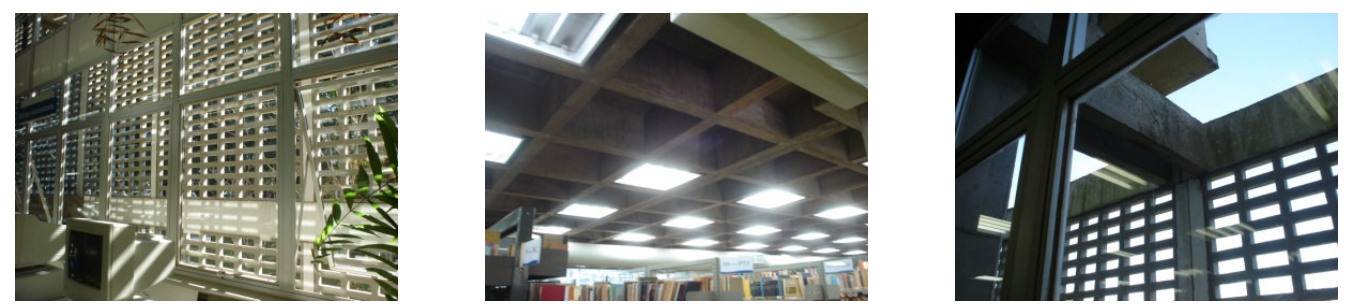

Figuras 125, 126 e 127 - Partido arquitetônico da biblioteca: elementos vazados e dimensionamento modular

- $\quad$ Programa arquitetônico da biblioteca: A biblioteca ocupa uma área construída de $1.745 \mathrm{~m}^{2}$, contendo um acervo de 77.400 volumes de livros, 1.801 teses e dissertações, aproximadamente 2.329 títulos de periódicos nacionais e internacionais, além de mapas, slides e bases de dados. Além disso, a biblioteca foi projetada para conter coleções de bancadas com microcomputadores para acesso às múltiplas fontes de informação; espaço cultural; área administrativa; acomodação para os usuários; depósito; sala de reprografia e sala para se assistir a vídeos técnicos.

A ocupação desses espaços acontece da seguinte forma: 


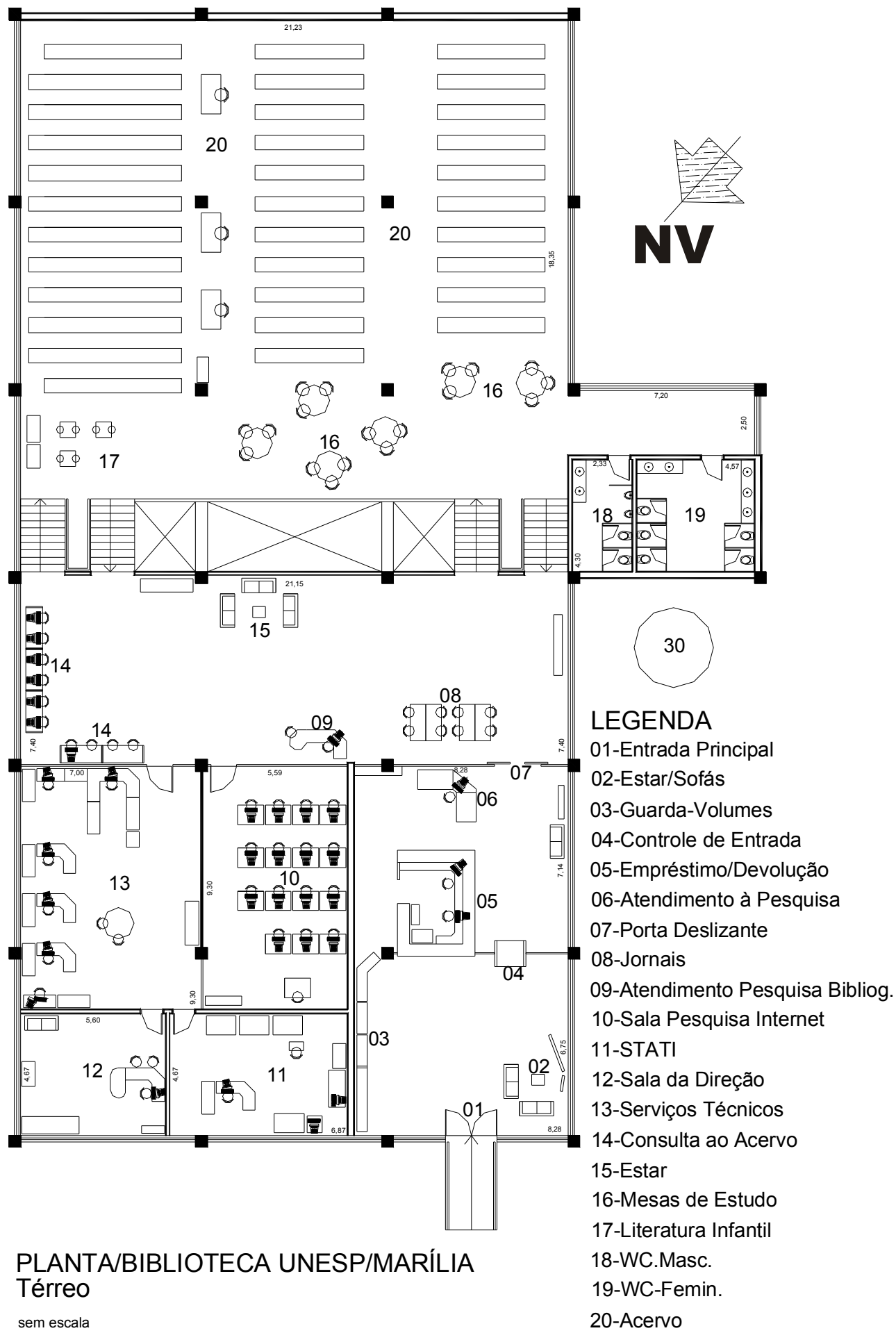

Figura 128 - Pavimento térreo/Biblioteca Unesp/Marília 
a ) - Recepção, Guarda-Volumes e Área de Exposição: Este espaço abriga a entrada principal da biblioteca, o guarda-volumes e a área de exposição. Nesse local, uma pequena área de convívio e descanso é destinada aos usuários, na qual dois sofás de dois lugares ficam dispostos na lateral direita da entrada. Em horários de maior fluxo da biblioteca, principalmente nos intervalos de aulas e nos horários de abertura e fechamento do edifício, esse local recebe um grande número de pessoas que se acomodam nos sofás, nas proximidades da porta de entrada e nos guarda-volumes. Em função disso, não é raro acontecer o conflito entre, as pessoas que permanecem neste espaço de convivência com o fluxo permanente de entrada do edifício. Além disso, com freqüência a direção da biblioteca organiza mostras de pinturas, fotografias/exposições para divulgar o trabalho de artistas e informações de eventos da própria comunidade universitária, acarretando, em algumas situações, o acúmulo demasiado de pessoas no local.

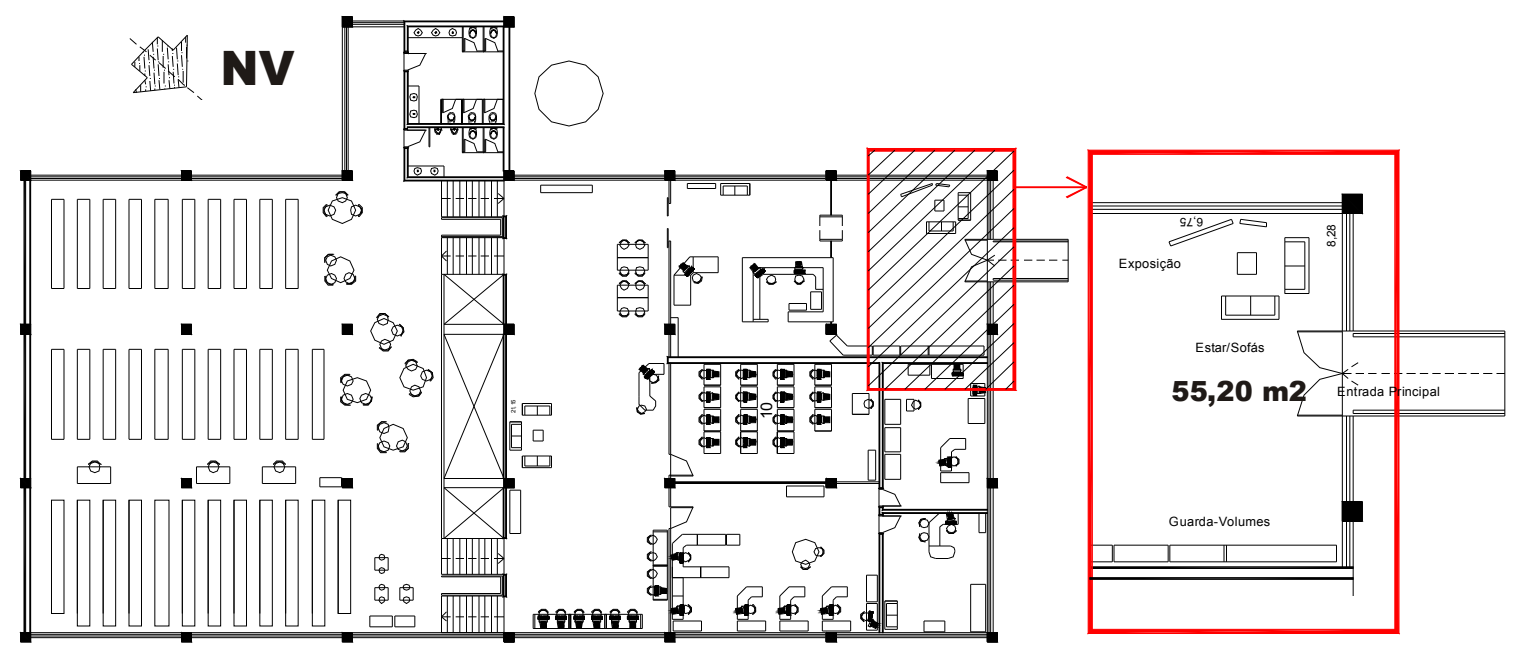

Entrada Principal/Biblioteca Unesp/Marília Térreo

sem escala

Figura 129 - Pavimento inferior/Biblioteca Unesp/Marília 

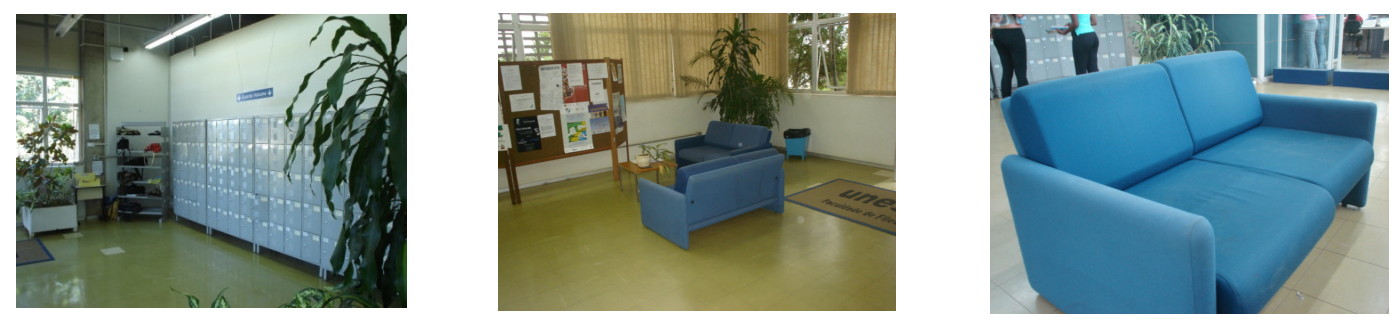

Figuras 130, 131 e 132 - Recepção, Guarda-Volumes e Exposição da Biblioteca

b ) - Empréstimo e Devolucão: O local tem a função de controlar o empréstimo e a devolução de todo o acervo da biblioteca, bem como o gerenciamento digital da movimentação do acervo no interior da biblioteca. Esse espaço é composto por um balcão de madeira em formato de "U", acomodando dois (2) micro-computadores e local reservado para dispor todo o material que é devolvido e entregue pelos usuários. Além disso, internamente, armários auxiliares armazenam outros tipos de documentos, como por exemplo, pedidos de livros para empréstimos, controle bibliográfico e fichas dos usuários. Geralmente, dois funcionários executam as funções de empréstimo e devolução e, bem ao lado deste balcão, um funcionário ocupa uma mesa lateral, justamente para dar suporte às atividades desenvolvidas. Este balcão é uma aquisição relativamente nova da biblioteca e é fruto de um projeto de apoio às bibliotecas universitárias, do Governo Estadual, destinado à atualização do mobiliário presente nestes edifícios. Logo em frente, um portal de controle equipado com sensor eletrônico auxilia na entrada e na saída do material bibliográfico e separa o espaço de empréstimo e de devolução com a entrada principal da biblioteca. E finalmente, logo a seguir, uma porta de vidro temperado deslizante, executa a função no controle de entrada e saída dos usuários. 


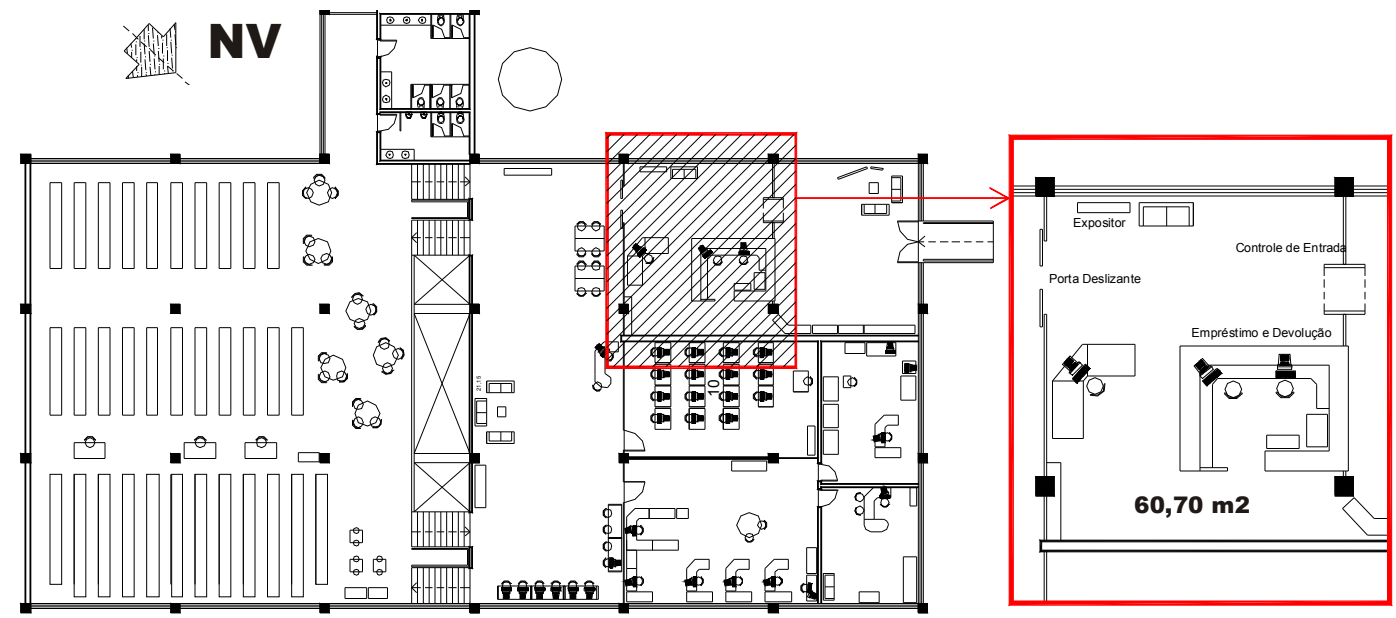

Empréstimo e Devolução/Biblioteca Unesp/Marília Térreo

sem escala

Figura 133 - Planta Empréstimo e Devolução/Biblioteca Unesp/Marília
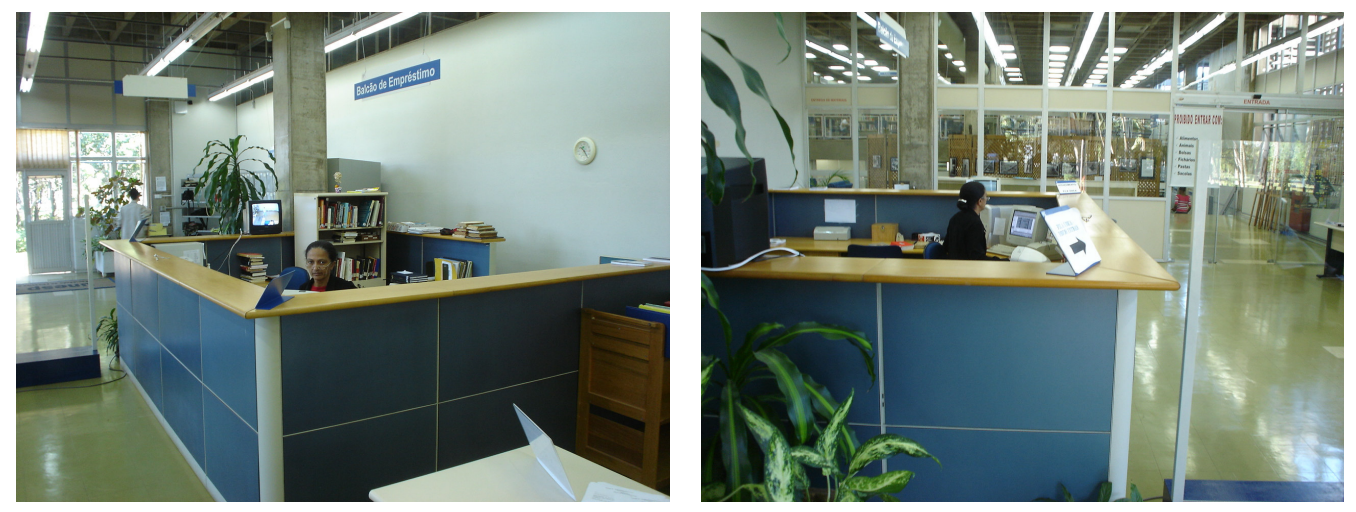

Figuras 134 e 135 - Vista Externa Balcão de Devolução, Empréstimo e Controle 

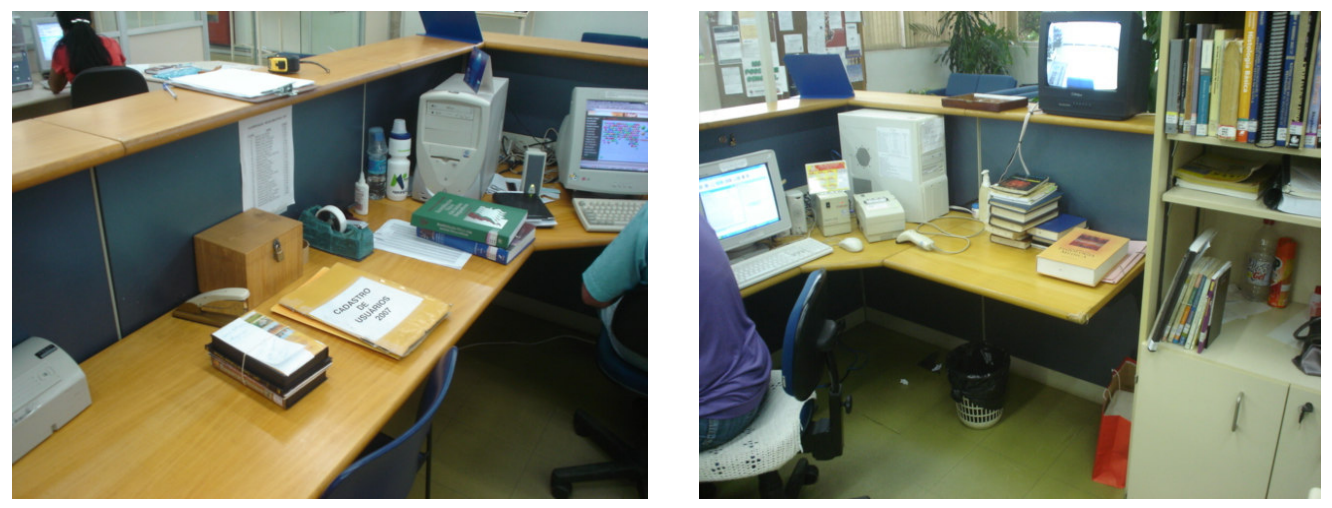

Figuras 136 e 137 - Vista Interna Balcão de Devolução, Empréstimo e Controle
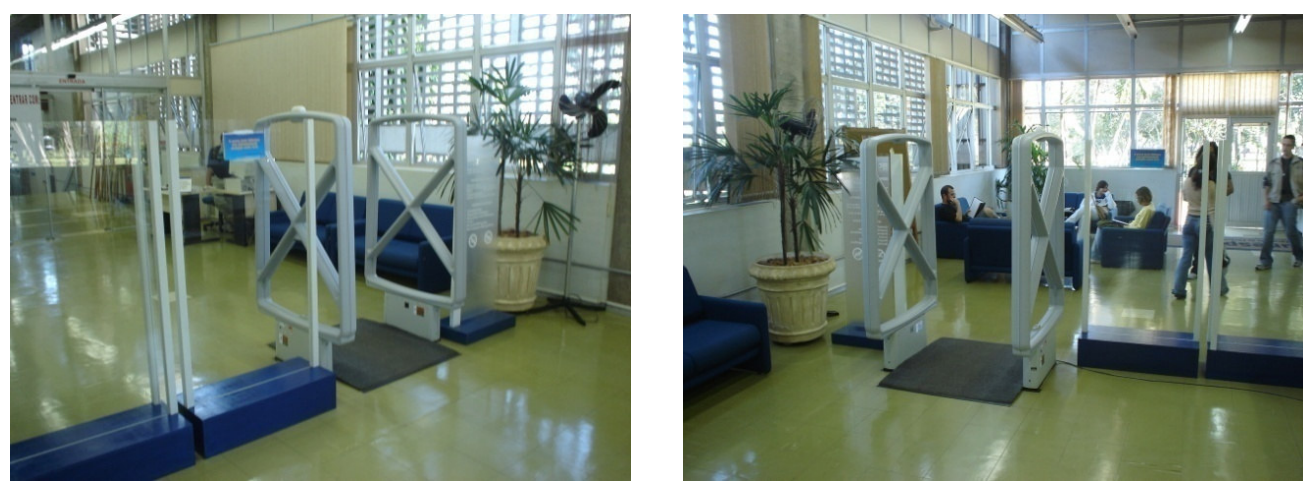

Figuras 138 e 139 - Portal de controle

c ) - Hall Principal: Espaço onde ficam localizadas algumas atividades importantes da biblioteca como a Base de Dados da biblioteca, com microcomputadores interligados ao acesso às bases de dados e Internet; o atendimento à pesquisa, que permite a troca de documentos e fontes externas de informações e a seção de jornais e revistas. Além disso, é local destinado às pequenas exposições, consulta manual ao acervo e local de descanso. Neste grande hall principal, localizam-se as escadas que dão acesso ao mezanino na cota superior, onde se encontra o acervo bibliográfico, as mesas de estudo e os sanitários destinados ao público em geral; as escadas também dão acesso à cota inferior, ambientes onde estão instaladas as salas de estudo individuais, área de pesquisa e leitura, mapoteca, periódicos e auditório. Finalmente, este ambiente permite o acesso à área administrativa e a sala de pesquisa na internet. $\mathrm{O}$ espaço do hall caracteriza-se por ser o eixo estruturador de circulação da biblioteca, permitindo a grande passagem de usuários e funcionários e o desenvolvimento de muitas atividades em um mesmo local. Portanto, é possível afirmar que esse espaço desempenha papel fundamental no contexto 
do partido arquitetônico da biblioteca, na medida em que direciona e estrutura o fluxo dos usuários, colocando em evidência os elementos de mobilidade, flexibilidade e hierarquia espacial da própria biblioteca. Entretanto, as impressões colhidas neste ambiente deixam claro que, com relação ao nível de ruído

produzido no local, tanto dos funcionários quanto dos usuários, que existem problemas sérios a serem resolvidos no âmbito do conforto sonoro.

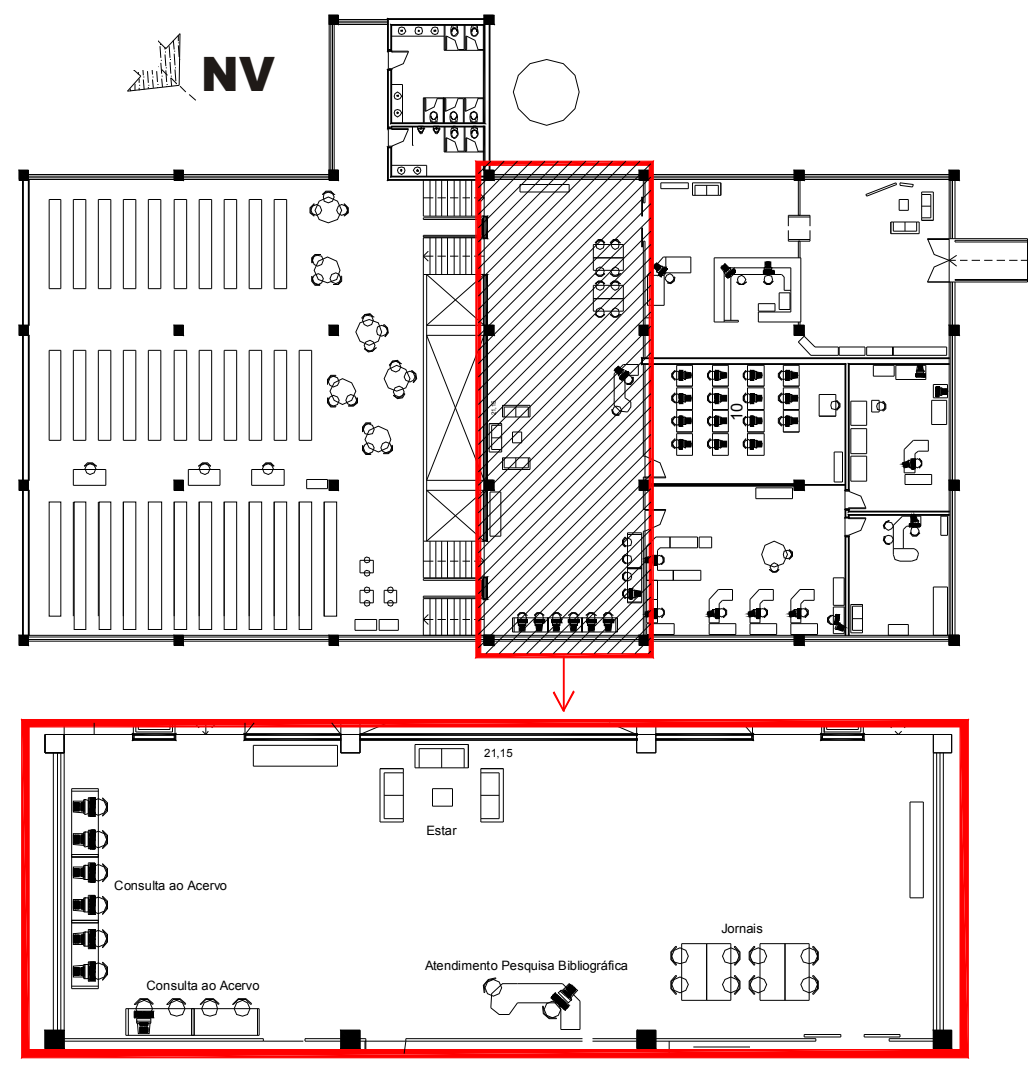

Hall Principal/Biblioteca Unesp/Marília Térreo

sem escala

Figura 140 - Hall Principal Biblioteca Unesp/Marília 

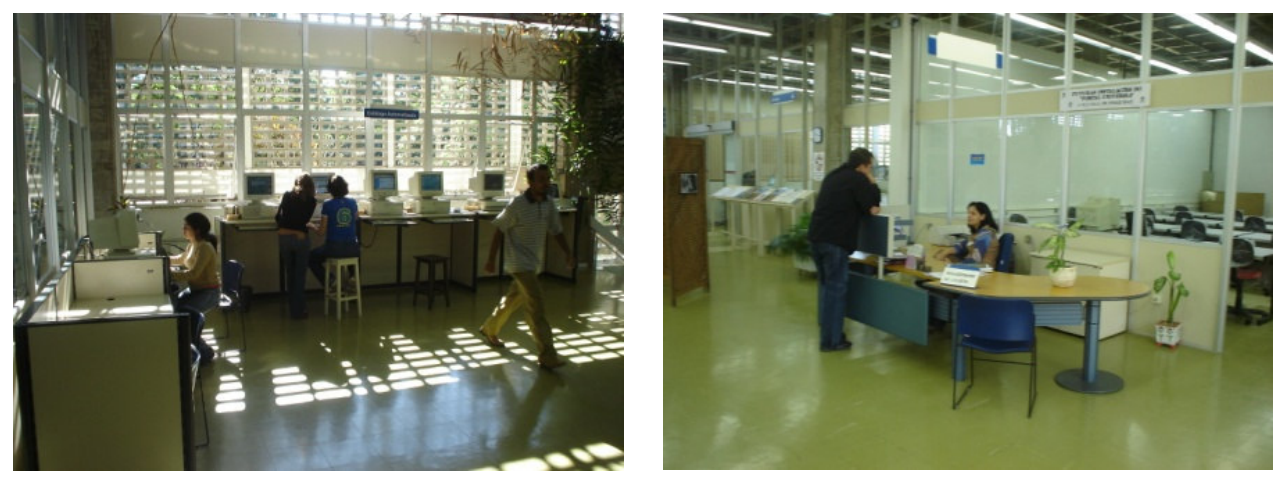

Figuras 141 e 142 - Hall principal: consulta base de dados e atendimento pesquisa bibliográfica
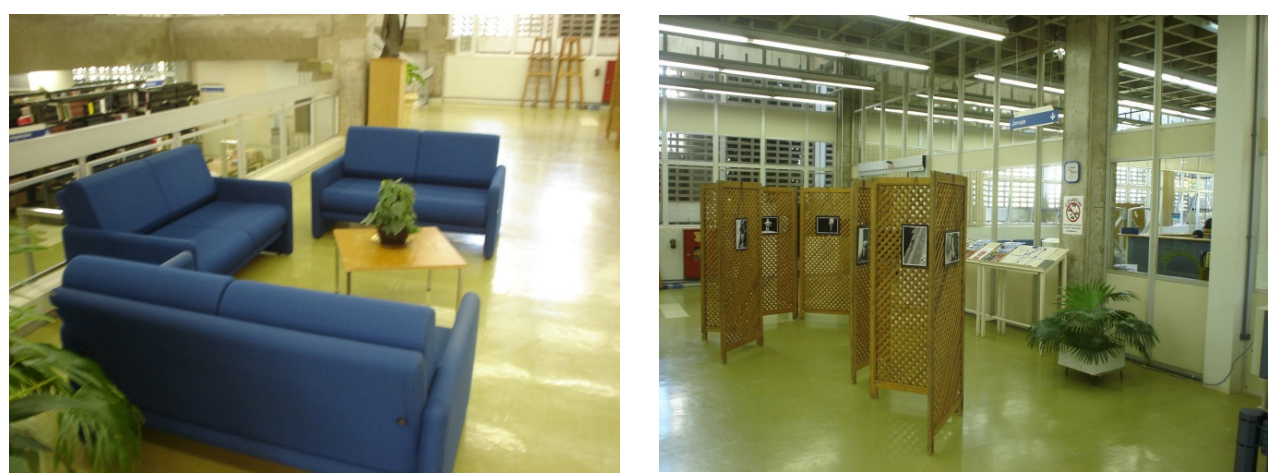

Figuras 143 e 144 - Hall principal: estar e consulta manual/acervo

d ) - Área para leitura e acervo: Trata-se do salão principal onde estão instaladas as estantes com os livros, dissertações e teses, ordenados pelo número de tombo e classificação geral. Nessa área estão as mesas para o estudo e a leitura, sendo de livre acesso a todo acervo disponível da biblioteca. Duas escadas laterais dão acesso ao ambiente e distribuem a circulação ao longo das várias fileiras de estantes e prateleiras do acervo. A disposição dos pilares e a formatação da laje evidenciam o aspecto modular do ambiente na separação das estantes, na distribuição das mesas e na instalação do duto de ar-condicionado. É importante destacar que esse espaço tem uma grande visibilidade em relação ao conjunto da biblioteca, principalmente porque se localiza na cota intermediária dos pavimentos e agrega ao conceito do partido arquitetônico a idéia de um "grande mezanino". Além de ter uma área destinada especificamente para leitura e pesquisa, os usuários também se distribuem ao longo do salão, junto ao acervo bibliográfico, utilizando as mesas e cadeiras que foram separadas 
para tal função. Geralmente essas mesas são locadas próximas aos pilares de concreto e procuram acompanhar a própria modulação existente entre as estantes e a estrutura de concreto armado. Com o crescente aumento do acervo da biblioteca nos últimos anos e o conseqüente acréscimo de estantes e prateleiras, esse ambiente perdeu consideráveis áreas destinadas à pesquisa e leitura, reduzindo espaços vitais no contexto do edifício. Outra característica importante verificada neste salão diz respeito ao pé-direito: enquanto nos outros espaços da biblioteca, a altura do piso ao teto tem dimensões bem maiores, no salão do acervo bibliográfico o pé-direito apresenta a altura máxima de 2,90 $\mathrm{m}$, demonstrando que a temperatura, no período do verão, atinge valores considerados preocupantes no controle do conforto ambiental. Por fim, o salão permite o acesso aos sanitários dos usuários localizados em uma das extremidades deste ambiente.

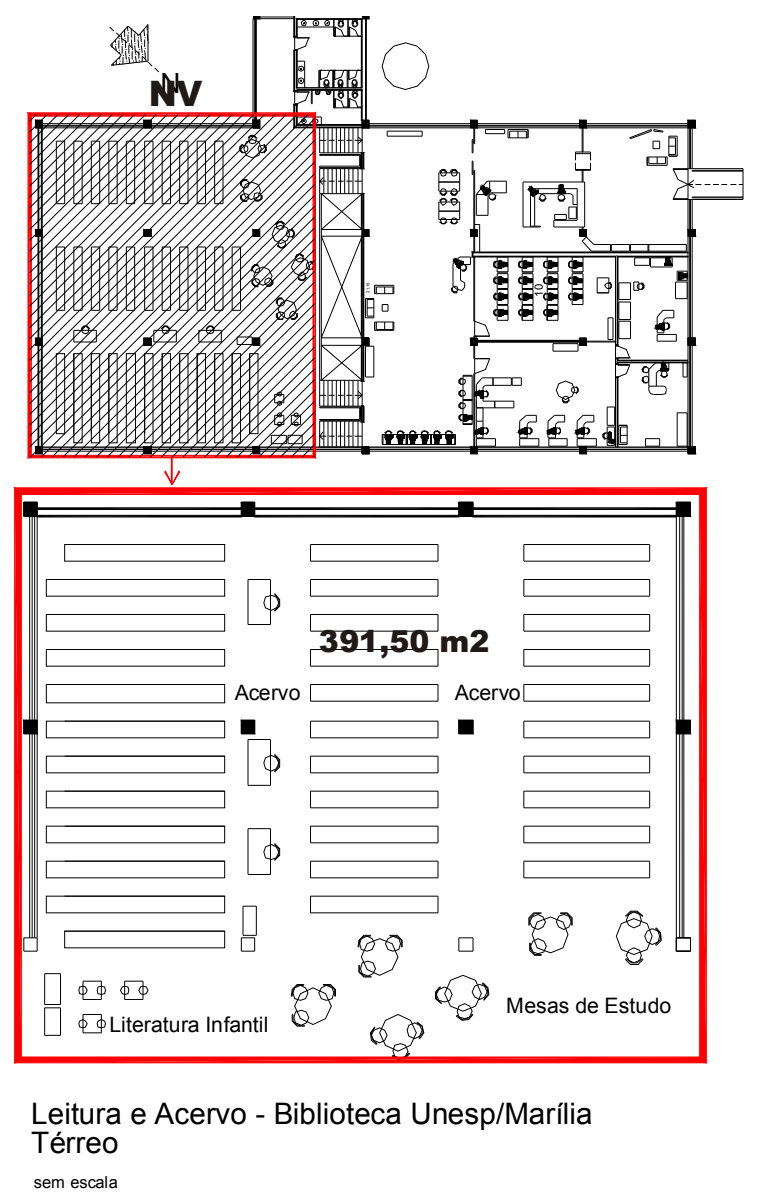

Figura 145 - Planta Área de Leitura e Acervo/Biblioteca Unesp/Marília 

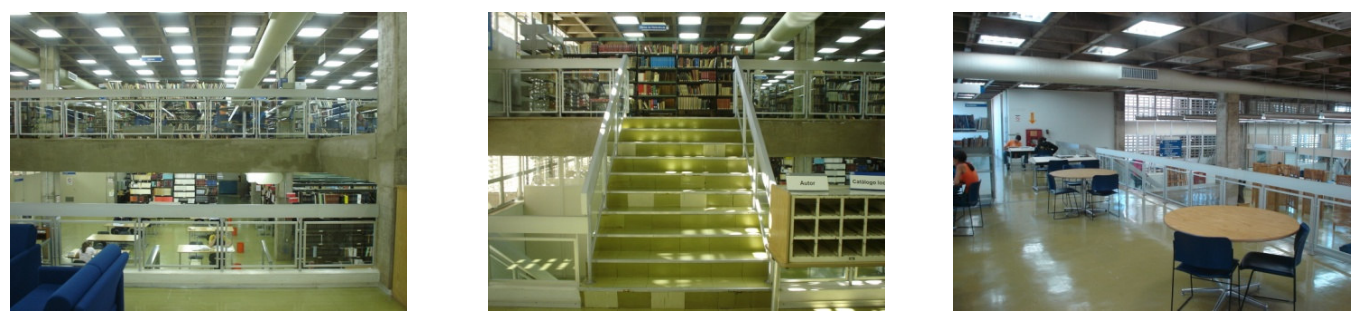

Figuras 146, 147 e 148 - Acesso escada e áreas de leitura
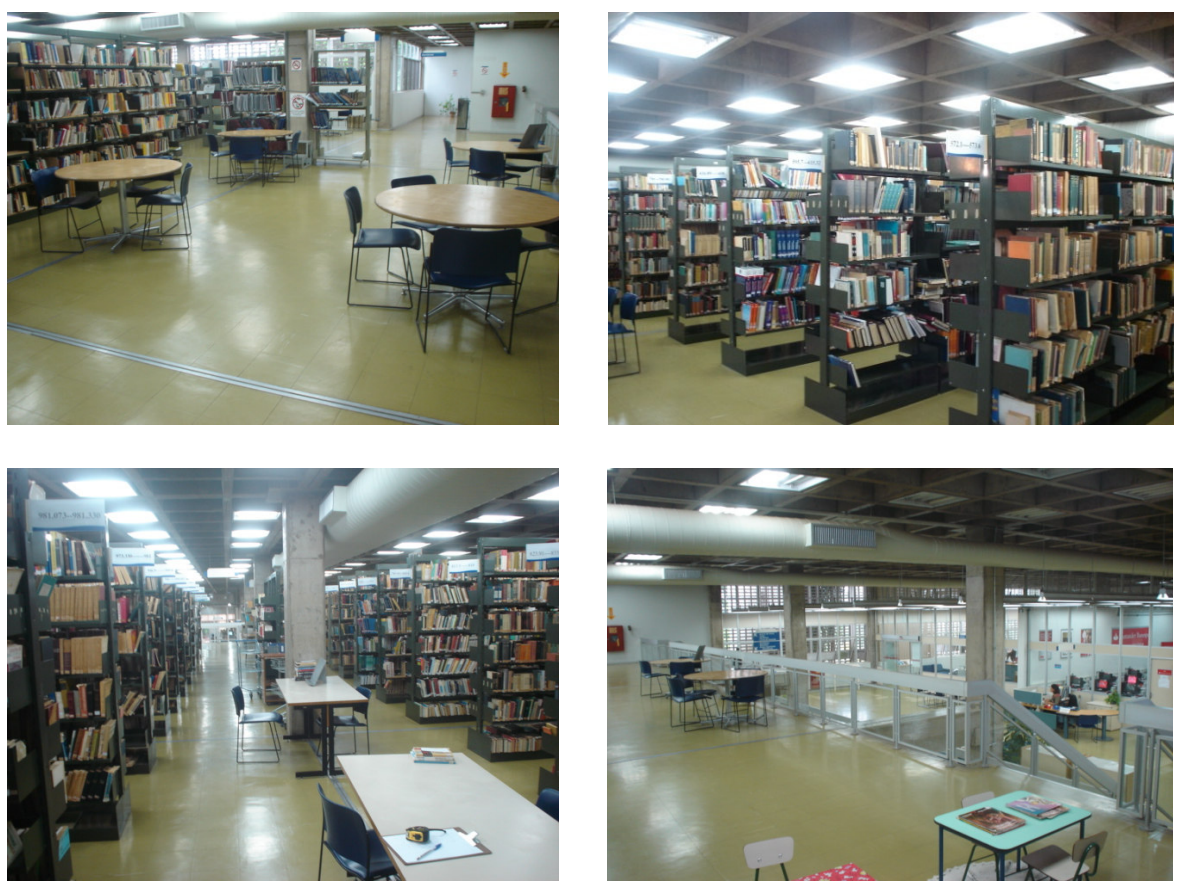

Figuras 149, 150, 151 e 152 - Área do acervo e leitura

e ) - Pavimento inferior: Várias atividades são desenvolvidas no pavimento inferior da biblioteca, entre elas: expositor de periódicos recebidos durante a semana; expositor de novos livros e teses, que ali permanecem por um determinado período; expositor para materiais bibliográficos diversos, recebidos por doação e ainda não patrimoniados pela biblioteca; seção de consulta de periódicos, salas fechadas de estudos e pesquisa; um pequeno auditório, seção de literatura infantil, mapoteca e depósito/almoxarifado. Ainda, compõem o programa arquitetônico deste pavimento os sanitários destinados aos funcionários e uma pequena copa. É possível ter acesso à sala de reprografia, localizada bem ao lado destes ambientes, mas tem entrada exclusiva pelo lado externo da biblioteca. Uma das principais dificuldades encontradas neste setor que vem causando constantes dificuldades operacionais e funcionais, tanto da parte dos 
funcionários quanto dos usuários, são as áreas destinadas às circulações que hoje, indevidamente, têm desempenhado a função de espaços de armazenagem e depósito de materiais ou mobiliário. Esses ambientes não foram previamente projetados para tal função e essa ocupação dificulta em muito a passagem e o tráfego dos usuários que estão nas áreas próximas. Além disso, todo esse conjunto de materiais (caixas, mobiliário, livros e equipamentos informáticos) que estão armazenados indevidamente nos corredores de passagem, interfere nas condições relacionadas à segurança patrimonial e aos riscos de incêndio no prédio da biblioteca. De modo geral, o pavimento inferior apresenta uma característica espacial um pouco diferenciada dos outros pavimentos da biblioteca, na medida em que seus ambientes estão mais resguardados da movimentação dos usuários e dos problemas relacionados ao conforto acústico. Em função disso, a localização estratégica das salas de estudos, tanto individual quanto em grupo, está justamente neste pavimento. A única sala que não se enquadra às condições ambientais descritas anteriormente, principalmente com relação ao nível de ruído produzido e ao grande número de usuários que fazem uso dela é o auditório. A falta de um tratamento acústico adequado para esse espaço tem sido apontada como uma das principais causas de desconforto acústico nas áreas circunvizinhas do auditório, gerando problemas de concentração e níveis de ruídos excessivos nas mesas de estudo. 

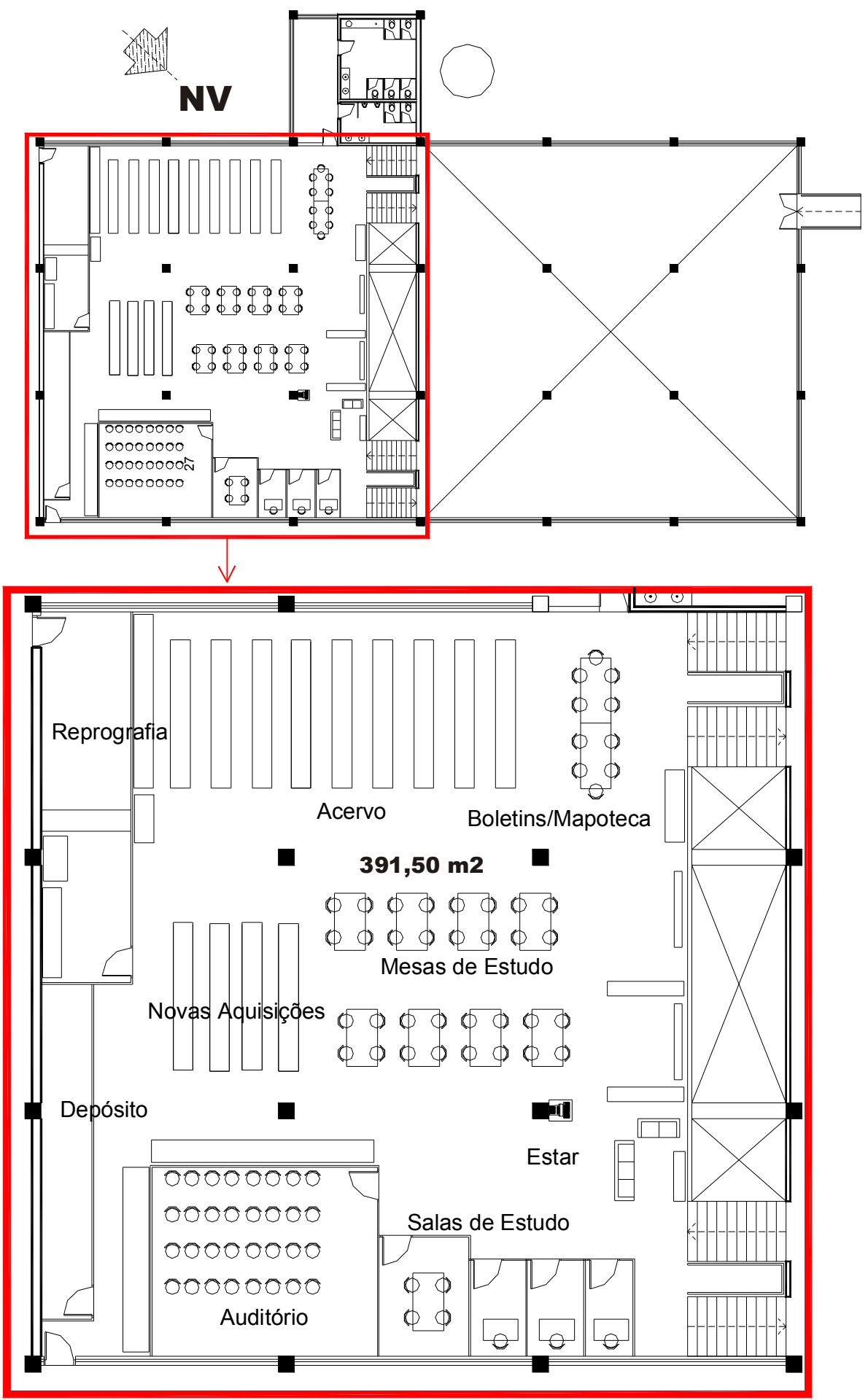

\section{PLANTA/BIBLIOTECA UNESP/MARÍLIA} Pavimento Inferior

sem escala

Figura 153 - Planta Pavimento Inferior/Biblioteca Unesp/Marília 
f ) - Área administrativa e serviços técnicos: Este setor está localizado entre o hall principal e o acervo da biblioteca e diferencia-se dos demais ambientes por apresentar uma separação espacial por meio de grandes panos de vidros e divisórias pré-fabricadas. Vários ambientes se destacam: sala da diretoria conjugada com a sala de reuniões; salas para a STATI - Seção Técnica de Aquisição e Tratamento da Informação (em uma delas encontra-se a supervisão e ali são feitas a seleção e com aquisição de livros, preparo dos periódicos, seleção de todo material que chega à biblioteca por doação, tratamento das teses e serviços administrativos de toda seção. Em outra sala, são feitas a classificação, catalogação de livros e tratamento técnico de outros materiais bibliográficos). Há ainda uma pequena sala que serve de depósito e armazenamento do material doado já selecionado e que aguarda para entrar no acervo. Todo o mobiliário presente nestes ambientes são modulados conforme às condições locais e estão adequados a receber terminais de micro-computadores e estantes de armazenamento. A principal dificuldade encontrada na área administrativa diz respeito ao pouco espaço disponível no desenvolvimento das atividades, justamente porque todas as funções pertinentes ao setor administrativo da biblioteca foram agrupadas em um mesmo setor, gerando inevitavelmente, sérios conflitos funcionais e organizacionais. Com relação ao espaço, ainda conforme relato, os armários e estantes de armazenamento são insuficientes, acarretando em vários locais da área administrativa acúmulo de papel e material bibliográfico. Outra característica relevante no setor administrativo, que se relaciona com os desajustes dimensionais e organizacionais do espaço, diz respeito aos reflexos luminosos indesejados, produzidos nos monitores dos micro-computadores do ambiente. Vários funcionários relataram a dificuldade com relação a esse quesito, demonstrando que se sentem incomodados com os reflexos, além de indicar a diminuição da produtividade no trabalho e a dificuldade de concentração das atividades do dia-a-dia. Como principal vantagem detectada, com relação à proximidade destes ambientes, é o posicionamento estratégico da sala de direção em relação aos outros espaços do setor administrativo, permitindo o contato sempre direto com os funcionários e controle visual das atividades desenvolvidas no setor administrativo. 


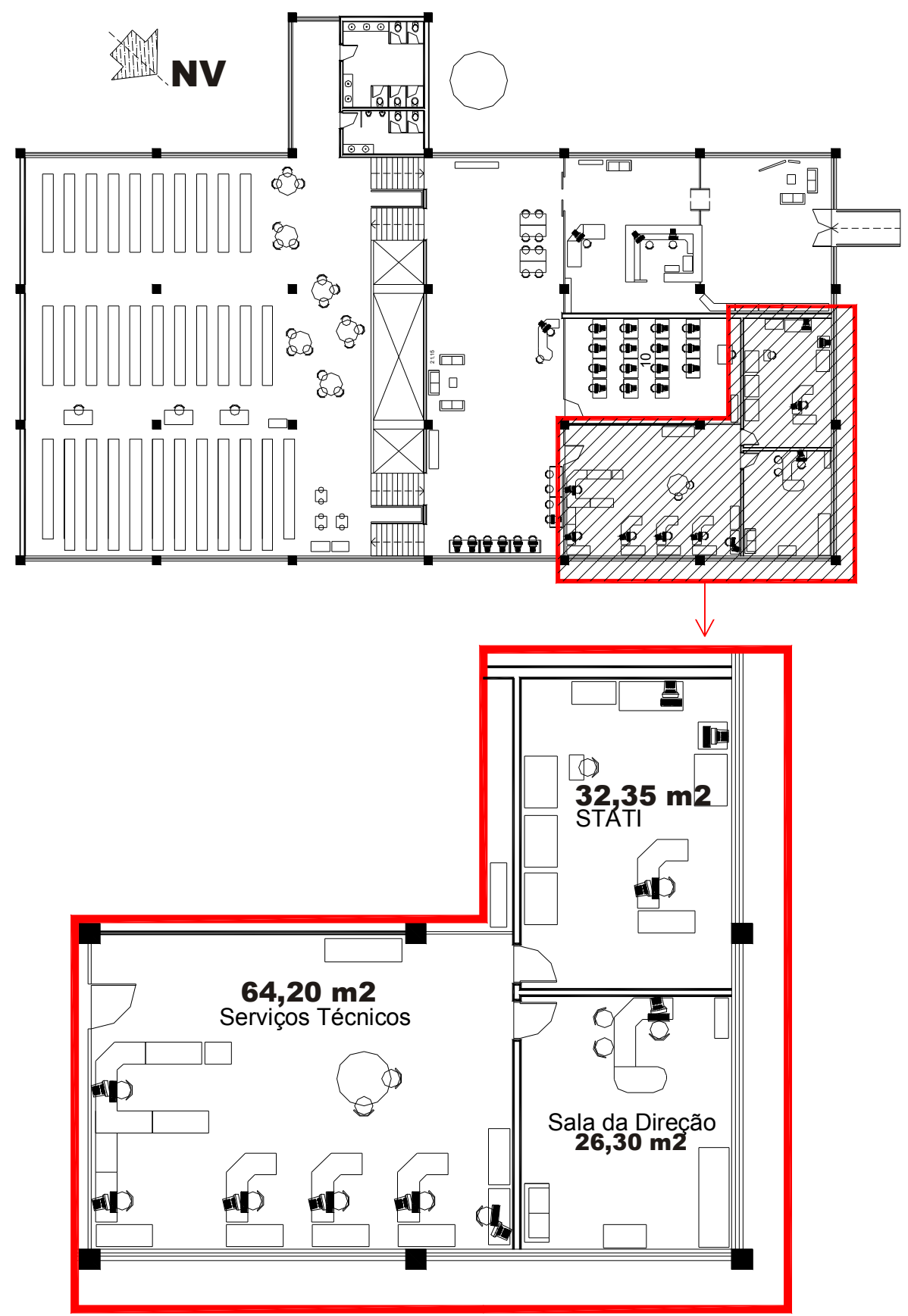

Área Administrativa - Biblioteca Unesp/Marília Térreo

sem escala

Figura 154 - Planta Área Administrativa - Biblioteca Unesp/Marília 

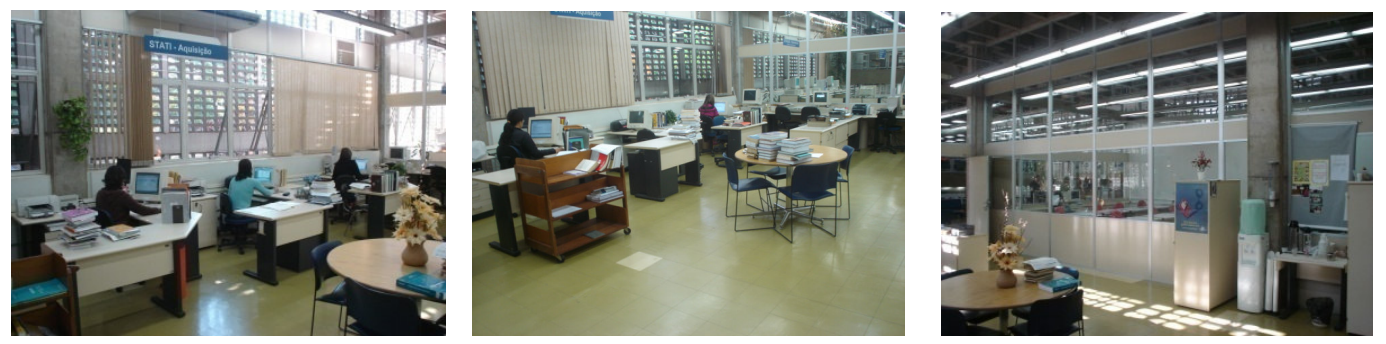

Figuras 155, 156 e 157 - Área administrativa e serviços técnicos
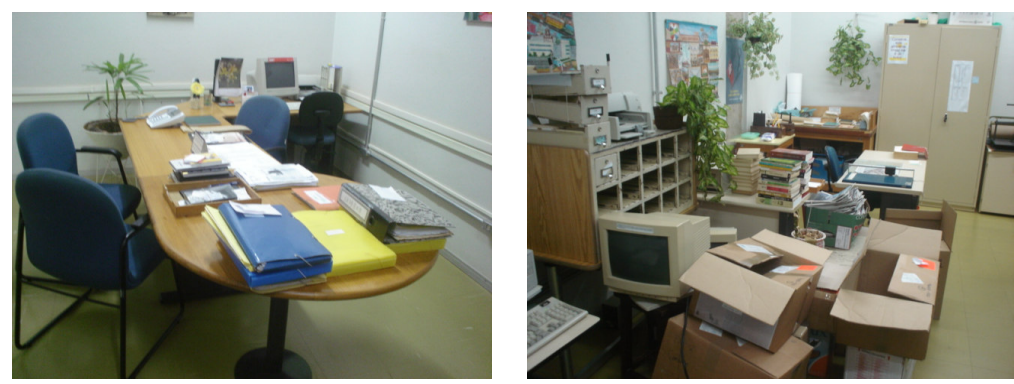

Figuras 158 e 159 - Sala da Direção e STATI - Seção Técnica de Aquisição e Tratamento da Informação

g ) - Sanitários: Os sanitários estão localizados nos dois pavimentos da biblioteca, sendo os do pavimento superior reservados ao público em geral e os do pavimento inferior, aos funcionários. A principal diferença existente entre eles é a área útil construída destes ambientes, reservando ao sanitário feminino espaços mais amplos e maior quantidade de peças. Vale lembrar que, apesar de estarem bem conservados e não apresentarem problemas quanto ao seu funcionamento, os sanitários contam com peças e acabamentos antigos, datados da inauguração da biblioteca, portanto, ainda não passaram por nenhuma reposição ou troca de equipamentos hidráulicos. O pior elemento analisado diz respeito à acessibilidade de pessoas com dificuldades de locomoção. Nenhum dos quesitos mínimos necessários como larguras, equipamentos e peças adaptadas estão enquadrados na NBR 9050/2004. Esse quadro se agrava porque, além destes problemas localizados nos sanitários, os acessos que conduzem até estes ambientes não são providos de rampas ou elevadores, impossibilitando o acesso adequado de pessoas com dificuldades de locomoção, portadoras de deficiência física. Ou seja, mesmo que todos os sanitários tivessem passado pelo processo de adaptação, o acesso de pessoas com dificuldades de locomoção estaria comprometido nas etapas anteriores até a chegada ao ambiente dos banheiros. 


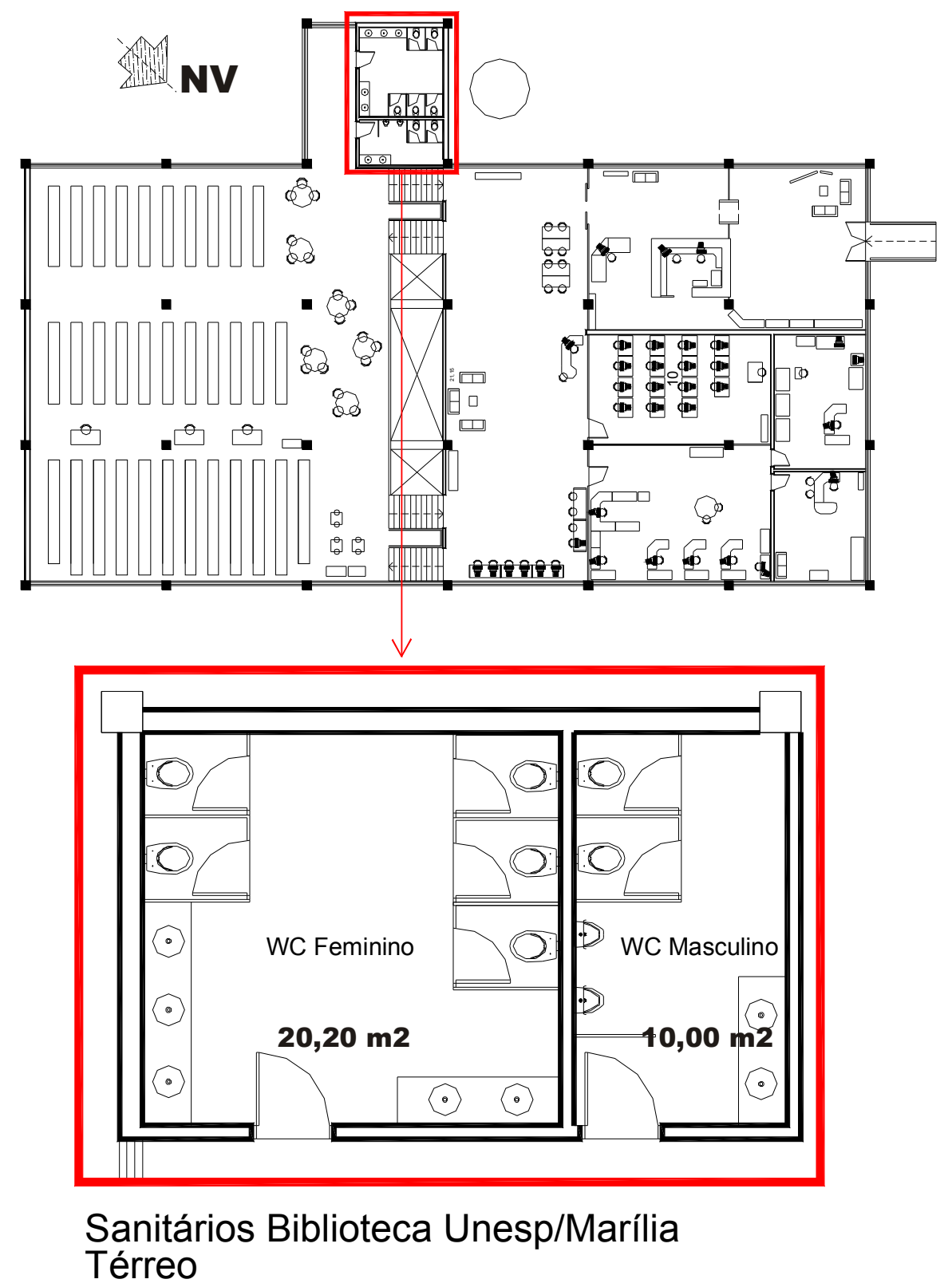

sem escala

Figura 160 - Planta Sanitários - Biblioteca Unesp/Marília

h ) - Sala Pesquisa Internet: A Sala de Pesquisa/Internet está localizada anexa ao Hall Principal e do lado do Setor Administrativo da biblioteca. Este espaço tem a função de fornecer ao usuário o serviço informático e computacional, pesquisa na internet, consulta à base de dados digitais, consulta ao acervo da biblioteca local e outras bibliotecas, manipulação de programas multimídias, cursos vinculados à bibliotecas e 
apoio digital à comunidade acadêmica. O espaço é fruto de um convênio firmado entre a biblioteca e o Banco Santander, visando a suprir uma necessidade antiga da biblioteca, que era a disponibilização de serviços informacionais on line no âmbito da comunidade acadêmica. A sala foi montada com um conjunto de 15 micro-computadores interligados em rede e, além disso, 15 módulos de mesas e cadeiras completam a disposição espacial da sala. Como foi relatado anteriormente, o espaço também fornece várias atividades ligadas à biblioteca como a ministração de cursos e palestras, ou seja, além dos micro-computadores instalados, a sala dispõe de tela de projeção e equipamento multimídia. A sala não apresenta dimensões significativas tanto para as instalações dos equipamentos de informática quanto para a circulação e desenvolvimento das atividades dos usuários. Uma vez que o ambiente tem uma freqüência grande de pessoas, a reduzida área da sala pode-se transformar num impedimento para o pleno funcionamento das atividades ali desenvolvidas.

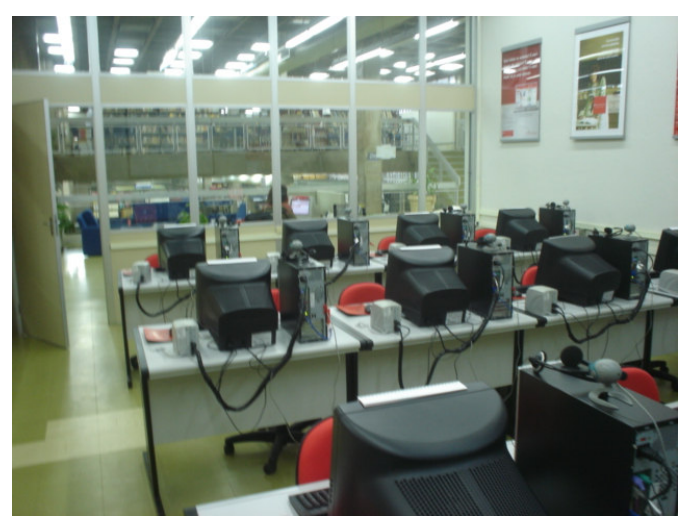

Figura 161 - Sala Pesquisa Internet - Biblioteca Unesp/Marília 


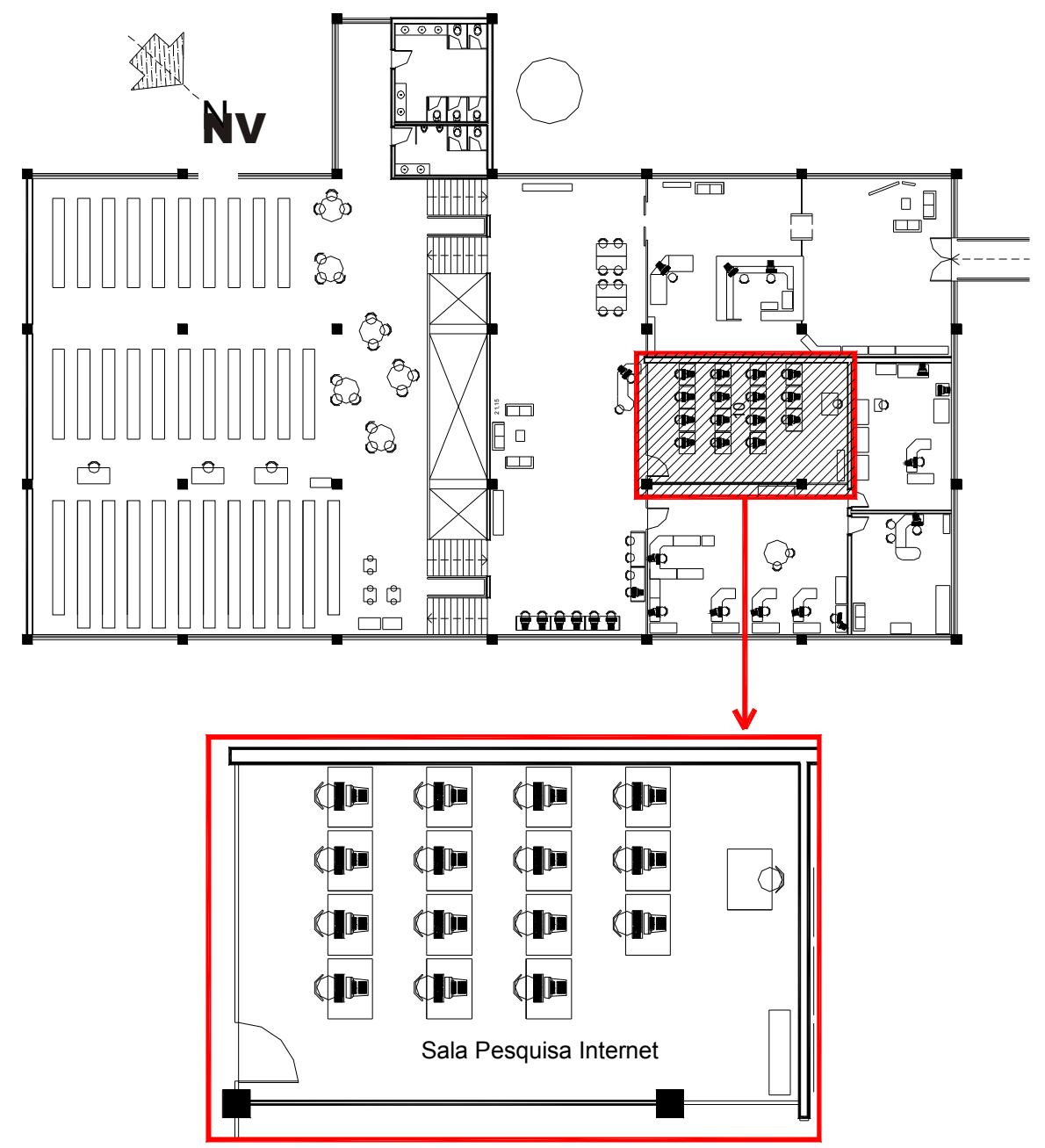

Planta Sala Pesquisa Internet Biblioteca Unesp/Marília

sem escala

Figura 162 - Planta Sala Pesquisa Internet - Biblioteca Unesp/Marília 


\subsubsection{O Senac}

O Senac surge com o Decreto-lei 8.621, de 10 de janeiro de 1946, em que o Governo Federal atribui à Confederação Nacional do Comércio a organização e administração, em todo o País, de escolas de aprendizagem comercial para empregados do setor, fornecendo também aos menores entre 14 e 18 anos cursos de continuação e de especialização. Por meio desse decreto-lei, estava delegada à Confederação Nacional do Comércio a criação do Serviço Nacional de Aprendizagem Comercial - SENAC, sediado na capital federal e descentralizado por meio de Conselhos Regionais e Departamentos Regionais em cada um dos Estados da União.

\subsubsection{O Senac/São Paulo}

O Senac de São Paulo nasce da descentralização e administração pelos Estados, dando origem aos conselhos regionais (deliberativos) e departamentos regionais (executivos). De forma resumida, as principais atividades desenvolvidas no Senac de São Paulo, durante os vários anos de atuação, são:

- Anos 40: começam a ser implantados os cursos de Praticante de Comércio e Escritório, na cidade de São Paulo, como forma de fornecer educação e treinamento aos trabalhadores. Além disso, nos anos seguintes, são abertas unidades nos municípios de Campinas, Ribeirão Preto, Bauru, São José do Rio Preto, Taubaté e Botucatu.

- Anos 50: são instituídos cursos de especialização de Garçom, Datilografia e Idiomas; a formação de jovens é intensificada por meio do Ginásio Comercial; e é lançado o Colégio Técnico Comercial, com ensino de Contabilidade e Secretariado equivalente ao atual ensino médio, e do Curso de Auxiliar de Vendas e Escritório.

- Anos 60: as áreas de atuação passam a incluir Moda/Manequim e Fotografia; é inaugurado o hotel-escola Grande Hotel São Pedro.

- Anos 70: o Senac cria seu primeiro Centro de Estudos Avançados, dirigido a Turismo e Hotelaria; é lançado o curso Programador de Computadores Eletrônicos; é apresentada a Unidade Móvel de Formação e Treinamento, que leva cursos a cidades distantes da rede física. 
- Anos 80: a rede física é ampliada com o lançamento de unidades especializadas nas diversas áreas de atuação: Gestão Educacional, Saúde, Beleza, Moda, Decoração, Turismo e Hotelaria, Varejo, Administração e Gestão de Negócios, Idiomas e Informática; o Senac entra no ensino superior com o curso Tecnologia em Hotelaria.

- Anos 90: a instituição define estratégia em que enfatiza a auto-sustentabilidade das operações; programação inclui cursos de Design de Interiores, Saúde Ambiental, e Gastronomia; são inaugurados a Editora Senac São Paulo, da TV Senac (hoje Rede SescSenac de Televisão), o hotel-escola - Grande Hotel Campos do Jordão e o sistema de Educação a Distância mediado pela web.

\subsubsection{Centro Universitário Senac/São Paulo}

O novo complexo arquitetônico do Centro Universitário do Senac/Santo Amaro, em São Paulo, ocupa uma área de aproximadamente $118 \mathrm{mil} \mathrm{m2,} \mathrm{localizada}$ entre a marginal Pinheiros e um campo de golfe, no bairro de Santo Amaro. A primeira fase da obra, concluída em março de 2004, contempla uma área total de $51 \mathrm{mil} \mathrm{m} 2 \mathrm{e}$ engloba os edifícios novos do curso de gastronomia com uma cozinha-escola e reformulação de três prédios antigos para abrigarem a biblioteca, a reitoria e 50 salas de aulas. Além disso, o projeto tem como objetivo desencadear um processo de revitalização urbana regional, a partir da renovação das estruturas arquitetônicas existentes e a proposta de construção de novas edificações com a finalidade educacional. 


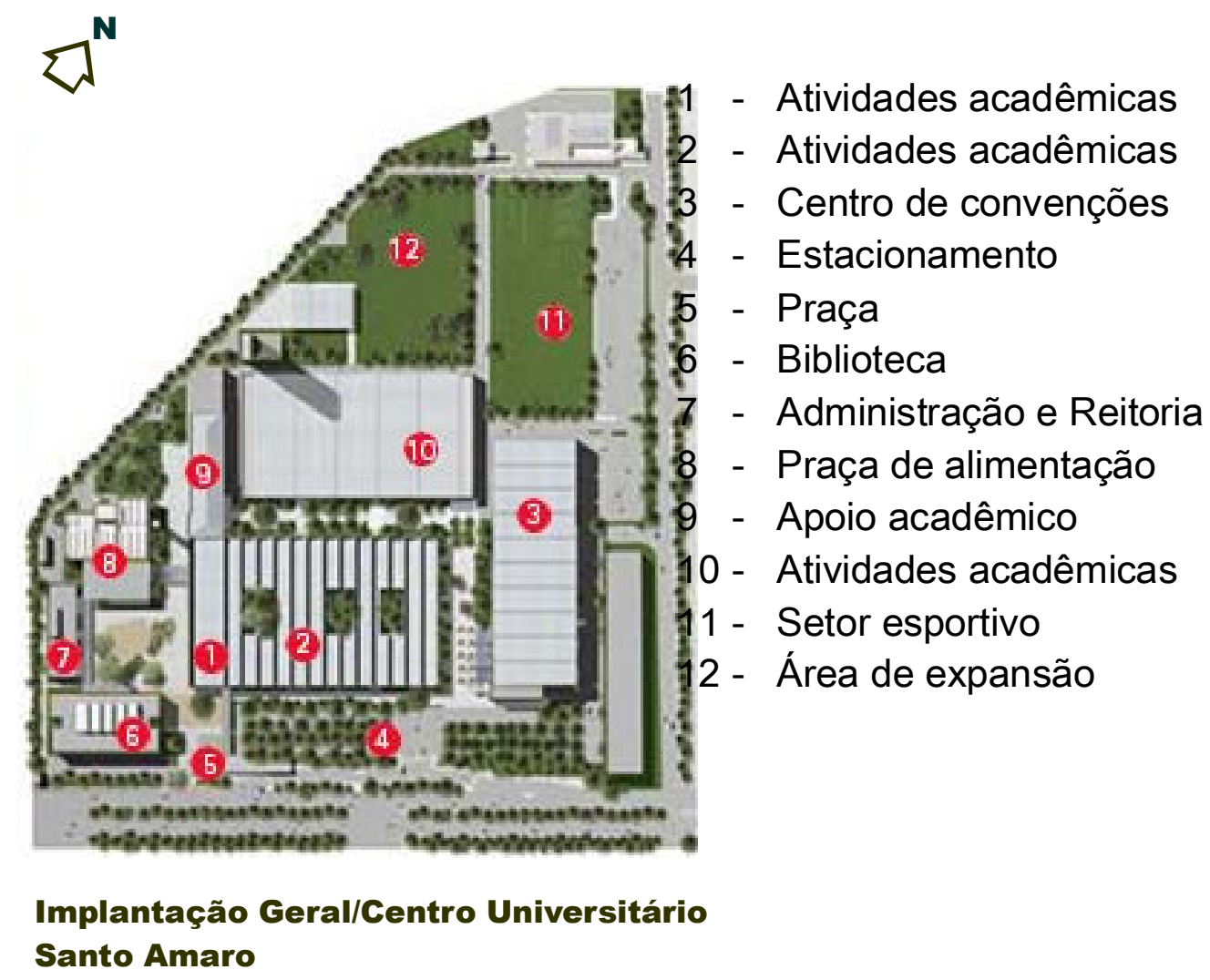

Sem escala

Figura 163 - Implantação - Centro Universitário Senac/Santa Amaro Fonte: www.arcoweb.com.br

O projeto foi desenvolvido pelos arquitetos Gian Carlo Gasperini, Roberto Aflalo Filho e Luiz Aflalo Herman, que fixaram um plano diretor em várias etapas para a implantação da proposta. Um dos principais objetivos do partido arquitetônico foi definir uma linguagem estética que preservasse algumas características do conjunto de cerca de 40 anos de idade, composto por edificações horizontais em estrutura de concreto e em bom estado de conservação. Além disso, os edifícios tinham o pé-direito livre de mais de seis metros livre, coberturas metálicas com aberturas de sheds e fachadas parcialmente revestidas por cerâmica vermelha. Essas condições físicas favoráveis contribuíram positivamente no sentido de tirar o máximo de proveito necessário às soluções encontradas, além de propor a racionalização do consumo de água e energia elétrica e o conforto dos usuários. 


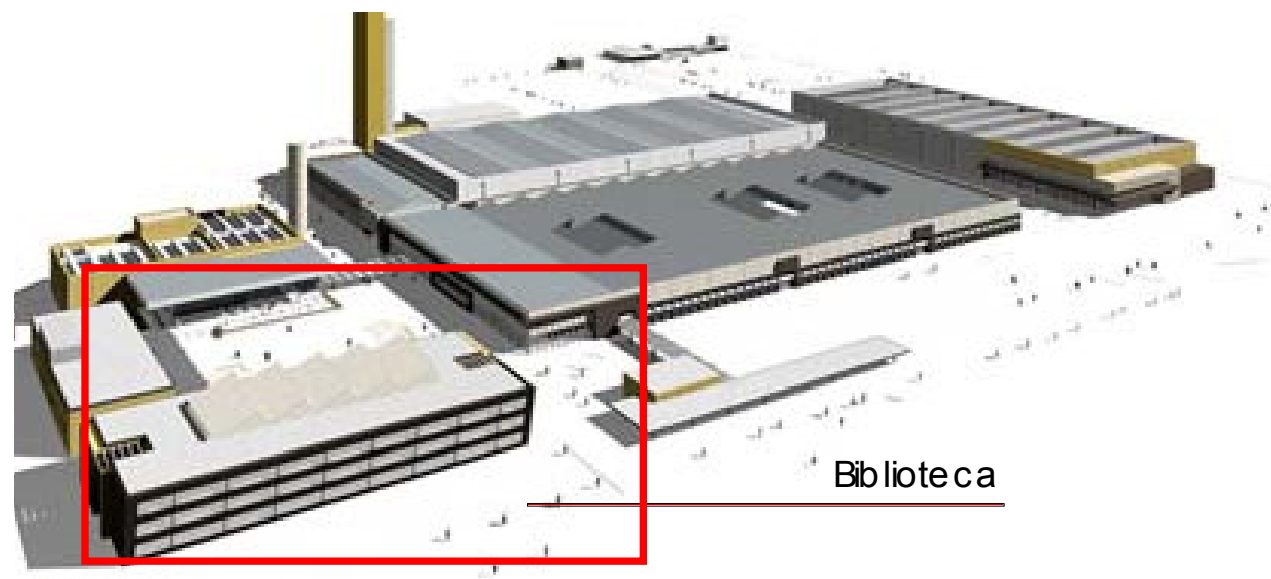

Figura 164 - Ilustração - Centro Universitário Senac/Santo Amaro Fonte: www.arcoweb.com.br

Uma das prerrogativas apresentadas pelo partido arquitetônico foi à separação da circulação de automóveis e pedestres, possibilitando a criação de novos desenhos nas unidades arbóreas e o estabelecimento de praças e recantos nos jardins. Esse procedimento é encontrado em todo o contexto de implantação das áreas do centro universitário, criando um ambiente harmônico entre o espaço construído e o espaço nãoedificado. Como exemplo disso, algumas árvores e espécies vegetais de grande porte receberam destaque especial no projeto paisagístico do conjunto, evidenciando mais uma vez o caráter de integração entre paisagem/edifício.

Um dos problemas enfrentados pela equipe de arquitetos foi a adaptação do espaço destinado ao refeitório. Como solução, projetou-se um novo edifício em torno de cinco mil metros quadrados, abrigando uma estrutura completa de aulas de gastronomia e cozinha-piloto. Sua estrutura formula uma combinação entre concreto convencional e elementos pré-fabricados e as fachadas foram montadas com o mesmo sistema de pré-moldados. Com a preocupação de manter a mesma linguagem formal, o projeto adotou o sistema shed presente nos outros blocos, mas estabeleceu ajustes quanto ao sistema de energia solar que fornece água quente à cozinha. Além disso, o bloco da gastronomia contempla um grande salão de uso a ser definido em sua ocupação.

O maior bloco do conjunto das edificações,o acadêmico, recebeu um mezanino em estrutura metálica, que dobrou a área disponível para o novo uso de salas de aula. As salas do térreo foram destinadas às aulas que necessitam de computadores e de ar condicionado. No mezanino foram locadas as salas de aulas expositivas que não necessitam de ar-condicionado, visto que há ventilação cruzada conquistada por 
aberturas restauradas dos sheds industriais e de janelas laterais nas fachadas externas e internas voltadas para os três novos pátios criados. A solução encontrada para a inserção do ar-condicionado central e de todo cabeamento necessário ao novo uso foi criar uma fachada sobressalente, em pré-moldado de concreto, que de uma só vez resolveu a nova identidade plástica do prédio, abrigando toda tubulação e cabeamento (sem redução do pé-direito disponível) e servindo de proteção e enquadramento da caixilharia.

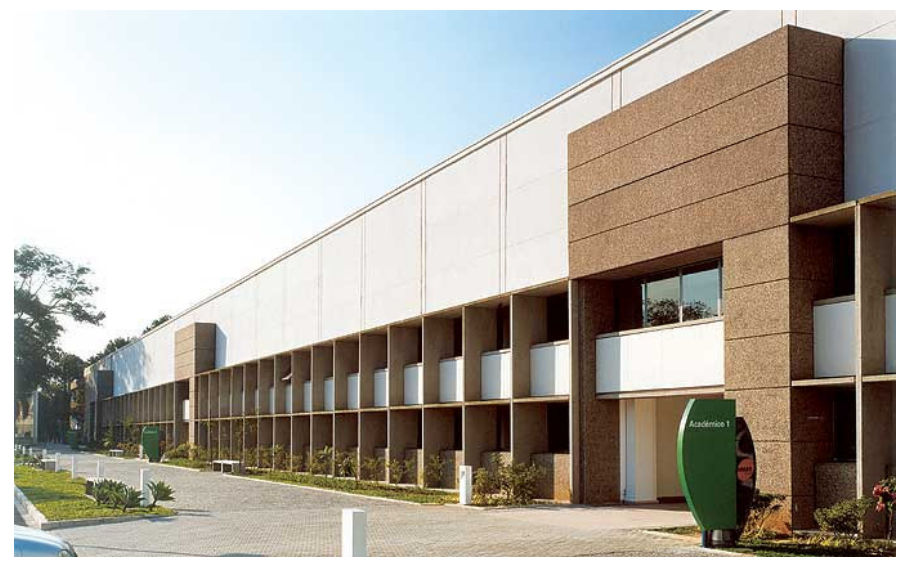

Figura 165 - Bloco Acadêmico/Senac Santo Amaro

\subsubsection{Caracterização Arquitetônica da Biblioteca do Centro Universitário}

\section{Senac/São Paulo}

Entre os principais elementos norteadores do projeto arquitetônico da Biblioteca do Centro Universitário Senac/Santo Amaro destacam-se:

- Partido Arquitetônico: A Biblioteca do Centro Universitário Senac/Santo Amaro é parte integrante de um dos antigos prédios administrativos existentes no local e foi completamente reformulado, passando de 2 mil para 6 mil metros quadrados com a construção de um volume simétrico ao existente e a implantação de um novo pavimento, ambos com estrutura metálica. Uma das principais características do partido arquitetônico da biblioteca é a utilização da idéia de um átrio central com pé-direito livre total, concretizando, assim, a proposta de integração dos espaços por meio da fluição e da flexibilização de seus ambientes. O partido arquitetônico procurou valorizar a construção de vistas e campos visuais “abertos" por parte dos usuários, na medida em 
que os espaços não possuem divisões definidas ou demarcações de paredes. Esta estratégia propiciou num conjunto arquitetônico extremamente "leve" e integrado, possibilitando que as atividades relacionadas à biblioteca como busca, pesquisa e leitura, acontecessem de maneira produtiva e funcional. Uma estrutura de forro laminado em curvas, com um desenho bastante representativo esteticamente, foi instalada no último pavimento e serve de iluminação zenital para todos os outros pavimentos da biblioteca. Esta estrutura não fazia parte do conjunto existente no edifício e foi especialmente desenhada para esta nova fase da construção. Além disso, o partido arquitetônico fixou mais dois elementos importantes no projeto da biblioteca: um novo conjunto de caixilharia recuada e o fechamento em pré-moldado de concreto com acabamento texturizado, recursos que possibilitaram criar uma nova identidade visual nas fachadas, além conferir um caráter contemporâneo aos elementos volumétricos.
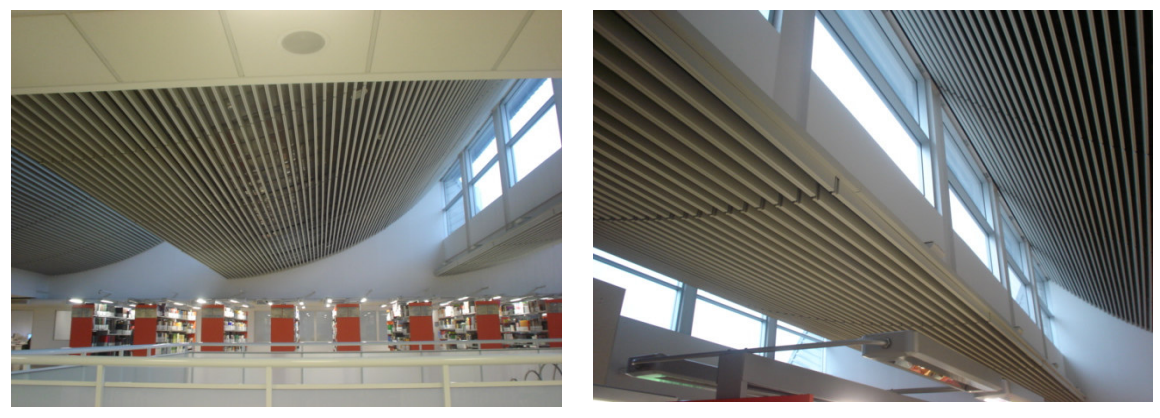

Figuras 166 e 167 - Forro metálico ondulado - Biblioteca Senac/ Santo Amaro
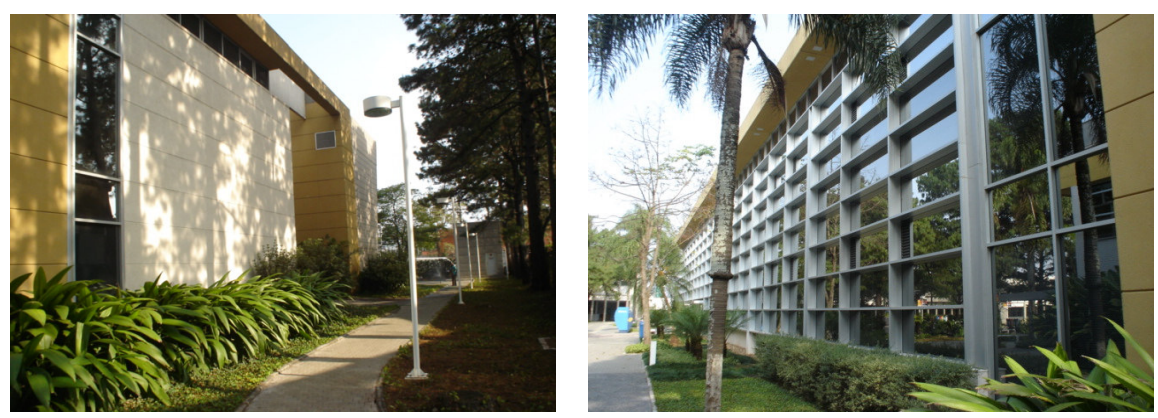

Figuras 168 e 169 - Vistas Externas: caixilharia recuada e acabamento texturizado / Biblioteca Senac/ Santo Amaro 
Como todo o espaço da biblioteca é estruturado na centralidade e na simetria, o átrio central acabou se transformando no ponto principal do projeto, organizando todos os outros ambientes em volta dele e proporcionando uma proveitosa iluminação natural por meio de sheds na cobertura. Outra característica marcante do partido é a flexibilidade do layout promovida pela planta livre e a distribuição estruturada em diversos setores sem divisões aparentes. Por meio disso, o usuário consegue visualizar de forma completa todas as salas de leitura, o acervo bibliográfico, os terminais de computadores e todo setor administrativo, como se estivesse participando ativamente do contexto espacial.
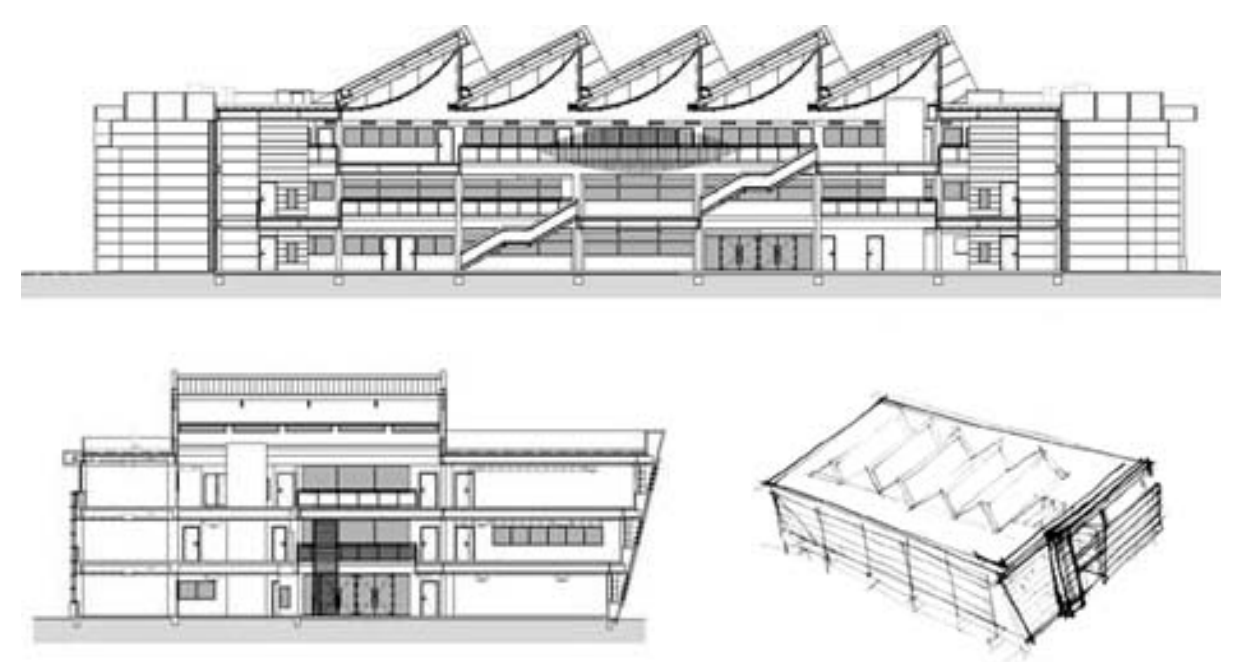

Figura 170 - Corte esquemático/ Biblioteca Senac/ Santo Amaro

Fonte: www.arcoweb.com.br
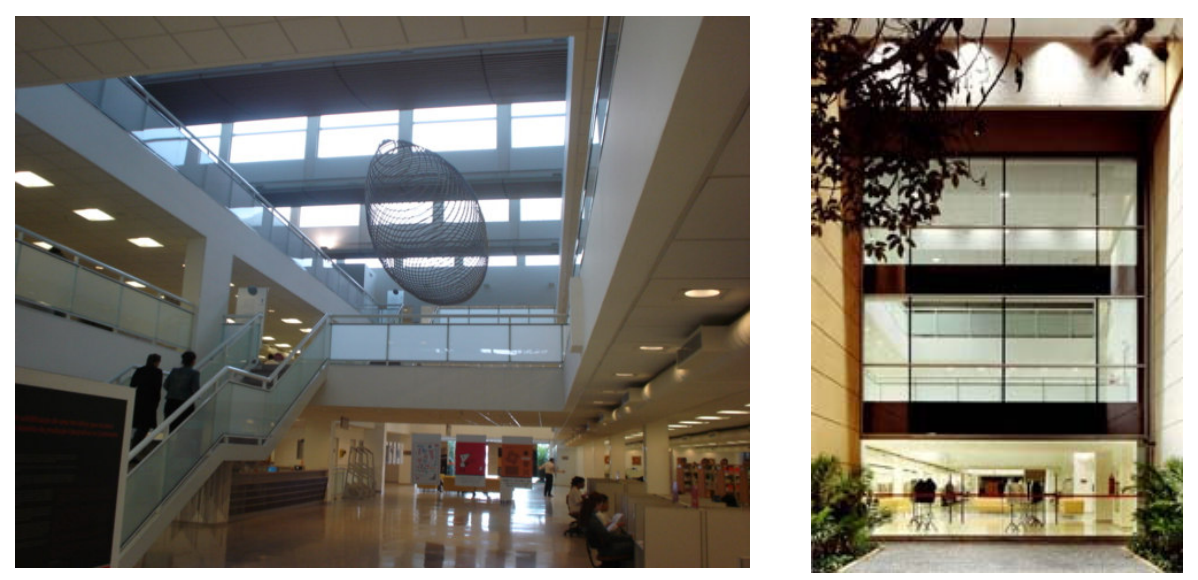

Figuras 171 e 172 - Vista átrio central e entrada lateral - Biblioteca Senac/ Santo Amaro 
- Programa arquitetônico da biblioteca: A biblioteca abriga um acervo de 90 mil itens, entre livros, periódicos, mapas, CD-ROMs, CDs, DVDs e fitas VHS. Além disso, são 200 terminais de computadores que disponibilizam acesso aos bancos de dados bibliográficos do Senac ou de outras fontes de informação. Como forma didática de apresentação dos ambientes da biblioteca, dividiu-se o rol do programa arquitetônico por pavimento, enumerando suas principais atividades desenvolvidas:

a) - Pavimento Térreo: A entrada principal do prédio da biblioteca fica localizada ao lado de uma grande praça do centro universitário, exibindo aspecto imponente ao usuário que adentra ou sai por este lado do edifício. Uma grande porta de correr automatizada permite o controle de entrada e saída dos usuários, além de executar o serviço necessário de segurança. $\mathrm{O}$ acesso à pessoa com dificuldades de locomoção e deficiência visual é garantido por meio de guias rebaixadas, tanto na porta principal de entrada como nos acessos próximos à entrada. Desta forma, é possível afirmar que a acessibilidade ao edifício está enquadrada na $N B R$ - 9050/2004, não só na entrada principal como também nas outras duas entradas que estão localizadas nas laterais da biblioteca. Os arquitetos propuseram para o lado principal da entrada, uma grande fachada/pele de vidro, permitindo, além de iluminação natural para os ambientes, uma forte sensação de transparência. Esse recurso vem ao encontro do partido arquitetônico adotado, preconizando como conceito básico, a limpeza dos elementos compositivos funcionais e estéticos, clareza na distribuição dos volumes de fachadas e nova proposta estética para as edificações existentes. 


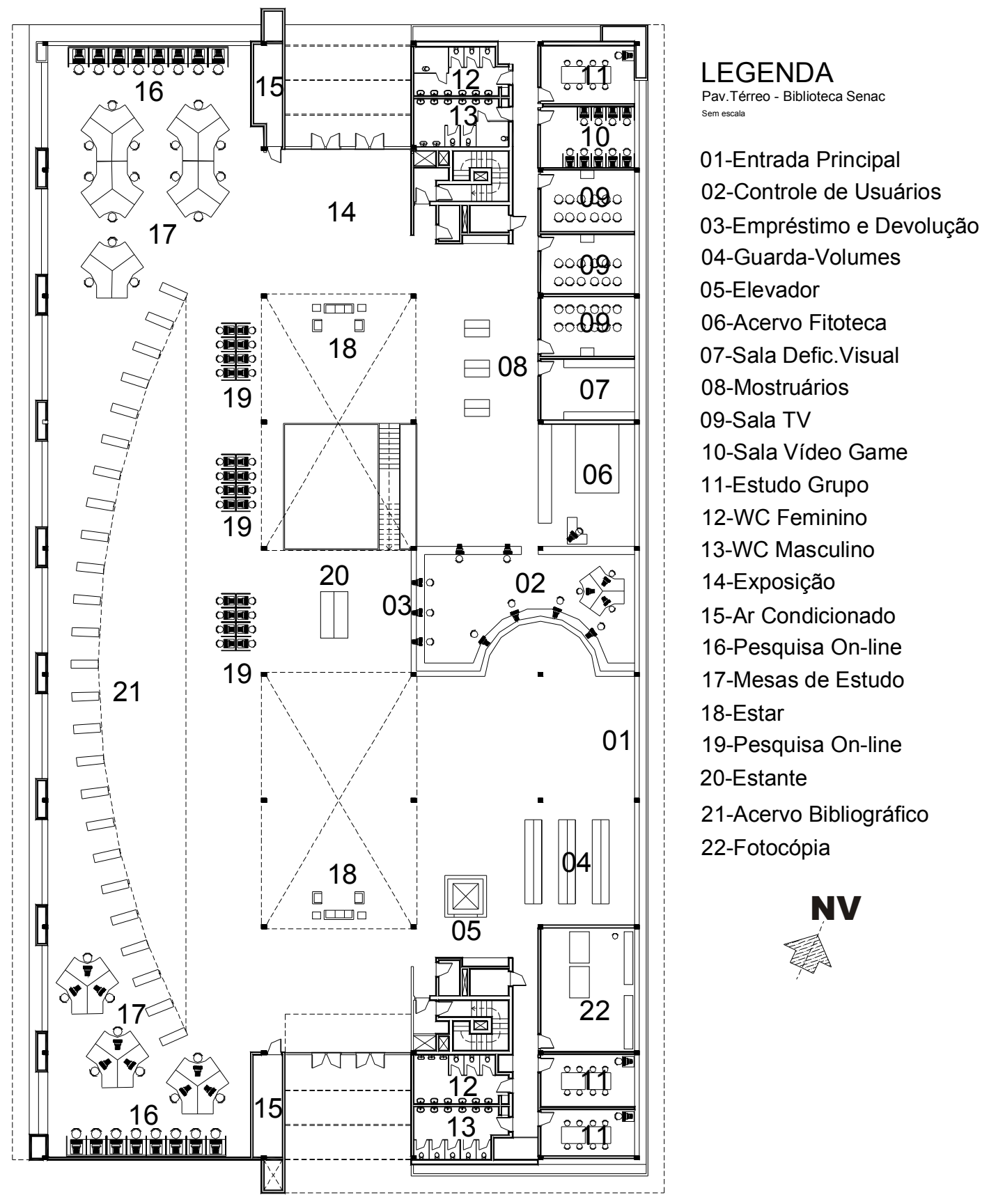

Figura 173 - Pavimento térreo/ Biblioteca Senac/ Santo Amaro 

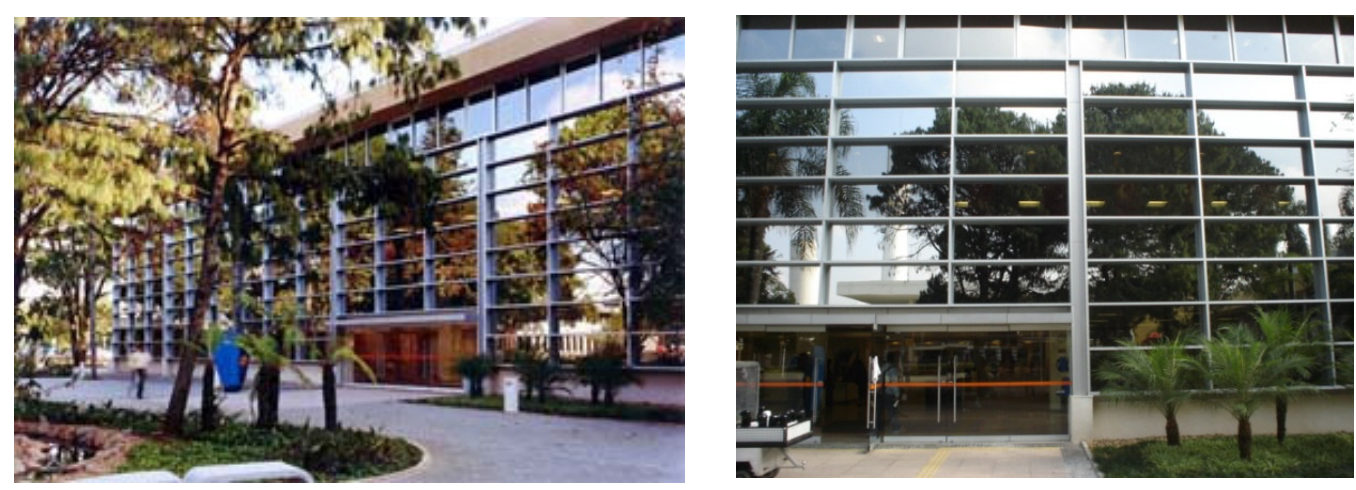

Figuras 174 e 175 - Entrada principal/ Biblioteca Senac/ Santo Amaro

A seguir, após a porta de entrada e do lado direito, está postado o balcão principal do controle de Empréstimo e Devolucão (Figura 178) da biblioteca. Em formato semicircular e executado em alvenaria, granito e pranchas de madeira, o balcão se destaca por sua apresentação imponente e grande destaque visual neste ambiente. $\mathrm{O}$ espaço conta ainda com um local destinado às bibliotecárias auxiliares e estagiários, que apóiam as atividades dos usuários e dos funcionários. Todo controle de entrada e saída da biblioteca, empréstimo e devolução é feito neste local, além da supervisão o fluxo dos usuários da própria unidade educacional e também dos visitantes que adentram o recinto. Este local apresenta excelentes medidas espaciais, tanto na disposição do mobiliário e dos equipamentos informáticos quanto na forma de apropriação por parte dos funcionários, permitindo que o atendimento aos usuários seja executado de maneira bastante rápida. Ao lado desta área, está localizado o Acervo da Fitoteca da biblioteca, que conta com um arquivo deslizante, disponibilizando DVDs e CDs do acervo central. Do lado esquerdo, estão localizados os Guarda-Volumes (Figura 179), destinados à guarda dos matériais dos usuários e visitantes da biblioteca. Um corredor interno, logo a

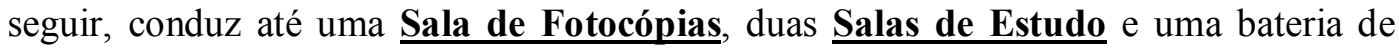

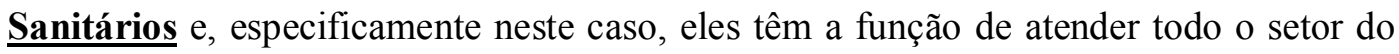
pavimento térreo. Frontalmente ao balcão de atendimento está instalado o sensor eletrônico de segurança, destinado à segurança de entrada e saída dos usuários. Além de desempenhar a função de segurança na biblioteca, esta área estabelece um limite “invisível” entre a entrada principal e os ambientes componentes do pavimento térreo. Esta demarcação territorial é importante no direcionamento das atividades desenvolvidas e no posicionamento dos usuários com relação ao espaço. 


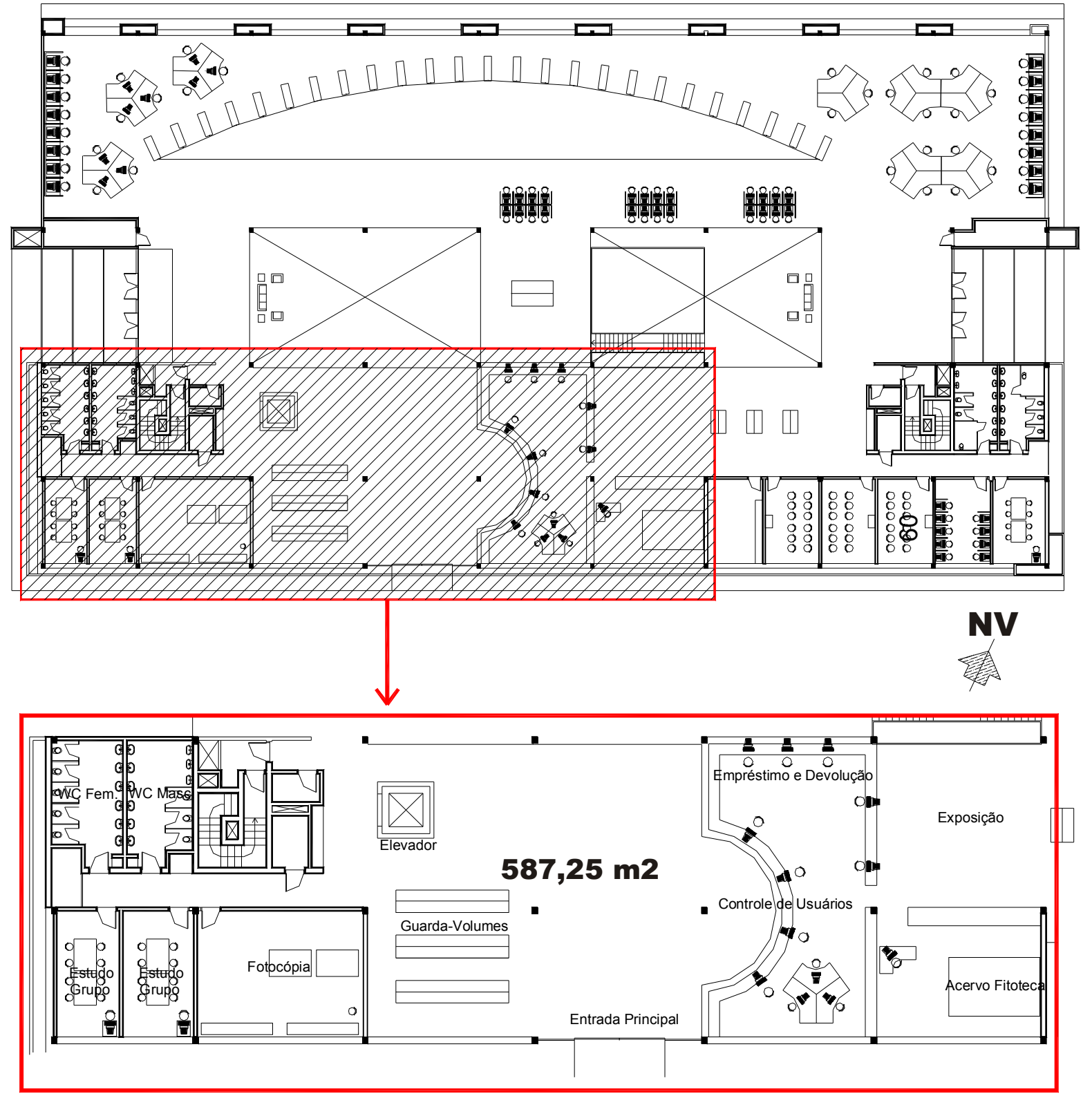

Pav.Térreo - Biblioteca Senac

Sem escala

Figura 176 - Pavimento térreo - Entrada Principal/ Biblioteca Senac/ Santo Amaro 


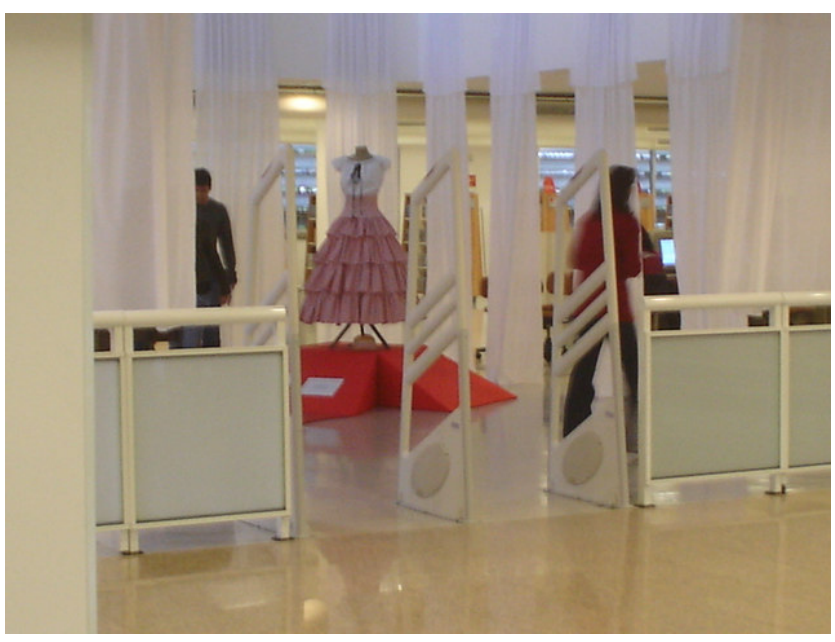

Figura 177 - Hall de Entrada e Sensor de Segurança- Biblioteca Senac/ Santo Amaro

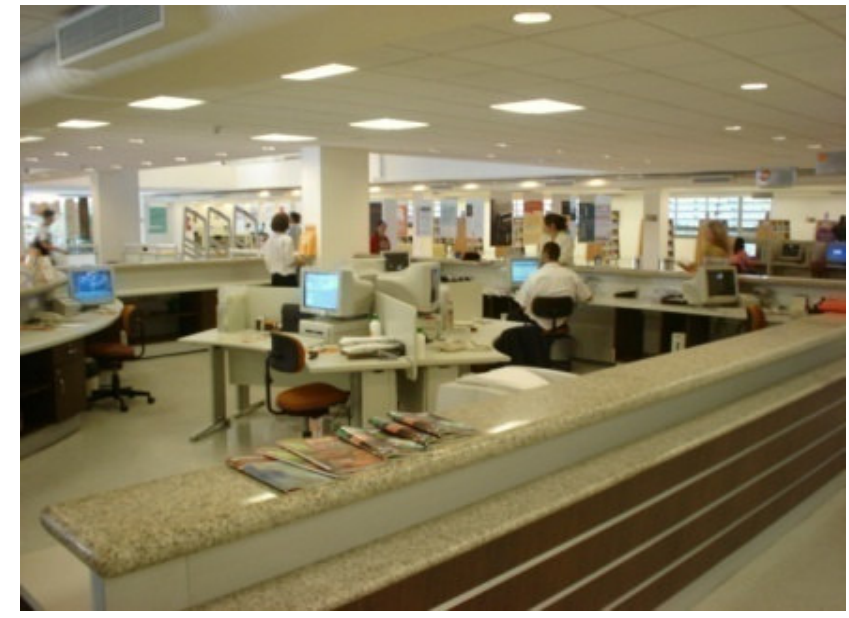

Figura 178 - Empréstimo/Devolução - Biblioteca Senac/ Santo Amaro

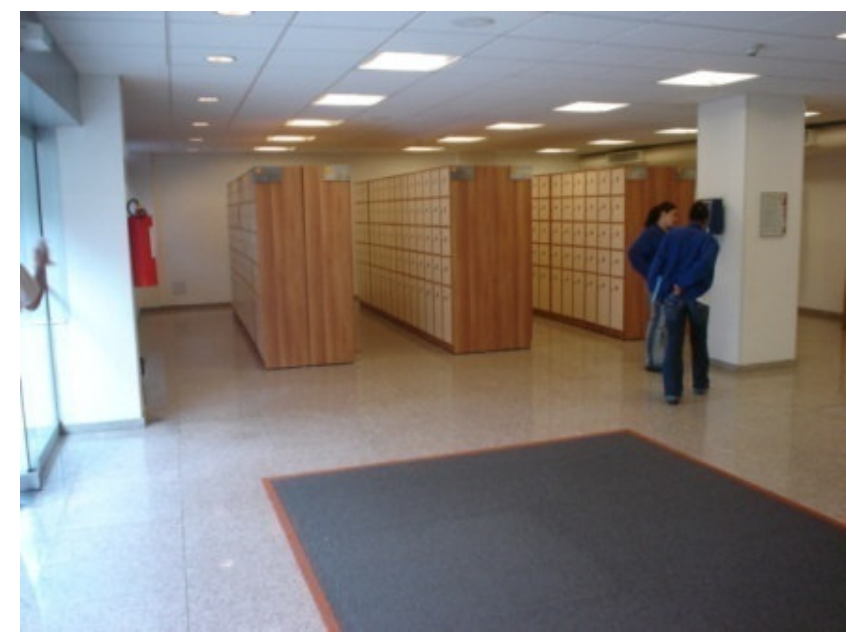

Figura 179 - Guarda-Volumes- Biblioteca Senac/ Santo Amaro 
A biblioteca utiliza o conceito de acervo aberto, ou seja, todo o material bibliográfico está disponível para consulta, leitura e pesquisa em todos os seus ambientes. Utilizando essa idéia, o partido arquitetônico optou em distribuir todo acervo de livros, periódicos, fitas, teses, etc, por todo o conjunto dos três pavimentos da biblioteca. Apesar de cada pavimento contar com terminais de busca e de ajuda concernentes às informações desejadas e os acervos bibliográficos estarem presentes nestes locais, o pavimento térreo desempenha função estratégica fundamental no encontro e no direcionamento do material a ser alcançado. Portanto, a partir do momento em que o usuário localiza a informação desejada nos terminais de busca, ele se direciona ao local específico e retira o material para a consulta.

Um elemento que ajuda consideravelmente na localização da informação no acervo é o sistema de comunicação adotado nas estantes, ou seja, cada designação de número de tombo, tipo de área atendida e tipo de documento procurado são identificados por uma cor previamente estabelecida e vinculada ao documento (Figura 180). Este sistema foi desenvolvido especialmente para esta biblioteca e tem a pretensão de ser implantado em toda a rede de bibliotecas do Senac, espalhadas pelas outras unidades da capital e interior do Estado de São Paulo. Além do acervo presente no pavimento térreo, o local ainda conta com Espaço para Exposições bem próximo ao acesso da escada e fica bem ao centro do átrio principal (Figura 182). Este local, além de servir para exposições, tem a finalidade de abrigar várias atividades ligadas aos cursos de graduação, com função multiuso, sendo especial para divulgação de programação da própria instituição. Em vista disso, o ambiente agrega uma vertente bastante cultural no contexto espacial, na medida em que permite o desenvolvimento de atividades, em intercâmbio com o modelo tradicional de biblioteca.
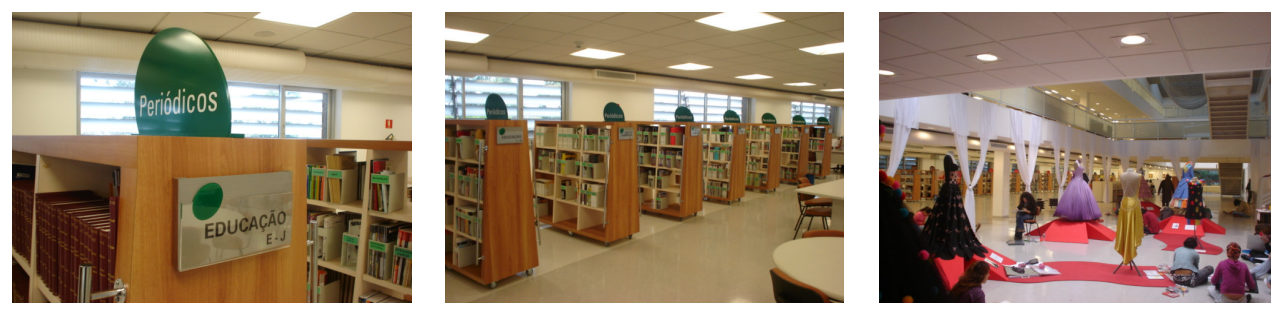

Figuras 180, 181 e 182 - Sistema de Comunicação nas Estantes e Espaço para Exposição/ Biblioteca Senac/ Santo Amaro 
Outro espaço bastante utilizado pelos usuários da biblioteca é a Área de Descanso e Estar que está posicionada entre a entrada principal lateral e a escada central. Neste local, um conjunto de três sofás e uma mesa central disponibiliza diariamente jornais e revistas às pessoas sendo bastante freqüentado nos períodos de intervalos de aulas e nos horários de almoço. Trata-se de um espaço aconchegante, pela combinação de diferentes qualidades espaciais e geração de múltiplos acontecimentos Além disso, em função destas características, a área de descanso e lazer tornou-se importante espaço de ponto de encontro e local de aglutinação de usuários, reforçando forte identificação que a Biblioteca do Senac/Santo Amaro tem no contexto do campus universitário, como espaço referencial e marcante.

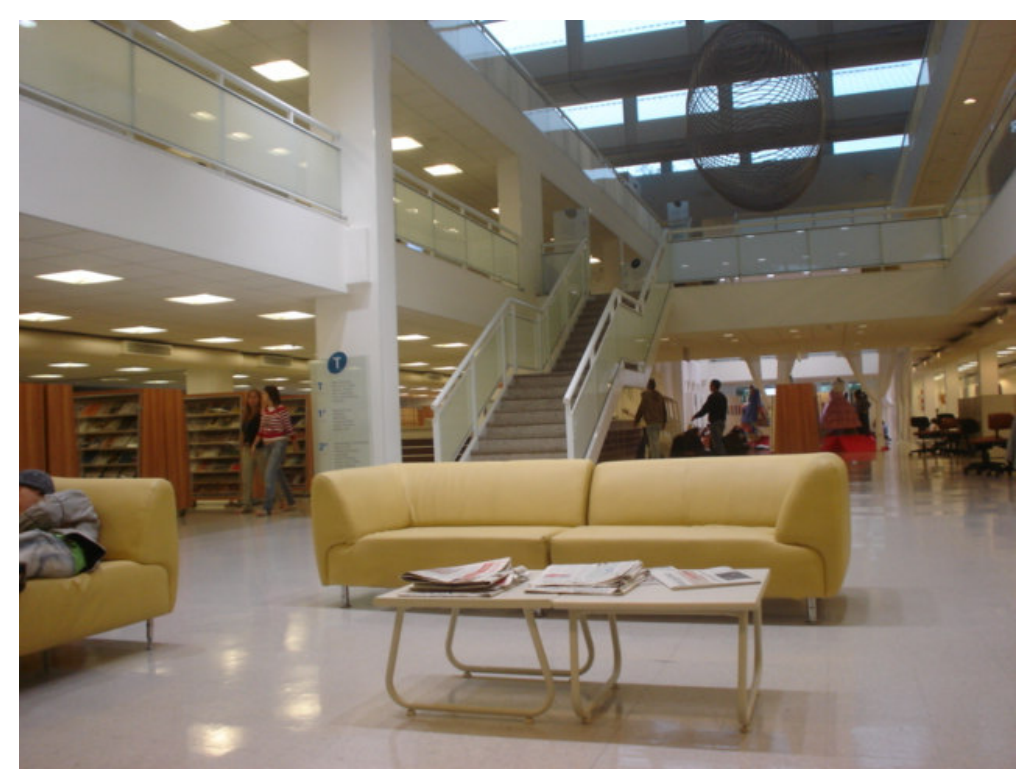

Figura 183 - Área de Descanso e Lazer/ Biblioteca Senac/ Santo Amaro

Alguns serviços essenciais da biblioteca, como a Sala de Fotocópias (Figura 184), também tem sua localização estabelecida no pavimento térreo, bem próximos aos sanitários deste piso. O principal inconveniente com relação a esse ambiente é a dificuldade de acessibilidade: a sala de fotocópias está instalada em um corredor, fora do alcance visual e espacial dos espaços do pavimento térreo, dificultando em muito o acesso rápido dos usuários. Uma das alternativas encontradas para minimizar esta situação foi justamente a abertura de uma janela fixa localizada entre o corredor de acesso à sala de fotocópias e o guarda-volumes. Esse recurso, além de 
estabelecer uma aproximação visual entre esses dois espaços, ajudou na localização da sala de fotocópias por parte do usuário

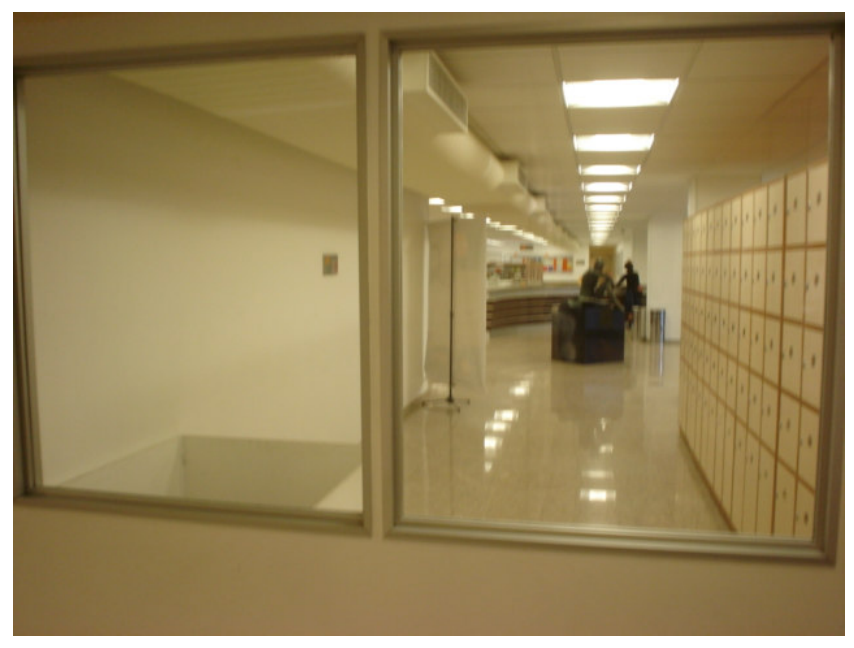

Figura 184 - Janela fixa entre o Guarda-Volumes e a Sala de Fotocopias Biblioteca Senac/ Santo Amaro

Passando a catraca eletrônica e o balcão de empréstimo/devolução, logo à direita, encontram-se outros ambientes que complementam o programa arquitetônico do pavimento térreo: Copa, Depósito, Espaco de Exposições, Salas de TV, Mesas de Estudo, Pesquisa On-line, Sanitários, Sanitários e Sala destinada ao público infantil. A Copa está localizada próxima à escada enclausurada e serve prioritariamente aos funcionários do pavimento térreo da biblioteca, justamente por ter dimensões reduzidas e pouco espaço de uso. Na concepção do projeto arquitetônico do edifício, a direção requisitou a incorporação de três $\underline{\text { Salas de } \mathbf{T V}}$ justamente porque existia uma grande demanda não só por parte da comunidade acadêmica, mas também de toda a população circunvizinha carente atendida pela biblioteca. Portanto, com o objetivo de evitar os problemas gerados pelo ruído excessivo e desconforto auditivo, as salas foram localizadas distantes das mesas de estudo e do acervo bibliográfico, próximo ao corredor de acesso aos sanitários. Desta forma foi possível garantir isolamento acústico necessário às salas quando de sua utilização. Bem ao lado das salas de TV, encontra-se o Espaço destinado ao público infantil, onde se desenvolvem atividades específicas ao estudo, pesquisa, leitura e jogos infantis. É bastante comum, no espaço da biblioteca, o recebimento de vários grupos de crianças pertencentes às escolas estaduais e municipais 
de bairros e zonas adjacentes, com o objetivo de desenvolver visitas guiadas ao acervo bibliográfico e ministração de cursos nas mais diversas áreas do conhecimento. Além disso, como apresentado anteriormente, várias Mesas de Estudo e estações de trabalho dedicado à Pesquisa On-line estão espalhados ao longo do pavimento térreo, executando o papel primordial de acesso, busca e disseminação da informação no contexto da biblioteca. E finalmente, os Sanitários Femininos e Masculinos localizamse no final do corredor do lado direito e, destacam-se por estarem enquadrados na NBR 9050/2004, legislação específica no atendimento às pessoas com dificuldade de locomoção.
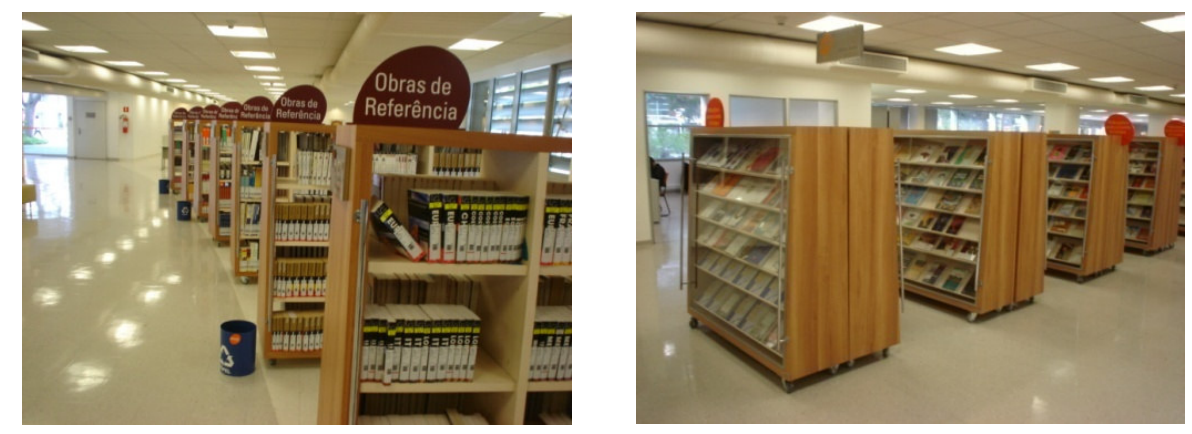

Figuras 185 e 186 - Acervo pav. Térreo - Estantes - Biblioteca Senac/ Santo Amaro 


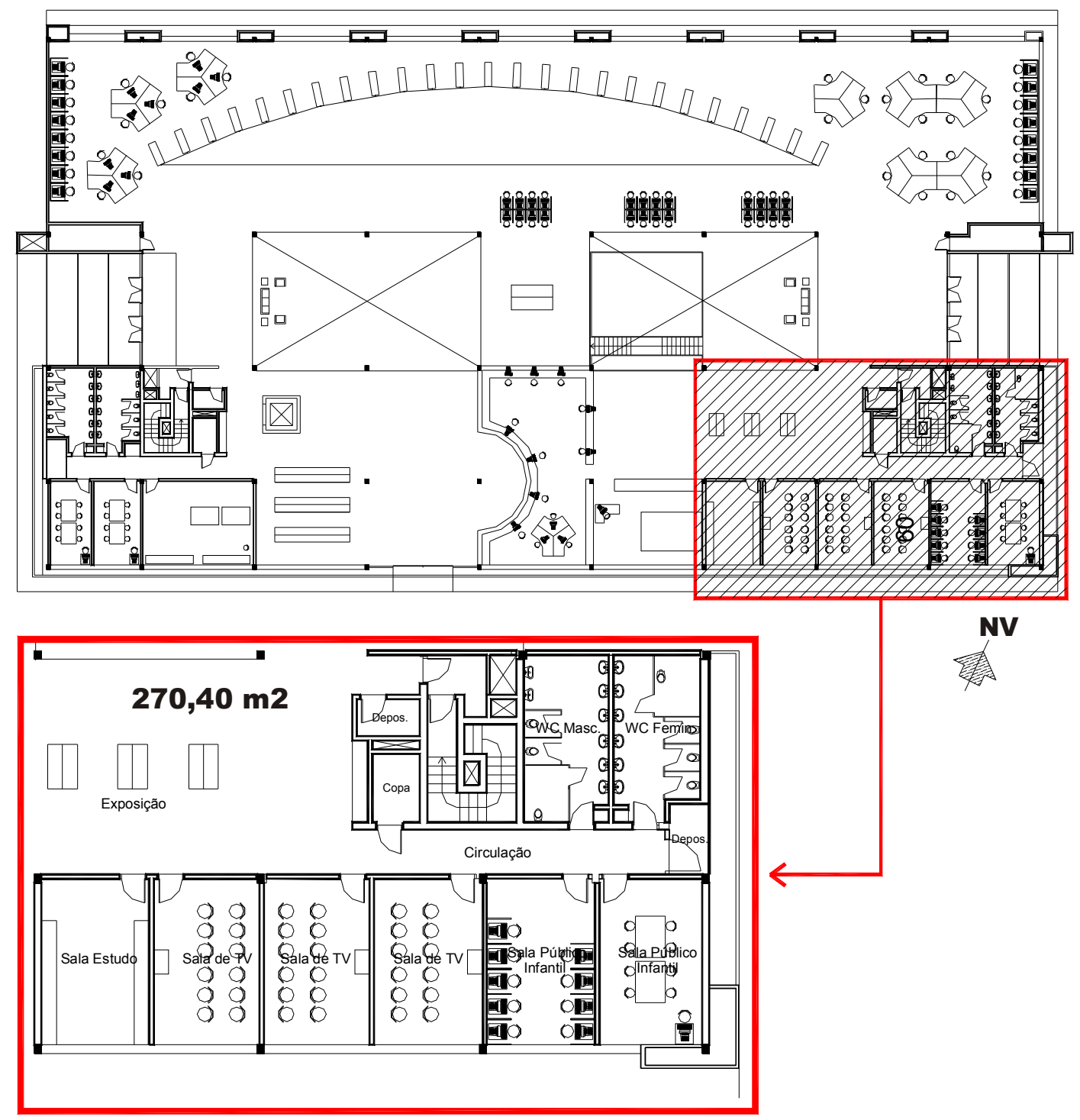

Pav.Térreo - Biblioteca Senac

Sem escala

Figura 187 - Pavimento térreo - Entrada Principal/ Biblioteca Senac/ Santo Amaro

b) - Primeiro Pavimento: Esse andar, além de contar com mais uma parte do acervo bibliográfico, dispõe de um conjunto completo de espaços e locais destinados à leitura e à pesquisa, tanto em nichos individuais de trabalho como em Mesas Multiuso agregando grupos de usuários. Todos esses ambientes são bastante concorridos pelos usuários (principalmente alunos de graduação), que ocupam diariamente esses locais ao longo do primeiro pavimento. Mas, sem 
dúvida nenhuma, os espaços mais utilizados são os terminais de microcomputadores (Pesquisa On-line), espalhados em todas as direções deste pavimento, em que não só é possível executar consultas às bases de dados da biblioteca, como também navegar pela internet e manipular programas de multimídia que estão disponíveis nestes micro-computadores. Para isso, os terminais contam com um mobiliário específico e estão prontos para serem ampliados quando necessários.
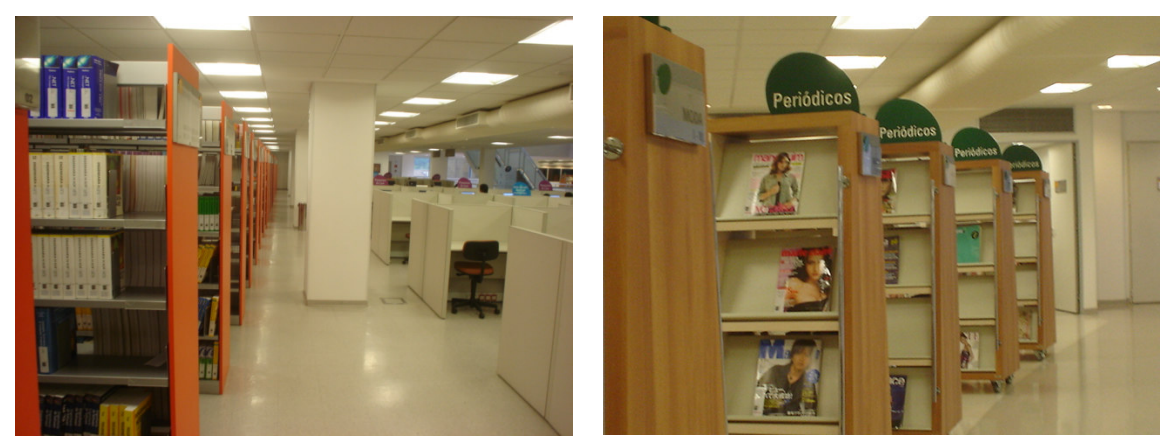

Figuras 188 e 189 - Acervo pav. Térreo - Estantes - Biblioteca Senac/ Santo Amaro 


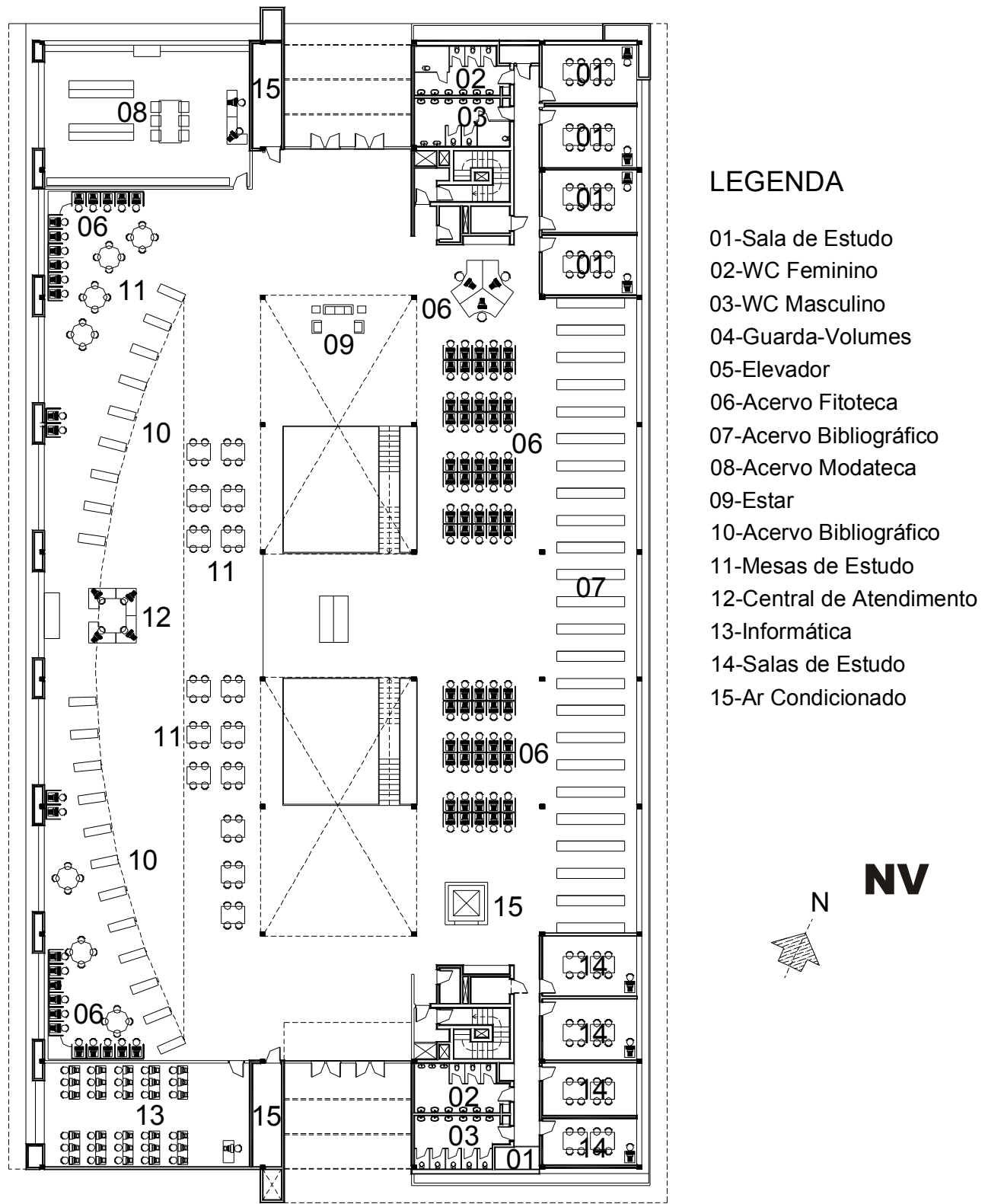

Primeiro Pavimento - Biblioteca Senac Sem escala

Figura 190 - Primeiro Pavimento-Biblioteca Senac Santo Amaro 

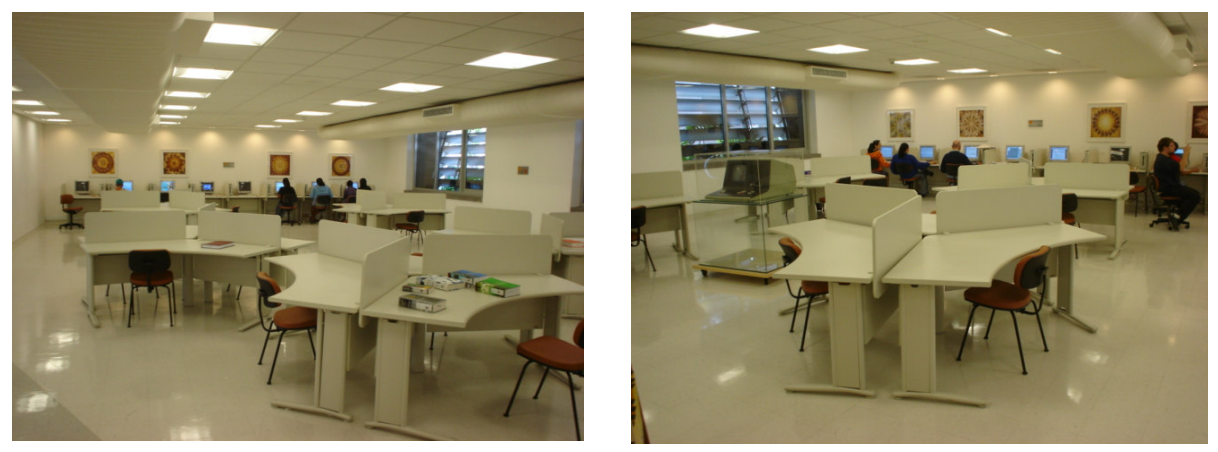

Figuras 191 e 192 - Mesas de Leitura e Pesquisa-Biblioteca Senac Amaro

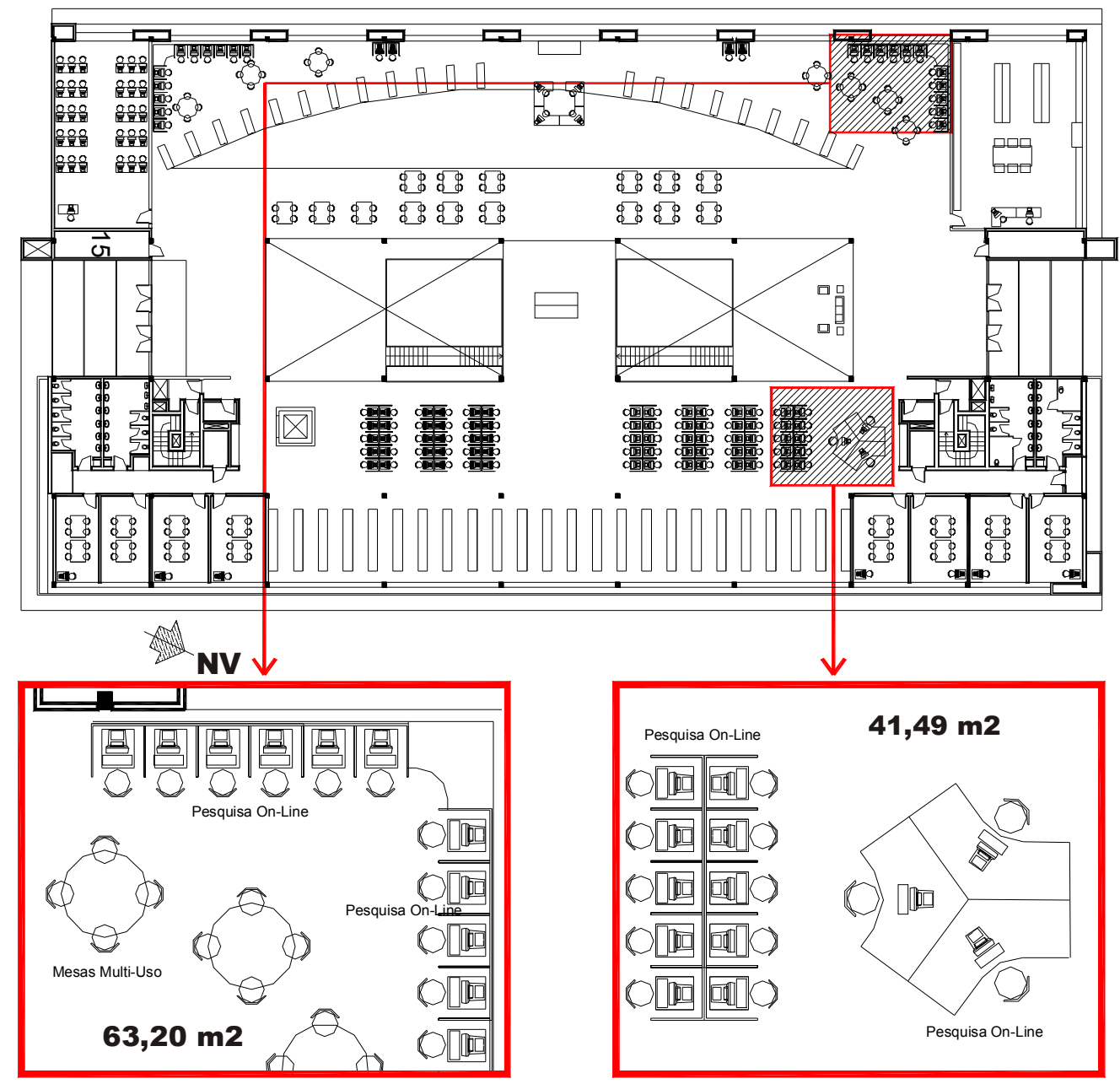

Primeiro Pavimento - Biblioteca Senac Sem escala

Figura 193 - Primeiro Pavimento- Biblioteca Senac/ Santo Amaro

O programa arquitetônico estipulou também, como forma de atender as

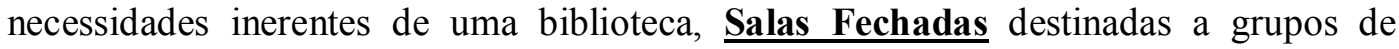


usuários na elaboração de pesquisas e de trabalhos acadêmicos e computadores interligados em rede (Figura 195). As salas contam com um conjunto modulado de mobiliário, que permite, além do desempenho satisfatório das atividades do usuário, um serviço bastante diferenciado no espaço da biblioteca. Como estes ambientes estão localizados nas laterais do primeiro pavimento e são isolados com divisórias moduladas, não existe a possibilidade de interferências acústicas com o restante dos outros espaços, ou seja, é possível ter um controle adequado ao nível de ruídos. Isso se explica principalmente porque as salas fechadas garantem isolamento acústico, o movimento de pessoas é bem mais reduzido e os lay outs dos espaços são mais "restritivos".
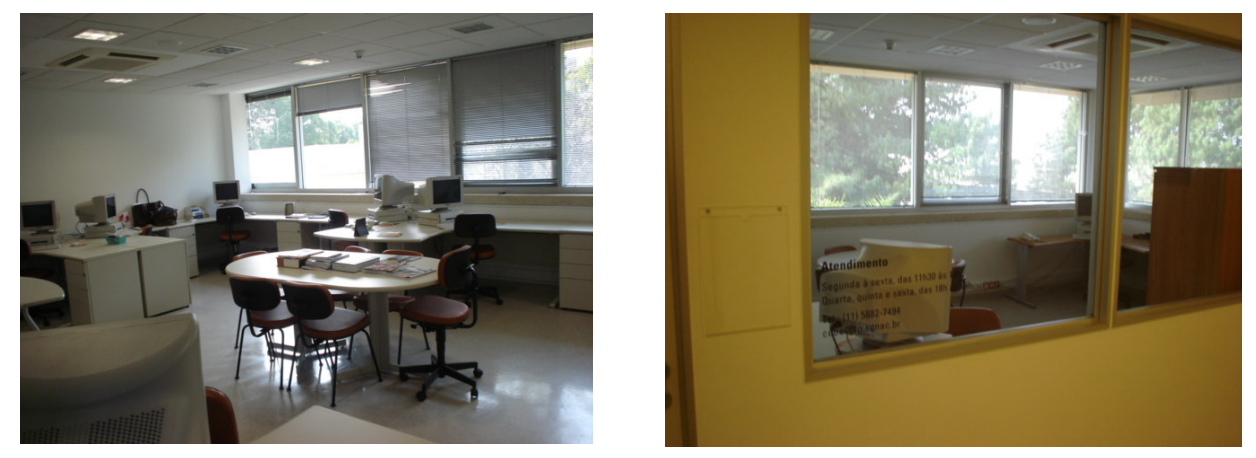

Figuras 194 e 195 - Salas de Estudo/Pesquisa Individual - Biblioteca Senac/ Santo Amaro

Esse pavimento agrega também um programa especial criado pela própria direção da biblioteca, o Atendimento prioritário aos Portadores de Dificuldades Visuais, que mantém uma sala com micro-computadores e programas específicos direcionados a esses usuários (Figuras 197 e 198). Esse programa se tornou referencia nacional no âmbito das bibliotecas universitárias e despertou o interesse da própria direção da instituição para a possibilidade de implantação do programa nas outras bibliotecas do Senac. O espaço tem o mesmo esquema de layout das salas fechadas, entretanto, o mobiliário modulado e as instalações têm suas especificações direcionadas às pessoas com dificuldades de locomoção. 


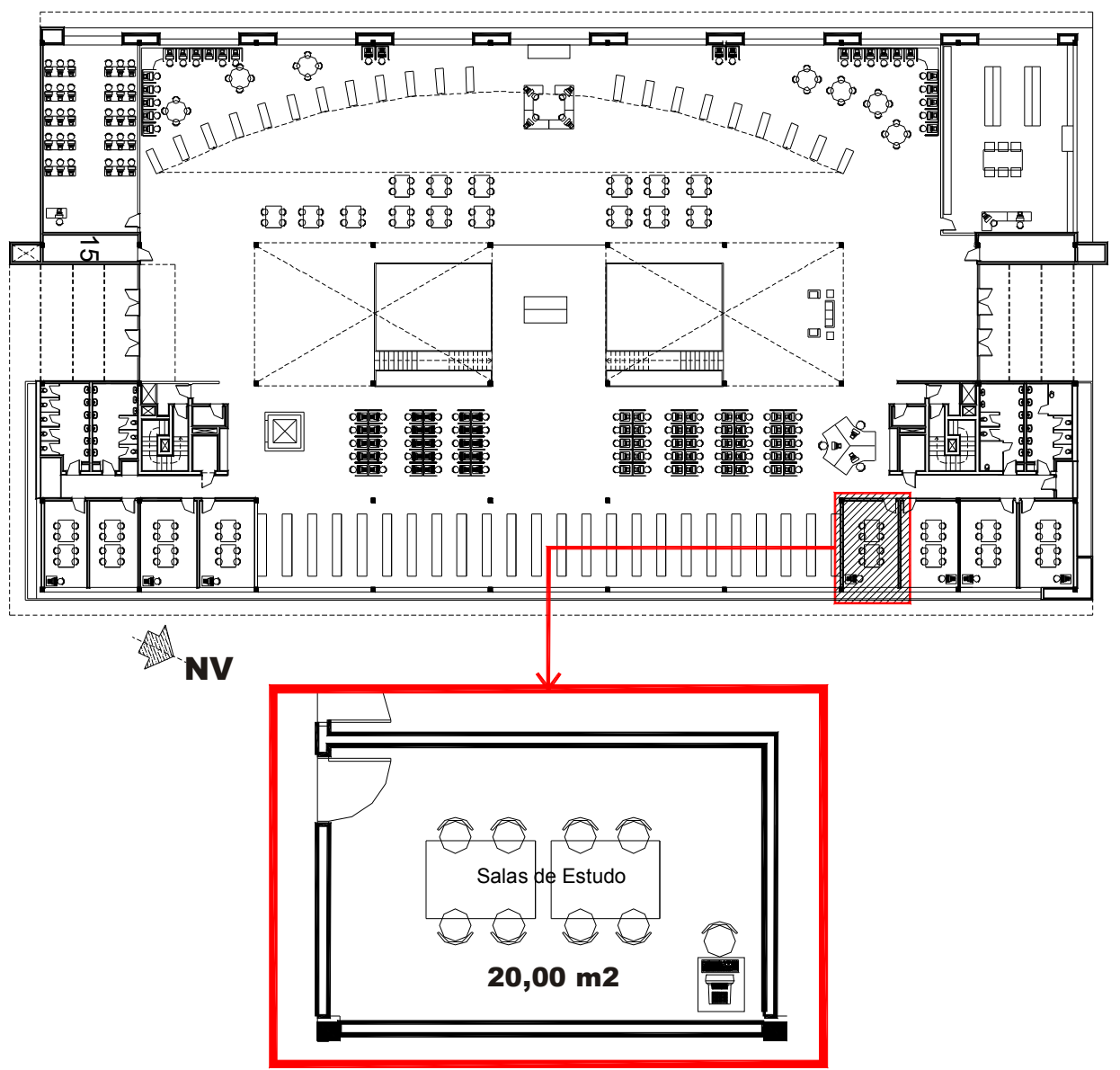

Primeiro Pavimento - Biblioteca Senac Sem escala

Figura 196 - Primeiro Pavimento- Biblioteca Senac/ Santo Amaro
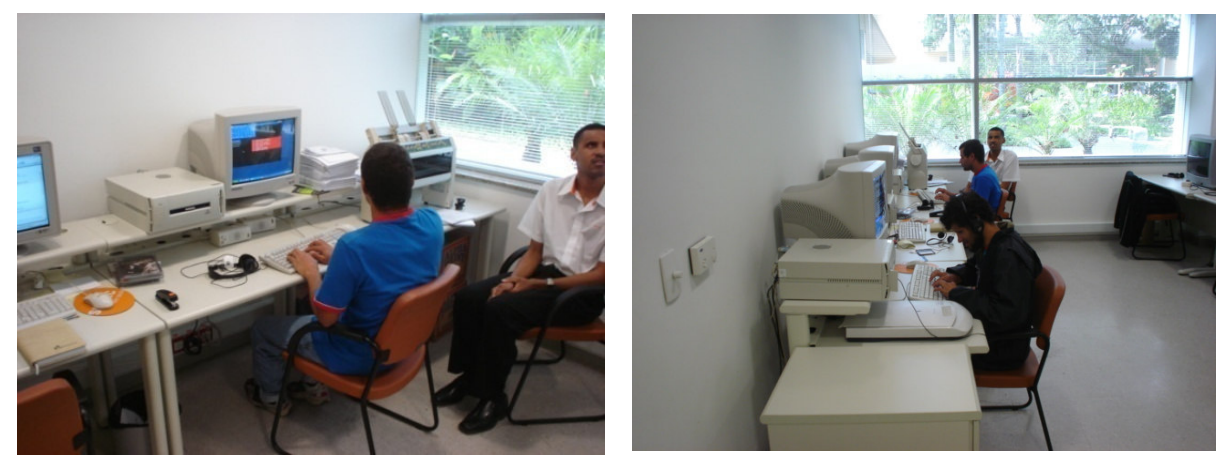

Figuras 197 e 198 - Sala de Atendimento à Pessoas Portadoras de Necessidades Visuais - Biblioteca Senac/ Santo Amaro 
A biblioteca conta ainda com um Acervo especial dedicado ao Curso de Moda (Figuras 199, 200 e 201), disponibilizando e apresentando peças, utensílios, roupas e chapéus pertencentes aos principais períodos históricos da moda. $\mathrm{O}$ acervo ainda está em processo de catalogação, contudo, já é possível acessar e consultar os objetos que estão em exposição. Outro quesito importante é o projeto inovador das instalações e do mobiliário, especificamente criado para atender às necessidades funcionais da sala de exposição como, por exemplo, mesas expositoras, armários para guarda dos manequins, porta - estojos, estantes especiais e mesas especiais de exposição.
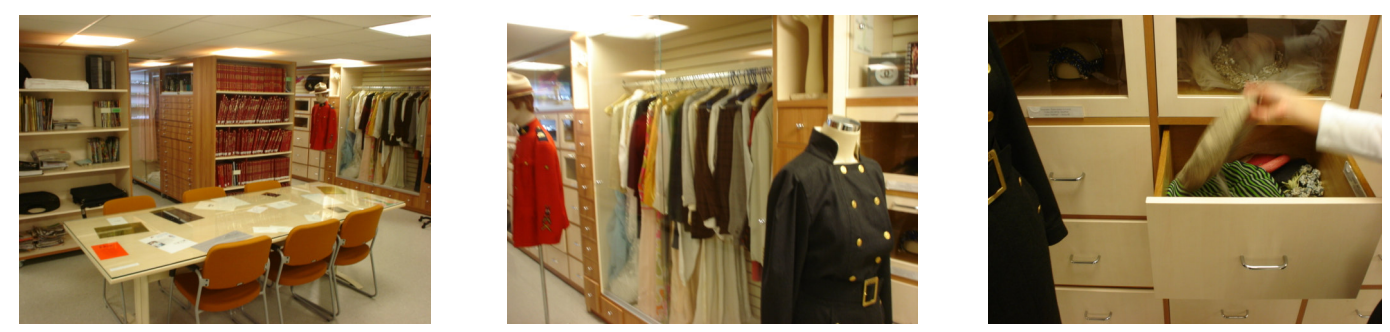

Figuras 199, 200 e 201 - Acervo de Moda/ Biblioteca Senac/ Santo Amaro
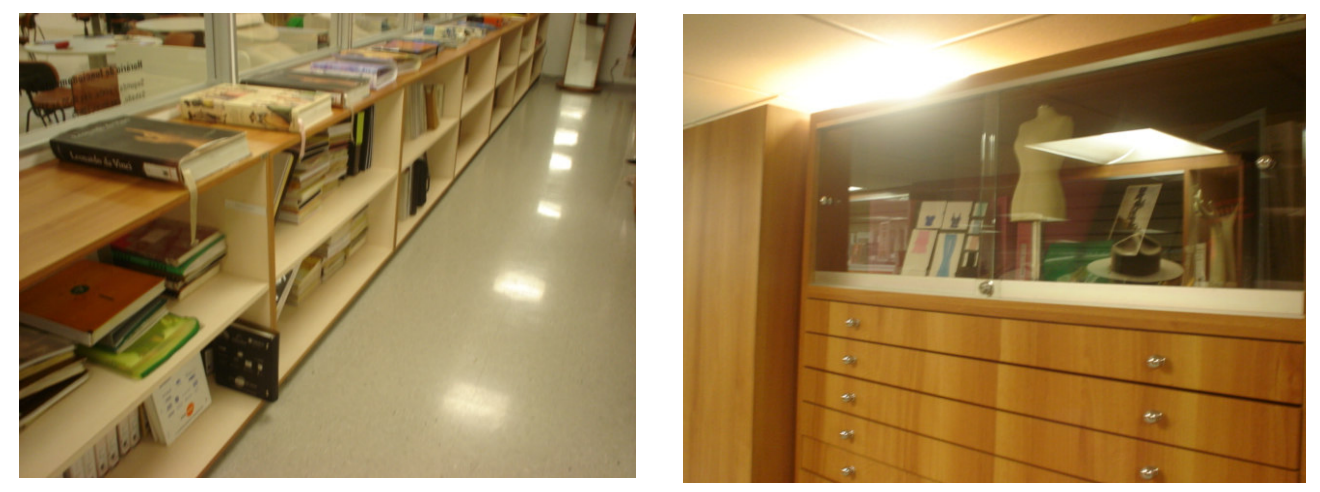

Figuras 202 e 203 - Acervo de Moda/Biblioteca Senac/ Santo Amaro 


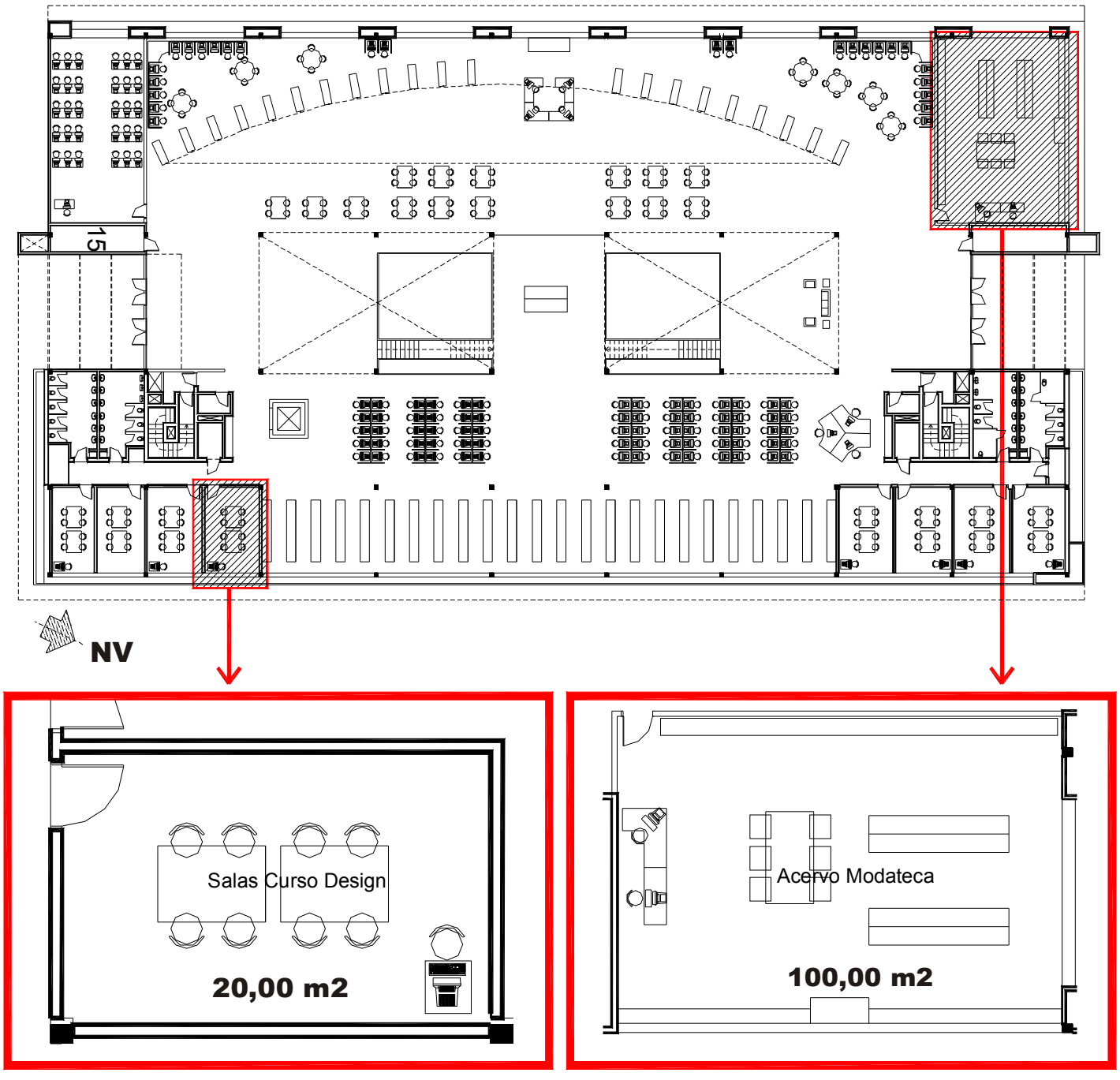

Primeiro Pavimento - Biblioteca Senac

Sem escala

Figura 204 - Primeiro Pavimento-Biblioteca Senac/ Santo Amaro 
Outro espaço que tem destaque neste pavimento é a Sala de Atividades manuais do Curso de Design (Figura 205). Este local tem as mesmas características funcionais das outras salas fechadas da biblioteca, porém dispõe de equipamentos auxiliares para sua utilização como, por exemplo, pranchetas de desenho, mesas especiais e módulos de apoio. A desvantagem apresentada está relacionada ao tamanho reduzido da sala, porque pela proporção do número de alunos matriculados no Curso de Design, o ambiente necessitaria de um espaço maior ou de mais salas para o desenvolvimento das atividades. Em função da grande procura de alunos ou pessoas interessadas na ocupação da sala, existe um processo de agendamento para a utilização do ambiente.

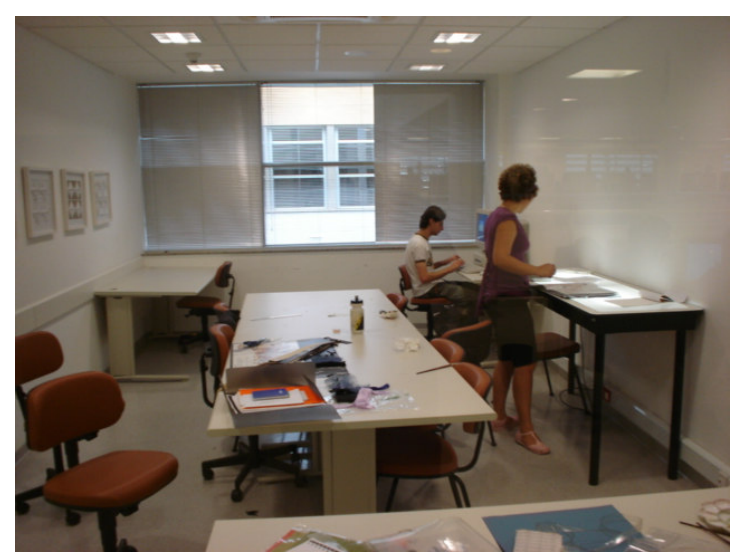

Figura 205 - Sala de Atividades Manuais do Curso de Design - Biblioteca Senac/ Santo Amaro

Finalmente, além desses ambientes descritos anteriormente, o primeiro pavimento conta com Sanitários e Caixa de Elevadores, todos eles localizados nos eixos das prumadas do edifício da biblioteca. Com relação à utilização e à freqüência do uso do elevador, os usuários em geral têm a tendência natural direcionada à escada central, reservando aos funcionários internos da biblioteca o uso mais freqüente do elevador, principalmente porque, um instrumento mais versátil e rápido no trabalho diário do funcionário. 


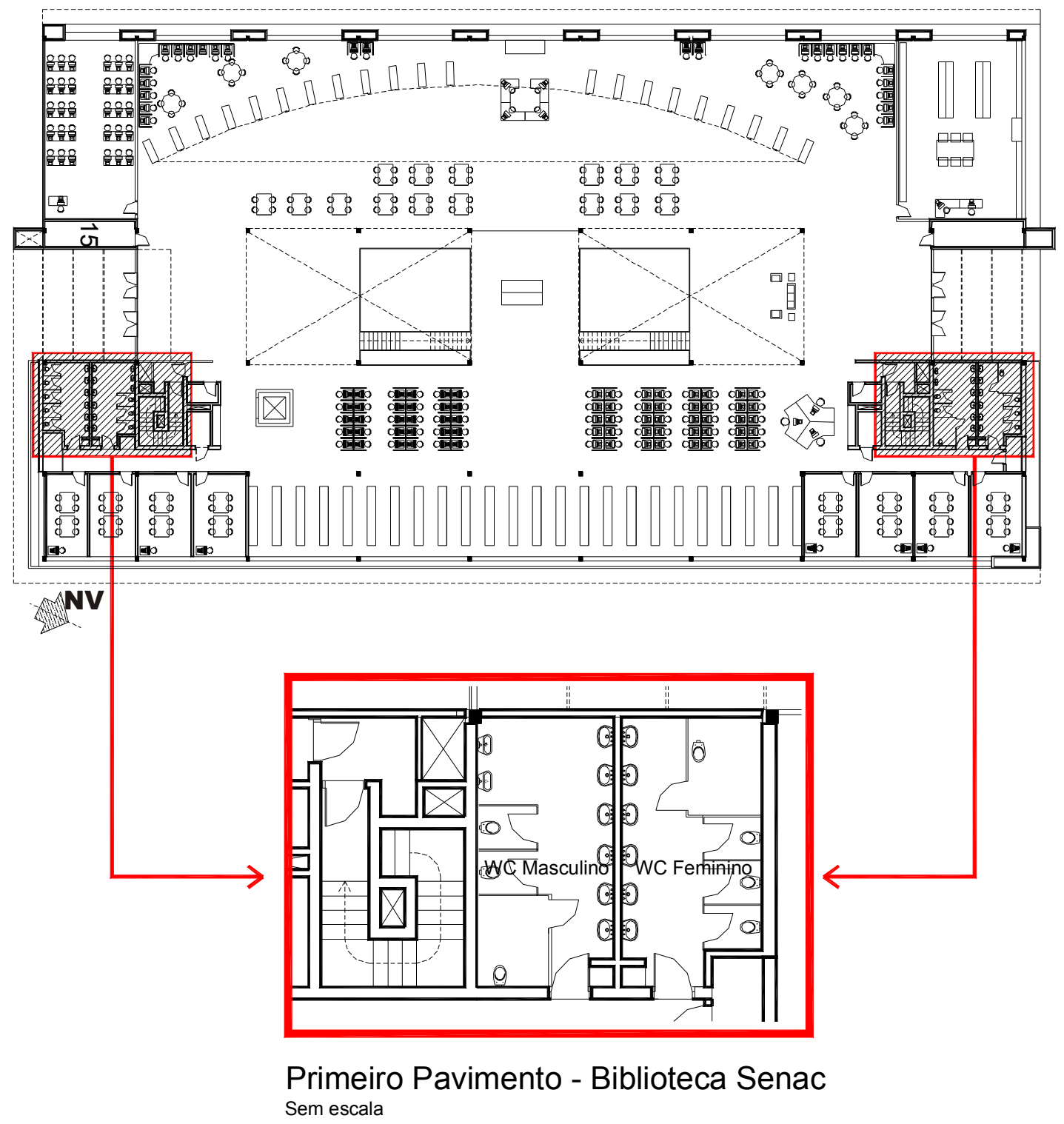

Figura 206 - Primeiro Pavimento Biblioteca Senac/Santo Amaro

c) - Segundo Pavimento: Quanto às especificações arquitetônicas direcionadas a este pavimento, dois grandes setores definem claramente suas atividades: o Setor Técnico-

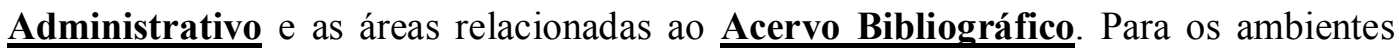
direcionados às funções técnicas de compra, seleção, indexação e catalogação do material bibliográfico, bem como os locais da diretoria da biblioteca e suas subdivisões, foram desenhadas várias salas (Figuras 209 e 210) com a proposta especial de manter a privacidade e a funcionalidade do ambiente construído. Todo esse conjunto de salas é 
articulado com divisórias e mobiliários modulados, permitindo que haja eventualmente remanejamentos e adaptações na planta original ao longo do período de utilização.

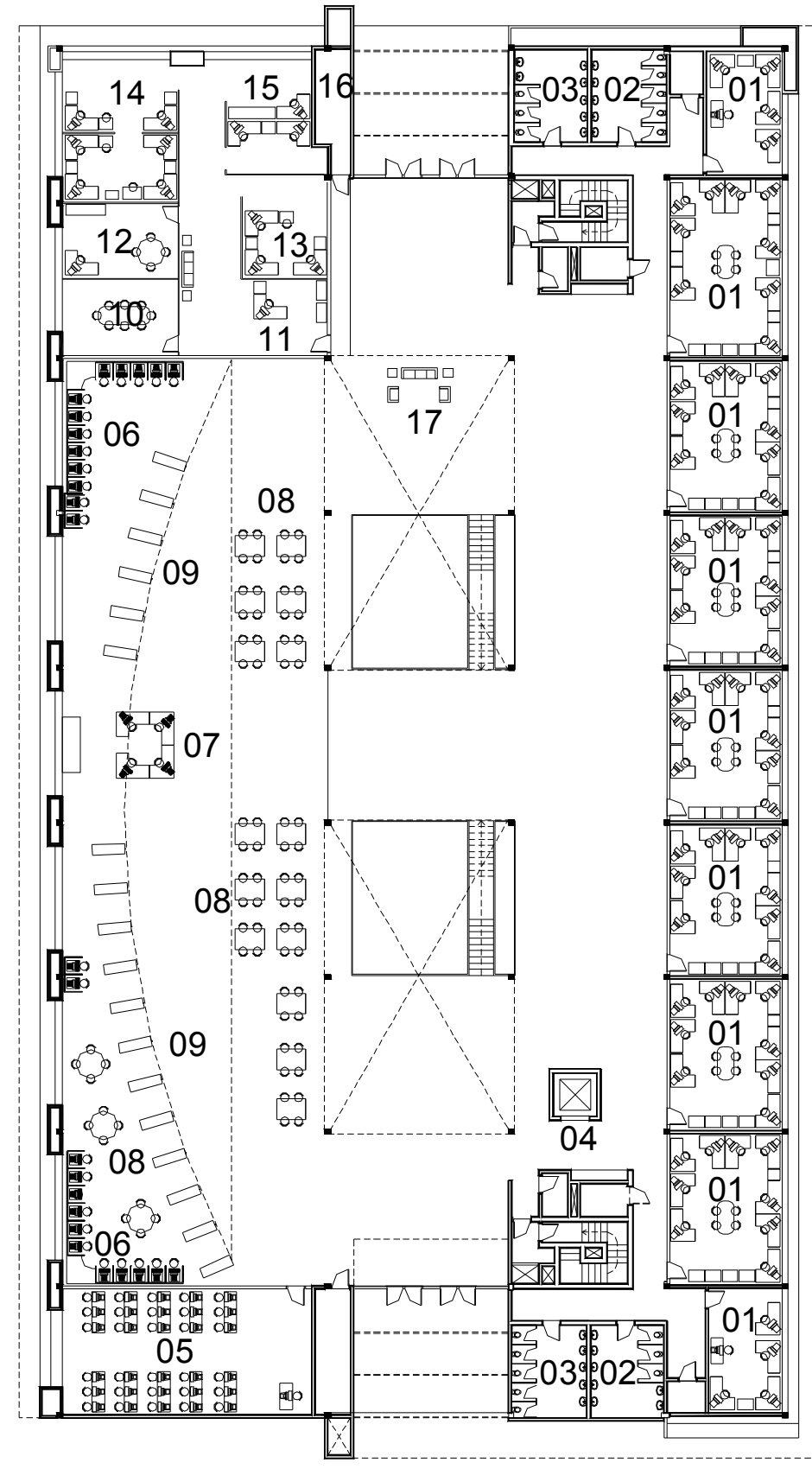

\section{LEGENDA}

01-Sala de Estudo

02-WC Feminino

03-WC Masculino

04-Elevador

05-Sala Palestras

06-Pesquisa On-line

07-Central de Atendimento

08-Mesa de Leitura

09-Acervo Bibliográfico

10-Sala Reunião

11-Secretaria

12-Bibliotecária

13-Compras

14-Cadastro

15-Apoio

16-Ar-Condicionado

17-Estar

NV

Segundo Pavimento - Biblioteca Senac

Sem escala

Figura 207 - Segundo Pavimento-Biblioteca Senac/ Santo Amaro 


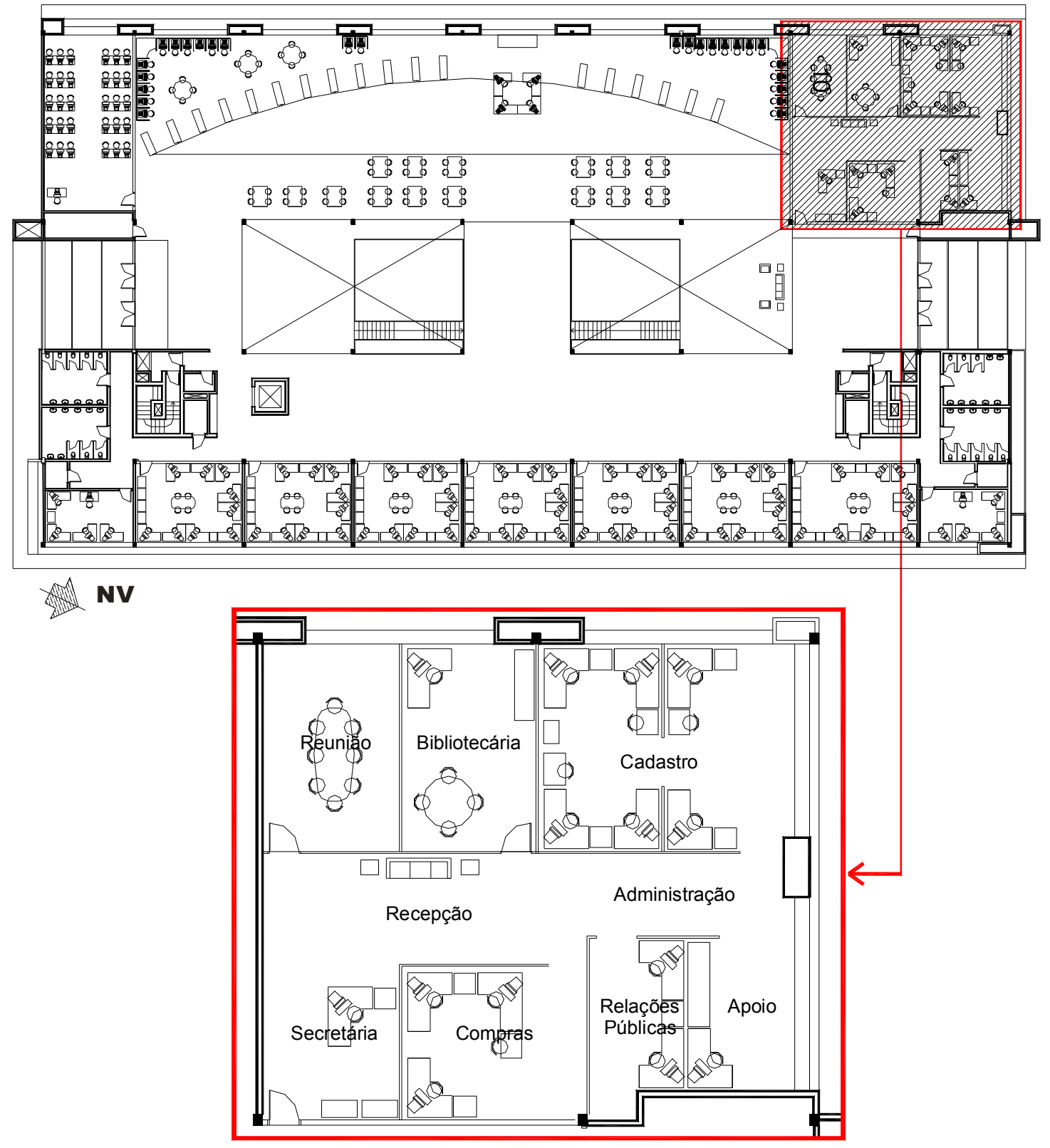

Segundo Pav.Admin. - Biblioteca Senac Sem escala

Figura 208 - Segundo Pavimento Administração -Biblioteca Senac/Santo Amaro 

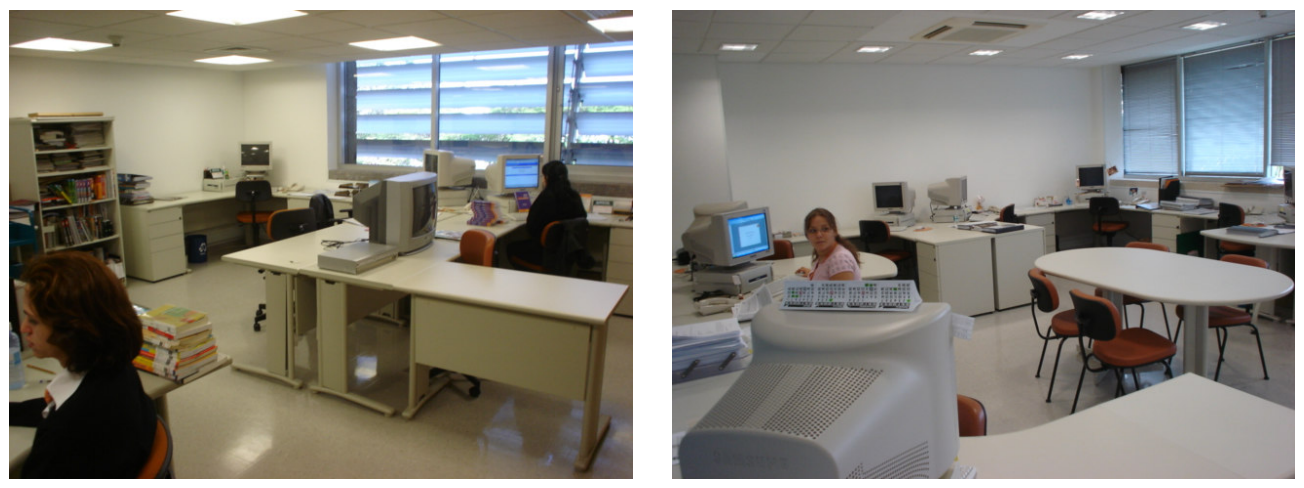

Figuras 209 e 210 - Setor técnico-administrativo - Biblioteca Senac/ Santo Amaro

Outro quesito relevante no controle do conforto ambiental desse setor é a utilização de brises metálicos (fachada oeste) nas aberturas das janelas, possibilitando que haja o controle da incidência solar ao longo das quatro estações do ano. Outra área importante atendida no segundo pavimento é a parte final do Acervo Bibliográfico, os ambientes fixados para as Mesas de Estudo e Pesquisa, $\underline{\text { Terminais de Computadores }}$ , Salas Individuais de Pesquisa e Áreas de apoio aos usuários. Todos esses espaços estão distribuídos ao longo do átrio central e em volta da escada que dá acesso aos outros pavimentos da biblioteca. Destacam-se, neste andar, os elevados índices de iluminação natural banhando o ambiente, provindos principalmente das aberturas dos sheds que estão localizados no teto. Vale lembrar que as visitas técnicas foram feitas na primeira semana de novembro. O pavimento ainda conta com o bloco de $\underline{\text { Sanitários }}$ localizado nas duas extremidades do edifício e no acesso aos elevadores.
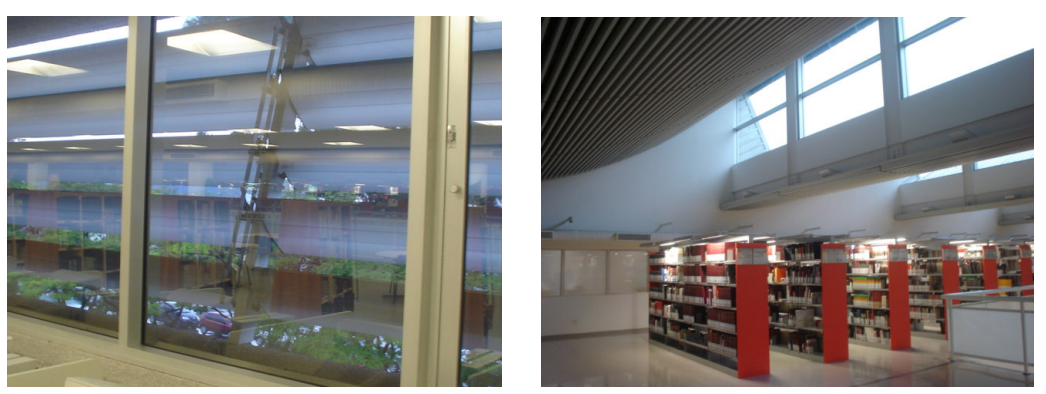

Figuras 211 e 212 - Brises Metálicos e Iluminação Zenital - Segundo Pavimento-Biblioteca Senac/ Santo Amaro 

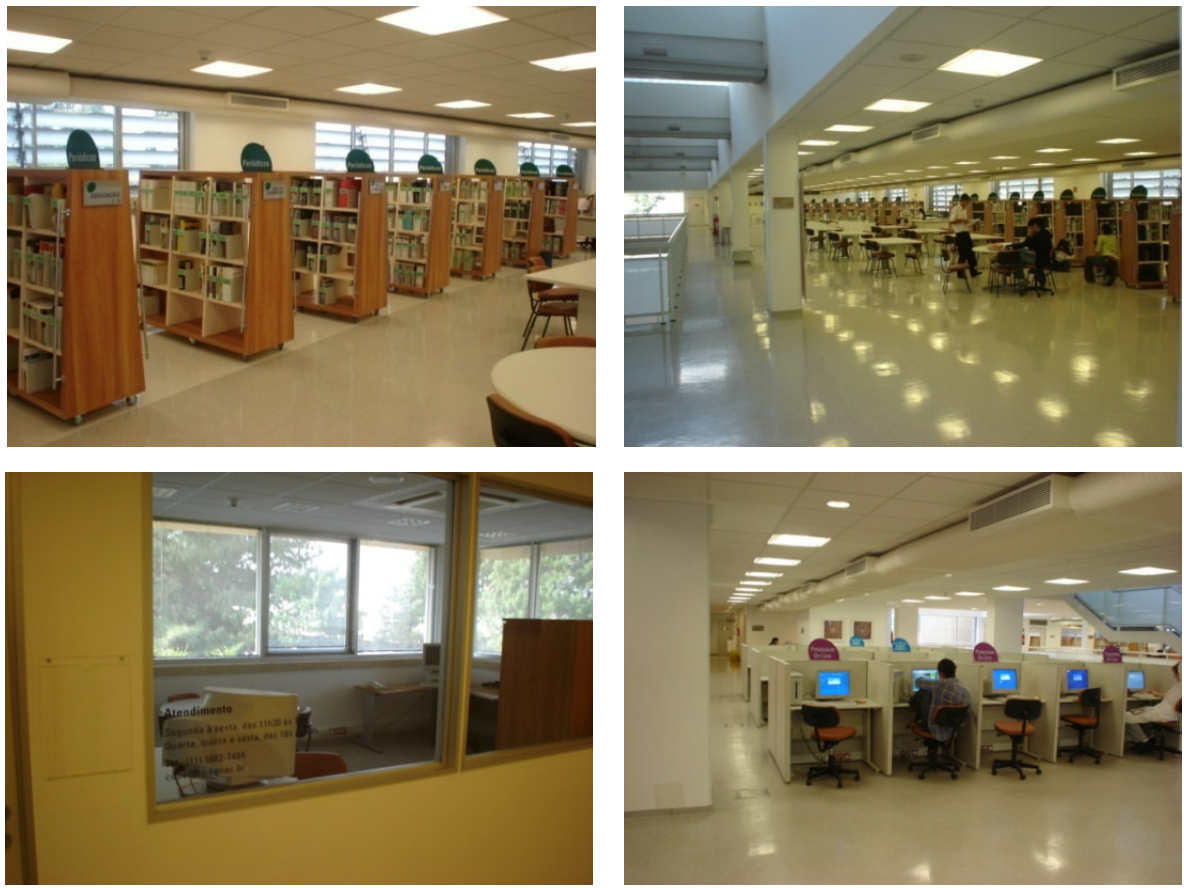

Figuras 213, 214, 215 e 216 - Acervo, consulta terminais e sala individual de pesquisa - Segundo Pavimento-Biblioteca Senac/ Santo Amaro 


\section{CAPÍTULO 7 - PROCEDIMENTOS METODOLÓGICOS PARA APLICAÇÃO DA APO}

\subsection{Métodos, Técnicas e Instrumentos}

A sistematização de métodos utilizados no entendimento do processo de produção de edificações, mais precisamente os métodos de avaliação aplicados ao ambiente construído, vem sendo utilizado já há vários anos por importantes pesquisadores (ORNSTEIN, 1997; PREISER, 1998; SANOFF, 2001; FEDERAL FACILITIES COUNCIL, 2001). A aplicação continuada de metodologias de projeto, como forma de se conceberem instrumentos confiáveis na geração e no gerenciamento de equipes multidisciplinares de projeto tem se mostrado o caminho mais adequado para minimizar e reduzir falhas nas etapas de criação, execução e operação do ambiente construído (PREISER \& VISCHER, 2005). Em países desenvolvidos, com freqüência, o emprego de avaliações, como forma de compreender melhor os problemas de projeto, tem sido uma importante contribuição para a qualidade do produto acabado, destacando quais soluções atendem melhor às necessidades dos usuários.

Os procedimentos metodológicos utilizados nas APOs são considerados parte integrante do processo de projeto, de forma que as informações geradas nas avaliações de cada edifício cooperam para o avanço do conhecimento baseado, principalmente, nas experiência anteriores (erros e acertos), gerando subsídios para novos projetos. O uso contínuo da APO pode gerar conhecimento cumulativo nas próximas gerações de avaliações, auxiliando tanto na manutenção e na adaptação de ambientes existentes, bem como na criação de um processo cíclico de reavaliação de projetos semelhantes.

Entretanto, na realidade brasileira, a utilização de métodos direcionados à obtenção de resultados a partir do ponto de vista do usuário, ainda é pouca utilizada se comparadas com a produção arquitetônica do país. Isto é, os profissionais arquitetos brasileiros ainda hoje têm explorado muito pouco os métodos de avaliação, enquanto fontes realimentadoras do processo projetual. No caso específico desta pesquisa, que trata da avaliação do ambiente construído de bibliotecas universitárias, poucos ou quase inexistentes são os casos em escala nacional, que mensurem e quantifiquem por meio de testes e normas, a aplicação de uma metodologia científica voltada à APO. 
Como descrito anteriormente, foram definidos dois estudos de caso para a pesquisa, a Biblioteca do Senac/Santo Amaro, na cidade de São Paulo e a Biblioteca da Unesp instalada na cidade de Marília, considerando principalmente os aspectos relacionados aos aspectos funcionais (análises de desempenho físico) e a aferição de satisfação dos usuários, empregando-se a metodologia recomendada por Preiser (1988), Ornstein (1992) e Roméro \& Ornstein (2003).

\subsection{Informações e Memória dos Objetos de Estudo}

No caso específico desta pesquisa, a coleta de dados relacionada aos edifícios das bibliotecas universitárias escolhidas, objetivou identificar, em linhas gerais, como esses espaços se organizavam fisicamente, sob que tipo de partido arquitetônico estava estruturado a edificação e sob que conceitos de ocupação dos diversos componentes do layout (tipos de uso) foram concebidos. Baseados nisso, Roméro \& Ornstein (2003) recomendam para que haja confiabilidade em uma APO, é necessário obter o cadastro atualizado do edifício em estudo e que contenha a divisão espacial contemplada no projeto original, além da divisão espacial na data do levantamento. Essa estratégia foi imprescindível para garantir que o cadastro atualizado funcionasse como uma ferramenta útil na análise funcional dos edifícios das bibliotecas universitária analisadas.

Desta forma, o procedimento de observação incluiu a análise dos projetos executivos de arquitetura, infra-estrutura e de interiores dos edifícios escolhidos, assim como vistorias técnicas nas bibliotecas e, em seguida, recolhimento dos dados e informações mais detalhados de cada item técnico analisado.

\subsection{Atualização e Cadastro do Objeto de Estudo}

Os levantamentos da coleta de dados e das informações cadastrais dos edifícios analisados seguiram as seguintes etapas de trabalho, conforme apresentado na Figura 217: 


\section{Levantamento - Memória do projeto}

e da construção

(1)

Cadastro atualizado do

ambiente construído

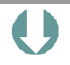

Cadastro atualizado do

mobiliário e dos equipamentos

Figura 217 - Cadastro do Objeto de Estudo

a )- Levantamento- Memória do projeto e da construção: Esta primeira etapa teve como objetivo principal executar o levantamento da 'memória' projetual do ambiente construído das bibliotecas universitárias escolhidas, por meio do resgate do projeto original (plantas, cortes, fachadas, implantação, etc), bem como o levantamento de dados e informações visuais (fotos da época da época da construção e dados cadastrais). Esses procedimentos construem um panorama geral das edificações, de forma a compreender o contexto atual e histórico de objeto a ser analisado. Nessa fase ainda, ocorreram as entrevistas com as pessoas-chave envolvidas no processo de projeto e construção das bibliotecas como, por exemplo, o arquiteto (Biblioteca do Senac/Santo Amaro) e o Departamento de Projetos (Biblioteca Unesp/Marília). Outro objetivo nesta etapa foi buscar informações pertinentes à existência ou não de estudos preliminares ou pré-projetos anteriores ao projeto executado, para interpretar análises críticas posteriores. Essas informações também foram úteis no processo de entendimento sobre o uso, a operação, a manutenção e o gerenciamento de sistemas e espaços dos edifícios, bem como relacioná-los às características das atividades e os níveis de satisfação com o ambiente de trabalho.

b )- Cadastro atualizado do ambiente construído: Intitulada também 'as built' ${ }^{1}$ esta operação teve a função de atualizar as informações cadastrais das plantas e projetos complementares dos ambientes selecionados e constituem um acervo importante, tanto para a pesquisa de APO direcionada aos edifícios escolhidos, como para as próprias instituições envolvidas. Nesta fase do reconhecimento exploratório dos ambientes, as built se tornou fundamental para a seleção de microambientes e da população amostral a

\footnotetext{
${ }^{1} \mathrm{O}$ termo 'as built' na área da arquitetura para designar 'como construído' tem a função de indicar as medidas reais executadas na obra. No caso específico da APO, as atividades se direcionam para a execução do completo levantamento dimensional de todos os ambientes do edifício analisado, à época da pesquisa.
} 
ser entrevistada, assim como para o levantamento técnico dos aspectos funcionais e do conforto ambiental.

c) - Cadastro atualizado do mobiliário e dos equipamentos: Na terceira fase da coleta de dados, os esforços foram direcionados ao levantamento completo do conjunto de mobiliário e dos equipamentos presentes nas bibliotecas universitárias da pesquisa. $\mathrm{O}$ conhecimento desses dados leva ao entendimento dos quesitos pertinentes ao conceito de ocupação mais utilizado nos espaços estudados, a densidade de ocupação em função do mobiliário e do tamanho e das características das estações de trabalho por função. Além disso, a seleção dos ambientes a serem submetidos à APO recebeu análises gráficas dos aspectos ergonômicos destes espaços.

Portanto, todo esse material ora referenciado serviu de base para uma visualização geral dos edifícios escolhidos, tanto no que se refere às suas dimensões, localização, orientação, forma de distribuição dos usuários e outros elementos, como também seus acabamentos internos e externos além de modificações realizadas. Além disso, foi possível traçar um perfil da ocupação física do ambiente construído das bibliotecas universitárias selecionadas, identificando que tipos de espaço ocupam, que conceitos de ocupação usam, quais os critérios para definição dos padrões dos diversos componentes do layout, tais como salas de reunião, áreas administrativas, estações de trabalho, áreas de armazenamento, entre outros.

\subsection{Ambientes Analisados}

Em linhas gerais, os critérios adotados para a seleção dos ambientes representativos foram distintos para cada um dos extratos de usuários avaliados, embora no final do processo da APO, o objetivo comum tendo sido o de avaliar o usuário em seu local de trabalho ou estudo. Nesse raciocínio, e baseado na representatividade destes ambientes junto aos diversos extratos, optou-se por estabelecer alguns critérios básicos na seleção dos ambientes representativos:

- Areas destinadas aos locais de trabalho: Por serem considerados locais onde se despende a maior parte do dia trabalhando e executando tarefas profissionais, a análise da ocupação espacial destas áreas mostrou-se importante no contexto para se estabelecerem parâmetros de análises quanto às condições mínimas de funcionalidade, conforto, segurança e saúde. Além disso, foi possível identificar e confrontar, nas 
análises dos resultados, aproximações confiáveis com normas orientativas e diretrizes de projetos de bibliotecas universitárias. O conhecimento apurado destes locais auxiliou na determinação dos principais itens priorizados nas recomendações, reforçando ou até dirimindo dúvidas, quando necessário.

- Areas destinadas ao trabalho em grupo ou de reuniões: Em ambientes de bibliotecas e, especialmente neste estudo das bibliotecas universitárias, as áreas destinadas ao trabalho em grupo, tanto de alunos como de pesquisadores e funcionários, se mostram bastante comuns. Em relação a este item, é importante destacar que, a cada dia que passa, cada vez mais as bibliotecas universitárias têm reduzido estas áreas à medida em que o número de funcionários vai aumentando. Essa falta de critério prejudica a eficiência de uso destes espaços e ter gerado descontentamentos por parte, principalmente, dos funcionários.Portanto, a análise de ocupação destes espaços gerou importantes resultados e índices de satisfação no contexto da pesquisa.

- Áreas destinadas à circulação principal: Por serem locais consideradas rotas de fuga e espaços planejados para desempenharem importantes articulações de funcionalidade no contexto da biblioteca, o mínimo de espaço destinado à circulação principal é aquele que deverá respeitar o determinado pela legislação de proteção e combate a incêndio. Pode-se afirmar que a dimensão e o posicionamento das áreas destinadas à circulação em espaços de bibliotecas podem ser determinantes no sucesso ou fracasso desses ambientes. As análises dos percentuais encontrados possibilitaram encontrar referências nas análises finais e nas recomendações. Além disso, as análises vinculadas das larguras máximas e mínimas das circulações, os conflitos entre fluxos de materiais/equipamentos e pessoas, fluxos entre funcionários das bibliotecas e seus usuários finais (alunos), troxeram contribuições importantes no contexto da pesquisa. Nessa medida, a análise destes quesitos possibilitou checar junto à legislação pertinente, pontos positivos e pontos negativos das distâncias mínimas encontradas, no sentido de promover possíveis recomendações projetuais.

- Areas de estocagem e armazenamento: Geralmente essas áreas são renegadas ou não merecem o devido valor no âmbito das bibliotecas universitárias. Poucas bibliotecas têm investido o suficiente no planejamento dos espaços destinados ao armazenamento do acervo ou das atividades consideradas "arquivo morto". Muitos dos 
espaços que não têm exatamente a função de armazenamento e não estão discriminados no projeto original de arquitetura acabam se 'transformando' em áreas de estoque sem a devida adaptação. O que se pode notar é que as bibliotecas universitárias têm dado pouco destaque para esta questão, reportando um alto índice de insatisfação por parte das equipes de funcionários. A avaliação de desempenho desses locais pôde comprovar tal fato e serve de parâmetro para possíveis alterações espaciais.

- Areas destinadas aos setores técnicos: Nestes setores, todas as atividades técnicas bibliográficas relacionadas à catalogação, indexação e distribuição dos documentos presentes na biblioteca universitária, passam necessariamente por um apurado processo técnico específico. Ora, o pleno funcionamento dessas funções é de vital importância, tanto para satisfação do trabalho dos funcionários como para o pleno andamento das atividades normais da biblioteca universitária. Além disso, a avaliação dessas áreas técnicas se fez urgente, principalmente em razão de tentar justificar o grande investimento que os setores competentes direcionam à aquisição de tecnologia para modernização dos setores técnicos. Nessa visão, as especificações envolvidas na infra-estrutura de equipamentos, layout das salas e ergonomia das tarefas necessitaram ser investigadas no contexto da avaliação do desempenho físico dos edifícios.

- Areas destinadas ao acervo bibliográfico: Consideradas o 'pulmão' da biblioteca, as áreas de acervo desempenham papel fundamental na somatória das outras áreas abrigadas na biblioteca universitária, não só pelo seu tamanho de área proporcional, mas também pelo seu grau de importância no conceito de fornecimento de informação e de conhecimento à comunidade universitária. Dependendo do tipo de arranjo espacial do acervo, muitas bibliotecas garantem sucesso ou fracasso junto aos usuários e funcionários.

\subsection{Vistorias técnicas (walkthrough)}

Este procedimento teve a função de realizar visitas exploratórias nos edifícios analisados, levando em conta os aspectos construtivos, dimensionais, funcionais e ergonômicos, com o objetivo de proceder futuras comparações e análises dos elementos encontrados. Um dado importante desse procedimento refere-se ao fato de que foi feito um roteiro walkthrough com o objetivo de se ter uma boa compreensão 
do ambiente a ser analisado, o domínio da percepção espacial das bibliotecas analisadas. As visitas se deram em épocas distintas, porém, relativamente próximas entre si, sendo a do Edifício da Biblioteca da Unesp, no segundo semestre de 2006 e no Edifício da Biblioteca do Senac, no primeiro semestre de 2007. Foram realizadas quatro (4) visitas exploratórias em cada edifício. Na vistorias, os prédios foram percorridos em toda a sua extensão, respeitando-se as restrições de acesso específicas de cada instituição; durante todo o processo de visitas, houve o acompanhamento de pessoal técnico (uma bibliotecária auxiliar). Desta maneira, foi possível, além da familiarização com os edifícios, obter informações técnicas relevantes a respeito do funcionamento dos mesmos, bem como de alguns comportamentais.

Tanto o edifício da Biblioteca da Unesp/Campus - Marília quanto o edifício da Biblioteca do Senac/Santo Amaro alojam atividades relacionadas aos acervos bibliográficos; entretanto, cada um deles possui características particulares quanto ao seu funcionamento, densidade e modo de ocupação dos ambientes. Outras características também foram constatadas quanto à funcionalidade e à eficiência de áreas cujos fluxos e processos de trabalho se relacionam e se interdependem e, em certa medida, colaboram na privacidade do usuário, eficiência e boa atmosfera do ambiente construído.

Foram visitadas todas as dependências, inclusive as de apoio aos edifícios, ou seja, casa de máquinas de elevadores (no caso da Biblioteca do Senac/Santo Amaro), shafts hidráulicos e elétricos, salas de no breaks e outros, para a compreensão preliminar dos princípios de operação dos edifícios, bem como as características e número de pessoal envolvidos na operação e manutenção. Como os edifícios escolhidos possuem graus diferenciados em suas características de apoio técnico, essas observações relativas ao pessoal envolvido colaboraram na análise técnica de desempenho.

Neste processo de vistorias técnicas, as observações físicas também auxiliaram a elaboração de diagnósticos, tanto com relação ao nível de satisfação dos usuários quanto à avaliação técnica e foram executadas por meio de uma planilha tipo checklist (ver Anexo 01). Foram desenvolvidas, paralelamente, as fases de visitas exploratórias e registros fotográficos. Para tanto, foi possível destacar aspectos voltados à compreensão de percepções e opiniões dos usuários como, por exemplo, aqueles elementos relacionados com a disposição do mobiliário, acessibilidade e conforto ambiental, entre outros. Os aspectos observados nesta etapa foram destacados no item 
referente aos diagnósticos, ou seja, os mesmos serão melhor compreendidos se associados aos resultados de questionários aplicados e que fazem parte de uma etapa deste trabalho, a ser abordada em itens posteriores.

\subsection{Registros fotográficos}

Registros fotográficos permitem ao pesquisador apoiar as análises de evidências coletadas naquele momento, nos seus aspectos ligados à percepção visual e, além disso, executar análises em momentos posteriores ao da realização das visitas ao local. Esta técnica foi utilizada com o objetivo de registrar os aspectos construtivos mais relevantes dos edifícios escolhidos, bem como evidenciar os aspectos funcionais presentes no ambiente construído. Portanto, as imagens coletadas foram relacionadas com os aspectos levantados no questionário aplicado aos usuários.

A partir das fotos realizadas foi possível identificar detalhes como, por exemplo, tipo de divisórias, material de acabamento, textura e cor; tipos de layouts; disposição das estações de trabalho; tipos de equipamentos utilizados nos escritórios; acabamentos de piso, paredes e forro, entre outros, sem a necessidade de deslocamentos repetitivos ao local em análise.

\subsection{Contatos com os usuários}

O contato com alguns usuários-chave - diretoria, coordenação e chefes das bibliotecas analisadas - teve a finalidade de ter uma percepção geral dos problemas mais importantes ou os pontos mais positivos em relação ao ambiente construído. Esse contato com os usuários não teve o mesmo caráter estruturado das entrevistas, mas constatou de perguntas rápidas, objetivas e direcionadas a quatro ou cinco pessoas apenas sobre os principais pontos positivos e negativos do ambiente. Nesse contato com os usuários foi possível se conhecer o organograma da instituição, sua filosofia de trabalho e outros aspectos considerados necessários ao entendimento adequado das condições de ocupação e funcionamento dos edifícios. Além disso, essas informações representaram uma referencia básica para dar seqüência às etapas seguintes. 


\subsection{Grupos focais}

Esta técnica teve o objetivo de reunir pessoas-chave envolvidas no trabalho diário do ambiente analisado, como bibliotecárias assistentes, chefes de departamento, por exemplo, para provocar discussões e debates em torno dos aspectos positivos e negativos do espaço em questão. Para se executar a dinâmica dos grupos focais, foi importante ter em mãos um roteiro básico de perguntas previamente elaboradas (Anexo 02), visando estabelecer um 'fio condutor' à prósito dos temas abordados nesta atividade.

A definição para a amostra dos grupos focais está baseada em Zeisel (1984), que estabelece um número máximo de 15 pessoas por grupo. O entrevistador/moderador teve o objetivo de se ter o domínio da discussão dos participantes e o estabelecimento de melhores condições de comunicabilidade entres as pessoas. No caso específico deste trabalho, optou-se pela realização de grupos focais com funcionários (chefia, bibliotecários e assistentes), de ambos os sexos, ocupando suas funções em diversos locais dos edifícios escolhidos e que trabalhavam na biblioteca há mais de um ano.

Para que fosse possível, posteriormente, estabelecer comparações entre os estudos de caso, procurou-se constituir os grupos focais, definindo primeiramente, a quantidade necessária de pessoas participantes, tanto na Biblioteca do Senac/Santo Amaro como na Biblioteca da Unesp/Marília, de modo que as pessoas fossem levadas a pensar sobre as principais questões envolvidas nesta pesquisa. Em seguida, apresentaram-se aos grupos focais, as questões relacionadas aos aspectos ambientais dos edifícios escolhidos, procurando sempre manter os principais objetivos da pesquisa no âmbito da discussão dos grupos. Com base nestas perguntas, os participantes discutiram e chegaram as afirmações apresentadas, auxiliando no processo cooperativo de ajuda entre o avaliador e avaliados. Como fase final deste trabalho, identificou-se os itens, que na opinião deles, deveriam ser melhorados no ambiente e classificou-se de acordo com seu grau de importância.

\subsection{Entrevistas}

As entrevistas têm a função de resgatar informações no contexto do processo evolutivo do projeto, construção, uso, operação e manutenção, além de auxiliar 
na elaboração posterior de questionários a serem aplicados a gama ampla de usuários. As entrevistas também objetivam determinar possíveis elementos positivos e negativos presentes no ambiente construído.

No nosso caso, definiram-se usuários-chave que poderiam colaborar na avaliação dos ambientes escolhidos, detalhando aspectos funcionais e evidenciando, particularmente, os elementos comportamentais do espaço. Executou-se uma entrevista com o próprio arquiteto-autor do projeto da Biblioteca do Senac/Santo Amaro, tentando resgatar os principais aspectos relacionados à arquitetura da edificação, os elementos funcionais e a verificação das principais interpretações espaciais. Entretanto, no caso da Biblioteca da Unesp/Marilia, não se conseguiu localizar o autor do projeto, porque o planejamento arquitetônico foi desenvolvido por uma equipe da Unesp que trata especificamente da construção e da reforma de edificações da instituição.

Em termos técnicos, as entrevistas foram executadas a partir da préelaboração do roteiro sobre isso (ver Anexo 06) dos fatores funcionais (dimensionamentos mínimos, circulações, comunicação visual, conforto ambiental, etc.), permitindo que os respondentes pudessem ser encorajados a abordar não só os temas apresentados, mas também outros itens que fossem pertinentes às áreas correlatas (armazenamento do acervo, bem-estar na área de trabalho, entre outros). Com relação à escolha do extrato dos entrevistados dos não-leigos que responderam à pesquisa, o procedimento se deu de forma aleatória, procurando se escolher pessoas de idade, formação e escolaridade diversificadas e que utilizassem as bibliotecas em diferentes horários e situações.

\subsection{Questionários}

Outra técnica utilizada foi o questionário e teve a função de medir a satisfação dos usuários no ambiente construído em relação aos aspectos funcionais das bibliotecas universitárias analisadas junto à população amostral envolvida. Com relação a este trabalho, foi utilizado o questionário estruturado, uma vez que possibilitou a quantificação das respostas por meio de escalas de valores. Com relação à escala de valores adotada nos questionários, utilizou-se uma escala de seis pontos: Péssimo, Ruim, Regular, Bom, Excelente e nenhuma das anteriores para quando o usuário não tivesse como responder a questão. No sentido de formatar o questionário aplicado, buscou-se o seguintem roteiro: 
- definição das informações necessárias no questionário;

- $\quad$ elaboração do questionário pré-teste;

- $\quad$ aplicação o pré-teste;

- $\quad$ verificação e eventual revisão das questões;

- $\quad$ formatação do questionário definitivo;

- $\quad$ especificação dos procedimentos para a aplicação do questionário definitivo.

Na aplicação dos questionários da pesquisa, a realização do pré-teste foi relevante para se dirimirem dúvidas enfrentadas pelo entrevistador, bem como as relativas à estrutura, à abrangência e à inteligibilidade testadas junto aos usuários, visaram garantir a confiabilidade dos resultados. O questionário, então, constitui o principal instrumento para coleta de dados para a aferição do nível de satisfação dos usuários. Por esse motivo, enfocaram-se, neste tópico, os procedimentos relativos à elaboração, ajustes e aplicação dos mesmos, bem como a apresentação do seu conteúdo, destacando apenas os itens específicos da área de interesse desta pesquisa.

A elaboração do pré-teste foi precedida de duas reuniões ocorridas com a participação da direção das bibliotecas escolhidas, com os objetivos seguintes: compreender como seria executada a pesquisa que avaliaria o ambiente construído das bibliotecas universitárias, quanto aos aspectos avaliados e, em particular, quais os aspectos relacionados ao ambiente físico como, por exemplo, dimensionamentos, arranjo espacial, sinalização, acessibilidade, conforto ambiental, mobiliário e a utilização das tecnologias da informação no espaço pesquisado. Assim, aplicou-se o pré-teste a 12 usuários da Biblioteca do Senac/Santo Amaro e a $\mathbf{1 0}$ usuários da Biblioteca da Unesp/Marília, sendo eles escolhidos aleatoriamente. Entendo que os usuários das duas bibliotecas analisadas são os alunos, professores e funcionários. Como resultado da aplicação e execução do pré-teste, houve a necessidade de ajustes como, por exemplo:

- mudança de vocabulário em algumas questões, sem a qual à compreensão do significado, por parte do usuário leigo, ficaria relativamente prejudicada;

- formulação de questões objetivas que evitassem dupla interpretação; 
- separação do questionário por temas específicos, tais como, aspectos funcionais e dimensionais, aspectos relativos ao conforto ambiental, questões ligadas à tecnologia da informação e aspectos relativos ao mobiliário;

- concepção de um questionário relativamente sintético, evitando uma demanda excessiva de tempo nas respostas;

- elaboração de um questionário que evitasse eventuais pareceres técnicos por parte dos usuários, já que, na maioria das vezes, esses não conheciam o assunto tecnicamente.

A elaboração do questionário final resultou em 61 (sessenta e uma) perguntas, divididas em cinco partes, conforme pode ser visto no Anexos 03, 04 e 05 desta tese. A primeira parte procurou buscar informações sobre o perfil dos respondentes como, sexo, idade, tipo de atividade na instituição e quanto tempo de utilização no edifício. A segunda parte teve como objetivo identificar os aspectos funcionais relacionados ao mobiliário presente na biblioteca como tipo de mesa e cadeira, ajustes do mobiliário, distância entre a circulação e o mobiliário e privacidade no posto de trabalho. Já na terceira parte, as informações ficaram concentradas nos aspectos do conforto ambiental no edifício como, por exemplo, temperatura, umidade, ventilação, iluminação natural e artificial. A quarta parte objetivou obter informações a respeito dos dimensionamentos mínimos, arranjo espacial, sinalização interna $e$ acessibilidade. $\mathrm{Na}$ última parte contou com perguntas relacionadas à aplicação, no espaço construído das bibliotecas universitárias escolhidas, das tecnologias da informação.

\subsection{Levantamento da População}

O levantamento da população avaliada foi vinculado com a elaboração do cadastro dos edifícios das bibliotecas universitárias escolhidas, visando dimensionamento amostral representativo dos diversos extratos que compõem estes edifícios. No caso deste estudo de bibliotecas universitárias, por exemplo, priorizaramse os seguintes extratos:

- alunos (graduação); 
- alunos (pós-graduação);

- professores por tipo de regime de trabalho;

- funcionários;

- funcionários e alunos de outras instituições superiores;

- visitantes;

- pessoal da manutenção e limpeza.

\subsection{Determinação da Amostra}

No caso de uma APO, tem-se amostra de ambientes e amostra da população usuária destes ambientes divididas por extratos. Devem ser adotadas medidas capazes de controlar as propriedades da amostra, isto é, instrumentos capazes de aumentar a probabilidade de que os resultados esperados da amostra não fiquem muito distantes de como a população de usuários se apresenta. Assim, é sempre necessário estabelecer um plano de amostragem representativa que vincule a menor margem de erro possível e o maior nível de confiabilidade em função dos objetivos propostos. Outro lado que não pode ser deixado de lado, assegurando confiabilidade aos resultados da amostra, é a questão da proporcionalidade de todos os distintos extratos presentes na população total, Neste caso, adotou-se a amostra estratificada objetivando incluir, proporcionalmente, os elementos de cada extrato da pesquisa. Nos casos em que os ambientes construídos são bem definidos e a população de usuários é bem conhecida (amostra finita), tem-se, como exemplos, hospitais, escolas, bibliotecas, entre outros.

À época do levantamento de dados (abril de 2007) junto ao campus do Centro Universitário Senac/Santo Amaro, conforme Tabela 02, contatou-se que a ocupação do mesmo se caracterizava por $\mathbf{3 2 4}$ funcionários no campus universitário, sendo deste total, $\mathbf{4 4}$ funcionários e estagiários atuando diretamente na biblioteca; 273 professores (graduação e pós-graduação) e $\mathbf{2 6 7 1}$ alunos de graduação e pós-graduação. Do total da população do campus universitário, foram avaliados 636 usuários, sendo 187 professores, 355 alunos e 94 funcionários. No processo de aplicação dos questionários, considerou-se que o único extrato de usuários com permanência efetiva no prédio da biblioteca era o grupo dos $\mathbf{4 4}$ funcionários descritos anteriormente. Desse total, apenas 8 funcionários não devolveram o questionário aplicado. Quanto aos outros extratos de usuários que participaram da pesquisa e que, de certa maneira, não eram 
estabelecidos no ambiente da biblioteca, como é o caso dos professores e alunos, todos eles confirmaram sua participação constante no espaço da biblioteca e a sua utilização dos serviços oferecidos. Contudo, entre os três extratos de população existentes no edifício, aquele que apresentou maiores dificuldades de aplicação dos questionários e retorno do mesmo foi o grupo de alunos. Embora todos eles apresentassem grande disponibilidade e vontade de cooperação nas atividades da pesquisa, especialmente apontando soluções relacionadas aos problemas funcionais do ambiente da biblioteca, muitos dos questionários não foram devolvidos, acarretando certa descontinuidade nos trabalhos da pesquisa. Entretanto, no contexto do trabalho e no percentual dos extratos levantados junto aos usuários, esses pequenos desajustes não prejudicaram os resultados finais das avaliações, mantendo assim o nível de confiança adequado e uma margem de erro bastante razoável para pesquisas no âmbito da APO.

\begin{tabular}{|l|r|r|r|r|}
\hline \multicolumn{5}{|c|}{ Tabela 02 - Amostragens - Biblioteca Senac/ Santo Amaro } \\
\hline $\begin{array}{l}\text { Extrato } \\
\text { Biblioteca } \\
\text { Senac/Santo } \\
\text { Amaro }\end{array}$ & População & $\begin{array}{c}\text { (\%)População } \\
\text { Total }\end{array}$ & \multicolumn{1}{|c|}{ Amostra } & $\begin{array}{c}\text { (\%)Amostra } \\
\text { Total }\end{array}$ \\
\cline { 2 - 5 } & A & B & C & D \\
\hline $\begin{array}{l}\text { Professores: } \\
\text { Graduação e } \\
\text { Pós-Graduação }\end{array}$ & 273 & 68,7 & 187 & 29,4 \\
\hline $\begin{array}{l}\text { Alunos: } \\
\text { Graduação e } \\
\text { Pós-Graduação }\end{array}$ & 2671 & 13,3 & 355 & 55,8 \\
\hline Funcionários & 524 & 18 & & 14,8 \\
\hline \multicolumn{1}{|c|}{ TOTAL } & $\mathbf{3 4 6 8}$ & $\mathbf{1 0 0 , 0}$ & $\mathbf{6 3 6}$ & $\mathbf{1 0 0 , 0}$ \\
\hline
\end{tabular}

O mesmo procedimento foi realizado no edifício da Biblioteca da Unesp/Marília, onde foi definida a amostra de 310 usuários, representando 14,1\% do total. A Tabela 03 demonstra o número total de usuários e os extratos correspondentes. $\mathrm{Na}$ aplicação dos questionários direcionados aos professores da unidade, além do contato pessoal com os usuários nos departamentos dos cursos de graduação e pósgraduação, foram enviados via correio eletrônico a todos os professores, os questionários com as perguntas correspondentes. Do total da amostra dos 79 professores avaliados, 38 utilizou o correio eletrônico como forma de responder aos questionários enviados, ou seja, 48,1 \% fizeram uso dessa tecnologia. Esse 
procedimento, no âmbito da pesquisa, determinou agilidade na aplicação das questões e permitiu uma participação mais efetiva deste extrato de usuários. Como aconteceu no edifício da Biblioteca do Senac/Santo Amaro, foi adotada a mesma orientação estatística também na Biblioteca da Unesp/Marília, ou seja, todos os funcionários que trabalhassem nos ambientes escolhidos deveriam ter seus níveis de satisfação avaliados. Nesse caso, apenas 2 estagiários que atuam no setor administrativo da biblioteca não deram retorno aos questionários.

\begin{tabular}{|l|r|r|r|r|}
\hline \multicolumn{5}{|c|}{ Tabela 03 - Amostragens - Biblioteca Unesp/Marilia } \\
\hline $\begin{array}{l}\text { Extrato } \\
\text { Biblioteca } \\
\text { Senac/Santo } \\
\text { Amaro }\end{array}$ & População & $\begin{array}{c}\text { (\%)População } \\
\text { Total }\end{array}$ & Amostra & $\begin{array}{c}\text { (\%)Amostra } \\
\text { Total }\end{array}$ \\
\cline { 2 - 5 } & A & B & C & D \\
\hline $\begin{array}{l}\text { Professores: } \\
\text { Graduação e } \\
\text { Pós-Graduação }\end{array}$ & $123^{*}$ & 64,8 & 79 & 25,5 \\
\hline $\begin{array}{l}\text { Alunos: } \\
\text { Graduação e } \\
\text { Pós-Graduação }\end{array}$ & 1933 & 10,2 & 197 & 63,5 \\
\hline Funcionários & 137 & 2193 & & \\
\hline \multicolumn{1}{|c|}{ TOTAL } & \multicolumn{2}{|c|}{25} & & 11 \\
\hline * Número de professores na Unidade do Campus Marília \\
\hline
\end{tabular}

\subsection{Tabulação dos Dados}

Cumpridas as etapas descritas anteriormente, o próximo passo foi a tabulação dos dados dessa pesquisa, feitas a partir das freqüências absolutas, das quais se obteve a freqüência relativa em percentuais, a moda e o desvio padrão. A tabulação dos dados terá como base, os levantamentos realizados em campo, a partir dos quais os usuários e os técnicos atribuíram valores a distintas variáveis e, a partir daí, são executados os diagnósticos dos principais pontos positivos e negativos do ambiente construído. Para esse processo de tabulação de dados da pesquisa, seguiu-se os seguintes passos:

- $\quad$ organização e tabulação dos dados;

- $\quad$ modelo/matriz de tabulação;

- $\quad$ tabulação das questões. 


\subsection{Mapa de Descobertas}

O mapa de descobertas é uma forma gráfica de demonstração sintetizada dos diagnósticos (itens a serem melhorados) no ambiente construído do estudo de caso e tem a principal característica de fazer parte da observação direta da avaliação. Esse procedimento procura aliar o levantamento fotográfico da situação, as informações colhidas no local pelos especialistas e relativas à satisfação dos usuários, nas plantas arquitetônicas dos edifícios escolhidos, agrupando numa seqüência de tópicos e de observações. Ao final, os elementos levantados pelo mapa de descobertas servirão de base para o diagnóstico final, as recomendações de curto, médio e longo prazos norteando as tomadas de decisão, de forma mais ágil e consistente futuras análises e observações do diagnóstico final.

O próximo capítulo demonstra de que forma o levantamento dos elementos de desempenho físico das bibliotecas universitárias analisadas foi executado, evidenciando os objetivos e a metodologia utilizados. 


\section{CAPÍTULO 8 - FATORES FUNCIONAIS ANALISADOS}

\subsection{Elementos Preliminares}

No que diz respeito à avaliação de desempenho físico da APO dos edifícios de bibliotecas universitárias analisadas, as informações e os levantamentos junto aos usuários e as análises efetivamente executadas tiveram prioridade em relação aos levantamentos de desempenho físico, servindo apenas como suporte de informação. Este recurso é válido, como neste estudo de caso, em que os ambientes selecionados não oferecem risco de vida em relação aos usuários. Portanto, as atividades de observação foram focadas nas atualizações cadastrais das plantas dos ambientes (as built), no levantamento do mobiliário básico, além de executar visitas exploratórias, visando a obter informações in loco das condições espaciais e problemas técnico-construtivos visíveis a olho nu. Esses procedimentos foram complementados com entrevistas com outros técnicos especializados envolvidos nas etapas de produção e uso do estudo de caso, no sentido de complementar as respostas provindas dos usuários (BECHTEL, 1987; PREISER, 1988, 1989;ORNSTEIN \& ROMÉRO, 1992; ORNSTEIN, 2003; PREISER; VISCHER, 2005; VOORDT; WEGEN, 2005; ZEISEL, 2006; entre outros).

Entendendo melhor a abrangência destas análises relacionadas aos fatores físicos no processo de avaliação dos ambientes selecionados, estes atuaram em três níveis, conforme Ornstein \& Roméro (1992):

- Macroescala: analisa o edifício como um todo;

- Microescala: analisa os espaços de forma individual;

- $\quad$ Equipamentos: analisa mobiliário (fixos ou móveis) e fatores de ergonomia.

No estudo de caso proposto para as bibliotecas universitárias, o levantamento macro abrangeu os tópicos que são relacionados dentro de um contexto de visão geral da edificação, ou seja, referenda não uma análise individual das partes, mas sim uma perspectiva global de elementos que se inter-relacionam. Nessa visão, alguns elementos são comuns e interferem em todo o conjunto do edifício, provocando em certas situações, alterações positivas ou negativas no ambientes construído. No caso de 
bibliotecas universitárias, os fatores físicos relacionados ao nível macro têm gerado importantes alterações nos aspectos funcionais e organizacionais do ambiente.

Quanto ao levantamento espacial no nível da microescala, todos os apontamentos foram direcionados às análises individuais dos itens selecionados. Uma das principais vantagens foi associar dados reais e mensuráveis que, depois de serem checados com critérios de desempenho como, normas técnicas, padrões de qualidade e legislação, as avaliações permitiram extrair recomendações e conclusões junto às informações dos usuários.

\subsection{Fatores Funcionais}

Nessa fase da pesquisa, os trabalhos foram direcionados para as análises e as avaliações das variáveis funcionais, principalmente, nos elementos que apóiam as atividades dos usuários e o desempenho organizacional. O principal foco de interesse nestes fatores relaciona a importância que eles oferecem para o aumento do desempenho dos edifícios das bibliotecas universitárias no âmbito da pesquisa. Preiser (1998) reforça essa visão dizendo que os fatores funcionais dão base a todas as funções internas do edifício, sendo co-autores nas necessidades específicas da organização e do usuário, de forma quantitativa e qualitativa.

A partir dos resultados da tabulação dos dados coletados com base nos questionários, nas observações físicas, das entrevistas executadas com os usuárioschave e nos grupos focais, foram construídos diagnósticos específicos para cada biblioteca universitária escolhida, tendo em vista os principais aspectos abordados nesta tese.

Nestes estudos de casos, os fatores funcionais fixados são:

- $\quad$ Dimensionamentos mínimos;

- $\quad$ Armazenamento;

- $\quad$ Flexibilidade;

- $\quad$ Circulações;

- Acessibilidade;

- $\quad$ Comunicação visual;

- $\quad$ Ergonomia; 
- $\quad$ Conforto ambiental;

- $\quad$ Tecnologia da informação.

\subsubsection{Dimensionamentos mínimos}

Objetivo: a avaliação deste tópico consistiu em comparar quais as principais áreas internas e externas dos edifícios em questão, com as áreas mínimas previstas em códigos e parâmetros pré-definidos por normas. Com esta verificação dos dados referentes às restrições existentes, foi possível realizar propostas de ajustes de aumento ou redução de áreas nos vários setores do ambiente construído. Além disso, as comparações com os parâmetros existentes de dimensionamentos mínimos demonstraram quais áreas podem estar aptas a reduzir ou a aumentar espaços nos diversos setores estudados.

Instrumentos utilizados: Os ambientes previamente selecionados (item 7.4) foram medidos in loco e, na seqüência, comparados às restrições e códigos existentes às normas relativas a cada caso (ex: salas de leitura, acervo, circulações, sanitários, halls, etc).

\subsubsection{Armazenamento}

Objetivo: detectou as características, as localizações e as condições dos ambientes definidos como áreas de armazenamento e estocagem das bibliotecas universitárias analisadas. O conhecimento detalhado desses fatores, bem como a avaliação do desempenho físico das atividades desenvolvidas nesses espaços, contribuiu na análise dos setores e as possíveis recomendações de mudanças.

Instrumentos utilizados: foi utilizado as built e visita exploratória tendo como ferramenta de apoio planilhas de anotação tipo checklist, para a detecção de possíveis defasagens em espaços destinados à armazenagem ou locais que foram 'transformados' em áreas de estoque ou depósitos. 


\subsubsection{Flexibilidade}

Objetivo: a principal função deste tópico está voltada para a análise da facilidade de as bibliotecas universitárias analisadas em sofrer modificações e alterações no arranjo espacial no decorrer do uso, ou seja, mediu o nível de flexibilidade agregado aos espaços internos das edificações. Os aspectos relacionados à flexibilidade espacial atuam diretamente na maioria das intervenções desenvolvidas em projetos de ampliações, aumento de área útil, adaptações e rearranjo espacial. A análise desses processos contribuiu positivamente nas fases seguintes de recomendações técnicas voltadas às bibliotecas universitárias.

Instrumentos utilizados: foi necessário resgatar, além da macroanálise do projeto original e entrevista com os profissionais envolvidos no projeto arquitetônico, as informações colhidas in loco pela verificação de elementos reais de intervenções em ambientes, posicionamento de divisórias, existência de modulações estruturais e posicionamento das alvenarias.

\subsubsection{Circulações}

Objetivo: foram avaliadas nesta etapa as circulações verticais, horizontais, incluindo rampas e escadas e os principais acessos aos edifícios escolhidos nestes estudos de casos. A análise deste item também pode ser aplicada aos aspectos espaciais e ergonômicos relacionando os fluxos de circulação, intensidades, direcionamento, pontos de conflito, dentre outros. No caso de bibliotecas universitárias, a circulação tem papel fundamental no direcionamento de fluxos dos usuários aos acervos, no ordenamento de entrada e saída do material bibliográfico, na definição dos melhores acessos às prateleiras, entre outras. A completa análise desses fatores e a posterior comparação com as percepções dos usuários poderão contribuiu sobremaneira nas soluções e nas recomendações para futuros projetos.

Instrumentos utilizados: para estas análises foram utilizados métodos gráficos (plantas, esquemas, fluxograma), além de tomadas de medidas nos locais escolhidos. 


\subsubsection{Acessibilidade ${ }^{1}$}

Objetivo: a avaliação deste item envolveu a análise de todos os componentes relacionados à acessibilidade ao ambiente construído das bibliotecas universitárias analisadas, tanto interna como externamente. Além disso, o objetivo foi compreender claramente as gradações de acessibilidade dos usuários e seus elementos de operação espacial em relação às demandas das áreas especificadas. A partir da aferição desta rede de percursos dos usuários foi possível compreender os elementos quantitativos e qualitativos da acessibilidade dos espaços estudados. Outra abordagem desta etapa remeteu à análise em relação às condições exigidas à adequação do ambiente construído e do mobiliário às pessoas portadoras de necessidades especiais. Em todos esses fatores apresentados, o estudo da acessibilidade considerou as seguintes linhas de investigação:

- $\quad$ posicionamento, altura e largura de portas;

- $\quad$ larguras e posicionamentos de escadas;

- $\quad$ largura e inclinação de rampas;

- $\quad$ dimensões de elevadores e de monta-cargas;

- $\quad$ largura de corredores;

- $\quad$ dimensões dos equipamentos e mobiliário;

- $\quad$ acessibilidade aos sanitários;

- $\quad$ sinalização.

- $\quad$ acessos de ônibus;

- $\quad$ áreas de estacionamento;

- $\quad$ deslocamentos e acessibilidade no entorno (vizinhança próxima);

Instrumentos utilizados: o primeiro procedimento foi a identificação nos edifícios analisados, a partir de vistoria detalhada por meio de medições e verificações in loco, da norma NBR - 9050/2004, detectando-se os principais problemas enfrentados pelos usuários em relação à acessibilidade. $O$ segundo passo foi comparar os índices constantes da legislação, pertinentes à acessibilidade e à adequação da edificação e do

\footnotetext{
${ }^{1}$ Do ponto de vista arquitetônico, acessibilidade é o potencial, ou a capacidade que os espaços têm, de ser alcançado, pelas pessoas em decorrência de seu posicionamento relativo dentro de um sistema de rotas qualquer.
} 
mobiliário à pessoa portadora de necessidade especial. Outros índices também foram utilizados comparativamente, inclusive aqueles constantes de código de obra para dimensionamento de aberturas, por exemplo. Com esses instrumentos, a avaliação forneceu insumos para a elaboração das recomendações finais para o estudo de caso.

\subsubsection{Comunicação Visual}

Objetivo: esta avaliação englobou o sistema de sinalização e de comunicação visual interna e externa existentes dos edifícios analisados. Nesse âmbito, o projeto de comunicação visual tem, entre outras tantas, a função de valorizar o espaço, atrair para focos e orientar o processo de funcionalidade dos espaços das edificações. Portanto, nesta etapa do trabalho, o objetivo principal foi detectar e propor correções, se necessário, algumas deficiências existentes nessas áreas.

Instrumentos utilizados: além de utilizar a técnica as built e visita exploratória, tendo como ferramenta de apoio planilha de anotação tipo checklist, foi feito o levantamento fotográfico como forma de facilitar as avaliações e comprovações das análises efetuadas.

\subsubsection{Ergonomia}

Objetivo: investigou e avaliou as demandas de projeto ergonômico dos edifícios de bibliotecas universitárias analisadas, para assegurar a otimização de interação entre o trabalho, o ambiente construído, as capacidades dos usuários e suas limitações, além de questões relacionadas à mobilidade em áreas de circulação, passagens mínimas, movimentos compensatórios, comprimentos e larguras de layout de mobiliário e suas variações.

Instrumentos utilizados: foi feita a identificação dos fatores relacionados à ergonomia, a partir de uma vistoria detalhada e completa por meio de medições e verificações in loco,

procurando observar a aplicação da norma correspondente à ergonomia e também detectar os principais problemas enfrentados pelos usuários em relação a este item. A entrevista com o autor dos projetos arquitetônicos e também com os usuários trouxe mais subsídios para as análises das relações de uso e operação do ambiente construído. 


\subsubsection{Conforto Ambiental}

Objetivo: analisou os aspectos relativos à temperatura, umidade, ventilação, iluminação natural, iluminação artificial e níveis de ruído Além destes fatores, foram verificados os elementos relacionados aos ofuscamentos em superfícies de trabalho, paredes e pisos, posicionamento dos computadores em relação às janelas e o uso de luminárias com proteção adequada e verificação do equilíbrio das luminâncias.

Instrumentos utilizados: não foram aplicadas medições técnicas, mas as observações foram embasadas nas opiniões dos usuários e complementadas com as observações físicas obtidas pelas visitas exploratórias nos edifícios escolhidos. Também se consideraram as percepções mais significativas referentes às respostas dos questionários e grupos focais aplicados.

\subsubsection{Tecnologia da Informação}

Objetivo: investigou e avaliou as demandas da Tecnologia da Informação nos edifícios de bibliotecas universitárias analisadas, para assegurar a otimização de interação entre o trabalho, o ambiente construído, as capacidades dos usuários e suas limitações.

Instrumentos utilizados: foi feita a identificação dos fatores relacionados à Tecnologia da Informação por meio de uma vistoria detalhada e completa por meio de medições e verificações in loco. 


\title{
CAPÍTULO 9 - RESULTADOS DA AVALIAÇÃO DOS FATORES FUNCIONAIS
}

\begin{abstract}
A tabulação dos dados e os resultados foram consolidados no geral, baseados nas informações fornecidas pelos grupos focais, na aplicação dos questionários em amostra de usuários, definida para cada edifício escolhido, nas observações técnicas efetuadas e nos resultados dos grupos focais realizados. Além disso, este item tem o objetivo de descrever análises comparativas entre os edifícios das bibliotecas universitárias pesquisadas, a partir de diagnósticos concebidos para cada uma.
\end{abstract}

\subsection{Perfil dos usuários}

O primeiro item analisado em relação ao Perfil dos Usuários relaciona o sexo dos respondentes. Neste caso, existe uma predominância do sexo feminino nos dois edifícios analisados, sendo que o maior índice verificado entre os funcionários (87\%) e alunos (78\%) está localizado na Biblioteca da Unesp/Marília. Isto se explica porque a maioria dos cursos oferecidos na unidade da Unesp na cidade de Marília atrai, na maioria dos casos, um contingente muito maior de pessoas do sexo feminino. Isto se aplica também ao perfil dos funcionários atuantes na área de biblioteconomia, sendo sempre o percentual maior de pessoas do sexo feminino.

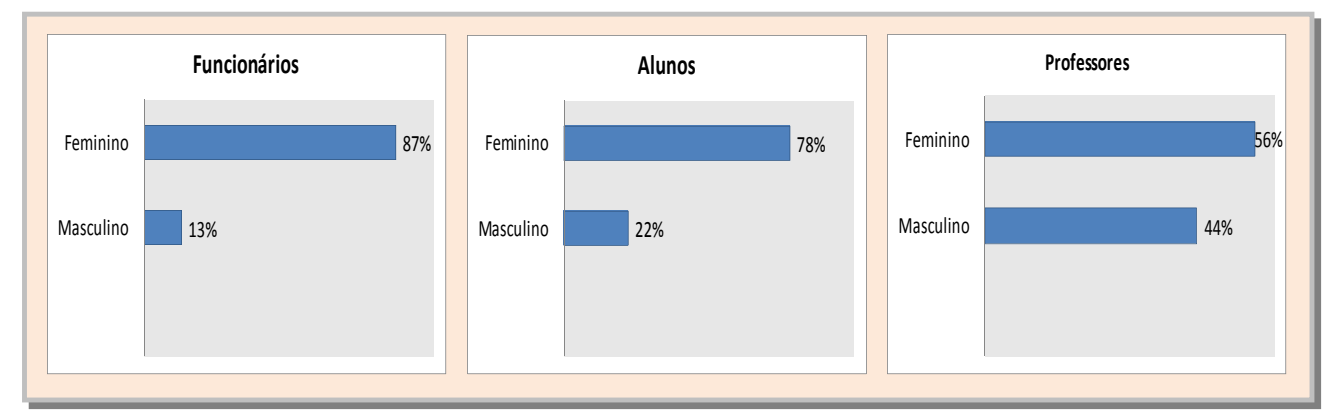

Figura 218 - Sexo/Biblioteca Unesp/Marília 
Estes resultados são também condizentes com o perfil de usuários no edifício da Biblioteca do Senac/Santo Amaro; entretanto os resultados apresentados apontam percentuais bem equilibrados entre o sexo masculino e feminino.

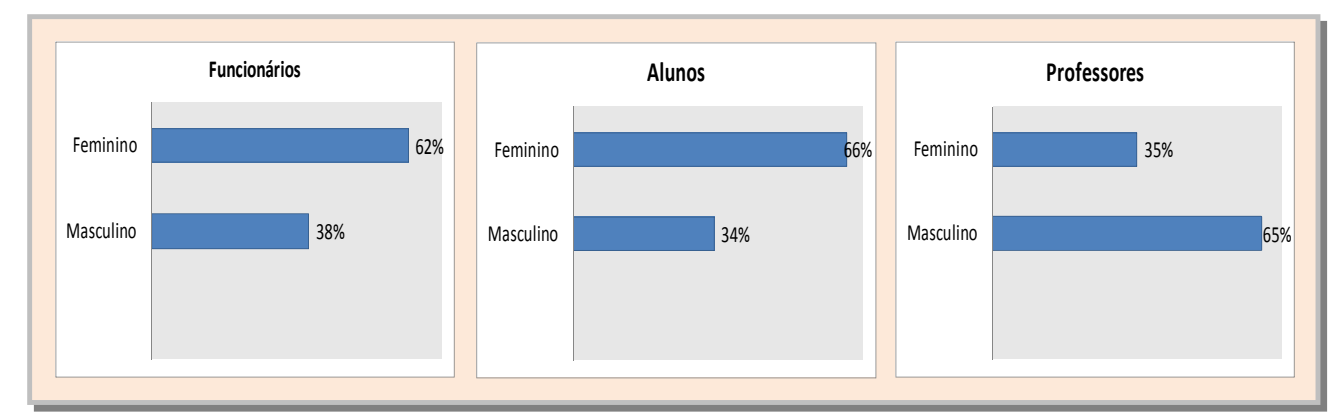

Figura 219 - Sexo/Biblioteca Senac/Santo Amaro

Com relação à faixa etária, o percentual mais significativo dos dois estudos de caso é dos alunos da Biblioteca da Unesp/Marília, compreendido entre vinte (20) e trinta (30) anos (65\%); depois vêm dos alunos da Biblioteca do Senac/Santo Amaro com 51\%. O restante do percentual tem uma distribuição mais igualitária entre as outras faixas de idade. A única situação em que existe uma predominância percentual mais elevada é a verificada na amostra dos professores da Biblioteca da Unesp/Marília; 50\% está localizada entre quarenta (40) e cinqüenta (50) anos. A explicação mais plausível é que, em uma instituição pública como da Unesp, as exigências para o ingresso de docentes nos planos de carreira são extremamente rígidas, fixando para os professores das unidades universitárias alto grau de titulação e, conseqüentemente, faixas etárias mais elevadas. Além disso, a Unesp é uma instituição mais antiga e oferece cursos considerados mais tradicionais.

Quanto aos dados relacionados à faixa etária da Biblioteca do Senac/Santo Amaro, observa-se que se situa majoritariamente entre 20 e 30 anos, entre os alunos (51\%), indicando a predominância de uma população de jovens adultos bastante significativa, que faz uso freqüente da biblioteca, fato decorrente principalmente da grande quantidade de vagas oferecidas nos cursos de graduação desta unidade. 


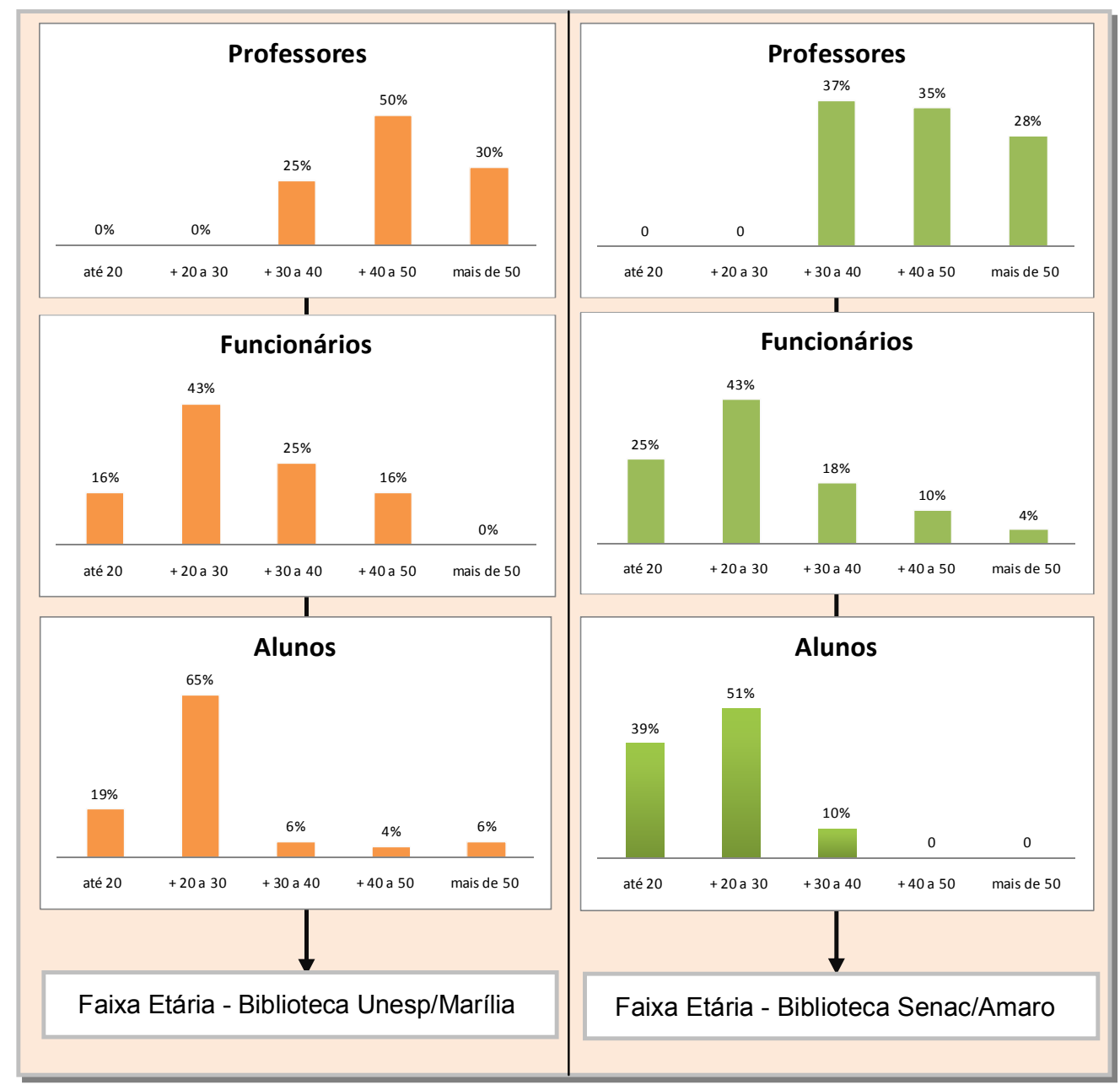

Figura 220 - Faixa Etária - Estudos de Caso

Quanto ao perfil dos respondentes, o nível de escolaridade superior (69\%) foi considerado preponderante entre todos os usuários entrevistados dos estudos de caso. Esses resultados são compatíveis com o perfil de atividade de base mais intelectual, no caso, a área da biblioteconomia e ciência da informação, em que o nível de exigência de atualização de informação, conhecimento teórico e destreza profissional requerem habilidades de usuários de nível superior completo ou terminando um curso superior. Outro dado característico importante da pesquisa em relação ao nível de escolaridade, que eleva consideravelmente a quantidade de usuários com curso superior completo, recai obviamente, por serem edifícios de bibliotecas universitárias, na presença maciça dos professores das unidades pesquisadas. 


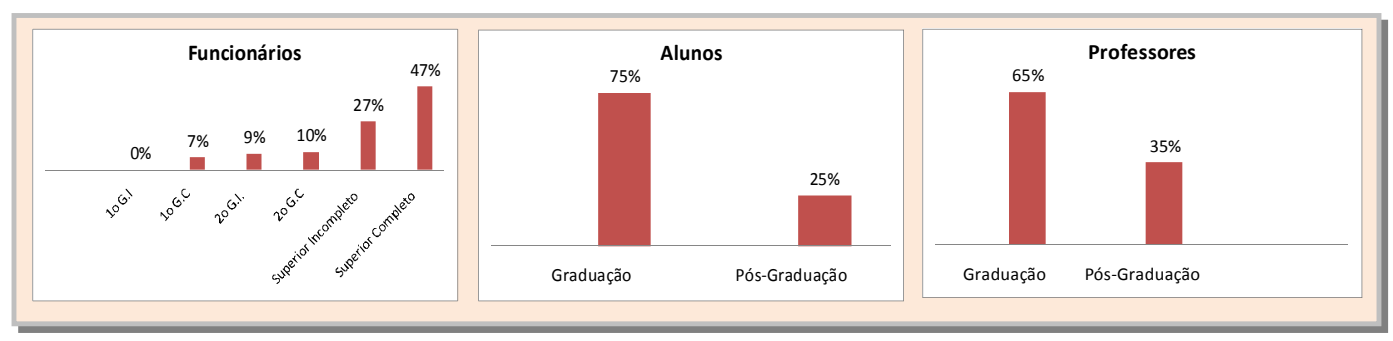

Figura 221 - Escolaridade - Biblioteca Senac/Santo Amaro

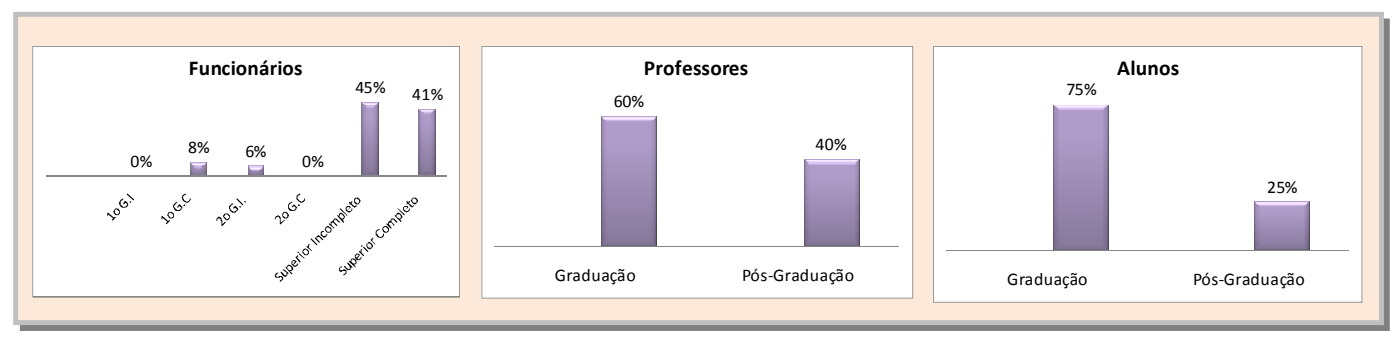

Figura 222 - Escolaridade - Biblioteca Unesp/Marília

\subsection{Aspectos Funcionais}

Antes de apresentar os resultados das avaliações dos usuários a respeito dos aspectos do mobiliário em relação ao trabalho, é importante destacar que os ambientes pesquisados tiveram como base a configuração presente em um programa arquitetônico de uma biblioteca, ou mais especificamente, de um projeto de biblioteca universitária, composto por áreas de armazenamento da coleção (acervo); locais destinados ao trabalho dos funcionários; e, por último, locais de leitura para os usuários. O conhecimento das rotinas dos serviços bibliográficos, no caso desta pesquisa, possibilitou um entendimento mais completo das questões relacionadas ao mobiliário, suas disposições nos ambientes e as necessidades de seus usuários. Observou-se ainda que, nos dois estudos de caso escolhidos, tanto na Biblioteca do Senac/Santo Amaro quanto na Biblioteca da Unesp/Marília, há realidades distintas a respeito da configuração do mobiliário e seus vários desdobramentos como, por exemplo, tipos de mesas e cadeiras, tipos de acabamentos, dimensões e configuração de layout.

Outra questão importante, que reporta às avaliações e às análises dos aspectos funcionais deste trabalho, diz respeito às referências técnicas e às normas estabelecidas para o dimensionamento dos espaços físicos e das estações de trabalho 
direcionadas às bibliotecas universitárias. Em função disso, é possível apoiar o desenvolvimento e a execução de projetos de bibliotecas universitárias, na legislação vigente que está estabelecida em quatro níveis: internacional, federal, estadual e municipal. No internacional, a Association of School Librarians ${ }^{1}$, no âmbito federal encontramos o Código de Segurança e Medicina do Trabalho e as Normas Técnicas da ABNT - Associação Brasileira de Normas Técnicas; na esfera estadual o Código Sanitário e IT - Instruções Técnicas dos corpos de bombeiros estaduais e no nível municipal o Código de Obras (Marília e São Paulo) e Edificações e as Leis de Parcelamento, Uso e Ocupação do Solo Urbano.

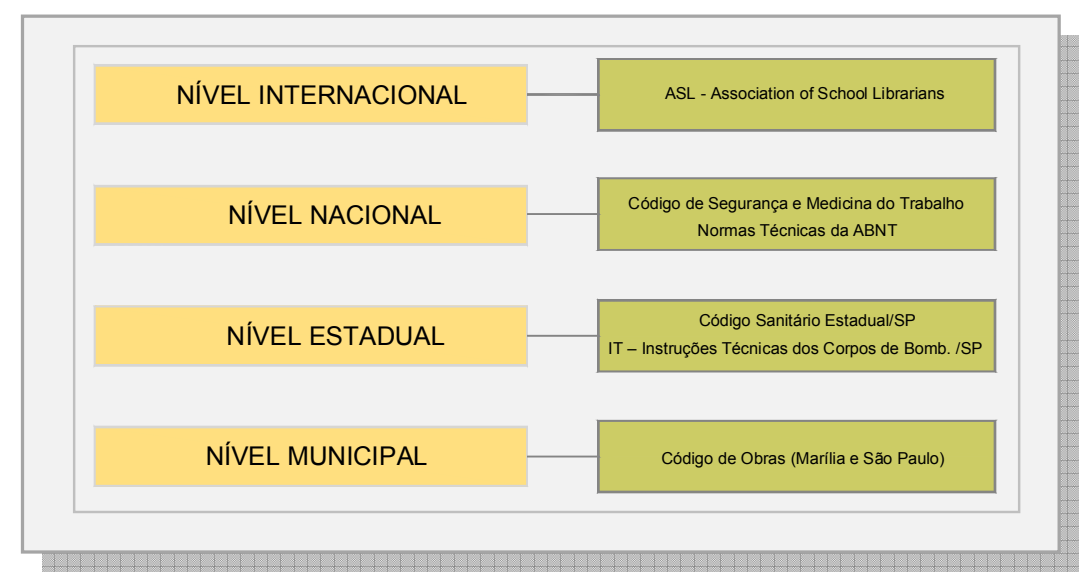

Figura 223 - Referências técnicas adotadas nos estudos de caso

A seguir, apresentam-se os resultados das avaliações dos usuários a respeito dos aspectos funcionais, tendo como base não só os elementos de desempenho físico e as percepções desses sobre os ambientes, mas também as referências técnicas vigentes para os itens constantes da avaliação. Além disso, o objetivo não é somente relacioná-las, mas também, quando necessário, emitir análises críticas ou pontos de vista concernentes aos quesitos funcionais, objeto desta avaliação.

Os resultados apresentados em relação à adequação do tipo de mobiliário dos edifícios analisados demonstram que os melhores índices estão localizados na Biblioteca do Senac/Santo Amaro e entre os alunos (66\%), podendo-se

\footnotetext{
${ }^{1}$ A Association of School Librarians é uma entidade vinculada a IFLA (International Federation of Library Associations and Institutions), sede nos EUA, órgão internacional que tem como objetivo principal representar os interesses dos serviços de bibliotecas universitárias e centros de informação em universidades do mundo inteiro. Além disso, este organismo estabelece algumas referências técnicas para o dimensionamento destes espaços físicos e seu funcionamento.
} 
afirmar que o mobiliário existente está plenamente adequado às condições espaciais, segundo os usuários. Já no caso da Biblioteca da Unesp/Marília, a convergência maior das respostas considera o mobiliário pouco adequado às condições de usabilidade 65\% dos alunos acha-os pouco adequados. Esses valores são explicados, principalmente, em função das características e da tipologia do mobiliário presente em cada um dos edifícios. No primeiro caso, a Biblioteca do Senac/Santo Amaro, o conjunto do mobiliário presente define um alto padrão de acabamento, variedade nas disposições espaciais, dimensionamento adequado e design contemporâneo.

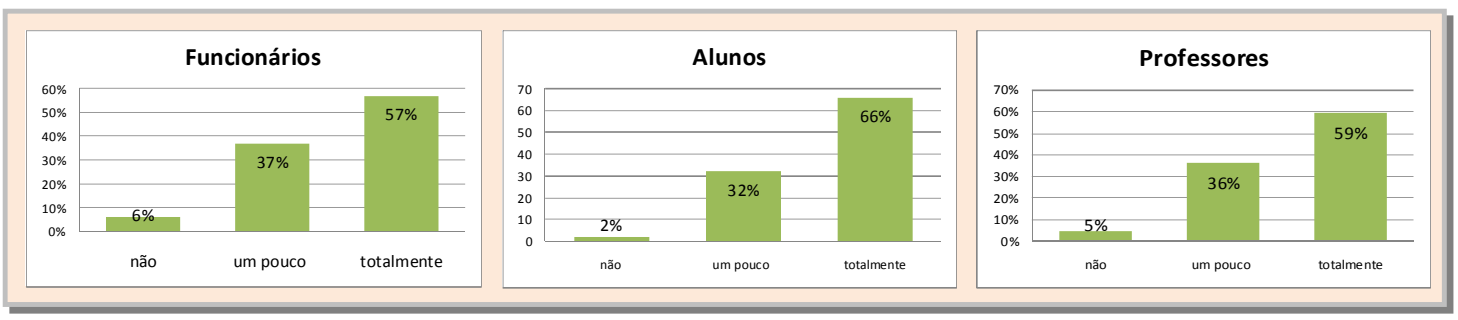

Figura 224 - Nível de Satisfação: adequação do tipo de mobiliário Biblioteca Senac/Santo Amaro

Observou-se que a grande preocupação da instituição em fornecer e determinar um padrão de mobiliário realmente adequado às reais necessidades dos usuários refletiu favoravelmente nos altos índices de aceitação deste quesito. Entretanto, no caso da Biblioteca da Unesp/Marilia, a realidade apresentada quanto às características e os padrões de mobiliário estabelecidos pela instituição aponta situações desfavoráveis como, por exemplo, dimensões reduzidas das mesas de leitura/pesquisa e cadeiras sem possibilidade de ajustes. Essa situação é encontrada, nas áreas de leitura dos usuários; por outro lado, no setor administrativo, as estações de trabalho atualizadas e adequadas (mobiliário auto-portante/tampo com boa profundidade/configuração aberta) garantiram bons índices de satisfação entre os usuários.

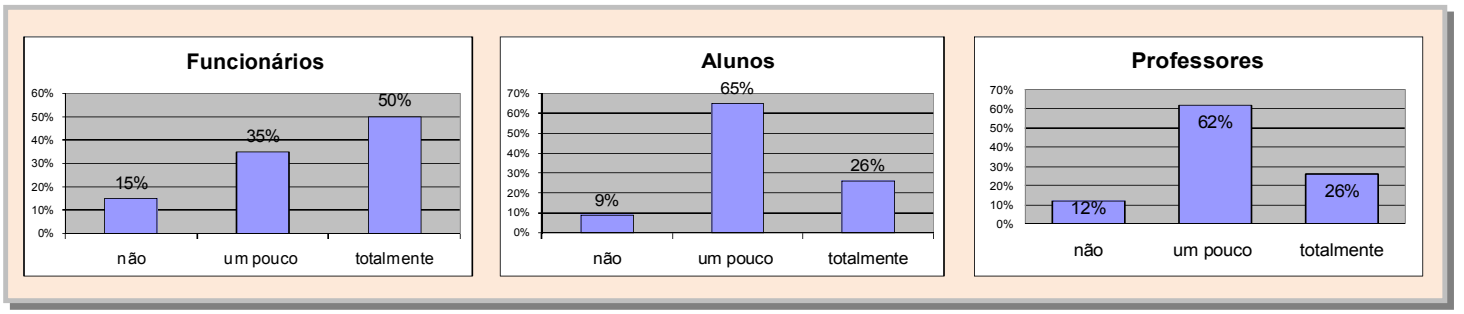

Figura 225 - Nível de Satisfação: adequação do tipo de mobiliário - Biblioteca Unesp/Marília 


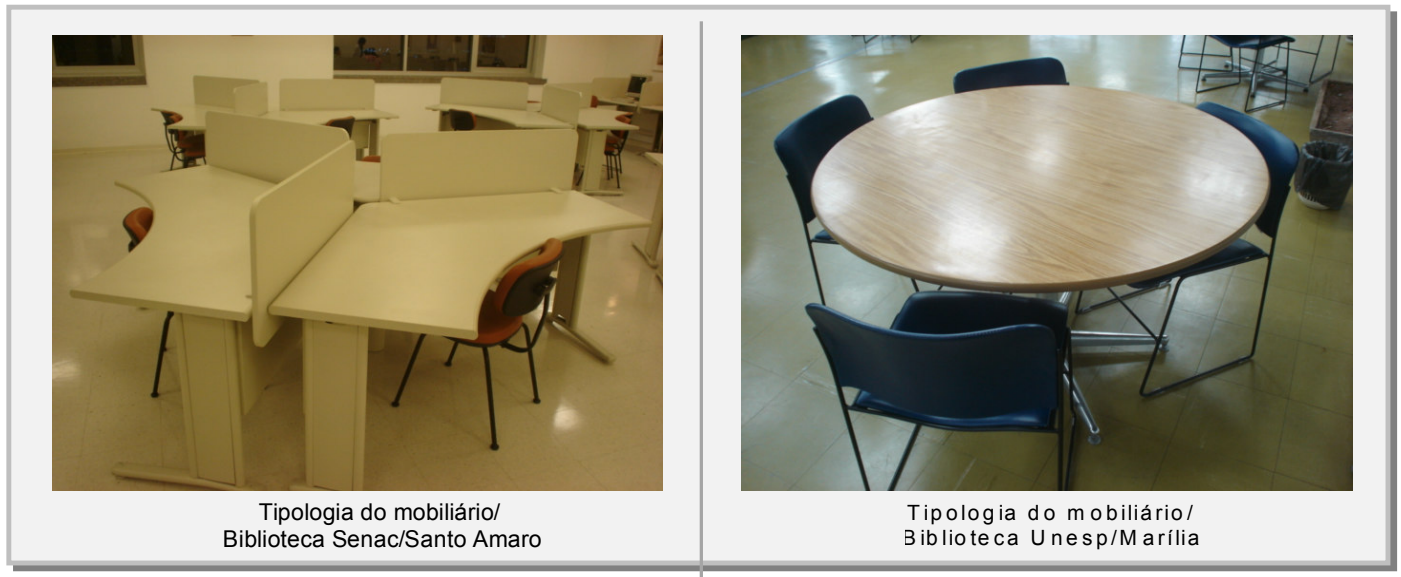

Figura 226 - Tipologia do mobiliário - Estudos de caso

Na seqüência, foram analisados outros itens pertinentes às características relacionadas de altura e tipos de regulagens das cadeiras. A avaliação constatou que os maiores índices de satisfação ainda estão localizados no edifício da Biblioteca do Senac/Santo Amaro, justamente por fornecer melhores condições no mobiliário. É importante destacar que as estações de trabalho da diretoria possuem configuração diferenciada e, mais especificamente, às cadeiras são dotadas de mecanismo de regulagem, com formato em concha e braços fixos, propiciando melhores condições de usabilidade. Neste caso, $67 \%$ dos funcionários deste setor consideraram excelente o tipo de regulagem das cadeiras e $\mathbf{5 0 \%}$ avaliaram boa a altura da cadeira.

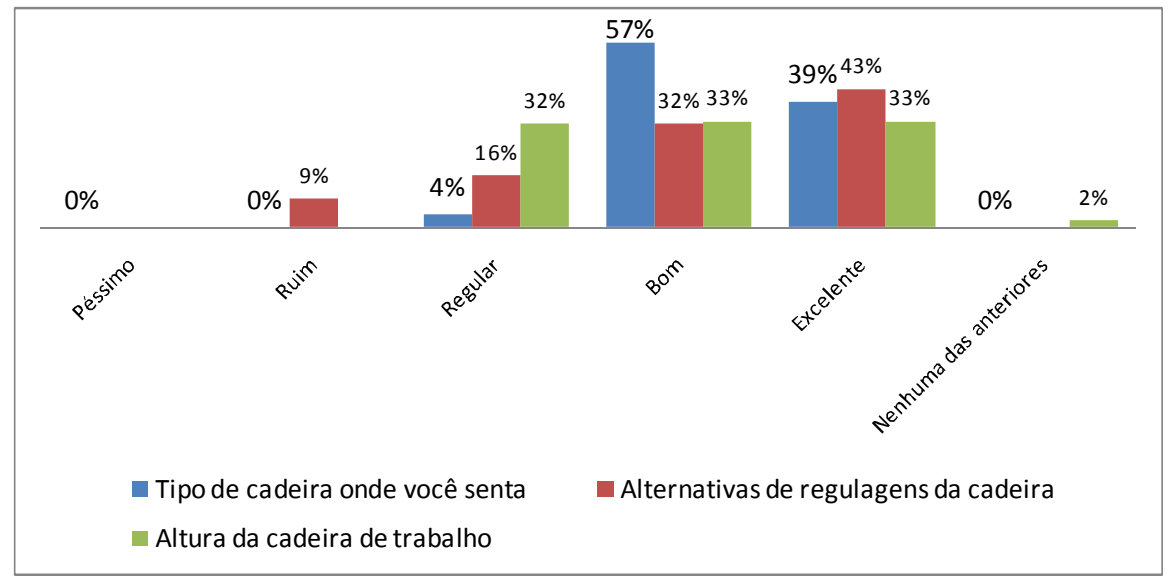

Gráfico 01 - Nível de Satisfação dos Alunos Biblioteca Senac/Santo Amaro: características das cadeiras 


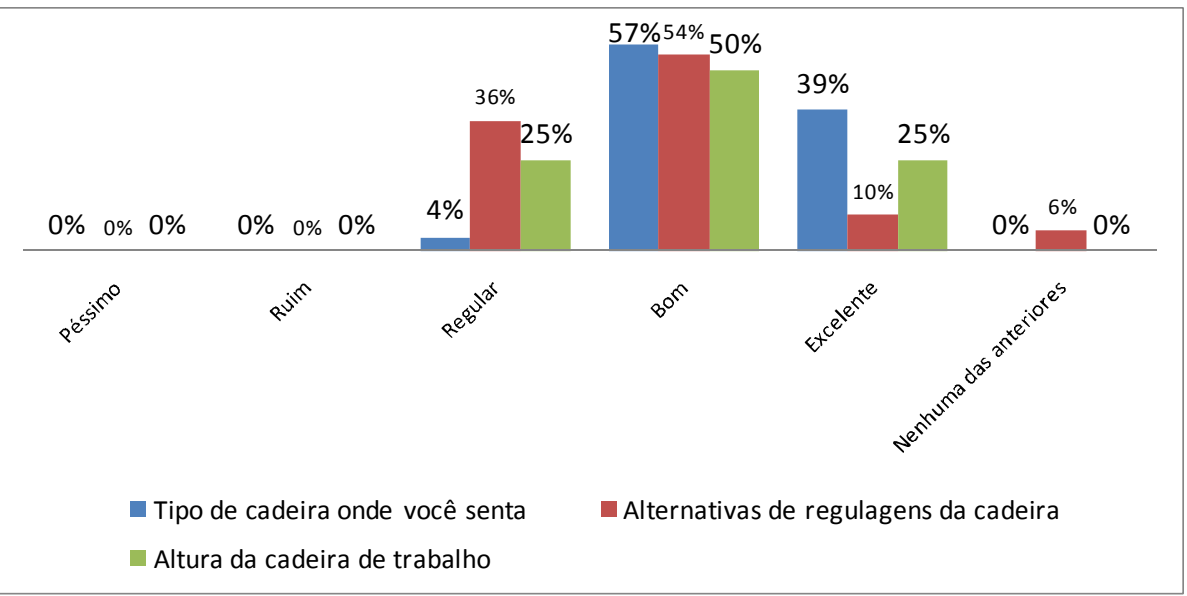

Gráfico 02 - Nível de Satisfação dos Professores Biblioteca Senac/Santo Amaro: características das cadeiras

Quanto aos modelos e às dimensões de cadeiras encontradas na Biblioteca do Senac/Santo Amaro, encontramos (04) quatro tipos básicos distribuídos ao longo dos ambientes do edifício: o primeiro (Figura 227 - Modelo 01), como foi mostrado anteriormente, cadeiras com mecanismo de regulagem, formato em concha e braços fixos, estão posicionadas nas salas da diretoria e área administrativa; o segundo (Figura 228 - Modelo 02), cadeiras com rodas, giratórias e mecanismo de regulagem, colocadas na área administrativa e nas mesas de pesquisa on-line; o terceiro (Figura 229 - Modelo 03), cadeiras com braços fixos, posicionadas em ambientes especiais como na sala do acervo de moda e na sala destinado ás pessoas portadoras de deficiência visual; e o quarto modelo (Figura 230 - Modelo 04), cadeiras fixas, com encosto retrátil, distribuídas nos ambientes das mesas e áreas de estudo. 

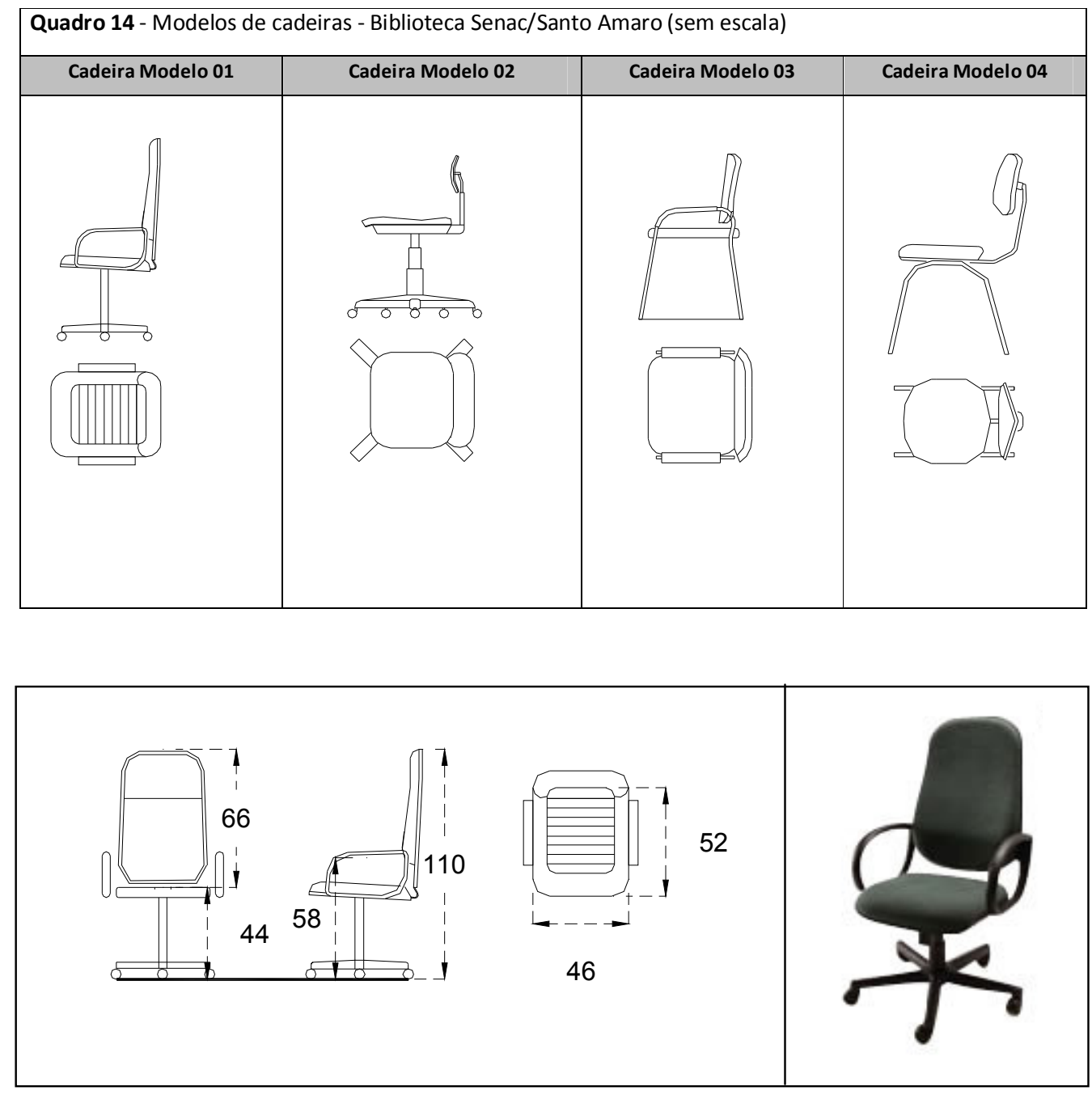

Figura 227 - Cadeiras - Modelo 01 - Biblioteca Senac/Santo Amaro (medidas em centímetros e sem escala)

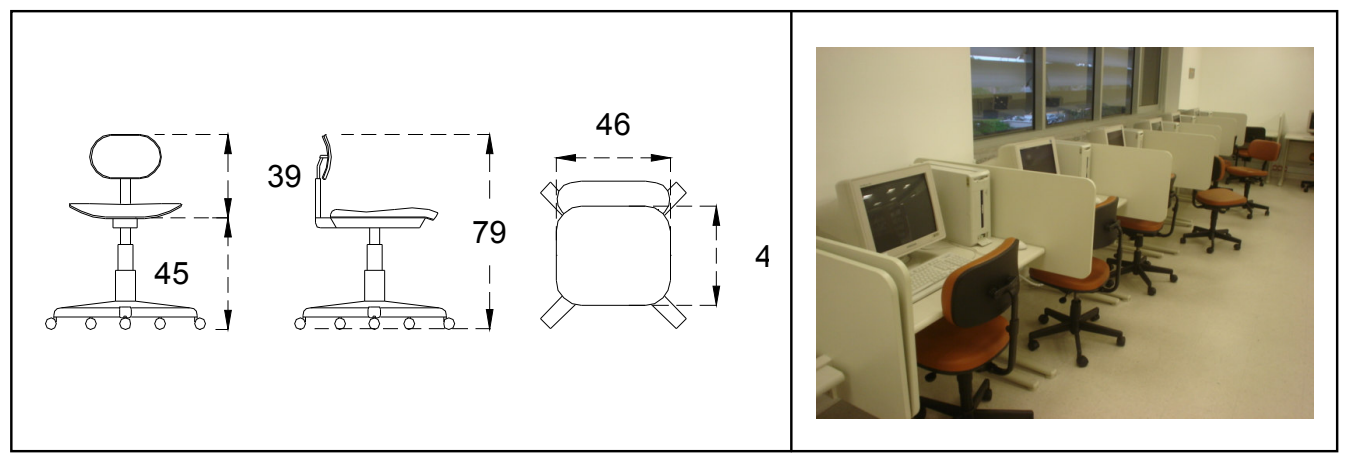

Figura 228 - Cadeiras - Modelo 02 - Biblioteca Senac/Santo Amaro (medidas em centímetros e sem escala) 


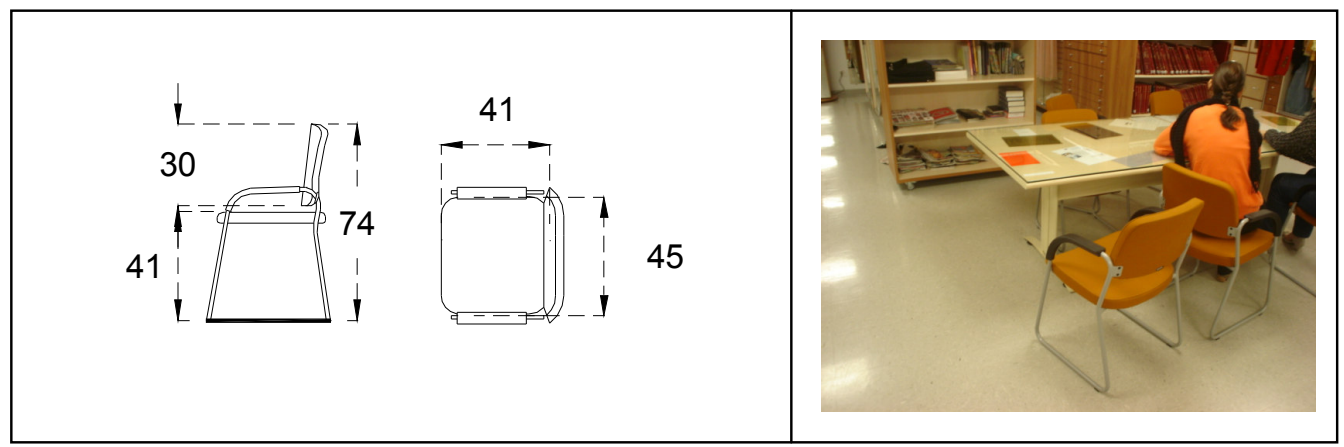

Figura 229 - Cadeiras - Modelo 03 - Biblioteca Senac/Santo Amaro

(medidas em centímetros e sem escala)

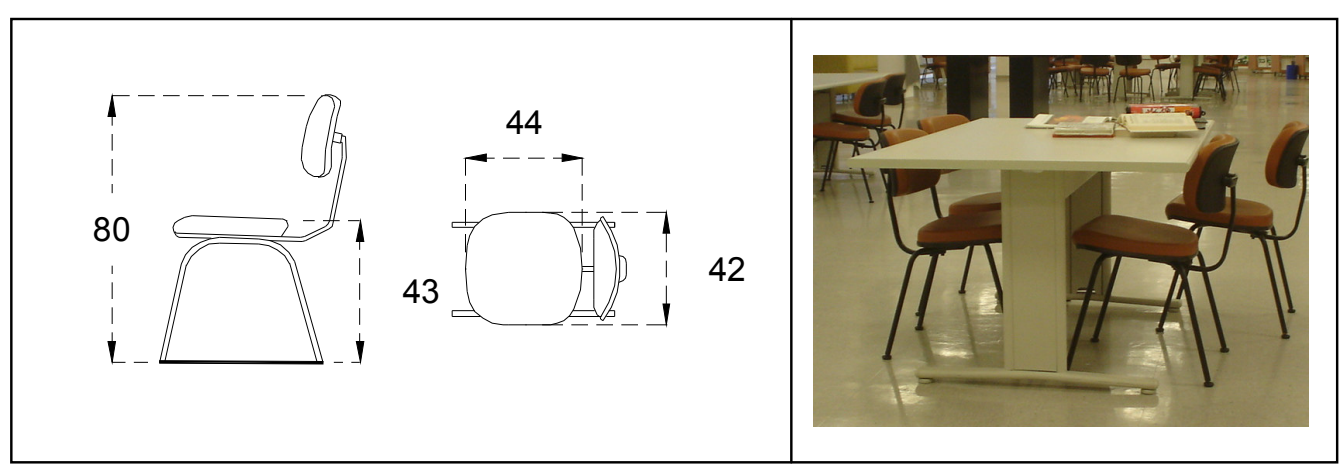

Figura 230 - Cadeiras - Modelo 04 - Biblioteca Senac/Santo Amaro

(medidas em centímetros e sem escala)

Todos os modelos de cadeiras analisados nos ambientes da Biblioteca do Senac/Santo Amaro apresentaram dimensões adequadas à norma $A B N T-N B R$ 13.967/1997, ou seja, demonstraram que estão atendendo aos requisitos estabelecidos pela legislação vigente, além de permitir boas condições de usabilidade por parte dos usuários. Este fato é constatado nos resultados das avaliações de satisfação, qualificando principalmente o modelo de cadeira que permite regulagens: o quesito melhor avaliado. Entretanto, identificou-se, nas cadeiras com braços fixos da área administrativa, algum desconforto revelado pelos usuários na correta aproximação da superfície de trabalho, impedindo que determinadas tarefas fossem executadas. 


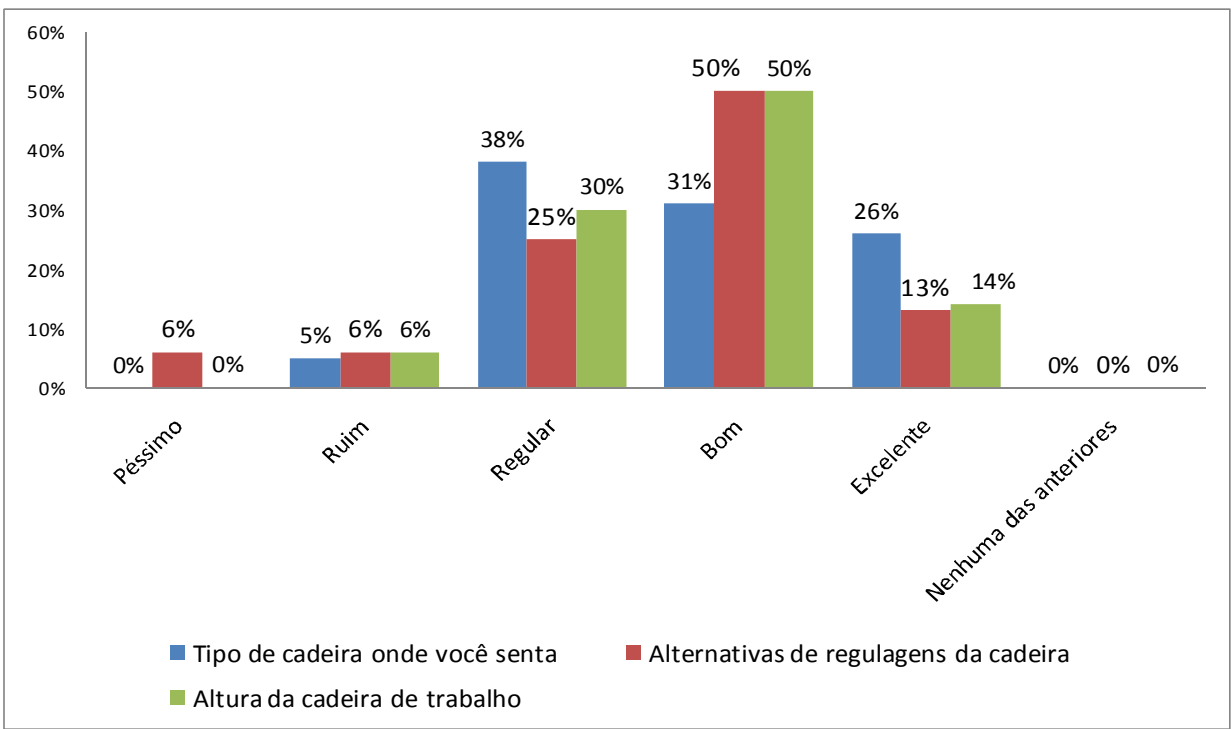

Gráfico 03 - Nível de Satisfação dos Funcionários Biblioteca Senac/Santo Amaro: características das cadeiras

Observou-se ainda que a diversificação nos modelos de cadeiras, presente nos ambientes da Biblioteca do Senac/Santo Amaro, variando suas dimensões, disposições e aplicações no edifício, permitiram que as atividades desenvolvidas do espaço, por parte do usuário, transcorresse de maneira mais confortável e funcional, principalmente, nos ambientes de leitura e pesquisa da biblioteca, que privilegiam a concentração do indivíduo e o maior controle de conforto ergonômico. Ou seja, é possível concluir preliminarmente que as diversas atividades desenvolvidas no âmbito da biblioteca, tanto aquelas direcionadas à pesquisa e à leitura, que exigem alto grau de concentração dos usuários, quanto àquelas que identificam a interação com os diversos indivíduos, necessitam receber, na Biblioteca do Senac/Santo Amaro, mobiliário adequado, neste caso, cadeiras integradas ao ambiente de trabalho. 


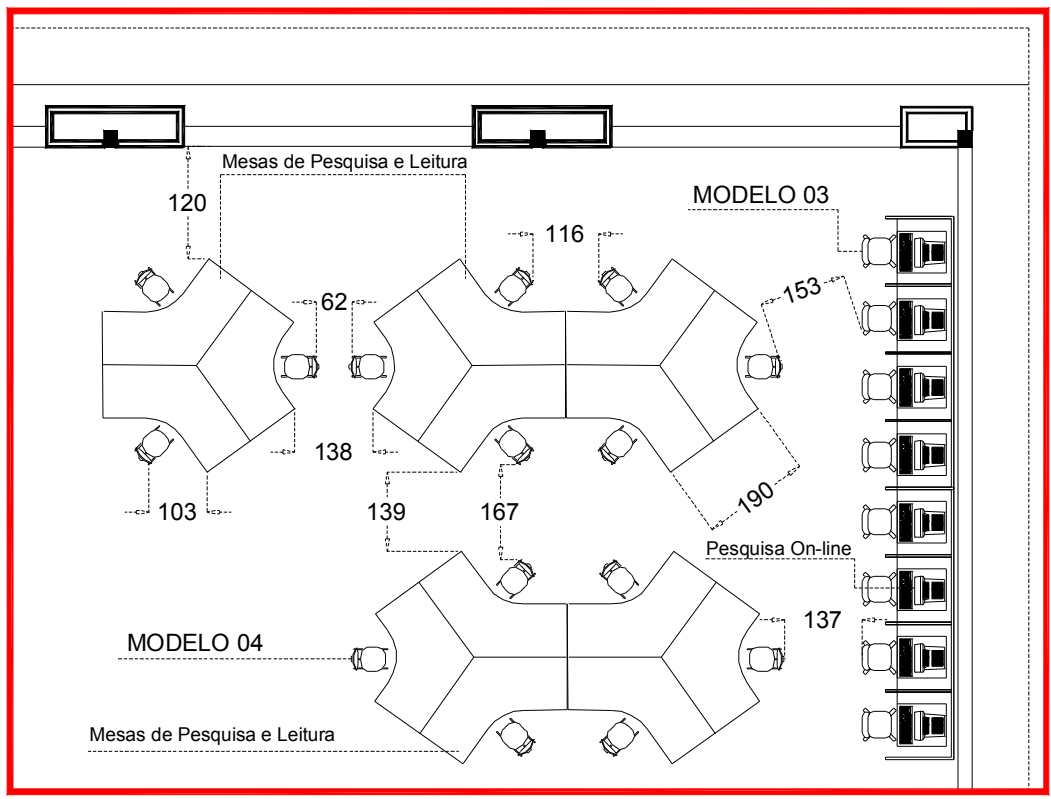

Figura 231 - Layout Cadeiras/Modelo 03 e 04 / Biblioteca Senac/Santo Amaro (medidas em centímetros e sem escala)

Um panorama um pouco diferenciado de satisfação do usuário é encontrado na Biblioteca da Unesp/Marília, no que diz respeito à avaliação quanto às condições da cadeira. Neste caso, os níveis de satisfação foram considerados inferiores e a percepção dos ocupantes dos ambientes, principalmente dos estudantes, foi detectada como preocupante. Isso se explica porque o Modelo 5 (Figura 234) presente nos espaços destinados às áreas de leitura e pesquisa e nas mesas de trabalho, não apresenta possibilidades de ajustes ou variações de alturas, apesar de estar enquadrada na $N B R$ 13.967/1997. Por outro lado, nas áreas da administração e da diretoria, onde constam com os mesmos Modelos 01 e 02 de cadeiras presentes na Biblioteca do Senac/Santo Amaro, com possibilidades de ajustes de altura e inclinação, os funcionários relataram que estão satisfeitos com as condições das cadeiras no ambiente de trabalho. 


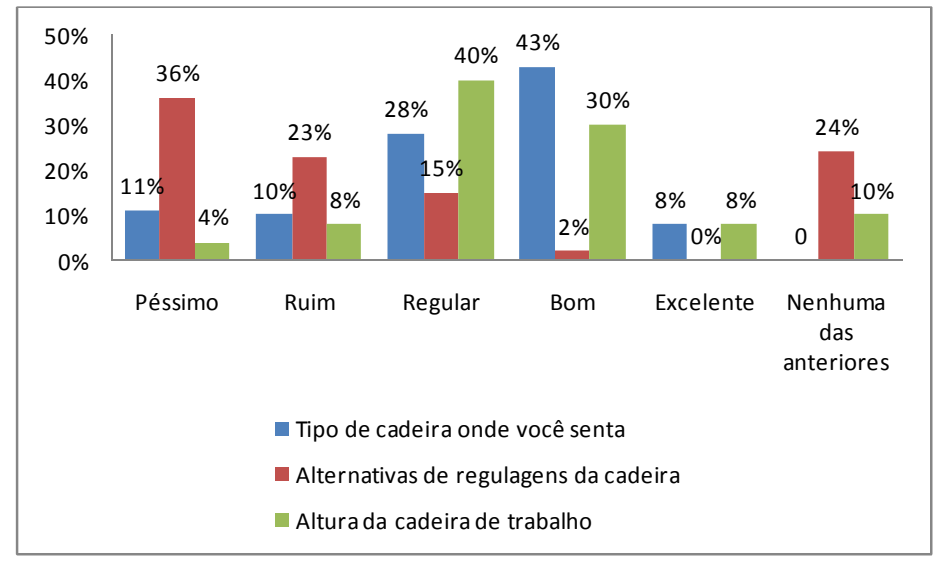

Gráfico 04 - Nível de Satisfação: adequação do tipo de mobiliário: alunos - Biblioteca Unesp/Marília

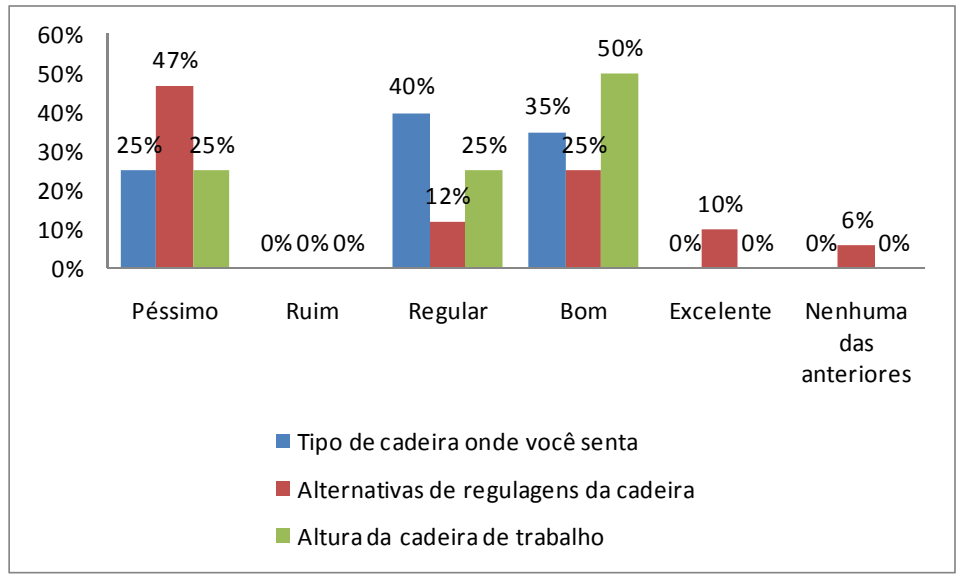

Gráfico 05 - Nível de Satisfação: adequação do tipo de mobiliário: professores - Biblioteca

Unesp/Marília

Outro local que apresenta problemas sérios quanto ao baixo nível de satisfação foi a área destinada à pesquisa on-line da biblioteca. Neste ambiente, os terminais de computadores ficam posicionados em uma bancada de madeira, a uma altura $(\mathrm{h}: 120 \mathrm{~cm})$ inadequada, fazendo com que o usuário opere em uma posição ergonômica desconfortável, além de estar fora dos padrões estipulados pela norma $N B R$ 13.967/1997. Vale lembrar que, o local dispõe de banquetas de madeira (Figura 235), com altura de $70 \mathrm{~cm}$, sendo apontado como um dos principais elementos de desconforto do quesito relacionado às altura e tipos de regulagens das cadeiras. Além disso, é importante apontar que o ambiente não possui bancadas rebaixadas ou medidas compatíveis com a norma $N B R$ - 9050/2004, no que diz respeito ao atendimento às 
pessoas portadoras de deficiência física que estabelece o mínimo de $70 \mathrm{~cm}$ de altura. Como relatado pela própria direção da biblioteca, já existem estudos para eliminação destes problemas, visando ao ajuste das alturas das bancadas dos computadores e a troca dos modelos de cadeiras existentes, porém, até o presente momento, essas ações não tinham sido colocadas em prática.

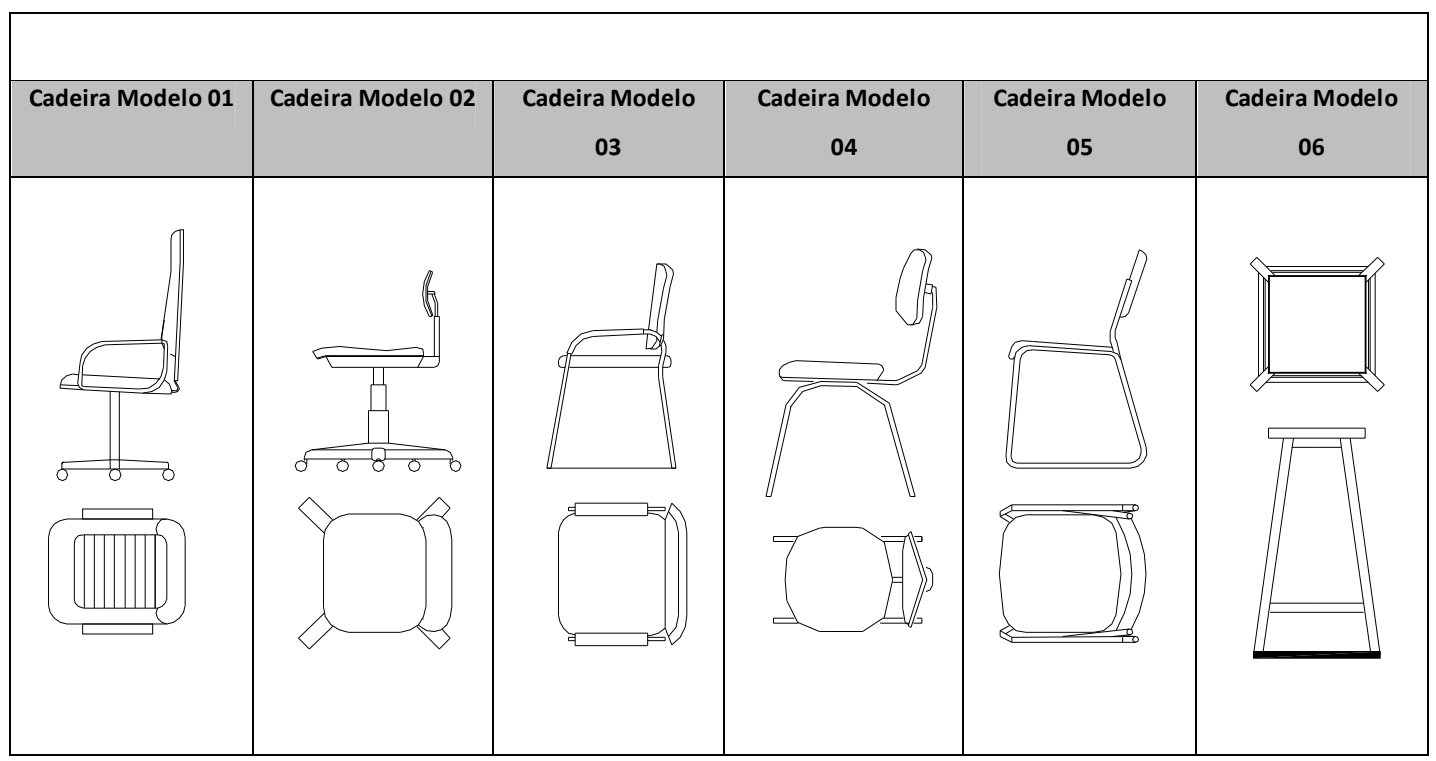

Figura 232 - Cadeiras - Biblioteca Unesp/Marília

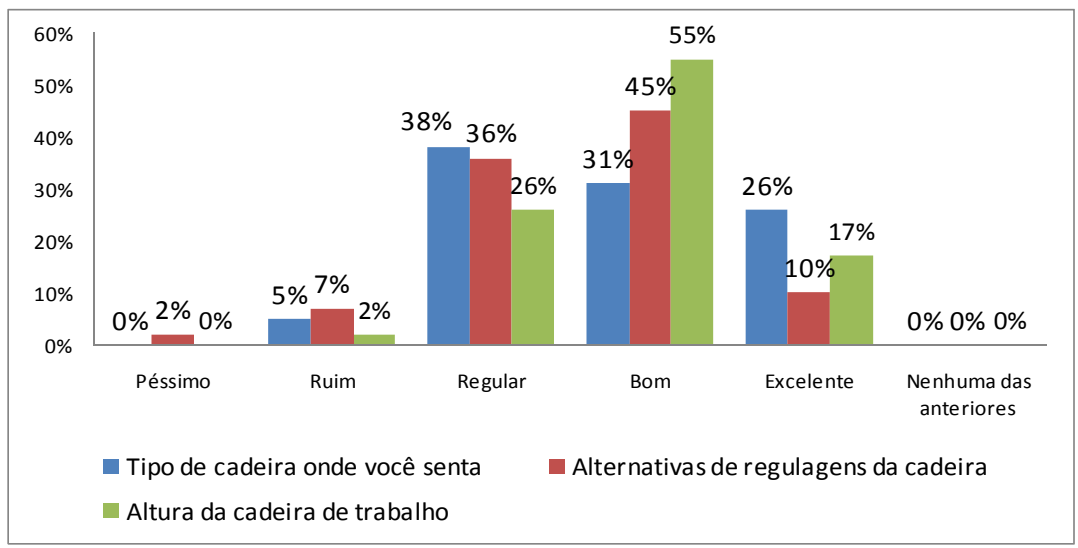

Gráfico 06 - Nível de Satisfação: adequação do tipo de mobiliário: funcionários - Biblioteca Unesp/Marília

De modo geral, o contexto das instituições de ensino superior vinculadas ao governo, como é o caso da Biblioteca da Unesp/Marília, tem estabelecido percentuais de repasses de verbas inferiores às demandas das bibliotecas universitárias. 
Esse quadro tem sugerido claramente, a inadequação, tanto da quantidade quanto da qualidade dos elementos compositivos do mobiliário destas bibliotecas universitárias.

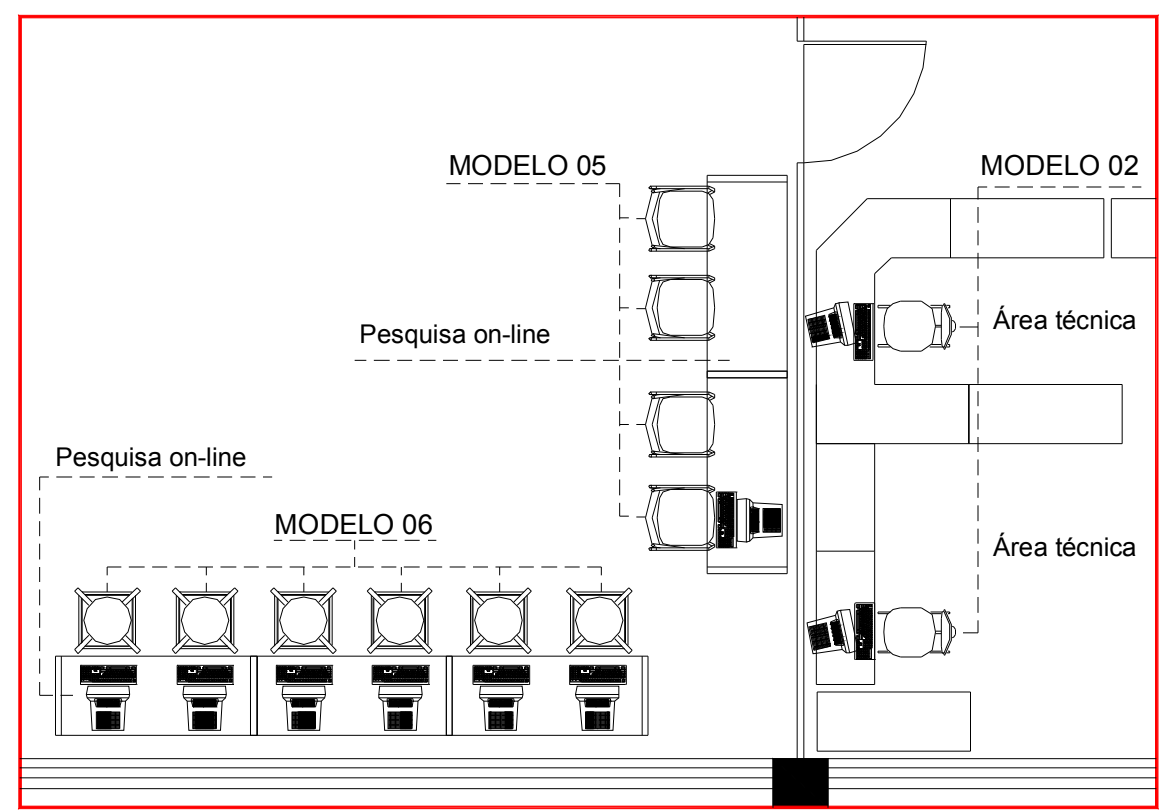

Figura 233 - Layout Cadeiras/Modelo 05 e 06 / Biblioteca Unesp/Marília (sem escala)

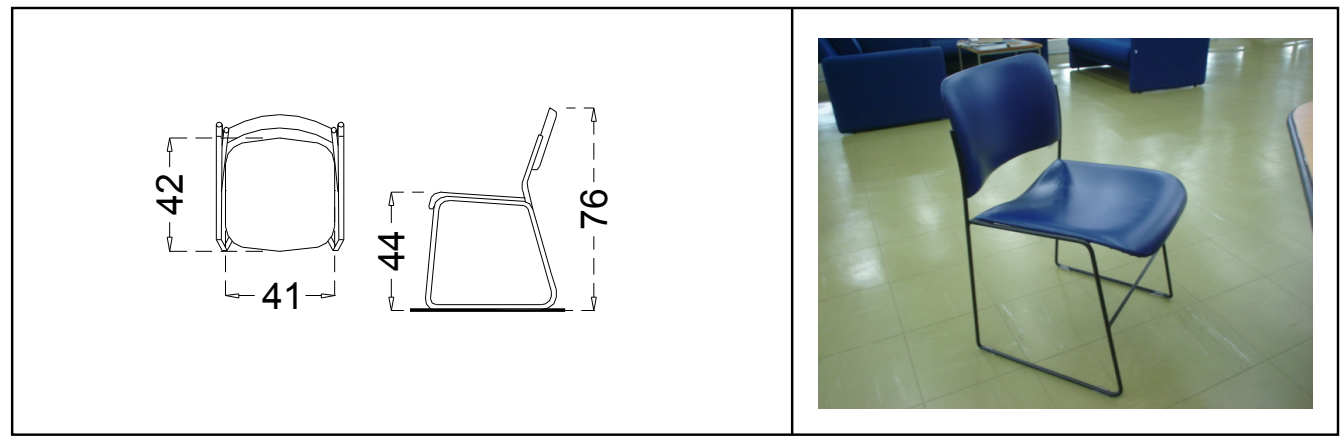

Figura 234 - Cadeiras - Modelo 05 - Biblioteca Unesp/Marília (medidas em centímetros e sem escala) 


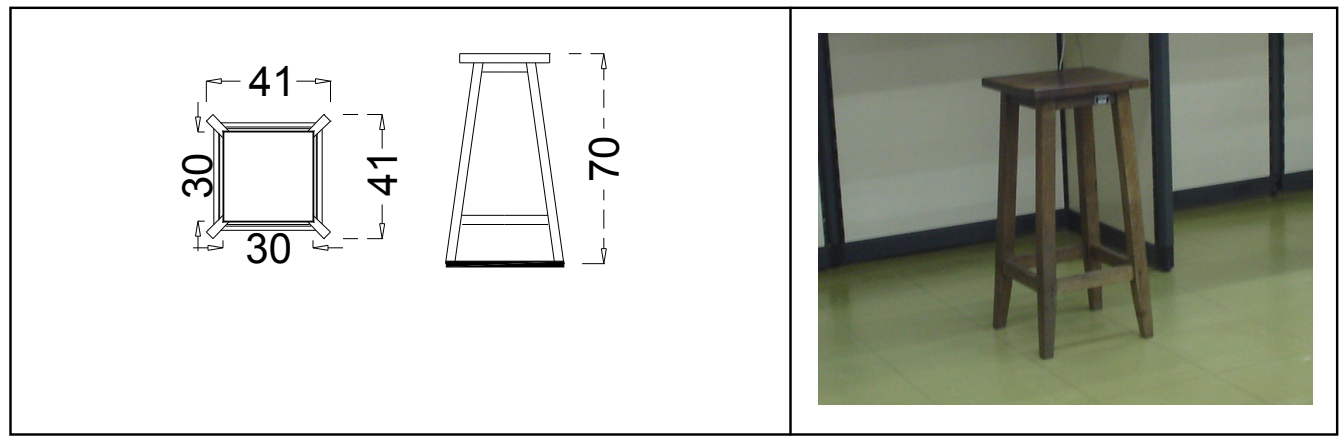

Figura 235 - Cadeiras - Modelo 06 - Biblioteca Unesp/Marília (medidas em centímetros e sem escala)

Quanto às avaliações direcionadas à altura e ao dimensionamento das mesas nas áreas de leitura/pesquisa e nas áreas de trabalho, os resultados dos dois estudos de caso foram considerados muito semelhantes, consideradas como boas a avaliação e a aceitação por parte dos usuários. Porém, neste tópico, os maiores índices de satisfação ficaram concentrados entre os alunos do edifício da Biblioteca do Senac/Santo Amaro. No geral, as mesas localizadas tanto nas áreas de leitura e pesquisa como as que estão posicionadas nas áreas administrativas, do ponto de vista ergonômico, atendem aos requisitos estabelecidos pela norma NBR 13.967/1997 quanto à altura dos tampos e às dimensões.

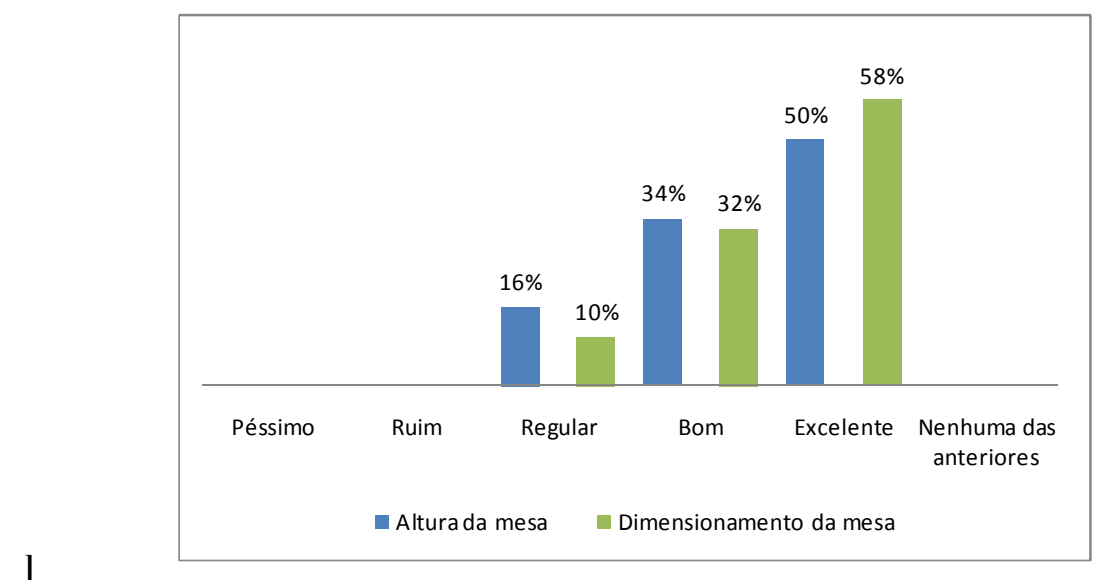

Gráfico 07 - Nível de Satisfação: adequação tipo de mobiliário: alunos - Biblioteca Senac/Santo Amaro 


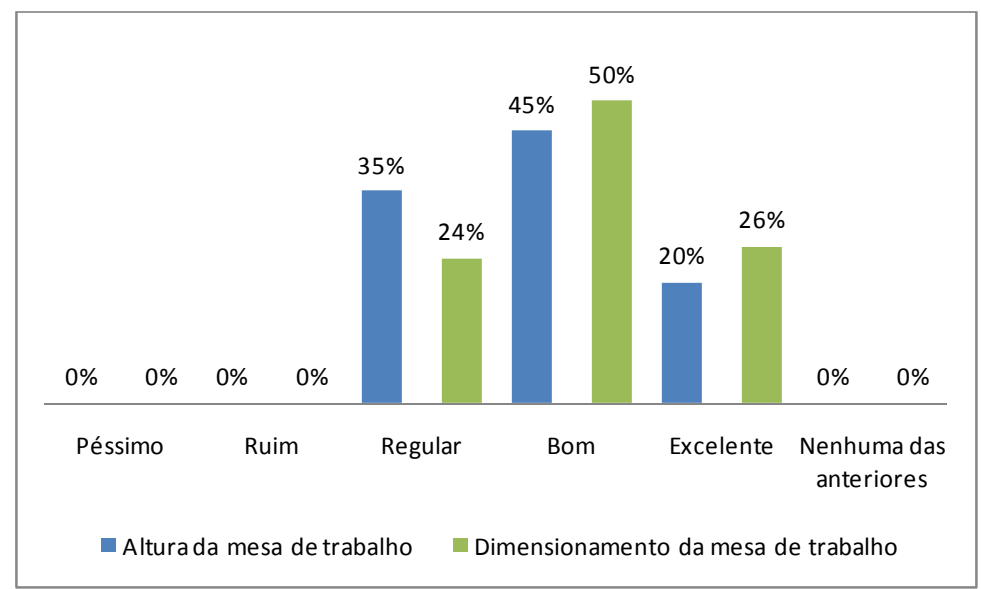

Gráfico 08 - Nível de Satisfação: adequação tipo de mobiliário: professores - Biblioteca Senac/Santo Amaro

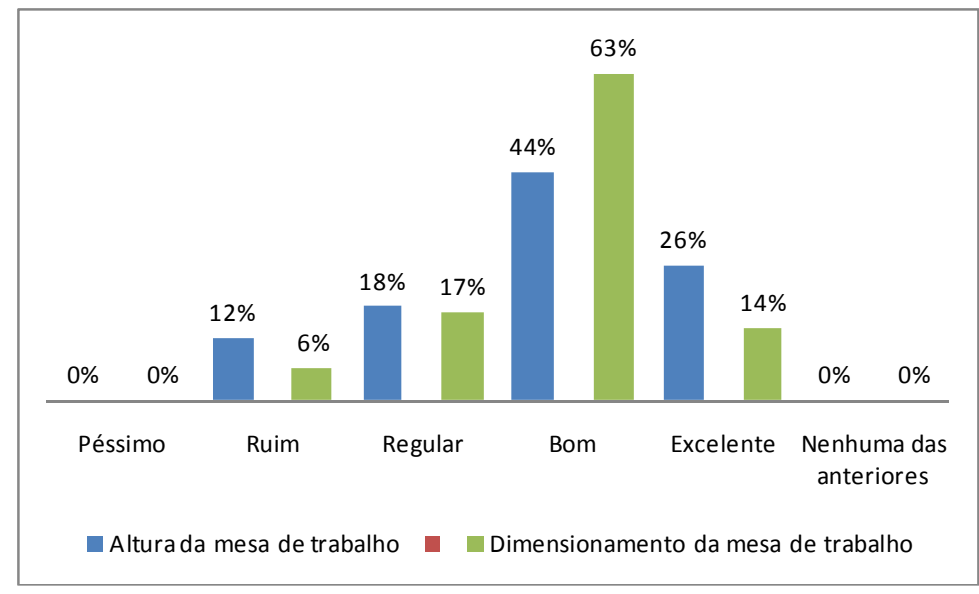

Gráfico 09 - Nível de Satisfação: adequação tipo de mobiliário: funcionários - Biblioteca Senac/Santo Amaro

Observou-se, nas áreas destinadas à leitura e pesquisa, que a configuração básica da biblioteca obedece a seis (6) grandes modelos de ocupação: o primeiro (Figura 236 - Modelo 07), módulos triplos de mesas retangulares e ovais $(130 \mathrm{~cm}$ x $60 \mathrm{~cm}$ ), acomodando para cada módulo 1 cadeira; serve tanto para pesquisa e leitura como para os terminais de microcomputadores; o segundo e o terceiro (Figuras 238 e 239 - Modelo 9 e 10), as mesas circulares com diâmetro de $140 \mathrm{~cm}$, destinando 4 lugares e mesas retangulares $(140 \mathrm{~cm} \times 100 \mathrm{~cm})$; esse conjunto de mesas está disposto nos três pavimentos da biblioteca, nas áreas de pesquisa e leitura, e são distribuídas ao longo do átrio central e em volta da escada central que dá acesso a outros pavimentos do 
edifício; o quarto (Figura 237- Modelo 08) conjunto de mesas, são módulos de cabines individuais destinadas ao trabalho de leitura, pesquisa e terminais de microcomputadores e são constituídos por biombos de 1,60 de altura; o quinto (Figura 240 - Modelo 11), mesas (220 cm x $120 \mathrm{~cm}$ x $60 \mathrm{~cm})$ destinadas às áreas onde ficam instalados os funcionários responsáveis ao atendimento dos usuários nos ambientes da biblioteca e, em algumas situações, formam módulos de 2 a 4 peças, estabelecendo "ilhas" de atendimento; e finalmente, o sexto modelo (Figura 241 - Modelo 12), as mesas encontradas nas salas fechadas de estudos $(200 \mathrm{~cm}$ x $100 \mathrm{~cm})$ e são destinadas a acomodar de 6 a 8 pessoas, geralmente utilizadas nas reuniões de grupos de alunos ou professores que utilizam o espaço da biblioteca.
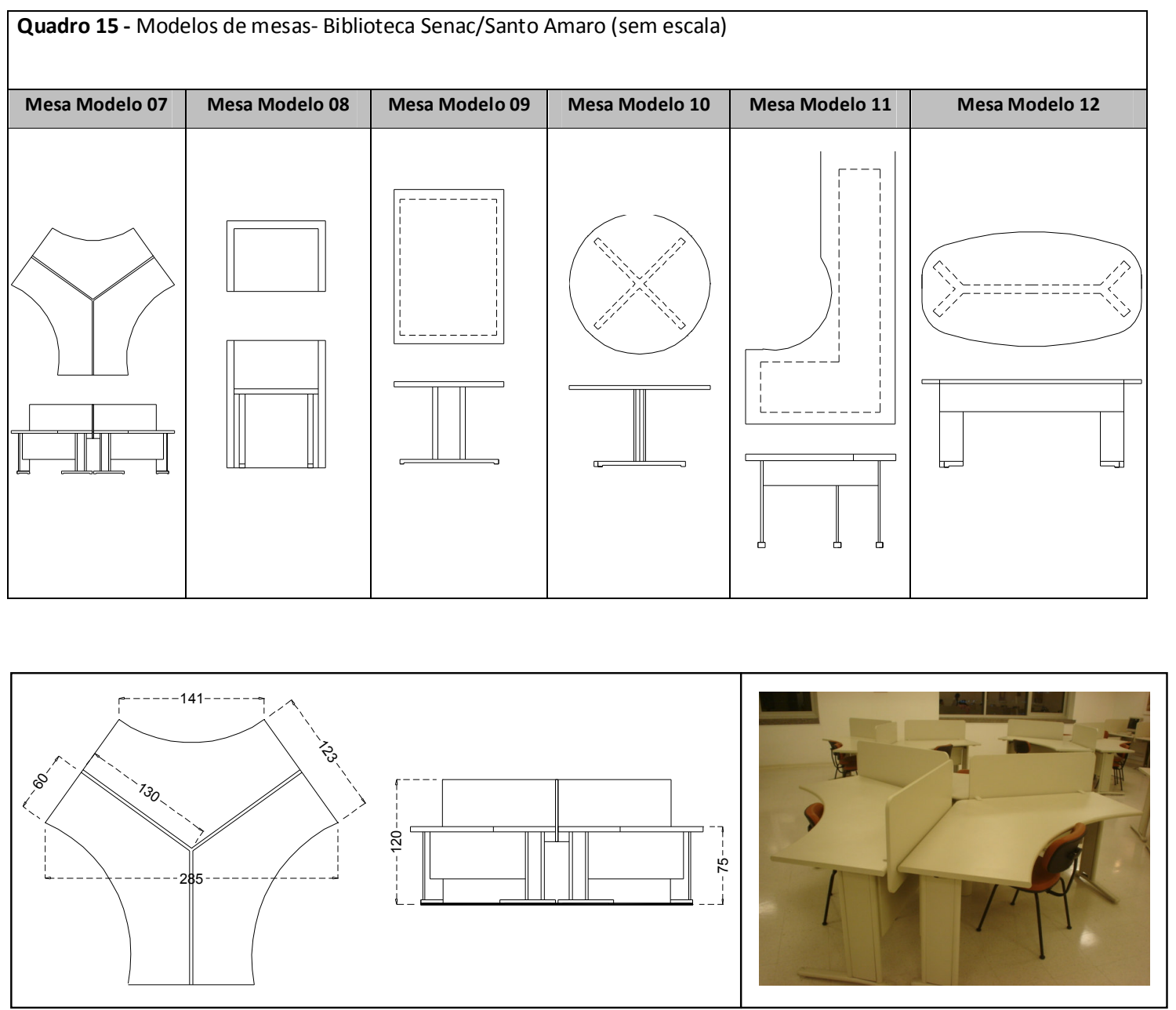

Figura 236 - Mesas - Modelo 07 - Biblioteca Senac/Santo Amaro (medidas em centímetros e sem escala) 

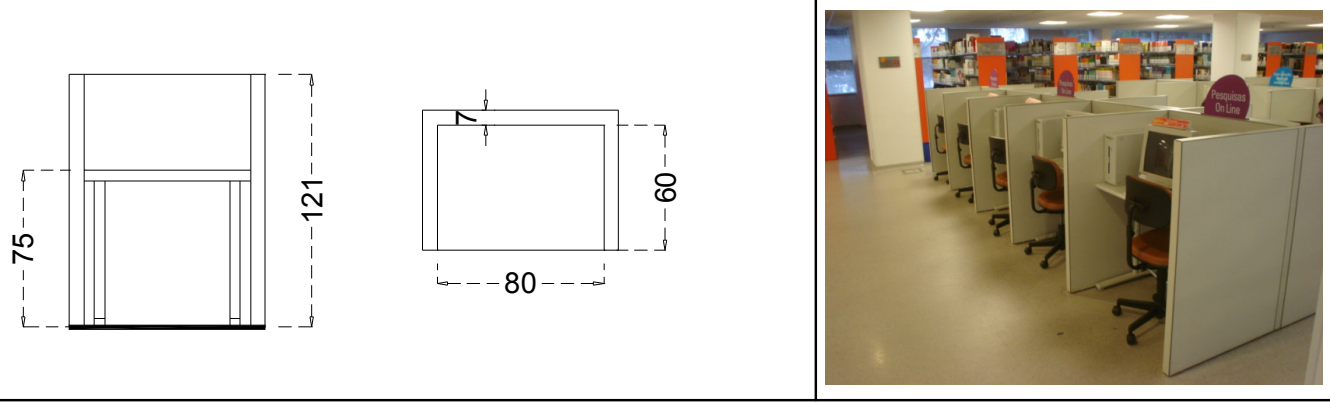

Figura 237 - Mesas - Modelo 08 - Biblioteca Senac/Santo Amaro

(medidas em centímetros e sem escala)
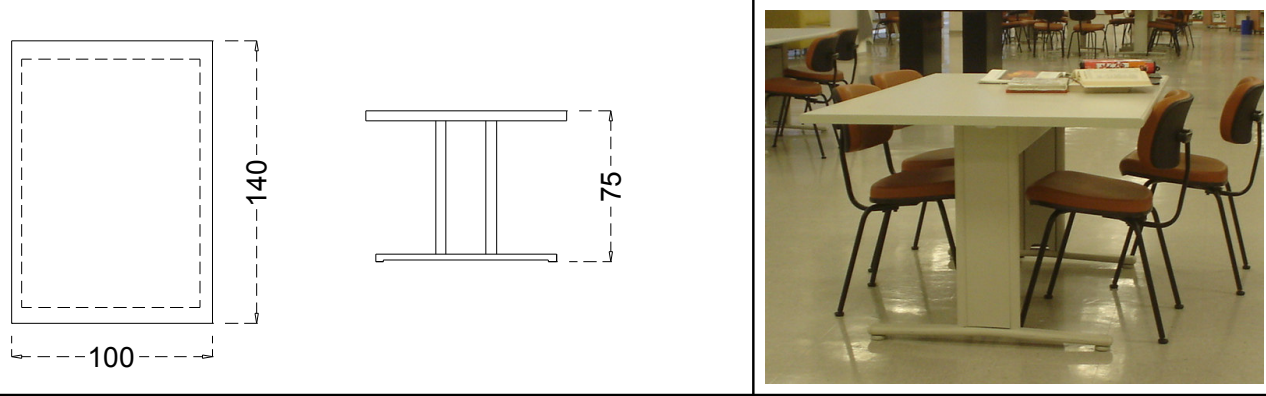

Figura 238 - Mesas - Modelo 09 - Biblioteca Senac/Santo Amaro

(medidas em centímetros e sem escala)

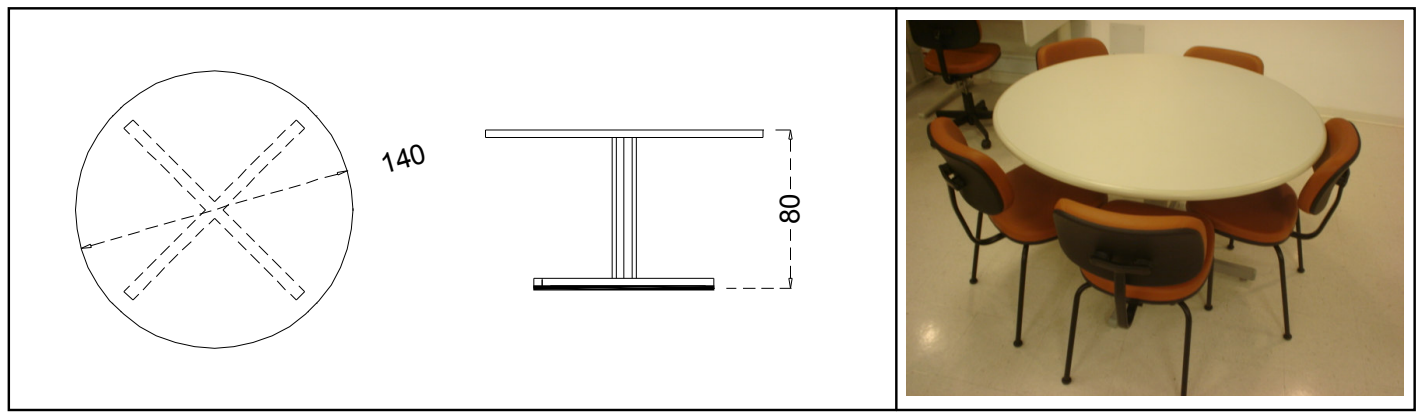

Figura 239 - Mesas - Modelo 10 - Biblioteca Senac/Santo Amaro (medidas em centímetros e sem escala) 


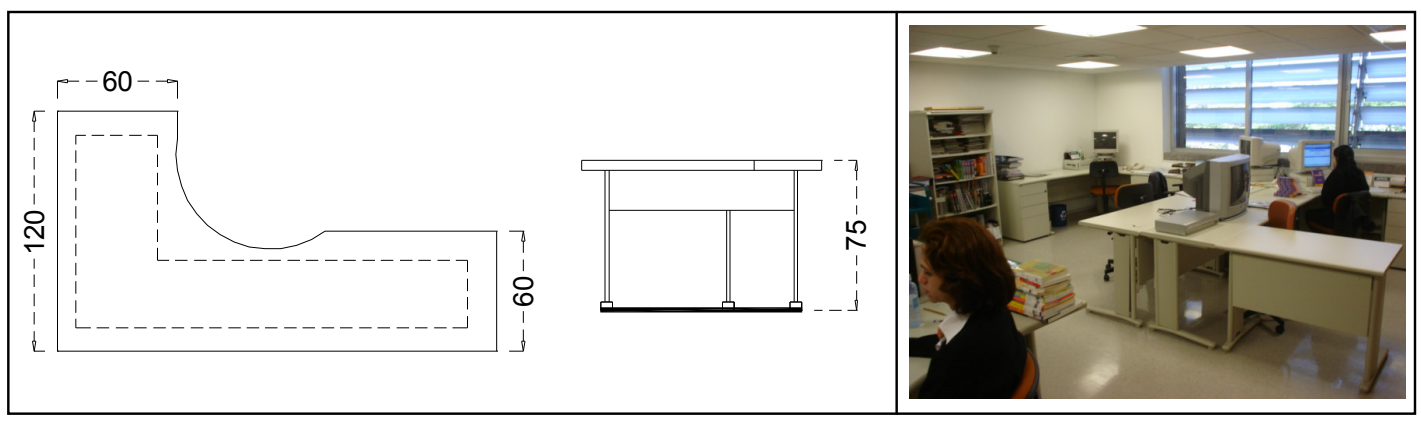

Figura 240 - Mesas - Modelo 11 - Biblioteca Senac/Santo Amaro (medidas em centímetros e sem escala)

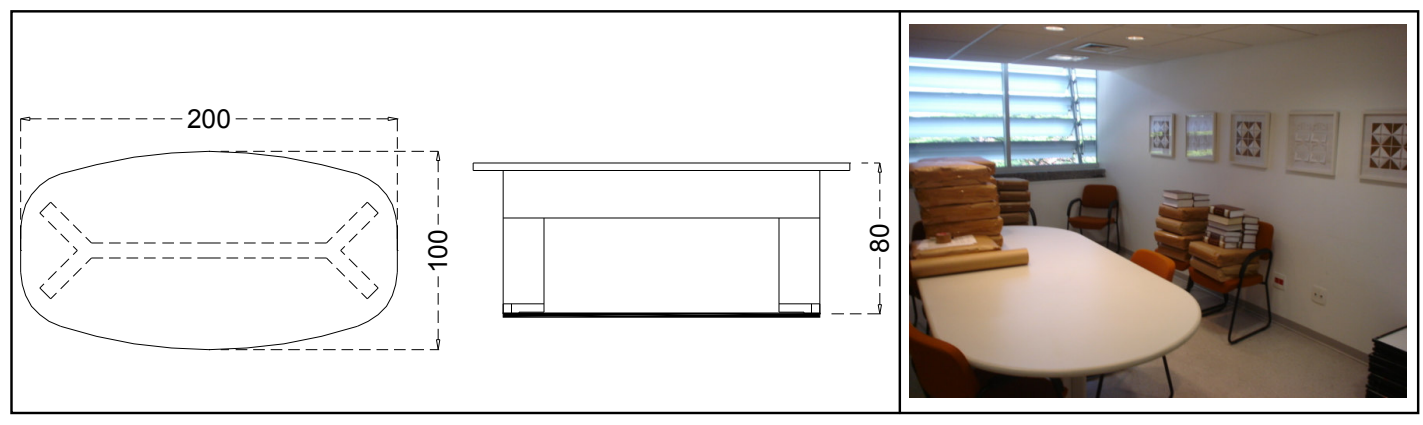

Figura 241 - Mesas - Modelo 12 - Biblioteca Senac/Santo Amaro (medidas em centímetros e sem escala)

Quanto aos modelos de mesas na Biblioteca da Unesp/Marília, seis (06) tipos estão divididos nos diversos ambientes do edifício, discriminados da seguinte forma: o Modelo 13 (Figura 243) está direcionado basicamente para as atividades administrativas, ou seja, utilizado entre os funcionários da biblioteca nas funções técnicas e tem como característica principal o desenho em "L" (140 cm x $75 \mathrm{~cm}) \mathrm{de}$ seus módulos; o Modelo 14 (Figura 244) são as mesas circulares (R: $120 \mathrm{~cm}$ ) e estão presentes nas área de leitura e pesquisa, junto ao acervo bibliográfico; o Modelo 15 (Figura 245) fica posicionado na área reservada à leitura de jornais e apresenta um desenho diferenciado das demais mesas, possuindo um ângulo de inclinação maior no tampo da mesa; às mesas de leitura e pesquisa ficaram reservados o Modelo 16 (Figura 246) localizado na área do acervo central da biblioteca; o Modelo 17 (Figura 247) é uma mesa com desenho especial e atende aos usuários da pesquisa e comutação 
bibliográfica; e, finalmente, o Modelo 18 (Figura 248), são as mesas destinadas à pesquisa on-line e ao catálogo bibliográfico.

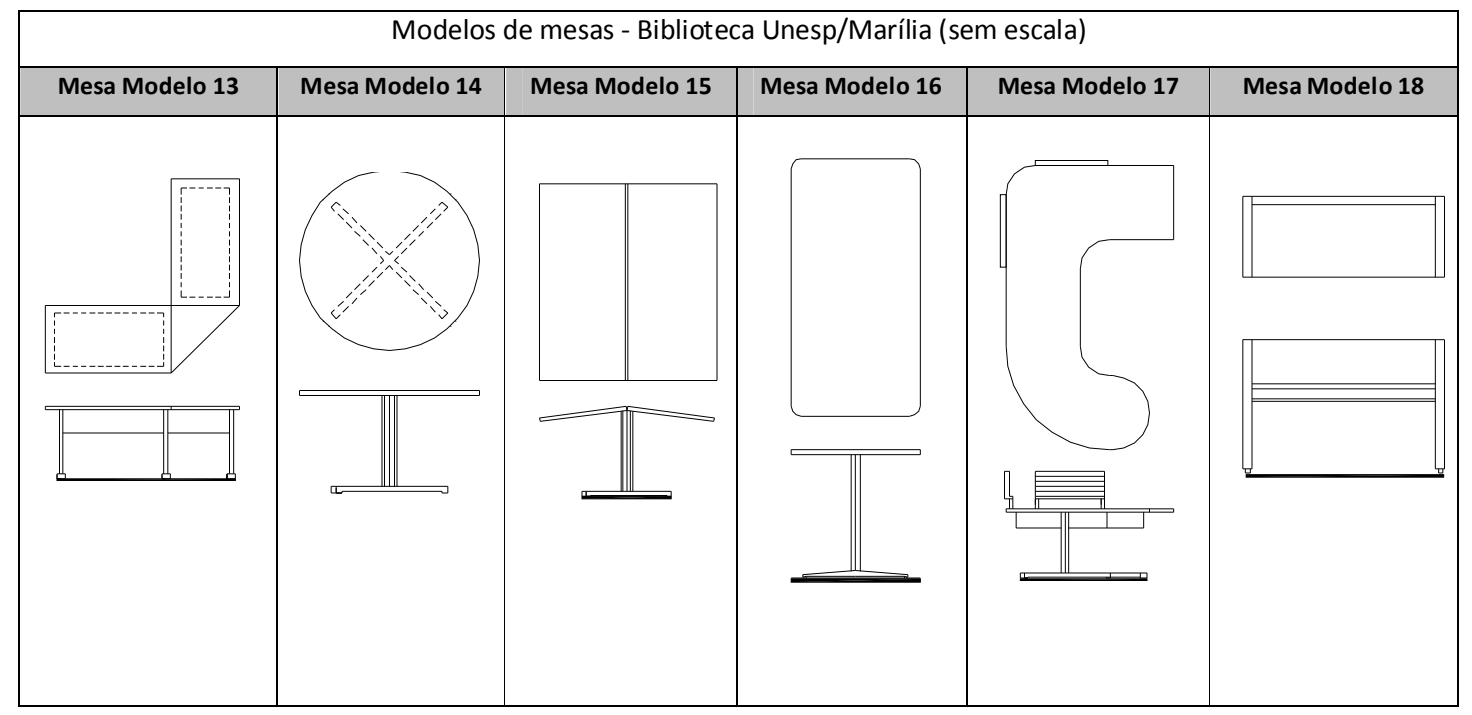

Figura 242 - Modelos de mesas - Biblioteca Unesp/Marília

Quanto ao nível de satisfação com a altura e o dimensionamento das mesas da biblioteca, observa-se que, de um modo geral, os usuários consideram boas as condições avaliadas, sendo o quesito que alcançou maior percentual (57\% - Bom), entre o extrato de funcionários da biblioteca, foi o dimensionamento da mesa de trabalho. Este fato se explica, principalmente, porque na área administrativa foi constatada uma maior variação na configuração e no dimensionamento das mesas, ou seja, são abertas com diálogo e mantêm configuração diferenciada dos demais ambientes da biblioteca.

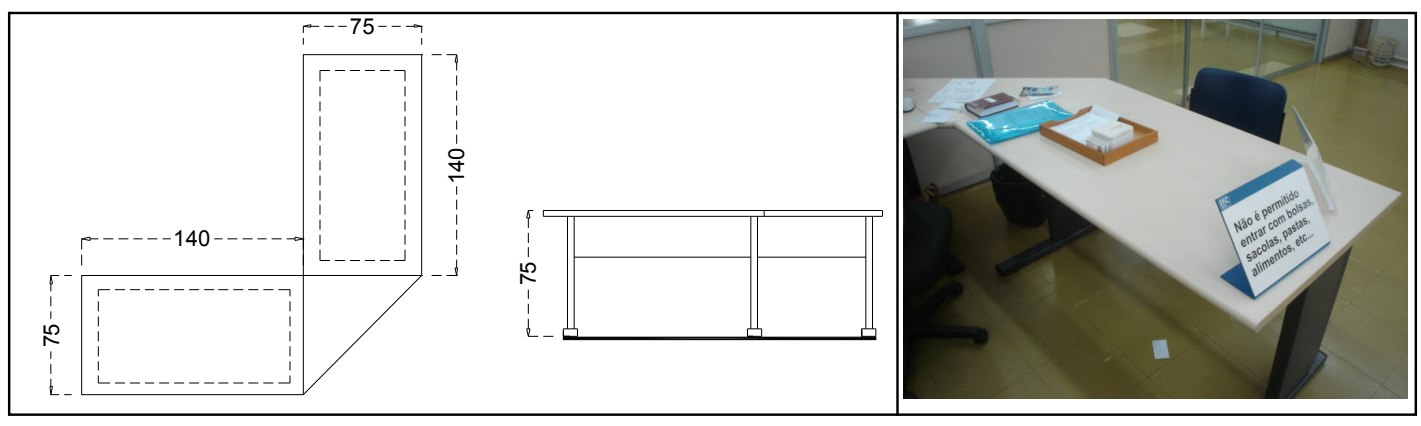

Figura 243 - Mesas - Modelo 13 - Biblioteca Unesp/Marília (medidas em centímetros e sem escala) 


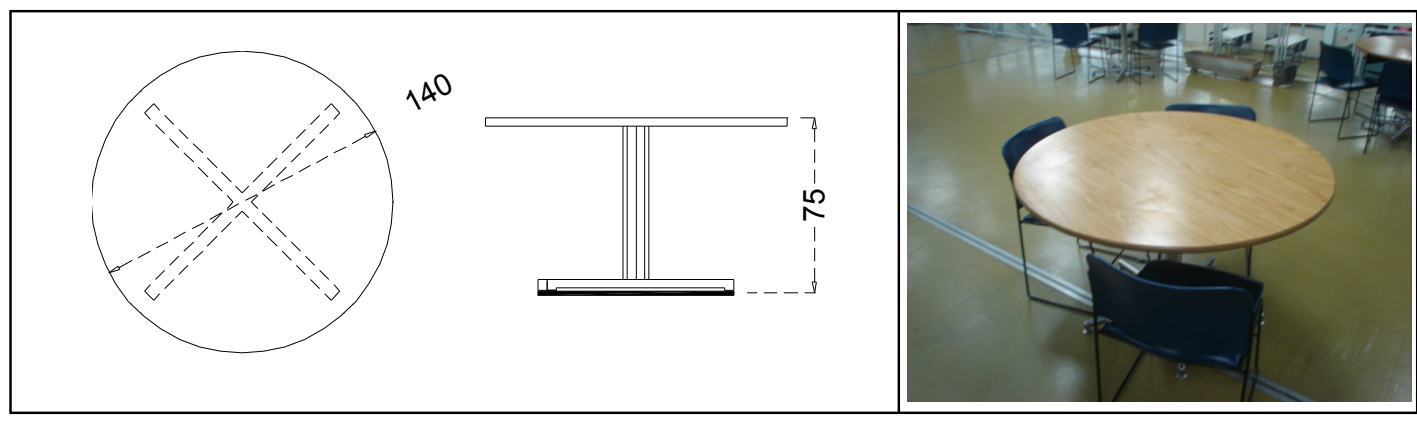

Figura 244 - Mesas - Modelo 14 - Biblioteca Unesp/Marília (medidas em centímetros e sem escala)

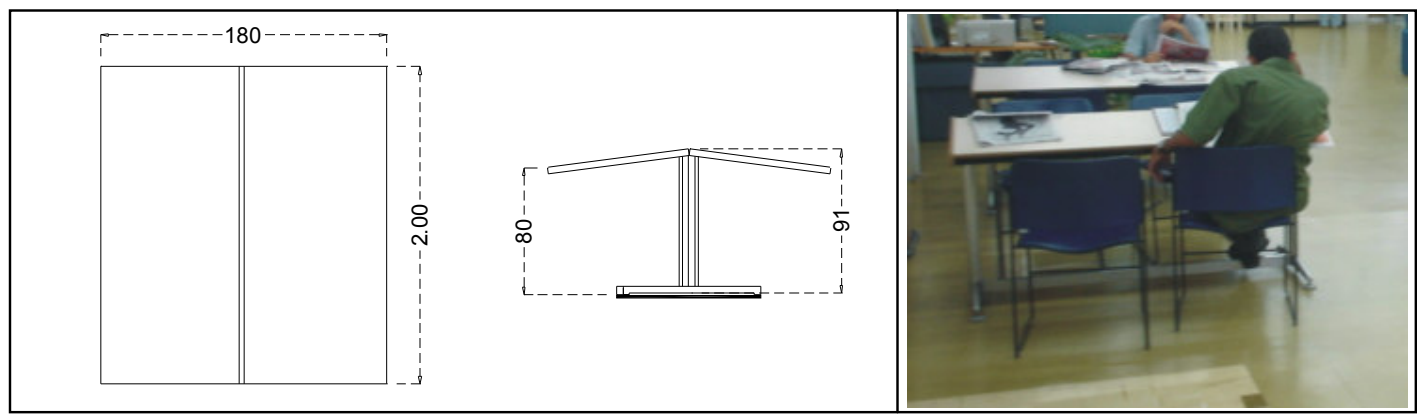

Figura 245 - Mesas - Modelo 15 - Biblioteca Unesp/Marília (medidas em centímetros e sem escala)

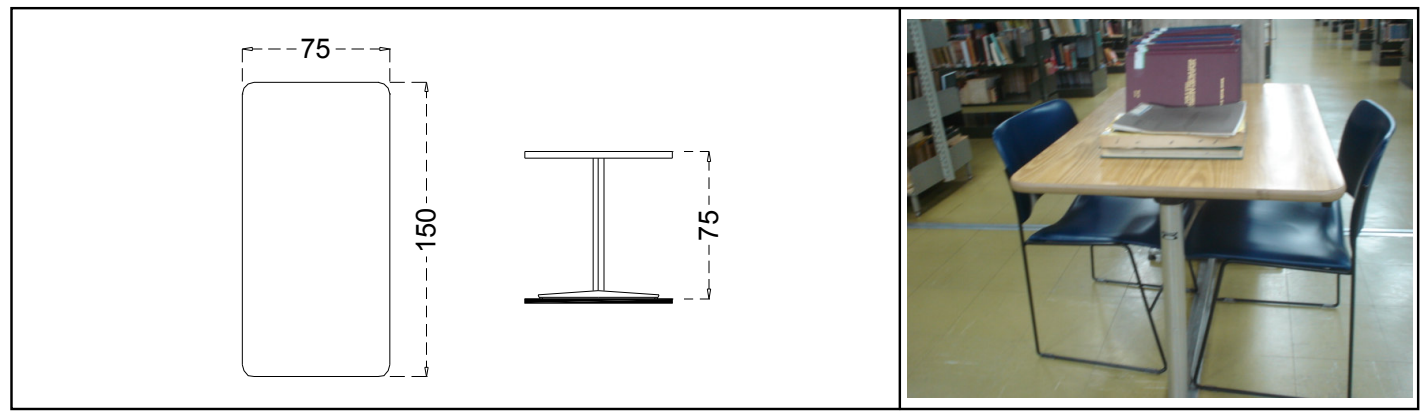

Figura 246 - Mesas - Modelo 16 - Biblioteca Unesp/Marília (medidas em centímetros e sem escala) 


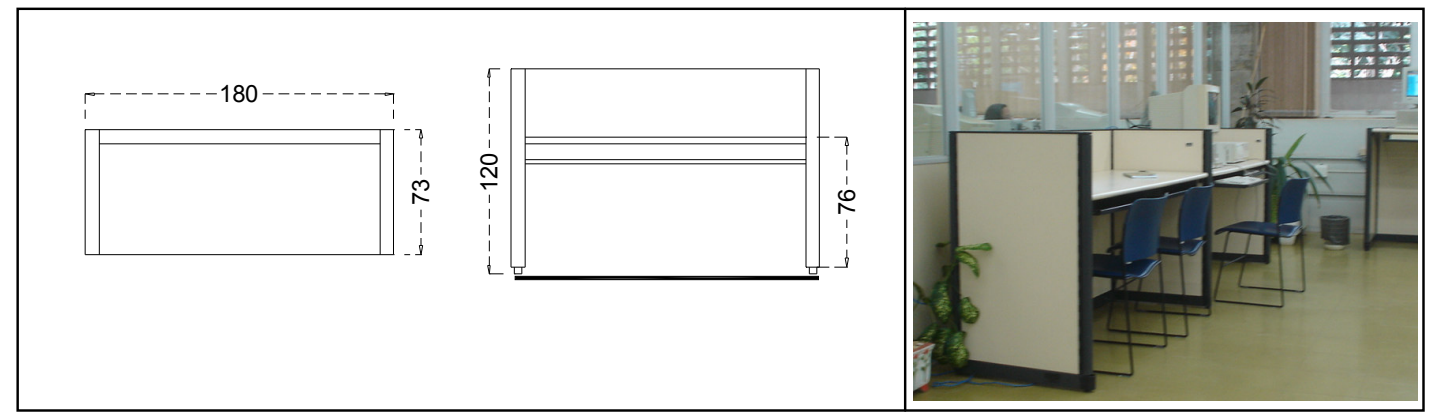

Figura 247 - Mesas - Modelo 17 - Biblioteca Unesp/Marília (medidas em centímetros e sem escala)

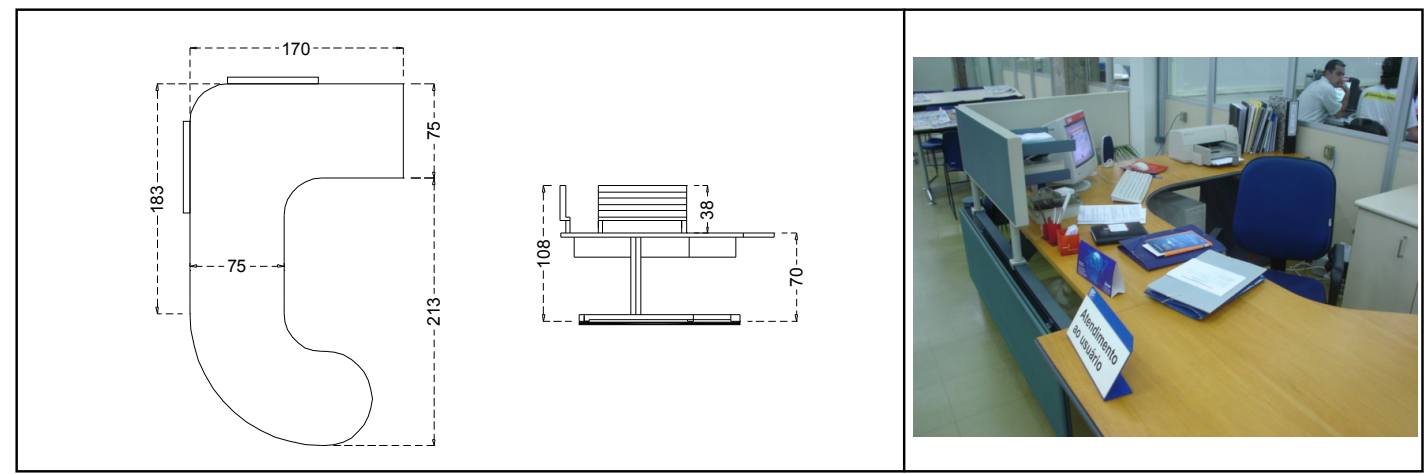

Figura 248 - Mesas - Modelo 18 - Biblioteca Unesp/Marília (medidas em centímetros e sem escala)

Outro aspecto importante a observar é que o menor índice de satisfação em relação à altura da mesa (25\% - Ruim) foi constatado entre os professores que utilizam as áreas de pesquisa e leitura da biblioteca. Como a justificativa apontada pelos insatisfeitos é que as mesas são um pouco baixas, presume-se que haja uma sensação de desconforto nos longos períodos de utilização do mobiliário nas áreas de pesquisa e leitura. Portanto, esse resultado indica a necessidade de adequar a altura das mesas, não somente direcionada ao extrato de professores, mas também a todos os usuários que efetivamente desempenham alguma atividade nestes ambientes. 


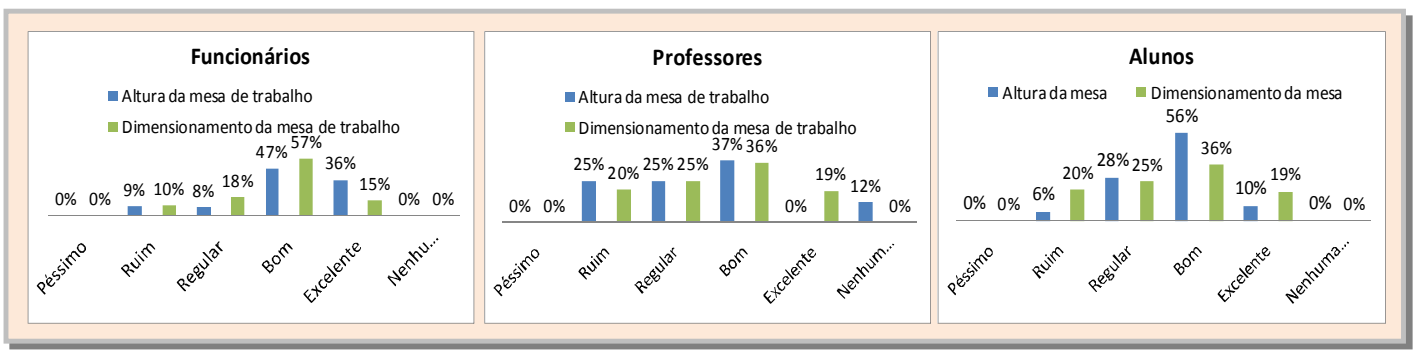

Figura 249 - Nível de Satisfação: adequação tipo de mobiliário: Biblioteca Unesp/Marília

No tocante à avaliação da configuração das mesas no edifício da Biblioteca da Unesp/Marília, encontrou-se questões consideradas importantes relacionadas ao dimensionamento, ao posicionamento e os elementos ergonômicos das mesas no ambiente estudado. Pelo próprio partido arquitetônico do edifício, as mesas de leitura e pesquisa são divididas em três grandes áreas:

- a primeira, localiza-se logo após a entrada e controle dos usuários (alunos e professores), estabelecendo mesas de leitura de jornais e revistas (Modelo 15) com dimensão de $200 \mathrm{~cm}$ x $120 \mathrm{~cm}$ (considerado bom 43\% - entre os usuários); entretanto, o principal problema detectado neste ambiente relaciona-se à quantidade de mesas disponíveis para tal função, revelando-se insuficiente no atendimento às pessoas que usufruem deste serviço. Este dado foi plenamente comprovado, primeiramente, com o contato de usuários no período de 'as built' e depois, apontado pela própria direção da biblioteca pela entrevista. Fica demonstrada a necessidade da adequação, por parte da direção e dos projetistas, na compatibilização do número de mesas de acordo com a quantidade de usuários presentes na biblioteca, já que uma grande parte do tempo dos usuários é despendido na leitura de jornais e revistas;

- a segunda área, localizada na cota intermediária dos pavimentos, abriga o local de estudo, leitura e estantes do material bibliográfico e se destaca por manter uma grande visibilidade em relação ao conjunto da biblioteca. As mesas estão dispostas ao longo da parte frontal desse ambiente e também se intercalam entre corredores e estantes dos livros. Dois padrões básicos de mesas são assinalados: mesas com dimensões muito compactas $(80 \mathrm{~cm} \times 120 \mathrm{~cm}$ e $100 \mathrm{~cm} \times 120 \mathrm{~cm})$ e mesas circulares $(d: 120 \mathrm{~cm})$. Quando questionados sobre o tamanho das mesas, todos os extratos dos usuários (alunos, professores e funcionários) aprovam o existente, o que demonstra que as medidas 
existentes não constituem um problema. Entretanto, a ressalva que se faz, por parte dos entrevistados, diz respeito à necessidade de variações nos tamanhos das mesas, com o objetivo de propiciar a variabilidade e a melhoria nas atividades de pesquisa e leitura dos usuários;

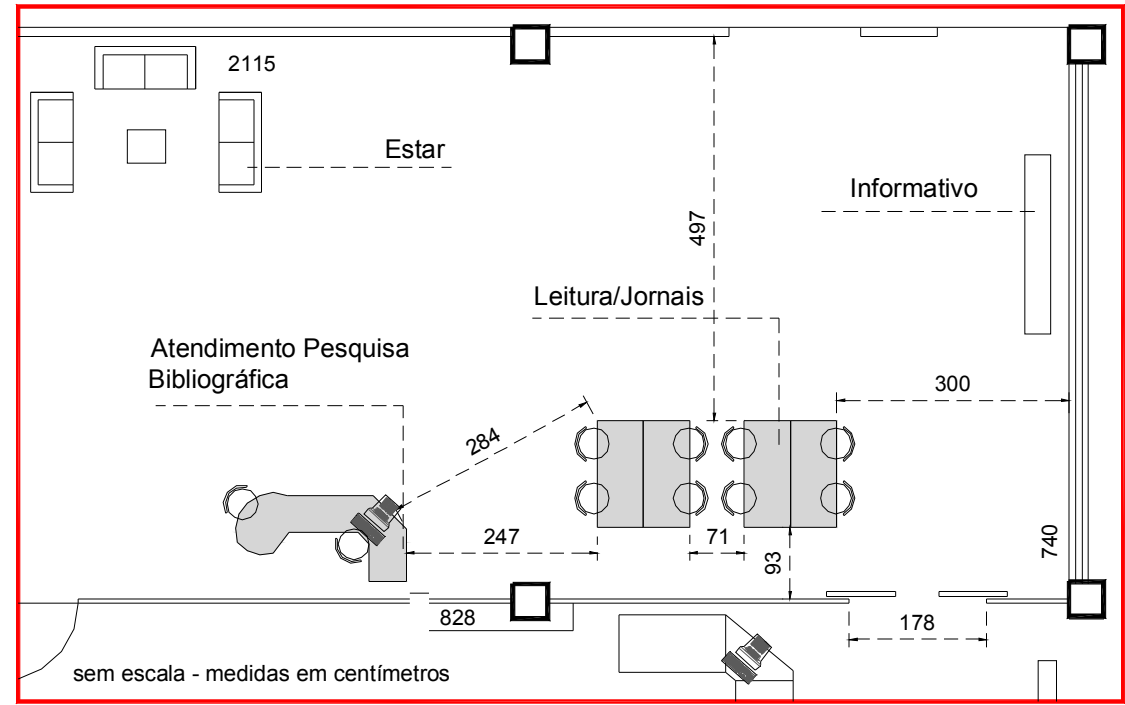

Figura 250 - Área de Leitura de Jornais- Mesas (Modelo 15) - Biblioteca Unesp/Marília

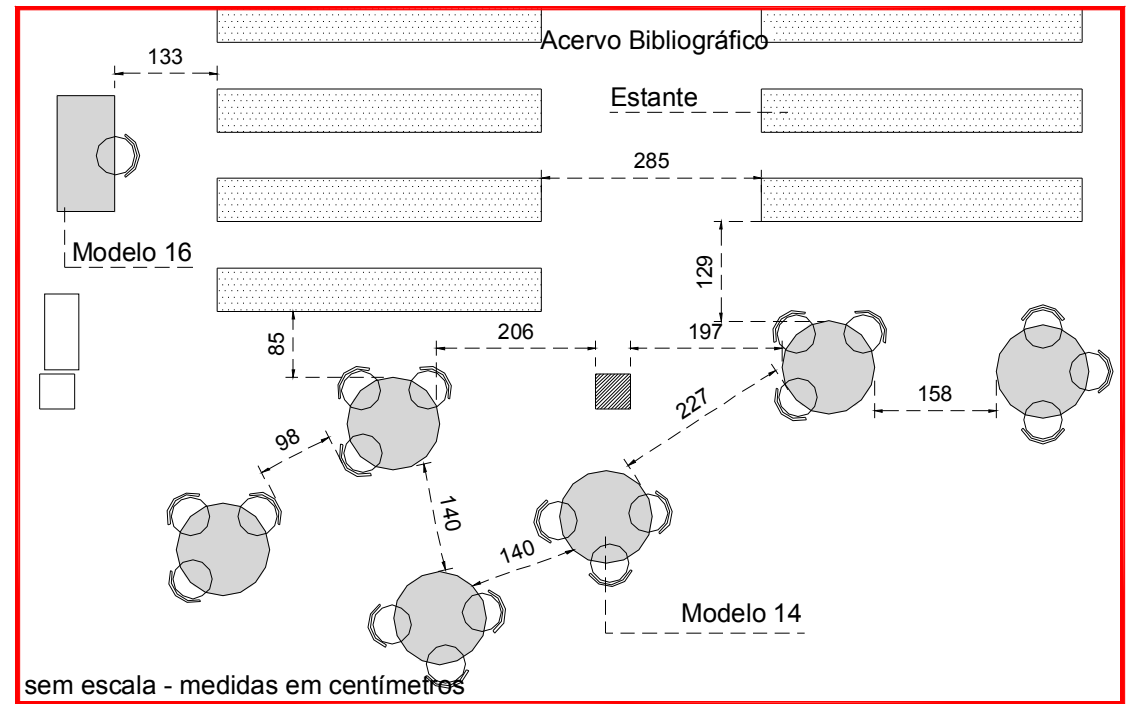

Figura 251 - Área do Acervo Bibliográfico- Mesas (Modelo 14 e Modelo 16) - Biblioteca Unesp/Marília

- a terceira área, localizada no pavimento inferior da biblioteca, onde se agrupam alguns espaços importantes como expositor de periódicos, expositor de novos livros e teses, expositor para materiais bibliográficos diversos, salas fechadas de estudos e 
pesquisa; um pequeno auditório, seção de literatura infantil e depósito- almoxarifado. Nesta área, especificamente, as mesas possuem um dimensionamento um pouco maior $(120 \mathrm{~cm} \times 1,60 \mathrm{~cm})$, bem como no que se refere à quantidade de mesas; neste caso, a maioria dos usuários (alunos e professores) está de acordo com as condições do mobiliário que atendem aos requisitos estabelecidos pela norma NBR 13.965/13.9661997 de altura e dimensionamento das mesas;

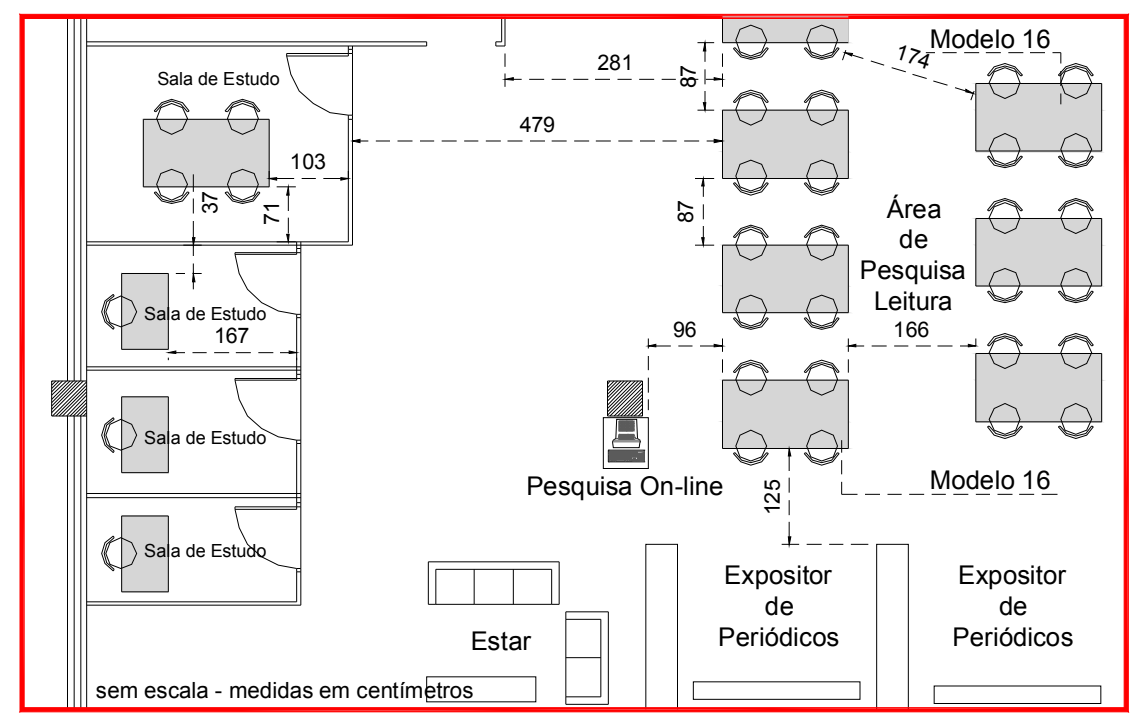

Figura 252 - Área do Pavimento Inferior - Mesas (Modelo 16) - Biblioteca Unesp/Marília

- a quarta área, abrange os setores atendidos pela administração e diretoria e, de modo geral, apresenta dimensões das mesas compactas $(1,50 \mathrm{~m} \times 0,50 \mathrm{~m})$, em forma de "L" e acopladas. Na sala da direção, a mesa atende ao mesmo modelo do setor dos funcionários, mas apresenta dimensões um pouco maiores $(1,70 \mathrm{~m} \times 0,60)$. Apesar dos respondentes considerarem boas as dimensões da mesa (57\%), dois importantes problemas foram verificados nesta área: primeiro, o espaço destinado aos monitores de vídeo e/ou CPU são insuficientes, impedindo a regulagem do tampo do teclado para cima e do monitor para baixo; e, segundo, a trava do mecanismo de regulagem sob o tampo com profundidade é de $34,5 \mathrm{~cm}$, inferior à profundidade livre para os joelhos de $45 \mathrm{~cm}$ - estabelecida pela norma NBR 13.965/1998. Portanto, esses resultados indicam a necessidade de espaços adequados para esse fim, levando em consideração a satisfação na dinâmica das atividades da biblioteca ao longo de uma jornada de trabalho 


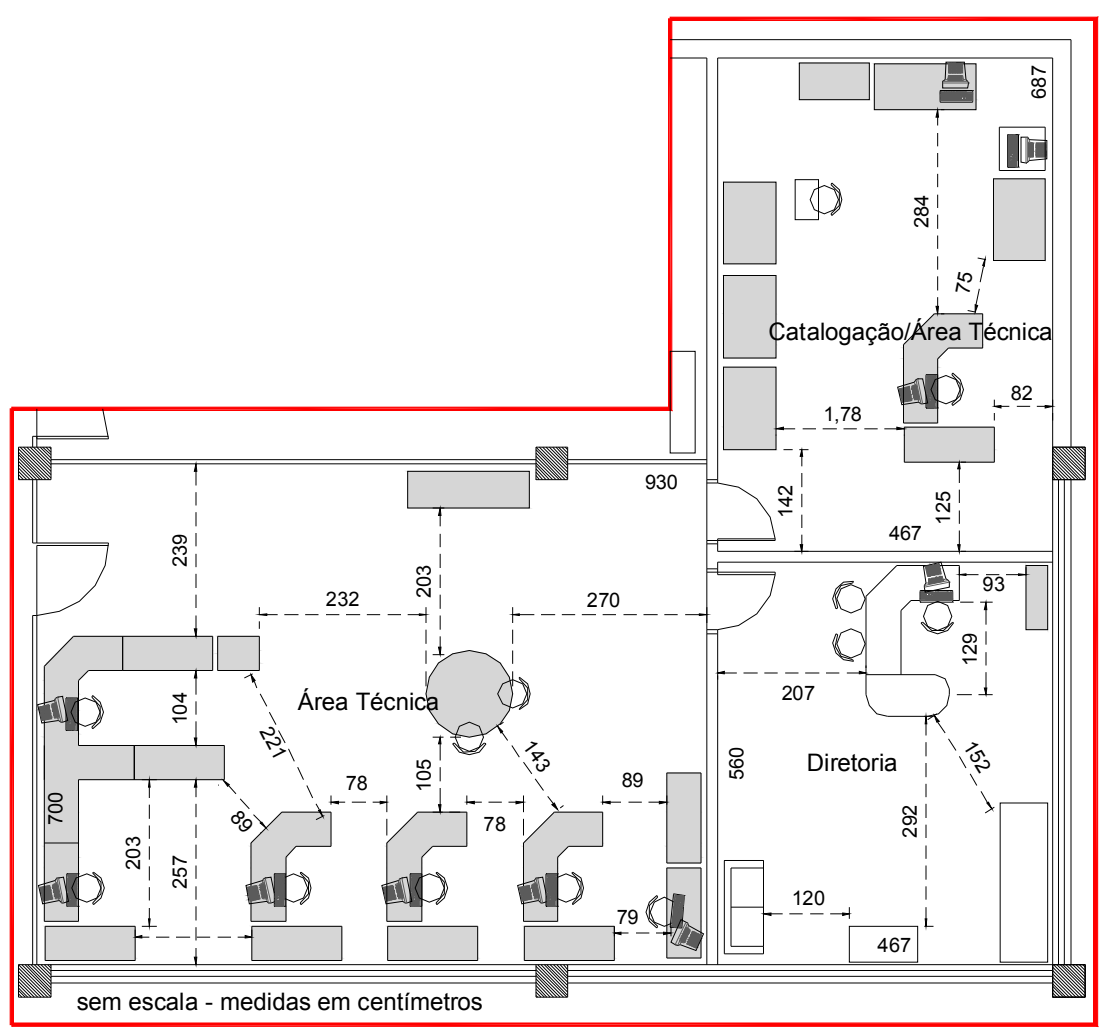

Figura 253 - Área Administrativa - Biblioteca Unesp/Marília

Analisando os dados pertinentes à NBR 13.965 e à NBR 13.666/1997, relacionados às dimensões mínimas e máximas (altura, largura e profundidade) exigidas para as mesas fixas no ambiente de trabalho da biblioteca, pode-se construir um quadro comparativo entre os valores dimensionais da norma vigente e a realidade da Biblioteca da Unesp/Marília:

\begin{tabular}{|l|c|c|c|}
\hline \multicolumn{2}{|c|}{ Tabela 04 - Mesas fixas: dimensões gerais comparativas - Biblioteca Unesp/Marília } \\
\hline & \multicolumn{2}{|c|}{ Biblioteca Unesp/Marília } & ABNT - NBR 13.965/13.966-1997 \\
\hline Itens & $\begin{array}{l}\text { Medidas } \\
\text { Mínimas - cm }\end{array}$ & $\begin{array}{l}\text { Medidas } \\
\text { Máximas - cm }\end{array}$ & Medidas (cm) \\
\hline $\begin{array}{l}\text { Altura da mesa de } \\
\text { trabalho }\end{array}$ & $70 / 75 / 76$ \\
\hline $\begin{array}{l}\text { Largura mínima da } \\
\text { mesa fixa }\end{array}$ & $73 / 75 / 90$ & 80 & 72 \\
\hline $\begin{array}{l}\text { Profundidade da } \\
\text { mesa fixa }\end{array}$ & & & 60 \\
\hline
\end{tabular}


Quanto à altura e à disposição dos equipamentos de informática nas áreas de trabalho e pesquisa, observou-se que, de um modo geral, os usuários dos edifícios analisados estão satisfeitos, mostrando bons índices de aceitação no tocante às dimensões e aos modelos ergonômicos adotados. Outro aspecto importante a observar é que a Biblioteca do Senac/Santo Amaro tem percebido a importância na estruturação de um novo conceito de ambiente de biblioteca, reduzindo os espaços, mas dotando-os de todas as facilidades decorrentes da implantação dos equipamentos de informática e dos sofisticados sistemas de comunicação (local e à distância), preocupando-se também com a adequação do mobiliário destinado às novas tecnologias informacionais $\mathrm{e}$ comunicacionais. Em contato com a diretoria da biblioteca, comprovam-se tais iniciativas de atualização do design do mobiliário, mesmo porque parece que a direção está sempre preocupada em evitar males decorrentes de vícios de comportamento e doenças a eles associadas. Os percentuais presentes nos gráficos, apresentados a seguir, da Biblioteca do Senac/Santo Amaro quanto à altura e à disposição dos equipamentos de informática nas áreas de trabalho e pesquisa, demonstram tal fato: 


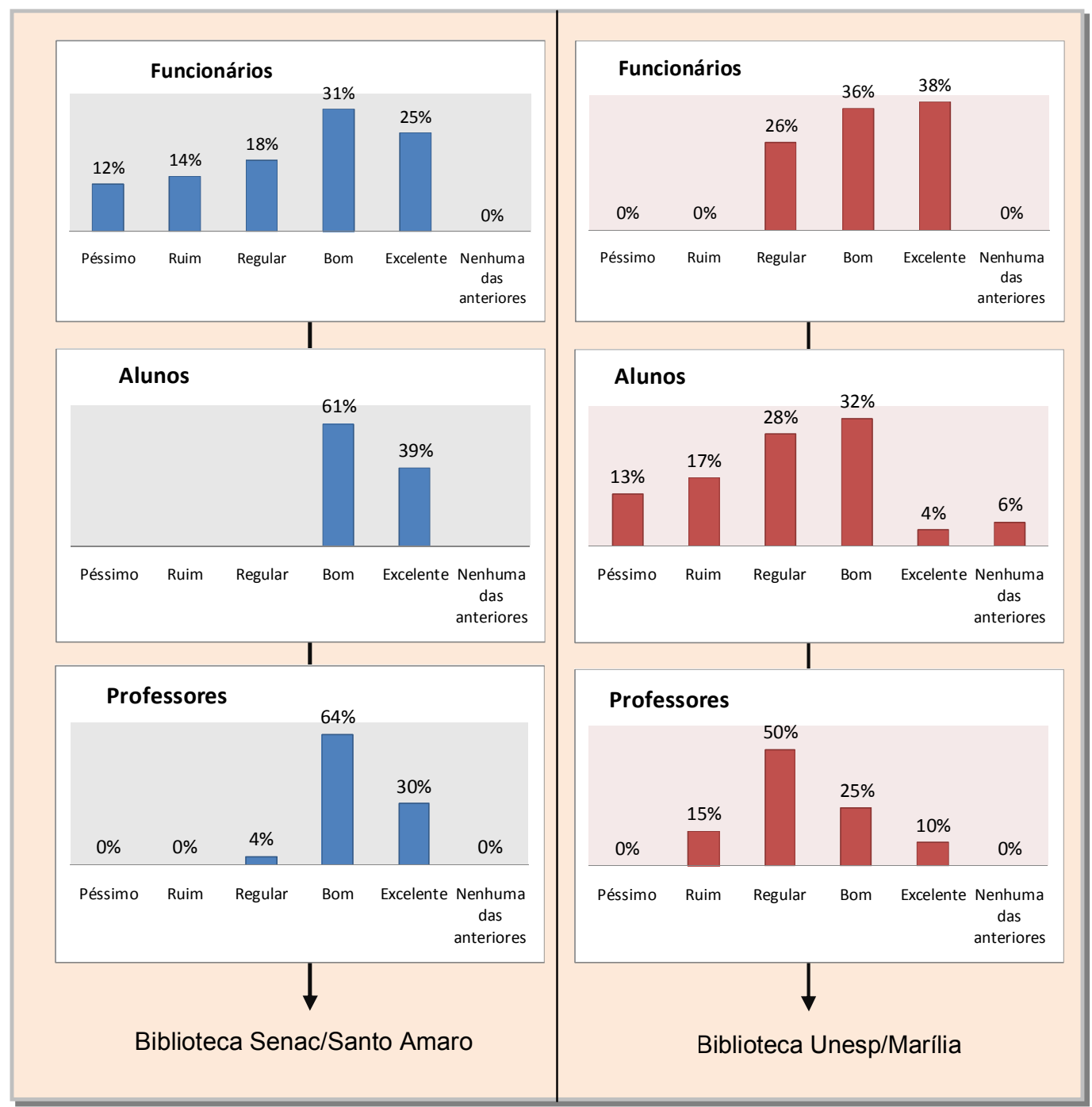

Figura 254 - Nível de Satisfação: altura e disposição dos equipamentos de informática (comput./impressora ) no posto de trabalho Biblioteca Senac/Santo Amaro e Biblioteca Unesp/Marília

Analisando os dados presentes na Tabela 05, constatam-se elementos importantes concernentes ao quesito analisado: (a) - todas as medidas anotadas na Biblioteca do Senac/Santo Amaro, referentes à disposição dos equipamentos de informática nos ambientes analisados, indicam que respeitam as normas vigentes quanto às dimensões máximas e mínimas de altura, largura e profundidade, demonstrando garantir bom desempenho junto aos usuários; (b) - mesmo que a norma estipule a largura mínima para o tampo do teclado de $50 \mathrm{~cm}$, este indicador não contempla o uso do mouse na maioria das estações de trabalho que utilizam microcomputadores. Neste estudo de caso, em que os valores giram em torno de 60,120 e $140 \mathrm{~cm}$, as condições de apoio e manipulação do mouse e de documentos não estão conflitantes com aqueles estabelecidos pela norma. (c) - com relação ao posicionamento do monitor de vídeo, 
mesmo considerando que as dimensões de profundidade do tampo analisadas estão dentro da norma, notou-se nas mesas individuais de pesquisa on-line da biblioteca, a dificuldade de regulagem do monitor impedindo ajustes para cima e para baixo.

\begin{tabular}{|c|c|c|c|}
\hline & \multicolumn{2}{|c|}{ ABNT - NBR 13.965/13.966-1997 } & \multirow{2}{*}{$\begin{array}{c}\text { Biblioteca Senac/Santo Amaro } \\
\text { Medidas - cm }\end{array}$} \\
\hline Itens & $\begin{array}{l}\text { Medidas } \\
\text { Mínimas }(\mathrm{cm})\end{array}$ & $\begin{array}{l}\text { Medidas } \\
\text { Máximas (cm }\end{array}$ & \\
\hline $\begin{array}{l}\text { Altura do tampo } \\
\text { regulável } \mathrm{p} / \text { monitor }\end{array}$ & 64 & 98 & 80 \\
\hline $\begin{array}{l}\text { Altura do tampo } \\
\text { regulável } \mathrm{p} / \text { teclado }\end{array}$ & 64 & 75 & 75 \\
\hline $\begin{array}{l}\text { Largura do tampo } \\
\text { regulável } \mathrm{p} / \text { teclado }\end{array}$ & 50 & - & $60-120-140$ \\
\hline $\begin{array}{l}\text { Profundidade do } \\
\text { tampo } \mathrm{p} / \text { monitor }\end{array}$ & 46 & - & $55-60$ \\
\hline $\begin{array}{l}\text { Profundidade do } \\
\text { tampo } p / \text { teclado }\end{array}$ & 22 & - & $60-75$ \\
\hline $\begin{array}{l}\text { Distância } \mathrm{p} / \\
\text { visualização do } \\
\text { monitor }\end{array}$ & 45 & - & $55-60$ \\
\hline
\end{tabular}

Em contrapartida, observou-se que o outro edifício analisado do estudo de caso, a Biblioteca da Unesp/Marilia, os resultados apresentados das avaliações, principalmente os extratos separados dos usuários, demonstraram níveis relativamente baixos de satisfação.

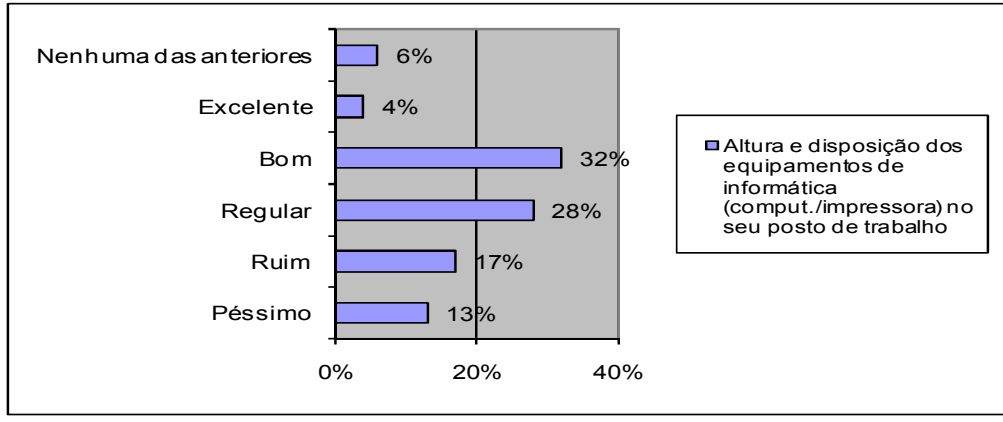

Gráfico 10 - Nível deSatisfação alunos: altura e disposição dos equipamentos de informática (comput./impressora) no posto de trabalho Biblioteca Unesp/Marília 


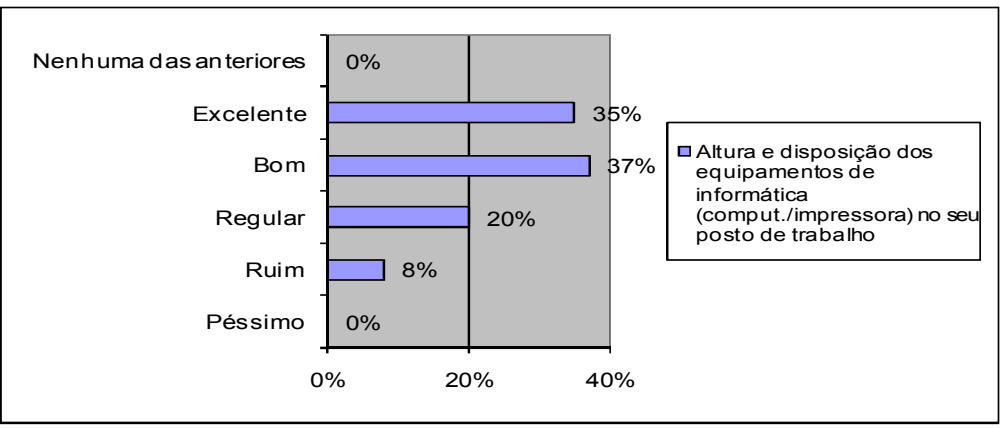

Gráfico 11 - Nível de Satisfação funcionários: altura e disposição dos equipamentos de informática (comput./impressora) no posto de trabalho Biblioteca Unesp/Marília

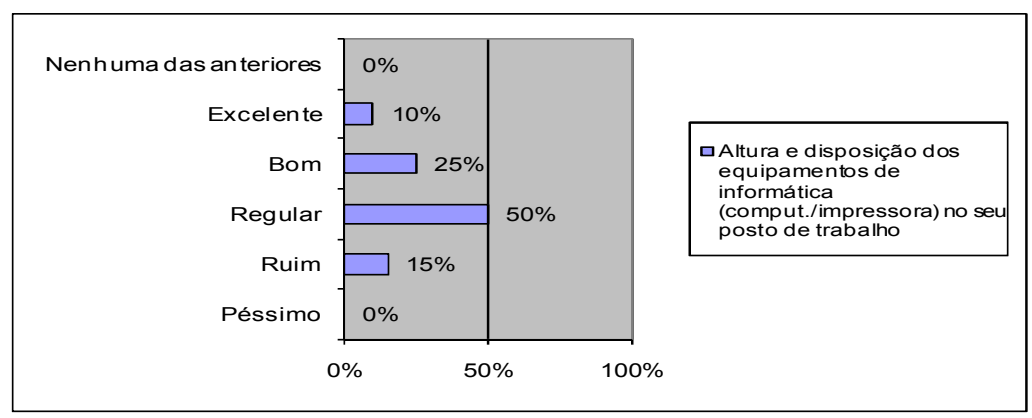

Gráfico 12 - Nível de Satisfação professores: altura e disposição dos equipamentos de informática (comput./impressora) no posto de trabalho Biblioteca Unesp/Marília

De acordo com os usuários, o local que apresenta os principais problemas quanto à disposição dos equipamentos de informática e, efetivamente, dificuldades quanto ao posicionamento de teclados e monitores, é a área destinada à consulta de bases de dados da biblioteca. Nesse espaço, os microcomputadores ficam posicionados em bancadas com altura de $130 \mathrm{~cm}$ e cadeiras, tipo banqueta, ficam à disposição dos usuários para as consultas. Do ponto de vista do uso, há dois problemas principais que acontecem no dia-a-dia das atividades de consulta nas bases de dados: o primeiro, a altura e o posicionamento dos monitores de vídeo não estão devidamente ajustados às necessidades ergonômicas dos consulentes; o segundo, as banquetas não possuem encosto e inclinação, sendo muito altas desconfortáveis para o uso diário, evidenciando o desconforto para o usuário, além de dificultarem a correta aproximação à superfície de trabalho. Outra questão anotada foi quanto ao uso da CPU embaixo do monitor de vídeo, o que pode causar desconforto e postura inadequada para determinadas pessoas. Do ponto de vista da norma NBR 13.965/13.966-1997, que estabelece o padrão de medidas para as mesas e móveis de informática, observa-se que 
as dimensões apresentadas na área destinada à consulta de bases de dados estabelecem valores incompatíveis e conflitantes, especificamente no item relacionado à altura do tampo para o monitor e teclado, como pode ser verificado na Tabela 06:

\begin{tabular}{|c|c|c|c|}
\hline \multirow[b]{2}{*}{ Itens } & \multicolumn{2}{|c|}{ ABNT - NBR 13.965/13.966-1997 } & \multirow{2}{*}{$\begin{array}{c}\text { Biblioteca Unesp/Marília } \\
\text { Medidas - cm }\end{array}$} \\
\hline & $\begin{array}{c}\text { Medidas } \\
\text { Mínimas }(\mathrm{cm})\end{array}$ & $\begin{array}{c}\text { Medidas } \\
\text { Máximas (cm }\end{array}$ & \\
\hline $\begin{array}{l}\text { Altura do tampo } \\
\text { regulável } \mathrm{p} / \text { monitor }\end{array}$ & 64 & 98 & 130 \\
\hline $\begin{array}{l}\text { Altura do tampo } \\
\text { regulável } p / \text { teclado }\end{array}$ & 64 & 75 & 130 \\
\hline $\begin{array}{l}\text { Largura do tampo } \\
\text { regulável } p / \text { teclado }\end{array}$ & 50 & - & 85 \\
\hline $\begin{array}{l}\text { Profundidade do } \\
\text { tampo p/ monitor }\end{array}$ & 46 & - & 60 \\
\hline $\begin{array}{l}\text { Profundidade do } \\
\text { tampo } \mathrm{p} / \text { teclado }\end{array}$ & 22 & - & 60 \\
\hline $\begin{array}{c}\text { Distância } \mathrm{p} / \\
\text { visualização do } \\
\text { monitor }\end{array}$ & 45 & - & 50 \\
\hline
\end{tabular}
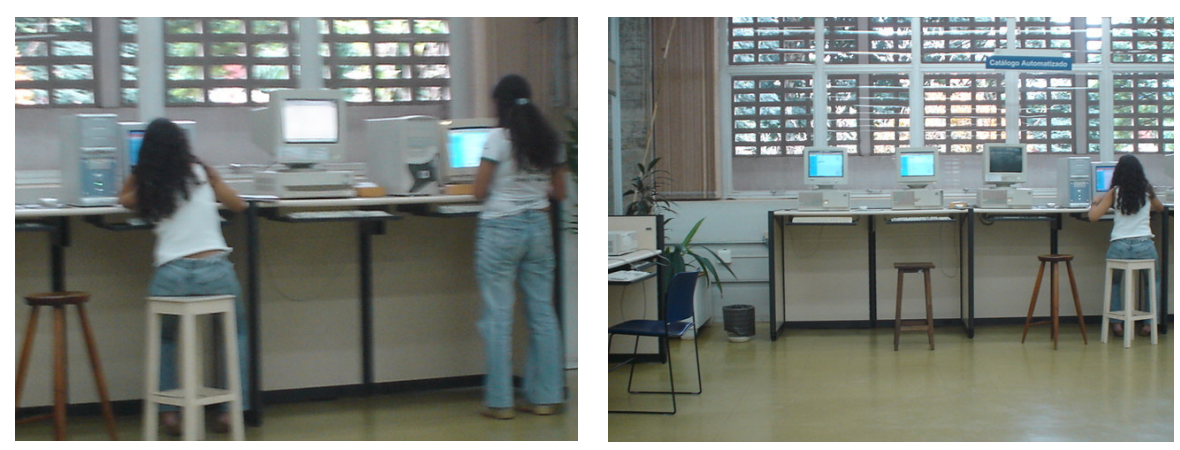

Figuras 255 e 256 - Área consulta base de dados - Biblioteca Unesp/Marília

No Capítulo 7 mencionou-se a importância da organização e da disposição espacial das coleções bibliográficas no âmbito da biblioteca universitária, para tanto, uma série de regras antropométricas e dimensionais deve acompanhar a busca e a recuperação da informação como, por exemplo, livros que devem estar ao 
alcance das mãos, prateleiras devidamente adequadas às cargas dos livros e dimensões das estantes suficientemente amplas para circulação de pessoas.

Analisando e comparando as condições dos dimensionamentos dos arquivos, estantes e armários dos estudos de caso da pesquisa, resultantes das observações técnicas e das informações fornecidas pelos usuários nos questionários da amostra, é possível estabelecer análises comparativas preliminares entre os edifícios. A seguir, são apresentadas as principais análises a respeito desse quesito:

- de modo geral, os níveis de satisfação foram considerados bastante satisfatórios, tanto no edifício da Biblioteca do Senac/Santo Amaro (65\% - excelente) quanto na Biblioteca da Unesp/Marília (48\% - excelente). No entanto, os piores percentuais de satisfação estavam entre o extrato de professores da Biblioteca da Unesp/Marília (50\% consideram regular). Como poderá ser visto posteriormente, na análise funcional das estantes e dos armários presentes nos ambientes das bibliotecas analisadas, esses baixos índices de satisfação estão relacionados, basicamente, com a dimensão crítica da estante no sentido vertical - 205 cm de altura - ou seja, essas medidas estão fora do padrão estipulado pela $N B R$ - 12743/1997, que prevê o valor máximo da altura de $200 \mathbf{c m}$ do solo. Além disso, os dados dimensionais citados anteriormente não são suficientes para enquadrar as dimensões mínimas adequadas à NBR - 9050/2004, norma que trata especificamente da acessibilidade de pessoas portadoras de dificuldade de locomoção;

- o maior índice de satisfação na Biblioteca do Senac/Santo Amaro ficou entre os alunos - $\mathbf{6 8} \%$ consideram excelentes as medidas e as dimensões relacionadas às estantes. Neste caso, os dados comprovaram que as instalações destinadas às estantes, principalmente entre o extrato de usuários que mais utiliza a biblioteca, respondeu afirmativamente às demandas de utilização.

- outro elemento verificado, principalmente por meio das visitas exploratórias, tanto na Biblioteca do Senac/Santo Amaro quanto na Biblioteca da Unesp/Marília, foram os aspectos relacionados às prateleiras horizontais: elas atendem o que estipula a $N B R-12743$ e $N B R-11678$, com largura de $91 \mathrm{~cm} \mathrm{e}$ altura de sete estantes para o armazenamento das coleções da biblioteca; 
- o maior índice de insatisfação na Biblioteca da Unesp/Marília está entre os funcionários que atuam diretamente nas áreas das estantes. Já no período das visitas técnicas e no contato com os funcionários, contaram-se algumas situações problemáticas levantadas por eles como, por exemplo, determinadas áreas do acervo bibliográfico não respeitavam a largura mínima necessária $(90 \mathrm{~cm})$ para a circulação de pessoas e, nas estantes dedicadas ao acervo Braile, algumas peças não estavam satisfazendo as normas dimensionais de armazenamento;

- outro dado importante verificado na Biblioteca do Senac/Santo Amaro foi a previsão de alguns espaços adicionais entre algumas estantes, de forma a deixar o trabalho bastante confortável e seguro entres os usuários e os funcionários;

- A profundidade das estantes também desempenharam papel fundamental na elevação das taxas de satisfação dos itens relacionados ao dimensionamento dos arquivos, estantes e armários presentes nas bibliotecas avaliadas. Os valores encontrados nas profundidades das prateleiras giraram em torno de $20 \mathrm{~cm}$; portanto, suficientemente adequados para o alcance dos livros e enquadrado na NBR $-10518 / 1997$. 


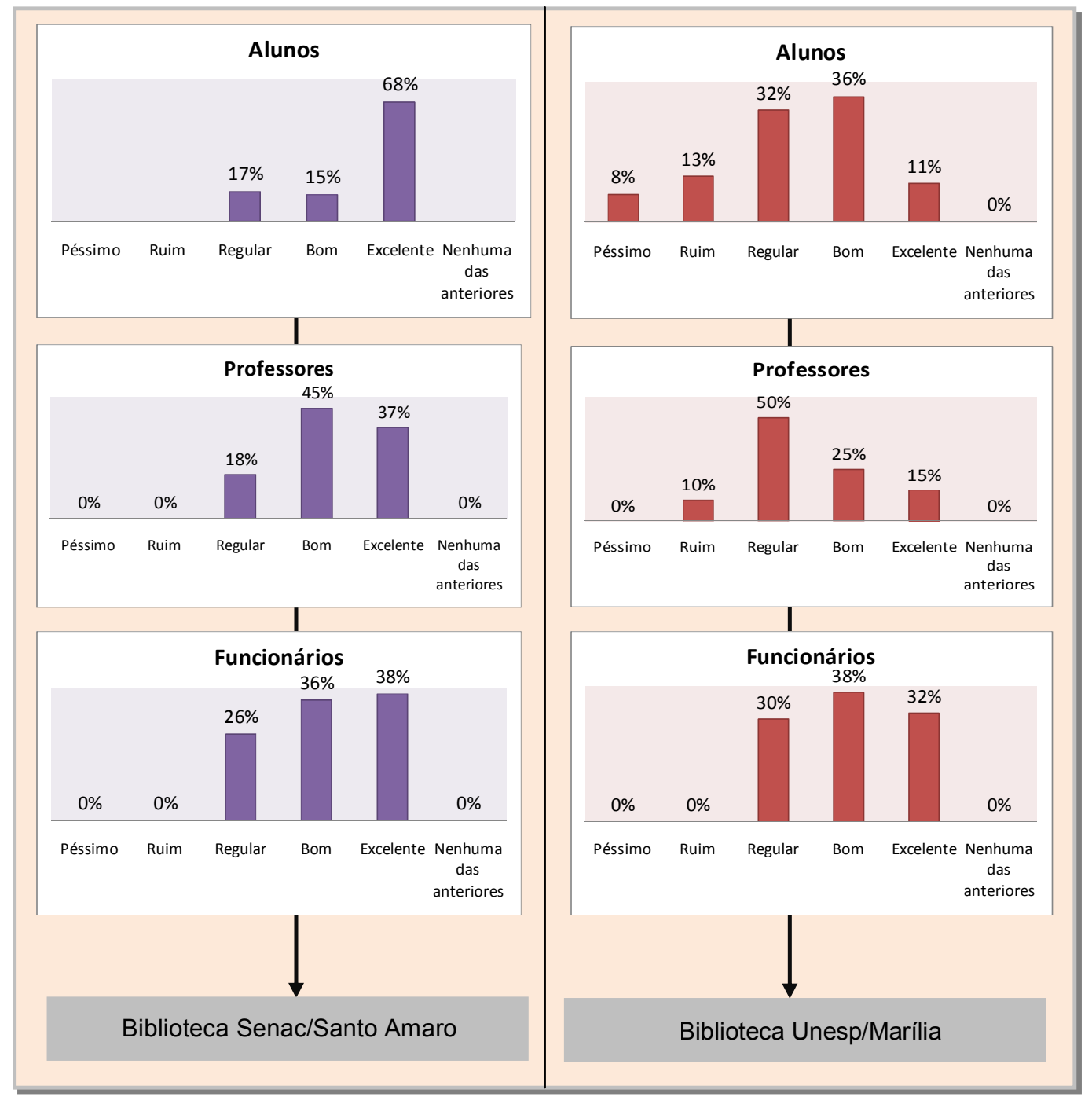

Figura 257 - Nível de Satisfação professores: dimensões dos arquivos, armários e estantes de trabalho Biblioteca Senac/Santo Amaro e Biblioteca Unesp/Marília 


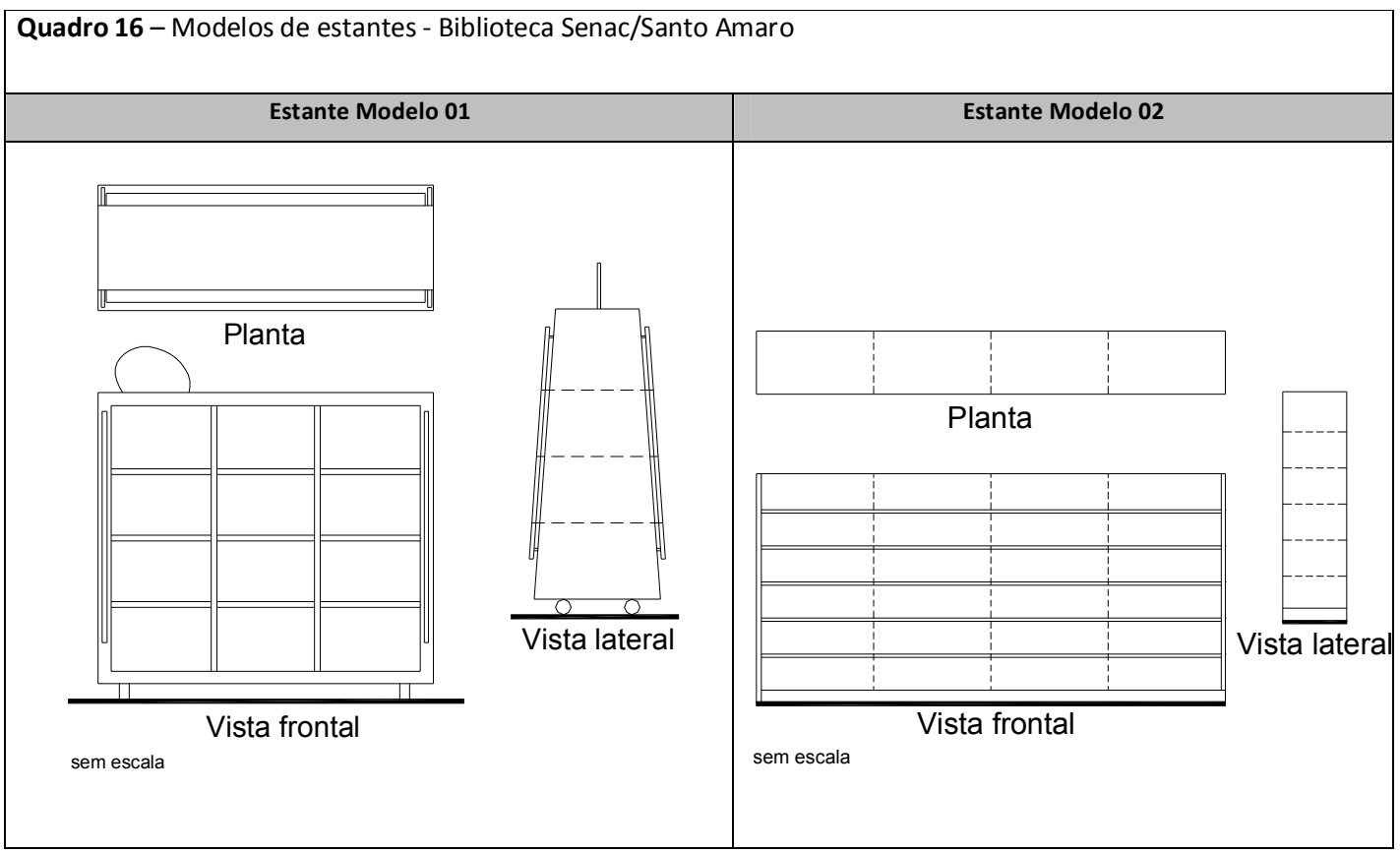

Observou-se que, na Biblioteca Senac/Santo Amaro, nas áreas destinadas ao acervo bibliográfico, a configuração básica das estantes estabelece dois (2) modelos de ocupação: o primeiro (Figura 258 - Modelo 01), é um tipo de estante desenhado especialmente para esta biblioteca, feita de madeira, com medidas compactas ( $h: 147$ $\mathrm{cm}, \mathrm{c}: 160 \mathrm{~cm}, \mathrm{l}: 40 \mathrm{~cm}$ ), dotadas de rodas e alça metálica nas laterais e são distribuídas ao longo do térreo e no primeiro pavimento. Além disso, este modelo apresenta uma variação na sua utilização; em algumas situações nos ambientes do acervo bibliográfico, a estante está agrupada em dois módulos espelhados; o segundo (Figura 259 - Modelo 2), são estantes metálicas e com medidas mais generosas ((h:200 cm, c:408 cm, l: 55 $\mathrm{cm}$ ) e estão localizadas no primeiro e segundo pavimento da biblioteca. 


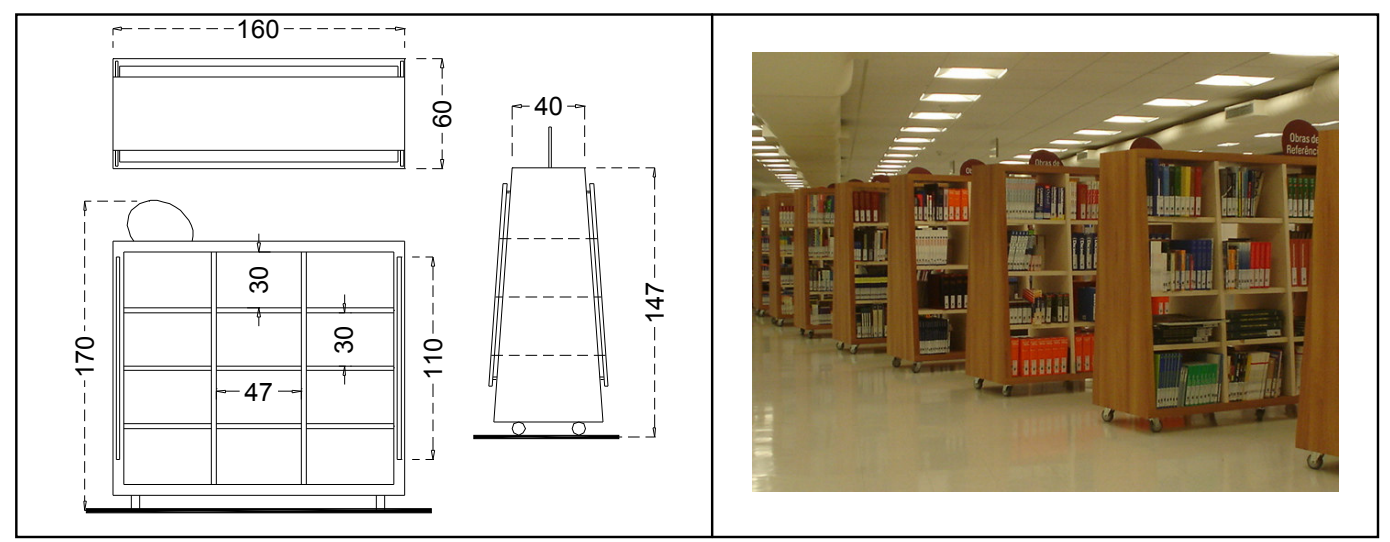

Figura 258 - Estantes - Modelo 01 - Biblioteca Senac/Santo Amaro (medidas em centímetros e sem escala)

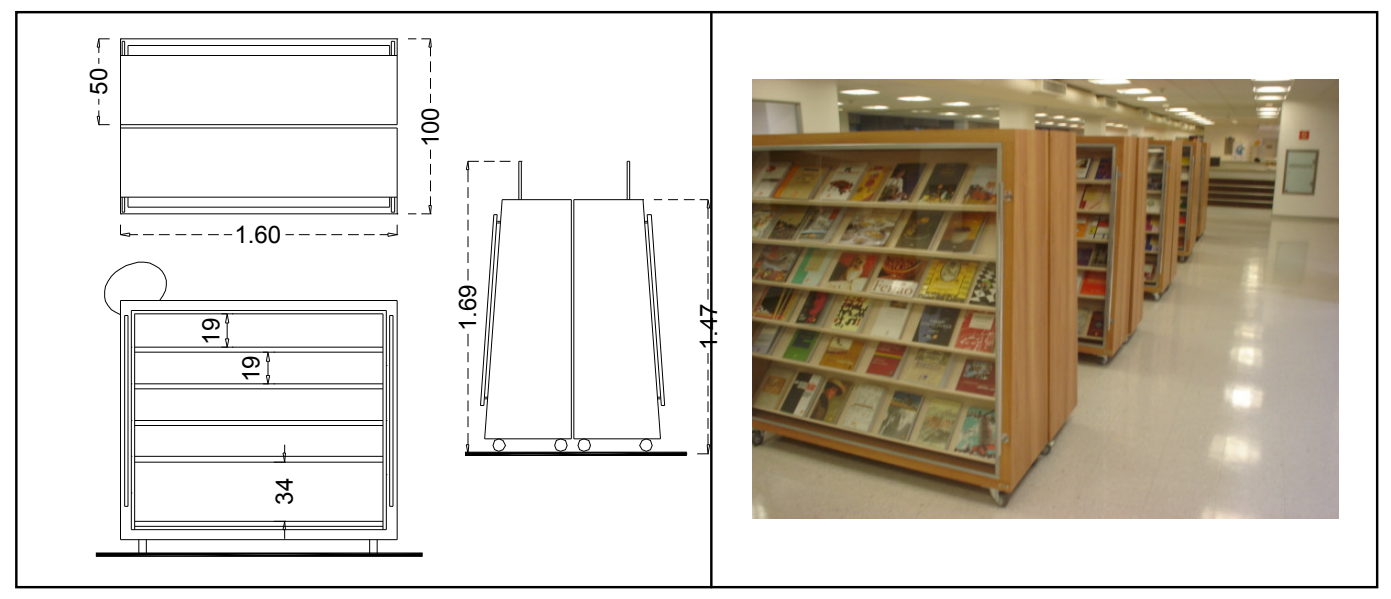

Figura 259 - Estantes - Modelo 01 - Biblioteca Senac/Santo Amaro (medidas em centímetros e sem escala)

Como foi descrito anteriormente, as estantes do Modelo 01 estão prioritariamente distribuídas no pavimento térreo e no primeiro pavimento e acomodam quase todos os itens do acervo da biblioteca, como por exemplo, Cd's, DVD's, revistas, periódicos, livros, material referencial, etc. Com a vantagem de possuírem rodas, as estantes podem ser movimentadas e posicionadas conforme a necessidade do arranjo espacial da biblioteca. No entanto, essa questão hoje tem seguido uma orientação bastante clara por parte da direção da biblioteca: a reconfiguração das estantes só será posta em prática com a análise e avaliação da equipe de arquitetos e da própria diretoria, no caso de um possível aumento do acervo bibliográfico. Outro elemento bastante 
relevante no design do Modelo 01 das estantes é o projeto de comunicação visual empregado, utilizando cores diferenciadas para cada área do conhecimento do acervo da biblioteca e variação nos tamanhos das placas indicativas. A procura de inovação e de melhoria no sistema de comunicação visual das estantes, por parte dos projetistas da Biblioteca do Senac/Santo Amaro, foi determinante nos bons resultados alcançados das avaliações junto aos usuários, principalmente, nos quesitos relacionados à facilidade e à rapidez na busca do material do acervo bibliográfico.

No caso específico da Biblioteca do Senac/Santo Amaro, a desvantagem encontrada no Modelo 01, que emprega a madeira como material principal, diz respeito à possibilidade de infestação de pragas, como o cupim, e a dificuldade na preservação dos documentos do acervo bibliográfico presente nas estantes. Este fato é explicado, principalmente, porque alguns seladores e adesivos emitem ácidos e outras substâncias danosas ao acervo, danificando não só o papel, mas todo o conjunto do material bibliográfico exposto. Nestes casos, Ogden (2001) recomenda uma série de medidas de segurança em relação às estantes de madeira que estejam sendo utilizadas como, por exemplo, a utilização de seladores, bloqueadores e resinas alquídicas com o objetivo de formar uma camada protetora contra as agressões físicas. Além de selar a madeira, as estantes devem ser revestidas com um material eficaz, com o intuito de fornecer uma proteção suficientemente intransponível ao material. Com relação a estas medidas de proteção, verificou-se que as estantes do Modelo 01 possuem revestimentos de laminados/MDF em suas faces internas, ou seja, na área onde está localizado o material (livros, revistas, etc) do acervo. 


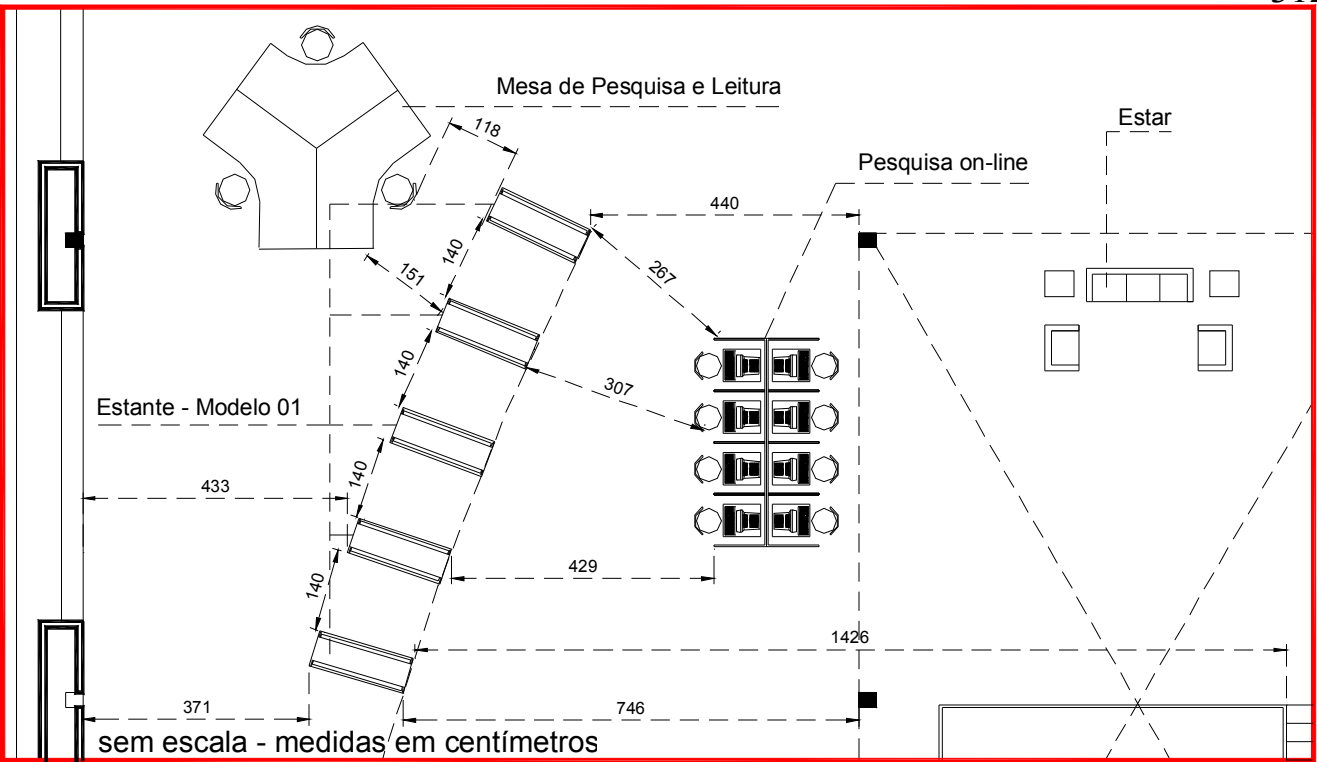

Figura 260 - Área do Pavimento Térreo - Estantes (Modelo 01) - Biblioteca Senac/Santo Amaro (medidas em centímetros e sem escala)

As estantes do Modelo 02 estão posicionadas no primeiro e segundo pavimento da Biblioteca Senac/Santo Amaro, e são diferenciadas do Modelo 01 por apresentarem medidas maiores, sendo $408 \mathrm{~cm}$ de comprimento, $55 \mathrm{~cm}$ de largura e 200 cm de altura. Com relação ao tipo de material empregado, o Modelo 02 utiliza o aço, diferentemente do que acontece com o Modelo 01, que utiliza a madeira. Nesse caso, foi possível verificar que o emprego do aço possibilitou vantagens relevantes como, por exemplo, facilidade na manutenção e na limpeza, excelente resistência e dificuldade de combustão. Além disso, as peças são confeccionadas em aço SAE 1010/1020 e atendem às exigências de segurança e resistência à abrasão e a umidade. Um dado importante, anotado junto aos funcionários durante o período da visita técnica na Biblioteca Senac/Santo Amaro, destacou pontos relevantes presentes nas estantes: o acabamento liso e não abrasivo, resistente a aranhões e a prateleira mais baixa, a uma altura de 10 $\mathrm{cm}$ do piso, protegendo as coleções dos danos provenientes da água, no caso de inundações, ou mesmo danos provocados durante a limpeza da biblioteca. 


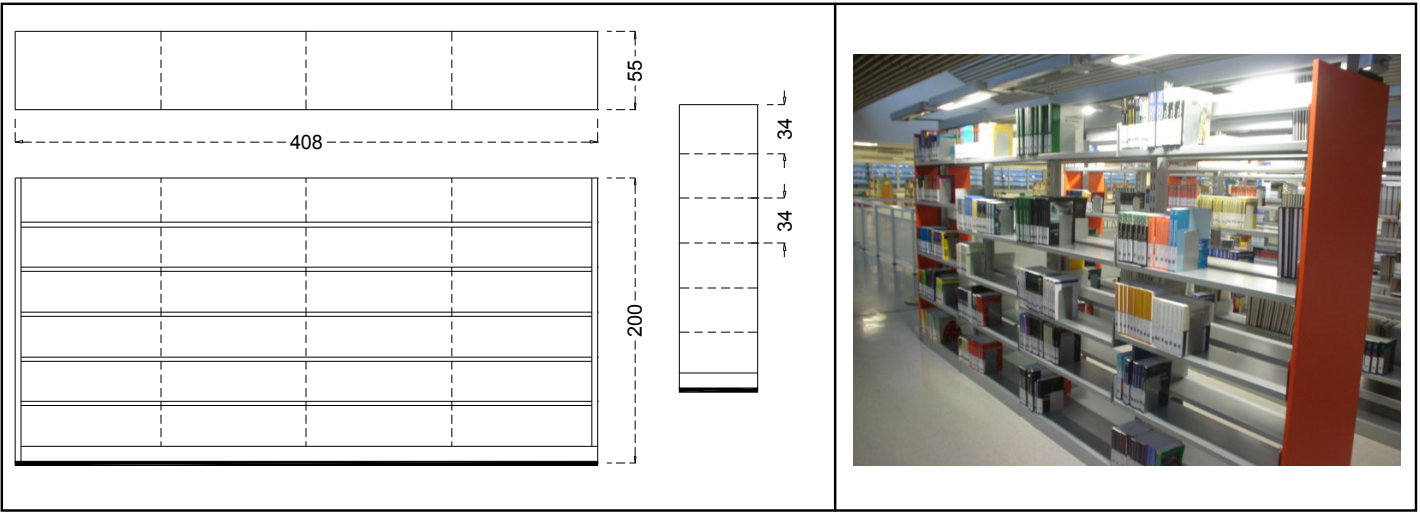

Figura 261 - Estantes - Modelo 02 - Biblioteca Senac/Santo Amaro (medidas em centímetros e sem escala)

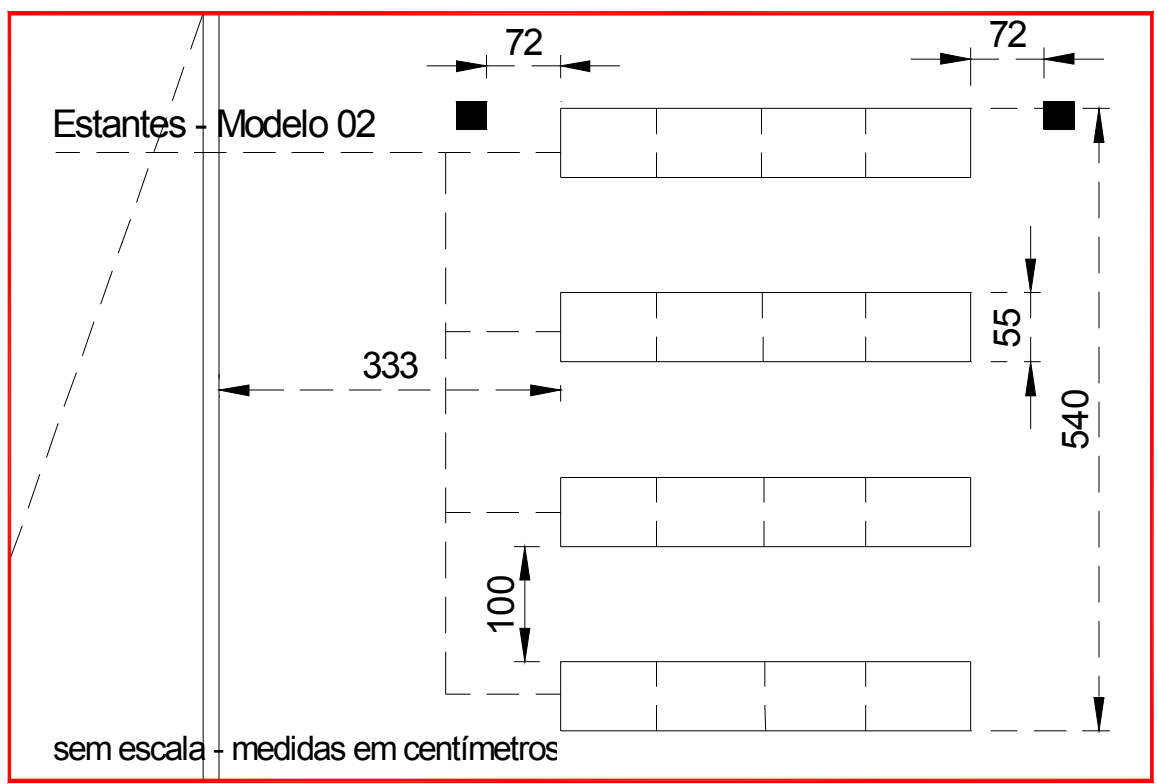

Figura 262 - Área do Segundo Pavimento - Estantes (Modelo 02) - Biblioteca Senac/Santo Amaro 


\begin{tabular}{|l|l|l|l|l|}
\hline Tipologias & Tabela 07 - Áreas/percentuais: edifício e estantes - Biblioteca Senac/Santo Amaro \\
\hline & & & \\
\hline
\end{tabular}

Com relação ao posicionamento das estantes na Biblioteca do Senac/Santo Amaro, no pavimento térreo estas (Estante - Modelo 01) ocupam um percentual de 3,35 \% da área útil construída, ou seja, 153,10 m2 dos 1.834,42 m2 de área útil; já no primeiro pavimento, as estantes (Estante - Modelo 01) ocupam uma parcela menos significativa, com um percentual de 7,38\%, sendo a área útil de $\mathbf{1 6 7 0 , 7 0}$ $\mathbf{m} 2$ e a área das estantes de $123,40 \mathrm{~m} 2$; e finalmente, no segundo pavimento, agregamse os dois tipos de estantes, a do Modelo 01 que ocupa um percentual de 8,44\%, área de 153, $10 \mathrm{~m} 2$ dos 1.730, $50 \mathrm{~m} 2$ e do Modelo 02, com um percentual de 17,04 \%, 
ocupando área de 295,40 m2. Comparando esses percentuais com os parâmetros recomendados pela Association of School Librarians, que considera $1 \mathrm{~m}^{2}$ de área de piso para 50 volumes, observa-se que o montante da área destinada às estantes do acervo bibliográfico é bastante suficiente e que o espaço para o crescimento do acervo da biblioteca estaria assegurado. Hoje, o acervo total da Biblioteca do Senac/Santo Amaro é de 90.450 unidades, distribuídos ao longo dos três pavimentos do edifício, perfazendo um total de área útil construída de 5.235,62 m2. Neste caso, aplicando-se os parâmetros da Association of School Librarians os percentuais dedicados ao espaço das estantes corresponderiam à ocupação de apenas $1 / 3$ da capacidade da biblioteca.

\begin{tabular}{|c|l|l|}
\hline \multicolumn{2}{|c|}{$\begin{array}{c}\text { Tabela 08 - Percentual de ocupação e crescimento das estantes - Biblioteca Senac/Santo Amaro } \\
\text { Referência - Association of } \\
\text { School Librarians }\end{array}$} & \multicolumn{2}{|c|}{ Biblioteca Senac/Santo Amaro } \\
\hline $1 \mathrm{~m} 2$ para 50 volumes & Área útil construída & $5.235,62 \mathrm{~m} 2$ \\
\cline { 2 - 3 } & Acervo atual & 90.450 volumes \\
\cline { 2 - 3 } & $\begin{array}{l}\text { Previsão final do acervo } \\
\text { bibliográfico }\end{array}$ & 261.781 volumes \\
\cline { 2 - 3 } & \begin{tabular}{l} 
Percentual ocupado \\
\cline { 2 - 3 }
\end{tabular} & $34,55 \%$ \\
\hline
\end{tabular}

Do ponto de vista da eficiência e do uso das estantes do acervo bibliográfico da Biblioteca do Senac/Santo Amaro, existe uma relação importante entre a área útil, construída e o percentual de ocupação em cada pavimento do edifício. $\mathrm{O}$ planejamento e a distribuição adequada das estantes nos ambientes analisados influenciaram positivamente não só na distribuição coerente dos diversos sistemas componentes do layout, mas também na eficiência do pavimento sob os aspectos da flexibilidade, do espaçamento e da distribuição no ambiente. No caso da Biblioteca do Senac/Santo Amaro, os percentuais das áreas das estantes, tanto do Modelo 01 quanto do Modelo 02, apresentaram valores acima do mínimo indicado pela norma $N B R-$ 1274 e isso, de certa maneira, pode justificar o fato de este item ter sido o mais bem avaliado por parte dos usuários. Além disso, é importante frisar que o planejamento 
eficiente das estantes, em conjunção com um desenho de modulação de pilares por pavimentos, ocasionou poucas perdas na distribuição dos espaços e circulações adjacentes do acervo bibliográfico. Portanto, é possível concluir preliminarmente que a correta conexão entre a área útil construída, os percentuais de ocupação das estantes e o processo de planejamento interno do edifício de biblioteca é fator decisivo e direto para a qualidade espacial, contribuindo para que as interferências no layout dos ambientes aconteçam de forma eficiente ao longo do ciclo de vida útil do edifício.

Quanto às estantes instaladas na Biblioteca da Unesp/Marília, observa-se apenas uma tipologia existente (Modelo 03), utilizando as seguintes características: são construídas em aço SAE 1010/1020; possuem tratamento anti-corrosivo e pintura eletrostática a pó; são pintadas na cor cinza e apresentam altura $200 \mathrm{~cm}$, largura $100 \mathrm{~cm}$ e $55 \mathrm{~cm}$ de profundidade. Esse modelo está posicionado tanto no pavimento térreo quanto no pavimento inferior da biblioteca e as necessidades de armazenamento do acervo bibliográfico. Ao longo dos ambientes onde ficam distribuídas as estantes do Modelo 03 e, conforme a necessidade de acomodação do acervo, existe uma pequena variação dimensional no sentido da largura, ora utilizando peças de $100 \mathrm{~cm}$ de largura e ora tendo que reduzir este valor para a metade, ou seja, $50 \mathrm{~cm}$. No caso do pavimento térreo, esta situação acontece de maneira mais constante, em virtude principalmente do baixo percentual de área destinada ao acervo da biblioteca e a necessidade natural de acomodar mais espaço para as estantes.

Outro parâmetro importante, analisado anteriormente, diz respeito às vantagens de utilização do aço nas estantes. Tanto na Biblioteca do Senac/Santo Amaro quanto neste caso, na Biblioteca da Unesp/Marília foi também possível confirmar que o emprego do aço, do ponto de vista da manutenção, limpeza e resistência possibilitou o aproveitamento correto das estantes nos ambientes analisados. Contudo, notaram-se em algumas peças do Modelo 03, desgastes nas superfícies e nas junções das prateleiras, deixando o aço exposto e ocasionando possíveis problemas de oxidação das estantes. Tentando compreender as causas desse problema, constatou-se que as estantes que apresentaram essa deficiência foram aquelas que possuíam maior tempo de vida na biblioteca e que deveriam passar por um processo de restauro ou troca completa. 


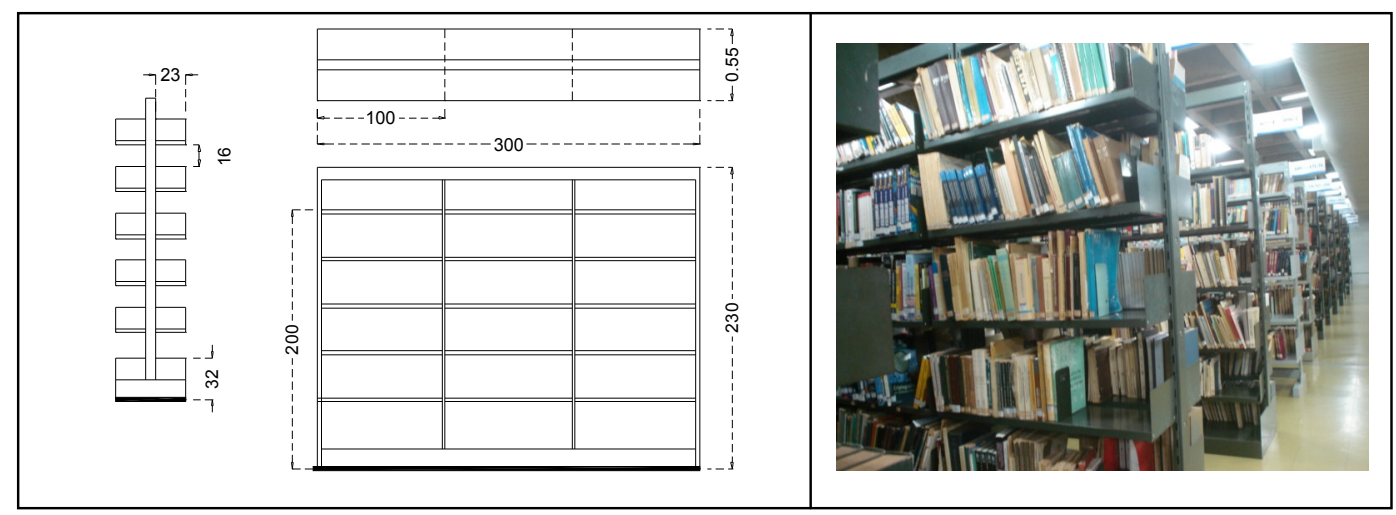

Figura 263 - Estantes - Modelo 03 - Biblioteca Unesp/Marília (medidas em centímetros e sem escala)

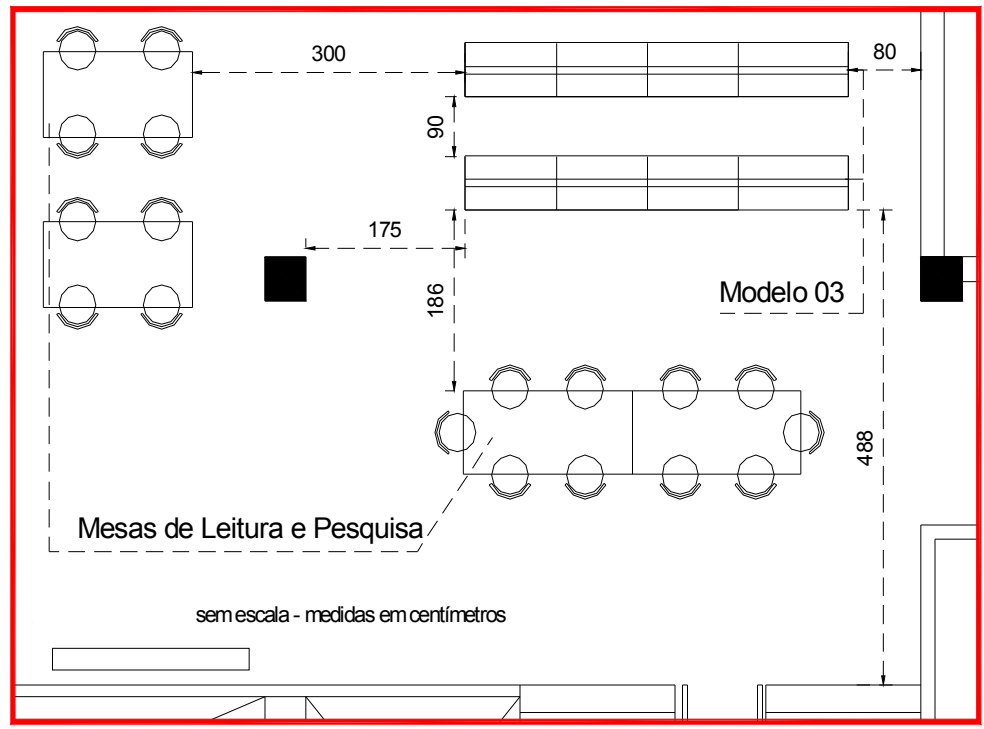

Figura 264 - Área Pavimento Inferior - Estantes (Modelo 03) - Biblioteca Unesp/Marília

Quanto ao posicionamento e aos percentuais das estantes nos pavimentos da Biblioteca da Unesp/Marília, são evidentes as diferenças em relação ao edifício da Biblioteca do Senac/Santo Amaro, tanto nas tipologias existentes quanto nas áreas destinadas às estantes dos pavimentos analisados. Em termos de área destinada às estantes (Modelo 03) no pavimento térreo o percentual é de 22,45\% para uma área útil construída de $\mathbf{9 0 7 , 5 0 ~ m 2 ~ e , ~ n o ~ p a v i m e n t o , ~ i n f e r i o r ~ t e m - s e ~ 1 5 , 2 9 \% ~ o ~ p e r c e n t u a l ~ d e ~}$ estantes para uma área útil construída de 441,20 m2. Comparando com os parâmetros da Association of School Librarians (Tabela 09), os percentuais destinados às estantes estão proporcionalmente acima dos valores recomendados pela norma, ou seja, o ambiente já está com sua capacidade de acervo esgotada, sugerindo que o edifício 
avaliado seja ineficiente sob esse ponto de vista. Como foi mostrado anteriormente, o crescente aumento dos cursos de graduação e pós-graduação na unidade do campus/Marília, e, por conseguinte, o natural acréscimo do acervo bibliográfico nos últimos anos, influenciou sobremaneira no esgotamento do espaço físico da biblioteca, principalmente, sob o aspecto da acomodação do acervo. É importante frisar que, mesmo com todos os esforços da direção no sentido de flexibilizar o ambiente do acervo, adaptar os espaços de utilização das novas coleções e planejar novas alternativas de ocupação, a falta de espaço no acervo bibliográfico tornou-se um grande problema a ser enfrentado. Além disso, em detrimento desse aumento, alguns espaços destinados às áreas de leitura e pesquisa foram sendo substituídos paulatinamente por estantes para acomodação do acervo. Ainda, esse quadro tem sido fator limitador no processo de crescimento do acervo e na aquisição de novos volumes, já que a restrição no espaço físico tem sido uma realidade bastante presente. No entanto, nesse caso, recomenda-se uma averiguação mais aprofundada e integrada das coleções do acervo, a freqüência de sua manipulação, as exigências de armazenamento e a análise das características do partido arquitetônico do edifício para que se possa, então, formatar um possível aumento ou haja proposta da construção de um novo prédio.

\begin{tabular}{|c|l|l|}
\hline \multicolumn{2}{|c|}{\begin{tabular}{l} 
Tabela 09- Percentual de ocupação e crescimento das estantes - Biblioteca Unesp/Marília \\
\hline $\begin{array}{c}\text { Referência - Association of } \\
\text { School Librarians }\end{array}$
\end{tabular}} & \multicolumn{2}{|c|}{ Biblioteca Unesp/Marília } \\
\hline $1 \mathrm{~m} 2$ para 50 volumes & Área útil construída & $1.348,70 \mathrm{~m} 2$ \\
\cline { 2 - 3 } & Acervo atual & 77.861 volumes \\
\cline { 2 - 3 } & $\begin{array}{l}\text { Previsão final do acervo } \\
\text { bibliográfico }\end{array}$ & 67.435 volumes \\
\cline { 2 - 3 } & Percentual ocupado & $115,46 \%$ \\
\hline
\end{tabular}




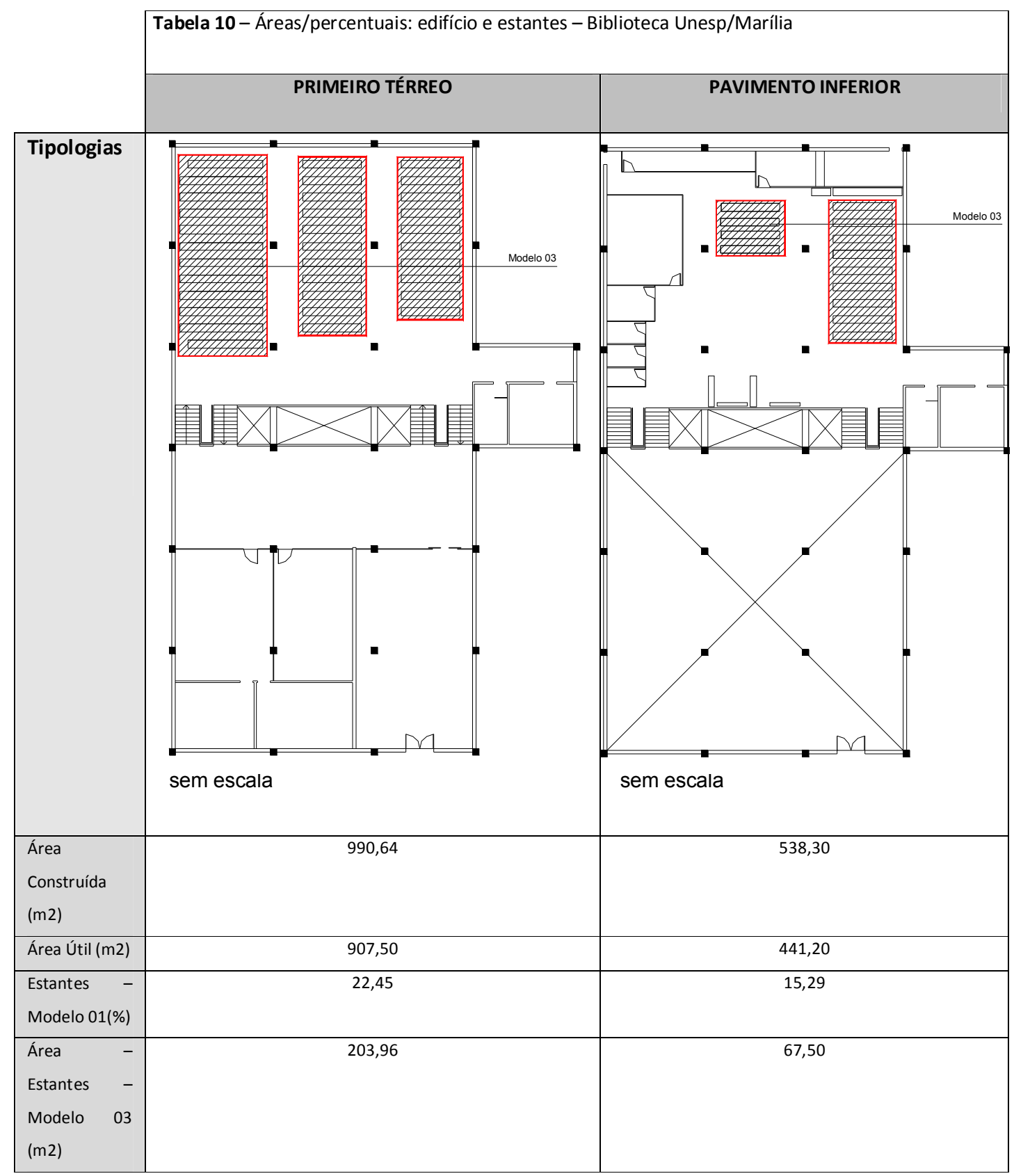

Há 13 modelos de armários presentes na Biblioteca Da Unesp/Marília destinados à função de armazenagem de documentos e papéis, prioritariamente nas áreas administrativas (salas da direção, gerência, auxiliares técnicos, bibliotecários, etc.) dos três pavimentos da biblioteca. Nos ambientes do primeiro e segundo pavimento, localizam-se duas ilhas de atendimento ao usuário da biblioteca, nas quais se posicionam módulos de armários baixos acoplados às mesas. Além disso, algumas salas 
destinadas aos usuários como, por exemplo, salas de estudo em grupo, salas de reuniões e sala de design também recebem alguns modelos de armários para armazenagem. Fora isso, a sala de reprografia, que utiliza as funções de cópia/impressão e armazenamento de documentos dos usuários, dispõe de uma organização física planejada de modelos de armários própria para esta função. Outro aspecto importante na disposição do layout das áreas de armazenamento da biblioteca é a presença de arquivos deslizantes posicionados no Acervo da Fitoteca, localizado no pavimento térreo e junto ao setor de empréstimo e de devolução.

Os armários presentes nos ambientes de trabalho da Biblioteca Senac/Santo Amaro utilizam dois tipos de materiais: o primeiro, de madeira aglomerada de $18 \mathrm{~mm}$, revestimento superior em BP dupla face, bordas acabadas em fita de poliestireno de $2 \mathrm{~mm}$ e base de apoio de aço; o segundo, em chapa de aço, com bases duplas e pintura eletrostática. Com relação ao emprego deste tipo de material, as vantagens são as mesmas apresentadas nas estantes do acervo bibliográfico: facilidade na manutenção e na limpeza, excelente resistência e dificuldade de combustão. No caso específico da Biblioteca do Senac/Santo Amaro, a exigência da correta adequação dos armários e, principalmente neste tópico, a qualidade dos acabamentos que deveriam estar presentes nos ambientes de trabalho, ficam evidentes na instalação de um mobiliário com alto grau de qualidade e acabamento, não somente nas áreas destinadas à administração, mas também em todos os locais utilizados pelos demais usuários. Ainda, com relação ao acabamento dos armários, as tonalidades utilizadas (tons de cinza claro e branco) deixam transparecer uma impressão de ambiente mais formal e, em certa medida, evidenciam uma rigidez hierárquica, até mesmo no uso dos espaços. 


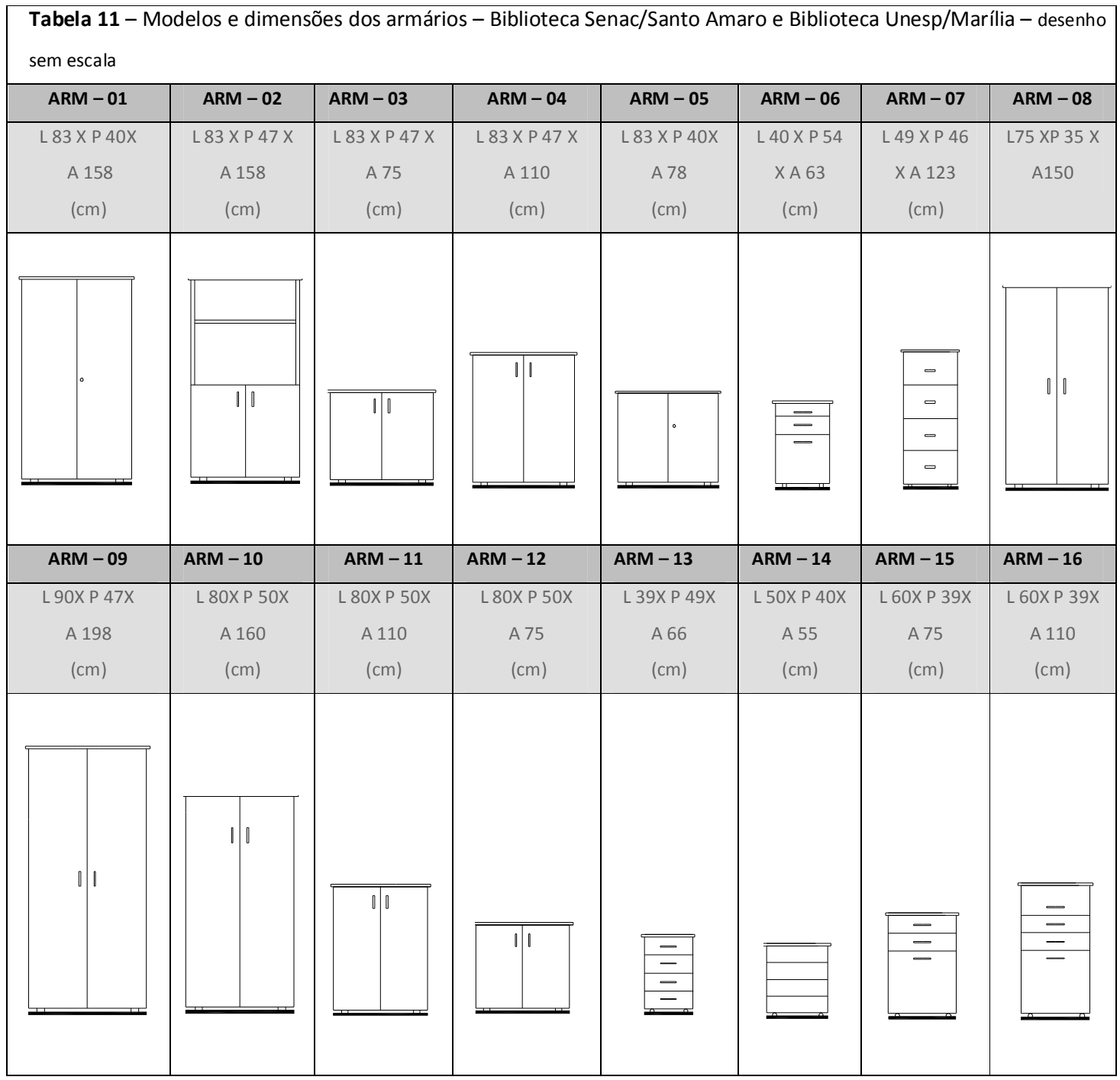

Do ponto de vista das medidas dos armários da Biblioteca do Senac/Santo Amaro, é pertinente estabelecer um grau de comparação entre os valores estabelecidos pela norma da NBR 13.961/1997, a qual referencia os valores mínimos e máximos da largura, profundidade e altura dos armários no ambiente de trabalho e o nível de satisfação do usuário obtida em relação a esse item. É possível, também, verificar se estes resultados são condizentes com valores mínimos exigidos pela norma vigente.

Como pode ser visto na Tabela 11, o único arquivo deslizante da Biblioteca Senac/Santo Amaro, localizado no Acervo da Fitoteca, respeita os valores mínimos da norma da $N B R$ - 13.961/97 quanto à largura mínima do arquivo e do espaço de circulação entre eles. No caso específico deste quesito, o índice de satisfação entre os 
funcionários que operam este setor de armazenamento da biblioteca foi bastante positivo, indicando que as medidas e as dimensões dos armários colaboram no uso e na operação dos mesmos. Da mesma forma, esses índices reforçam que o sistema de arquivos deslizantes, que possibilita um número muito maior de armazenamento, é uma das principais alternativas a serem utilizadas em ambientes de bibliotecas, reduzindo em até $50 \%$ o uso do espaço, com uma organização melhor e um acesso mais fácil e rápido ao acervo. Porém, no Brasil, esse procedimento ainda não parece ser realidade, principalmente porque o custo de aquisição deste arquivo deslizante é muito alto e aí a impossibilidade da utilização deste sistema fica bastante clara entre as bibliotecas brasileiras. Além disso, se a instituição optar por esta solução, todo o processo de implantação deverá ser acompanhado de um minucioso planejamento do ambiente, principalmente se a arquitetura do edifício ou do local não foi previamente dimensionada estruturalmente e preparada para receber este tipo de instalação. Portanto, levando-se em consideração, no caso da Biblioteca do Senac/Santo Amaro, de ser um edifício de alto padrão e ter instalações e equipamentos de última geração, seria bastante coerente que a instituição revertesse seus investimentos na aquisição de mais arquivos deslizantes, mesmo tendo bons índices de satisfação entre os usuários.

Quanto aos outros armários existentes Biblioteca do Senac/Santo Amaro, os dados comparativos entre as Tabela 11 e 12 revelam itens importantes, como se pode constatar a seguir:

- todos os modelos de armários presentes nos ambientes da biblioteca estão adequados ao item relacionado à largura, com exceção de dois modelos, ARM 06 e o ARM - 12, com larguras de $40 \mathrm{~cm}$ e $39 \mathrm{~cm}$, respectivamente, ou seja, estão fora da medida mínima estipulada pela norma de $41 \mathrm{~cm}$;

- quanto ao quesito da profundidade do armário, vários modelos não se enquadram na norma, que estipula valores mínimos de $45 \mathrm{~cm}$ e máximos de 63 cm. Assim, os modelos de armários que apresentaram problemas dimensionais são: ARM - 01, ARM - 05, ARM - 06, ARM - 08, ARM - 13, ARM - 14, $\mathrm{ARM}-15$ e ARM - 16;

- no item que relaciona a altura do armário baixo, apenas o modelo ARM - 05 apresentou o valor em discordância com a norma, que configura $75 \mathrm{~cm}$ como medida máxima para o armário; 
- o índice que indica a altura do armário médio, estabelecendo a faixa entre a medida mínima de $75 \mathrm{~cm}$ e medida máxima de $141 \mathrm{~cm}$, foi o que apresentou melhor aproveitamento em relação à norma vigente, com todos os modelos adequados;

- na análise do quesito que trata da altura do armário alto, somente um modelo está fora da norma, o ARM - 09, que indica $198 \mathrm{~cm}$, contra os $185 \mathrm{~cm}$ estabelecidos pela NBR 13.961/97.

Esses resultados comprovam que, mesmo tendo sido considerados bons os índices de satisfação dos usuários nos ambientes da Biblioteca do Senac/Santo Amaro, relacionados ao dimensionamento dos armários, existem problemas pontuais nas medidas que poderão afetar de modo adverso a produtividade no trabalho das pessoas no âmbito da biblioteca. Contudo, constatou-se que o espaço destinado ao armazenamento, principalmente nas áreas administrativas da biblioteca, não se constitui em um problema diante da grande quantidade de documentos a serem guardados, ou seja, os padrões dimensionais utilizados pelos armários com função de armazenamento, no geral, seguiram medidas adequadas.

Observou-se, também, que a importância da participação do usuário no processo de projeto e a escolha do mobiliário dos ambientes de trabalho, vislumbrando uma melhor compatibilidade entre a norma específica de ergonomia e a realidade específica do próprio usuário, pode torná-lo mais comprometido e ajustado às necessidades do dia-a-dia. Portanto, sugere-se neste caso da Biblioteca do Senac/Santo Amaro, mesmo que esteja seguindo orientações e padrões estabelecidos pela instituição, pertinentes às medidas e dimensões de armários, que não haja rigidez na padronização dos diversos componentes do mobiliário e que se insista na constante consulta destes itens junto aos usuários nos ambientes de trabalho. 


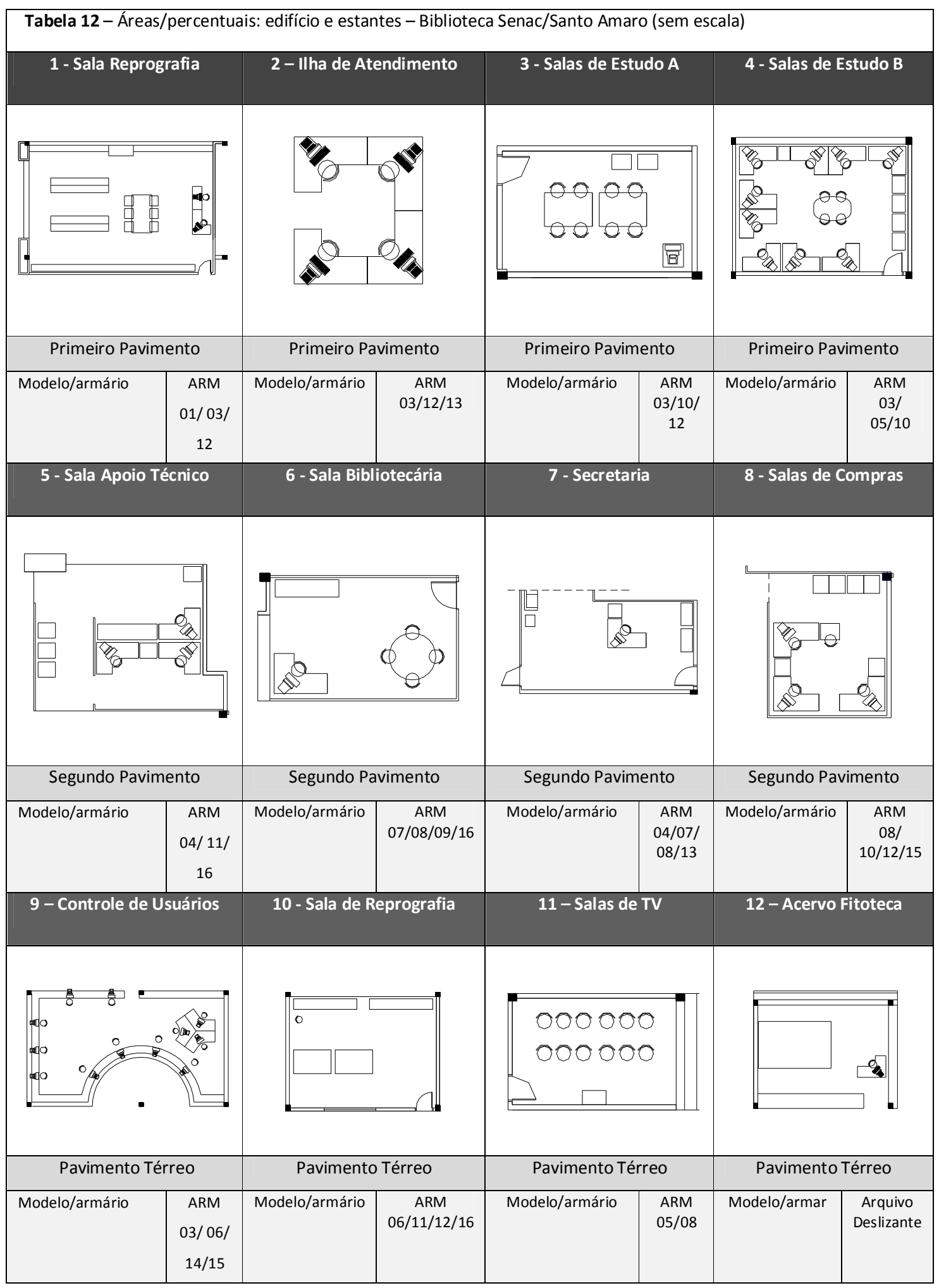




\begin{tabular}{|l|c|c|}
\hline \multicolumn{2}{|l|}{ Tabela 13 - Armários e arquivos deslizantes: dimensões (baseado em dados da norma ABNT - NBR 13.961/97) } \\
\hline Itens & Medidas Mínimas (cm) & Medidas Máximas (cm) \\
\hline Largura do arquivo deslizante & 45 & ------ \\
\hline $\begin{array}{l}\text { Largura do armário } \\
\text { baixo/médio/alto }\end{array}$ & 41 & 63 \\
\hline $\begin{array}{l}\text { Profundidade do armário baixo/ } \\
\text { médio/alto }\end{array}$ & 45 & 75 \\
\hline Altura do armário baixo & ---- & 141 \\
\hline Altura do armário médio & 75 & 185 \\
\hline Altura do armário alto & 141 & \\
\hline
\end{tabular}

A Biblioteca da Unesp/Marília conta com 09 modelos de armários -

Tabela 11 - destinados especificamente à função de armazenamento, atendendo às áreas administrativas e alguns setores de atendimento ao usuário. A maioria dos armários é de aglomerado de $18 \mathrm{~mm}$ e, como no caso da Biblioteca do Senac/Santo Amaro, recebe revestimento superior em BP dupla face, bordas acabadas em fita de poliestireno de $2 \mathrm{~mm}$ e base de apoio de aço. Apenas um modelo de aço é utilizado na Sala de Novas Aquisições, localizada no Setor Técnico da biblioteca e, neste caso, os armários tem a função de receber e armazenar uma quantidade grande de livros, sempre em intervalos de tempos entre 15 dias a um mês. Ou seja, passaram a executar uma tarefa de carga de armazenamento não indicada para esse modelo, como relatado pelos próprios funcionários do setor. A mesma situação acontece no Setor de Fotocópias, onde alguns armários destinados originalmente ao armazenamento de material leve, como papéis e similares, são destinados a receber uma quantidade excessiva de livros, comprometendo consideravelmente o sistema estrutural do armário de aço.

Outro aspecto importante diz respeito às medidas dos armários da Biblioteca da Unesp/Marília e suas relações estabelecidas com a norma da NBR 13.961/1997. Os levantamentos e as análises técnicas efetuadas nos ambientes da biblioteca indicaram que, dos 9 modelos de armários estudados, destinados à função de arquivamento, apenas dois modelos se encontram em desacordo com a norma vigente: $\mathrm{o}$ primeiro, o ARM - 09, localizado no Setor de Catalogação, apresenta altura de $198 \mathrm{~cm}$, fora da faixa indicada pela norma que é de $185 \mathrm{~cm}$; o segundo, o ARM - 14, um arquivo baixo instalado na área atendimento ao usuário, no pavimento térreo, apresenta a profundidade de $40 \mathrm{~cm}$, pouco abaixo do que a norma estipula, de $41 \mathrm{~cm}$. O restante dos modelos enquadra-se nas medidas de altura, profundidade e largura requerida pela NBR 13.961/1997. No entanto, os resultados apresentaram respostas diferentes entre os 
usuários e um nível de satisfação um pouco baixo, se comparado com as avaliações da Biblioteca do Senac/Santo Amaro. Provavelmente esses resultados podem indicar problemas relacionados não com as dimensões e medidas dos armários em si, mas com fatores diretamente ligados à percepção dos funcionários na disposição do layout dos armários no ambiente de trabalho. Ou seja, o usuário relaciona e confunde a possível falta de espaço do armário no ambiente da biblioteca (layout), com as próprias especificações técnicas das dimensões dos armários (altura, profundidade e largura).

Ainda com relação ao nível de satisfação do dimensionamento dos armários nos edifícios, especificamente relacionado ao armazenamento documental administrativo, todos eles tiveram índices menores de satisfação, em função da quantidade de documentos a serem guardados. De fato, nos últimos três anos, o acervo bibliográfico da Biblioteca da Unesp/Marília obteve um aumento considerado bastante grande, na ordem de $18 \%$ do total, em função da instalação de quatro novos cursos de graduação e um curso de pós-graduação. Em contato com a coordenação da unidade universitária e a direção da biblioteca, ambas confirmaram constante aquisição de material bibliográfico destinado não só aos departamentos dos cursos de graduação e pós-graduação, mas também, prioritariamente, grande quantidade de material encaminhada ao acervo da própria biblioteca. O reflexo direto dessas ações é o aumento natural de documentos destinados à aquisição, controle e distribuição de todo acervo bibliográfico, bem como o acúmulo das demandas burocráticas inerentes a esse tipo de serviço.

Do ponto de vista da presença de arquivos deslizantes na Biblioteca da Unesp/Marília, não existe nenhum modelo deste arquivo no acervo, mesmo que o índice de ocupação dos armários de arquivamento seja considerado muito grande na área administrativa. Em meio a esta realidade, questionou-se a direção da biblioteca se existia, no planejamento da instituição, a possibilidade da compra deste tipo de mobiliário. A resposta foi afirmativa, entretanto, os entraves burocráticos e a falta de repasses por parte do governo, que administra a instituição, vêm constantemente bloqueando o processo de aquisição dos arquivos deslizantes. Em função disso, as visitas exploratórias puderam comprovar, por meio das entrevistas com os funcionários e das fotografias registradas, que o setor que mais sofre é o que executa as funções de catalogação e controle bibliográfico. 


\section{3 Áreas destinadas ao armazenamento de uso comum}

Apesar de todo avanço no processo de digitalização e virtualização do material bibliográfico, poucas bibliotecas têm investido o suficiente para migrar sua documentação administrativa em papel para arquivos eletrônicos. Ignorando as novas tecnologias informacionais e comunicacionais, muitas vezes os programas de redução de papel revelam efeitos passageiros e, claramente, vêm cumprido pouco a função adequada para o tipo de material a ser arquivado. Em função disso, alguns problemas têm sido enfrentados nas áreas destinadas ao armazenamento de uso comum, principalmente nos quesitos relacionados à utilização e à distribuição dos layouts dos mobiliários destinados a função de armazenamento.

No caso específico da Biblioteca do Senac/Santo Amaro, no geral, os índices de satisfação foram considerados Bons e estão relacionados diretamente com o extrato dos funcionários, ou seja, pessoas que atuam exclusivamente nas áreas de armazenamento do setor administrativo. Analisando as condições funcionais dos setores vinculados às áreas de armazenamento, pode-se verificar, junto aos layouts dos espaços destinados para esse fim, que bons percentuais de armários e estantes foram designados, reforçando a idéia de que, este quesito se encontra adequado às exigências que lhe são conferidas. Nesse aspecto, os principais elementos funcionais que, de certa maneira, colaboram nos bons índices de aproveitamento de armazenamento no setor, destacamse: (a) - medidas e alturas do mobiliário coerentes com a norma vigente; (b) percentual adequado do mobiliário destinado ao armazenamento; (c) - posicionamento e distribuição corretos das peças no ambiente; $(d)$ - respeito às normas vigentes quanto às distâncias e às circulações existentes do mobiliário de armazenamento. 


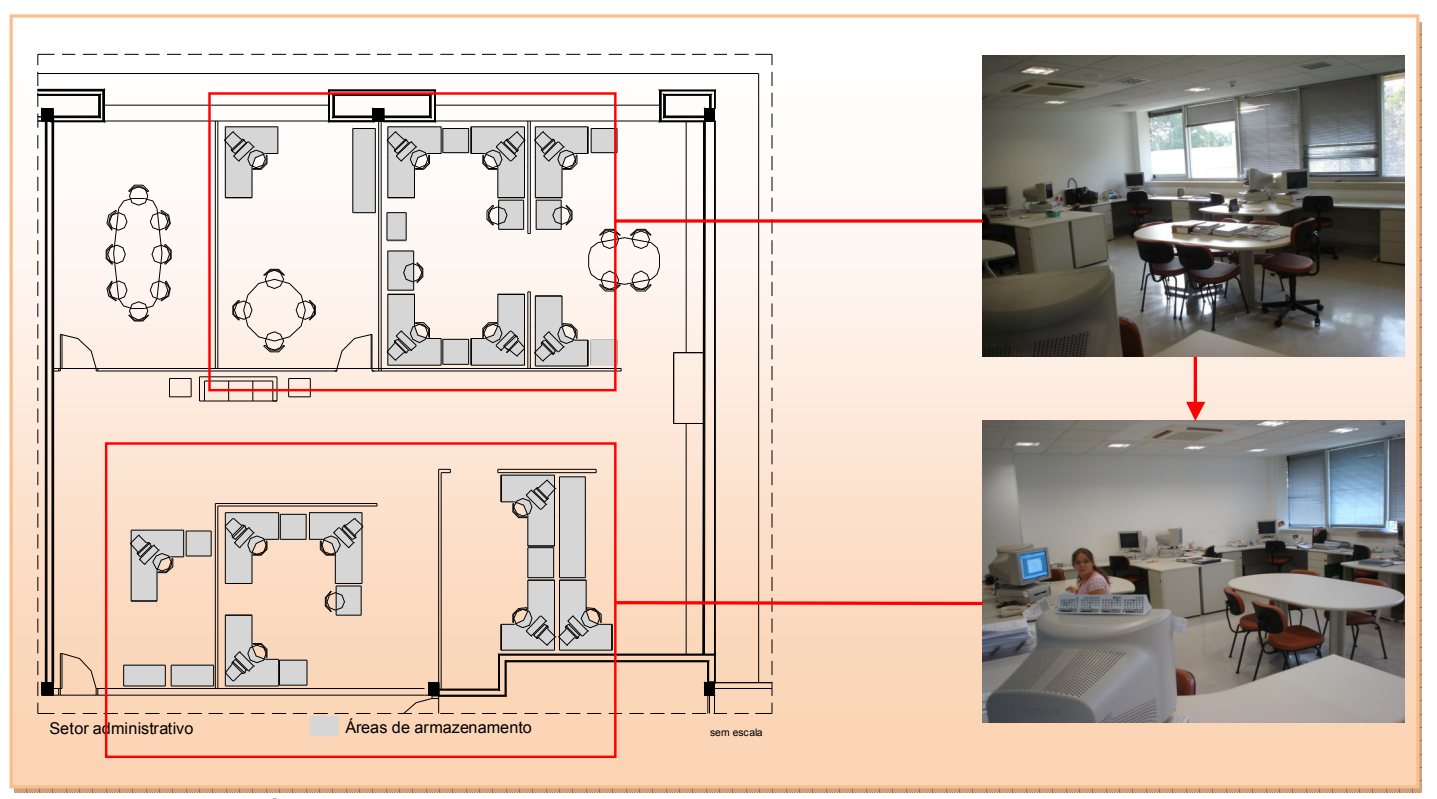

Figura 265 - Áreas de armazenamento - Segundo Pavimento - Biblioteca Senac/Santo Amaro

A política de armazenamento de uso comum é evidente na rede de bibliotecas do Senac, refletindo-se claramente no caso da Biblioteca de Santo Amaro e nos layouts de distribuição dos armários existentes, bem como nos percentuais de atividades correlatas de cópia, impressão e armazenamento de documentos. O partido adotado do layout e da estação de trabalho, em formato de " $U$ " e de "L", permite que o usuário desempenhe sua atividade distribuindo, ora mesas e armários de arquivamento acoplados, e ora armários individualizados dispostos em torno do ambiente. No caso específico destas áreas de armazenagem, os referenciais adotados reportam-se à $N B R$ 13.967/1997 e à NBR 9050/2004, ou seja, as medidas presentes nestes armários e as estações de trabalho destinadas ao arquivamento estão, na maioria dos casos, adequadas à norma. Como resultado disso, a circulação interna na estação é confortável, já que existe espaço para abertura das portas dos armários e mobilidade das respectivas cadeiras. Para estes casos ainda, os valores das medidas internas dos armários estão compatíveis com a norma NBR 13.967/199, quanto às atividades de armazenamento e à guarda de documentos administrativos. 


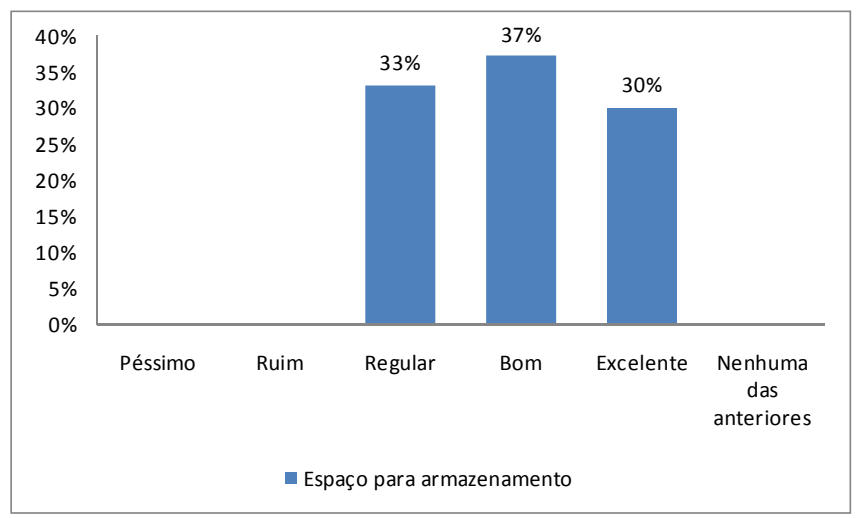

Gráfico 13 - Nível de Satisfação funcionários: espaço de armazenamento- Biblioteca Senac/Santo

Amaro

Em contrapartida, os resultados apresentados na Biblioteca $d a$ Unesp/Marília, obtiveram índices de satisfação mais baixos, comprovando que, com relação a este item, intervenções e alterações deverão ser executadas no âmbito das áreas destinadas ao armazenamento de uso comum. Entretanto, é importante destacar que as medidas apresentadas nos armários estão enquadradas na NBR 13.967/1997, ou seja, respeitam os parâmetros mínimos ergonômicos de utilização nas áreas relacionadas.

No âmbito das áreas destinadas ao armazenamento de uso comum na Biblioteca da Unesp/Marília, basicamente cinco (5) problemas foram considerados inadequados, interferindo substancialmente nos baixos índices de satisfação dos funcionários do setor e na qualidade dos ambientes relacionados. São eles:

- Especificamente na área administrativa, como tal, apresentou deficiências, não só com relação ao aspecto quantitativo do mobiliário, mas também com relação ao posicionamento dos armários nestes elementos. O grande acúmulo de papel faz com que os funcionários armazenem material em seus postos de trabalho, gerando grandes dificuldades estéticas e inadequação de arquivamento; 


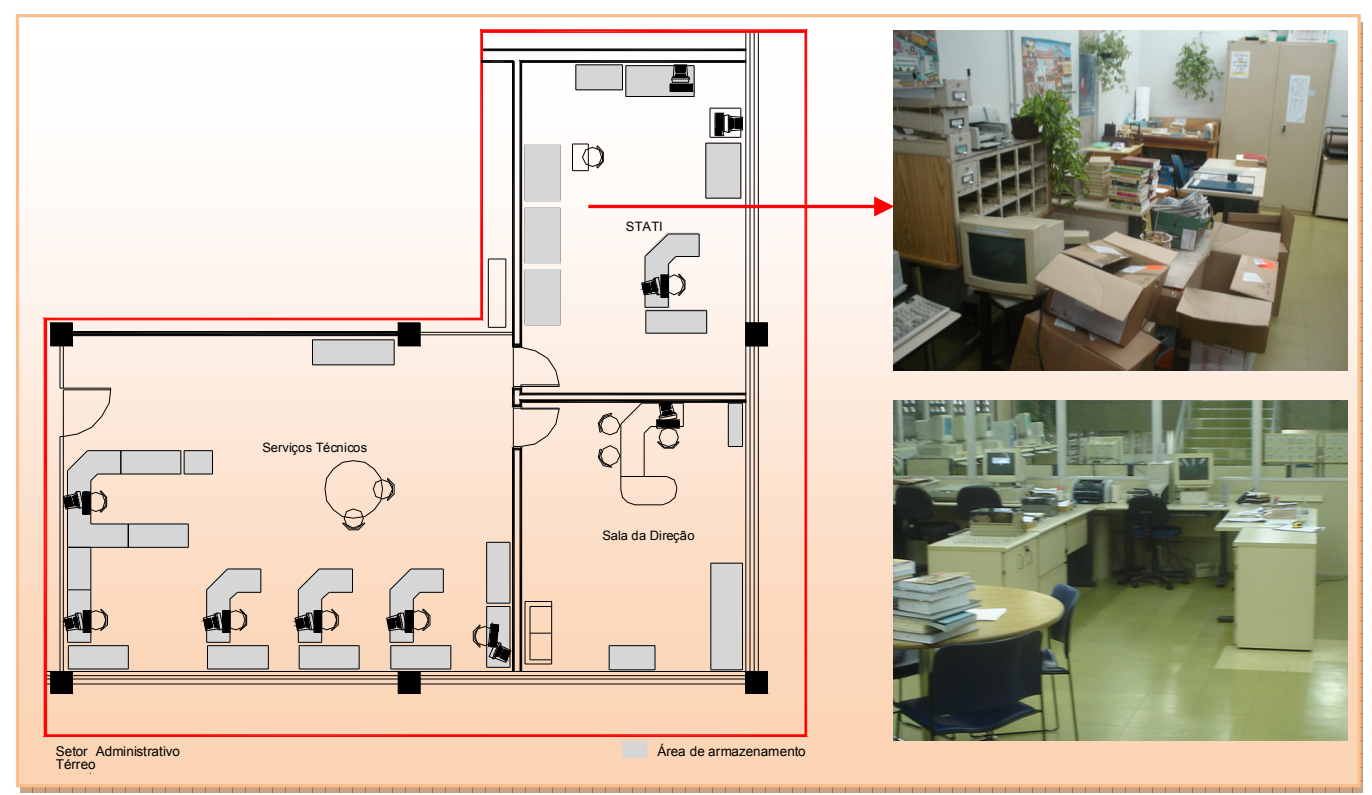

Figura 266 - Áreas de armazenamento - Pavimento térreo - Biblioteca Unesp/Marília

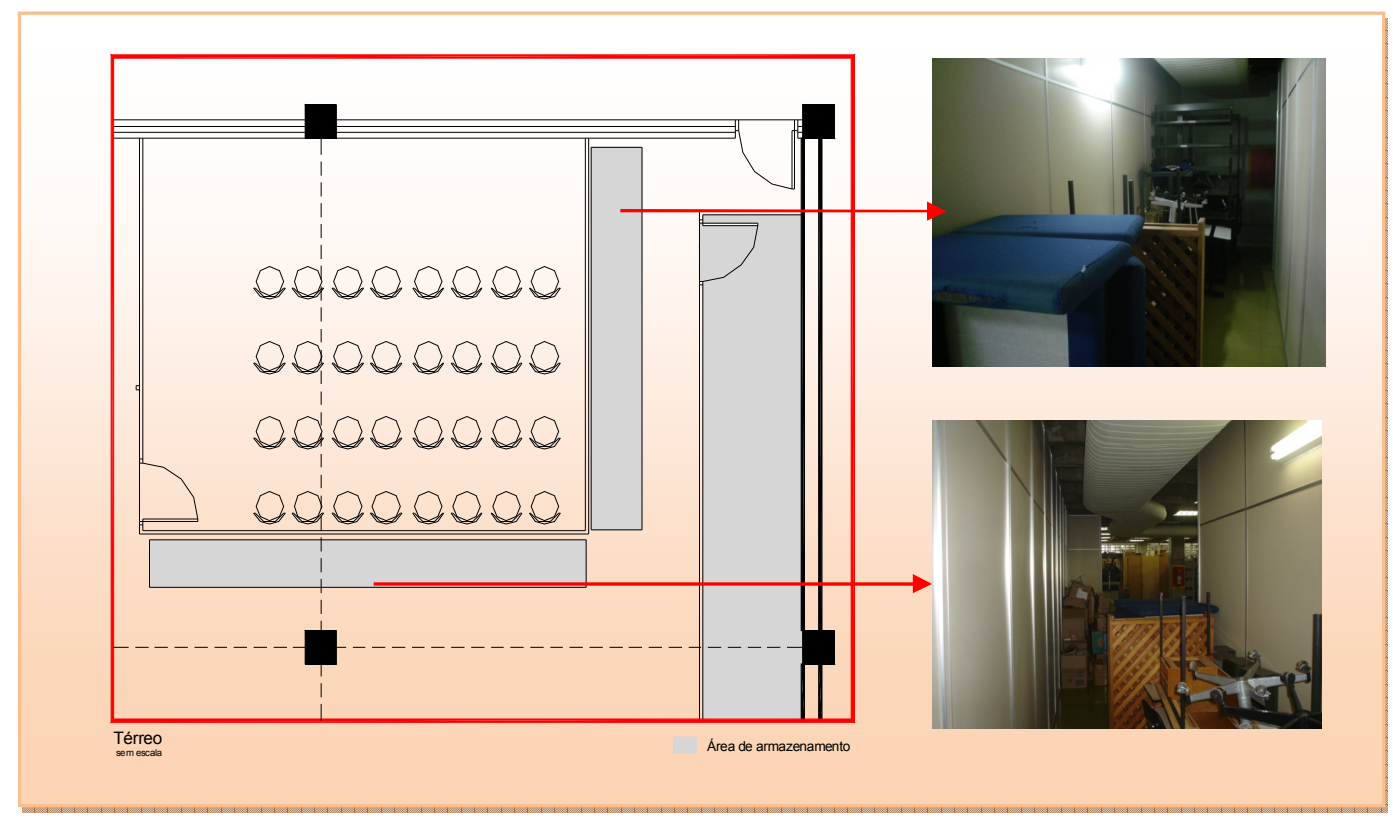

Figura 267 - Áreas de armazenamento - Circulação - Biblioteca Unesp/Marília

- A falta de armários e estantes específicas gera readaptações em outras áreas, transformando-as em "depósitos" setorizados para armazenagem de material em geral. Estas "invasões" acontecem justamente porque qualquer espaço pode ser adaptado para 
este fim,uma vez que existem deficiências nos setores de armazenagem. É interessante perceber que, neste caso, o funcionário do setor administrativo, diante de uma situação não prevista, se apropria do espaço no decorrer do uso, fazendo as necessárias adaptações e mudanças para o arquivamento de material, mesmo não sendo o melhor arranjo espacial para tal atividade;

- As adaptações de arquivamento também são freqüentes nas áreas próximas do acervo bibliográfico como, por exemplo, nos locais destinados à guarda temporária de livros que foram utilizados pelos consulentes e que deverão retornar às estantes de consultas. Observou-se que, nestes casos, os carrinhos e as mesas que executam tais tarefas não comportam a quantidade necessária de livros no decorrer das atividades diárias de armazenamento, gerando muitas vezes incômodos para os próprios funcionários e usuários da biblioteca;

- Outro dado constatado aponta que os resultados dos níveis baixos de satisfação dos funcionários refletiram a complexidade relacionada a este item, uma vez que os percentuais de espaço destinados ao armazenamento na biblioteca são baixos. Como dado comparativo, a Biblioteca da Unesp/Marília ocupa uma área de 2,09 \% em relação à área útil construída destinada ao mobiliário de armazenamento, enquanto que a Biblioteca do Senac/Santo Amaro, apresenta 4,44\% do espaço direcionado às áreas de arquivamento Portanto, preliminarmente, é possível apontar que é preciso perseguir um referencial mínimo de eficiência em razão principal dos custos envolvidos na instalação de sistemas de armazenamento em bibliotecas universitárias. 


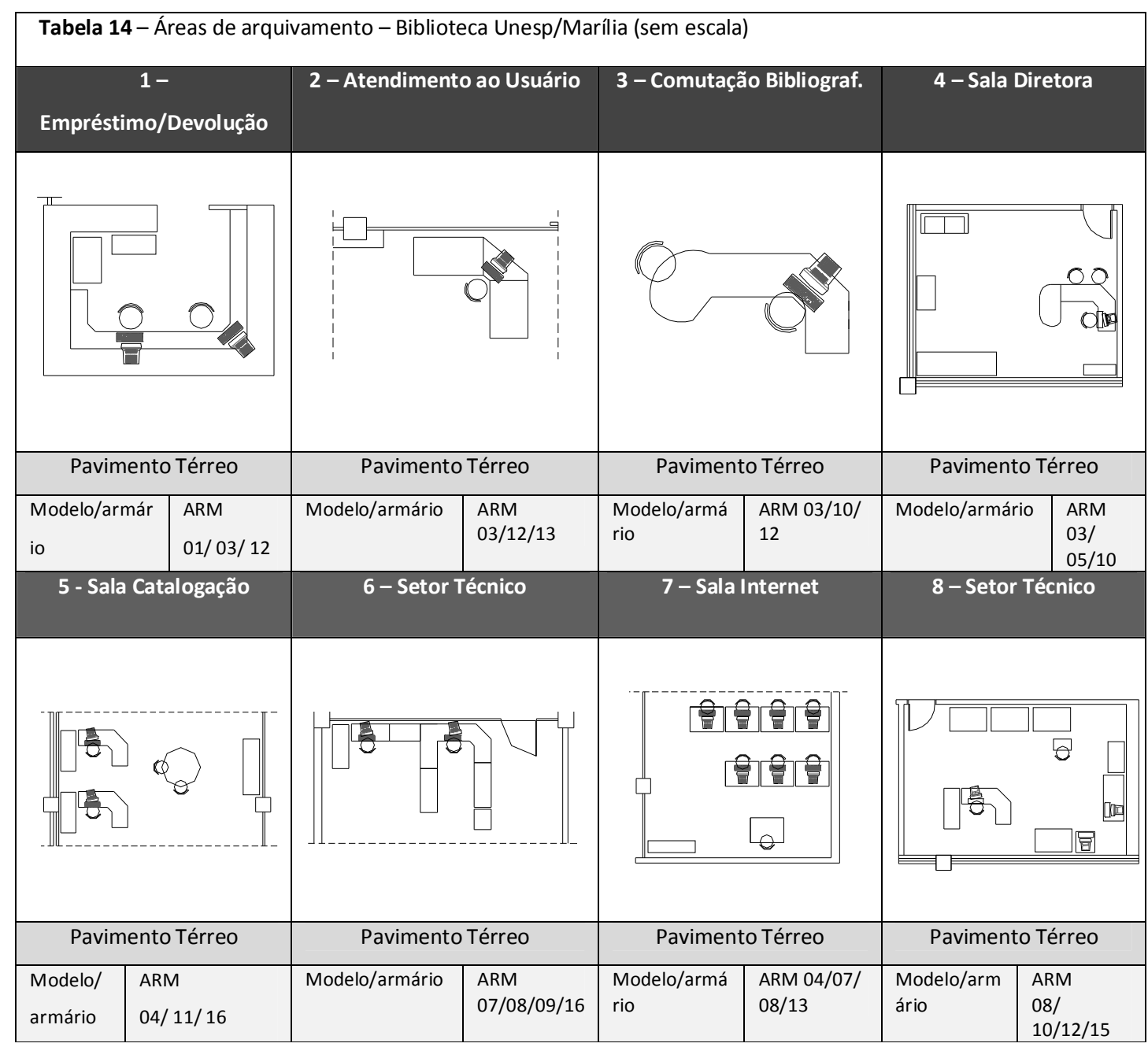

No que se refere ao estado de conservação do mobiliário presente nos dois estudos de caso, percebeu-se que os resultados apresentados somam valores considerados excelentes, demonstrando que a percepção dos usuários em relação a este item é bastante favorável. Entretanto, atentando-se para os extratos separados dos edifícios (alunos, funcionários e professores), verificaram-se, especificamente neste caso, algumas particularidades importantes na análise. A pior situação encontrada está entre os professores do edifício da Biblioteca da Unesp/Marília, 40\% dos entrevistados consideram Regular a conservação do mobiliário. Este dado foi plenamente comprovado no contato entre os usuários e visitas 'as built', evidenciando, no caso deste edifício, que o mobiliário já começa a apresentar sinais de desgaste e problemas de conservação, principalmente nas áreas de leitura, pesquisa e estantes da biblioteca. Por outro lado, os resultados da Biblioteca do Senac/Santo Amaro, principalmente entre os professores, apresentaram altos índices de satisfação (85\% consideraram Excelente o 
estado de conservação do mobiliário). Isto é comprovado por este pesquisador - o conjunto do mobiliário presente na biblioteca denota alto grau de conservação, vinculado principalmente à data de inauguração do edifício (março de 2004).

Como apresentados anteriormente, os valores obtidos de todos os extratos de usuários da Biblioteca da Unesp/Marília apresentaram percentuais de satisfação um pouco mais baixos, se comparados com o caso da Biblioteca do Senac/Santo Amaro. Isso reflete, de certa maneira, a insuficiência de ações direcionadas à conservação do mobiliário existente na biblioteca. Cabe lembrar ainda que um dos principais problemas enfrentados nos ambientes de bibliotecas é a rápida deterioração dos livros impressos, principalmente em função das condições ruins de armazenamento, rotinas de processamento, desgaste causado pelo uso e as condições do mobiliário. Além disso, observa-se que quase todo o papel disponível é muito ácido e com os novos meios de informação, como as fitas magnéticas, discos óticos e fotografias coloridas, todos com vida surpreendentemente curtas, agrava-se ainda mais a capacidade de as bibliotecas garantirem a disponibilidade desses materiais. Nesse contexto, a preservação e a longevidade dos acervos bibliográficos estão intimamente ligadas à boa conservação do mobiliário da biblioteca.

Desta maneira, no caso da Biblioteca da Unesp/Marília, o correto planejamento da preservação do acervo não deve ser visto como um elemento novo, mas sim como um componente das operações e responsabilidades contínuas da instituição. Além disso, outras ações deveriam acompanhar o processo de conservação do mobiliário como, por exemplo, atenção à umidade relativa do ar do ambiente, limpeza das superfícies do mobiliário com soluções não agressivas e a utilização de estantes de metal esmaltado.

No contexto do quesito relacionado à conservação do mobiliário no âmbito da biblioteca universitária, aparece, invariavelmente, a questão da estética e suas várias implicações no ambiente de trabalho como, por exemplo, imagem da instituição, sensações dos usuários, qualidade dos acabamentos, etc. Tão importante quanto a funcionalidade do layout, a estética do mobiliário é um item cada vez mais valorizado naquelas organizações que priorizam a qualidade e a boa aparência do ambiente de trabalho. No caso da Biblioteca da Unesp/Marília, os piores resultados em relação às condições estéticas do mobiliário, foram encontrados nas áreas do acervo bibliográfico, junto às estantes de aço. Como demonstrado anteriormente, algumas peças estão passando por um processo de desgaste e oxidação, causando inconvenientes na 
preservação e na guarda dos documentos. Além disso, os índices mais baixos de satisfação sugerem que, na avaliação dos usuários, a estética do mobiliário ou a sua conservação não é tão adequada. Por outro lado, de um modo geral, nos ambientes correspondentes à área administrativa - sala da direção, catalogação, serviços técnicos a maioria dos funcionários apontou conservação do mobiliário como satisfatória, ou seja, a questão não é um problema a ser considerado neste setor. Sob este aspecto é possível destacar que, os bons resultados de satisfação entre os usuários estão vinculados ao pouco tempo de utilização do mobiliário nestes ambientes.

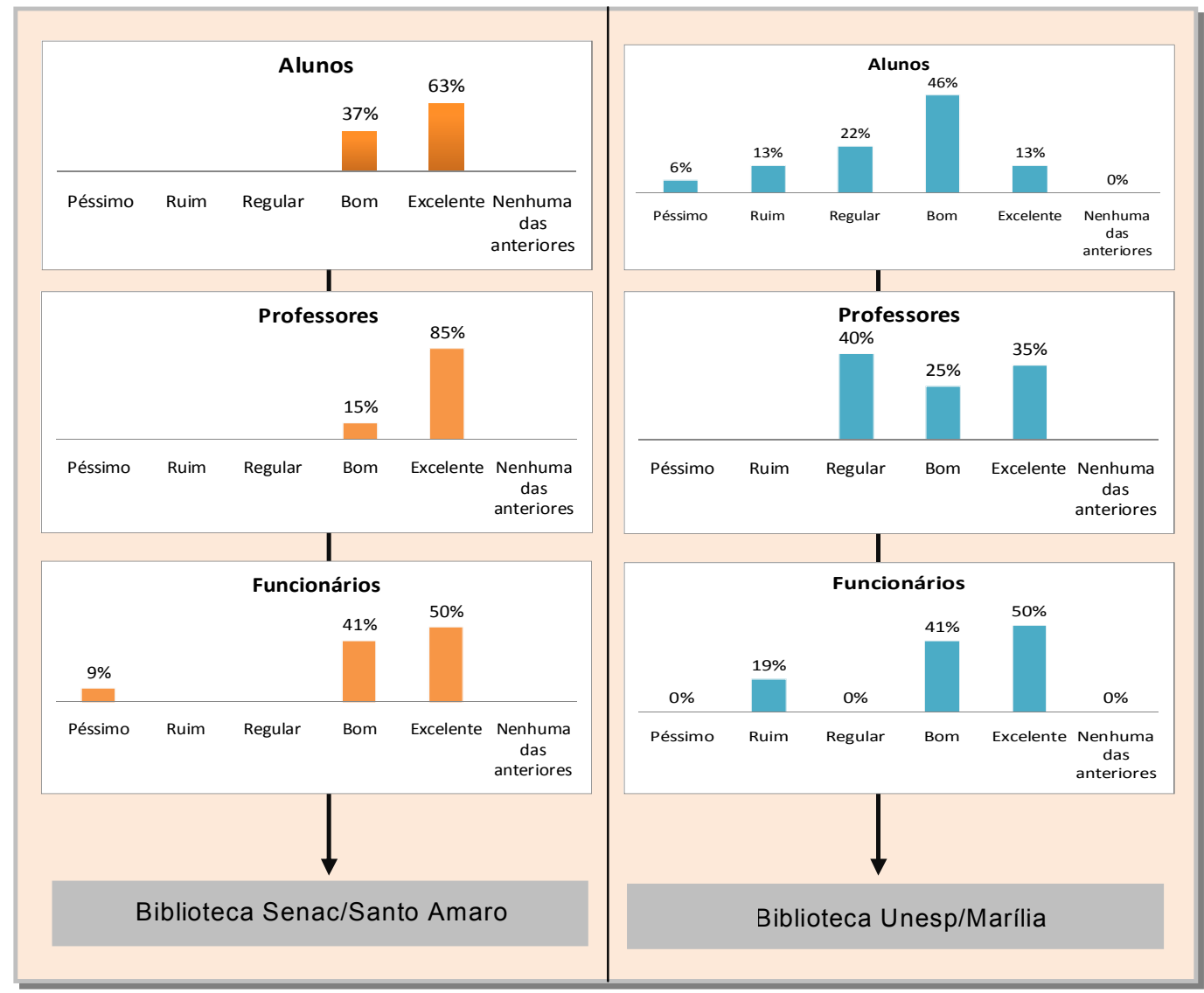

Gráfico 14 - Nível de Satisfação alunos: estado de conservação do mobiliário - Biblioteca Senac/Santo Amaro e Biblioteca Unesp/Marília 


\subsection{Privacidade $x$ comunicação}

Este item identifica a avaliação das tarefas relacionadas às atividades realizadas ao longo da jornada de trabalho e do dia, tanto as que exigem a interação (comunicação) quanto as que exigem concentração (privacidade). A privacidade e a comunicação são duas funções básicas de um edifício da biblioteca e, nesta perspectiva, convergem e direcionam todas as demais atividades que são relacionadas a ela. Tanto nos locais onde o estudo e a pesquisa devem ser mais intensos e reflexivos, quanto nas áreas onde o processo de comunicação deve permear as atividades bibliográficas, a avaliação identificou os elementos positivos e negativos do ambiente construído.

De uma maneira geral pode-se concluir que, nos dois estudos de caso, existem basicamente três diferentes tipologias de organização espacial do mobiliário e estações de trabalho, sendo a maioria assim configurada:

- $\quad$ As de gerência e administração

- $\quad$ As áreas de leitura e pesquisa aberta

- $\quad$ As áreas de leitura e pesquisa fechada

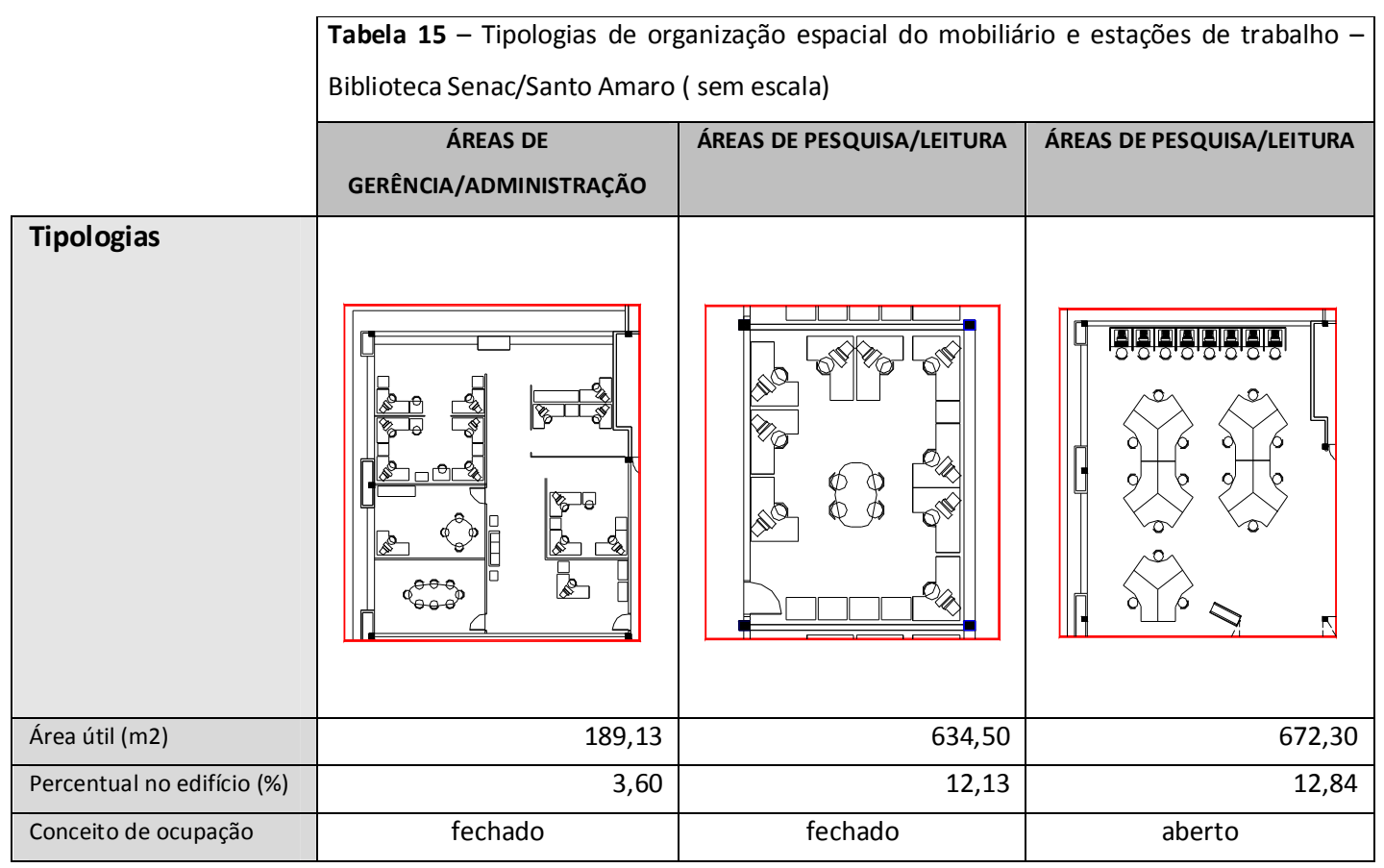




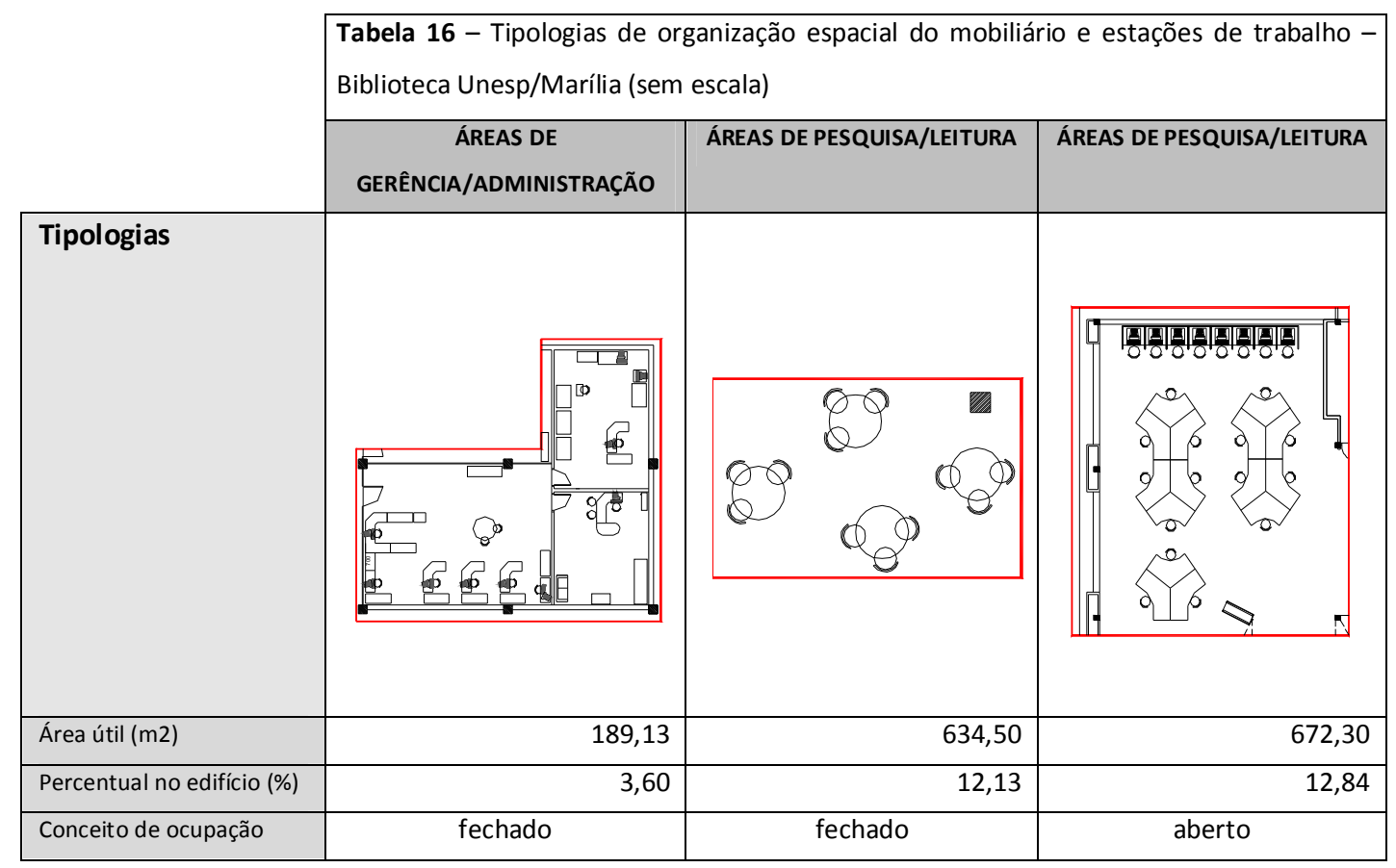

Ao consolidar os dados dos questionários aplicados aos estudos de caso referentes à questão da privacidade visual no seu posto/local de atuação, as respostas apresentadas nos referidos gráficos, se não comprovam, no mínimo indicam a necessidade de concentração, já que os resultados apontaram para a Biblioteca da Unesp/Marília índices baixos de satisfação, sempre concentrados entre Regular e Bom. Além disso, de acordo com as observações físicas feitas durante visitas exploratórias aos edifícios, aliadas às entrevistas com pessoas responsáveis, as colocações dos usuários se confirmaram. Contudo, é importante destacar ainda que, no edifício da Biblioteca da Unesp/Marília, as respostas dos usuários em relação à privacidade visual somaram um percentual ainda menor $-\mathbf{3 4 \%}$ dos alunos a consideram Ruim e $\mathbf{3 5 \%}$ dos professores avaliaram-na como Regular.

Provavelmente os fatores determinantes a fundamentar estas respostas que Biblioteca da Unesp/Marília provêm da própria configuração do mobiliário e das estações de trabalho da biblioteca citadas anteriormente e detalhadas a seguir:

1 - As áreas de gerência e administração: ficam localizadas no pavimento térreo e abrigam as funções técnicas de catalogação, indexação, pedidos de material e 
tratamento da informação, presentes no acervo da biblioteca. No total são três salas, divididas em diretoria, serviços técnicos e STATI. Do ponto de vista da privacidade, a sala de serviço técnico é separada dos demais ambientes por meio de divisórias e grandes painéis de vidro, permitindo que haja interação visual em todas as laterais. Nesta sala, a necessidade de concentração é muito grande, já que as atividades principais apontam para o trabalho individual como, por exemplo, tarefas no computador, leitura e/ou escrita manual, atendimento ao usuário e telefônico. Portanto, os índices mais baixos de satisfação, relacionados à privacidade no local de trabalho estão localizados nesta sala, em razão da falta de espaço adequado na estação de trabalho ou em volta dela e do excesso de ruído e das fontes de distração presentes. Neste caso, a colocação de biombos de altura de $110 \mathrm{~cm}$ ou anteparos entre as estações de trabalho reduziriam, em muito, os problemas ocasionados pela falta de privacidade. Em contrapartida, na sala de direção e na sala - STATI, por serem fechadas até o teto, o nível de privacidade é muito grande, privilegiando a concentração do usuário, além de maior controle, tanto das condições de trabalho quanto da interação com os colegas.

2 - As áreas de leitura e pesquisa: são dois locais destinados a essas áreas: o primeiro, a área de consulta à base de dados/internet, no hall principal do pavimento térreo, e o segundo, entre o acervo bibliográfico no pavimento intermediário superior do térreo. As áreas de leitura/pesquisa e os espaços de consultas às bases de dados de internet possuem uma relação muito próxima, levando indubitavelmente, a problemas sérios em relação à privacidade visual. No caso da Biblioteca da Unesp/Marília, as áreas de leitura/pesquisa estão distribuídas na faixa frontal e entre o acervo bibliográfico, ou seja, todas as atividades são desenvolvidas em um ambiente aberto. Em conseqüência disso, os resultados dos níveis de satisfação com a privacidade visual foram considerados baixos e determinados por um layout predominantemente aberto e disperso. No entanto, apesar da pouca privacidade nestes ambientes analisados e índices baixos de satisfação, esse tipo de configuração é inerente aos espaços de bibliotecas, onde mesas de estudo e leitura são arranjadas e distribuídas em conjunto com o acervo bibliográfico. É importante frisar que a privacidade no ambiente da biblioteca é, sem dúvida, um dos aspectos-chave para a produtividade nas atividades desenvolvidas e tem provocado um debate essencial na busca do que é funcionalmente mais adequado. Nesta questão é necessário, porém, avaliar esses resultados em conjunto com um entendimento das diferentes atividades exercidas na biblioteca, para identificar possíveis caminhos a 
seguir, sejam estes direcionados às novas configurações espaciais ou aos novos modelos de apropriação do espaço.

3 - As áreas de leitura e pesquisa fechada: essas áreas são salas fechadas com divisórias localizadas no pavimento inferior da biblioteca e destinadas a atender grupos de usuários de 3, 4 e 6 pessoas no máximo. O alto grau de privacidade visual se dá por dois fatores: um pela própria localização dos ambientes - as salas estão situadas em uma região da biblioteca bastante isolada e reclusa - e a outra, as salas possuem divisórias e apenas uma pequena janela na porta de entrada permite a visualização do lado externo. Esses fatores conferiram ao ambiente bons índices de satisfação entre os respondentes, além de provar que, em se tratando de bibliotecas, salas fechadas e bem localizadas são importantes instrumentos estratégicos para fornecer privacidade visual quando requerida.

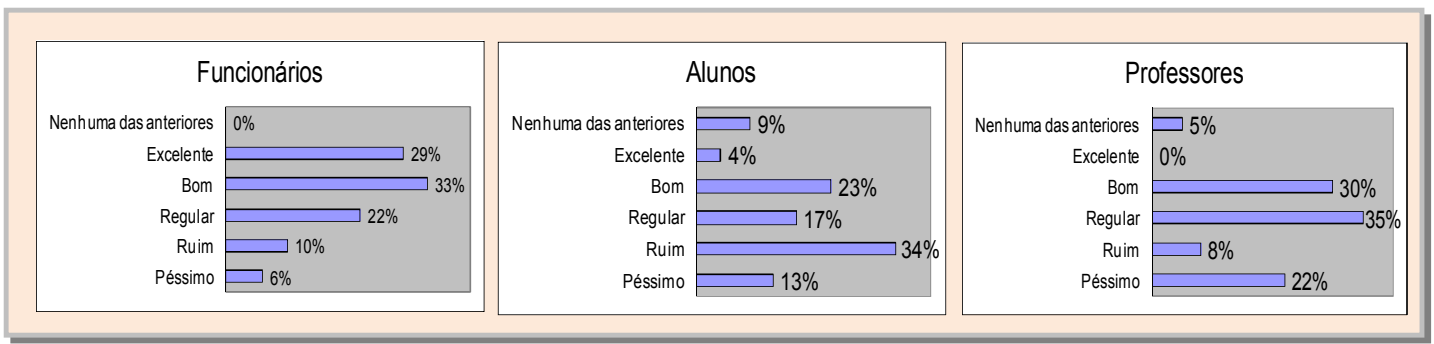

Gráfico 15 - Nível de Satisfação da Biblioteca Unesp/Marília: privacidade visual no posto de trabalho

No caso do edifício da Biblioteca do Senac/Santo Amaro, sobre a questão relacionada à privacidade visual, os resultados apontaram bons níveis em relação a satisfação dos usuários. Acredita-se que isso tenha ocorrido por algumas razões específicas: (1) o layout é mais compartimentado; (2) os grupos de estações de trabalho abertos, que foram pesquisados, são menores, gerando espaços mais controlados e protegidos como, por exemplo, os que estão posicionados na área administrativa possuem biombos de altura variável de $160 \mathrm{~cm}$ a $110 \mathrm{~cm}$. Este dado pode ser comprovado pelos resultados apresentados entre os usuários deste estudo de caso, em qual todos os extratos consideraram Boa a privacidade visual no ambiente construído (55\% os professores, $45 \%$ os alunos e $44 \%$ os funcionários).

Como pode ser analisado, os três extratos de usuários mantiveram praticamente os mesmos índices de satisfação, provando que existe certa concordância 
entre estes quanto à disposição do layout dos ambientes e do mobiliário, que garantem privacidade visual nos ambientes de trabalho. Os dados reforçam também a idéia de que o partido arquitetônico presente na Biblioteca do Senac/Santo Amaro colabora sensivelmente nas tarefas que lidam diretamente com os elementos de concentração, como é o caso da privacidade visual. Mesmo em situações em que os ambientes da biblioteca apresentam configurações abertas e desprovidas de fechamento, como divisórias, biombos e paredes, o padrão das estações de trabalho leva em consideração o conceito da privacidade visual entre as pessoas.

Um dado chamou, porém, a atenção nos índices de satisfação dos usuários presentes na biblioteca. Entre os funcionários, 30 \% consideram Regular a privacidade visual em sua área de trabalho. Mesmo não sendo um percentual muito alto, pode-se concluir preliminarmente que os funcionários nos ambientes da área administrativa mostraram-se insatisfeitos com a privacidade visual e isso reforça a existência de distorções que devem ser corrigidas no uso do espaço. Somando-se a isso, a falta de privacidade mostrou-se o principal problema neste setor, visto que todos os entrevistados alegaram que, em determinadas situações, experimentaram a sensação de vulnerabilidade e perda da individualidade. Também, em contato com os funcionários, alguns demonstraram insatisfação com a altura dos biombos, mesmo estes estando enquadrados na norma $N B R$ - 13.964/1997, o que estipula a altura de $110 \mathrm{~cm}$. Provavelmente, o problema detectado não está relacionado com a altura do biombo de divisão, mas sim com o modelo adotado no layout das estações de trabalho, permitindo que a privacidade visual seja prejudicada. Uma revisão e uma reconfiguração do desenho das salas desse setor poderiam trazer benefícios e minimizar os problemas advindos do excesso de interrupção ou distrações indesejáveis desses ambientes. Ou seja, o redesenho desses ambientes, incluso o layout do mobiliário, forneceria uma maneira simplificada para viabilizar e determinar áreas adequadas para maior privacidade, concentração e integração de seus usuários. Finalmente, é importante destacar que todos esses procedimentos e ações direcionadas às áreas localizadas juntos ao setor administrativo reforçariam não só a melhoria nas condições da privacidade visual, mas também os aspectos ligados ao bem-estar e à produtividade do ambiente de trabalho. 


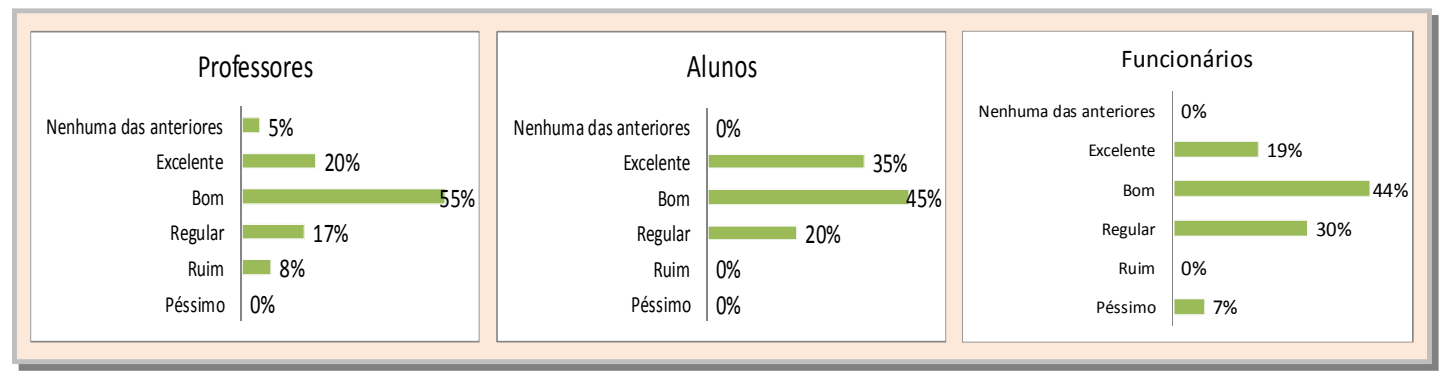

Figura 268 - Nível de Satisfação da Biblioteca Senac/Santo Amaro: privacidade visual no posto de trabalho

Quanto à questão da distância entre as outras áreas de atividade com os quais o usuário se relaciona - os respondentes definiram como Boa e estão satisfeitos com a localização de suas estações de trabalho e sua relação com as outras áreas. É importante destacar que a necessidade de inter-relação entre os espaços de uma biblioteca, seja parcial ou totalmente abertos, nem sempre estabelece de forma sustentável, ou pela falta de espaço adequado no ambiente ou próximo a ele, ou pela própria configuração inicial do projeto arquitetônico. Cabe aqui ressaltar que, nos dois estudos de caso, a relação que se estabelece entre as áreas do acervo bibliográfico (coleção de livros, periódicos, mapas, fitas, etc.) e as áreas ocupadas pelos usuários e destinadas à leitura e à pesquisa, mostra-se positiva. Este dado é importante porque, como as duas bibliotecas pesquisadas utilizam o Sistema Aberto do Acervo, em que o usuário tem livre acesso às prateleiras e pode retirar o livro que deseja, referenda este sistema a correta compatibilização que deve existir entre os ambientes destinados à leitura e pesquisa e as áreas de circulação de pessoas que estão adjacentes a essas salas. Além disso, se o sistema não for bem equacionado, um grande foco de conflito pode existir em função daquelas pessoas que querem preservar o silêncio e dos outros usuários que necessitam recorrer aos livros das estantes.

Particularmente, no caso da Biblioteca do Senac/Santo Amaro, apesar de a avaliação da percepção do usuário ser considerada satisfatória, as entrevistas e as visitas exploratórias constataram um excesso nas distâncias entre os ambientes da biblioteca. Além do edifício da biblioteca ser estruturado em três (3) pavimentos e possuir uma dimensão longitudinal bastante considerável (cerca de 60,00 m), algumas distâncias, principalmente aquelas que estão entre as áreas administrativas (terceiro pavimento) e a áreas de atendimento ao público, demandam um grande percurso a ser percorrido pelos funcionários. No entanto, do ponto de vista do uso, mesmo indicando 
elementos de ineficiência em relação ao excesso nas distâncias entres as áreas dos ambientes,fato mostrado principalmente pela avaliação técnica, os respondentes, a priori, estão acostumados com a dinâmica das atividades desenvolvidas no ambiente da biblioteca e não avaliam de modo negativo as grandes distâncias percorridas no seu diaa-dia.

\subsection{Largura e localização das escadas e corredores}

Conforme foi visto nos capítulos anteriores, por meio da circulação é possível conectar os usuários aos diversos ambientes existentes no espaço da biblioteca. Portanto, contextualizados nesta definição estão os dois elementos da circulação: as escadas e os corredores. Além da circulação vertical, que interliga todas as áreas componentes da edificação, existe a circulação específica de cada pavimento, tanto a circulação primária que conecta as áreas principais do edifício, quanto a circulação secundária que dá acesso às estações de trabalho. Cabe lembrar ainda que a configuração e a disposição dos elementos de circulação nos ambientes, interferiram substancialmente no posicionamento e no dimensionamento das rotas de fuga e segurança contra incêndio.

No caso específico da Biblioteca do Senac/Santo, percebeu-se que o sistema de circulação desempenha papel estratégico no funcionamento dos diversos componentes de distribuição dos ambientes, evitando, em certa medida, situações de circulação tortuosas e desperdício da comunicação dos usuários nos espaços. Além disso, o partido arquitetônico coopera igualmente na organização coerente dos fluxos de circulação, tanto nos deslocamentos dentro dos pavimentos (circulação horizontal) quanto nas conexões entre os três pavimentos (circulação vertical). Para isso, a biblioteca conta com dois sistemas de circulação primária: o primeiro, o sistema vertical, que é composto de uma escada instalada no corpo central do edifício e duas escadas enclausuradas posicionadas nas extremidades; o segundo sistema é o elevador que atende o acesso aos três pavimentos. 


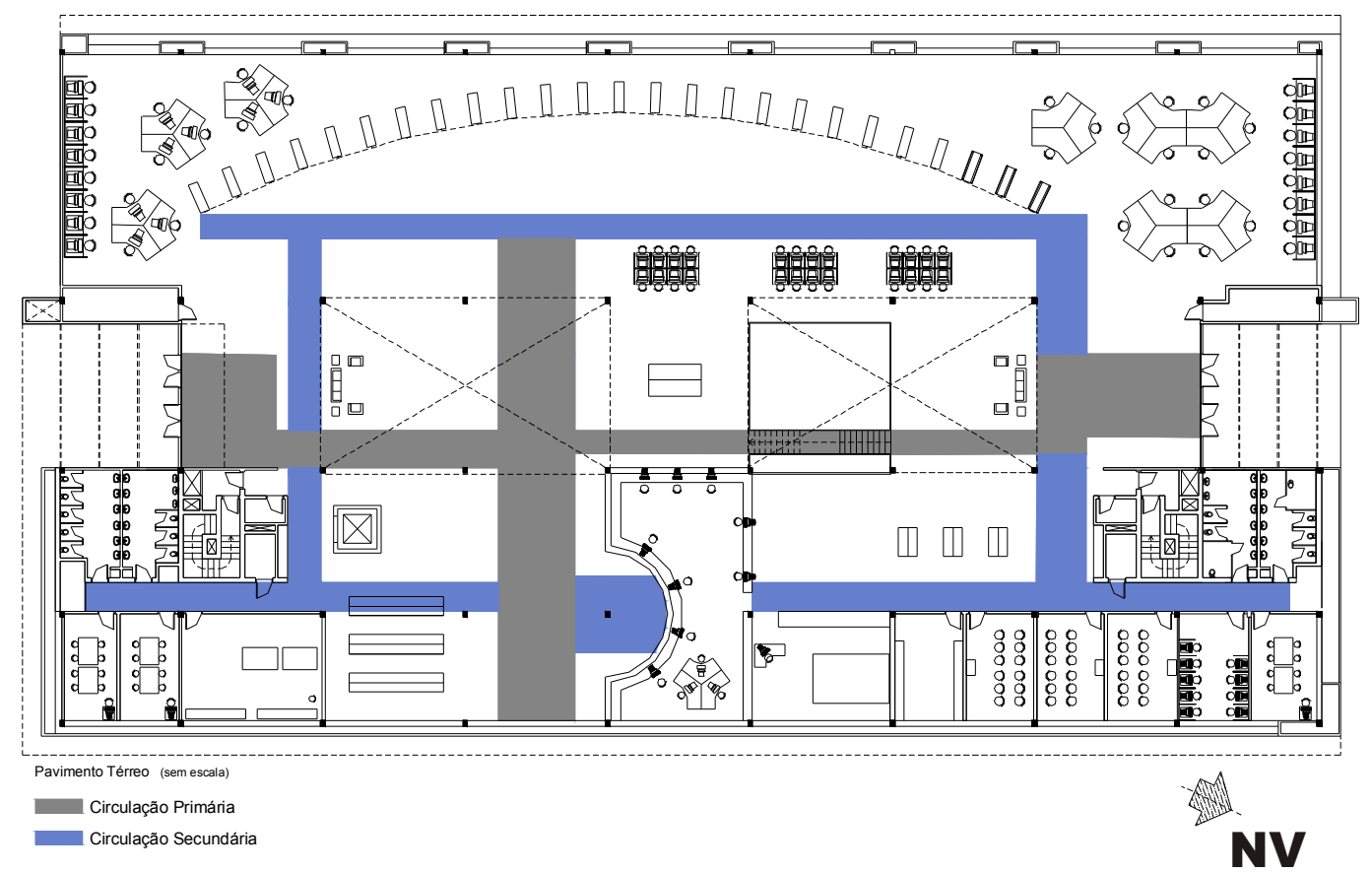

Figura 269 - Layout demarcado da circulação primária e secundária no pavimento térreo da Biblioteca Senac/Santo Amaro

No pavimento térreo, a circulação primária se inicia na entrada principal da biblioteca, que conduz, em um primeiro momento, ao primeiro ramal da circulação secundária, levando a dois lados: do lado direito, ao balcão de atendimento de empréstimo e devolução do acervo bibliográfico e, do lado esquerdo, às áreas do guarda-volume, elevador, sala de fotocópias, sala de estudos, escada enclausurada e sanitários. Logo à frente, a circulação primária se divide em três sentidos principais, encaminhando-se para a escada central, que dá acesso aos outros pavimentos; do lado esquerdo, ao encontro da entrada lateral do edifício e, finalmente, em direção às estantes do acervo e as mesas de pesquisa on-line.

A circulação secundária é aquela que vai dar acesso ao restante dos ambientes do pavimento térreo como as salas de TV, salas de reunião, acervo da fitoteca, a bateria de sanitários, depósito e todas as áreas relacionadas à pesquisa, leitura e estudo. Tanto a circulação primária quanto a secundária procuram estabelecer uma relação harmoniosa e equilibrada entre os espaços ocupados pelo mobiliário e as divisões das salas do pavimento, evitando assim a criação de faixas excedentes, sem o prejuízo das necessidades funcionais da biblioteca. 


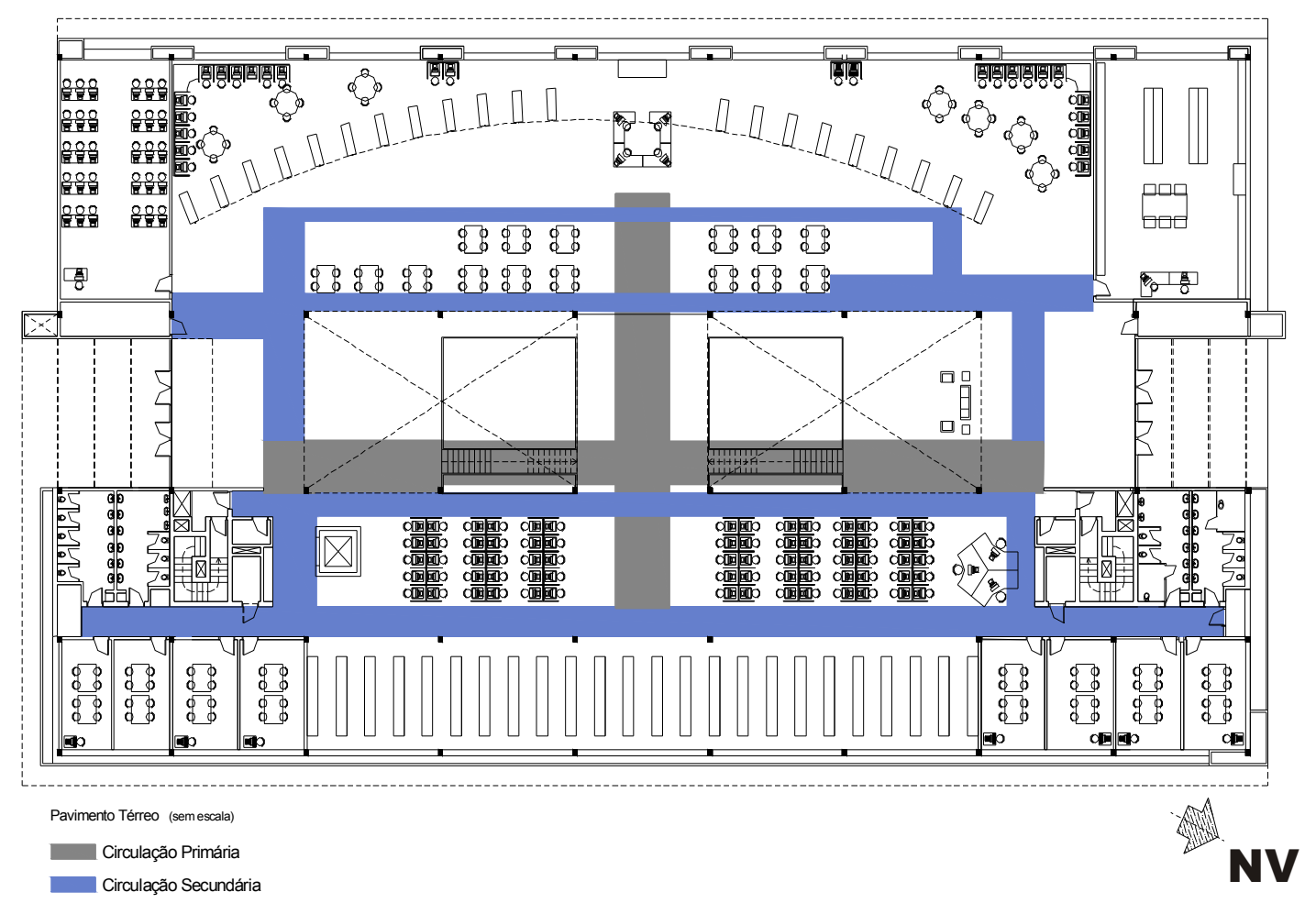

Figura 270 - Layout demarcado da circulação primária e secundária no primeiro pavimento da Biblioteca Senac/Santo Amaro

As circulações primárias e secundárias do segundo pavimento obedecem ao mesmo esquema de desenho do pavimento térreo, ou seja, a escada principal, localizada bem ao centro do andar, funciona como eixo estrutural na conexão aos acessos principais dos diversos ambientes. Depois que os usuários chegam ao pavimento, por meio da escada central, obedecem praticamente a dois caminhos: um pela circulação primária, cruzando transversalmente o ambiente e depois o outro, que dá acesso às circulações secundárias; na seqüência, os acessos se completam com as duas áreas laterais de estantes do acervo bibliográfico e, finalmente, os setores de pesquisa e leitura da biblioteca. Além disso, as circulações secundárias conduzem às demais salas de estudos, aos sanitários, às escadas enclausuradas, ao elevador, ao acervo da modateca e a um pequeno auditório, todos eles localizados nas extremidades do primeiro pavimento. 


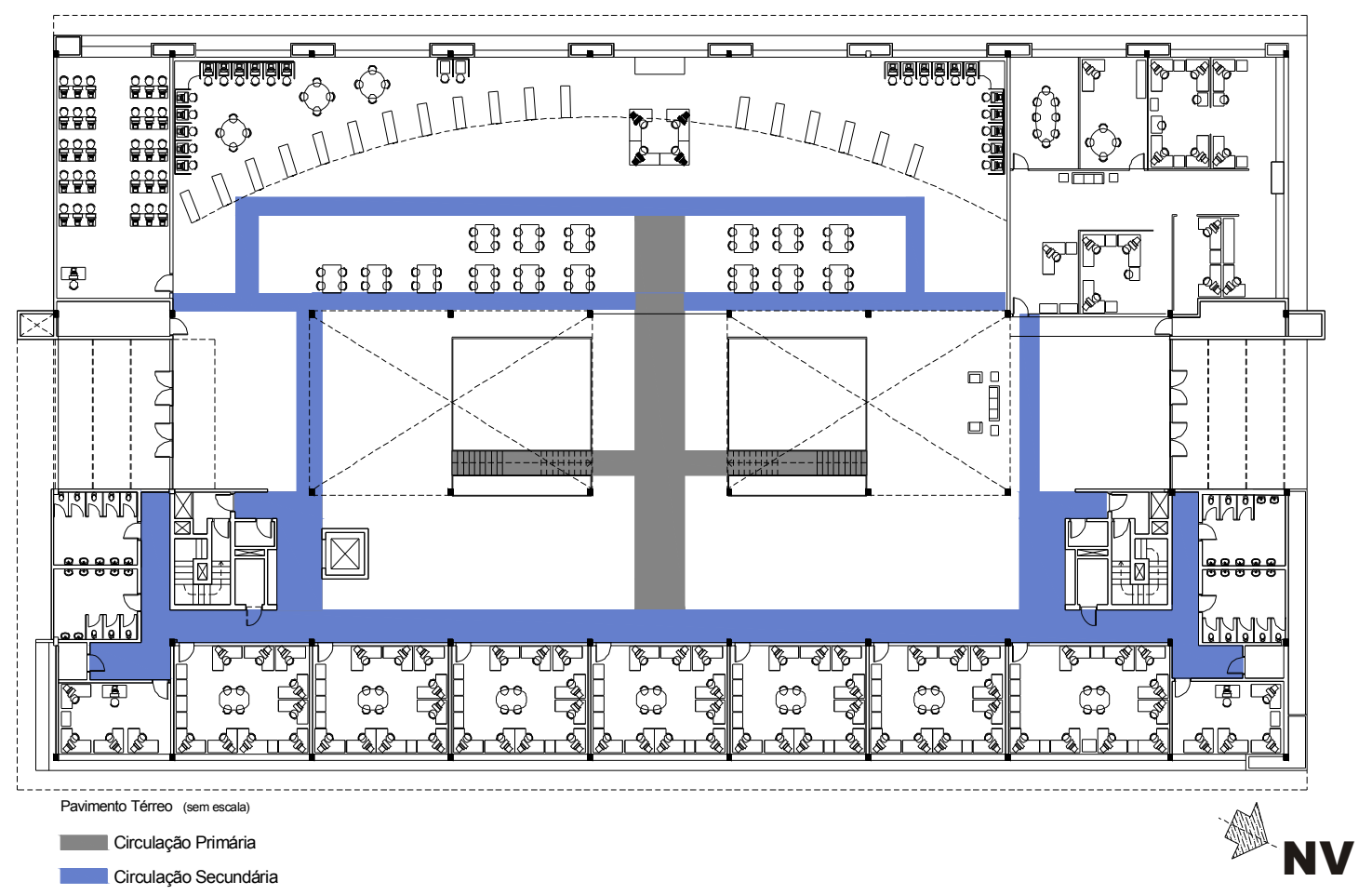

Figura 271 - Layout demarcado da circulação primária e secundária no segundo pavimento da Biblioteca Senac/Santo Amaro

O segundo e último pavimento da Biblioteca do Senac/Santo Amaro, como acontece com os outros dois andares do edifício, agrupa dois eixos principais de circulação primária, demonstrando que o partido arquitetônico procurou priorizar o mesmo sistema de circulação em todos os pavimentos da edificação. $\mathrm{O}$ acesso às salas de estudo que estão localizadas em uma das laterais do andar acontece por meio de uma das circulações secundárias, bem como dá ligação à bateria de sanitários, ao elevador e às escadas enclausuradas. A grande vantagem deste ambiente, evidentemente se comparado com o pavimento térreo e o primeiro pavimento, é o aumento no percentual destinado à circulação, chegando a ter um acréscimo de $25 \%$ em relação aos outros. Isso acontece porque a densidade do espaço destinado às salas fechadas não apresenta uma metragem muito grande, originando assim corredores e circulações maiores. Ainda com relação a essas áreas, observou-se que a compatibilização dos sistemas de circulação presentes nos três pavimentos, por meio de eixos centrais, foi fundamental para garantir a facilidade aos acessos e à comunicação entre as diversas áreas componentes do layout. 
Os resultados apresentados quanto à largura e à localização das escadas e corredores no edifício da Biblioteca do Senac/Santo Amaro mostraram que, tanto na média geral quanto nos extratos dos usuários separados, os índices de satisfação são considerados excelentes, revelando que este item está atendendo às condições funcionais da biblioteca. Com relação a esses espaços, existem algumas considerações importantes a serem feitas:

- a escada instalada no corpo central da biblioteca funciona como um grande eixo estruturador espacial, proporcionando grande facilidade de comunicação entre os pavimentos. Sua visibilidade e sua posição estratégica permitem que a escada seja utilizada com bastante freqüência por professores, alunos e funcionários. Outro fato importante anotado no projeto arquitetônico, e depois comprovado durante as visitas técnicas, foi o item relacionado ao dimensionamento da escada, com 1,40 m. De acordo com a norma municipal de São Paulo, o COE - Código de Obras e Edificações, no item 12.7/1993, estipula que as dimensões mínimas para as circulações principais e a rota de fuga devem estar livres de quaisquer obstáculos. Além disso, devem comportar a quantidade de população existente no pavimento e ter uma largura mínima de 1,40 m. Neste caso, a escada principal está de acordo com as normas vigentes e atende ao fluxo diário dos usuários.

- as duas escadas enclausuradas, localizadas nas extremidades de cada pavimento do edifício, garantem adequada capacidade de escoamento da população existente, estando de acordo com a Instrução Técnica n. 11 do Corpo de Bombeiros do Estado de São Paulo. Mais ainda, como se trata de uma edificação que possui duas escadas de emergência e equipamentos de prevenção e combate a incêndio de acordo com as normas vigentes, este quesito em si não constitui um problema. Além disso, com uma largura de 1,20 m, as escadas enclausuradas enquadram-se à norma do COE - Código de Obras e Edificações, do município de São Paulo, referente ao item 12.7/1993. Cabe lembrar ainda que essas escadas são mais utilizadas por funcionários e apresentam-se como uma alternativa mais rápida entre os pavimentos mais próximos, ou seja, não oferece essa possibilidade ao usuário mais comum, como os estudantes e visitantes.

- com relação às larguras mínimas de corredores de passagem entre as estantes do acervo bibliográfico, a ALA - American Library Association desenvolveu padrões e normas mínimas que vêm sendo utilizadas como parâmetro no contexto das bibliotecas brasileiras. Além disso, a norma $N B R$ - 9050/2004, que estipula importantes medidas e 
dimensões, para promover a acessibilidade no ambiente construído, com condições de mobilidade, autonomia e segurança, traz parâmetros não só destinados às pessoas portador de deficiência, mas também a todos que utilizam o ambiente da biblioteca. No caso da Biblioteca do Senac/Santo Amaro foi possível comparar as medidas mínimas existentes dos corredores entre as estantes do acervo bibliográfico, com as normas da $N B R-$ 9050/2004 e as normas da ALA - American Library Association. As estantes do Modelo 01, com circulação de $1,40 \mathrm{~m}$ entre elas, demonstraram apresentar melhor aproveitamento funcional em relação às normas que estipulam o valor mínimo de 0,90 m. As outras estantes do acervo, as do Modelo 02, apesar de apresentarem larguras um pouco menores, se comparadas com o outro modelo, estão todas enquadradas na norma vigente, com dimensões de 1,00 m, em todos os pavimentos da biblioteca. Finalmente, a $A L A$ recomenda, em casos em que a biblioteca adota uma circulação central entre duas secções de estantes (direita e esquerda), que o corredor deve ter uma largura mínima de 1,20 m. Mesmo não mantendo este layout, na Biblioteca do Senac/Santo Amaro, a circulação secundária de $2,70 \mathrm{~m}$ que fica entre as estantes e as mesas de pesquisa e leitura está dentro da norma vigente.

- $\quad$ os valores mínimos estabelecidos pela $A L A$ com relação à largura entre as mesas nas áreas de leitura e pesquisa, inclusos os assentos, é de $1,20 \mathrm{~m}$ e 0,60 m para as laterais das mesas. Neste caso, observou-se que existem três situações importantes nos ambientes da Biblioteca do Senac/Santo Amaro: a primeira, as mesas onde estão instalados os terminais de pesquisa on-line possuem largura de $1,35 \mathrm{~m}$, portanto acima do exigido; a segunda, as mesas circulares distribuídas ao longo das áreas de leitura e pesquisa, ficaram fora do valor mínimo estipulado pela norma, que é de 1,20 m e registraram valores de 0,90 m de largura; e por final, a terceira, as mesas de $100 \mathrm{~cm} \mathrm{x}$ $140 \mathrm{~cm}$, localizadas nas salas fechadas de estudo, mostraram que a largura do corredor entre a mesa e a divisória, ficou dentro do mínimo estipulado pela norma que é $1,00 \mathrm{~m}$ de largura.

- $\quad$ com relação ao espaço fronteiro às portas do elevador, a Biblioteca do Senac Santo Amaro se enquadra na norma, com uma largura de 2,40 m nos três pavimentos do edifício. Segundo o $C O E$ - SP (1993), as dimensões mínimas não devem ser inferiores a $1,50 \mathrm{~m}$.

- comparando as larguras do sistema de circulação da Biblioteca do Senac Santo Amaro, tanto as circulações primárias quanto as secundárias, foi possível destacar as seguintes dimensões: (a) - todas as circulações primárias presentes nos três pavimentos 
da biblioteca, com variações de 1,40 m a 3,50 m, respeitam as larguras mínimas previstas no $C O E$ - SP de 1,40 m; (b) - as circulações secundárias, com larguras que variam de 1,40 m e 1,50m, enquadram-se não só nas normas estipuladas pelo $C O E$ $S P$, mas também nos padrões estipulados pela ALA - American Library Association, que é de $1,20 \mathrm{~m}$.

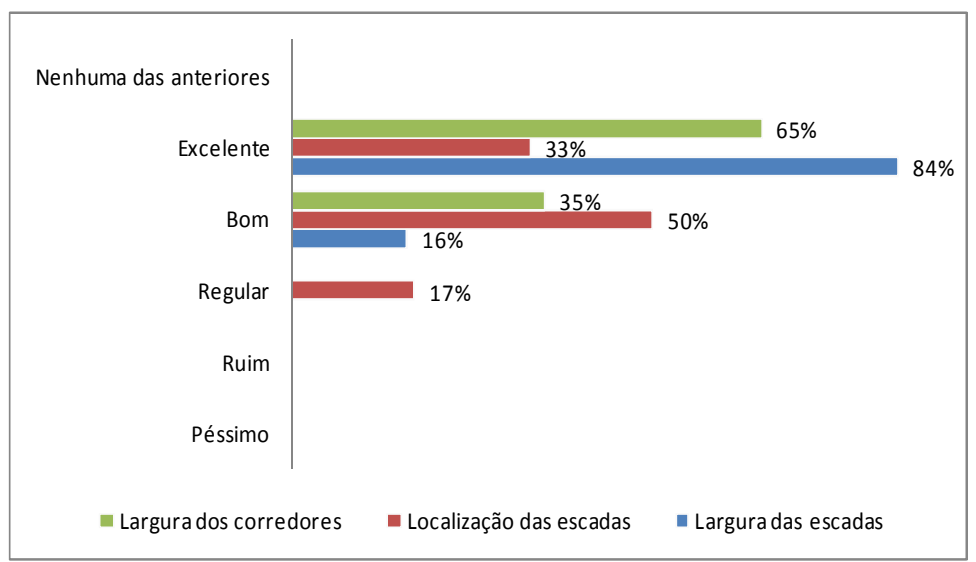

Gráfico 16 - Nível de Satisfação alunos da Biblioteca Senac/Santo Amaro largura e à localização das escadas e corredores

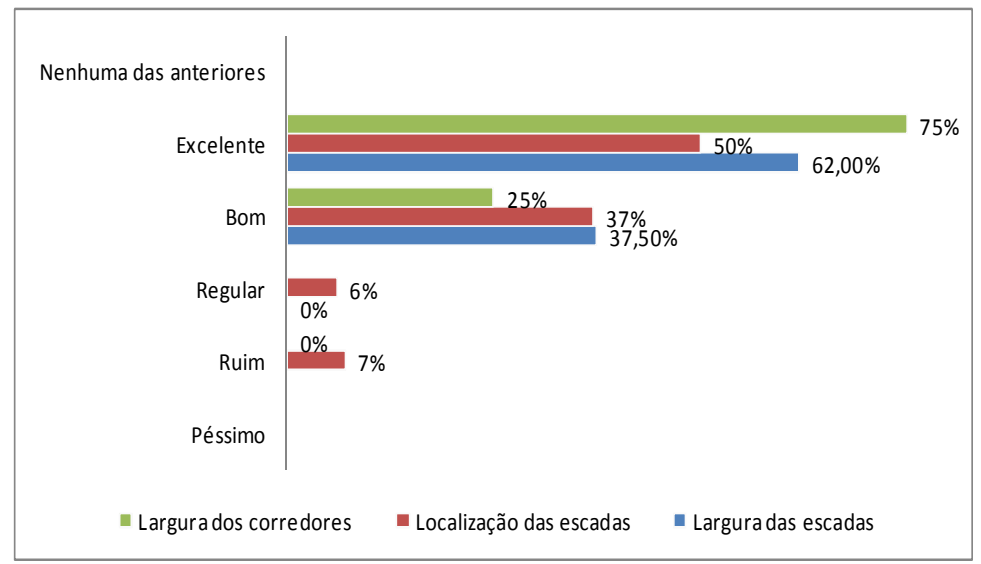

Gráfico 17 - Nível de Satisfação funcionários da Biblioteca Senac/Santo Amaro largura e à localização das escadas e corredores

Os altos índices de satisfação dos usuários e os levantamentos feitos das dimensões relacionadas às larguras de escadas, corredores, passagens e o acesso ao elevador comprovaram que os sistemas de circulação nos ambientes da Biblioteca do Senac/Santo Amaro usados atualmente são bem dimensionados e devidamente enquadrados nas normas vigentes, tanto do COE - Código de Obras e Edificações, do 
município de São Paulo, quanto da ALA - American Library Association, que regem os padrões internacionais e nacionais de ambientes de bibliotecas. No entanto, algumas dimensões de larguras de passagem, especificamente nas salas de estudo, ficaram com $65 \mathrm{~cm}$, ou seja, abaixo dos valores recomendados pela norma que é de $80 \mathrm{~cm}$. Nesse caso, recomenda-se uma averiguação mais aprofundada das medidas relacionadas aos corredores das salas ou no arranjo dos mobiliários presentes nestes espaços, visando não só a adequação à legislação, mas também melhoria nas condições de bem-estar e usabilidade do espaço. Portanto, qualquer alteração que possa vir a ser executada, no âmbito desse espaço, deve ser acompanhada de prévia consulta aos usuários, verificando suas necessidades e as potencialidades a serem exploradas.

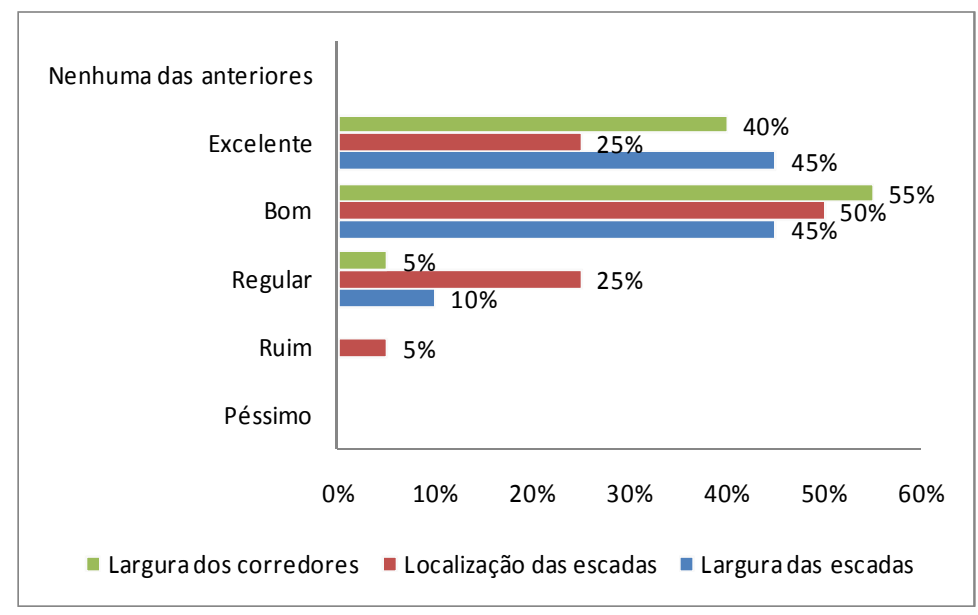

Gráfico 18 - Nível de Satisfação professores da Biblioteca Senac/Santo Amaro largura e à localização das escadas e corredores

O sistema de circulação da Biblioteca da Unesp/Marília também é definido por duas vias, primária e secundária, e atende os diversos pavimentos do edifício. O início da circulação primária se dá no pavimento térreo, junto à entrada principal e às áreas de atendimento ao público de empréstimo e devolução do material bibliográfico. Na seqüência, a circulação primária se estende por todo o hall principal da biblioteca, servindo às áreas de estar, sala de pesquisa on-line, área administrativa e os acessos das escadas e. A principal característica deste eixo de circulação é a grande quantidade de passagem de pessoas, pois leva não só aos espaços administrativos, mas também aos ambientes do acervo bibliográfico e das mesas de leitura e pesquisa. Ao 
final da circulação primária, iniciam-se os acessos das circulações secundárias que desembocam nos corredores das estantes, tanto do pavimento superior quanto do pavimento inferior.
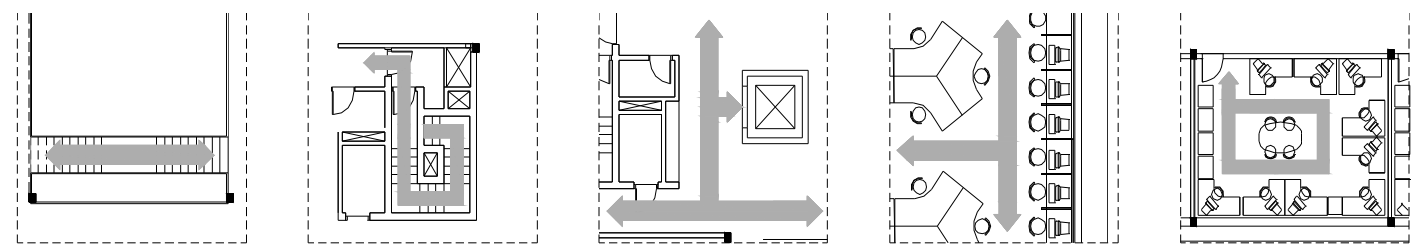

Figura 272 - Exemplos dos esquemas de circulação da Biblioteca Senac/Santo Amaro (sem escala)

Diferentemente do que acontece com a Biblioteca do Senac/Santo, a circulação primária da Biblioteca da Unesp/Marília não acontece no eixo principal do edifício, mas posiciona-se no faixa lateral, junto aos locais de maior acúmulo de pessoas, para depois então, encaminhar-se ao eixo transversal da biblioteca. Essa solução está vinculada, obviamente, ao próprio partido arquitetônico adotado no projeto da biblioteca, que privilegia acessos laterais e descontinuidade nas circulações. O que se percebe no planejamento das circulações da Biblioteca da Unesp/Marília foi a desarticulação dos diversos elementos internos como local do acervo, posicionamento das divisórias, componentes do layout e localização das estações de trabalho, ocasionando perdas e desajustes nas percentagens de ocupação das circulações. 

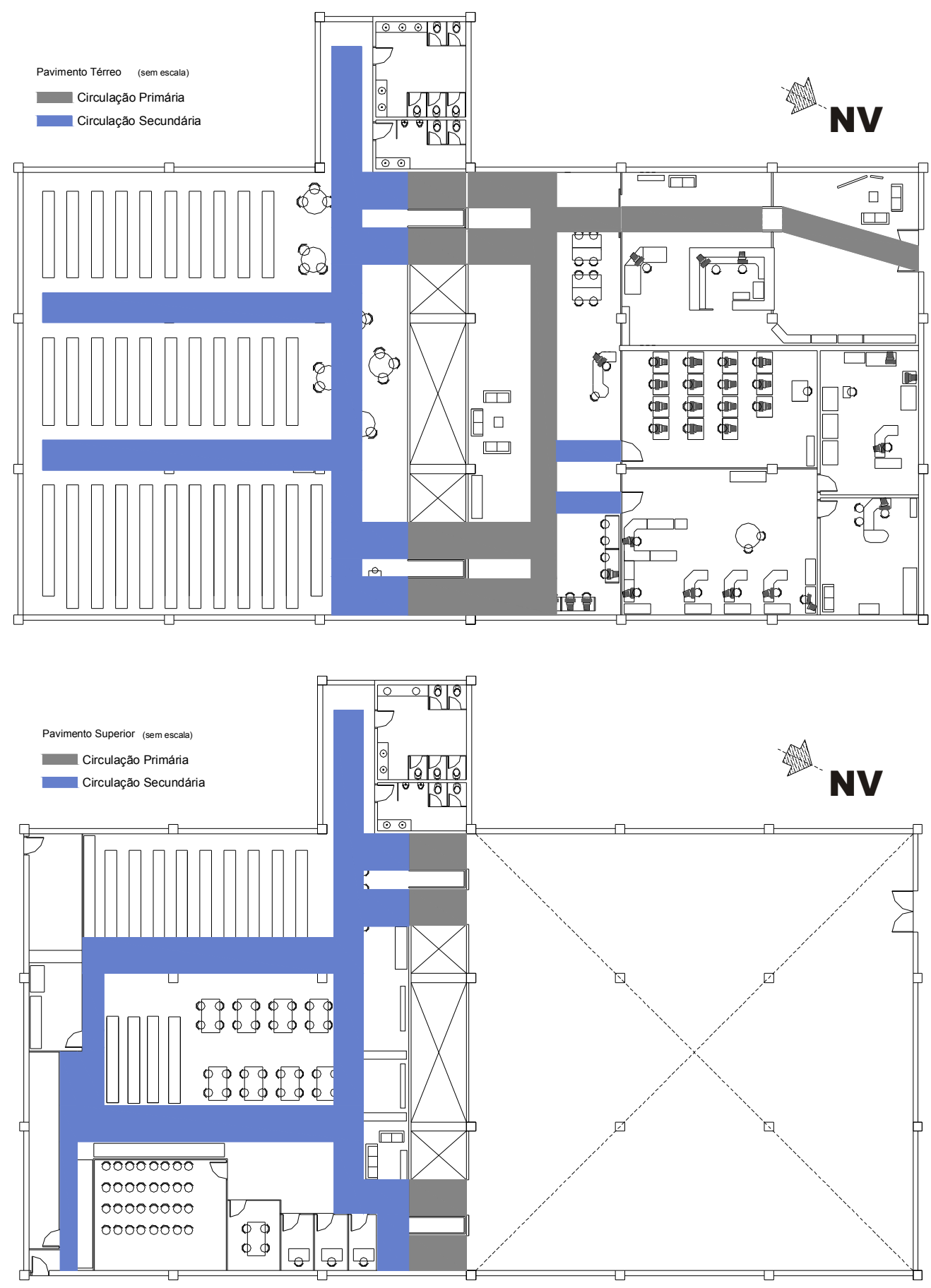

Figura 273 - Layout demarcado da circulação primária e secundária no segundo pavimento da Biblioteca Unesp/Marília

Os percentuais de satisfação na Biblioteca da Unesp/Marília, com relação à avaliação da largura e da localização das escadas, mostrou-se bastante satisfatório em todos os extratos de usuários dos ambientes analisados. Um dado 
importante a ser considerado nas análises funcionais deste quesito, e que está vinculado às avaliações e aos resultados apresentados, refere-se ao fato de o edifício estar localizado na cidade de Marília/SP, portanto, regido pelas leis do CMO - Código Municipal de Obras. Além disso, as normas da ALA - American Library Association trazem importantes parâmetros relacionados aos sistemas de circulação, ao posicionamento e à localização de corredores e escadas no caso Biblioteca da Unesp/Marilia.

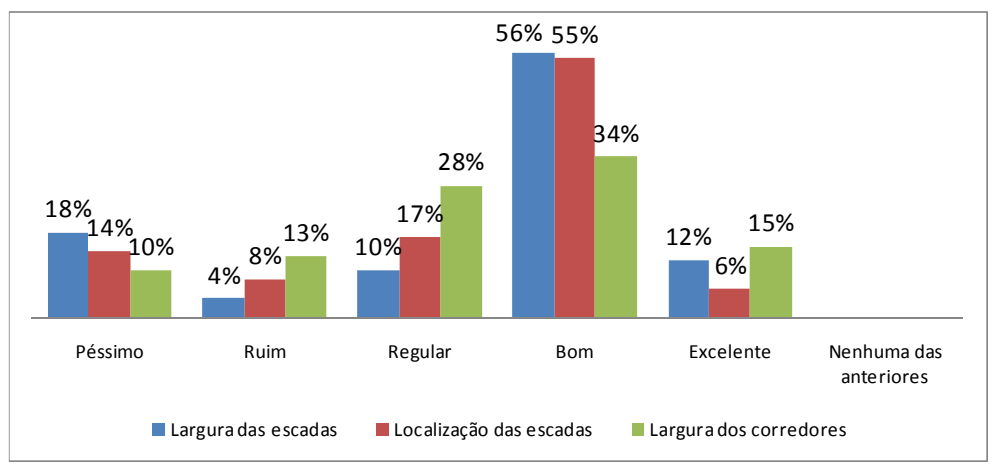

Gráfico 19 - Nível de Satisfação alunos da Biblioteca Unesp/Marília: largura e localização das escadas e corredores

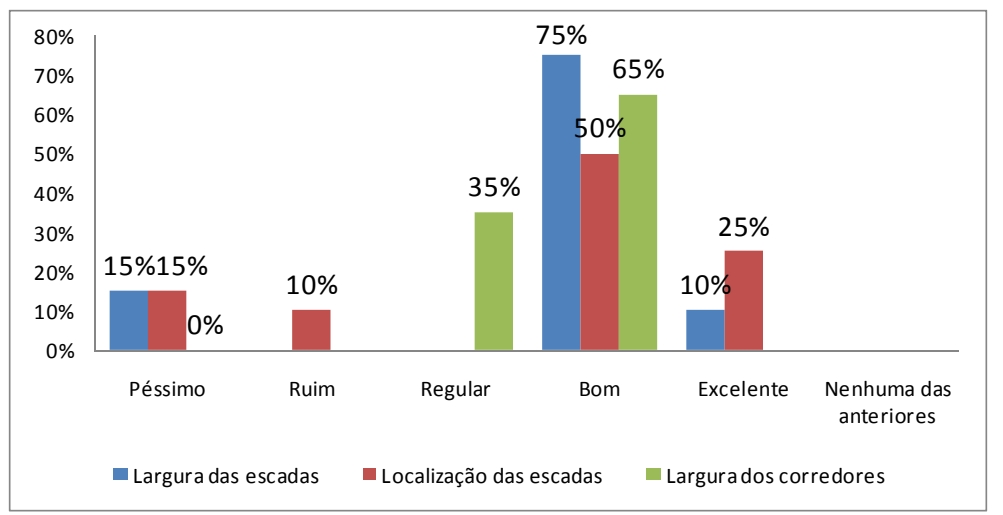

Gráfico 20 - Nível de Satisfação Professores da Biblioteca Unesp/Marília: largura e localização das escadas e corredores

Do ponto de vista da largura e da localização das escadas e corredores, a avaliação dos ambientes apresentou os seguintes resultados:

- a largura das escadas que dão acesso aos pavimentos superior e inferior possui $1,70 \mathrm{~m}$, ou seja, está enquadrada tanto nas normas da $A L A$ quanto do CMO/Marília, que determina a largura mínima de 1,40 m. Entretanto, em 
contato com os usuários, alguns deles relataram certo incômodo com relação à largura da escada, principalmente no período noturno, quando o fluxo da biblioteca aumenta consideravelmente. Este fato ocorre porque não existe um caminho alternativo interno que possibilite o acesso independente a funcionários e alunos e, invariavelmente, principalmente à noite, o contingente de usuários se torna bastante grande. Contudo, mesmo tendo este ponto desfavorável, as escadas proporcionam uma grande facilidade de comunicação entre os dois pavimentos e, no âmbito geral, apresentam boas condições de acessibilidade e usabilidade.

- na questão da circulação primária, as análises confirmaram que as dimensões e as larguras dos corredores que dão acesso aos principais ambientes da biblioteca, apresentam, na maioria dos ambientes analisados, medidas mínimas de 1,50 m adequadas à população existente e à legislação do $C M O$ Código Municipal de Obras de Marília e da ALA - American Library Association, que estipulam o mínimo de 1,40 m. Contudo, em alguns locais e corredores como, por exemplo, a saída de emergência localizada do pavimento inferior da biblioteca, a largura do corredor é de $0,90 \mathrm{~m}$, bem abaixo do que determina a norma vigente. Nos capítulos anteriores destacou-se a importância do dimensionamento correto das circulações e dos corredores no processo de organização e disposição espacial das coleções no âmbito da biblioteca universitária, influenciando, inclusive, a maneira com que o usuário executa a busca e recuperação de informação. Hoje em dia, a utilização dos sistemas tradicionais de arquivamento, pelo padrão de módulos estantes de 1,35 m, $20 \mathrm{~cm}$ de profundidade, $30 \%$ dos corredores dedicados ao armazenamento e $70 \%$ para as circulações, os sistemas de arquivamento compacto constituem uma tentativa de aproveitar, com maior eficácia, a relação entre circulação e armazenamento no ambiente da biblioteca (NBR - 9578 e NBR - 1141);

- dentro da realidade do acervo bibliográfico, a largura entre estantes não segue um padrão específico, registrando valores de $0,70 \mathrm{~m}$, outros de $0,60 \mathrm{~m}$ e ainda outros de 0,85 m. Essas distâncias evidenciam um problema a ser corrigido, uma vez que em relação à legislação vigente, a NBR - 9050/2004 e a $A L A$, determina-se que a largura mínima entre as estantes deve ser de 0,90 m. Nesse contexto, em determinadas ocasiões em que a passagem de duas pessoas no mesmo corredor acontece simultaneamente, o espaço não oferece condições 
adequadas de usabilidade. $\mathrm{O}$ ideal seria estabelecer um partido arquitetônico que propiciasse uma organização mais ordenada do espaço, ou seja, neste caso, a tarefa seria aumentar o espaçamento entre as prateleiras, deixando mais livre o acesso ao acervo bibliográfico, ou mesmo, reconfigurar o layout, com objetivo de corrigir possíveis desajustes funcionais da biblioteca. É possível diagnosticar preliminarmente que, a falta de um projeto específico direcionado à organização espacial do acervo bibliográfico, sem dúvida, acarreta diversas dificuldades tanto para o usuário que objetiva a busca da informação quanto ao funcionário que desempenha suas funções no edifício da biblioteca.
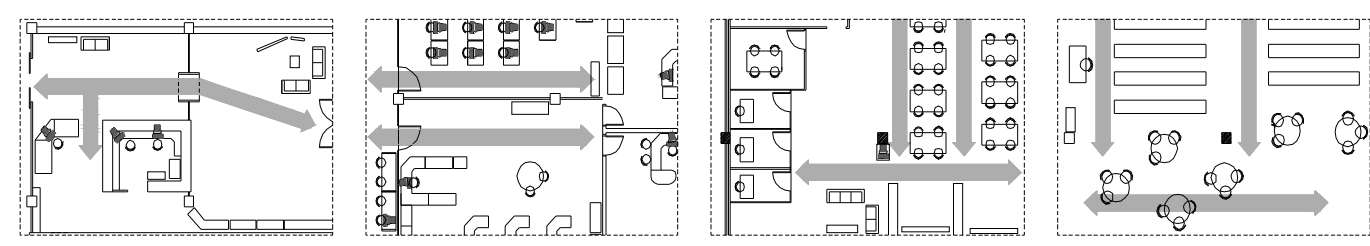

Figura 274 - Exemplos dos esquemas de circulação da Biblioteca Senac/Santo Amaro (sem escala)

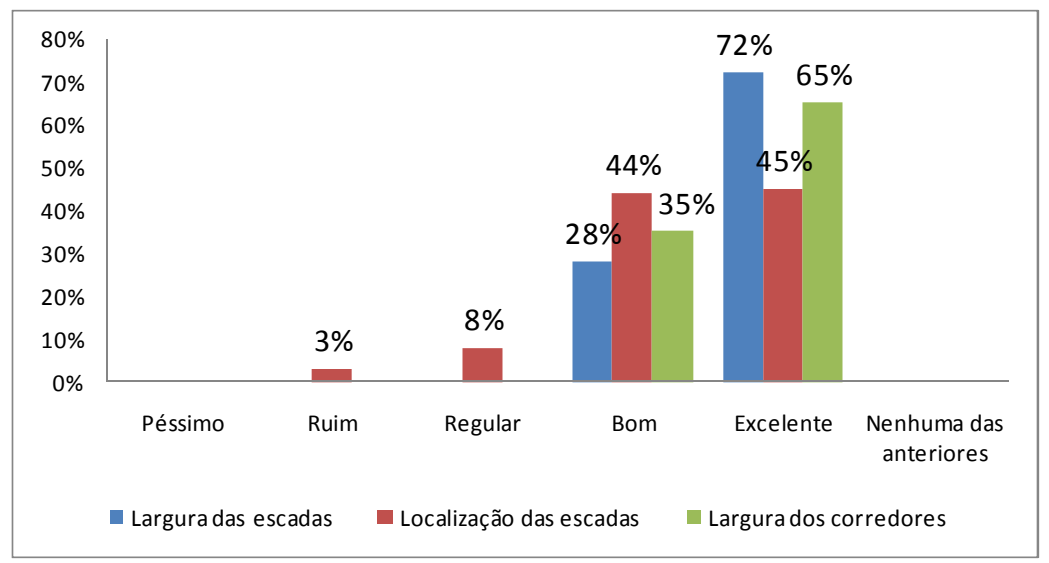

Gráfico 21 - Nível de Satisfação funcionários da Biblioteca Unesp/Marília: largura e à localização das escadas e corredores

\subsection{Acesso e adaptação do deficiente físico}

O objetivo da análise deste item foi avaliar o estado atual dos edifícios dos estudos de caso, com relação às condições de acesso e adaptação do defíciente 
físico ao ambiente. Como parte da avaliação, foi feita uma vistoria nos edifícios escolhidos, procurando observar a aplicação da norma e também detectar os principais problemas enfrentados pelos deficientes que utilizam os edificios atualmente. $\mathrm{Na}$ avaliação das condições de acessibilidade e da adaptação das bibliotecas universitárias analisadas, foram excluídas as condições de acessibilidade referentes ao entorno dos edifícios, uma vez que o propósito deste trabalho, como exposto anteriormente, concentra-se nos aspectos internos das bibliotecas. Em suma, buscou-se captar a percepção dos usuários com relação à acessibilidade para pessoas com deficiência.

O intuito da acessibilidade é permitir um ganho de autonomia e de mobilidade a uma gama bem maior de pessoas, até mesmo àquelas que tenham a sua mobilidade reduzida, para que usufruam os espaços com maior segurança, confiança e comodidade. Desta forma, é possível obter ambientes que atendam às propostas do desenho universal ${ }^{2}$, com possibilidades à adequação de ambientes e produtos não somente para o portador de deficiência física, mas também para todo ser humano que, por uma razão ou outra, não se encaixa no modelo pré-estabelecido de homem padrão.

Entretanto, apesar dos esforços promissores de entidades e organizações civis das pessoas com deficiência, a fim de que os direitos sejam garantidos e efetivados em todas as instâncias, na prática, a questão da acessibilidade nos espaços públicos e nos edifícios brasileiros vem sendo aplicada de forma lenta. De qualquer maneira, atualmente, todas as leis brasileiras estão atreladas às normas técnicas de arquitetura e urbanismo da $\mathrm{ABNT}$, que versam sobre a acessibilidade no espaço edificado. Nesse contexto, a NBR - 9050/2004 aparece como a norma que tem a função de orientar os profissionais de Arquitetura e Engenharia a respeito das condições de acessibilidade das pessoas com deficiência ao meio ambiente construído.

Do ponto de vista dos usuários, os resultados apresentados demonstraram que os índices de avaliação foram bastante diferenciados entre os edifícios selecionados para a pesquisa. Com base nas entrevistas com usuários-chave e nos resultados dos questionários aplicados, pode-se comprovar o que foi observado pelas visitas técnicas no decorrer da avaliação, ou seja, a existência de duas realidades diversas no que se refere a um edifício de biblioteca realmente adaptado ao deficiente físico e outro em processo de adaptação. A Biblioteca do Senac/Santo Amaro aparece como tendo a maior

\footnotetext{
${ }^{2}$ Desenho Universal abrange produtos e edifícios acessíveis e utilizados por todos, inclusive por pessoas portadoras de deficiências. [...]. Lida com a adaptação para toda uma gama de capacidade ou habilidades.[..] e não é uma tecnologia direcionada apenas aos que dela necessita, é desenhado para todas as pessoas. (STEINFELD, 1994).
} 
satisfação entre os usuários, $\mathbf{5 5 \%}$ consideram o acesso e a circulação de deficiente na biblioteca Excelente e $\mathbf{4 6 \%}$ consideram que a biblioteca está adaptada para o uso dos deficientes; por outro lado, no caso da Biblioteca da Unesp/Marilia, os índices apresentaram-se muito baixos, variando a satisfação entre os extratos dos usuários entre péssimo, ruim e regular.

$\mathrm{Na}$ Biblioteca da Unesp/Marília, portanto, do ponto de vista da acessibilidade, a avaliação dos níveis de satisfação dos usuários, considerada muito baixa, reafirmando que esses ambientes não estão completamente adequados e confortáveis para utilização de pessoas portadoras de deficiência locomotora, além de reforçar a existência de distorções que devem ser corrigidas (ver Figura 275).

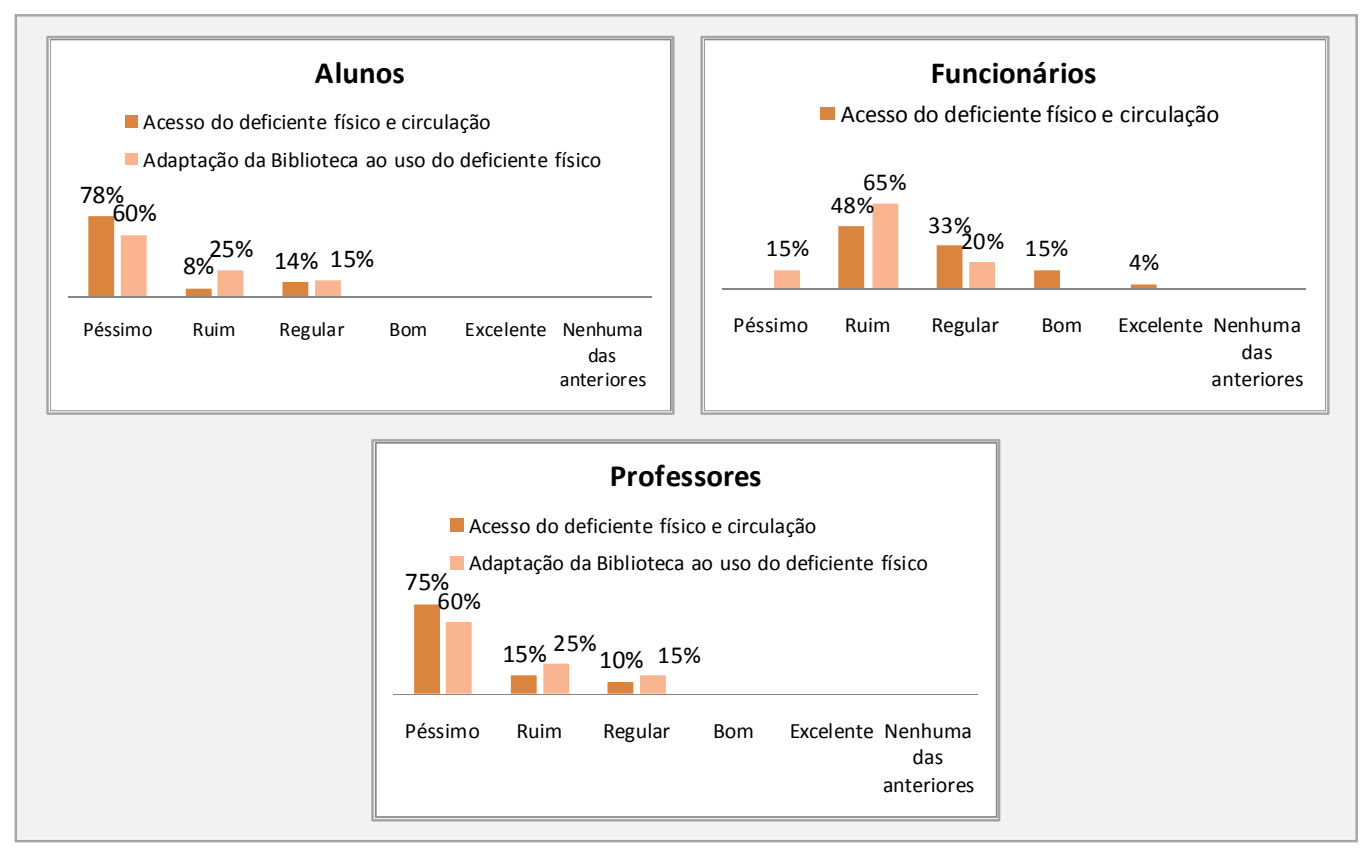

Figura 275 - Nível de Satisfação alunos da Biblioteca Unesp/Marília: acesso e adaptação do deficiente físico

Analisando detalhadamente as condições de acessibilidade e de circulação do deficiente na Biblioteca da Unesp/Marília, foi possível, além de entender e explicar os índices baixos de satisfação neste item, construir um quadro mais realístico e formatar algumas considerações importantes, a saber: 
- $\quad$ como o edifício é organizado em cotas de níveis diferenciadas entre os pavimentos (pavimento térreo, mezanino e pavimento inferior), existe uma grande dificuldade de acesso e circulação entre os vários ambientes da biblioteca, principalmente pelo usuário que possui alguma forma de deficiência, justamente porque a única maneira possível de acesso se faz por meio das escadas. Neste caso, duas alternativas poderiam minimizar os problemas quanto à acessibilidade: a primeira seria a instalação de um elevador ou de um montacarga, pois ocupariam muito menos espaço do que uma rampa e estaria disponível uma excelente alternativa de circulação vertical. Hoje a instalação desse equipamento não se configura em um custo muito elevado para os padrões de uma biblioteca universitária administrada por um órgão público estadual; $a$ segunda alternativa refere-se à possibilidade de instalação de uma rampa na biblioteca no sentido de facilitar o acesso aos vários ambientes. Contudo, em determinadas situações, como é este caso, as rampas não podem ser instaladas, em razão do pouco espaço disponível e a impossibilidade de se executar uma rampa com a declividade exigida pela norma $N B R-9050 / 2004$ de $6,25 \%$ e $8,33 \%$ e o alto custo de construção.

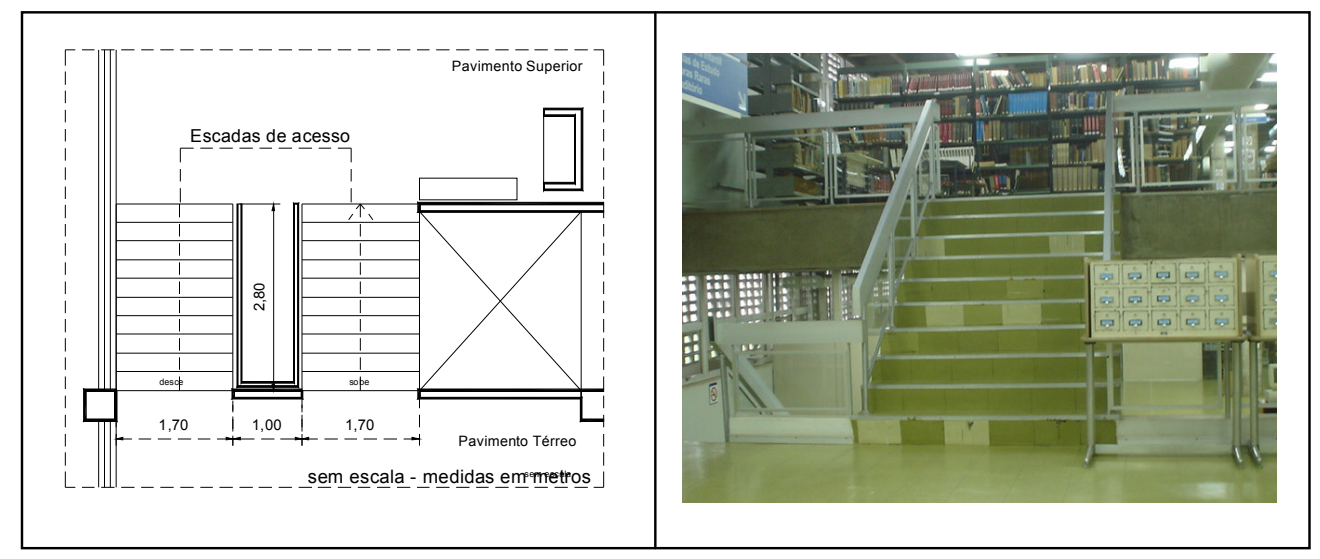

Figura 276 - Detalhe de circulação e foto da escada entre o Pav. Térreo e Pav.Superior Biblioteca Unesp/Marília

- com relação às escadas, a norma NBR - 9050/2004 recomenda sinalização tátil de alerta, estipulando que a superfície a ser sinalizada deve exceder em 0,60 m a projeção em obstáculo, como pode ser visto na Figura 276. Entretanto, as escadas presentes na biblioteca obedecem a esses requisitos 
estipulados pela norma vigente. $\mathrm{O}$ mesmo problema é constatado nos corrimãos das escadas, executados com arestas vivas e medidas fora da norma, com largura de 5,5 cm e seção retangular. Em contrapartida, a NBR - 9050/2004 recomenda largura entre $3,0 \mathrm{~cm}$ e $4,5 \mathrm{~cm}$, sem aresta viva e preferencialmente de seção circular em razão da empunhadura;

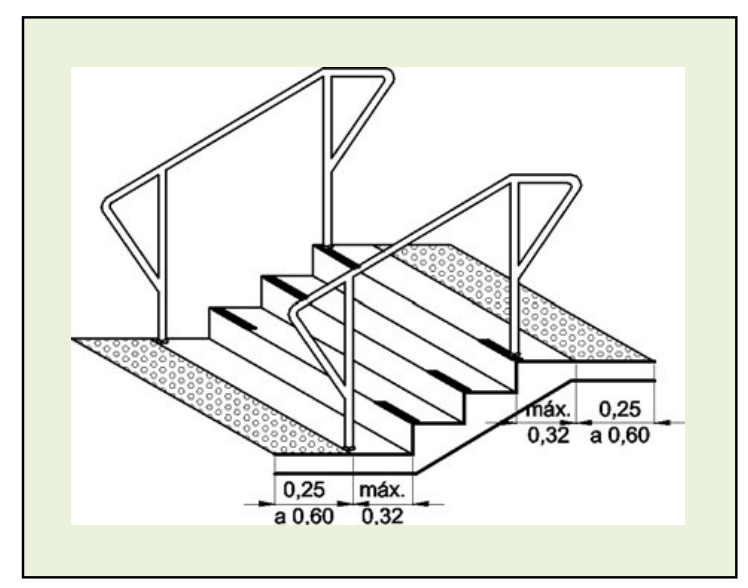

Figura 277 - Sinalização tátil de alerta nas escadas recomendado pela norma Fonte: ABNT - NBR - 9050/2004

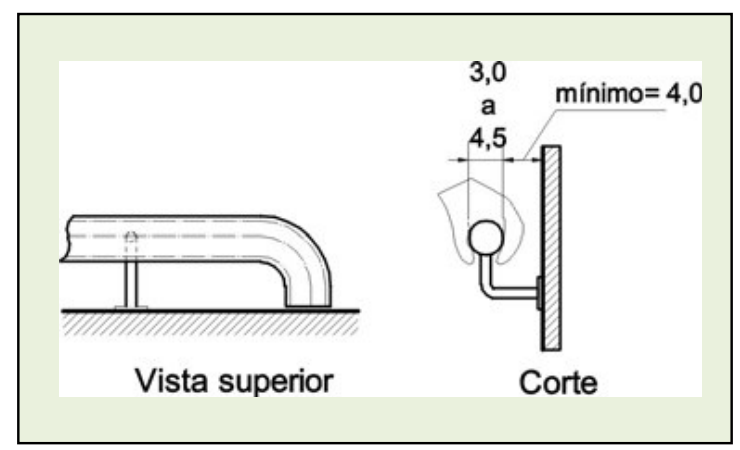

Figura 278 - Empunhadura de corrimão recomendado pela norma Fonte: ABNT - NBR - 9050/2004

- $\quad$ com relação aos sanitários da Biblioteca da Unesp/Marília foi possível observar que nenhum deles está adequado ao acesso de pessoas portadoras de deficiência física, nos quesitos relacionados à $N B R$ - 9050/2004 que são: (a) os sanitários da biblioteca não apresentam mínimo de $5 \%$ do total de cada peça instalada acessível; (b) - inexistência de barras de apoio metálicas com comprimento mínimmo de $0,80 \mathrm{~m}$ e altura de $0,75 \mathrm{~m}$ do piso acabado; (c) - as bacias sanitárias não apresentam áreas de transferência lateral, perpendicular e 
diagonal, bem como manobra para rotação de 180 graus; (d) - falta de área de aproximação frontal nos lavatórios, bacias e mictórios com o mínimo de 0,25 m; (e) - as torneiras não têm acionamento por alavancas ou célula fotoelétrica; $(f)$ não sendo sanitários adaptados, as portas não têm, pelo lado externo, a identificação visual de acessibilidade (símbolo internacional de acesso), além do elemento protetor em borracha ou laminado, no lado externo, a 0,30 $\mathrm{m}$ do piso; (g) - os boxes onde estão instaladas as bacias sanitárias não dispõem de área mínima de 1,20 m x 1,50 m e não garantem áreas de transferências e barras de apoio;

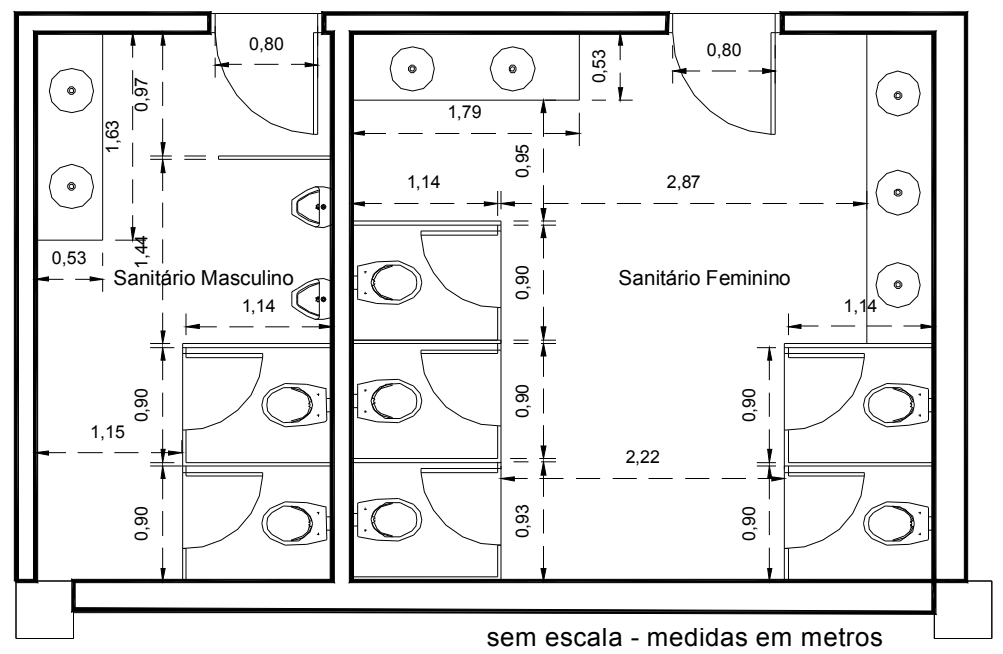

Figura 279 - Sanitários Biblioteca Unesp/Marília

- $\quad$ com relação a largura de portas e os elementos físicos, as dimensões encontradas dos ambientes estão dentro da norma $N B R$ - 9050/2004, que estipulam $0,80 \mathrm{~m}$ como valores mínimos. Os principais corredores de circulação da biblioteca também se enquadram na norma, que exigem 1,20 m para a circulação para uma pessoa e uma cadeira de rodas. Além disso, constatou-se que os locais destinados às manobras sem deslocamento obedeceu à área mínima de 1,20 m por 1,20 m para rotação a 90 graus e área mínima de $1,50 \mathrm{~m}$ por 1,20 $\mathrm{m}$ para rotação de 180 graus, obedecem aos valores da norma vigente. Entretanto, os corredores pertencentes ao acervo bibliográfico, que ficam

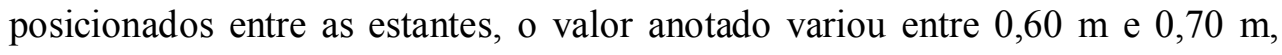
portanto, fora das dimensões mínimas estipuladas pela norma $N B R-9050 / 2004$, que é de $0,90 \mathrm{~m}$. Ou seja, na percepção dos alunos que possuem deficiência 
locomotora na Universidade e que se utilizam dos ambientes da biblioteca, estes locais foram considerados inacessíveis;

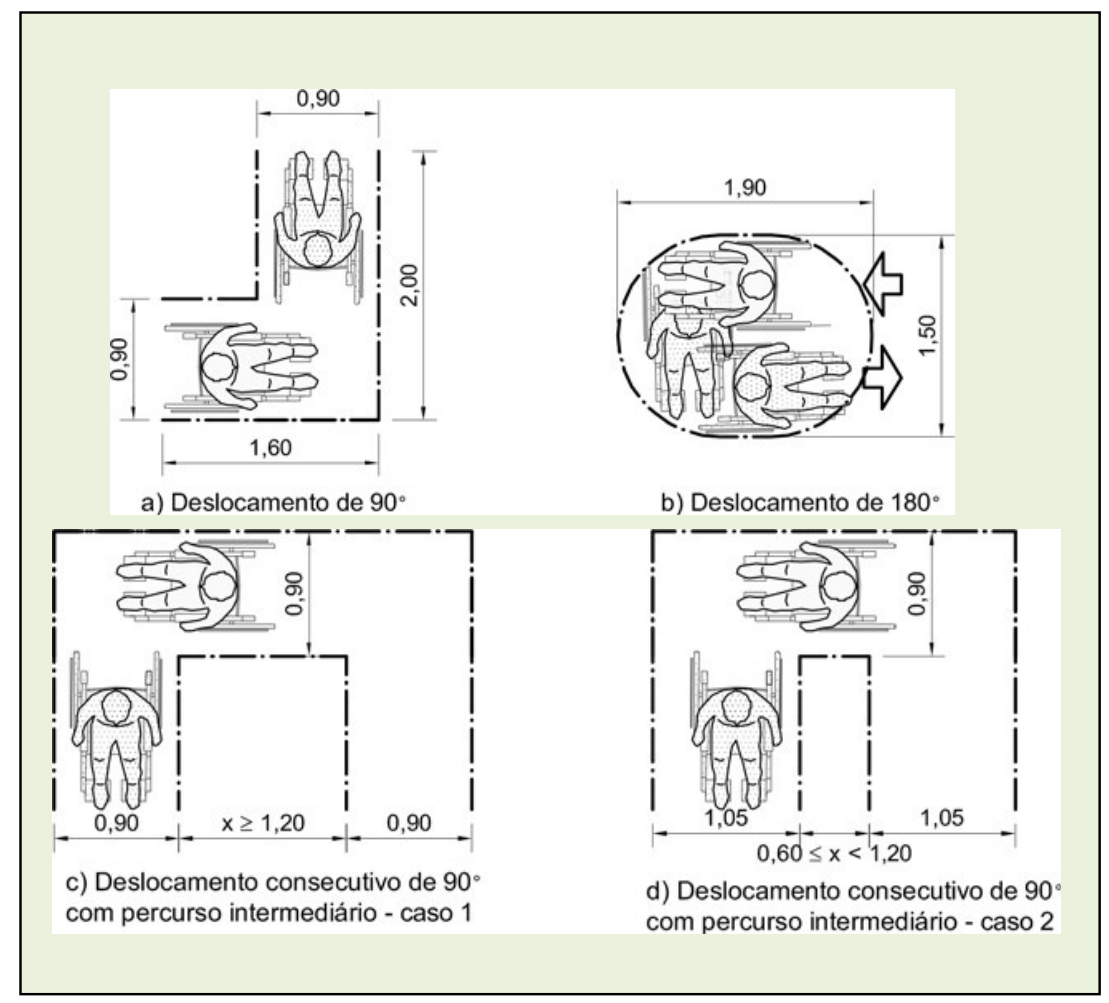

Figura 280 - Área para manobra de cadeiras de rodas com deslocamento recomendado pela norma Fonte: ABNT - NBR - 9050/2004

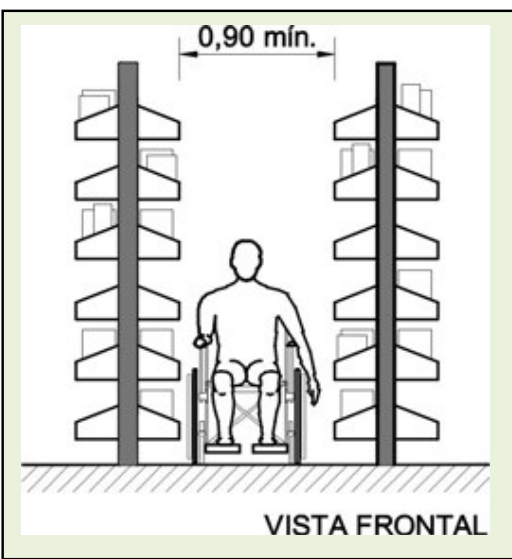

Figura 281 - Dimensionamento mínimo de estantes em bibliotecas Fonte: ABNT - NBR - 9050/2004 


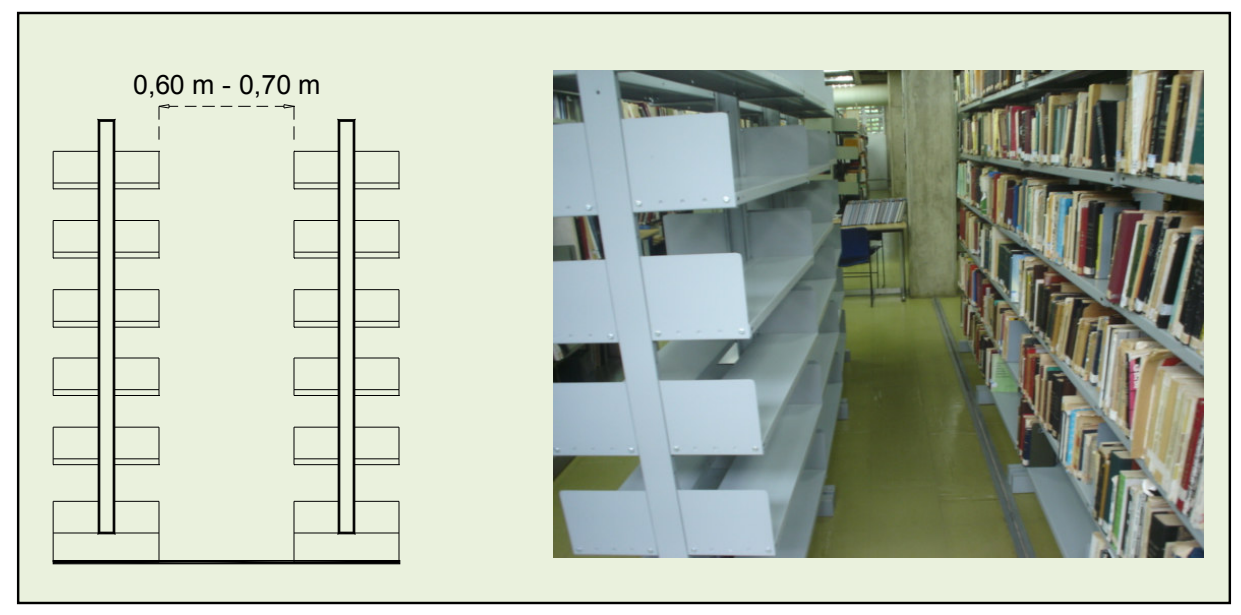

Figura 282 - Corredor de estantes Biblioteca Unesp/Marília (medidas em metros e sem escala)

- $\quad$ a $N B R$ - 9050/2004 estipula que a mesa deve estar a uma altura entre $0,75 \mathrm{~m}$ e $0,85 \mathrm{~m}$ do piso e que possibilite um avanço sob a mesa até no máximo de 0,50 m. Portanto, neste caso, as condições de acesso ao mobiliário e as mesas de trabalho dos ambientes da biblioteca foram consideradas boas pelos usuários e estão ajustadas à norma quanto ao uso da cadeira de rodas, tanto na altura como na área de aproximação. Esta mesma situação é encontrada nas áreas de circulação entre as mesas, permitindo que haja uma faixa livre de $0,90 \mathrm{~m}$, valor mínimo estabelecido pela norma. Já na área destinada à consulta em bases de dados, referente ao acervo bibliográfico digitalizado, as mesas onde ficam instalados os terminais de microcomputadores não proporcionam condições adequadas às pessoas portadoras de dificuldades de locomoção, registrando a altura de 1,00 $\mathrm{m}$ na superfície da mesa. $\mathrm{O}$ usuário de cadeira de rodas tem dificuldade de alcançar os equipamentos informáticos, principalmente em função da altura e dos ângulos de aproximação considerados impróprios para o desenvolvimento das atividades neste setor: 


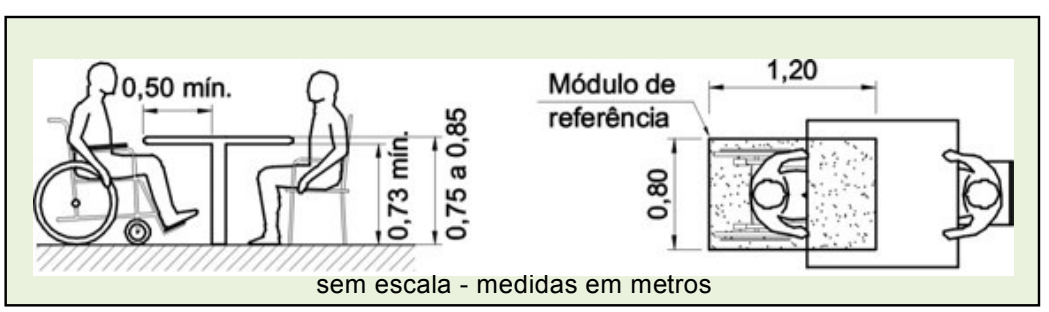

Figura 283 - Dimensionamento mínimo das mesas de trabalho recomendado pela norma Fonte: ABNT - NBR - 9050/2004

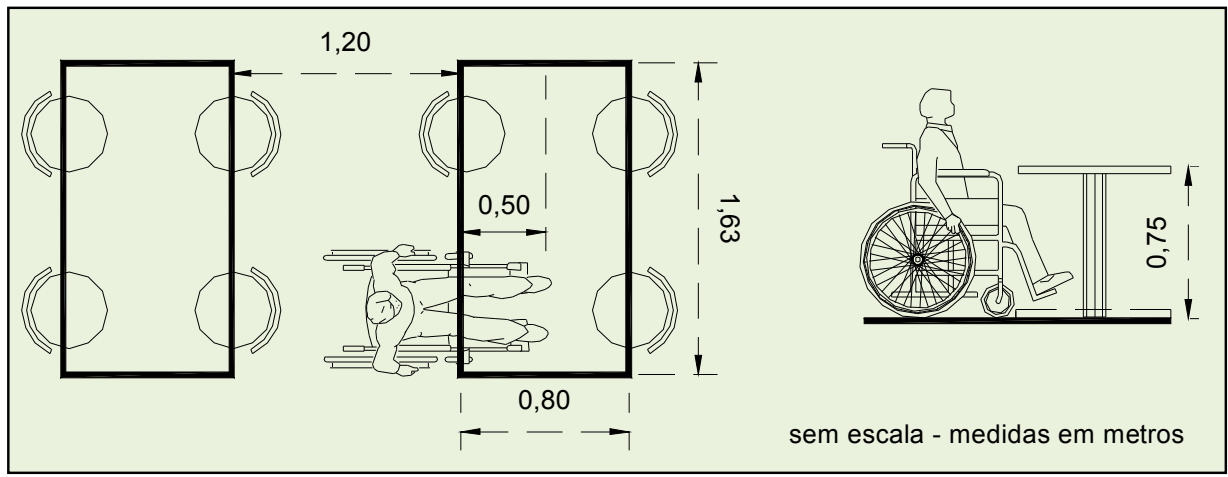

Figura 284 - Dimensionamento das mesas de trabalho Biblioteca Unesp/Marília

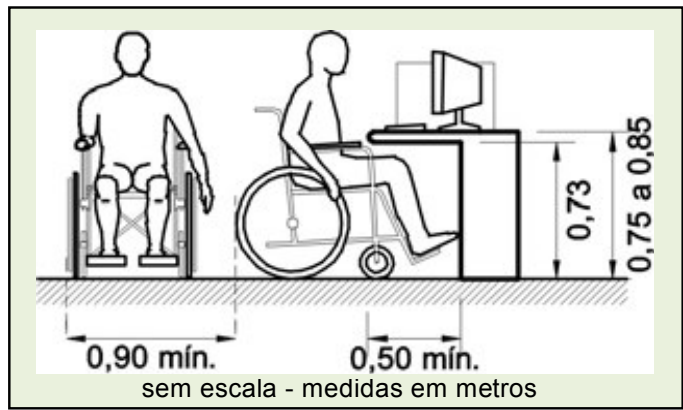

Figura 285 - Dimensionamento mínimo terminais de consulta Fonte: ABNT - NBR - 9050/2004

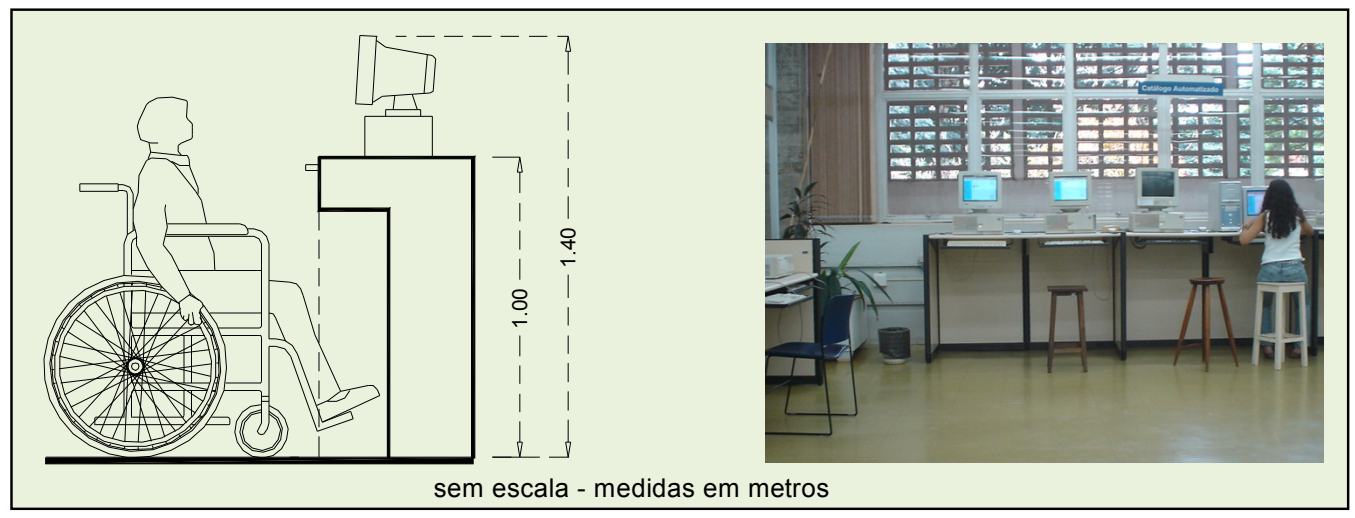

Figura 286 - Dimensionamento consulta em bases de dados Biblioteca Unesp/Marília 
- no setor administrativo, com relação à norma $N B R-9050 / 2004$, dois elementos importantes foram apontados: o primeiro, o corredor de passagem principal da sala de serviços técnicos, com largura de 2,40 m entre as mesas de trabalho e a divisória, atende ao padrão mínimo estipulado pela norma que é de 1,50 m. Porém, as medidas de 0,75 m entre as estações de trabalho estão fora do padrão fixado pela norma, sugerindo, neste caso, que a dimensão seja de $0,90 \mathrm{~m}$; e segundo, as portas com maçanetas de aço inox são inapropriadas e dificultam o manuseio por parte dos usuários. Neste caso, a reorganização do layout das estações de trabalho poderia resolver, de forma relativamente fácil, os problemas relacionados à acessibilidade de pessoas portadoras com dificuldade de locomoção

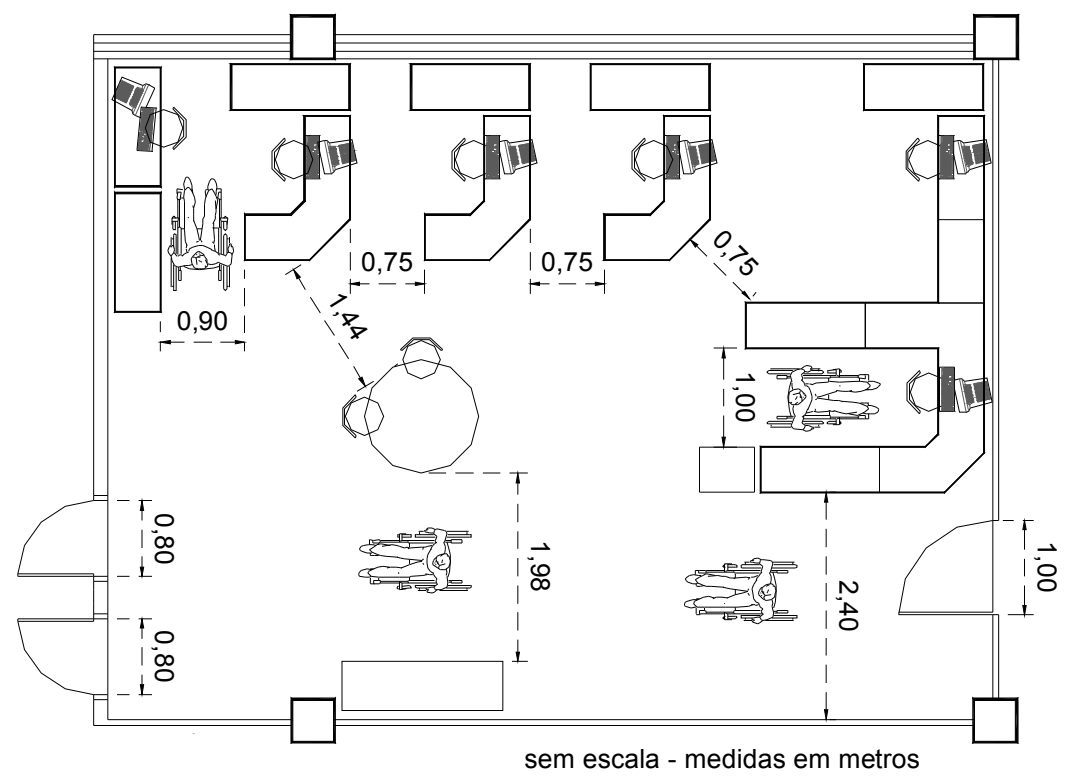

Figura 287 - Dimensionamento setor administrativo Biblioteca Unesp/Marília

- $\quad$ O balcão de empréstimo e devolução, localizado logo à entrada da biblioteca, não apresenta nenhuma infra-estrutura para receber cadeirantes. A norma $N B R$ - 9050/2004 recomenda que a altura mínima necessária para atender este tipo de usuário deve ser de $0,73 \mathrm{~m}$ de altura em relação ao solo, e que a profundidade livre no balcão para acomodação das pernas deve ser de $0,30 \mathrm{~m}$. Conforme constatado nas visitas técnicas, em toda a extensão de 4,00 m X 3,00 m, a altura do balcão se conserva em 1,14 m, não apresentando nenhuma faixa 
de altura menor destinada às pessoas que utilizam cadeiras de rodas. Além disso, não há nenhum recorte na profundidade livre no balcão para a acomodação das pernas. Com relação a este quesito, a norma considera que não seja necessário toda a extensão do balcão ter essa configuração, mas pelo menos numa largura mínima de $0,80 \mathrm{~m}$ deve haver este corte. A avaliação do balcão de empréstimo e devolução da Biblioteca da Unesp/Marília relacionada aos critérios da NBR 9050/2004 recomenda mudanças e readaptações, para proporcionar à maior quantidade de pessoas com limitação de mobilidade a utilização de maneira autônoma e segura do ambiente analisado

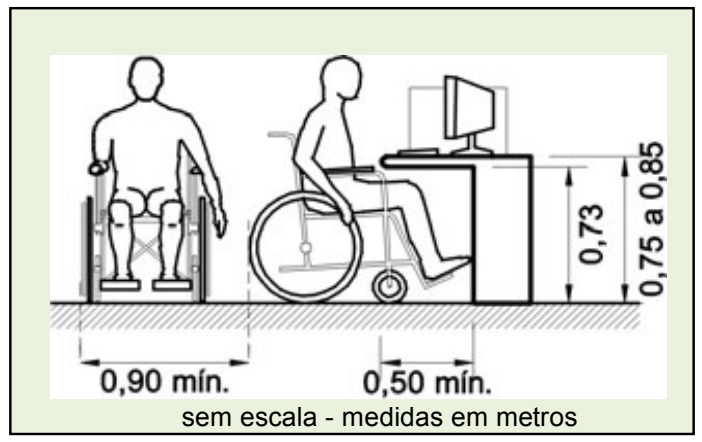

Figura 288 - Dimensionamento mínimo terminais de consulta Fonte: ABNT - NBR - 9050/2004

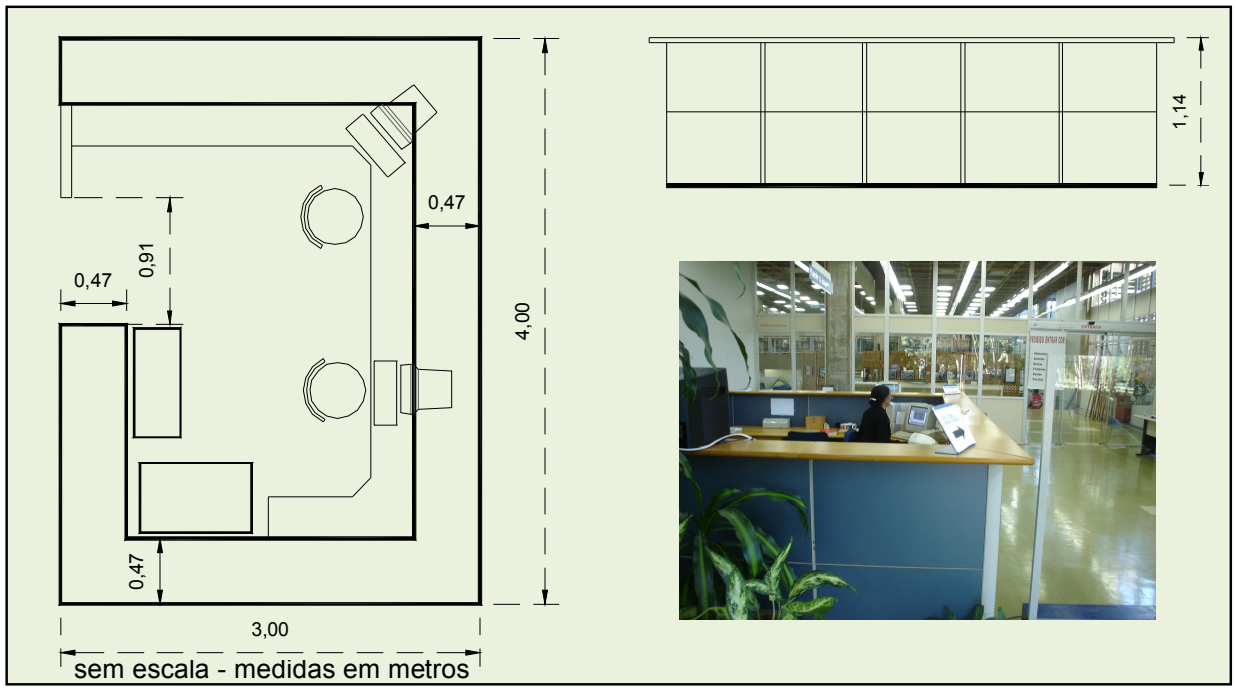

Figura 289 - Balcão de empréstimo e devolução Biblioteca Unesp/Marília

- $\quad$ Com relação aos bebedouros, a NBR - 9050/2004 estabelece critérios a serem observados como, por exemplo: devem ser acessíveis e permitir a aproximação de cadeiras de rodas; a bacia, as bicas e os comandos devem estar a 
uma altura de $0,80 \mathrm{~m}$; deve ser prevista a instalação de $50 \%$ de bebedouros acessíveis por pavimento; os dispositivos de acionamento devem permitir a operação manual e ser do tipo alavanca. No caso da Biblioteca da Unesp/Marília, os bebedouros estão na altura adequada, contudo, não permitem avançar sob o bebedouro com espaçamento mínimo de 0,50 m (Figura 00), como recomenda a norma;

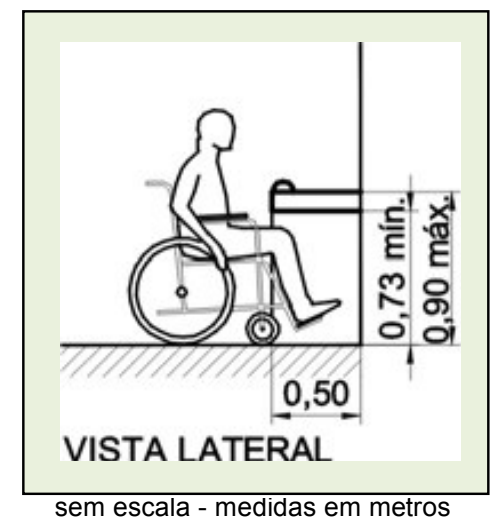

Figura 290 - Bebedouro recomendado pela norma

Fonte: ABNT - NBR - 9050/2004

No caso específico da Biblioteca da Unesp/Marília, ações constantes ligadas às entidades dos portadores de deficiência física da própria direção da universidade e da biblioteca local vêm sendo tomadas para minimizar ou resolver os problemas decorrentes da falta de adequação do edifício às condições de acesso e adaptação do deficiente físico. Dentre elas, destaca-se, na entrada principal do edifício, a construção de uma rampa de acesso com barras de apoio, atendendo a uma reivindicação antiga da própria biblioteca. Além disso, um grupo permanente de estudos, pertencente à própria universidade, tem desenvolvido atividades ligadas à melhoria das condições de acessibilidade nos ambientes do campus universitário e vem propondo, paulatinamente, diversos projetos no âmbito de remoção de barreiras arquitetônicas, adaptações espaciais, instalações de equipamentos direcionados às melhores condições de acessibilidade e o desenvolvimento de campanhas educativas junto à comunidade acadêmica. Observou-se, no entanto, que nem todas as propostas de intervenções têm sido centralizadas nos usuários, ou seja, existe ainda a dificuldade em entender quais as reais necessidades do portador de deficiência física frente a um 
ambiente de biblioteca universitária e como o espaço pode se tornar um elemento facilitador e impulsionador de motivação.

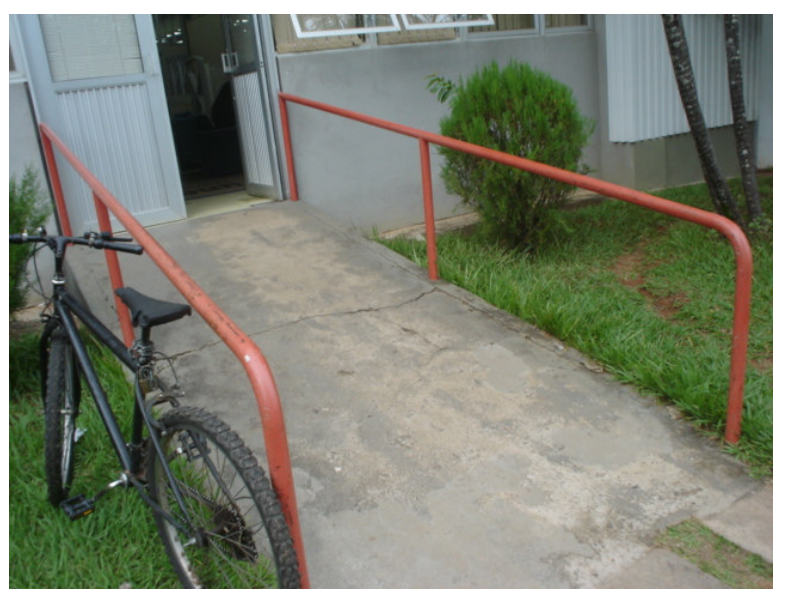

Figura 291 - Rampa de acesso e barros de apoio entrada principal da Biblioteca Unesp/Marília

Ao analisar as condições ambientais da Biblioteca do Senac/Santo Amaro, no item relacionado ao acesso e à adaptação do deficiente físico, percebe-se que o edifício tem uma proposta arquitetônica acessível, considerando os parâmetros arquitetônicos da norma NBR 9050 - 2004. Sabe-se que a iniciativa de incorporação dos elementos acessíveis do projeto arquitetônico foi decorrente de uma determinação imposta pela própria direção do Senac e da equipe de arquitetos responsáveis pelo projeto, com o objetivo de atender aos itens essenciais da acessibilidade no edifício. Os detalhes do projeto e os componentes principais da acessibilidade presentes no edifício reforçam a importância da introdução do Desenho Universal na concepção e execução do espaço da biblioteca. Como resultado disso, no final das avaliações, constatou-se que, na opinião dos funcionários, alunos e professores, os ambientes estão adequados e possibilitam autonomia às pessoas com deficiência (parcial ou total) visual, auditiva ou de locomoção. 


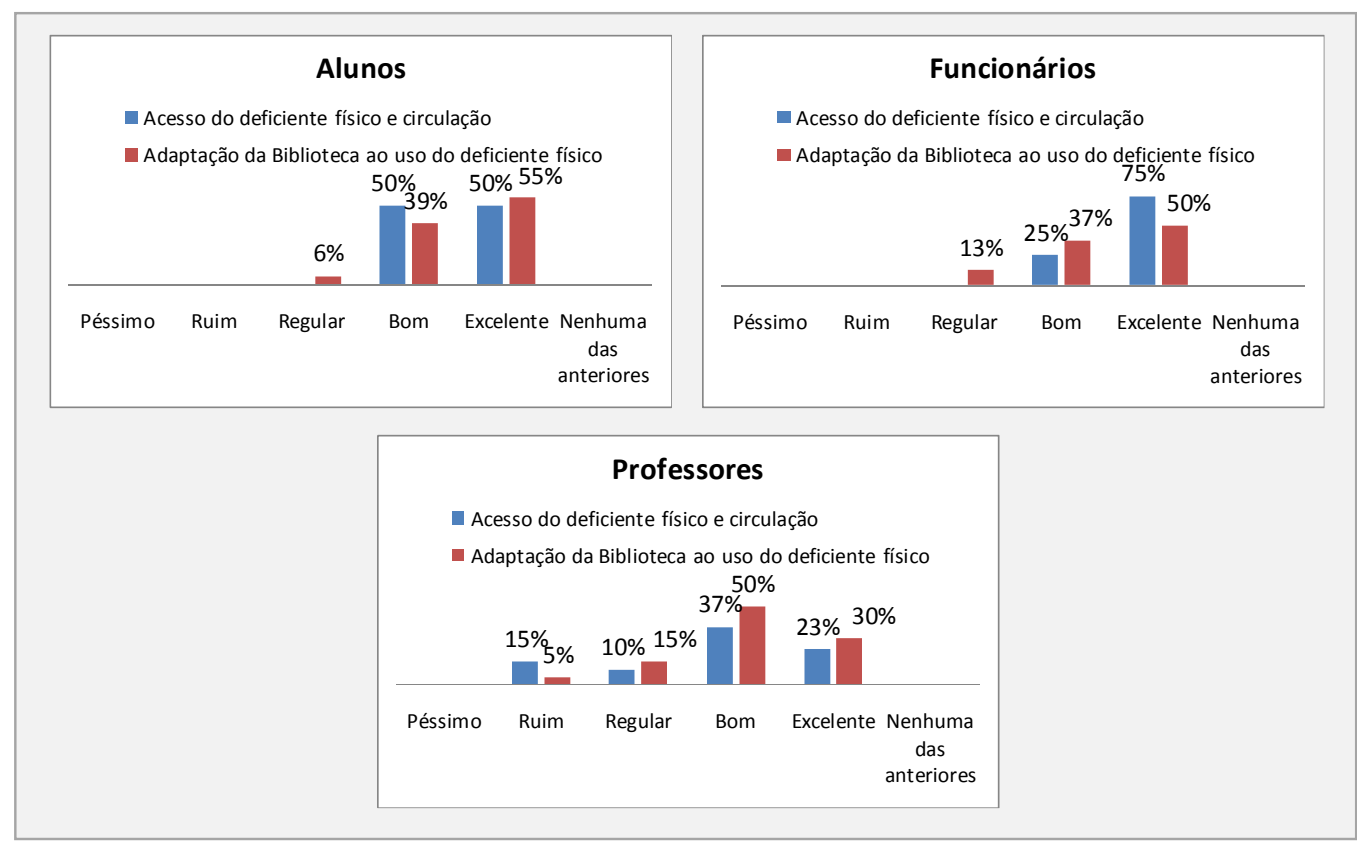

Figura 292 - Nível de Satisfação alunos da Biblioteca Senac/Santo Amaro: acesso e adaptação do deficiente físico

De modo geral, todos os ambientes pertencentes à Biblioteca do Senac/Santo Amaro (térreo, primeiro pavimento e segundo pavimento), analisados sob a ótica da acessibilidade e da adaptabilidade ao deficiente físico, tiveram níveis muito elevados de satisfação junto aos extratos de usuários e indicam que os espaços estão sendo utilizados de maneira autônoma e segura. Esses resultados também evidenciam o grande contraste em relação à Biblioteca da Unesp/Marília, cujo usuários apresentaram não só respostas bem inferiores de satisfação, como também condições técnicas e espaciais inferiores de funcionamento. Do ponto de vista da acessibilidade, os resultados apresentados a seguir estão baseados nas observações técnicas efetuadas e nas informações fornecidas pelos usuários dos ambientes analisados da Biblioteca do Senac/Santo Amaro. Nesse contexto, é possível destacar pontos importantes com relação a este item, a saber:

- A escada localizada bem ao centro do edifício, e que dá acesso aos dois pavimentos superiores, enquadra-se na $N B R$ - 9050/2004 com a largura de 1,40 m, mesma dimensão estabelecida pela norma. Assim, mesmo sendo um edifício distribuído em três pavimentos, os acessos aos ambientes se fazem por meio desta escada principal, o elevador desempenha papel fundamental no processo de acessibilidade de pessoas 
portadoras de deficiências. No caso da Biblioteca do Senac/Santo Amaro, o elevador atende integralmente ao dispositivo da NBR - 13994 quanto à sinalização, dimensionamento e características gerais. No atendimento aos requisitos da $N B R-$ 9050/2004, o elevador possui externamente a sinalização tátil e visual, informando a instrução de uso, indicação da posição para embarque e dos pavimentos atendidos. A única desvantagem apontada pelos usuários e constatada pela visita técnica é falta de sinalização indicativa relativa à posição e o acesso do elevador no pavimento, provocando muitas vezes, confusão nas condições de deslocamento destas áreas. Entretanto, o espaço fronteiriço à porta do elevador, destinado a manobra correta da cadeira de rodas, respeitou ao dimensionamento mínimo descrito pelo $C O E-S P$ (1993), não inferior a 1,50 m, assim como a porta que tem o vão livre de $0,80 \mathrm{~m}$.

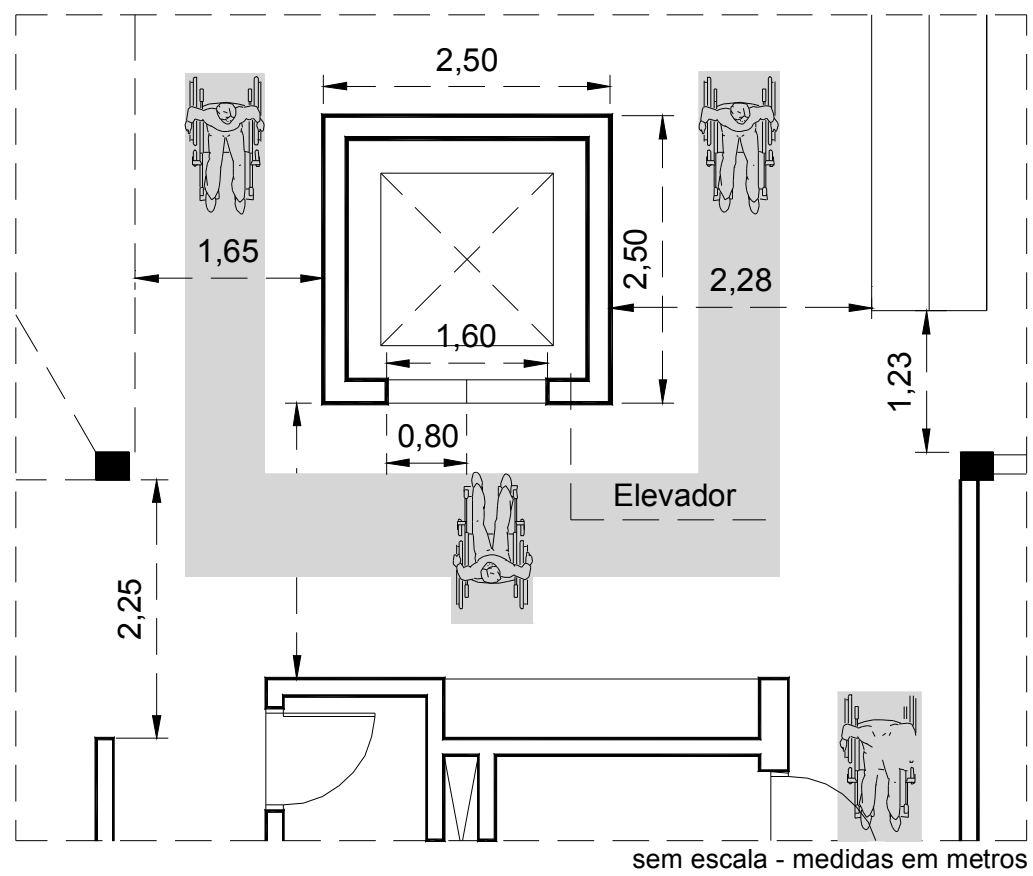

Figura 293 - Circulação em torno do elevador da Biblioteca Senac/Santo Amaro enquadrada na NBR $9050 / 2004$

- $\quad$ com relação às condições de alcance de balcões de atendimento, localizados junto ao hall de entrada do pavimento térreo e destinados aos serviços de empréstimo e devolução do acervo da biblioteca, informação e cadastro do público em geral, os resultados obtidos junto aos usuários indicaram índices baixos de satisfação. O que ocorre neste caso é que o balcão não está adaptado à norma $N B R-9050 / 2004$, a qual 
indica as medidas mínimas de aproximação e altura correta do usuário de cadeiras de rodas ou de crianças. Como acontece na Biblioteca da Unesp/Marília, neste caso também toda extensão do balcão tem a mesma altura de $1,18 \mathrm{~m}$, não reservando nenhuma área mínima de 0,80 de recorte como recomenda a norma vigente.

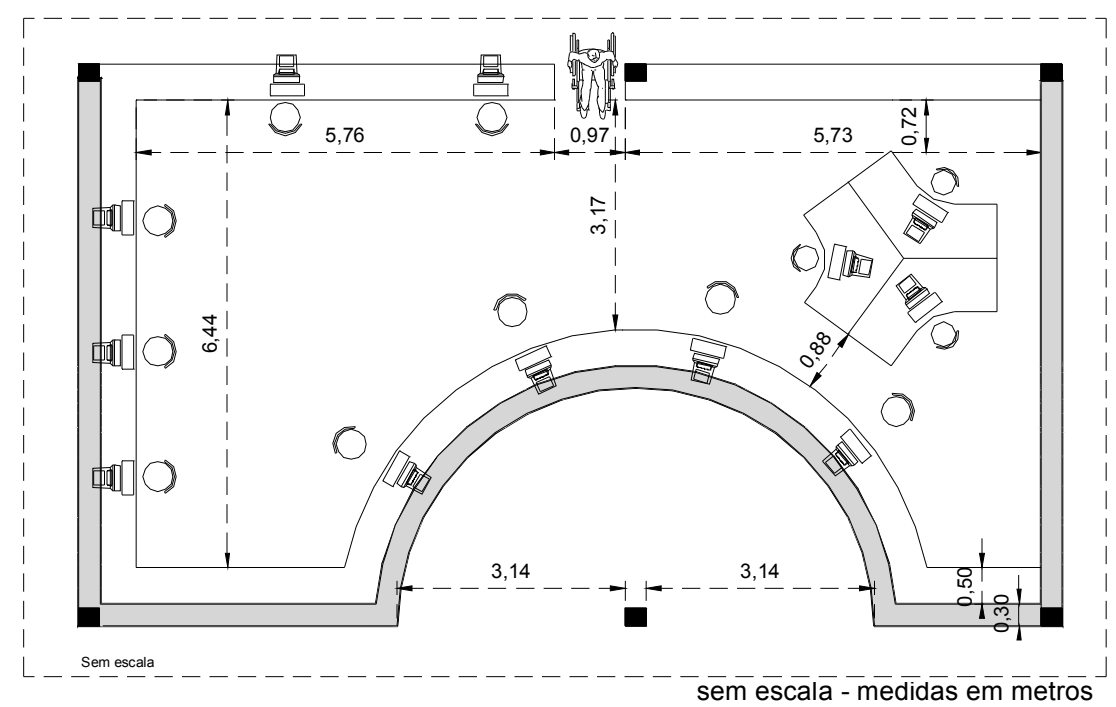

Figura 294 - Acessibilidade no balcão de atendimento da Biblioteca Senac/Santo Amaro

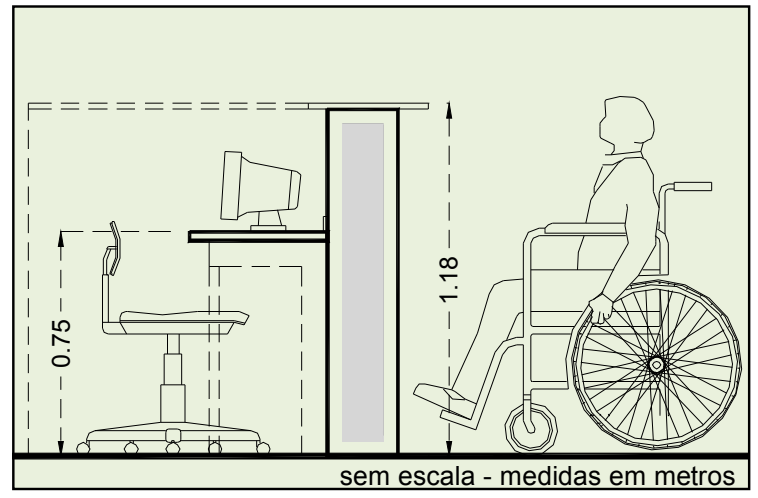

Figura 295 - Corte esquemático do Balcão de atendimento da Biblioteca Senac/Santo Amaro

- $\quad \mathrm{Na}$ área administrativa da biblioteca, todas as medidas estão compatíveis com a norma $N B R$ - 9050/2004 no que se refere às áreas de circulação e manobras, nos quesitos de largura de portas, circulação para uma pessoa e uma cadeira de rodas e manobras sem deslocamento. Outro ponto positivo neste setor é o posicionamento das mesas de atendimento, adequadas às áreas de aproximação e alturas acessíveis aos portadores de deficiência locomotora. Ainda com relação a isso, comprovou-se que a altura da mesa de atendimento ao público está dentro da dimensão definida pela norma, 
que é de 0,75 m. Quanto à altura de utilização dos armários no setor administrativo, todos eles se mostraram muito efícientes em relação à norma, posicionando-se na faixa de $0,40 \mathrm{~m}$ e $1,15 \mathrm{~m}$. Neste caso, a $N B R-9050 / 2004$ cita que as alturas devem estar entre $0,40 \mathrm{~m}$ e 1,20 m. Outro aspecto importante que a norma determina, diz respeito à altura de fixação dos puxadores e fechaduras que deve estar entre 0,80 e 1,20, além das prateleiras que devem ter profundidade entre 0,50 e 0,60 m. Nesses dois elementos, observou-se que todos os armários presentes neste ambiente estão respeitando os parâmetros da norma. Esses resultados comprovam a influência nos bons índices de avaliação dos usuários, demonstrando que a utilização de parâmetros relacionados à acessibilidade de pessoas portadoras de dificuldade de locomoção, no ambiente de trabalho, atende não só às expectativas de pessoas com deficiência, como aquelas que não possuem deficiência. Além disso, reforça a tese de que, independente da função exercida pelo espaço, ele deve proporcionar à maior quantidade de pessoas acessibilidade autônoma e segura, não só do ambiente, mas também do mobiliário.

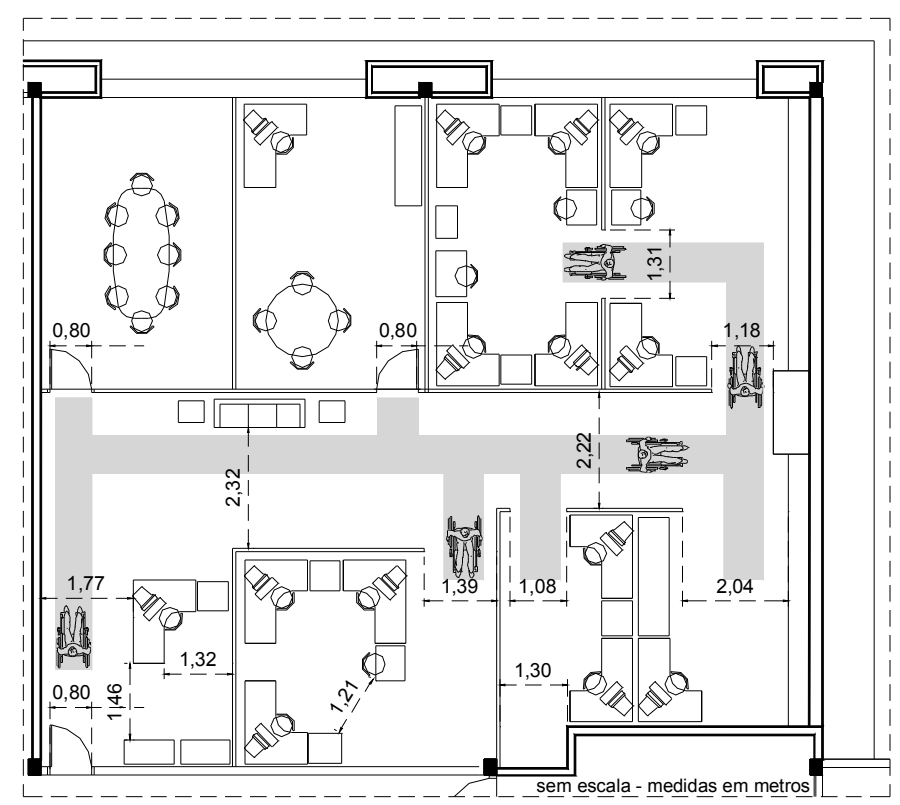

Figura 296 - Acessibilidade no setor administrativo da Biblioteca Senac/Santo Amaro

- Quanto aos locais destinados à leitura e à pesquisa da biblioteca, nos quais estão distribuídas as mesas de trabalho e os terminais de computadores, os usuários avaliaram de forma positiva as medidas e as dimensões do mobiliário no contexto dos elementos relacionados à acessibilidade de pessoas portadoras de dificuldade de locomoção. Analisando à luz da $N B R$ - 9050/2004, as mesas de leitura e pesquisa da 
biblioteca possuem basicamente duas alturas, $0,75 \mathrm{~m}$ e $0,80 \mathrm{~m}$, e espaço de avanço de até no máximo $0,50 \mathrm{~m}$. Esses indicadores respeitam as medidas de altura estipuladas pela norma, que giram em torno de $0,75 \mathrm{~m}$ e $0,85 \mathrm{~m}$ a patir do piso. Quanto aos espaços mínimos $0,90 \mathrm{~m}$ de circulação, bem como aqueles necessários para a correta movimentação da cadeira de rodas, todos se mostraram adequados, permitindo assim o desenvolvimento das atividades de pesquisa e leitura. A mesma situação é encontrada nas mesas de consulta on-line em bases de dados referente ao acervo bibliográfico; tanto os valores das alturas nos tampos, quanto o espaço de avanço para cadeira de rodas respeitam as dimensões estabelecidas pela norma.

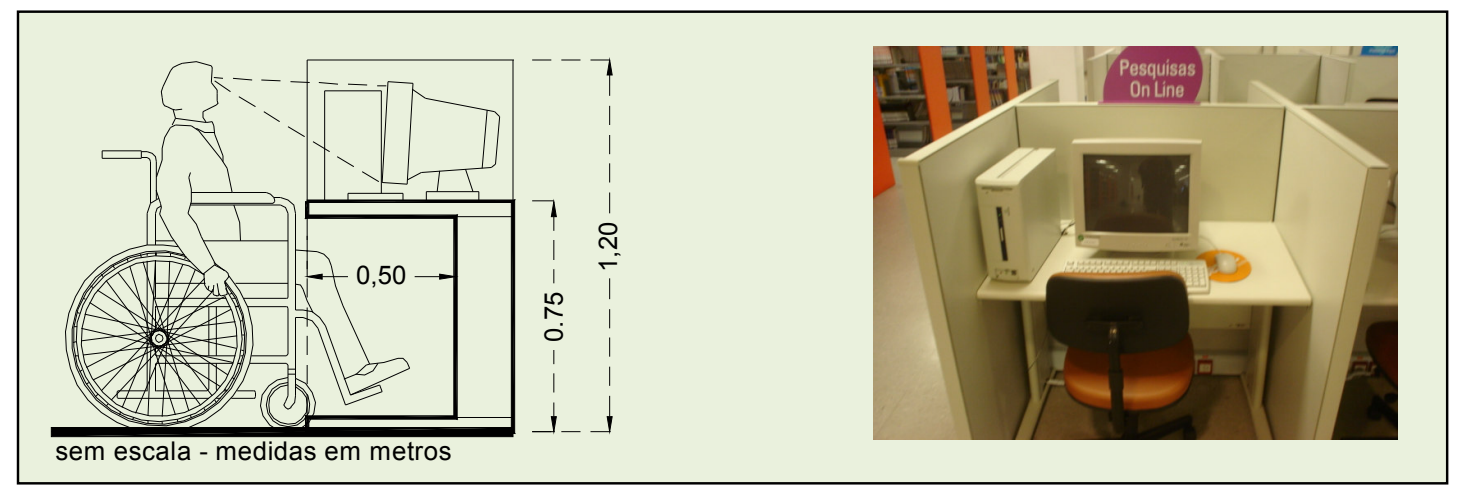

Figura 297 - Mesas de pesquisa on-line Biblioteca Senac/Santo Amaro: condições de acessibilidade

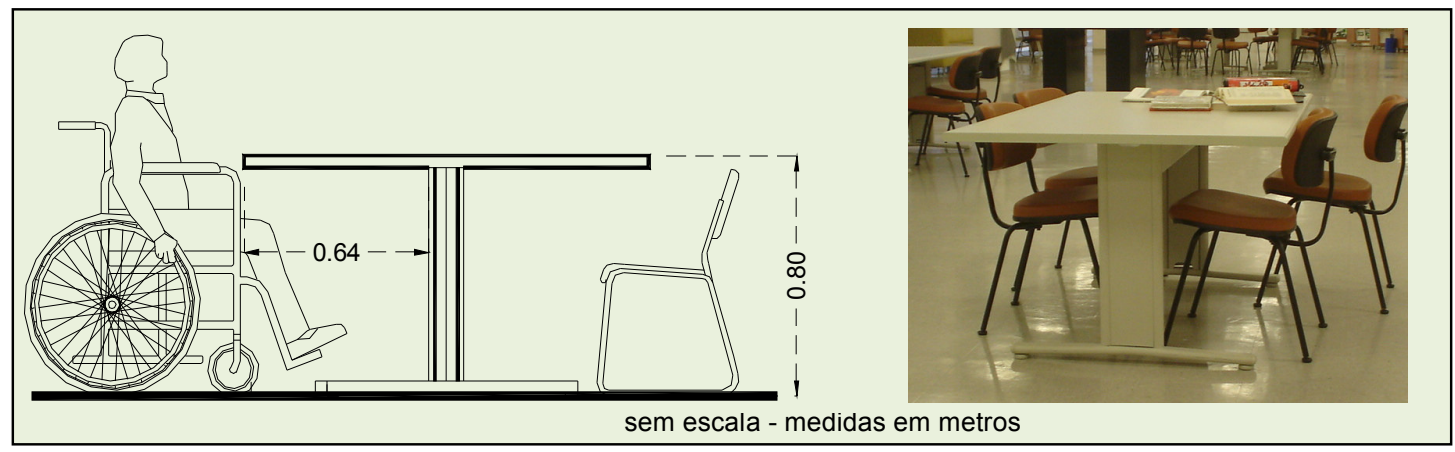

Figura 298 - Mesas de pesquisa e leitura Biblioteca Senac/Santo Amaro: condições de acessibilidade 


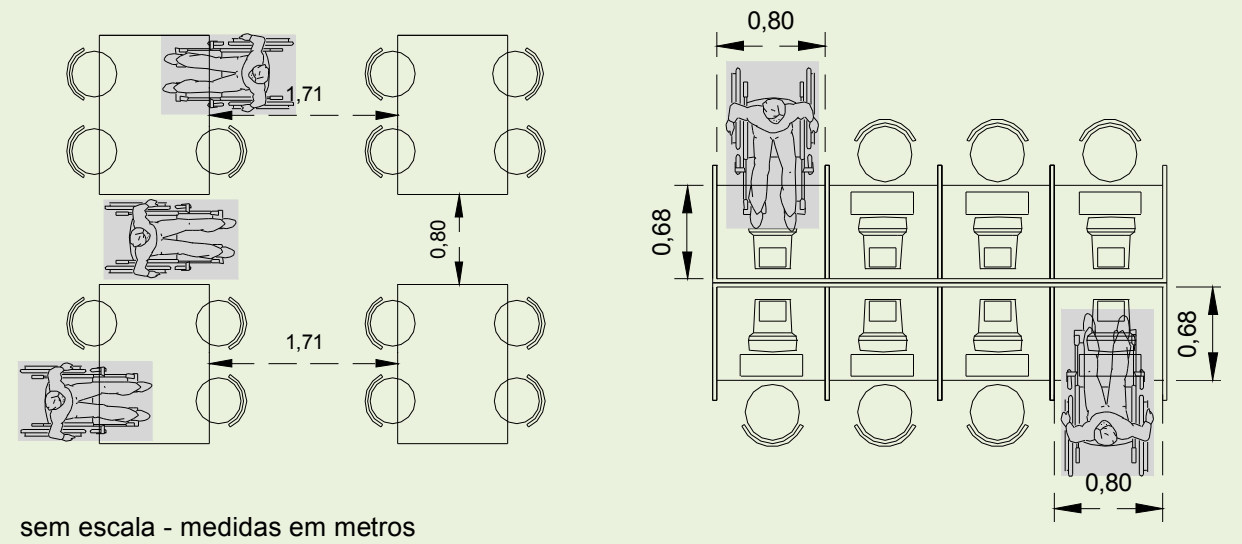

Figura 299 - Mesas de pesquisa/leitura e pesquisa on-line Biblioteca Senac/Santo Amaro: condições de acessibilidade

- Quanto às características das estantes do acervo bibliográfico da Biblioteca do Senac/Santo Amaro, todas elas foram avaliadas positivamente pelos usuários e enquadradas na $N B R$ - 9050/2004. O conjunto estabelecido de estantes do Modelo 01 da biblioteca foi projetado e adequado para permitir o acesso às pessoas portadoras de deficiência, estipulando a medida de 1,00 m entre elas, ou seja, valor acima do que determina a norma, que é de $0,90 \mathrm{~m}$. Por outro lado, as estantes do Modelo 02 foram previamente dimensionadas com valores de espaçamento bem maiores, girando em torno de 1,32 m de largura nos corredores das estantes. Como conseqüência disso, verificou-se, prioritariamente, entre o extrato de alunos, altos índices de satisfação e a comprovação de que essas medidas garantem adequada movimentação no ambiente por parte das pessoas portadoras de deficiência. Como foram mostradas anteriormente, as estantes do Modelo 02 se diferenciam das demais por possuírem um desenho especial com medidas menores, tanto na altura quanto no comprimento. Essa característica também é vista no posicionamento no ambiente do acervo bibliográfico, por conta de um grande espaço disponível dado a elas. Pode-se concluir que esses fatores foram fundamentais no aumento considerável das larguras entre as estantes, principalmente nas estantes do Modelo 02, além de influenciar os ótimos índices de satisfação dos extratos de usuários. 


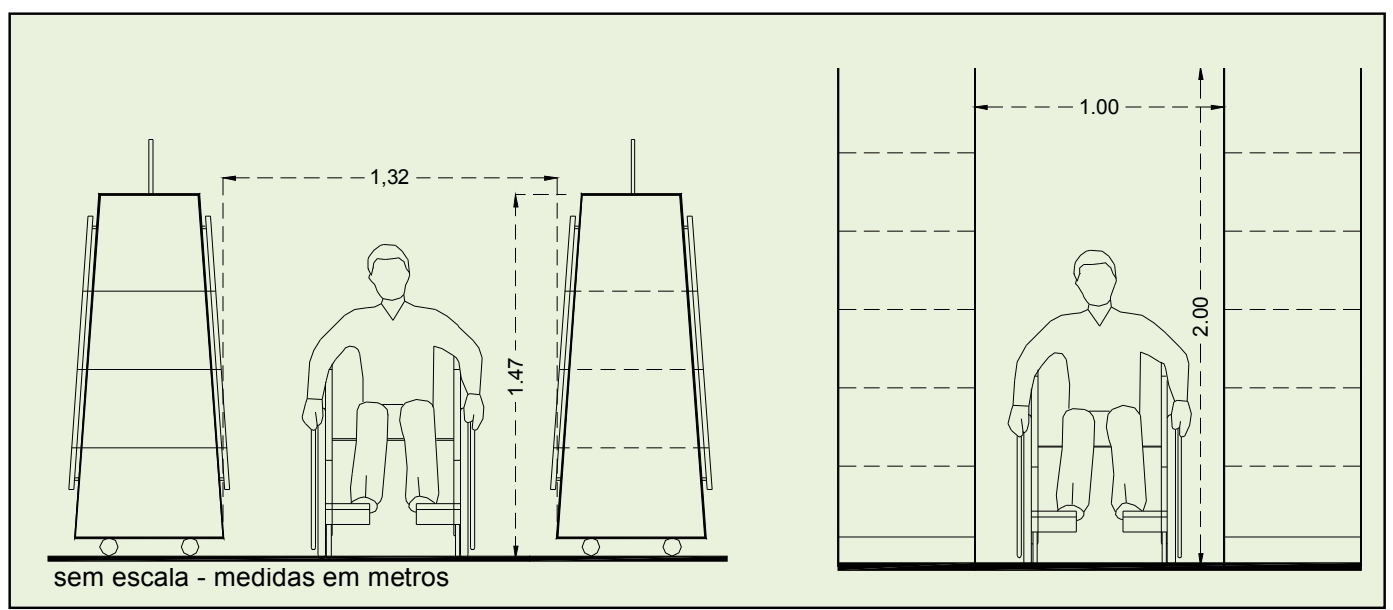

Figura 300 - Elevação estantes Modelo 01 e 02 Biblioteca Senac/Santo Amaro: condições de acessibilidade

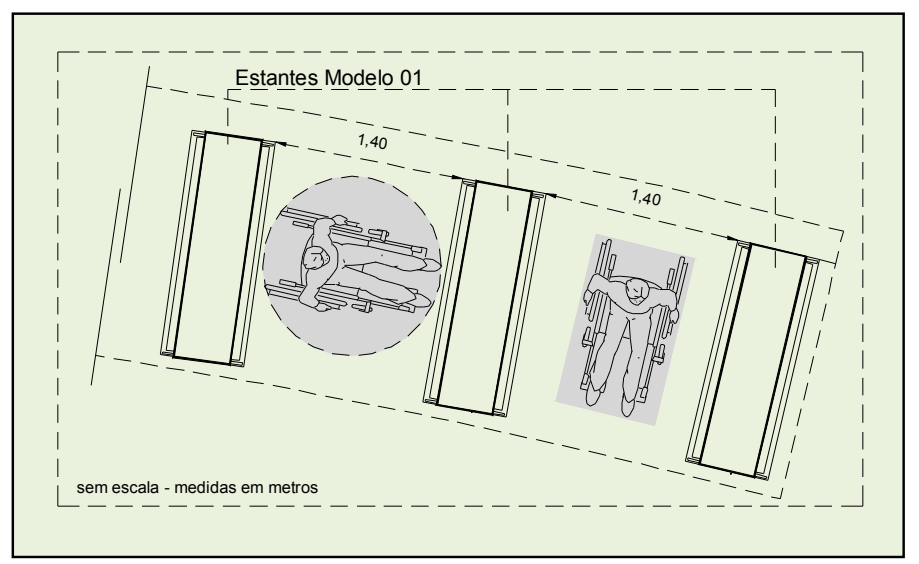

Figura 301 - Plantas estantes Modelo 01 e 02 Biblioteca Senac/Santo Amaro: condições de acessibilidade

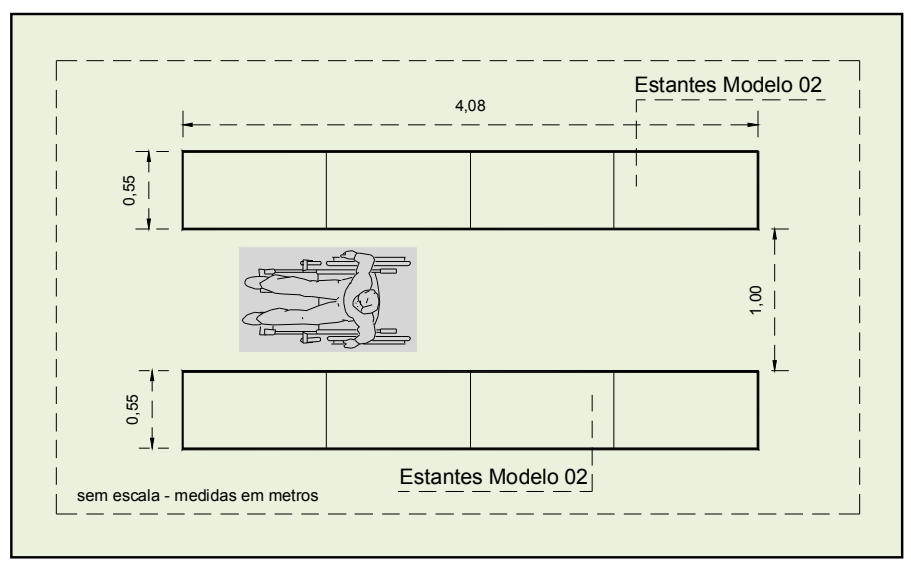

Figura 302 - Plantas estantes Modelo 01 e 02 Biblioteca Senac/Santo Amaro: condições de acessibilidade 
- A biblioteca conta com o Espaço Braille do Centro Universitário Senac desde a sua inauguração, em março de 2004. Além do atendimento aos quesitos e princípios básicos do desenho universal, esse espaço é mais uma iniciativa da parte direção no sentido de atender às pessoas portadoras de deficiência visual. Além da consulta, o espaço oferece cursos de informática para portadores de deficiência, utilizando os recursos mais modernos disponíveis no mercado. Computadores conectados à Internet, Impressora Braille, Acervo de livros em braille, Acervo de livros falados em fitas cassetes e CD e Lupa eletrônica EVS;

- $\quad$ o percentual dos resultados obtidos nos índices de satisfação foi muito elevado no item relacionado à acessibilidade dos sanitários da Biblioteca do Senac/Santo Amaro, demonstrando que o sistema está adequado para suas necessidades. Quanto ao posicionamento e as características das instalações sanitárias no edifício, pode-se afirmar que as mesmas estão enquadradas na norma $N B R$ - 9050/2004, respondendo a todos os requisitos necessários de acessibilidade. Os sanitários adaptados estão localizados no pavimento térreo, em função obviamente, da facilidade de acesso a esses ambientes. Os principais elementos relacionados à acessibilidade presentes nos sanitários são: (1) - o conjunto de sanitários atinge o mínimo de 5\% do total de cada peça, estipulado pela norma e que são adequados ao uso de pessoa portadora de deficiência física; (2) - os lavatórios estão a 0,80 m do piso e sem coluna, permitindo que haja a aproximação da cadeira de rodas; (3) - as portas possuem 0,90 m e identificação visual de acessibilidade, além de ter na altura de $0,30 \mathrm{~m}$ do piso elemento protetor laminado nos dois lados e barra de apoio no lado interno da porta; (4) - as dimensões mínimas de fixação das peças sanitárias estão de acordo com a norma o vaso sanitário está a $0,46 \mathrm{~m}$, barras de apoio metálico com comprimento de $0,80 \mathrm{~m}$ e altura de $0,75 \mathrm{~m}$ do piso acabado, as torneiras têm acionamento por célula fotoelétrica e as bacias sanitárias apresentam áreas de transferência lateral, bem como manobra para rotação de 180 graus; (5) - a borda inferior do espelho está a uma altura de 1,00 m, portanto dentro da faixa da norma que é de $0,90 \mathrm{~m} \mathrm{e} 1,10 \mathrm{~m}$. 


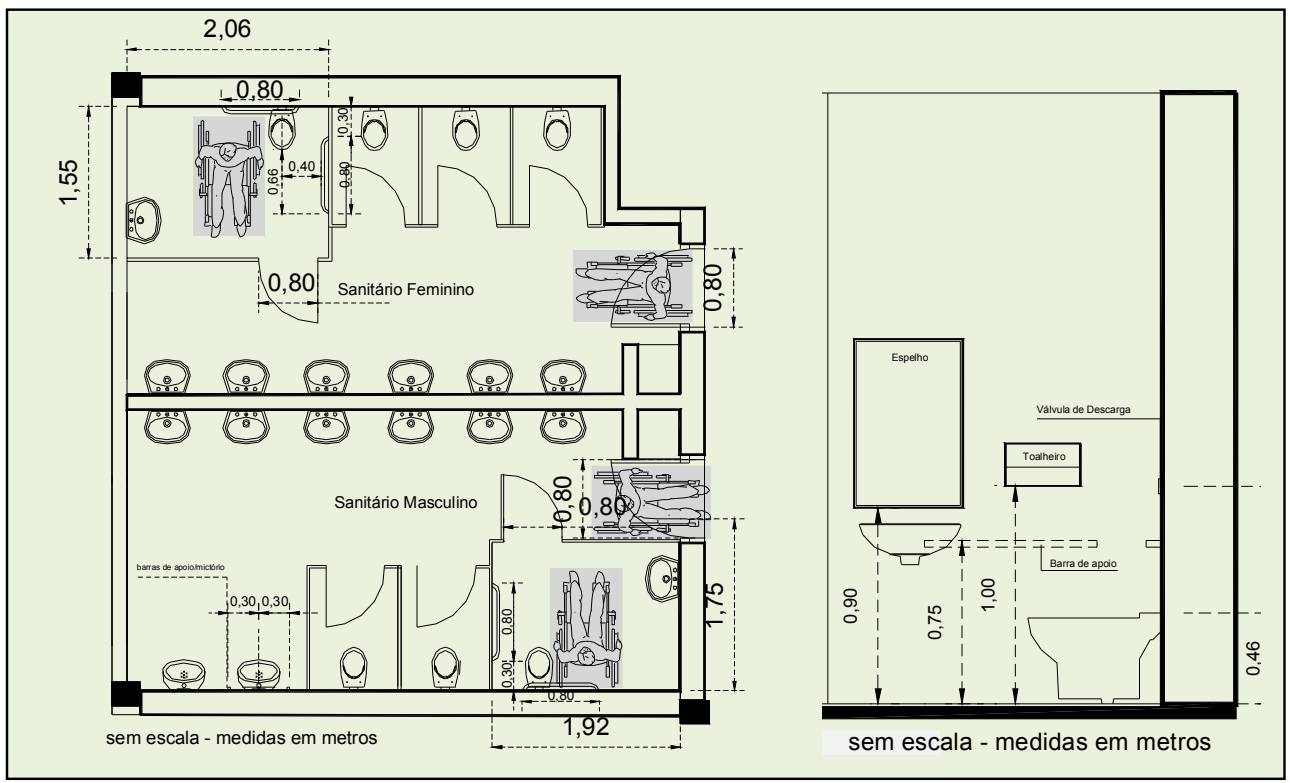

Figura 303 - Sanitários na Biblioteca Senac/Santo Amaro: condições de acessibilidade

\subsection{Espaços para encontros e contatos informais}

Outro importante item avaliado neste trabalho está relacionado aos elementos de satisfação dos usuários em relação aos espaços para encontros e contatos informais presentes nos dois estudos de caso. É válido afirmar que essas áreas têm sido cada vez mais valorizadas por serem consideradas espaços de encontro e de troca de experiências e informações entre os usuários. Entretanto, somente agora, os novos projetos arquitetônicos de bibliotecas universitárias no Brasil estão agregando a importância de prever e conceber ambientes direcionados aos encontros e contatos informais. Essas áreas são caracterizadas tanto pelo conceito espacial aberto (pequenas áreas de estar posicionadas ao longo do layout) quanto de ambientes fechados e especificamente definidos para isso (cafés, lanchonetes, copas, entre outros.). Vale lembrar que, no processo de estabelecimento desses espaços de convivência e contatos informais no contexto de uma biblioteca, todo cuidado deve ser direcionado para preservar os quesitos mínimos de privacidade e adequação de níveis de ruído no ambiente. Portanto, é muito comum, ao redor dessas áreas de convivência, em função da maior densidade de usuários, formarem-se bolsões de ruído, que prejudicam sensivelmente o conforto acústico da biblioteca. 
No caso desta pesquisa, os índices de satisfação relacionados aos espaços para encontros e contatos informais, apresentaram resultados bem positivos nos dois edifícios escolhidos. Contudo, é importante frisar que, os resultados médios de satisfação apresentados pela Biblioteca do Senac/Santo Amaro (67\% - Excelente), demonstraram índices mais elevados se comparados com os resultados da Biblioteca da Unesp/Marília (47\% - Bom). A explicação mais coerente está no fato de que, no caso da Biblioteca do Senac/Santo Amaro, esses ambientes foram previamente planejados e dimensionados no projeto arquitetônico original do edifício, ou seja, os espaços foram previstos para seu uso e não passaram por um processo de adaptação ou alteração espacial considerável. Em cada pavimento da biblioteca foram previstas áreas específicas de descanso e pontos de encontro, que ficam dotadas de sofás ou poltronas individuais e, nesse sentido, são completamente adequadas para o descanso na hora do almoço ou pausas ao longo da jornada de trabalho. É importante frisar que as áreas de convivência e descompressão mais utilizadas no edifício são aquelas que estão localizadas no pavimento térreo e desempenham papel fundamental de eficiência no tocante ao encontro de pessoas, horas de lazer para os funcionários, encontros informais, dentre outros. Em contato com os usuários, os resultados de níveis de satisfação foram ratificados com os questionários e demonstraram que esses espaços atendem às necessidades de seus ocupantes.

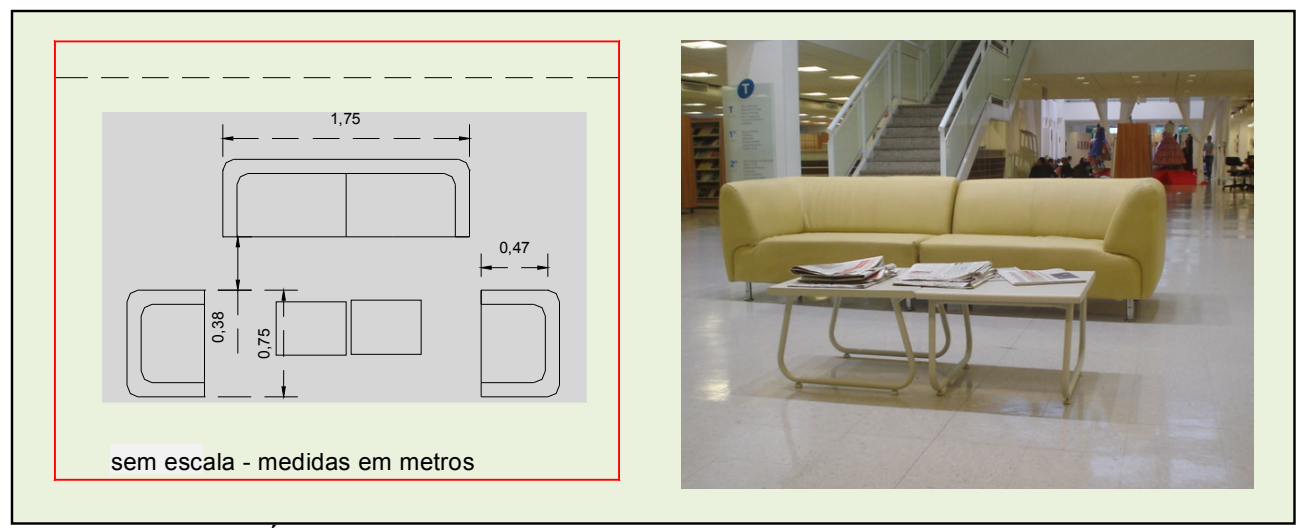

Figura 304 - Área de descanso e encontros informais Biblioteca Senac/Santo Amaro

Do ponto de vista do percentual de ocupação das áreas de descanso e encontros informais dos três pavimentos da Biblioteca do Senac/Santo Amaro, constatou-se que esses espaços ocupam 1,05\% do total de 5.235,62 $\mathrm{m} 2 \mathrm{da}$ área útil construída, indicando que existe uma certa coerência na distribuição desses ambientes e 
que atendem às necessidades quanto às áreas de descompressão da biblioteca. É importante frisar que, além dessas áreas que já estão definidas em planta, existem outras que acontecem de maneira espontânea ao longo dos pavimentos e que, de certa maneira, são compatíveis com os interesses dos usuários relacionados aos pontos de encontro do edifício. Em função desse fato, sugere-se que se estabeleçam, de forma ordenada, outras áreas de convivência e espaços destinados aos encontros informais, já que comprovadamente existe espaço suficiente para tal função.

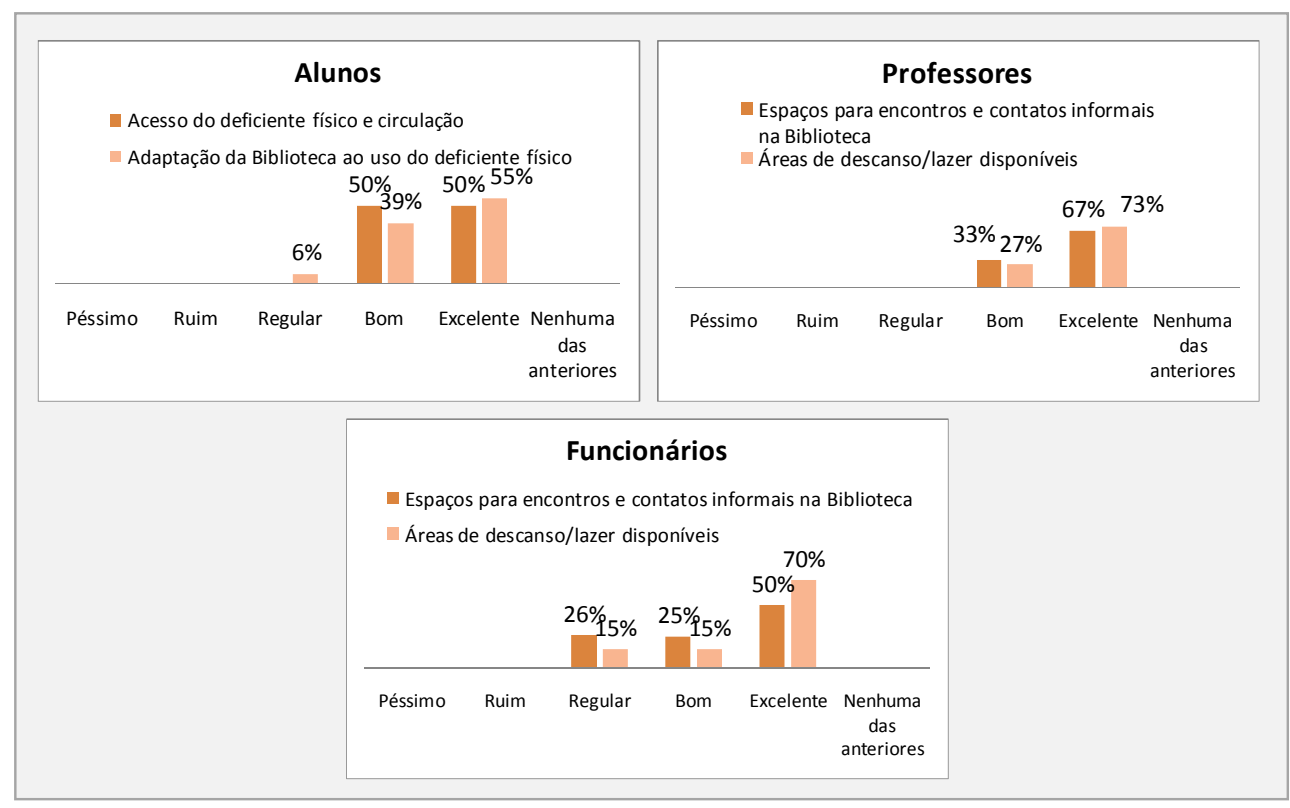

Figura 305 - Nível de Satisfação alunos da Biblioteca Senac/Santo Amaro áreas de descanso e encontros informais

Na Biblioteca da Unesp/Marília, cujo percentual de satisfação foi considerado um pouco abaixo, se comparado com o edifício da Biblioteca do Senac/Santo Amaro, não há ineficiência das áreas de convivência e descompressão existentes no ambiente. Neste caso, a menor necessidade de locomoção, em função das dimensões reduzidas do espaço e a quantidade menor de área de convivência no edifício parecem não restringir sua freqüência de uso, já que o nível de satisfação apontado para este item foi considerado Bom. Além disso, algumas áreas consideradas excedentes no espaço poderiam ser revertidas para mais áreas de convivência ou até mesmo serem redimensionadas, para possibilitar melhor funcionalidade e eficiência do ambiente. Entretanto, é preciso deixar claro que esses locais necessitam ser dotados de proteção acústica, de maneira que não causem transtornos às áreas de leitura e pesquisa situadas próximas. Fora isso, esses ambientes devem ser posicionados para fácil visualização e 
acesso a todos, além de serem agradáveis esteticamente, servindo como um recurso terapêutico que reduza as tensões e revitalize as energias dos usuários ao longo do dia.

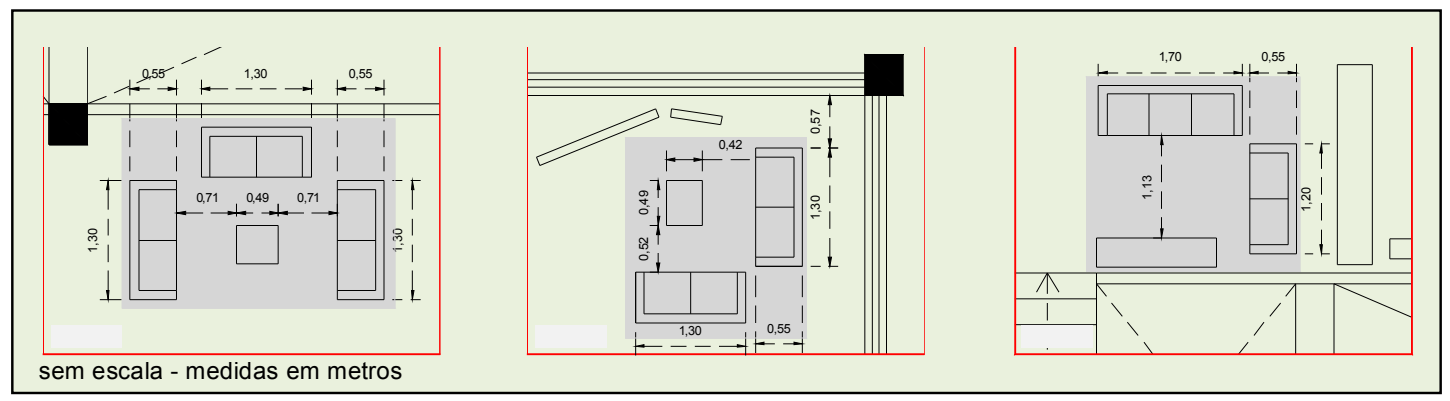

Figura 306 - Áreas de descanso e encontros informais Biblioteca Unesp/Marília

Os percentuais das áreas de descanso e encontros informais na Biblioteca da Unesp/Marília giram em torno de 1,32 \% com relação aos 1.348,70 m2 de área útil construída, referendando que os espaços destinados às atividades de convivência estão adequadas e condizem com a realidade do ambiente. Entretanto, a deficiência encontrada nestes ambientes e, plenamente comprovada nos baixos índices de satisfação entre os usuários, diz respeito à localização das áreas de descanso, estando sempre juntas aos setores de leitura e pesquisa da biblioteca. Esta questão é, sem dúvida, um dos aspectos-chave para se manter a qualidade, tanto das áreas destinadas à concentração (leitura e pesquisa), quanto dos ambientes de comunicação (pontos de encontro). Como foi relatado anteriormente, é preciso verificar cuidadosamente o posicionamento destes setores de descanso, a fim de que não se criem problemas relacionados ao ruído excessivo nas áreas de concentração, conflitos de circulação e desperdício das áreas do acervo bibliográfico. Apesar disso, esses fatores não podem impedir o estabelecimento de áreas destinadas à integração social em projetos de bibliotecas, se tornam efetivamente pontos de encontro. 


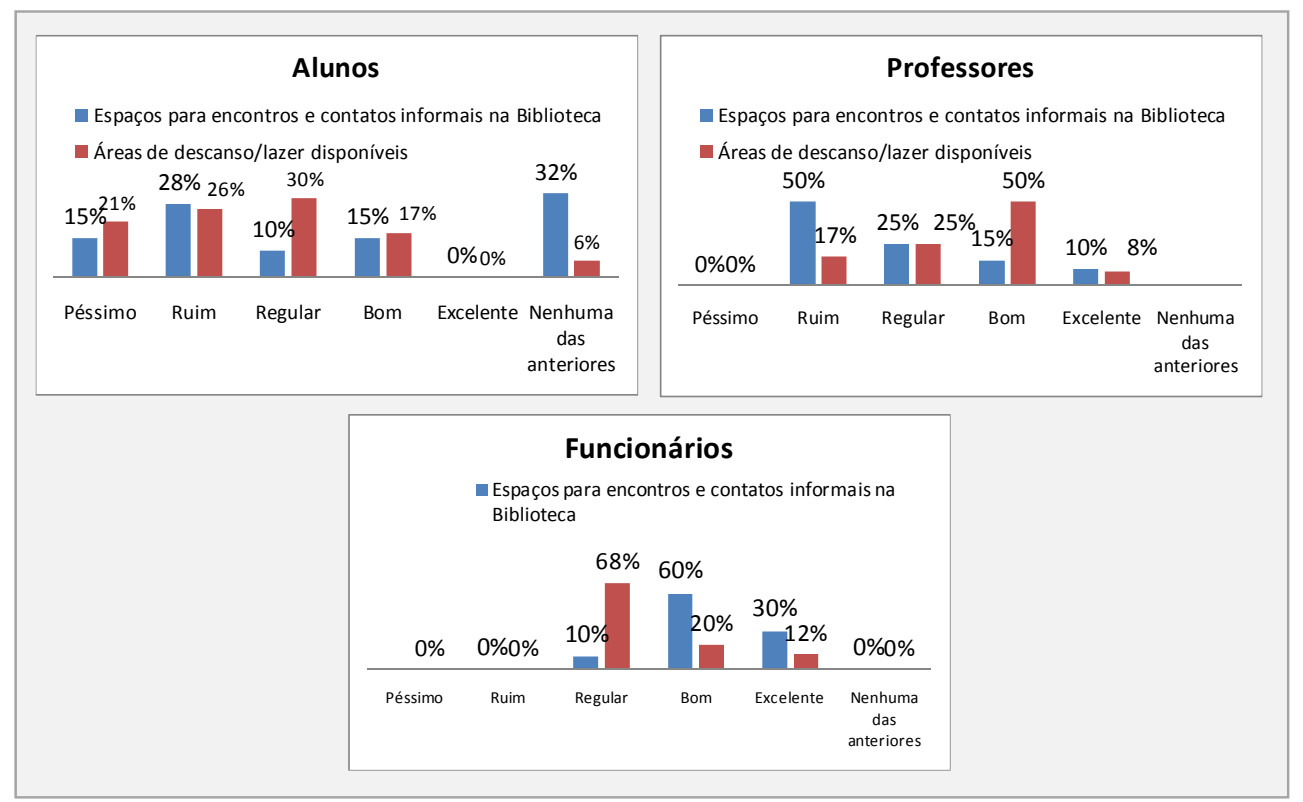

Figura 307 - Nível de Satisfação alunos da Biblioteca Unesp/Marília: áreas de descanso e encontros informais

\subsection{Segurança}

Outro aspecto importante avaliado diz respeito à questão da segurança presente nos edifícios escolhidos para esta pesquisa, mais especificamente, às saídas de emergência e à questão da segurança contra-incêndio no ambiente. Antes de apresentar e avaliar os resultados de satisfação dos usuários, é importante deixar claro que o programa de segurança de um edifício de biblioteca deve considerar a combinação dos elementos tecnológicos, arquitetônicos e operacionais, a fim de que possam dissuadir, impedir, atrasar e responder satisfatoriamente às ameaças. Neste processo, vários elementos passivos são incluídos ao edifício pelo arquiteto: cercas, muros, portas, janelas, sistemas construtivos, elementos de fachada e materiais de acabamento adequado para este fim. Além disso, vários sistemas complementares de segurança são incorporados como sistemas de detecção perimetral, sistemas de sensoriamento interno e sistemas de controle de acessos, com a função de atuar de forma integrada entre si e entre outros sistemas.

No Brasil, apesar da rápida evolução dos sistemas tecnológicos de segurança, o nível de medidas preventivas contra incêndios em bibliotecas não teve o mesmo desenvolvimento. O que se tem notado, principalmente, é a incompatibilidade entre os programas de sistemas de segurança e as concepções arquitetônicas de 
bibliotecas, focados não só nas mudanças de modos de ocupação espacial, mas também nas maiores concentrações de equipamentos de informática e na pouca familiaridade com as técnicas modernas de prevenção. É necessário dizer que as alterações ocorridas na concepção dos edifícios de bibliotecas universitárias nos últimos anos no Brasil, passando de construções compartimentadas, com grandes áreas de alvenaria, para construções leves, lajes livres e grande quantidade de painéis removíveis, provocaram profundas mudanças nos conceitos de segurança e sistemas de prevenção de incêndio. É obvio que, com essas alterações ocupacionais, onde o espaço aberto é compartimentado em áreas pequenas por divisórias, aumentam as chances de propagação do incêndio e dificulta-se a passagem dos usuários para o abandono do local, quando em caso de emergência. Portanto, de maneira geral, todas as áreas componentes do layout da biblioteca devem atender aos requisitos técnicos mínimos a serem observados para garantir segurança aos que nelas trabalham. De qualquer maneira, os novos projetos de bibliotecas universitárias no Brasil, principalmente nestes últimos anos, estão paulatinamente incorporando projetos, ações e medidas de segurança, destinadas a proteger a vida humana e bens materiais destes edifícios; ou seja, essas medidas visam a agir diretamente com ações preventivas e protetoras, facilitando efetivamente a detecção de eventos e intervenção.

$\mathrm{Na}$ pesquisa, a percepção dos usuários em relação às saídas de emergência e à questão da segurança contra-incêndio, os resultados dos percentuais indicaram valores diferenciados se comparados os dois estudos de caso. A Biblioteca do Senac/Santo Amaro apresentou o melhor resultado do nível de satisfação, indicando que os usuários avaliaram de forma positiva os elementos estudados. Por outro lado, no edifício da Biblioteca da Unesp/Marília, os resultados apontaram índices bem baixos, indicando insatisfação com relação a este item e, portanto, evidenciam a necessidade de melhorias nesta área.

Analisando as condições existentes de segurança na Biblioteca do Senac/Santo Amaro e, comparando com as normas vigentes do COE - SP - Código de Obras e Edificação da cidade de São Paulo, a NR 23 - Proteção Contra Incendios - do Ministério do Trabalho (1978) e a norma ABNT NBR - 9077/1993, é possível explicar não só os bons índices de satisfação dos usuários, como também elaborar análises quanto às configurações básicas de prevenção e proteção no interior do edifício estudado, nas quais se destacam: (1) - as dimensões das circulações primárias e secundárias nos ambientes estão adequadas ao mínimo exigido pelo COE - SP , ou seja, 
os corredores e as passagens de uso comum garantem a adequada capacidade de escoamento da população existente para a rota de fuga, sendo o mínimo de 1,20 m para a circulação primária e $0,80 \mathrm{~m}$ para a circulação secundária; (2) - quanto à extensão da circulação, as distâncias a serem percorridas nos pavimentos até a saída do edifício ou até as escadas estão compatíveis com valores estipulados pelo COE - SP e pela NBR 9077/1993. Segundo a norma, a distância deve ficar entre 25,00 m a 38,00 m, tendo chuveiros automáticos (sprinklers), como é o caso da Biblioteca do Senac/Santo Amaro; (3) - a biblioteca estudada não se enquadra no critério do COE - SP (1993), a qual estabelece que as edificações com altura superior a 27,00 m deverão ter seus espaços compartimentados em setores de incêndio, com área menor ou igual a $2.000 \mathrm{~m} 2$. Neste caso, a compartimentação foi substituída pela instalação de chuveiros automáticos em toda a área; (4) - as instalações de hidrantes, extintores de água, pó químico e $\mathrm{CO} 2$, alarmes sonoros e luminosos, portas corta-fogo, escada enclausuradas com sistema de exaustão e detectores respondem aos requisitos da a IT $\mathrm{N}^{\circ}$ 21/01 do Corpo de Bombeiros/SP; (5) - as duas escadas enclausuradas, posicionadas nas extremidades do edifício, estão de acordo com as normas estabelecidas pela NBR - 9077/1993: espessura da parede 0,25 m, duto de ventilação, portas corta-fogo seguem a PEB $\mathrm{n}^{\circ} 920$ e letreiro de inscrição bem visível; (6) - as rotas de fuga estão de acordo com a IT No 11/04 do Corpo de Bombeiros/SP, estando bem definidas e desobstruídas, bem sinalizadas, oferecendo facilidade de acesso para a brigada de incêndio; (7) - a sinalização de segurança contra incêndio e pânico está em todos os pavimentos do edifício, de acordo com a norma NBR - 13434/1995 e NBR - 13435/1995; (8) - do ponto de vista da segurança, o forro composto por fibras minerais nas salas internas, o forro metálico no restante dos ambientes e o piso granilite especial estão enquadrados com a legislação da NBR - 9442/1986, reduzindo em muito o potencial de risco de incêndio dessas áreas, uma vez que se trata das maiores superfícies existentes na biblioteca.

É importante ressaltar que, no edifício da Biblioteca do Senac/Santo Amaro, o partido arquitetônico adotado para o layout dos espaços, relativo ao posicionamento de salas, escadas e os ambientes das estantes do acervo bibliográfico, não prejudicam as rotas de fuga e preservam as dimensões mínimas livres de quaisquer obstáculos. A presença de um partido de ocupação bem definido, por meio de eixos de ligação e ambientes bem estabelecidos, faz com que as distâncias máximas a serem percorridas, no caso de uma evacuação, exigidas por lei, estejam dentro dos padrões de funcionamento. Além disso, mesmo não compreendendo e visualizando todo o sistema 
presente de segurança descrito anteriormente, os usuários conseguem ter uma boa percepção dos dispositivos de segurança instalados e demonstram sua aprovação em relação aos itens de segurança.

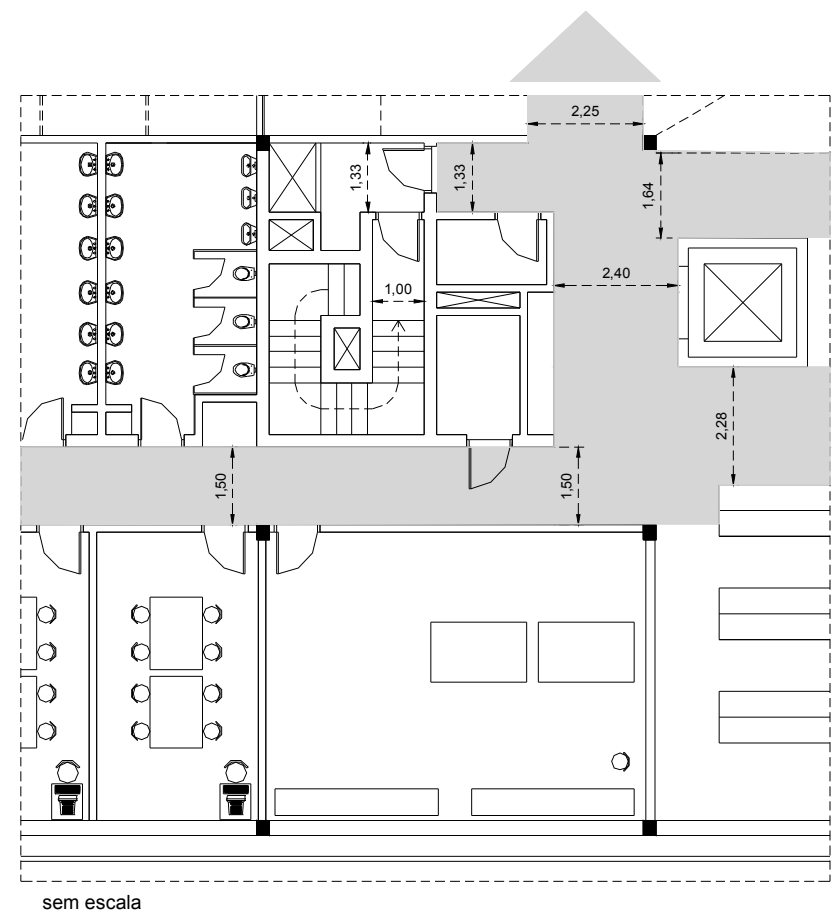

sem escala - medidas em metros

Figura 308 - Detalhes - rotas de fuga - Pavimento térreo Biblioteca Senac/Santo Amaro

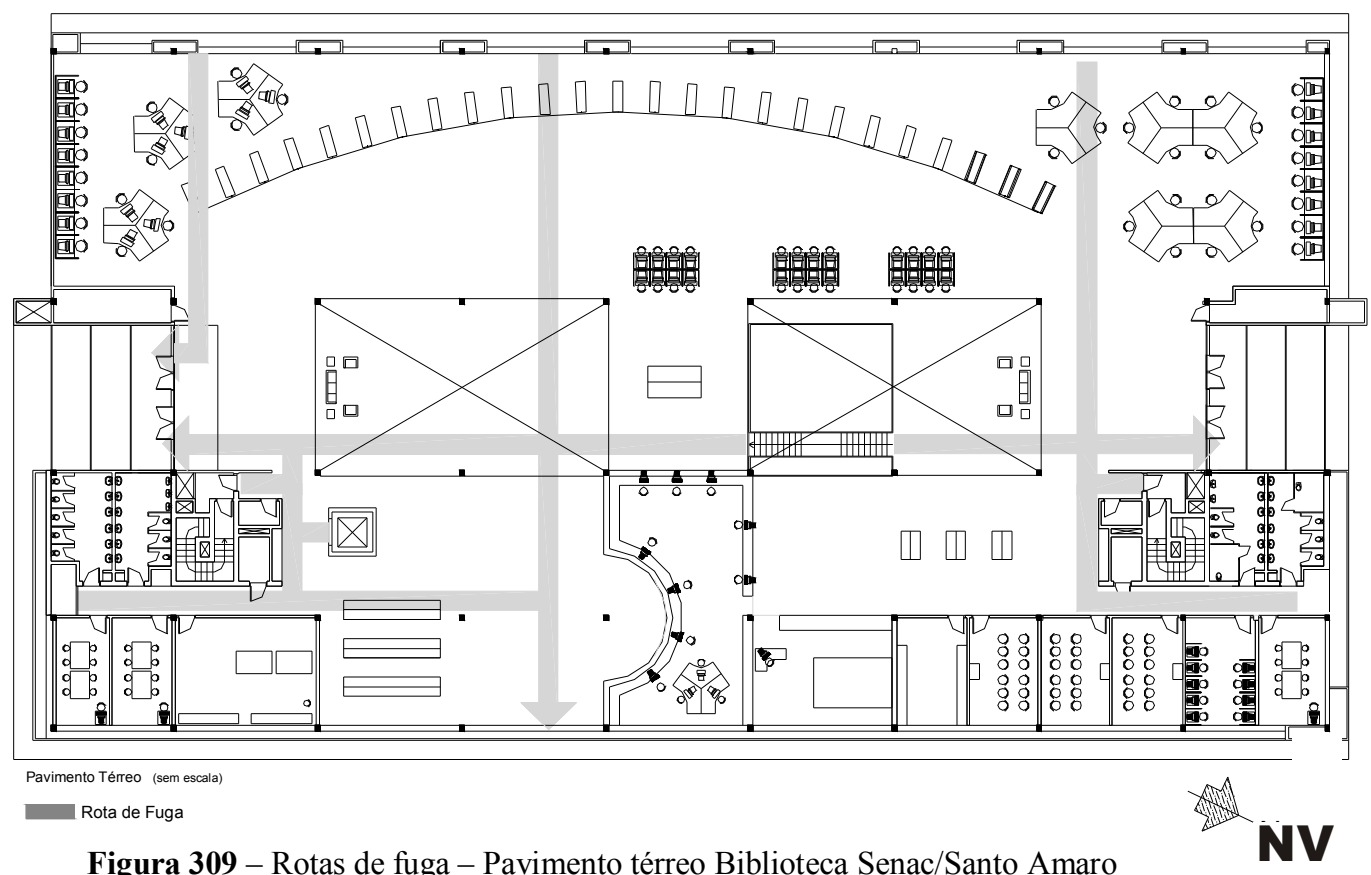

Figura 309 - Rotas de fuga - Pavimento térreo Biblioteca Senac/Santo Amaro 


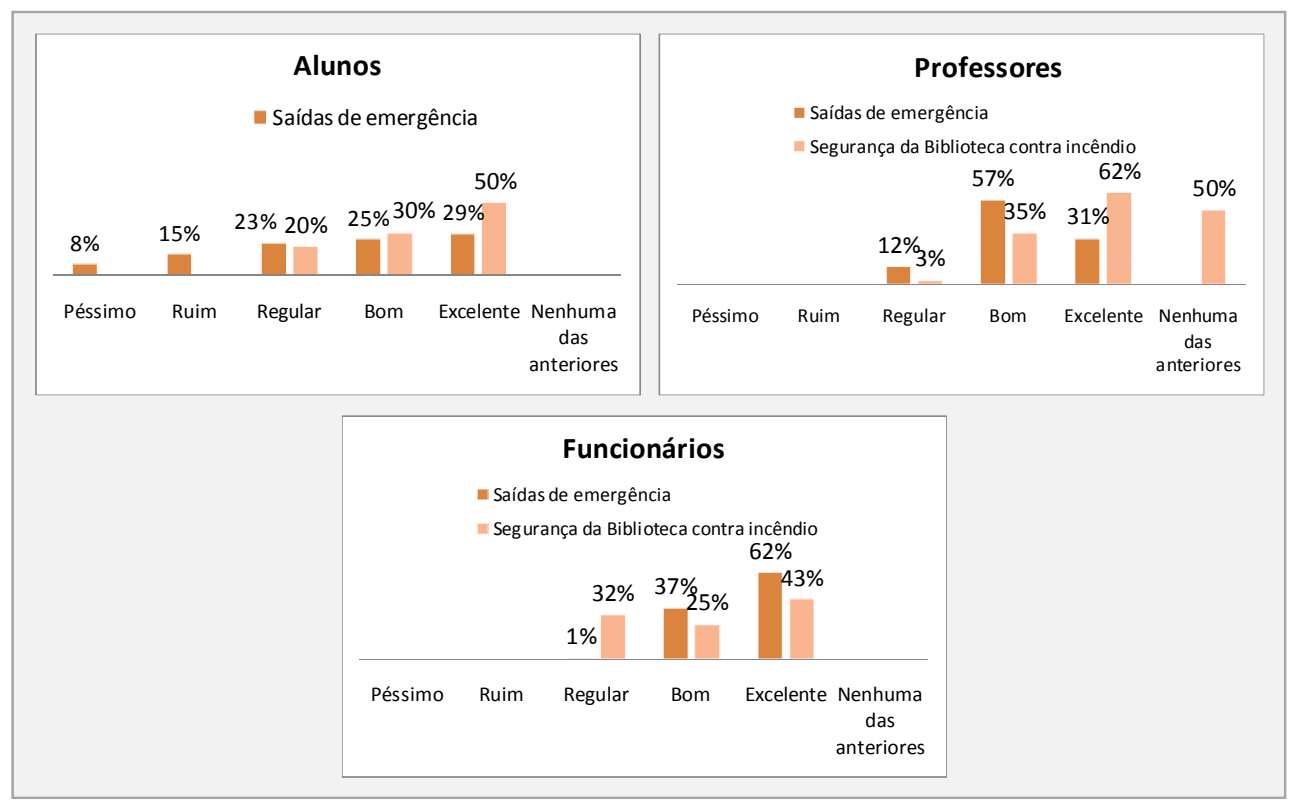

Figura 310 - Nível de Satisfação funcionários da Biblioteca Senac/Santo Amaro: saídas de emergência e segurança contra incêndio

Analisando as condições de segurança na Biblioteca da Unesp/Marilia, sob os aspectos relacionados à legislação vigente, fato confirmado nas avaliações de percepção e satisfação dos usuários, observou-se que a presença dos requisitos necessários não é suficiente para garantir segurança total ao edifício. As incompatibilidades relacionadas às normas de segurança podem ser comprovadas junto às observações técnicas efetuadas nos ambientes do estudo de caso e descritas a seguir:

- $\quad$ com relação às saídas de emergência, somente as circulações primárias e as escadas estão de acordo com a NBR - 9077/1993, mantendo as larguras acima do mínimo de 1,20 m permitido por lei. Nos corredores das estantes do acervo, os valores das larguras entre eles estão abaixo de 1,00 m estipulados pela norma técnica, prejudicando sensivelmente a rota de fuga em caso de incêndio. Esse mesmo fato acontece na saída de emergência localizada no pavimento inferior, com largura de $0,75 \mathrm{~m}$, ou seja, bem abaixo do que determina a legislação. Além disso, alguns armários distribuídos ao longo dos corredores no pavimento inferior contrariam a norma com relação ao favorecimento da acessibilidade nos locais de passagem, obstruindo a passagem e prejudicando a rota de fuga. Ainda com relação a esse quesito e baseado na quantidade de pessoas existentes e no tipo de ocupação do edifício, a quantidade de saídas de emergência está fora do recomendado pela $I T N^{o} 11 / 04$ do Corpo de Bombeiros/SP, estipulando, neste 
caso, o acréscimo de duas saídas de emergência. Isso reforça um dos principais problemas enfrentados por este edifício, relacionado ao problema da flexibilidade e da falta de espaço para a ampliação da biblioteca. Ou seja, com as mudanças internas, os espaços não foram preparados para receber novas funções, inclusas as área de saída de emergência. Portanto, a problemática reforça a necessidade de revisão e da implantação de saídas de emergência para facilitar de proteção à vida humana e bens materiais contra os efeitos nocivos do fogo;

- $\quad$ constatou-se que a presença dos símbolos gráficos de segurança contra incêndio responde aos requisitos básicos da norma $N B R-13434 / 1995$, estando dimensionados em uma mesma escala e permitindo a perfeita visualização dos sistemas e equipamentos de segurança contra incêndio;

- as instalações de hidrantes, extintores de água, pó químico e $\mathrm{CO} 2$, respondem aos requisitos da IT N $\mathrm{N}^{\mathrm{o}}$ 21/01 do Corpo de Bombeiros/SP, entretanto, verificou-se que os alarmes sonoros e luminosos não estão presentes em nenhum dos ambientes estudados, reafirmando neste caso, descumprimento às normas vigentes;

- $\quad$ os principais materiais presentes na biblioteca respondem à norma NBR - 9442/1986, quanto à redução do potencial de risco de incêndio nas áreas principais da biblioteca.

- $\quad$ quanto ao estabelecimento de espaços compartimentados, a Biblioteca da Unesp/Marília não se insere no critério da IT $\mathrm{N}^{0}$ 09/04 do Corpo de Bombeiros/SP, que estabelece setores de prevenção de incêndio. Entretanto, o principal problema enfrentado nesta questão é que a compartimentação não foi substituída pela instalação de chuveiros automáticos (sprinklers), o que demonstra descaso em relação à prevenção de incêndio no edifício.

- $\quad$ as áreas do depósito e do almoxarifado, destinadas à guarda de material bibliográfico não circulante, representam alto risco de combustão para o edifício da biblioteca, pois possuem somente instalações de pó químico e $\mathrm{CO} 2$, não respondendo, mais uma vez, à necessidade de chuveiros automáticos (sprinklers). 
No caso específico da Biblioteca da Unesp/Marília, o foco nas questões ligadas à segurança e às medidas preventivas contra incêndios mostra um quadro pouco motivador, na medida em que as tomadas de decisão, neste contexto, caminham de forma lenta. Nas análises efetuadas, ficou claro que o "estrangulamento" dos corredores do acervo bibliográfico, em função de seu rápido crescimento, interferiu sensivelmente nos eixos de posicionamento das rotas de fuga, impedindo que os valores mínimos da norma vigente sejam praticados. Além disso, a não observância, quanto ao mínimo de saídas de emergência, cria uma distância máxima a ser percorrida acima dos $38 \mathrm{~m}$ estabelecidos por lei, o que poderia ser evitado se mais saídas de emergência tivessem sido implantadas. Em relação à segurança da biblioteca e da preservação do acervo existente, é recomendável que se incluam diretrizes de prevenção e de extinção do incêndio, principalmente nos ambientes de rápida propagação de fogo. É preciso,também, analisar de forma consciente, em conjunto com a instituição, usuários e funcionários, as condições específicas da obra, tais como porte da edificação, número de usuários e tipo de utilização, além das exigências do crescimento do acervo para se proporem ações corretivas.

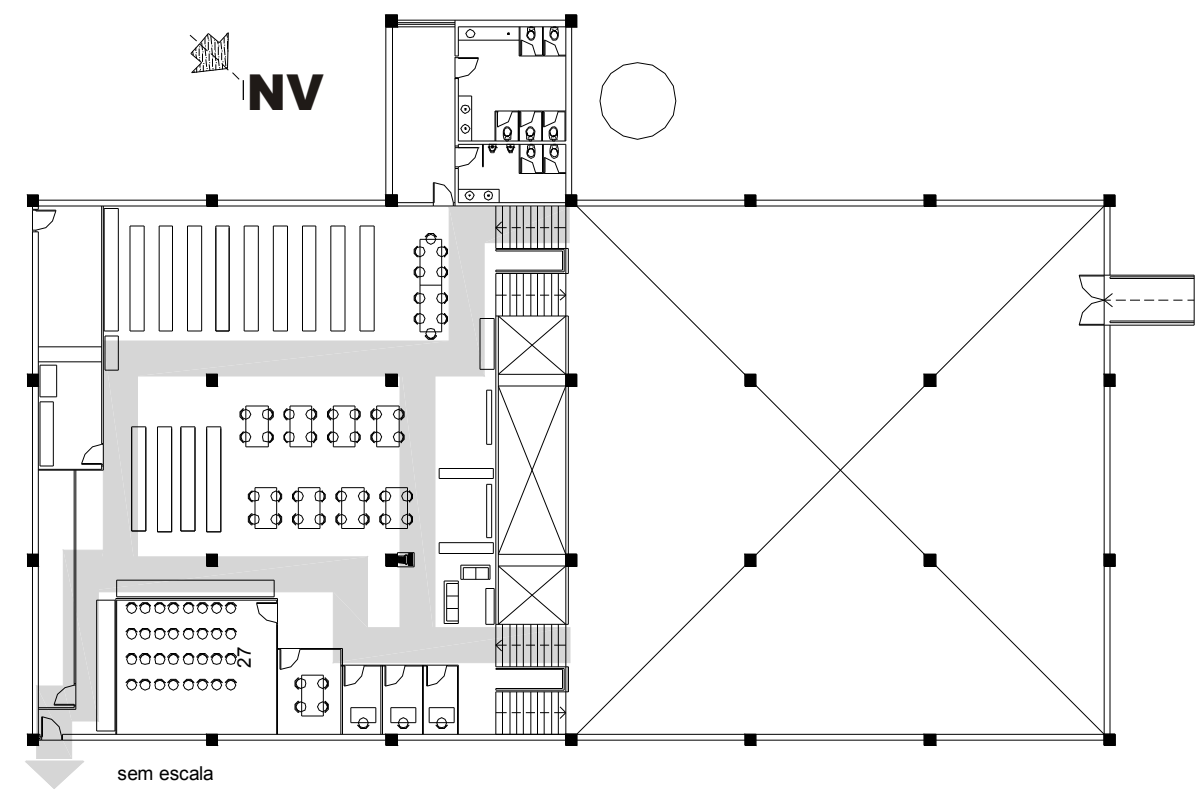

Figura 311 - Rotas de fuga - Pavimento térreo e superior Biblioteca Unesp/Marília 


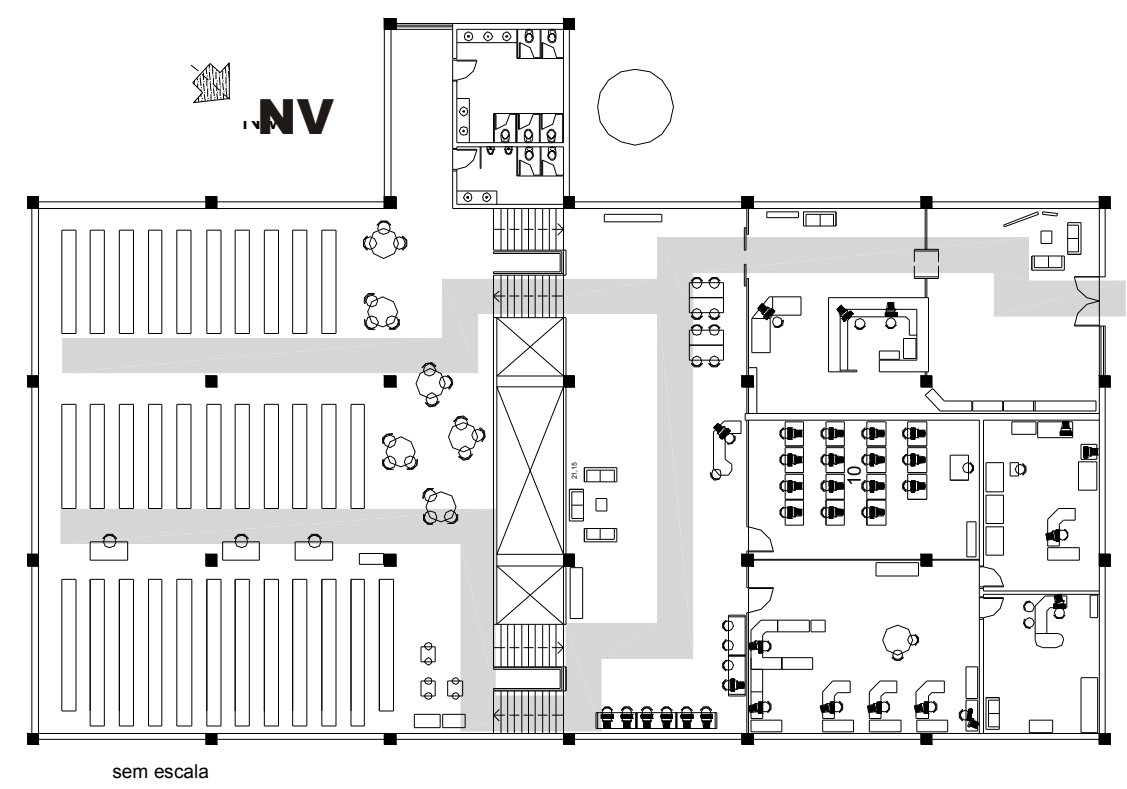

Figura 312 - Rotas de fuga - Pavimento inferior Biblioteca Unesp/Marília

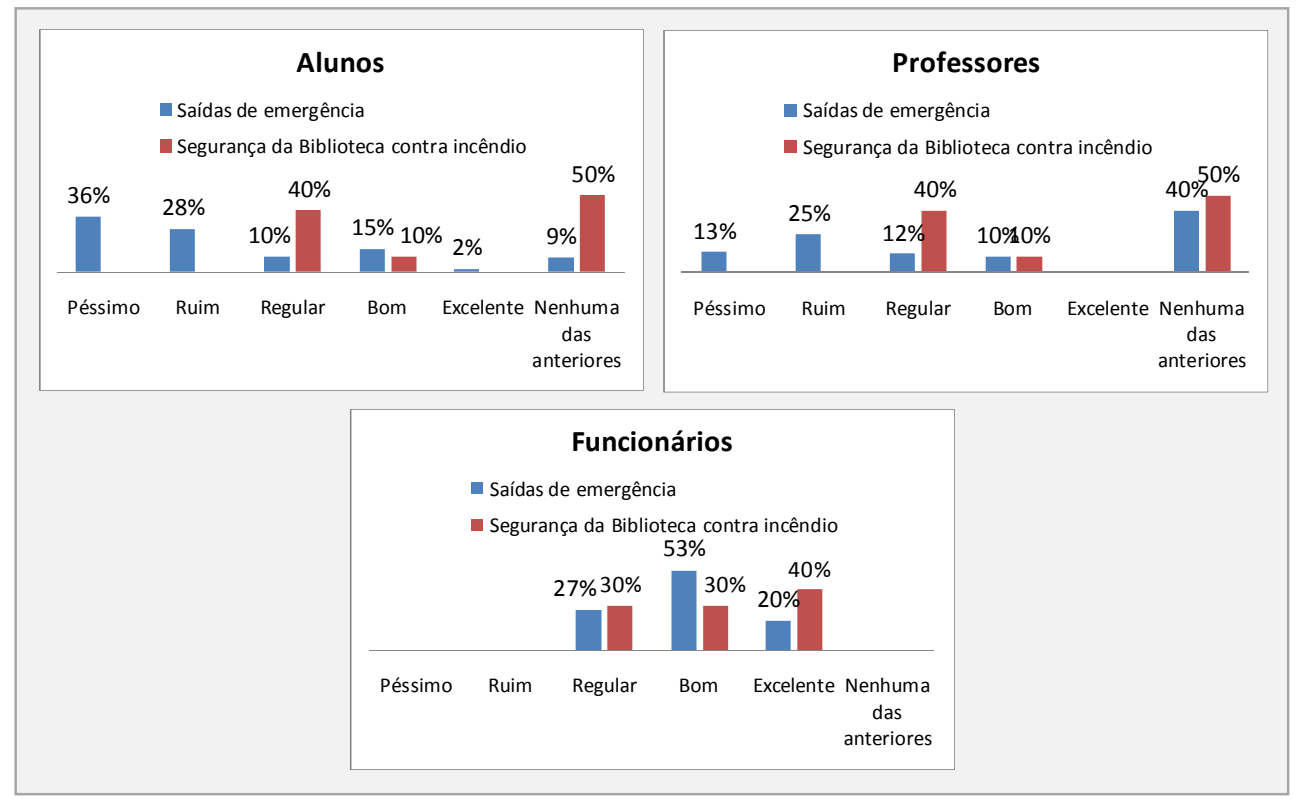

Figura 313 - Nível de Satisfação funcionários Biblioteca Unesp/Marília: segurança contra incêndio e saídas de emergência

\section{9 Áreas destinadas ao armazenamento no acervo}

Neste tópico, avalia-se o aspecto relacionado ao espaço destinado para armazenamento no acervo nos dois estudos de caso, tendo em vista os percentuais do nível de satisfação dos usuários obtido em relação a esse item. Os ambientes analisados 
das bibliotecas apontaram um índice de satisfação elevado, tanto na Biblioteca do Senac/Santo Amaro quanto na Biblioteca da Unesp/Marília, demonstrando que a quantidade e o sistema estão adequados para suas necessidades. Entretanto, a análise separada de cada caso leva à constatação de que o edifício da Biblioteca do Senac/Santo Amaro apresenta os melhores índices de satisfação em relação às áreas destinadas ao armazenamento do acervo. Esses resultados estão relacionados, principalmente, com as condições e a quantidade necessária de armários e estantes destinados ao armazenamento. Portanto, ficou bastante claro que o percentual medido entre o extrato de funcionários, apontou um índice de satisfação elevado, reafirmando que existe uma coerência no tipo e na distribuição do mobiliário destinado ao armazenamento.

É importante deixar claro que o armazenamento inadequado tem efeito direto sobre a vida útil do acervo. A guarda sem cuidado ou a superlotação de espaços resultam rapidamente em danos às coleções. As embalagens de má qualidade igualmente aceleram a deterioração dos materiais, quando o objetivo seria protegê-lo. Além disso, o manuseio inadequado também tem seu custo: se o manuseio normal produz, inevitavelmente, alguns danos, a manuseio descuidado rapidamente conduz a problemas sérios e irreparáveis.

As visitas técnicas comprovaram que todos os locais do acervo da Biblioteca do Senac/Santo Amaro dispõem de quantidade correta de mobiliário e atendem a todas as necessidades básicas de operação de arquivamento. Como foi mostrado anteriormente, as medidas mínimas dos armários estão de acordo a NBR 13.961/1997, bem como têm papel imprescindível no processo de arquivamento da biblioteca. Fora isso, a biblioteca conta com um espaço específico de armazenamento localizado em todos os pavimentos, com objetivo de suprir e armazenar o constante acúmulo de papel.

A partir dos padrões estipulados pelo $\mathrm{CBPA}^{3}$ - Conservação Preventiva em Bibliotecas e Arquivos e dos elementos relacionados às áreas destinadas ao armazenamento da área do acervo da biblioteca estudada, é possível estabelecer considerações importantes, descritas a seguir:

3 O Projeto Conservação Preventiva em Bibliotecas e Arquivos - CBPA é uma experiência de cooperação entre instituição brasileiras e a organização norte-americana Commission on Preservation and Access, atualmente incorporada ao CLIR - Council on Library and Information Resources (Conselho de Recursos em Biblioteconomia e Informação). O Projeto estipula normas de planejamento e gerenciamento de programas de conservação preventiva, onde se insere o controle das condições ambientais, a prevenção contra riscos e o salvamento de coleções em situações de emergência, a armazenagem e conservação de livros e documentos. Além disso, apresenta opções de mobiliário e soluções de armazenamento de todos os tipos de documentos no acervo da biblioteca. 
- de modo geral, nas estantes de livros, vários procedimentos adequados foram anotados: manutenção de boa circulação de ar nas áreas de armazenamento, evitando-se o contato direto com as paredes e a produção de bolsões de ar úmido; livros armazenados na posição vertical, de forma a evitar problemas na encadernação; no caso dos livros grandes, as prateleiras são largas e suficientes para apoiar completamente o volume; no acondicionamento com caixas foram encontradas do tipo articulada e com fechamento por encaixe (drop-spine box) e com cartão rígido, em forma de cruz (phase box), modelos mais indicados para o armazenamento em bibliotecas;
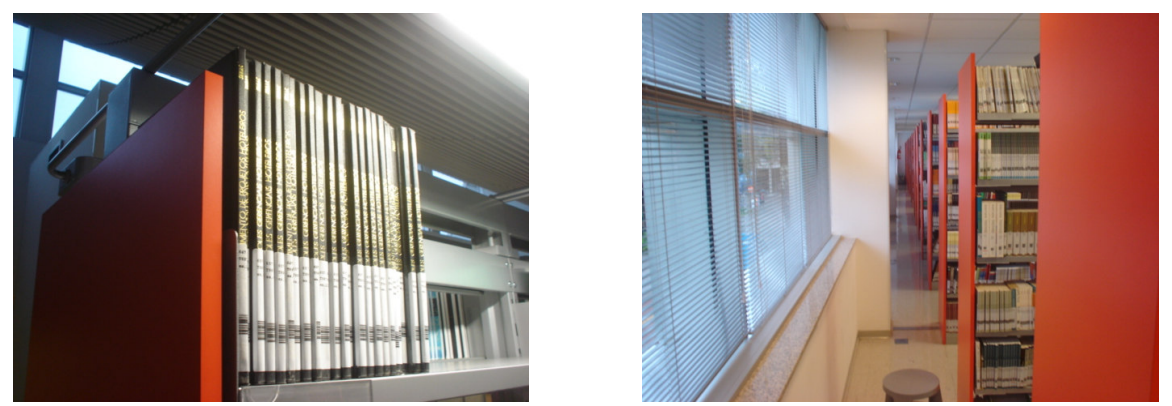

Figuras 314 e 315 - Área de armazenamento: disposição dos livros nas Biblioteca Senac/Santo Amaro

- os papeis encadernados, como documentos históricos, manuscritos e apostilas estão em compartimentos (caixas e envelopes) adequados, evitando assim, o enrolamento, o empilhamento, a perda e os danos às margens;
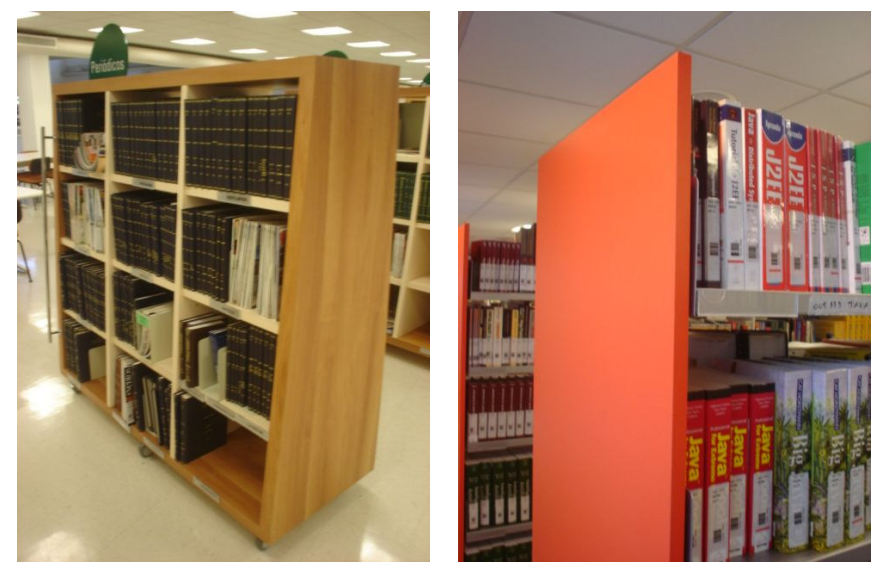

Figuras 316 e 317 - Documentos encadernados Biblioteca Senac/Santo Amaro 
- notou-se a ausência de mapotecas ou arquivos de grandes dimensões para a guarda de desenhos arquitetônicos, plantas e cartazes. Os poucos encontrados estão armazenados nos arquivos deslizantes do pavimento térreo. Entretanto, um tipo análogo de arquivamento foi encontrado na Modateca (acervo especial do curso de Moda e Estilo). Neste local estão presentes armários e estantes concebidos especialmente para a guarda de grandes materiais em forma plana ou vertical como amostras de tecidos, peças de vestidos de dimensões variadas, com o objetivo de assegurar boas condições de enrolamento e desenrolamento;
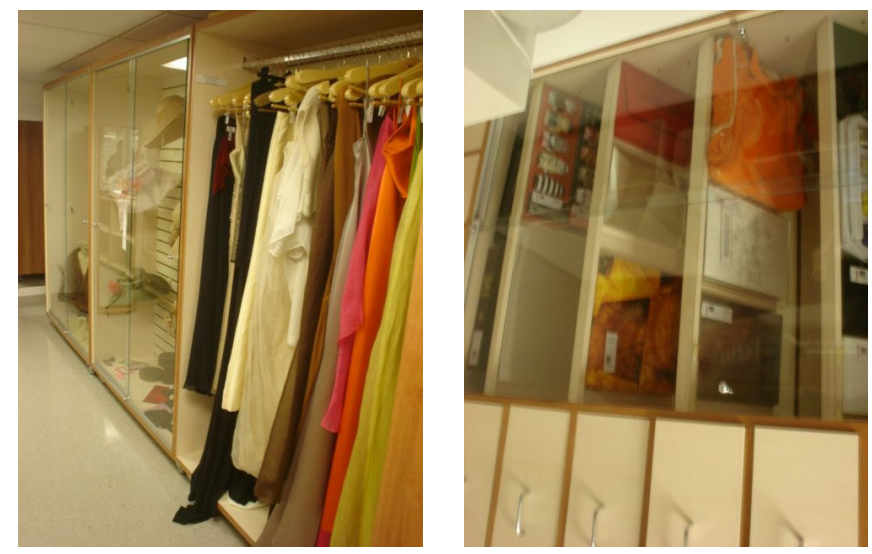

Figuras 318 e 319 - Área de armazenamento Modateca Biblioteca Senac/Santo Amaro

- folhetos, álbuns e fotografias estão devidamente armazenados em caixas especiais, além de estarem agrupadas por tipo, tamanho e formato diferenciados, já que esses itens apresentam enormes problemas de preservação no contexto da biblioteca;
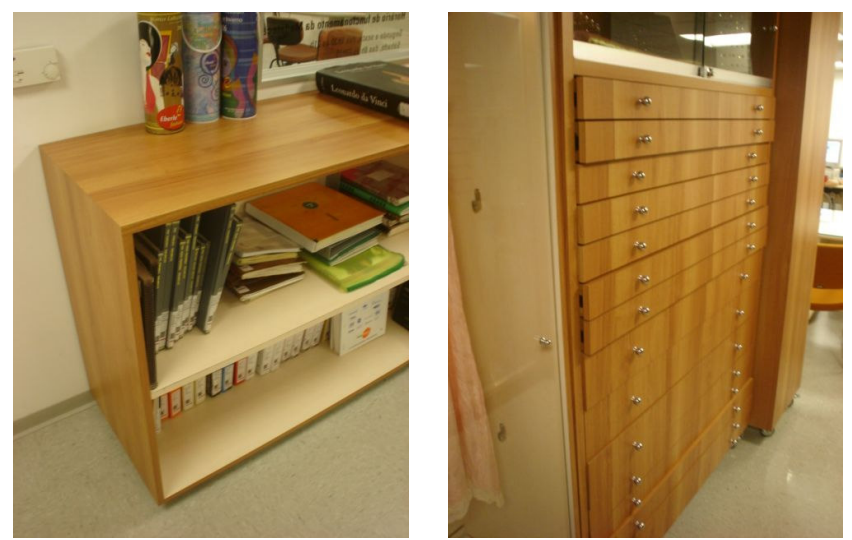

Figuras 320 e 321 - Armazenamento de folhetos, álbuns e fotografias Biblioteca Senac/Santo Amaro 
- com relação ao mobiliário de armazenamento presente na Biblioteca do Senac/Santo Amaro e sua adequação, nos quesitos de preservação e do tipo de material presente, tanto as estantes de madeira, quanto as de aço estão de acordo com as normas do CBPA, sendo considerados bons materiais e indicados devidamente à função de armazenagem;
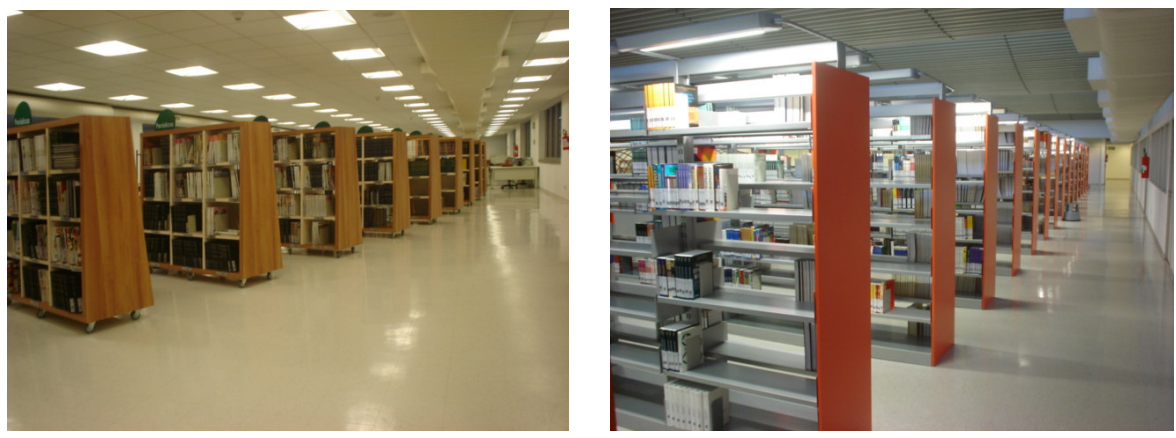

Figuras 322 e 323 - Áreas de armazenamento Biblioteca Senac/Santo Amaro

- a localização das estantes no ambiente da biblioteca procurou privilegiar áreas de menor insolação e radiação solar, evitando, assim, a presença de umidade nestes ambientes e garantindo a ventilação permanente nas áreas abrangidas do acervo bibliográfico;
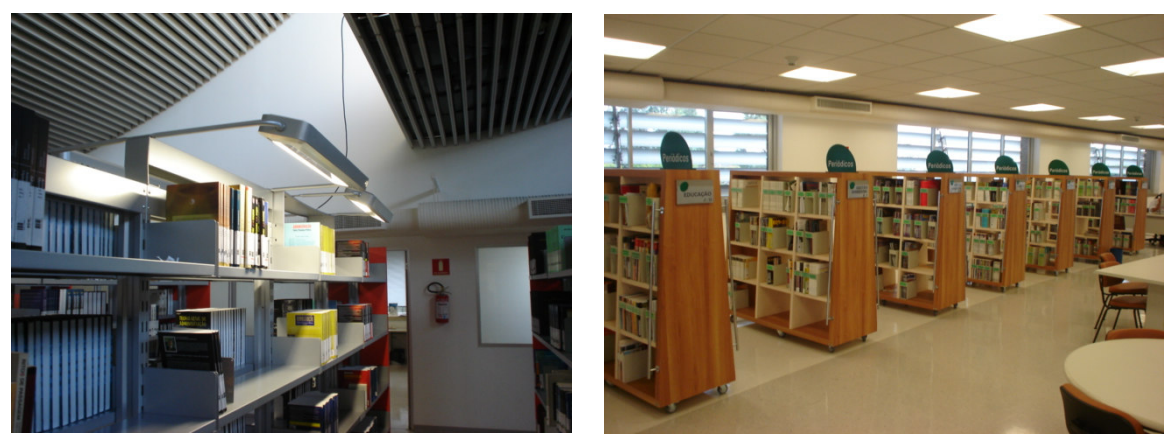

Figuras 324 e 325 - Áreas de armazenamento e o controle de insolação Biblioteca Senac/Santo Amaro 


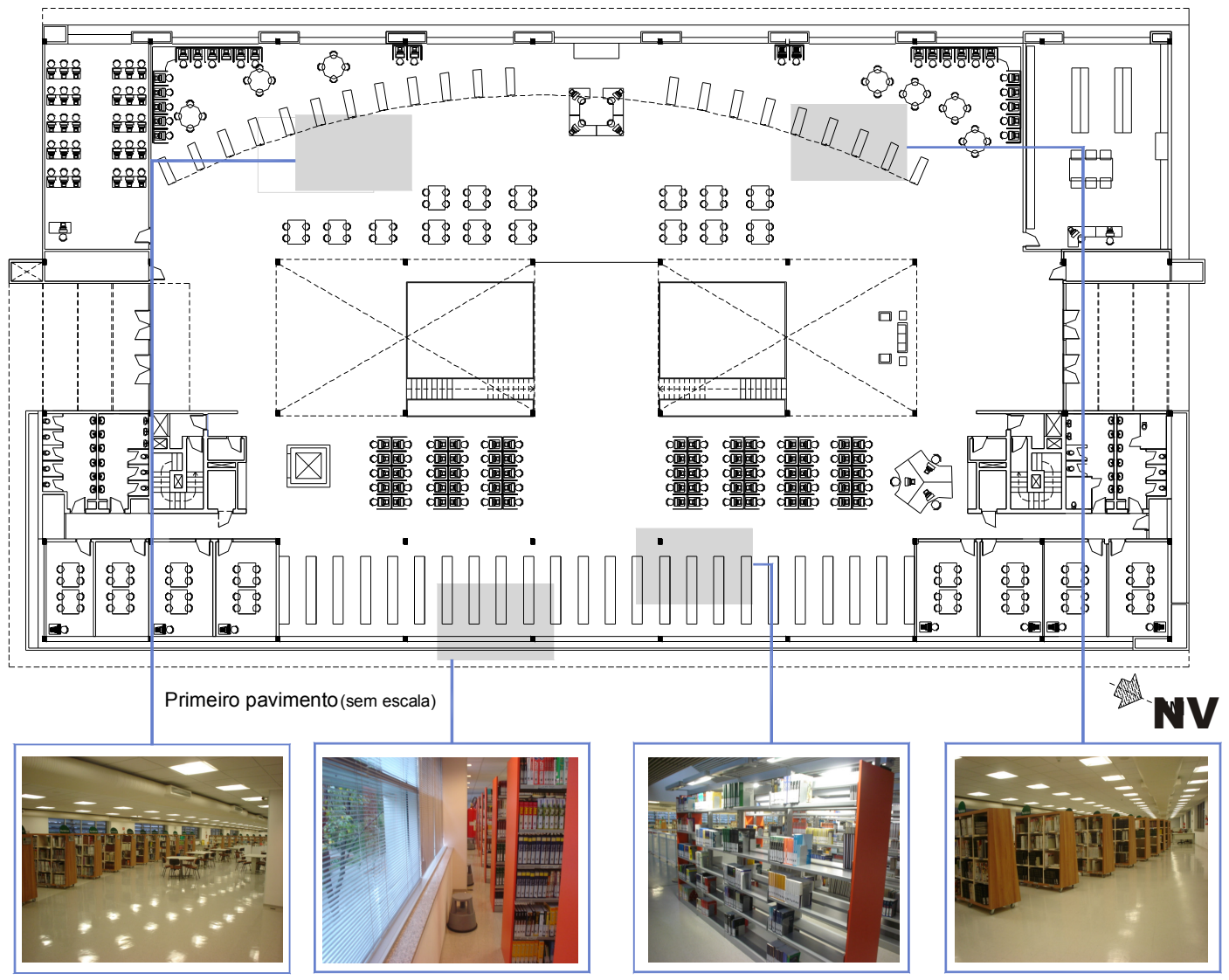

Figura 326 - Áreas de armazenamento Biblioteca Senac/Santo Amaro

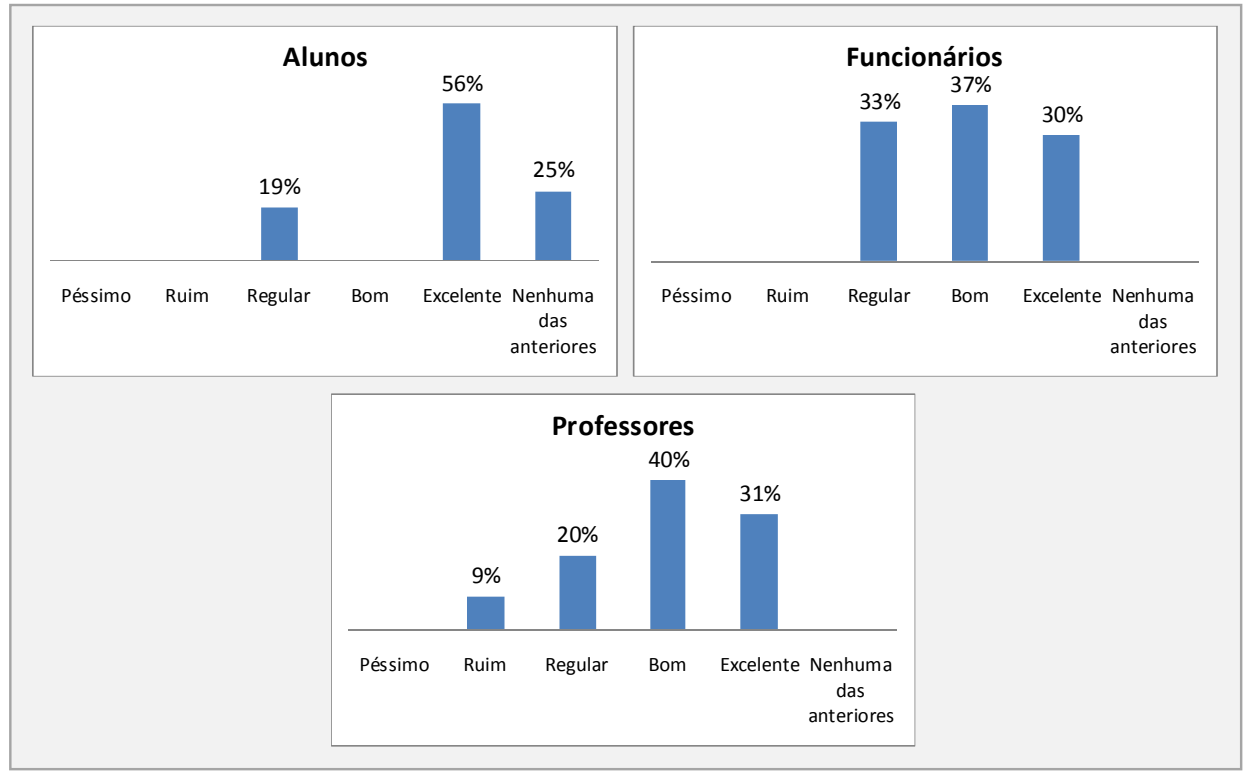

Figura 327 - Nível de Satisfação alunos Biblioteca Senac/Santo Amaro: espaço para armazenamento no acervo 
Na Biblioteca da Unesp/Marília, o quesito relacionado ao espaço para armazenamento no acervo obteve percentuais baixos de satisfação, principalmente entre o extrato de funcionários, ou seja, entre as pessoas que atuam diretamente nos serviços de guarda, reposição e distribuição do material bibliográfico.. Desta maneira, é possível apontar que o sistema utilizado de armazenamento, o tipo de mobiliário e a tendência de superlotação do acervo bibliográfico têm indicado distorções quanto à correta utilização desse serviço. Segundo apontaram os insatisfeitos, o principal problema enfrentado nos setores de armazenamento do acervo se deve ao rápido crescimento do acervo bibliográfico e, conseqüentemente, o aumento da quantidade de estantes e do espaço disponível. De modo geral, a Biblioteca da Unesp/Marília apresenta distorções em função deste problema:

- baixa circulação de ar nas áreas de armazenamento;

- estantes de livros em contato direto com as paredes, ou seja, fora do padrão mínimo de $7 \mathrm{~cm}$ exigido pelo CBPA;

- determinados livros ultrapassam as margens da prateleiras;

- determinadas encadernações de papel e tecido são armazenadas em contato direto com as de couro;

- livros armazenados na horizontal, desrespeitando a norma;

- nem todos os setores das estantes estão acompanhados de bibliocantos para manter o livro em pé.

Dentre todas as áreas de armazenamento do acervo da biblioteca, o ambiente onde está localizada a mapoteca foi o que obteve o maior percentual de aceitação e satisfação, indicando-o como um item a ser mantido. As dimensões da mapoteca estão adequadas em relação à norma do CBPA. Os materiais são colocados em pastas alcalinas e em formatos que acomodem o tamanho correto da gaveta. Vale lembrar que a mapoteca está preparada para o armazenamento de mapas de tamanho extra-grande, tendo a possibilidade de remoção com segurança e facilidade na sua utilização. A sugestão que se faz em relação a esse item é que se aumente a quantidade de peças em pelo menos mais duas mapotecas, acomodando o acervo de mapas que está à espera para ser catalogado 


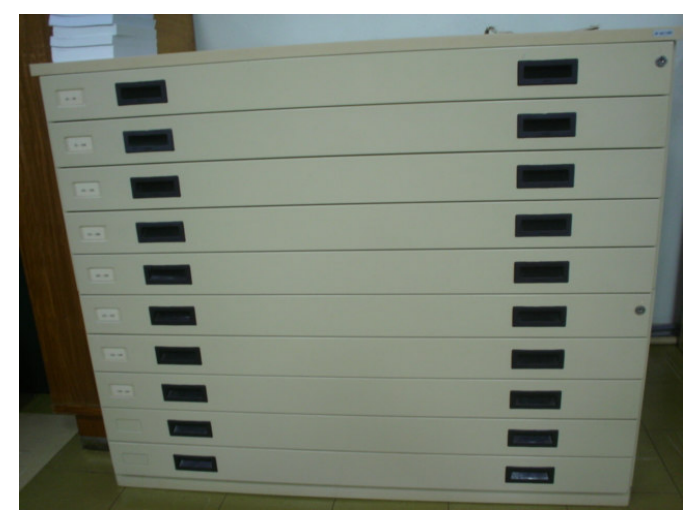

Figura 328 - Mapoteca Biblioteca Unesp/Marília

No caso da Biblioteca da Unesp/Marília, mesmo não apresentando grandes problemas em função de deficiências do sistema de armazenamento do acervo como, por exemplo, ataques de microorganismos, presença de bolor, documentos danificados por vários tipos de insetos, poluentes químicos e degradação ou perda relacionada à obsolescência de mídias magnéticas e eletrônicas, é recomendável que se criem procedimentos de conservação preventiva em todos os ambientes do acervo bibliográfico. Desta maneira, esses mecanismos teriam a função de promover e ajustar o sistema de armazenamento do acervo, minimizando e viabilizando ações concretas na procura, pesquisa e leitura do ambiente da biblioteca. Os procedimentos podem ser resumidos em:

- Planejamento, com base no conhecimento do acervo e dos materiais;

- Identificação de prioridades;

- Estabelecimento de rotinas e procedimentos padronizados / política institucional;

- Capacitação das equipes da biblioteca;

- Promoção de instalações e equipamentos, inclusive os de segurança de trabalho. 


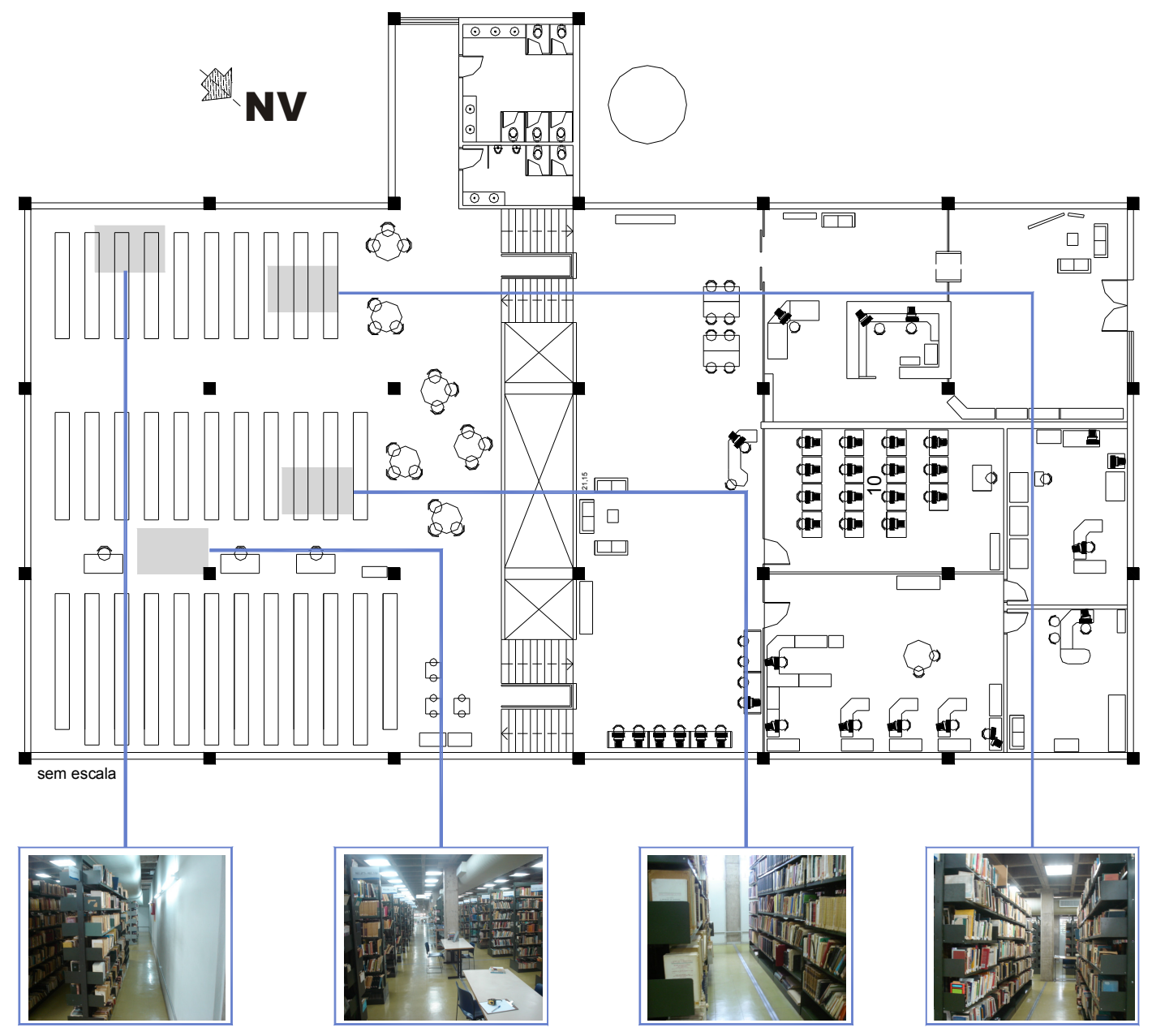

Figura 329 - Áreas de armazenamento Biblioteca Unesp/Marília

\subsection{Quantidade e tamanho dos sanitários}

$\mathrm{O}$ item que aborda a quantidade e o tamanho dos sanitários apresentou duas realidades contrastantes nos edifícios de bibliotecas universitárias analisados neste trabalho. Observando os resultados de satisfação colhidos junto aos usuários desses edifícios, confirmam-se dados que apontam a Biblioteca da Unesp/Marília como a mais problemática nos quesitos avaliados. Esses números são validados também por meio das visitas técnicas, demonstrando que o problema reside no seu sub-dimensionamento e na quantidade disponível ao usuário. 


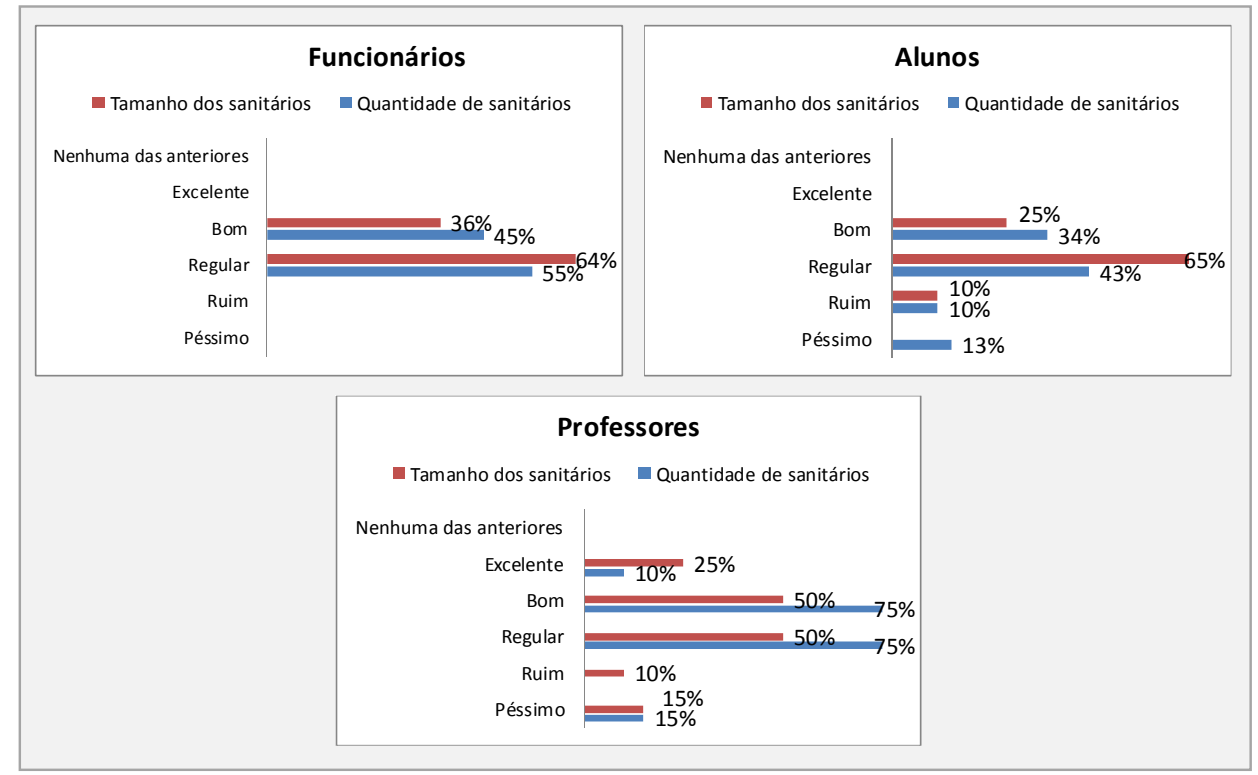

Figura 330 - Nível de Satisfação Biblioteca Unesp/Marília: tamanho e quantidade de sanitários

Analisando este item, um pouco mais detalhadamente com relação ao edifício da Biblioteca da Unesp/Marília, chega-se a algumas conclusões preliminares importantes:

- Apesar de possuir instalações sanitárias separadas por sexo, a quantidade é insuficiente no sanitário masculino. De acordo com o Código Sanitário do Estado de São Paulo (1998), o mínimo exigido é de 5 (cinco) conjuntos de bacia sanitária, lavatório e mictório. Somente no sanitário feminino acontece à aplicação da norma vigente;

- $\quad$ O conjunto de sanitários destinado ao publico está localizado somente no pavimento intermediário superior da biblioteca, obrigando aqueles usuários que, porventura, estejam no pavimento inferior, a se deslocarem a uma distância muito grande até acessarem os sanitários;

- Os sanitários não contemplam as pessoas portadoras de deficiência física, ou seja, não atendem à norma NBR 9050/2004, gerando, inevitavelmente, sérios transtornos no ambiente da biblioteca, já que a própria universidade possui em seus quadros acadêmicos vários exemplos de pessoas com tais características. 


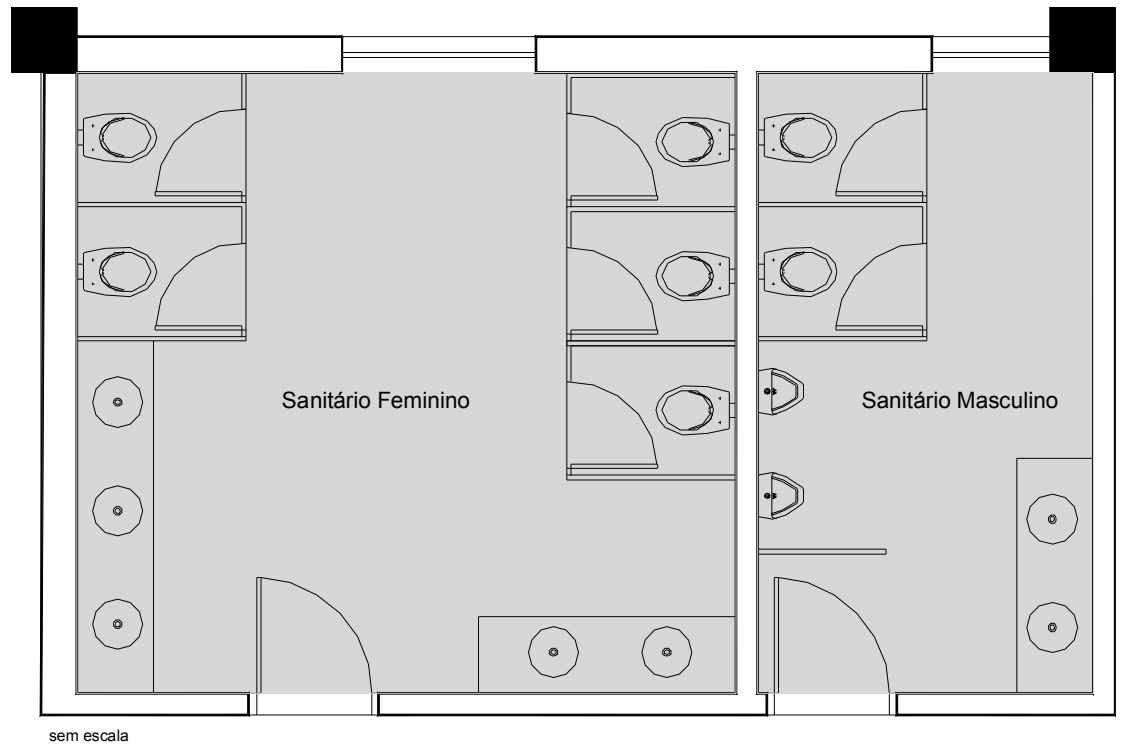

Figura 331 - Sanitários Biblioteca Unesp/Marília

Quanto à avaliação deste item no edifício da Biblioteca do Senac/Santo Amaro, como foi apresentado anteriormente, os resultados apresentados foram altamente positivos, demonstrando que a quantidade e o tamanho dos sanitários atendem perfeitamente às necessidades dos usuários. Desta maneira, é possível destacar alguns elementos importantes relacionados à avaliação de satisfação dos usuários e às condições encontradas deste item no ambiente:

- Dois elementos básicos influenciaram positivamente nas respostas dos usuários: primeiro, os sanitários são bem dimensionados, atendendo à legislação do COE - SP (1993) e, segundo, foram executados com materiais de acabamento de primeira e, além disso, estão em bom estado de conservação;

- $\quad$ Em relação à quantidade de sanitários, a biblioteca atende às normas estabelecidas do COE - SP (1993), destinando para cada pavimento da biblioteca, o conjunto necessário de sanitários. Mais ainda, a quantidade de conjunto de peças sanitárias (vasos e lavatórios) existentes nos andares é até maior do que estipula a norma para a população existente. Dessa forma, o alto índice da satisfação dos usuários se deve possivelmente a essas características apresentadas. 


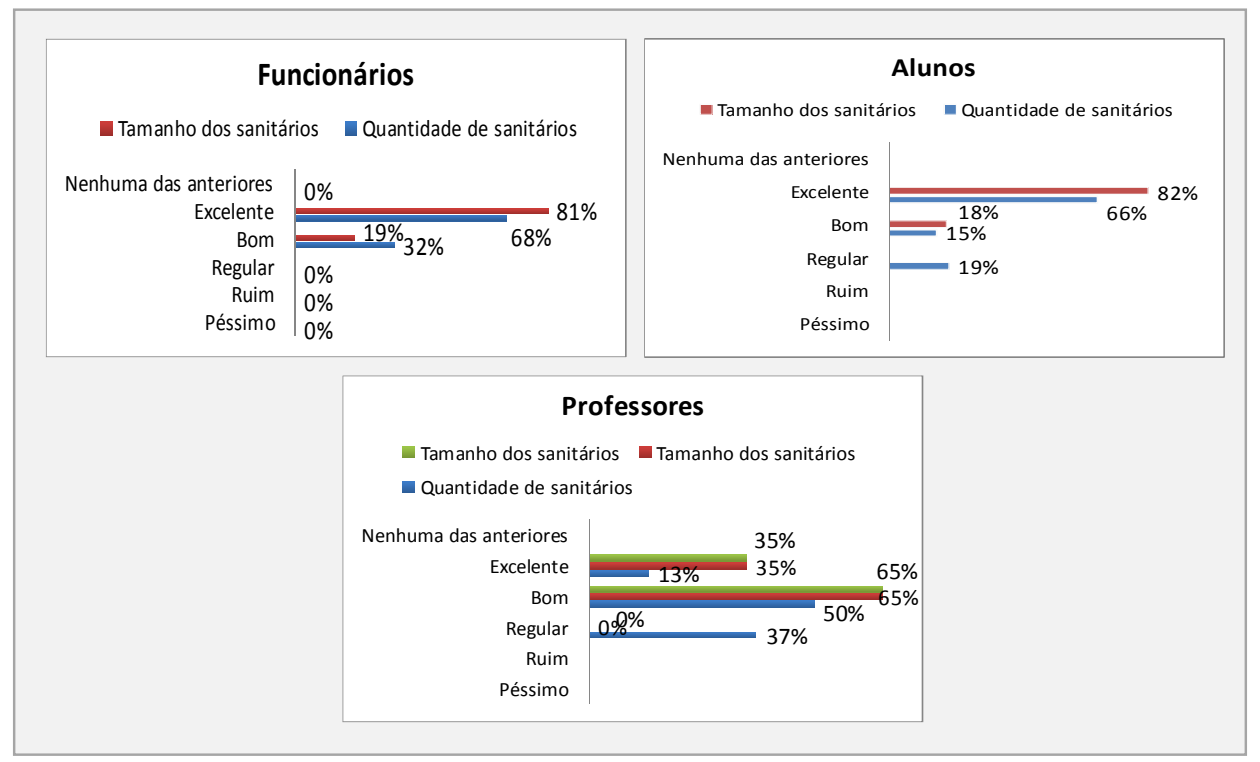

Figura 332 - Nível de Satisfação alunos Biblioteca Senac/Santo Amaro: tamanho e quantidade dos sanitários

\subsection{Sinalização interna da biblioteca}

A sinalização interna na biblioteca tem por objetivo a orientação dos usuários quanto aos serviços que ela oferece, facilitando seu acesso, seu uso e dinamização do funcionamento. Essa sinalização pode ser feita de várias formas: direcional (informação para pontos principais, materiais e serviços); instrucional (explicações de procedimentos, uso de materiais, coleções, equipamentos, etc), condicional ou reguladora (regulamenta o comportamento ou especifica os horários ou outras informações mutáveis) e de alerta.

Assim, uma sinalização bem planejada e executada pode trazer benefícios para a identificação e localização na biblioteca; orientação aos usuários para acesso e uso dos recursos humanos; melhora na acessibilidade dos usuários aos serviços oferecidos; identificação dos recursos, das áreas de serviços e das acomodações; informação sobre os regulamentos, horários e fatos especiais; promoção da informação instrucional e notificação das mudanças ou condições temporárias.

Este item abrange a avaliação de todo o sistema de sinalização e comunicação visual interna existente nos dois estudos de caso da pesquisa, além de apresentar a percepção de satisfação dos usuários com relação a este item. As avaliações também tiveram como objetivo apontar, preliminarmente, deficiências existentes não só 
no âmbito das bibliotecas analisadas, mas também no contexto dos futuros projetos arquitetônicos de bibliotecas universitárias.

Os resultados apresentados entre os dois edifícios analisados apontaram valores bastante diferenciados. Os índices mais positivos de satisfação foram aqueles referentes à Biblioteca do Senac/Santo Amaro, cuja maioria aprova o sistema de sinalização interna dos ambientes, enquanto que, na Biblioteca da Unesp/Marília, os valores de aceitação foram considerados muito baixos, indicando que o desempenho deste quesito no ambiente apresenta problemas de funcionamento.

Analisando as características básicas de sinalização interna da Biblioteca do Senac/Santo Amaro, foram organizados os modelos existentes nos ambientes, em quatro (4) tipos, conforme pode se observar na Tabela 17. Os modelos apresentados a seguir, baseiam-se nos padrões apresentados anteriormente, definidos em direcional, instrucional condicional e de alerta, fruto de um projeto de comunicação visual implantado em todo o contexto da biblioteca.

\begin{tabular}{|l|l|}
\hline \multicolumn{2}{|l|}{$\begin{array}{l}\text { Tabela 17 - Tipos de sinalização interna/Biblioteca Senac/Santo Amaro e Biblioteca } \\
\text { Unesp/Marília }\end{array}$} \\
\hline \multicolumn{1}{|c|}{ Tipo de sinalização interna } & $\begin{array}{l}\text { Informação para pontos principais, materiais e } \\
\text { serviços. }\end{array}$ \\
\hline SI1 - Sinalização Interna Direcional & $\begin{array}{l}\text { Explicações de procedimentos, uso de materiais, } \\
\text { coleções, equipamentos, etc. }\end{array}$ \\
\hline S12 - Sinalização Interna Instrucional & $\begin{array}{l}\text { Regulamenta o comportamento ou especifica os } \\
\text { horários ou outras informações mutáveis. }\end{array}$ \\
\hline SI3 - Sinalização Interna Condicional & Informação para situações de risco. \\
\hline SI4 - Sinalização Interna de Alerta &
\end{tabular}

Os quatro (4) modelos de sinalização interna estão distribuídos em todos os pavimentos do edifício, desempenham a função de auxiliar na autonomia dos usuários em encontrar os serviços e produtos oferecidos pela Biblioteca Senac/Santo Amaro. (1) A SI1 - Sinalização Interna Direcional - vincula às informações direcionadas às salas, circulações, materiais e serviços, com tamanhos variados e letreiro padronizado. Na maioria dos casos, as placas são executadas em aço escovado fosco. Além disso, todos os acessos de entrada e saída dos ambientes e os direcionamentos das circulações primárias e secundárias fazem parte desta sinalização; (2) Modelo SI2 - Sinalização Interna Instrucional - orienta os usuários quanto às 
informações das estantes do acervo bibliográfico, das coleções especiais e das estantes onde são comercializados os livros da Editora Senac. Neste caso, os modelos direcionados às estantes do acervo apresentam variação quanto à sua tipologia - as estantes do Modelo 01 adotam placas indicativas com material metálico e as estantes do Modelo 02 utilizam placas com aço escovado. O principal diferencial destes modelos é projeto gráfico de cores apresentado. Cores marcantes indicam às diversas áreas do conhecimento abrangido pelo acervo. (3) Modelo SI3 - Sinalização Interna Condicional - realiza a orientação visual a todas as informações pertencentes aos horários de funcionamento, regulamentos e regras e campanhas educativas no âmbito da Biblioteca do Senac/Santo Amaro. Nestes modelos, as tipologias utilizadas variaram muito em modelos, formatos e matérias, como por exemplo, placas indicativas de acrílico, placas de PVC, placas adesivas e placas de aço escovado. (4) O último modelo, SI1 - Sinalização Interna Direcional - é aquele direcionado aos avisos de segurança e alerta como saídas de emergência, entrada de locais proibidos, junto aos equipamentos de segurança (extintores) e em situações de risco, e estão enquadrados na NBR $13434 / 1995$ quanto aos formatos e modelos existentes.

A existência de um projeto de comunicação visual arrojado e contemporâneo na Biblioteca do Senac/Santo Amaro permitiu que as médias de satisfação atingissem excelentes índices de aceitação entre os usuários, comprovando que esse sistema de sinalização interna preenche os requisitos mínimos de utilização. Conforme relatado anteriormente, a comunicação visual adota, basicamente, um sistema de cores que vincula o número do tombo, o tipo de área atendida e o tipo de documento procurado, com o intuito de minimizar o tempo de procura nas estantes do acervo.

Conforme depoimentos colhidos entre os usuários, o sistema tem se mostrado bastante eficiente, tanto na agilização no processo de busca da informação no acervo bibliográfico quanto no direcionamento visual do usuário até as estantes de livros. Além disso, todos os ambientes da biblioteca garantem ao usuário um amplo sistema de sinalização e comunicação, indicando os acessos de sanitários, salas de pesquisa e leitura, salas de estudo, escadas, área administrativa, balcão de atendimento, circulações principais, etc. Um fato relevante que acabou chamando bastante atenção no contato com os usuários e nas visitas exploratórias: a constatação de que a presença de um projeto específico de sinalização e comunicação visual na biblioteca, sem dúvida alguma, colaborou em oferecer ao usuário condições para usufruir dos benefícios oferecidos pela biblioteca, na orientação e no acesso aos serviços e produtos existente 


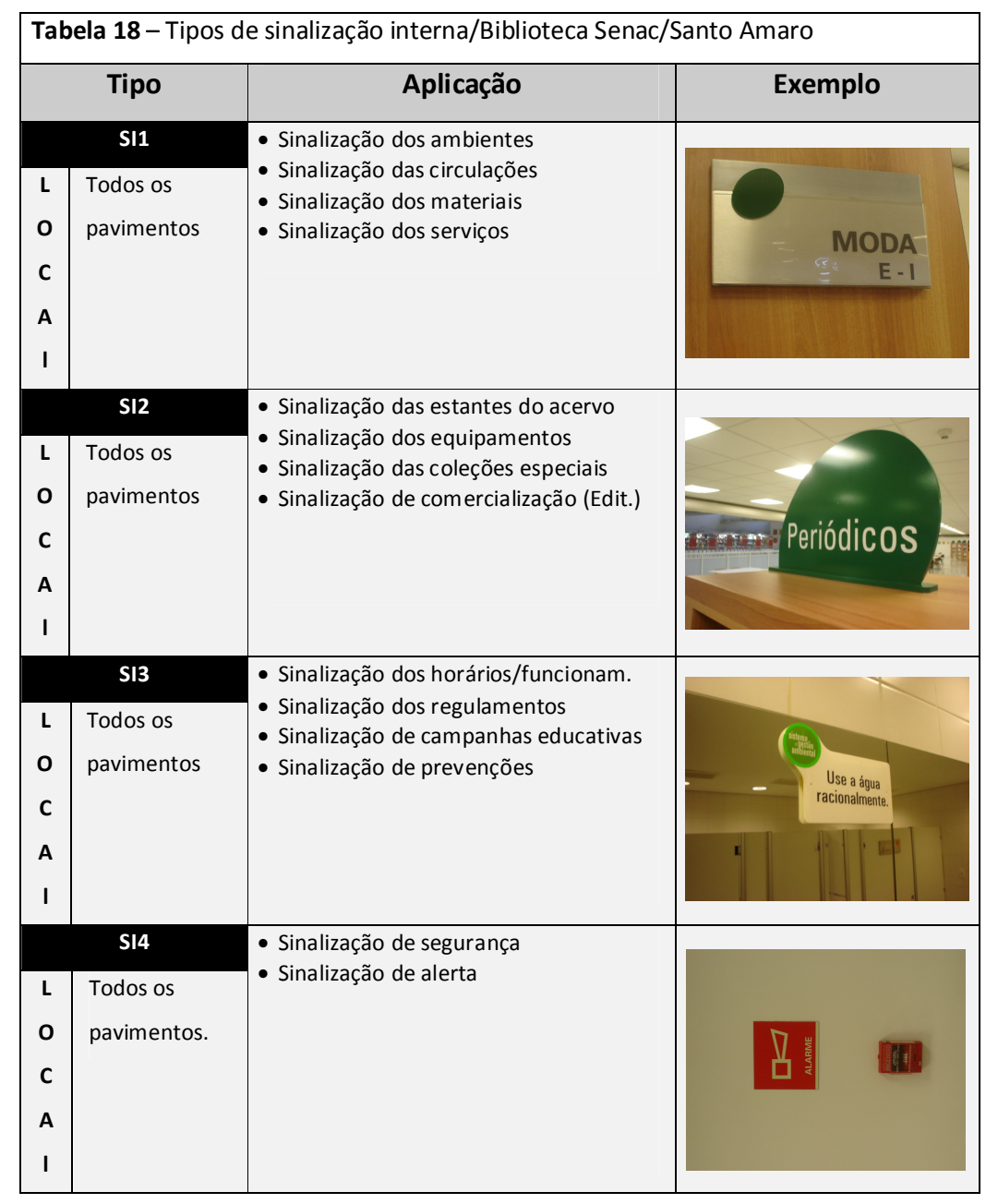

Finalmente, ficou também claro que as vantagens advindas do bom projeto de comunicação visual presente na Biblioteca do Senac/Santo Amaro acarretou não só benefícios na própria organização espacial do acervo bibliográfico, como também melhoria na qualidade do armazenamento e da disseminação de tudo que foi produzido e recebido no âmbito da biblioteca. Além disso, é importante deixar claro que a busca do projeto coerente e adaptado de sinalização interna otimizou tanto os serviços realizados pelos funcionários da biblioteca, quanto o daqueles usuários que são considerados visitantes esporádicos e acessam o ambiente com freqüência reduzida. A sugestão é que se mantenha a constante avaliação dos elementos de sinalização interna da biblioteca, na tentativa de detectar falhas no processo e elaborar possíveis melhorias. 


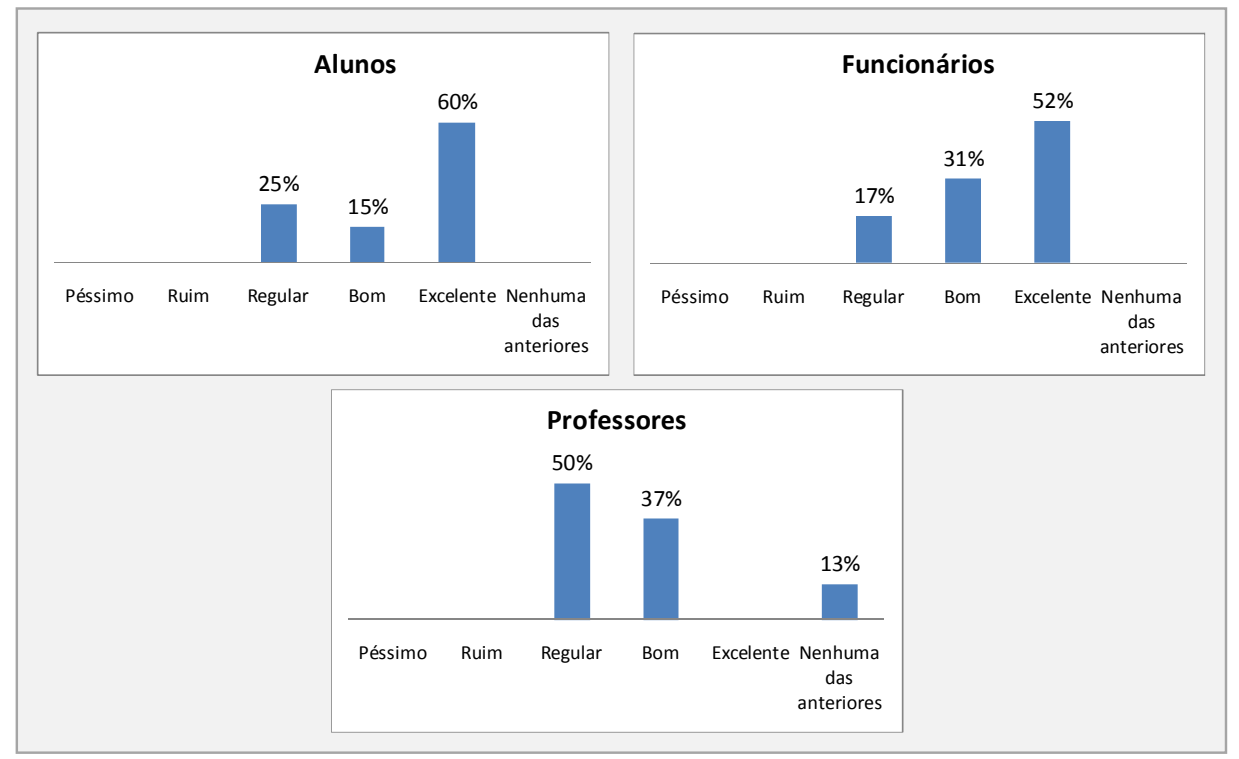

Figura 333 - Nível de satisfação funcionários Biblioteca Senac/Santo Amaro: sinalização interna

Como acontece na Biblioteca do Senac/Santo Amaro, o outro edificio deste estudo de caso, a Biblioteca da Unesp/Marília, também apresenta os mesmos modelos de sinalização interna, sendo assim distribuídos pelos ambientes: (1) o modelo SI1 - Sinalização Interna Direcional - demarca as informações direcionadas das salas, circulações e ambientes, sendo todos de placas metálicas na cor azul de fundo e letras brancas e sempre um mesmo tamanho $(15 \mathrm{~cm}$ x $50 \mathrm{~cm}$ ) (2) O SI2 - Sinalização Interna Instrucional - são os modelos que orientam os usuários quanto às informações das estantes do acervo bibliográfico e das coleções especiais. Neste caso, não existe uma variação muito significativa com relação aos modelos, sendo sempre dois formatos de placas, $30 \mathrm{~cm}$ x $35 \mathrm{~cm}$ e $45 \mathrm{~cm}$ x $30 \mathrm{~cm}$. (3) O modelo SI3 - Sinalização Interna Condicional - fixa a orientação visual das informações pertencentes aos horários de funcionamento, regulamentos e regras, e somente uma placa faz esta função, localizada no hall de entrada da biblioteca. (4) O SI1 - Sinalização Interna Direcional - são modelos direcionados aos avisos de segurança e alerta, saídas de emergência, extintores e entrada de locais proibidos,

Na Biblioteca da Unesp/Marilia, a percepção dos usuários quando perguntados com relação à sinalização interna do edifício, as respostas foram muito negativas, ou seja, em termos de média entre os usuários, $48 \%$ consideraram Regular a utilização da comunicação visual nos ambientes, evidenciando que este quesito apresenta problemas a serem equacionados: 
1. o primeiro deles está relacionado com projeto específico de comunicação visual e sinalização interna instalado na biblioteca, considerado deficitário tanto na quantidade de peças quanto no modelo adotado. O melhor caminho seria a reformulação completa do projeto visual, não só quanto à quantidade, mas também à possível atualização das cores, formatos e modelos adotados;

2. o segundo remete à sinalização das estantes do acervo bibliográfico. Mesmo estando enquadrados nos padrões estabelecidos da norma ABNT de catalogação e indexação de documentos, os usuários relataram a constante dificuldade de localização da informação requerida nas estantes, tendo sempre que recorrer à ajuda dos funcionários que apóiam a organização e a dinâmica do acervo bibliográfico. Portanto, esses resultados sugerem uma análise mais aprofundada no modelo adotado, tanto do design das placas (cores, formatos e disposições) quanto na localização estratégica dos elementos de sinalização interna das estantes do acervo.

A sinalização interna no ambiente da biblioteca é, sem dúvida, um dos aspectos-chave para o correto processo de acesso e busca do material de acervo bibliográfico e tem provocado um debate sem fim na busca do que é mais adequado. No caso da Biblioteca da Unesp/Marília, os dois problemas apresentados reforçam a importância da participação de não somente o pessoal da direção nas decisões de projetos de sinalização interna, mas também dos usuários, tornando-os mais comprometidos com o processo para que se apropriem do espaço de forma mais efetiva. Além disso, as estratégias relacionadas à comunicação visual poderiam uniformizar e padronizar os elementos de leitura no contexto da própria biblioteca, beneficiando a busca da informação pelo usuário e o trabalho diário dos funcionários. 

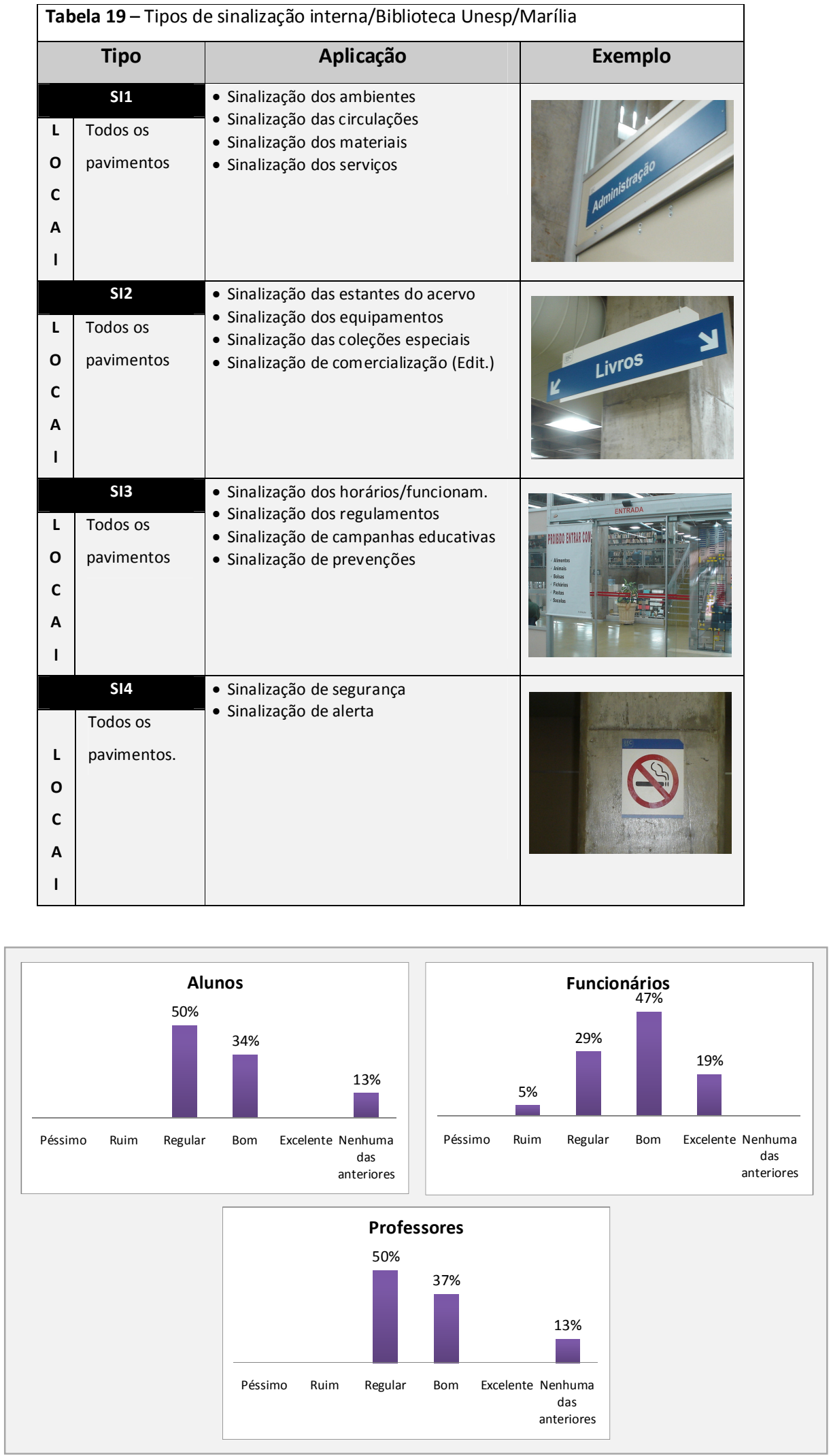

Figura 334 - Nível de Funcionários alunos Biblioteca Unesp/Marília: sinalização interna 


\subsection{Análise do conforto ambiental}

No espaço da biblioteca, os estímulos gerados pelo ambiente envolvem necessariamente todos os sentidos que intermedeiam a informação para o ser humano e são um canal de ligação da imaginação, interpretando as condições de conforto ambiental por meio das sensações resultantes dessa interação com o meio. No campo do conforto ambiental, nos últimos anos, os edifícios de bibliotecas universitárias têm executado mudanças em seus projetos arquitetônicos e métodos construtivos, no sentido de proporcionar um ambiente interno mais controlado e mais adequado às condições de conforto ambiental. Recomendações têm sido colocadas em prática como, por exemplo, escolha correta da tipologia dos materiais utilizados nos edifícios, cálculos das temperaturas máximas e mínimas diárias, forma do edifício, tipologia da cobertura, clima predominante, etc. Todas essas ações têm procurado fornecer intervenções para minimizar problemas relacionados aos requisitos de conforto ambiental melhorar os níveis de satisfação e desempenho de seus usuários.

Neste trabalho, com relação a analise do conforto ambiental, é importante deixar claro que a metodologia referente a esse aspecto está baseada em dois aspectos: o primeiro refere-se ao fato de que a análise não está vinculada à utilização dos equipamentos de medição, como acontece normalmente em outras pesquisas sobre o assunto. Isso se deve, principalmente, por a pesquisa previlegiar as questões relacionadas à funcionalidade e à eficiência dos ambientes de biblioteca universitária, entendendo que os elementos analisados podem ser medidos qualitativamente (sensação de frio ou calor, nível de satisfação com o ambiente, qualidade da iluminação, entre outros); o segundo aspecto propõe formatar diretrizes e recomendações preliminares relacionadas ao conforto ambiental, pautadas nos parâmetros das normas vigentes. Portanto, a avaliação das condições de conforto ambiental consiste na análise dos resultados dos questionários aplicados nos extratos dos usuários (alunos, professores e funcionários) e teve, como ponto de partida, as sensações manifestadas nos questionários.

$\mathrm{Na}$ análise, são abordados os aspectos relativos à temperatura, umidade, ventilação, iluminação natural, iluminação artificial e níveis de ruído. Mesmo não aplicando medições técnicas, salienta-se o fato de que os diagnósticos apresentados nesta etapa estão embasados nas opiniões dos usuários e complementados com as observações físicas obtidas pelas visitas exploratórias nos edifícios escolhidos. Destaca- 
se ainda que, para a elaboração destes diagnósticos, foram considerados basicamente os resultados mais significativos referentes às perguntas dos questionários, embora, em alguns casos, sejam feitas referências a índices menores. Portanto, o papel representativo dos diagnósticos dos elementos do conforto ambiental dentro do contexto desta pesquisa, não deve ser considerado isoladamente, mas sim fazer parte da interface dos demais aspetos já mencionados e a mencionar.

\section{Temperatura}

De acordo com Frota (1988), não há normas ou procedimentos para medidas térmicas ambientais, a não ser para ar-condicionado, como por exemplo, a NBR-6401, que trata especificamente do desempenho de equipamentos. Assim, estabeleceu-se que para aplicar o questionário junto ao usuário as condições ambientais deveriam estar adequadas quanto ao seu funcionamento. Por exemplo, todas as lâmpadas acesas, máquina e equipamentos da biblioteca em operação, ar-condicionado ligado e presença dos usuários; desta maneira, foi possível garantir a atuação simultânea dos agentes geradores e eliminadores de calor.

Com relação à opinião dos usuários, no que se refere à temperatura dos edifícios, as condições foram avaliadas satisfatórias e, sempre em quase todos os extratos, o padrão de satisfação foi considerado Bom, indicando que os respondentes estão em condições de conforto térmico com o ambiente. A pergunta formulada solicitava o nível de satisfação quanto à temperatura no ambiente de forma distinta para as condições de inverno e verão, embora os pavimentos dos edifícios selecionados sejam climatizados artificialmente e programados para funcionar a uma temperatura de $22{ }^{0} \mathrm{C}$, independente das condições climáticas externas. Entretanto, apesar deste panorama satisfatório, a tendência de todos os extratos dos usuários nos resultados nos estudos de caso da pesquisa, tanto da Biblioteca do Senac/Santo Amaro quanto da Biblioteca da Unesp/Marília, mostraram uma parcela razoável dos dados agrupados entre Regular e Bom, demonstrando portanto, condições de desconforto, pelo frio ou pelo calor.

Em relação ao desconforto por causa do frio, a Biblioteca do Senac/Santo Amaro apresentou alguns dados significativos neste item, comprovado não só pelos resultados dos questionários mas também nos contatos com os usuários nos ambientes. A interpretação mais coerente em relação a isso, sem dúvida nenhuma, é a própria 
operação do sistema de ar-condicionado, visto que as zonas mais próximas da casa de máquinas recebem temperatura mais baixas para garantir condições de conforto adequadas nas áreas periféricas dos pavimentos. Nas entrevistas e nos contatos com os usuários, o principal comentário indicou o desconforto pelo fato de estar posicionado embaixo das grelhas que insuflam o ar. Essas situações ocorrem principalmente nas áreas destinadas à leitura e pesquisa, onde o adensamento de pessoas se torna bastante crítico e também em função de se tratar de um ambiente aberto, cujas únicas salas fechadas são a da administração e da diretoria.

Analisando esta situação e seus desdobramentos em relação ao conforto ambiental dos edifícios das bibliotecas analisadas, pode-se verificar a grande dificuldade que um sistema, programado para trabalhar a uma temperatura uniforme em todas as áreas, tem para atender à alta variabilidade da percepção do conforto térmico dos usuários, em função principal de diversos fatores ambientais como, por exemplo, partido do projeto arquitetônico, sexo, idade, condições físicas, densidade ocupacional, vestimentas, saúde, etc. Como forma de exemplificar esse fato, pode haver ocorrências de mudanças de layout nos ambientes, acarretando uma maior densidade ocupacional em determinados setores, gerando maiores cargas térmicas; o fato mais comum neste caso é o aumento na sensação de calor entre os usuários instalados no local. Por outro lado, aquele espaço pode estar localizado próximo a outro servido pela mesma ramificação de dutos de insuflamento e, mesmo assim, ser menos densamente ocupado.
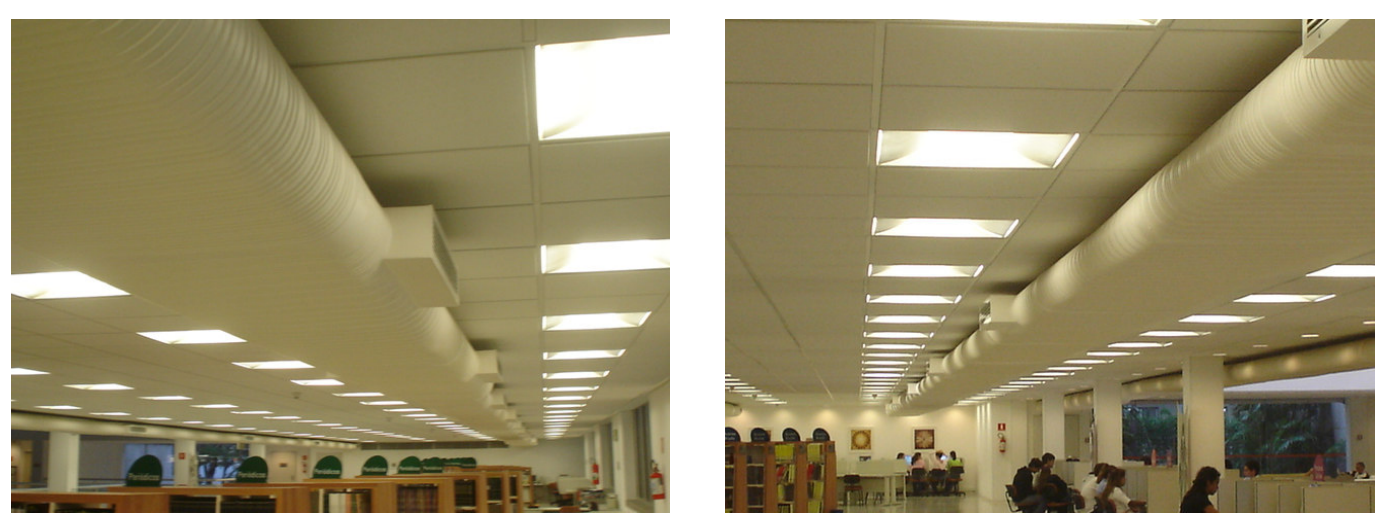

Figuras 335 e 336 - Sistema de ar-condicionado Biblioteca Senac/Santo Amaro 
No caso do edifício da Biblioteca da Unesp/Marília,os resultados sugerem praticamente os mesmos níveis de variação em relação ao caso da Biblioteca do Senac/Santo Amaro. Os usuários classificaram como "Boa" a temperatura do ambiente ocupado. Entretanto, em alguns casos, foram detectadas respostas diferentes e um nível de satisfação bem maior no inverno do que no verão. Esses resultados podem indicar temperaturas mais elevadas no período mais quente do ano (verão) e, por conseqüência, maior sensação de desconforto no ambiente. Além disso, embora não tenha sido incluído como perguntas nos questionários aplicados aos usuários, ocorreram vários comentários no contato com os usuários sobre a percepção de temperatura ao se locomoverem de um espaço ao outro no mesmo pavimento, indicando o desconforto das pessoas com as variações de temperatura naquele momento. Ainda com relação a este tópico, por meio de observações físicas, foi anotado um desconforto gerado pela diferença de temperatura entres os sanitários e as demais dependências, já que, nesses ambientes, a renovação de ar se dá através de exaustão mecânica.

Um dado importante na análise das condições de temperatura ambiente da Biblioteca da Unesp/Marília diz respeito à implantação do edifício em relação à radiação solar. A preocupação com a adequação dos fatores naturais do entorno e terreno, levaram à utilização de elementos vazados e brises horizontais ao longo das aberturas das janelas. Embora essa solução tenha trazido problemas à iluminação natural no interior do prédio, as condições de conforto ambiental estão razoavelmente coerentes com o partido arquitetônico adotado. Observou-se que, na fachada Leste (mais especificamente no Sudoeste), no período da manhã, onde se encontra grande parte das aberturas de janelas, os ambientes se apresentam mais quentes que os demais, elevando, consequentemente, as temperaturas internas. Por outro lado, à tarde, as áreas voltadas para o Oeste sofrem um acréscimo em sua temperatura e as voltadas para o Leste esfriam um pouco. Vale lembrar que, em contato com os usuários e verificando os resultados das médias dos questionários aplicados, verificou-se a grande incidência de desconforto ambiental justamente nestas áreas apresentadas anteriormente. Além disso, no tocante a este item, fora os dados quantitativos retirados das questões fechadas, parte das informações aqui contidas foram extraídas das observações físicas feitas por este pesquisador durante visitas exploratórias ao edifício.

Quanto ao sistema de proteção de radiação solar na Biblioteca do Senac/Santo Amaro, os três pavimentos do edifício contam com um completo sistema de brises de alumínio instalados em toda a extensão das fachadas oeste, ou seja, estão 
posicionados na orientação geográfica em que os níveis de incidência solar, no período da tarde, são considerados os mais intensos. Além disso, o brise permite ajuste manual, com acionamento interno e movimentação pivotante vertical, possibilitando que as variações de aberturas dos brises ocorram nos períodos mais críticos do ano, além de evitar os reflexos indesejáveis, principalmente, nos monitores dos computadores. A utilização desse sistema de controle de temperatura e incidência solar foi aprovada completamente pelos usuários, tanto por aqueles alunos que estão nas mesas e nos computadores fronteiriços às áreas dos brises metálicos quanto dos funcionários que operam e controlam esses ambientes.

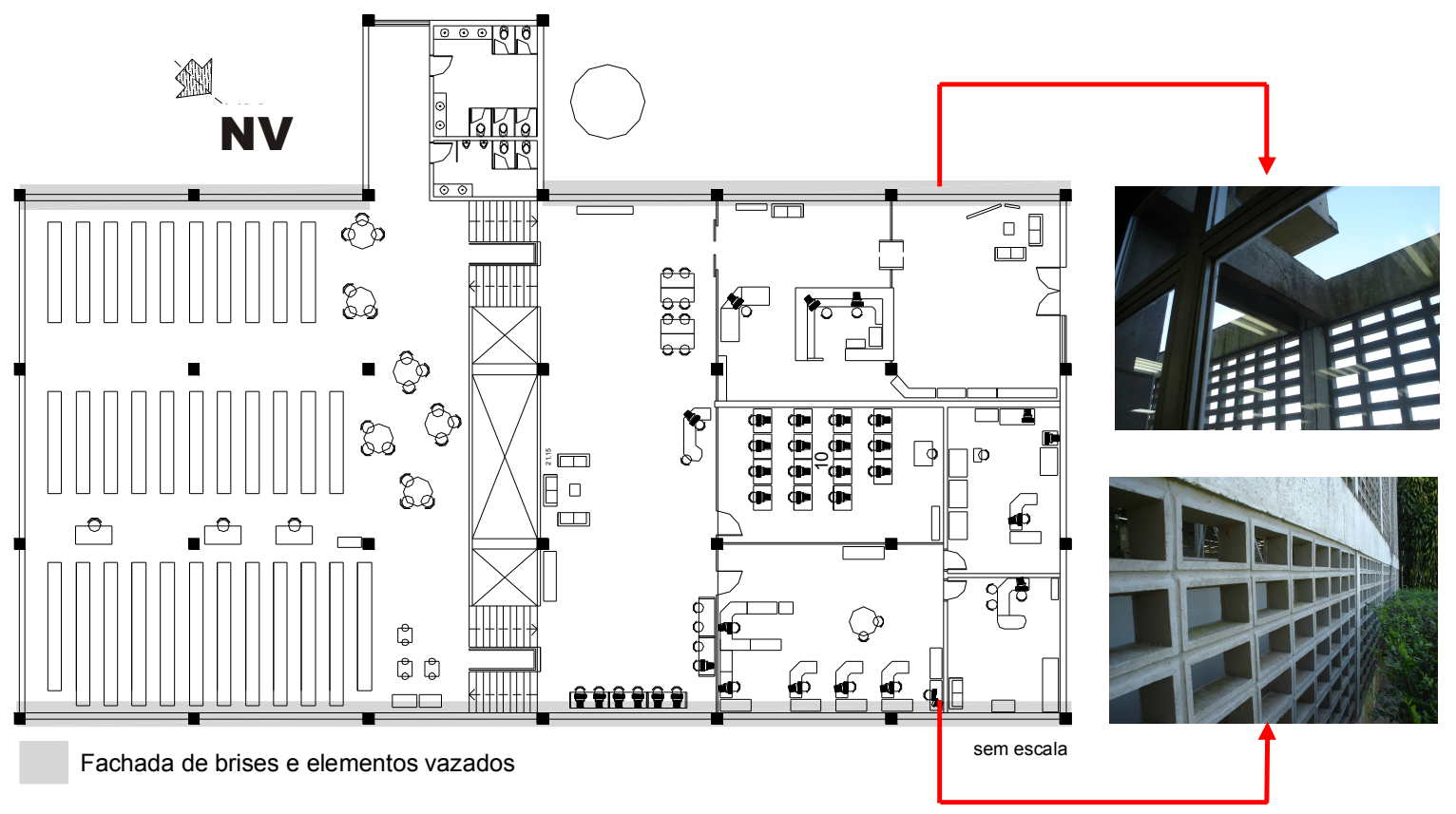

Figura 337 - Brises e elementos vazados Biblioteca Unesp/Marília 


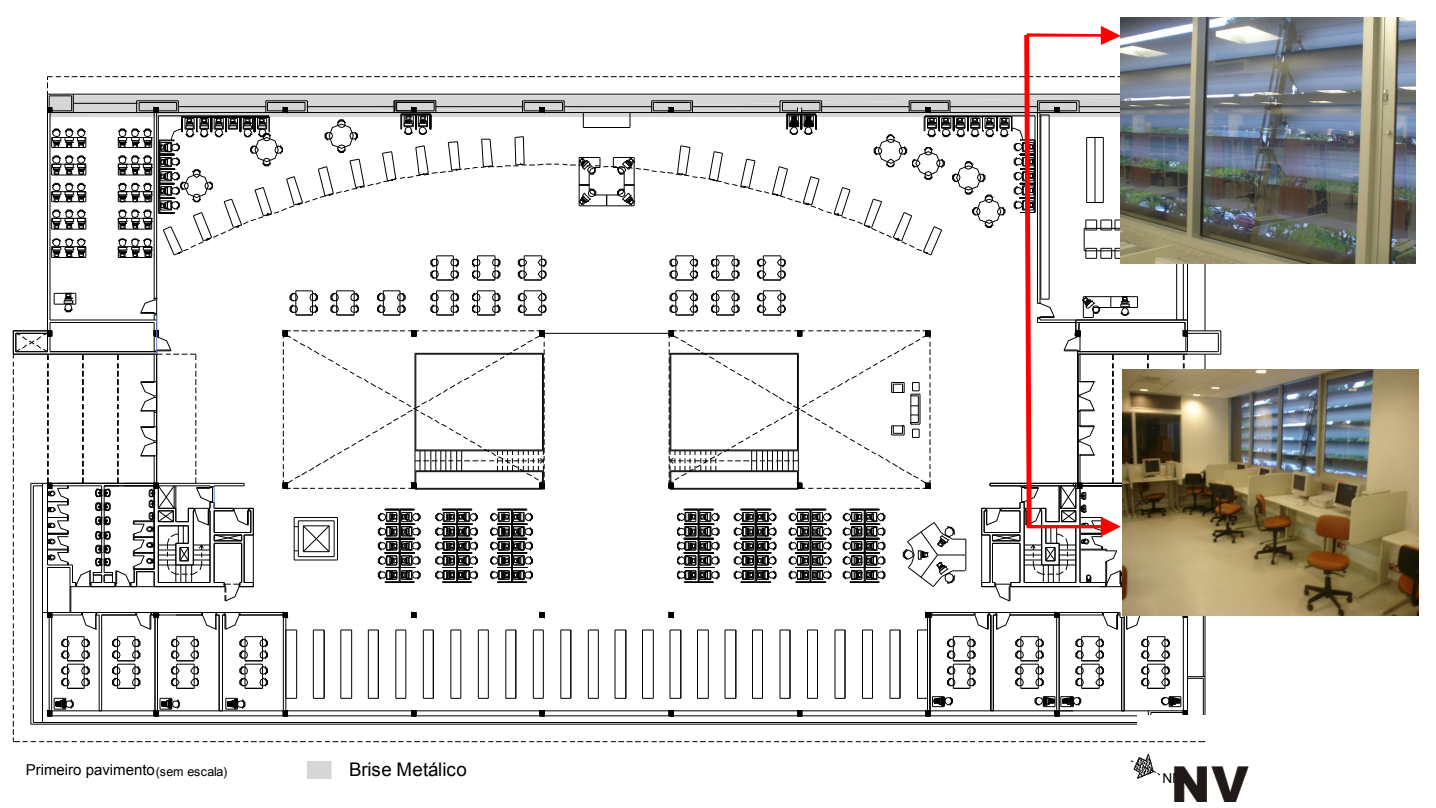

Figura 338 - Brises e elementos vazados Biblioteca Senac/Santo Amaro

Quanto aos efeitos da temperatura e da umidade relativa sobre os livros armazenados, existem padrões de referência fixados pelo método das isopermas ${ }^{4}$ que, naturalmente, devem ser seguidos no processo de preservação dos livros da biblioteca. Esse método considera que a temperatura ambiente deva ficar em torno de $20^{\circ} \mathrm{C}$ e $50 \%$ de umidade relativa (UR), por serem condições observadas com mais freqüência na preservação de livros. O método de isopermas considera que existe aumento da velocidade de uma reação química quando acontece um aumento da temperatura no ambiente. Nesse sentido, o controle da temperatura é fundamental para se evitar condições favoráveis às reações químicas e à proliferação de microorganismos que afetam o tempo de vida do livro. Portanto, nos dois estudos de caso desse trabalho, sugere-se que a temperatura no ambiente do acervo bibliográfico seja mantida em níveis adequados, retardando, em muito, os efeitos danosos da deterioração dos livros nas bibliotecas.

\footnotetext{
${ }^{4}$ Método de isopermas diz que a taxa de deterioração de matérias higroscópicos como o papel é influenciada pela temperatura e pelo percentual de umidade relativa de seu ambiente circundante (SEBERA, 1997,p. 10)
} 


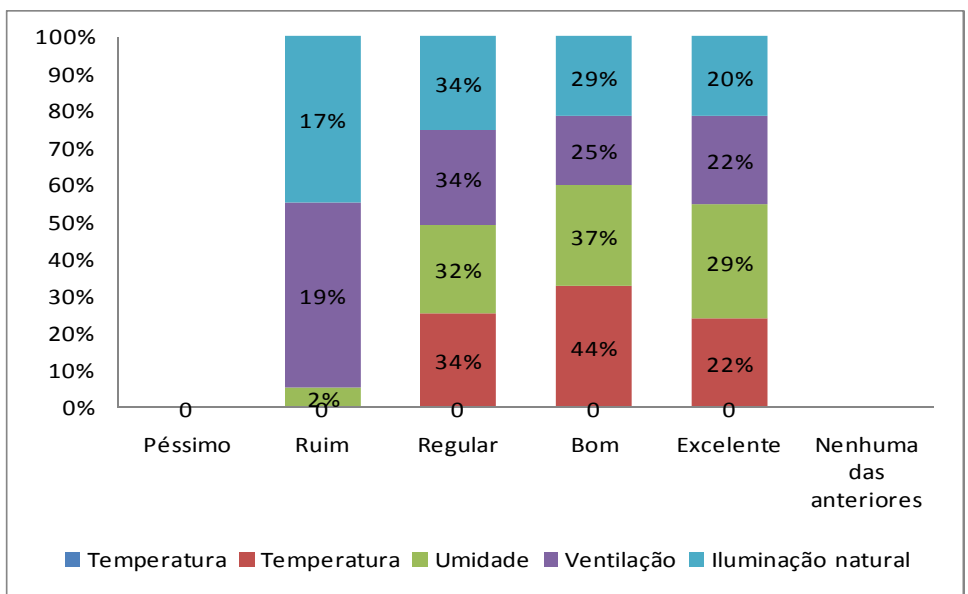

Gráfico 22 - Nível de conforto ambiental funcionários Biblioteca Unesp/Marília

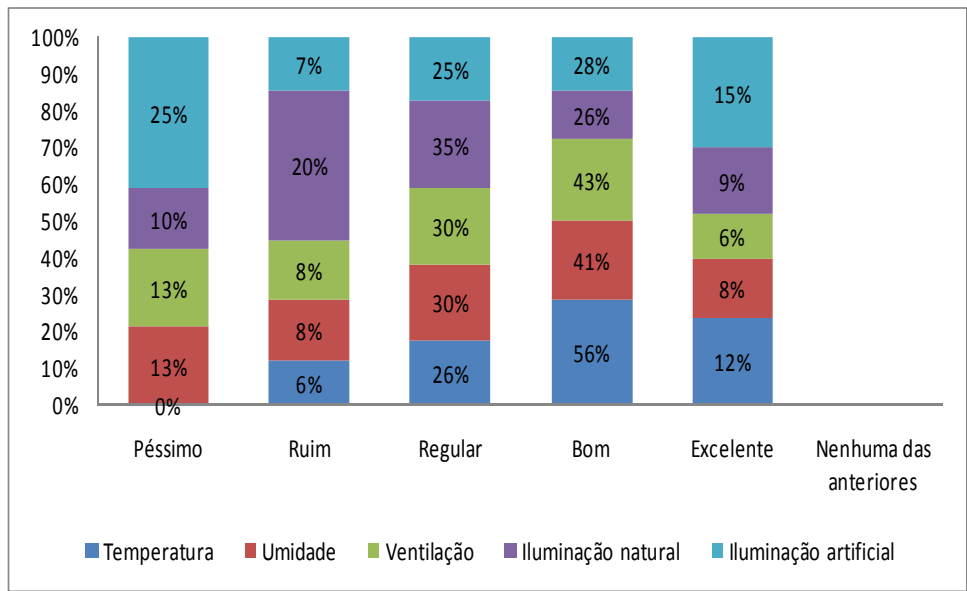

Gráfico 23 - Nível de conforto ambiental alunos Biblioteca Unesp/Marília

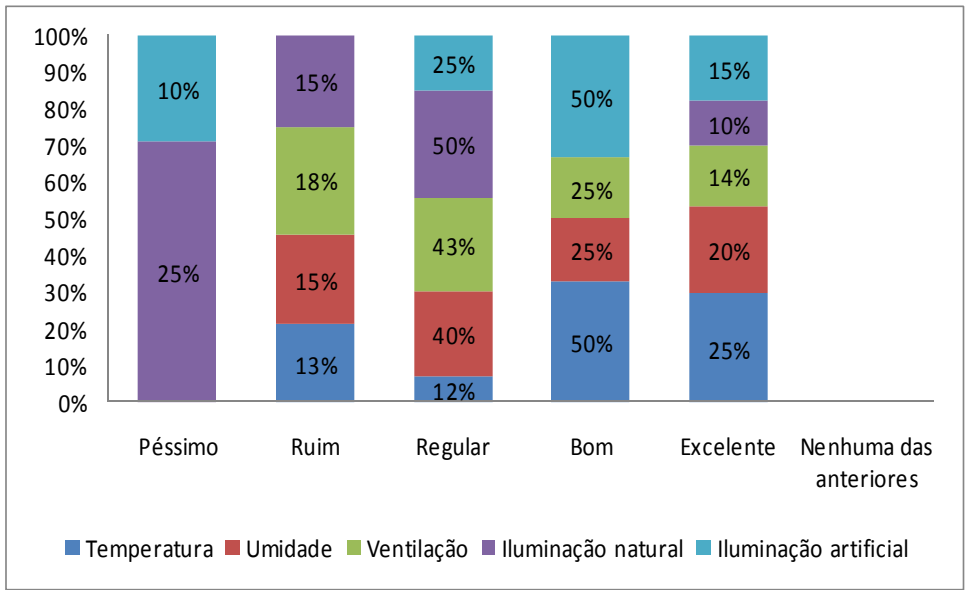

Gráfico 24 - Nível de conforto ambiental professores Biblioteca Unesp/Marília 
Ar-condicionado

Outro importante item avaliado, relacionado às condições de conforto ambiental e sua operação nos edifícios de bibliotecas universitárias escolhidos para esta pesquisa, contempla a avaliação e a percepção, por parte dos usuários, do sistema de arcondicionado instalado no ambiente. É importante frisar que o sistema de arcondicionado e seu controle automático constituem um assunto complexo e extenso, cuja abordagem profunda e detalhada não se faz necessária, considerando os propósitos desta pesquisa. As noções apresentadas a seguir serão suficientes para a compreensão das análises feitas, cujos resultados são apresentados ao final.

O projeto de distribuição do ar é elaborado antes da ocupação do edifício, bem como o dimensionamento das vazões, tendo em vista um layout proposto inicialmente. Como o projeto de ar-condicionado é elaborado considerando uma ocupação pré-definida uma vez dimensionado, instalado e em operação, qualquer modificação física de suas instalações se torna inviável, ou seja, a cada mudança de layout ocorrida, ajustes deverão que ser feitos em todo o sistema. Embora estas operações sejam aparentemente simples, requerem decisões que dependem tanto de conhecimentos técnicos específicos sobre ar-condicionado quanto de bom senso do operador, para promover bem estar a um número maior de pessoas, já que operações dessa natureza implicam em mudanças em condições locais.

No caso específico dos edifícios de bibliotecas, outro fator importante no sistema de ar-condicionado para garantia de bem-estar dos usuários é a distribuição dos pontos de insuflamento. Esse processo é feito de maneira relativamente homogênea, de modo que cada ponto de insuflamento atue sobre uma determinada aérea, cuja vazão é calculada em sua função. Entretanto, algumas situações que são apresentadas nos projetos de ar-condicionado, determinam discrepâncias consideráveis no comportamento das temperaturas no ambiente. Como exemplo, as alterações térmicas ocorridas ao longo das fachadas mais sujeitas à radiação solar direta, provocam diferenças reais na percepção da temperatura por parte dos usuários.

Quanto aos resultados da avaliação concernentes à pergunta "como considera trabalhar em um ambiente com ar-condicionado" a maioria dos respondentes, nos dois estudos de caso, considera a situação satisfatória e muito satisfatória, referendando, em certa medida, que as condições de conforto ambiental avaliadas sob este aspecto estão de acordo com os objetivos propostos. Assim sendo, 
nos questionários aplicados aos usuários dos edifícios analisados, os usuários não se opõem à presença do sistema de ar-condicionado, comprovando sua eficiência no controle da temperatura ambiental dos edifícios
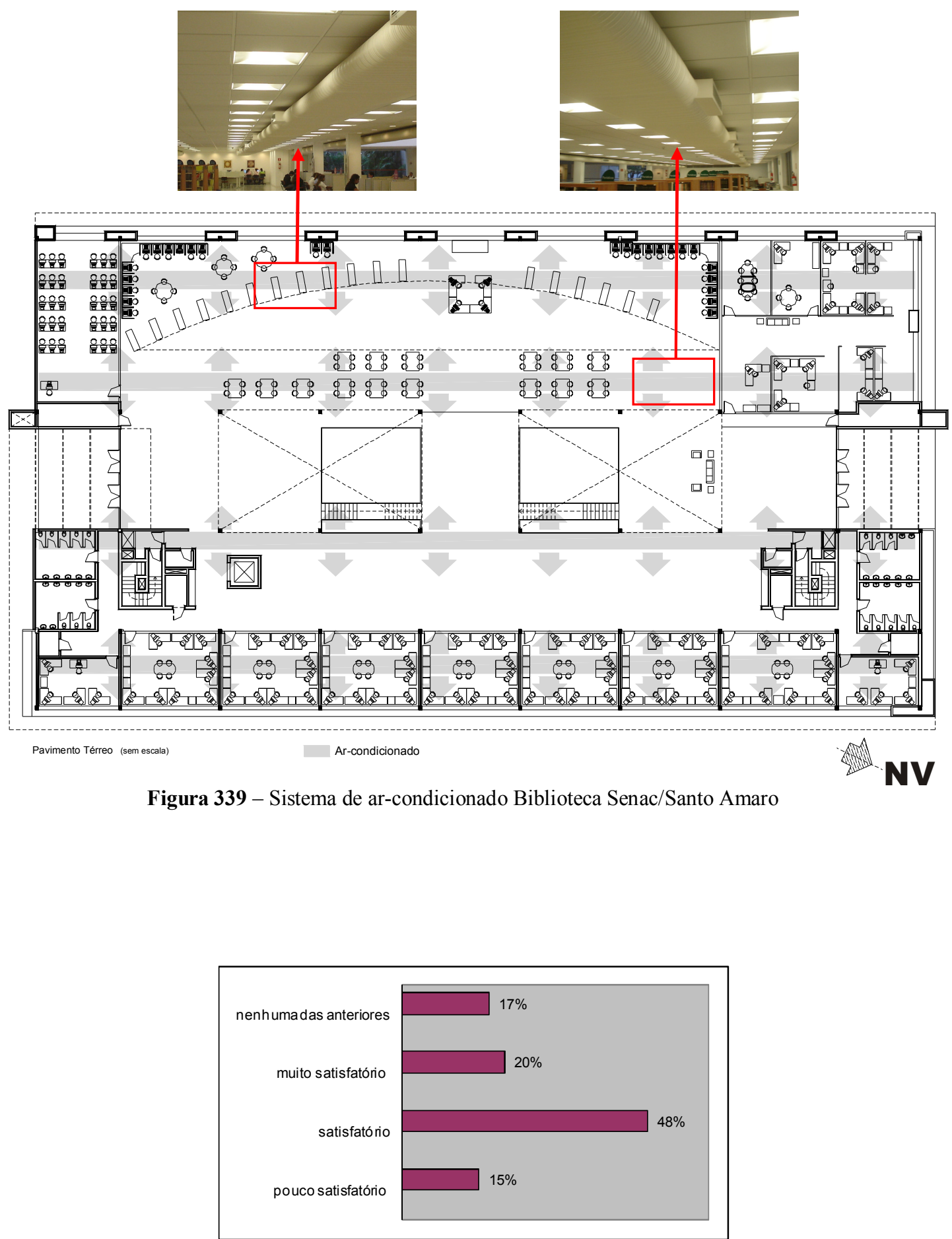

Gráfico 25 - Nível satisfação professores Biblioteca Senac/Santo Amaro: ar-condicionado no local de trabalho 


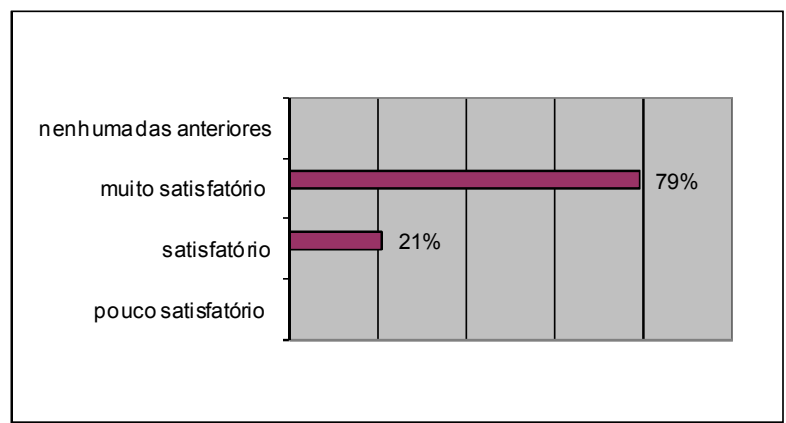

Gráfico 26 - Nível satisfação alunos Biblioteca Senac/Santo Amaro: ar-condicionado no local de trabalho

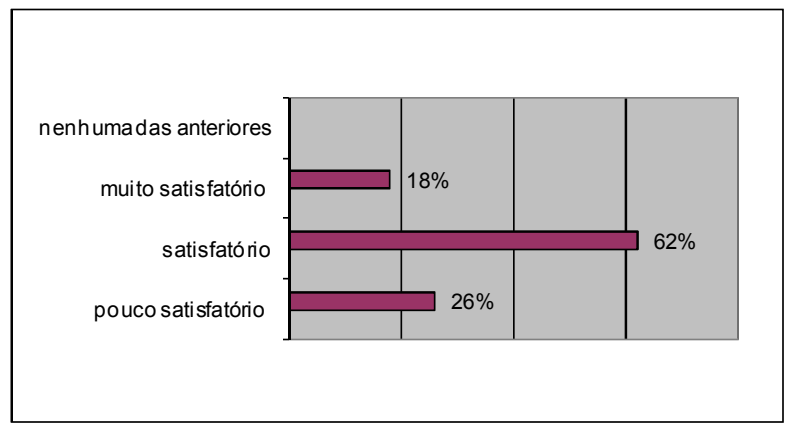

Gráfico 27 - Nível satisfação funcionários Biblioteca Senac/Santo Amaro: ar-condicionado no local de trabalho

Cabe observar ainda que, quando da aplicação dos questionários, detectou-se por meio do contato com aos usuários, uma preocupação constante: a insegurança com os riscos de poluição pelo sistema de ar-condicionado, principalmente em situações em que haja impossibilidade de aberturas de janelas e não em função de outros agentes contaminadores. Essas afirmações foram coletadas tanto na Biblioteca do Senac/Santo Amaro quanto no edifício da Biblioteca da Unesp/Marilia, e as reclamações sobre a qualidade do ar se restringiram aos ambientes com baixa ventilação e presença de eventuais odores. Por esta razão, os resultados das avaliações quanto à ventilação, nos dois estudos de caso, comprovaram índices regulares de percepção entre os respondentes; ou seja, é possível concluir preliminarmente que, na visão dos usuários, o ambiente não é tão saudável sob esse aspecto. Uma das explicações para este fato, provavelmente tem a ver com o desconhecimento, por parte do usuário, do real sistema de funcionamento de ventilação existente, fazendo que muitos acreditem que nos edifícios fechados, o mesmo ar é infinitamente reutilizado e circulado. 


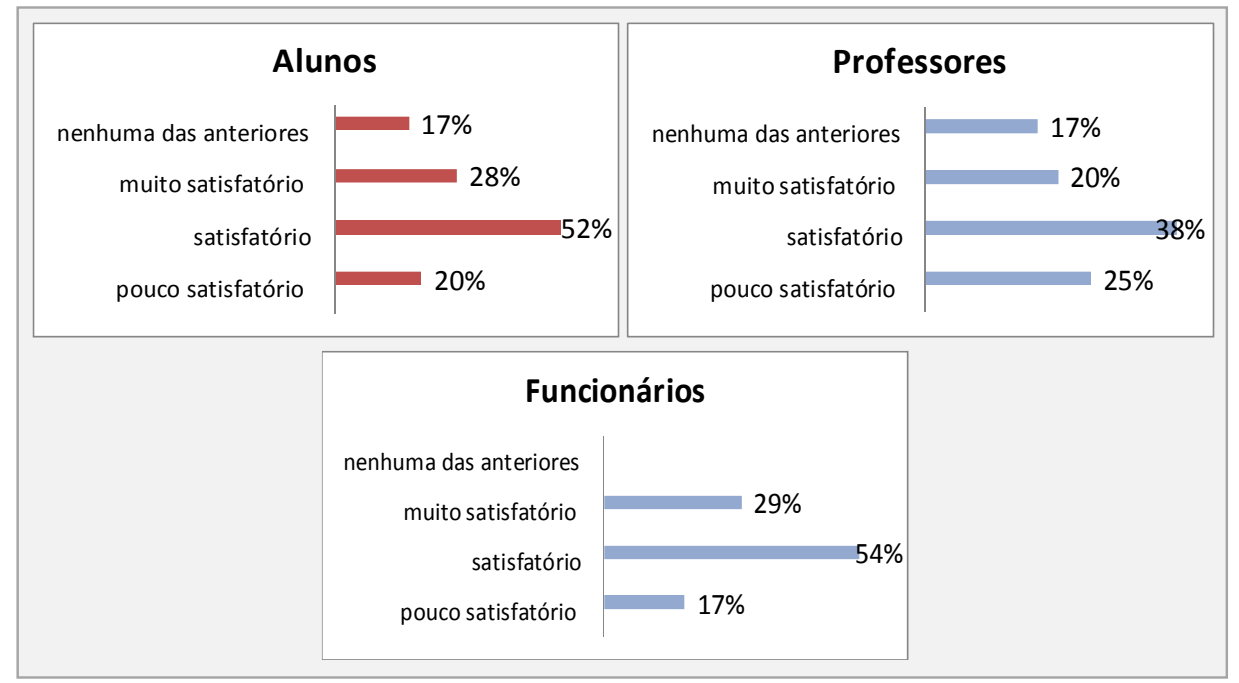

Figura 340 - Nível satisfação professores Biblioteca Unesp/Marília: ar-condicionado no local de trabalho

O principal aspecto negativo, em relação ao ar-condicionado implantado na Biblioteca da Unesp/Marilia, diz respeito às constantes interrupções de utilização do sistema, principalmente nos meses de temperaturas baixas, como no inverno ou nos períodos noturnos de abertura da biblioteca. Os comentários dos usuários indicam que a ausência de circulação de ar em determinados ambientes, principalmente nas zonas mais afastadas das janelas e nos espaços centrais do acervo bibliográfico, reforça a condição desconfortável por causa do calor quando o sistema de ar-condicionado está desligado. Neste caso, a direção da biblioteca admite tais procedimentos e justifica as ações, levando-se em consideração as questões de custo-benefício, dificuldades na operação do equipamento e os ajustes das temperaturas médias, além dos efeitos sobre outros aspectos como, por exemplo, a economia do ar-condicionado e o desconforto do ruído de fundo proveniente do equipamento.

Não obstante aos problemas relacionados à operação e à manutenção do sistema de ar-condicionado da Biblioteca da Unesp/Marília, é importante que os responsáveis pelo acervo bibliográfico conheçam as propriedades do espaço e dos dispositivos físicos de controle do ambiente onde trabalham, na tentativa de monitorar as variações de temperatura e umidade relativa, bem como trazer bem-estar aos usuários e preservação das coleções. Além disso, alternativas podem ser implementadas no que se refere ao conforto térmico, uma vez instituída a utilização do ar-condicionado, tais como: sistema de insulflamento de ar frio nos ambientes da biblioteca, mantendo a temperatura baixa apenas ao nível do acervo; controles individuais de temperatura e 
umidade nos postos de trabalho da área administrativa, mantendo um nível baixo de condicionamento central; e instalação de janelas controláveis para trocas de ar nas faces leste e oeste. Entretanto, é preciso deixar claro que, esses sistemas geralmente são complexos em termos de controle, requerendo, crescente aprimoramento e sofisticação dos sistemas de gerenciamento automatizados.

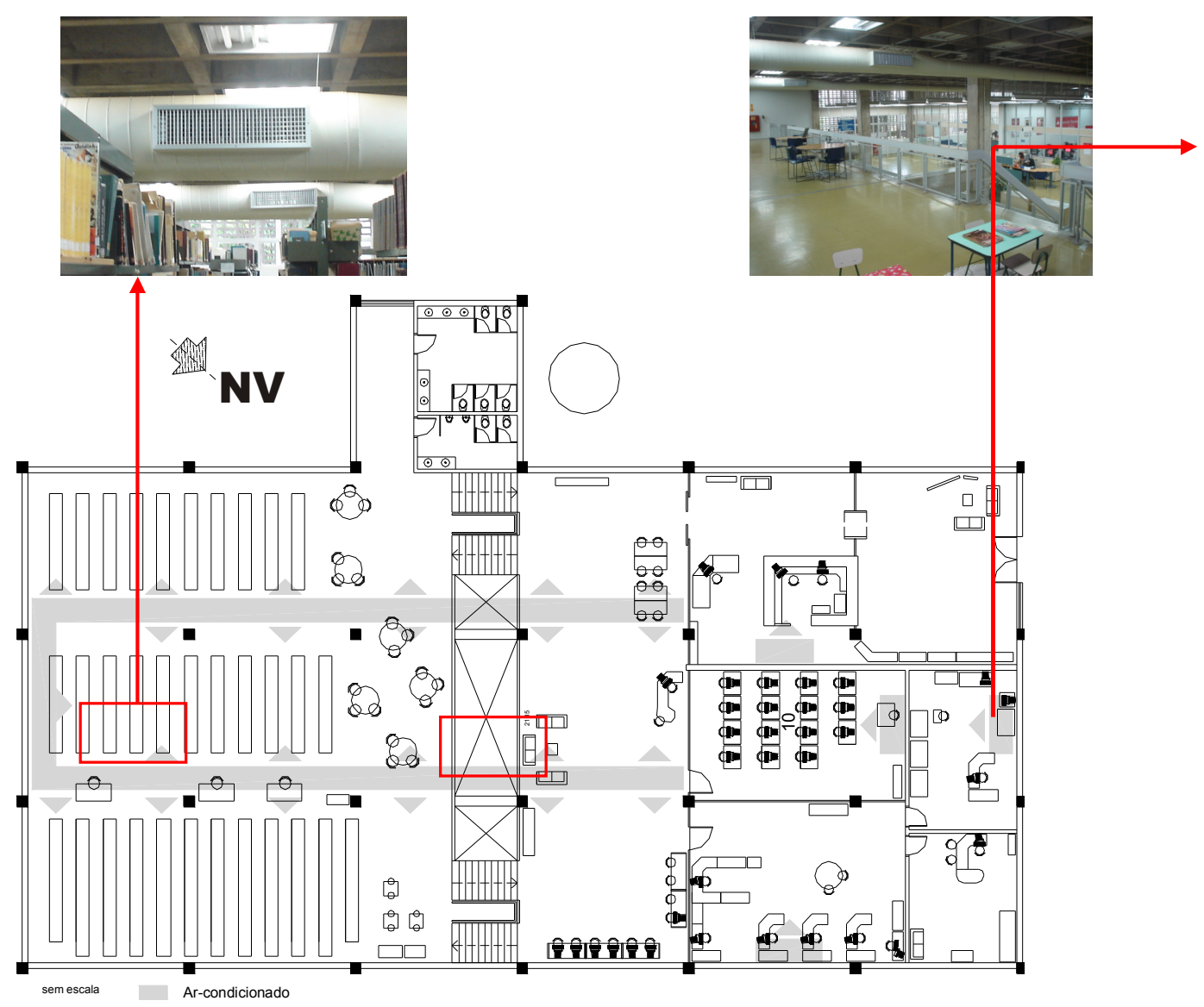

Figura 341 - Sistema de ar-condicionado Biblioteca Senac/Santo Amaro

Percepção em relação à iluminação

Os aspectos relacionados à iluminação dos ambientes em bibliotecas se apresentam como um dos mais importantes no contexto do planejamento desses espaços, tendo em vista o tipo de tarefa visual desenvolvida. É importante destacar que o espaço destinado para o desenvolvimento de todas as funções dessa natureza necessita de um projeto adequado de iluminação, bem como aberturas que propiciem a entrada de luz natural, atendendo às necessidades de conforto visual, principalmente as condições 
visuais em seus planos de trabalho e nas atividades desenvolvidas. Em vista disso, para o atendimento dos requisitos básicos de conforto lumínico em uma biblioteca, a escolha correta do sistema de iluminação artificial é peça-chave nesse processo.

O que se observa hoje em dia, na composição e na utilização dos sistemas de iluminação artificial destinados aos edifícios de bibliotecas, são basicamente dois modelos adotados: o primeiro, caracterizado pela distribuição regular de luminárias no teto, distanciadas regularmente por linhas, proporcionando iluminação horizontal uniforme sobre a área ocupada; e, o segundo modelo, luminárias individuais instaladas estrategicamente em mesas de estudos ou acopladas às estantes dos livros, permitindo ganho considerável na tarefa visual e na área de trabalho. Portanto, a correta escolha dentre esses dois modelos pode garantir boas condições visuais em seus ambientes, o que influencia positivamente em sua produtividade.

Entretanto, não somente os sistemas de iluminação artificial fazem parte da iluminância geral e o conforto visual de um edifício de biblioteca, mas também a utilização da própria luz natural através das janelas, sugerindo um ganho na qualidade da iluminação. É interessante notar que o efeito psicológico e fisiológico da luz natural no ambiente da biblioteca pode trazer benefícios relacionados à melhor utilização das atividades espaciais, complementando os níveis de iluminância, aproximando-se às condições naturais da iluminação natural. Além dessas vantagens apresentadas, pode-se ainda citar que a preservação e o equilíbrio dos níveis de luminosidade natural, principalmente nas áreas internas da biblioteca, envolvendo os ambientes destinados à leitura e à pesquisa, garantem qualidade nos aspectos de visualização, ofuscamento e distribuição adequada da iluminação nos vários ambientes adjacentes.

Portanto, como foi apresentado no Capítulo 4, para que haja aumento na eficiência energética e na qualidade dos ambientes de uma biblioteca, deve-se pensar na complementaridade entre a luz natural e artificial. O projetista deve sempre considerar a integração entre os dois tipos sistemas de iluminação, tanto o artificial como o natural; para isso, é fundamental o conhecimento básico tanto da luz natural quanto dos tipos de equipamentos de iluminação a serem utilizados nos espaços projetados. Cada componente desses sistemas (lâmpadas, luminárias, reatores, sistemas de controle e aberturas de janela) tem desempenho e qualidade diferentes, que dependem do tipo de tecnologia empregada em sua fabricação. Assim, a eficiência do sistema de iluminação artificial adotado no projeto depende do desempenho particular de todos os elementos envolvidos como da integração feita com o sistema de iluminação natural. 
Convém ressaltar que, em nesse trabalho, o contexto de avaliação da iluminação do ambiente, envolvendo questões relacionadas ao conforto visual que fixam variáveis da quantidade de luz, do contraste, da distribuição, dos reflexos e dos ofuscamentos, cujos prejuízos são sentidos ao longo de um tempo sob condições diversas, gerou dificuldade de se obter uma percepção precisa por parte dos usuários. Esse fato se deve, basicamente, em função do objetivo traçado em não utilizar equipamentos técnicos de medições de iluminação. Contudo, tentou-se compensar essa dificuldade inicial por meio das visitas exploratórias nos edifícios, que serviu de base de informação norteadora para os pontos a serem avaliados.

Com relação à opinião dos usuários, foi diagnosticado que, no que se refere à iluminação natural, os resultados apresentados nos estudos de caso foram diferenciados em relação ao nível de satisfação.No caso da Biblioteca do Senac/Santo Amaro os usuários apontam como Bom (42\% da média) esse quesito e no edifício da Biblioteca da Unesp/Marília, o resultado dos respondentes avalia como Regular (31\% da média) a percepção em relação à iluminação natural. Esse diagnóstico é comprovado, principalmente, quando se depara com as observações dos extratos individualizados de usuários nos edifícios analisados, fato demonstrado nas seguintes análises:

- $\quad 33 \%$ dos alunos da Biblioteca da Unesp/Marília responderam que o nível de iluminação natural no ambiente é Regular. Em contato com esses usuários percebeu-se que a explicação mais convincente em relação a este fato se dá pela existência de reflexos indesejados nos monitores de vídeo no local onde se encontra disponibilizada a Base de Dados para consulta. Esse problema se agrava no período da manhã, devido à orientação do edifício em relação à radiação solar, visto que a fachada recebe uma grande quantidade de luz natural, atingindo diretamente as telas dos microcomputadores. Mesmo com a presença do elemento vazado disposto ao longo de toda fachada longitudinal do edifício, exercendo a função no controle de radiação solar, o sol aparece como principal fonte causadora de desconforto e de insatisfação relacionados aos reflexos indesejáveis nos computadores; 


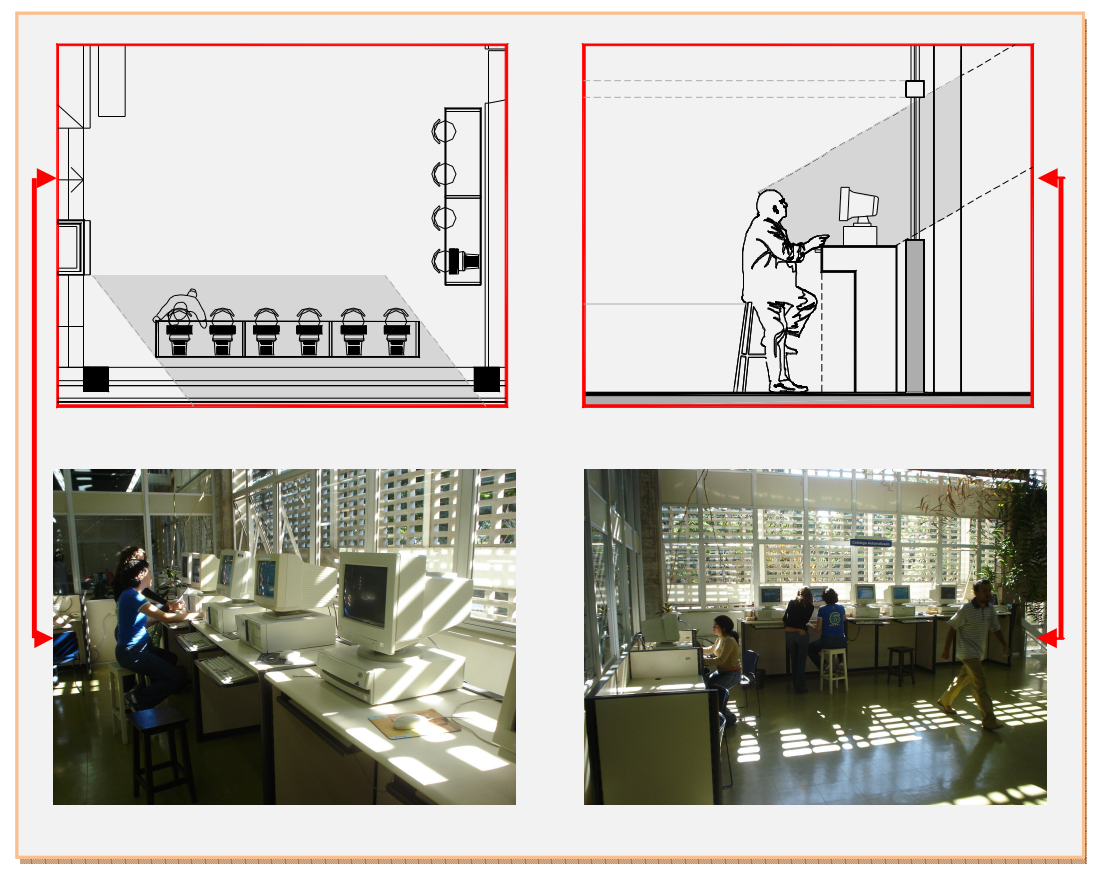

Figura 342 - Iluminação natural Biblioteca Unesp/Marília

- Quanto ao nível de iluminamento nas mesas de leitura e de pesquisa da Biblioteca da Unesp/Marília, tanto alunos como professores não estão totalmente satisfeitos com a iluminação natural em seus planos de trabalho. Esses dados foram constatados pelos resultados dos questionários aplicados e também com o contato direto com usuários no ambiente. Provavelmente, esse problema acontece porque, como o partido arquitetônico da biblioteca fixa o layout das mesas de leitura e pesquisa bem ao centro do salão, a quantidade de iluminação natural não é suficientemente capaz de chegar às áreas de trabalho e, conseqüentemente, os índices de satisfação são baixos entre os usuários. Somado a esses aspectos, é possível verificar, que em todos os ambientes da biblioteca, o emprego de matérias de acabamento com cores de tonalidades escuras (piso vinílico e concreto aparente), resultou no "escurecimento" dos espaços e, conseqüentemente, nos baixos níveis de iluminamento. 


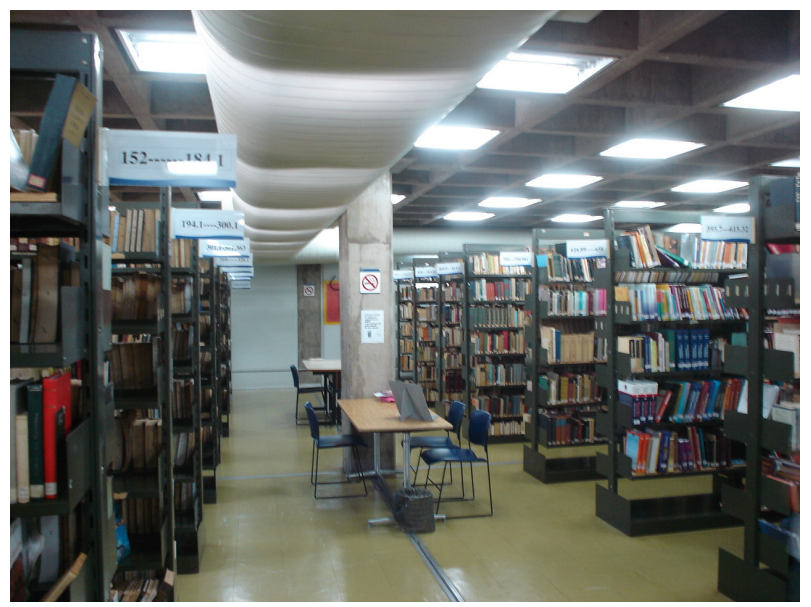

Figura 343 - Vista interna do acervo e mesas de leitura/pesquisa da Biblioteca Unesp/Marília: materiais de acabamento reduzem os níveis de iluminamento no ambiente

- Como mostrado anteriormente, um dado importante constatado na Biblioteca do Senac/Santo Amaro refere-se uso correto dos dispositivos reguladores de níveis de iluminação natural. O prédio conta com brises metálicos instalados nas aberturas das janelas, que possibilitam o controle da incidência solar ao longo das quatro estações do ano; além disso, o sistema minimizou os efeitos indesejáveis da luz solar direta sobre os planos de trabalho (por exemplo, o ofuscamento). Na prática, os resultados dos questionários aplicados aos usuários demonstram que as condições de iluminação natural nos ambientes pesquisados estão boas e adequadas às exigências ambientais. Outro ponto marcante da Biblioteca do Senac/Santo Amaro, relacionado ao correto aproveitamento da iluminação natural no interior do edifício, é o posicionamento de sheds na cobertura junto ao átrio central. Esse recurso, além de tirar partido da entrada de luz zenital, consegue equilibrar as medidas de iluminação total (natural e artificial) realizadas no espaço destinado às estantes do acervo bibliográfico e em todos os ambientes que estão posicionados em volta dele. 


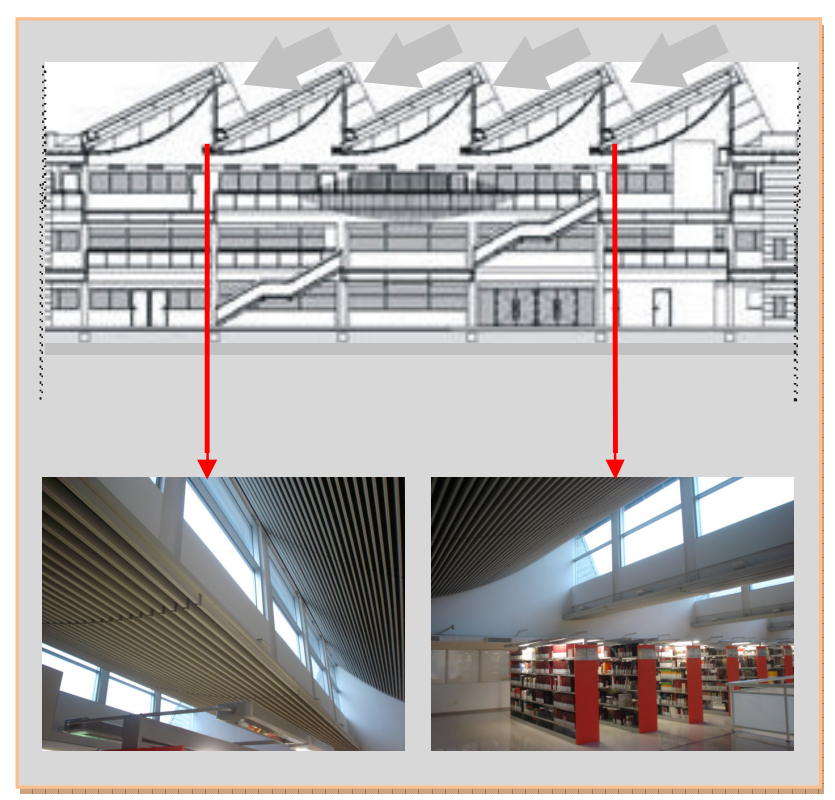

Figura 344 - Iluminação zenital Biblioteca Senac/Santo Amaro

Ainda em relação aos aspectos da iluminação natural nos edifícios analisados, a altura do pé-direito e a profundidade são elementos importantes para a qualidade espacial, pois influenciam diretamente o conforto visual. Nos estudos de caso deste trabalho, todos eles atendem à condição mínima de pé-direito e estabelecem alturas generosas em suas áreas. Por exemplo, na Biblioteca do Senac/Santo Amaro, o partido arquitetônico utiliza como premissa um átrio central com pé-direito livre total, estruturando os elementos básicos da centralidade e da simetria, além de proporcionar proveitosa iluminação natural por meio de sheds na cobertura. Neste caso, o pé-direito não restringe o acesso à iluminação natural, influenciando positivamente no volume útil por áreas de trabalho e ambientes utilizados.

Já no edifício da Biblioteca da Unesp/Marília, apesar de o pé-direito estar enquadrado na legislação vigente e possuir alturas adequadas, nas áreas de consulta e empréstimo, área administrativa e áreas de maior circulação de pessoas, notou-se que, no espaço destinado ao acervo bibliográfico (estantes e livros), o pédireito apresenta restrições quanto à altura, reduzindo a quantidade de entrada de luz natural neste ambiente.

Quanto à profundidade, apesar de não existir legislação restritiva no Brasil, sabe-se que as lajes mais profundas são mais ineficientes para a distribuição do 
layout, organização espacial de acessos e distribuição nas áreas de trabalho, prejudicando sensivelmente a comunicação entre os usuários e restringindo o acesso à iluminação natural nos espaços internos da edificação. Nesta pesquisa, a medida de profundidade dos pavimentos foi extraída de acordo com as características dos dois edifícios analisados e, em certa medida, influenciam os resultados de satisfação dos usuários em relação à iluminação natural. Pode-se constatar este fato na avaliação da Biblioteca do Senac/Santo Amaro: apesar de possuir uma medida de profundidade bastante considerável, seria óbvio que a iluminação natural estivesse prejudicada; entretanto, os índices apontam Boa a percepção dos usuários em relação ao nível de iluminamento nos ambientes. É importante esclarecer que isso deve, em grande medida, ao aproveitamento da luz natural zenital provinda dos sheds instalados na cobertura do edifício. Já na Biblioteca da Unesp/Marília a profundidade da edificação promoveu índice de satisfação inferior no tocante à iluminação natural, mesmo constando que essa profundidade não apresentava dimensões demasiadas.

Em comparação entre os estudos de caso, no geral, percebeu-se que os diagnósticos indicaram desempenhos diferentes para os dois edifícios, ou seja, no que se refere ao aproveitamento da luz natural destinada à iluminação dos ambientes e, consequentemente, à otimização do sistema de iluminação artificial com o objetivo de conservação de energia, a Biblioteca do Senac/Santo Amaro apresenta melhores condições

No caso da Biblioteca da Unesp/Marília, sugere-se que se apliquem os conceitos da NBR 5461/1992, referentes à iluminação natural e à estimativa da disponibilidade de luz natural nos ambientes. Baseado nas orientações da norma, o projeto de iluminação natural deverá tirar proveito e controlar a luz disponível maximizando suas vantagens e reduzindo suas desvantagens. A definição da prioridade em termos de exposição à luz natural, valores de iluminâncias e distribuição necessária para as atividades em cada ambiente deverá ser estabelecida, de maneira que, em alguns ambientes do acervo bibliográfico a iluminação uniforme seja a mais recomendada e, nos setores de leitura, pesquisa e administração, aconteça uma maior variação de iluminâncias. Além disso, sugere-se que se alterem as cores dos materiais de acabamento, como o piso vinílico e que se trabalhe com um forro-divisória sob a laje, em tonalidades claras para melhor os níveis de iluminamento nos ambientes principais do acervo e áreas de leitura e pesquisa. Os ambientes nos quais os usuários ocupam posições fixas, o critério deve ser diferente daqueles em que pessoas podem mover-se 
livremente na direção das aberturas ou para longe delas. E finalmente, a norma recomenda que o projeto de iluminação natural não deve ser um conjunto de valores absolutos, mas uma medida da iluminação natural interna dos ambientes, mesclado como uma percentagem da iluminação externa.

Os resultados das médias dos questionários relacionados ao nível de iluminação artificial, nos ambientes dos edifícios analisados indicam satisfação geral. Na Biblioteca do Senac/Santo Amaro, no verão, 50\% consideram-na Excelente e, no inverno, 42\% consideram-na também Excelente; já no caso da Biblioteca da Unesp/Marília, os usuários classificam como Boa as condições avaliadas (50\% no verão e 42\% no inverno). Quanto ao esquema de distribuição das luminárias, os dois estudos de caso apresentam o mesmo modelo de distribuição (todas no teto), caracterizado por circuitos independentes que são ligados e desligados em horários programados. A diferença básica entre os dois edifícios é justamente no tipo de luminária instalada, isto é, na Biblioteca do Senac/Santo Amaro todas as luminárias estão embutidas no forro termo-acústico, formando um desenho modular no teto e, na Biblioteca da Unesp/Marília, as luminárias-calhas estão fixas diretamente no teto (laje de concreto).

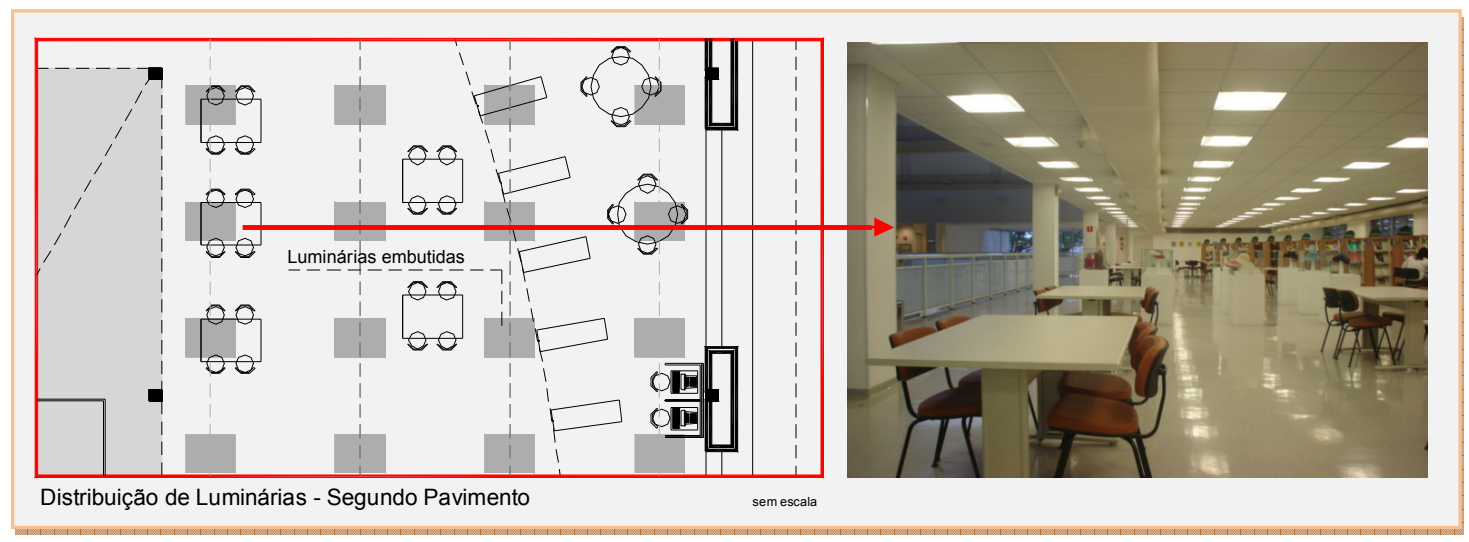

Figura 345 - Iluminação artificial Biblioteca Senac/Santo Amaro 


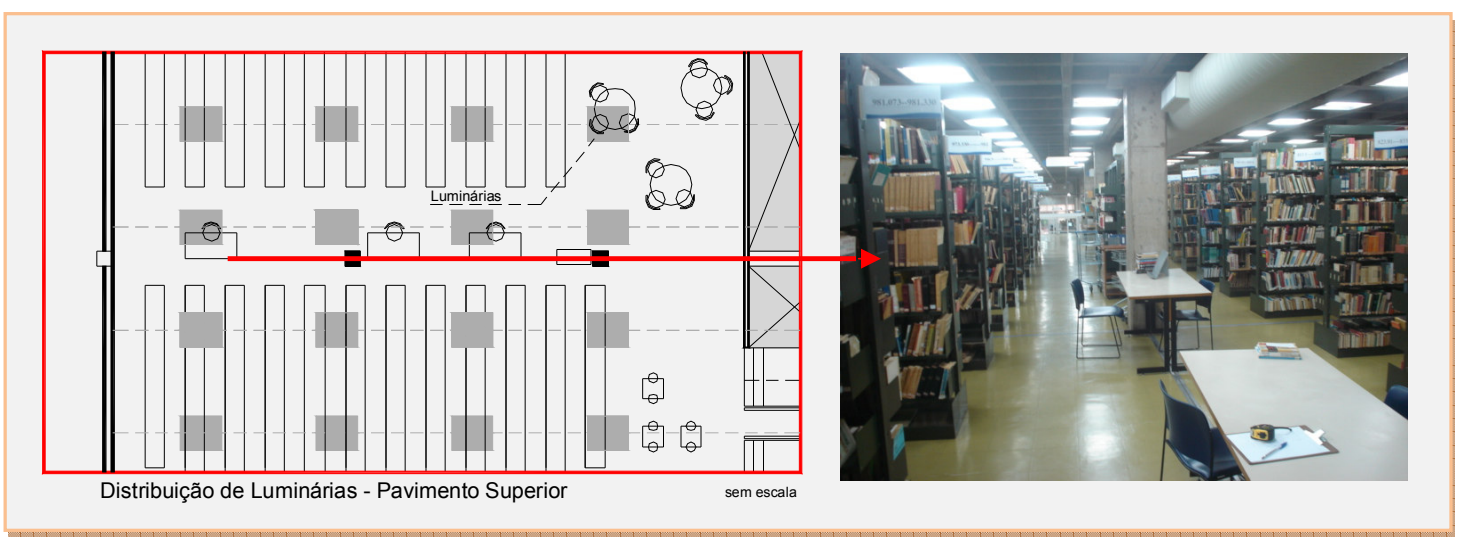

Figura 346 - Iluminação artificial acervo, setor de leitura e pesquisaBiblioteca Unesp/Marília

Pelos resultados avaliados quanto à iluminação artificial, percebeu-se que os níveis de iluminamento médios nos setores e nas áreas analisadas da Biblioteca da Unesp/Marília, apresentam condições compatíveis com as exigências para as tarefas desenvolvidas. É importante destacar que essas características se referem ao resultado da associação do sistema de iluminação artificial operando com toda a sua capacidade, em conjunto com a contribuição da fonte natural (iluminação natural) e articulados com as características construtivas dos edifícios. Nesse contexto, os resultados das avaliações só não foram mais positivos porque o tipo da luminária existente apresentou desempenho luminoso aquém do esperado, e também a intensidade de iluminação, em determinados locais de estudo, não está compatível com a organização espacial dos ambientes. Em alguns conjuntos das calhas, as luminárias estavam queimadas ou não estavam ligadas, ocasionando áreas deficitárias de iluminação. Além disso, alguns usuários reclamaram que, em determinados locais da sala de internet do pavimento térreo, a incidência direta da iluminação artificial proporcionava o ofuscamento, não só nos planos de trabalho como também nas telas dos monitores de vídeo dos computadores existentes.

Independente desta pesquisa não ter utilizado equipamentos precisos direcionados às medições técnicas de iluminação artificial, percebeu-se durante as visitas exploratórias na Biblioteca da Unesp/Marília, que os locais mais centrais dos ambientes, ou seja, as áreas um pouco mais distantes das janelas apresentaram condição desfavorável em relação ao conforto visual, mesmo em situação de iluminação total 
(artificial e natural), sendo incompatíveis com as tarefas desenvolvidas de pesquisa e leitura da biblioteca. Por outro lado, as faixas intermediárias entre a periferia e o centro dos ambientes apresentaram níveis de iluminância satisfatório, não sofrendo variações significativas devidas às mudanças nas condições de uso.

Notou-se que a distribuição coerente das luminárias instaladas no forro e vinculadas aos ambientes do setor administrativo colabora positivamente na eficiência luminosa desses locais, elevando conseqüentemente os níveis de satisfação entre os funcionários. Entretanto, pode-se concluir preliminarmente que nem todas as faixas do ambiente, em relação aos níveis de iluminação artificial, estão adequadas. Cabe ainda destacar que, nas datas de realização dessas avaliações, havia excelentes condições quanto ao nível de iluminamento externo (luz solar).

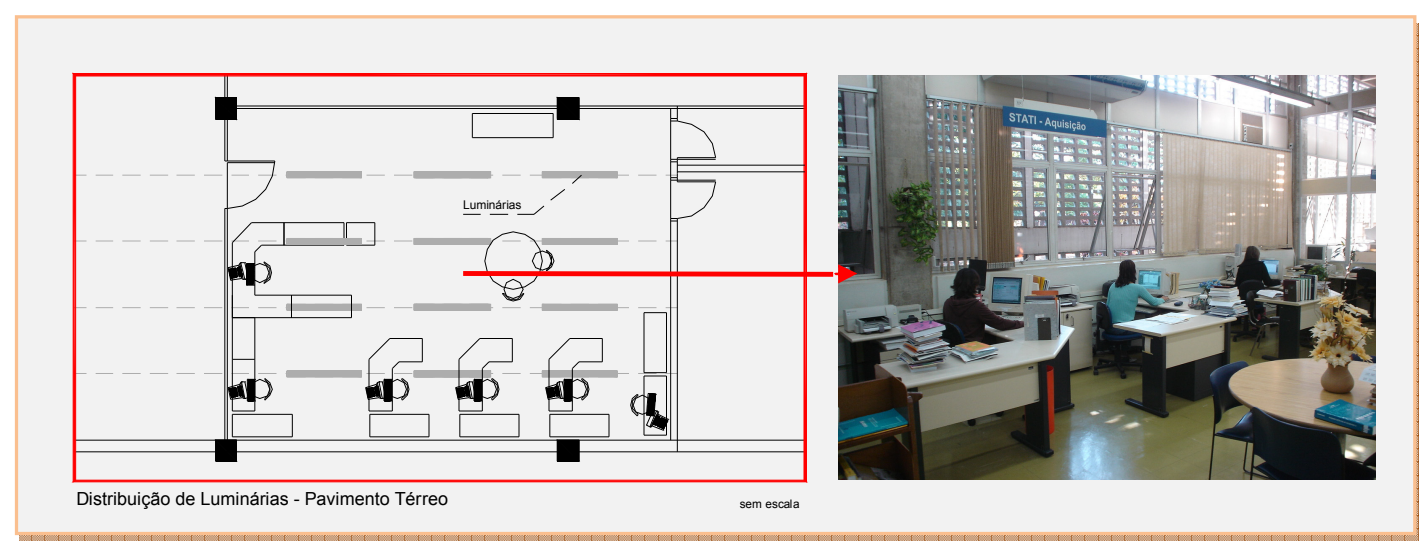

Figura 347 - Iluminação artificial setor administrativo Biblioteca Unesp/Marília

$\mathrm{Na}$ avaliação qualitativa desta sala, localizada junto ao setor administrativo, observa-se a existência de ofuscamento e sombras em alguns monitores dos computadores, principalmente, nos aparelhos que estão posicionados próximos às janelas da sala e que recebem maior quantidade de luz. Neste caso, os usuários afirmaram que a iluminação deveria ser melhorada, em razão, segundo eles, do excesso de iluminamento nesta faixa, ofuscando a visão em algumas telas. Esses resultados demonstram a dificuldade de estabilização e equacionamento dos quesitos de conforto visual em ambientes de biblioteca, onde a necessidade de apuramento técnico e credibilidade das informações devem ser consideradas uma preocupação constante. Neste caso, a instalação de vidros especiais poderia bloquear a faixa UV do espectro de radiação ou, ainda, o uso de filtros plásticos que absorvem a radiação UV (placas auto- 
sustentáveis de acrílico ou delgada policarbinato; lâmina de acetato ao vidro; lâmina delgada inserida no vidro). Além disso, como alternativa, a mudança de layout deve ser estudada, para distanciar os monitores da radiação solar direta.

Além das avaliações descritas anteriormente, relacionadas aos elementos da iluminação artificial nos dois edifícios da pesquisa, é de suma importância que, no caso da Biblioteca da Unesp/Marília, parâmetros e recomendações, concernentess não só à norma $N B R$ 5413/1992, mas também à aplicação do projeto de instalação elétrica, sejam observados com o objetivo de trazer qualidade aos ambientes, tanto para os usuários bem como para o acervo armazenado. Esses parâmetros podem ser listados da seguinte maneira:

1. A norma NBR 5413/1992 recomenda que, em ambientes de bibliotecas, as salas de leitura devem ter médias de iluminâncias de: 300 lux - 500 lux - 750 lux; recinto das estantes: 200 lux - 300 lux - 500 lux; fichários; 200 lux - 300 lux - 500 lux;

2. O projeto dos sistemas de iluminação interna deverá apresentar o esquema de ligação das luminárias, procurando-se a melhor divisão dos circuitos de maneira que se possibilite maior flexibilidade de acionamento do sistema, de acordo com a área ocupada de cada ambiente e de acordo com a disponibilidade de luz natural;

3. A utilização de lâmpadas de baixa intensidade e elevada qualidade;

4. A melhoria na distribuição e no tipo de luminárias (quanto mais luminoso o teto, menor o sombreamento e ofuscamento);

5. A redução da emissão de UV das lâmpadas fluorescentes, por filtragem. O limite de radiação UV das lâmpadas, para fins de preservação, deve ser de 75 uv/lúmen;

6. A criação de luminárias direcionais em mesas de "L".

7. Leitura e pesquisa nos ambientes específicos da biblioteca;

8. O planejamento espacial da biblioteca, para melhorar o desempenho luminoso deve enfocar os tipos de luminárias, a intensidade de iluminação em determinados locais de estudo e, até mesmo, a reorganização espacial dos ambientes de trabalho. 


\subsection{Tecnologia da informação e comunicação}

A biblioteca universitária, em função do crescente emprego das novas tecnologias de informação e comunicação, tem passado por profundas transformações, tanto no contexto administrativo quanto nos aspectos funcionais e ambientais. As tecnologias de informação e comunicação utilizadas nos ambientes das bibliotecas universitárias introduzem a introdução da informação em suportes eletrônicos. A possibilidade de consultas a bases de dados on-line, as trocas de mensagens eletrônicas por meio do correio eletrônico e a participação em videoconferências, entre outros recursos, intensificaram seu uso. Essas tecnologias permitem a manipulação a diferentes mídias (texto, imagem e som) e possibilitaram o estabelecimento de uma relação mais interativa entre o usuário e o conhecimento, trazendo maior rapidez no acesso e na transferência da informação em escala mundial. Finalmente, a automação das bibliotecas e, conseqüentemente, dos serviços prestados aos usuários implicam o uso cada vez maior das novas tecnologias de informação e comunicação e permitem que a sociabilidade entre os atores envolvidos se modifique substancialmente. O computador passa a executar o processo de mediação entre os profissionais, responsáveis pelos serviços de organização, busca e recuperação da informação e os seus usuários, tornando tais processos mais dinâmicos.

Os resultados apresentados, quanto ao uso das novas tecnologias de informação e comunicação, indicaram percentuais distintos de satisfação nos estudos de caso, reafirmando que os edifícios de bibliotecas analisados, enquadram-se em realidades diferentes de serviço, infra-estrutura e operação dos elementos eletrônicos. No caso da Biblioteca do Senac/Santo Amaro, os respondentes consideraram excelentes os serviços prestados nesse quesito e indicaram que o ambiente está bem servido no que se refere às atividades informáticas. Por outro lado, a Biblioteca da Unesp/Marília apresentou um quadro diverso, indicando nos seus percentuais de satisfação, índices menores de aceitação e, principalmente, descontentamento no oferecimento dos serviços vinculados à automação da informação do edifício. Vale lembrar que, nesses dados levantados, as referências não se referem somente às tarefas direcionadas aos usuários, mas também aos serviços administrativos desenvolvidos pelos funcionários de processamento técnico da informação, classificação, catalogação e indexação. 
Quanto aos itens pesquisados nos dois estudos de caso, envolvendo questões vinculadas à presença e ao manuseio das novas tecnologias de informação e comunicação no ambiente de trabalho, destacam-se:

1. Quantidade de microcomputadores;

2. Localização dos equipamentos informáticos no ambiente de trabalho;

3. Velocidade de transmissão de dados;

4. Facilidade no manuseio dos programas/equipamentos informáticos;

5. Tamanho e disposição espacial do seu posto de trabalho frente às atividades dos recursos informáticos;

6. Acesso do deficiente físico aos recursos informáticos

7. Presença na biblioteca da Tecnologia da Informação (TI);

8. Modernização da TI.

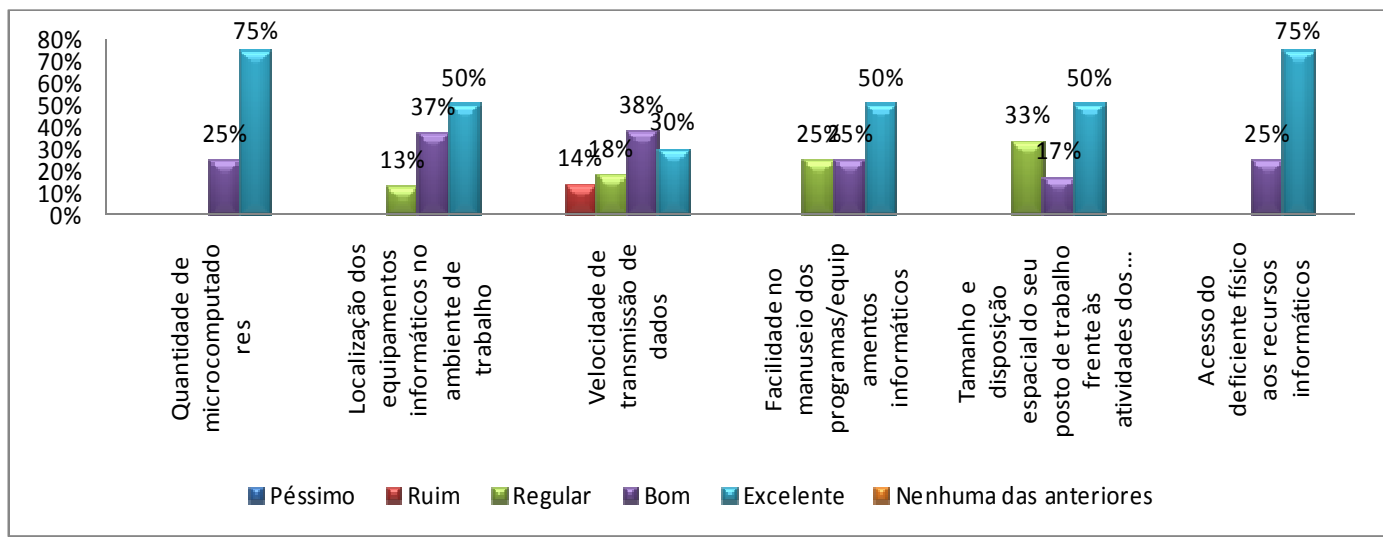

Gráfico 28 - Nível satisfação funcionários Biblioteca Senac/Santo Amaro: tecnologia da informação e comunicação

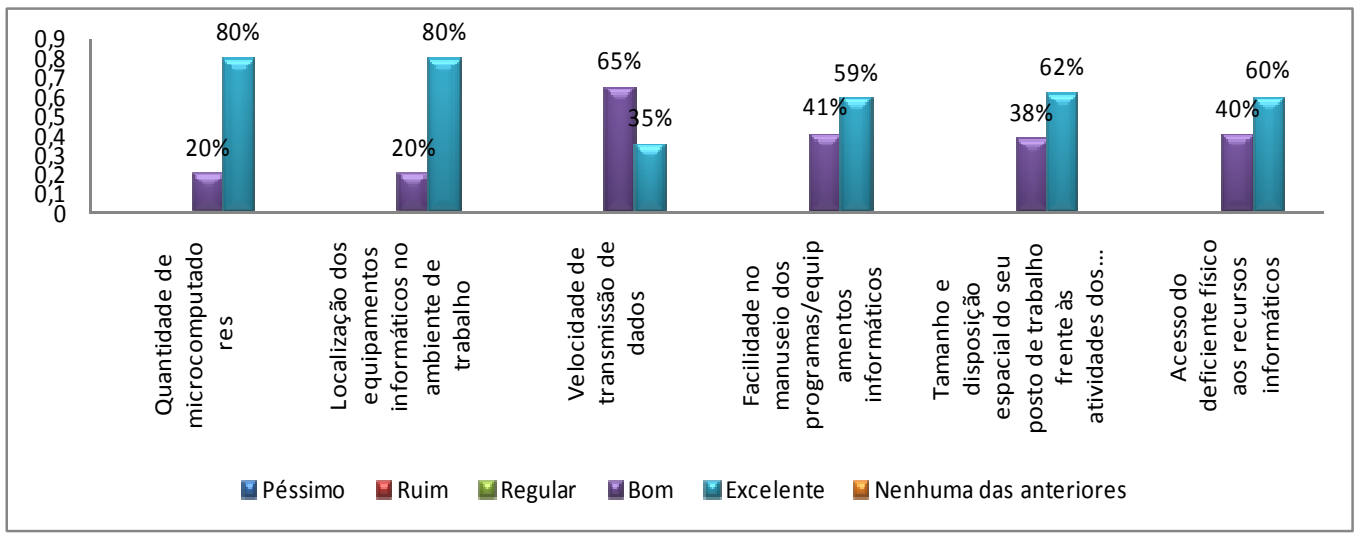

Gráfico 29 - Nível satisfação alunos Biblioteca Senac/Santo Amaro: tecnologia da informação e comunicação 


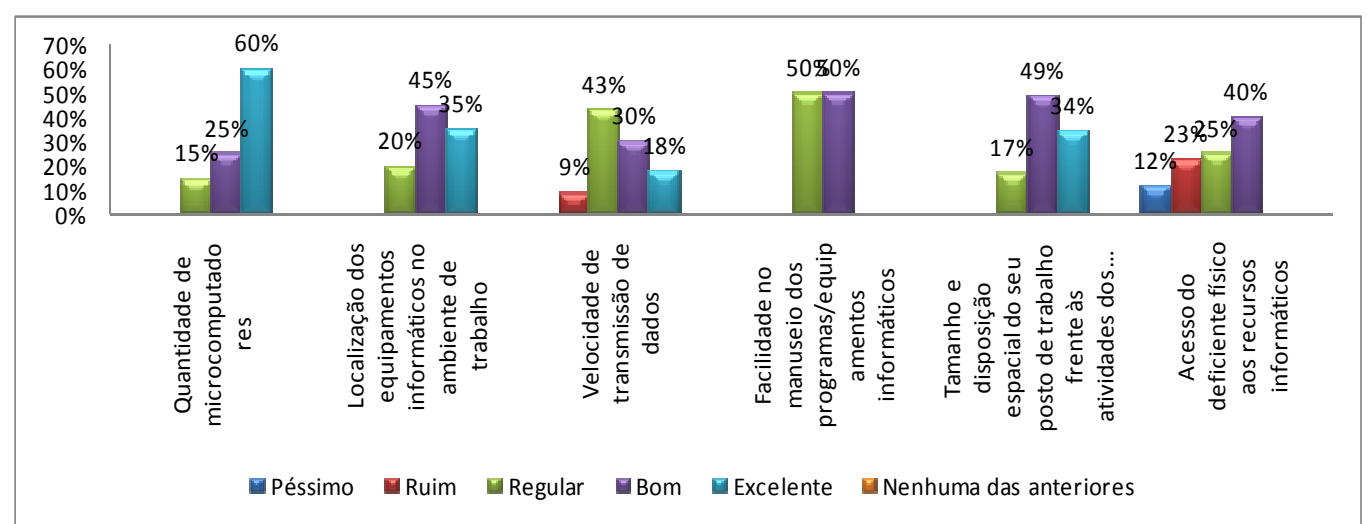

Gráfico 30 - Nível satisfação professores Biblioteca Senac/Santo Amaro: tecnologia da informação e comunicação

Como apresentado anteriormente, os melhores resultados foram verificados na Biblioteca do Senac/Santo Amaro, ou seja, de um modo geral, os respondentes estão satisfeitos em relação às condições apresentadas neste quesito e com percentuais acima de 75\% (Excelente). Entretanto, no extrato dos alunos, esses índices de satisfação ocupam um valor ainda maior, chegando a alcançar o percentual de $\mathbf{8 0 \%}$ (Excelente), especificamente nos aspectos de quantidade de microcomputadores $e$ localização dos equipamentos informáticos no ambiente de trabalho. $\mathrm{Na}$ distribuição dos percentuais entre os extratos de usuários, o índice que obteve o menor patamar entre os analisados foi o que trata da velocidade de transmissão de dados, onde $\mathbf{3 0 \%}$ dos entrevistados consideram eficientes os serviços relacionados. 


\begin{tabular}{|c|c|}
\hline & $\begin{array}{l}\text { Tabela } 20 \text { - Áreas destinadas à Tecnologia da Informação - Biblioteca Senac/Santo } \\
\text { Amaro }\end{array}$ \\
\hline & AVIMENTO TÉRREO \\
\hline \multicolumn{2}{|l|}{ Tipologias TI } \\
\hline $\begin{array}{r}\text { Atendimento } \\
\text { /Área Administrativa }\end{array}$ & \\
\hline $\begin{array}{r}\text { Atendimento } \\
\text { /Área do Usuário } \\
\text { Administrativa }\end{array}$ & 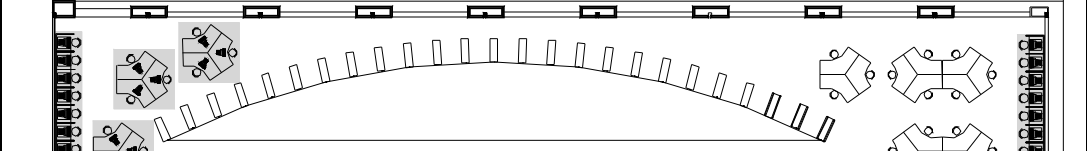 \\
\hline $\begin{array}{l}\text { Serviços TI: pesquisa on- } \\
\text { line/bases de dados, } \\
\text { catalogação, indexação, } \\
\text { controle bibliográfico }\end{array}$ & 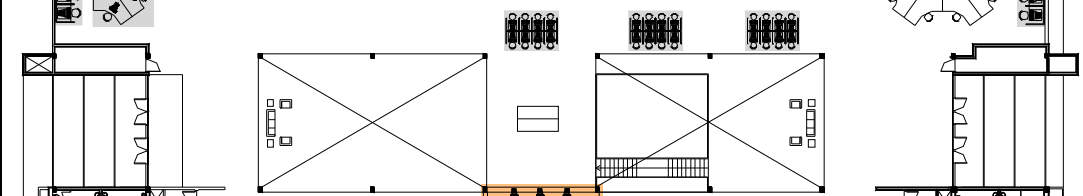 \\
\hline $\begin{array}{l}\text { informações em geral, acervo } \\
\text { digitalizado, e-books, serviços }\end{array}$ & 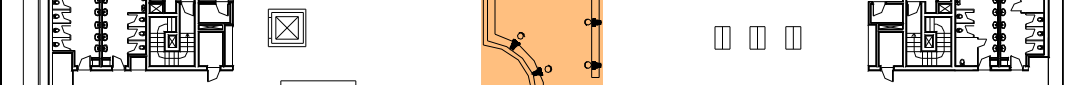 \\
\hline $\begin{array}{l}\text { multimidia, CD/Bases de } \\
\text { dados, controle documentário, }\end{array}$ & 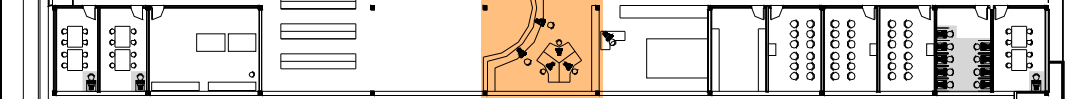 \\
\hline $\begin{array}{l}\text { periódicos eletrônicos, } \\
\text { referências bibliográficas } \\
\text { digitalizadas }\end{array}$ & sem escala \\
\hline Área Útil no Pavimento (m2) & $1.834,42$ \\
\hline Área de TI no Pavimento (m2) & 227,17 \\
\hline Percentual de TI no Pav.(\%) & 12,38 \\
\hline Quantidade de micros & 78 \\
\hline
\end{tabular}

Quanto ao posicionamento dos equipamentos informáticos no pavimento térreo da Biblioteca Senac/Santo Amaro, a Tabela 20 apresenta resumidamente os principais elementos de distribuição nos ambientes e suas principais aplicações. Esses espaços apresentam-se da seguinte forma:

(a) - O balcão de atendimento concentra 11 terminais de computadores, sendo operados pelos funcionários e destinam-se a executar a função de cadastro e consulta de usuários, consulta ao acervo bibliográfico, controle de entrada e saída do material da biblioteca e serviços administrativos como digitação de normas, informações e procedimentos. Todo o sistema computacional está interligado em rede intranet, permitindo que os dados e as informações geradas sejam acompanhados em todos os setores administrativos da direção e assistência da biblioteca; 
(b) - Junto ao acervo do pavimento térreo, localizam-se dois tipos de terminais de computadores que dão suporte às atividades informatizadas no setor. No primeiro tipo há $\mathbf{1 6}$ módulos de cabines individuais, dispostos simetricamente junto às paredes nas laterais esquerda e direita do ambiente, e têm a função de executar pesquisas on-line na internet e nas bases de dados do acervo da biblioteca. A operação do sistema somente é permitida com o cadastro prévio na secretaria geral e com a utilização de regras bem rígidas definidas pela direção. O segundo tipo também é caracterizado por módulos de cabines individuais, entretanto são 3 módulos de 8 terminais cada, posicionados bem ao centro do pavimento térreo e operando as mesmas atividades, ou seja, pesquisas on-line na internet e nas bases de dados do acervo bibliográfico;

(c) - Inseridos nas salas de estudo em grupo e localizados nas extremidades do pavimento, os computadores auxiliam tanto nos trabalhos de digitação e formatação em softwares gráficos dos trabalhos acadêmicos dos alunos quanto aquelas tarefas relacionadas à pesquisa na internet e pesquisa na base de dados.

(d) - O pavimento térreo comporta uma sala de vídeo game, destinada quase que exclusivamente ao público infantil e adolescente, dispondo 9 computadores e permitindo que os usuários utilizem jogos em rede, jogos interativos e pesquisa on-line na internet;

(e) - Na lateral esquerda do pavimento térreo, posicionam-se 3 módulos de mesas abertas, totalizando 9 computadores e fazendo o mesmo serviço de pesquisa online nas bases de dados.

(f) - Na lateral direita do pavimento térreo, localiza-se a sala de reprografia de documentos da biblioteca, contando com 2 computadores, que executam a função de scaneamento e armazenamento digital.

Analisando a Tabela 20, no item que discrimina o percentual de ocupação dos equipamentos informáticos nos ambientes do pavimento térreo, pode-se constatar que o valor de $\mathbf{1 2 , 3 8 \%}$ atende plenamente às áreas destinadas e os requisitos mínimos dos serviços informatizados, garantindo junto aos usuários, excelentes índices de satisfação. É possível afirmar, portanto, que o projeto arquitetônico destinou quantidade de área suficiente para a ocupação das atividades relacionadas, além de prever, corretamente, futuros espaços e ambientes a serem utilizados. 
Outro fator importante dentro do projeto é a relação de densidade entre o computador e o usuário, ou seja, o espaço disponível que cada pessoa tem em relação à área total do ambiente. O grau de descentralização dos módulos de computadores destinados à pesquisa on-line, distribuindo-os equilibradamente ao longo dos ambientes do pavimento térreo e evitando a presença de salas fechadas, permitiu claramente a formação de pontos de encontro e de "ilhas de socialização" nos espaços de cabines e mesas dos computadores. O que poderia ter se tornado um "problema" funcional e operacional nos locais de confluência de pessoas, reverteu-se no principal atrativo da biblioteca, por justamente desenvolver elementos de sociabilidade, trocas de informação e marco referencial entre os usuários. Contudo, mesmo estando afastadas dos setores de leitura e pesquisa da biblioteca, algumas pessoas próximas a estas áreas relataram a dificuldade com relação aos aspectos acústicos e os níveis de desconforto advindo do ruído excessivo. O ponto crucial neste caso seria estabelecer um plano de ação coerente, para se criar mecanismos de controle acústico nos ambientes e regras claras de utilização, sem, no entanto, desestimular as áreas de encontro e as trocas de experiências entre os usuários. Portanto, a manutenção desses espaços, com forte status de interatividade e o constante reforço do lócus de sociabilidade, poderia trazer, no âmbito do edifício da biblioteca, qualidade e caráter espacial diferenciado. 


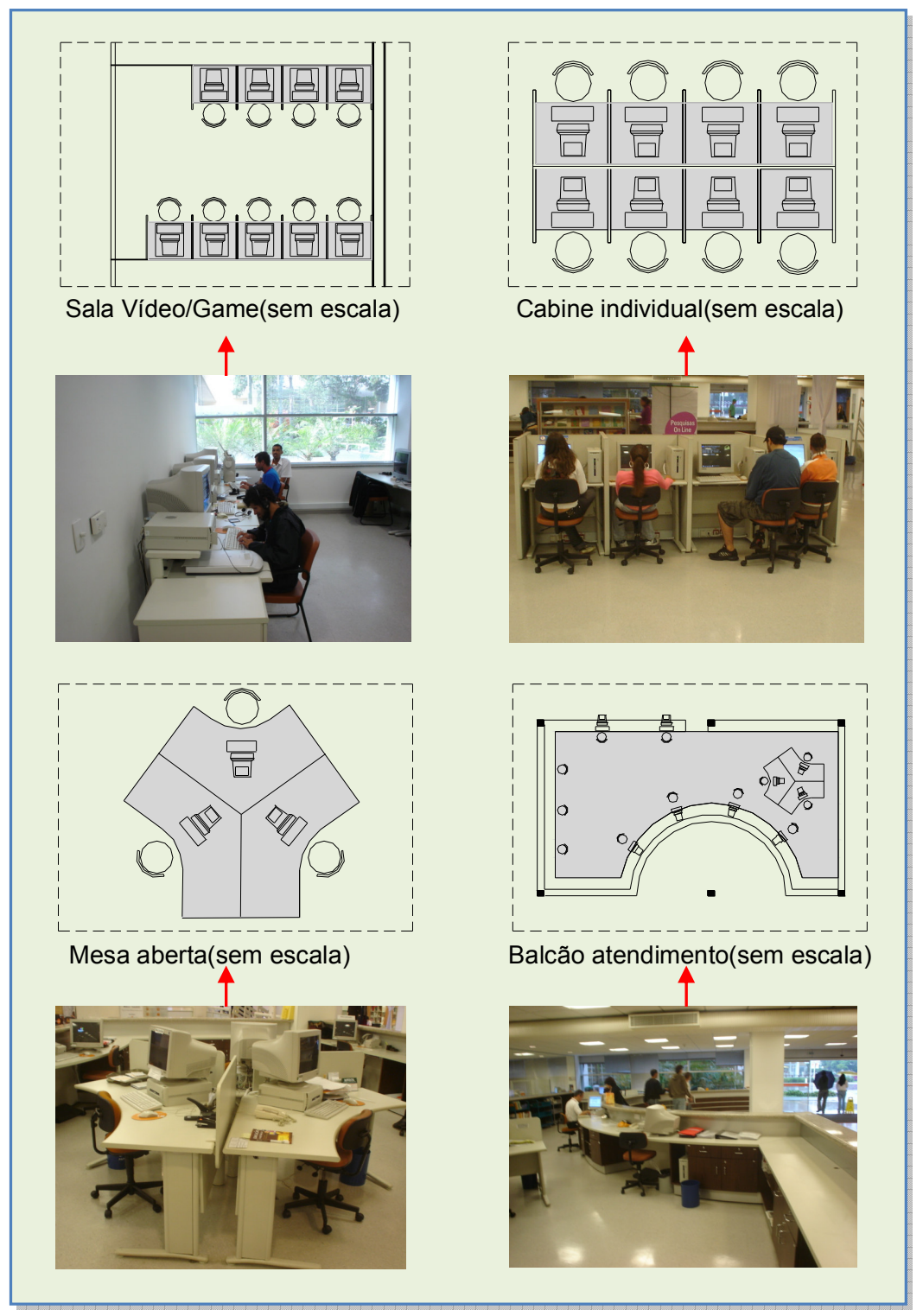

Figura 348 - Ambientes do primeiro pavimento Bbilioteca Senac/Santo Amaro: tecnologias de informação e comunicação

O primeiro pavimento da Biblioteca do Senac/Santo Amaro apresenta a mesma situação dos ambientes do pavimento térreo, do ponto de vista da aplicação das tecnologias de informação e comunicação, distribuídos em terminais de computadores para pesquisa on-line (internet) e nas salas fechadas de estudo em grupo com computadores interligados em rede. Entretanto, outros serviços são complementados aos existentes, tanto aqueles direcionados aos usuários quanto aos serviços administrativos desenvolvidos pelos funcionários para as informações às pessoas.

Dentre os novos serviços oferecidos neste pavimento, destaca-se o funcionamento do programa denominado Espaço Braille que, além da consulta, oferece 
cursos de informática para portadores de deficiência visual utilizando os recursos informatizados. O acervo, além de estar disponibilizado em livros, conta também em áudio e é composto de mais de 200 títulos compreendendo várias áreas de interesse que vão desde histórias infantis até livros técnicos das áreas de culinária, informática e saúde. No contexto da aplicação das novas tecnologias da informação, os ambientes oferecem 06 computadores conectados à internet, 02 impressoras Braille Everest, Mountbatten Brailler, versão moderna da máquina de escrever Perkins; 01 Scanner, acervo de livros falados em fitas cassetes e CD, Lupa eletrônica EVS que amplia os textos no monitor de TV e aplicação de softwares específicos como Jaws, DosVox, OpenBook, Magic, e Winbraille. Quanto ao número de usuários atendidos pelo programa, a direção da biblioteca contabiliza uma média de 90 pessoas por mês, entre cadastrados da própria unidade e de outras regiões do Brasil.

Dessa forma, sob o ponto de vista dos serviços informáticos oferecidos, os usuários estão muito satisfeitos e consideram adequadas as condições funcionais apresentadas nestes ambientes. As observações e os resultados da percepção dos usuários atestam que eles se identificam e se apropriam dos elementos espaciais, tais como, flexibilidade no layout da sala, apropriação do ambiente como ponto de encontro e significação do espaço como extensão de sua casa. Além disso, foi verificado junto à direção o interesse no aumento da capacidade de atendimento do programa, com o crescimento do acervo digitalizado e a compra de novos computadores e equipamentos de informática. Com isso, o espaço da biblioteca já conta com uma sala, que está ao lado do Espaço Braille e apenas está aguardando o processo de implantação do crescimento previsto.

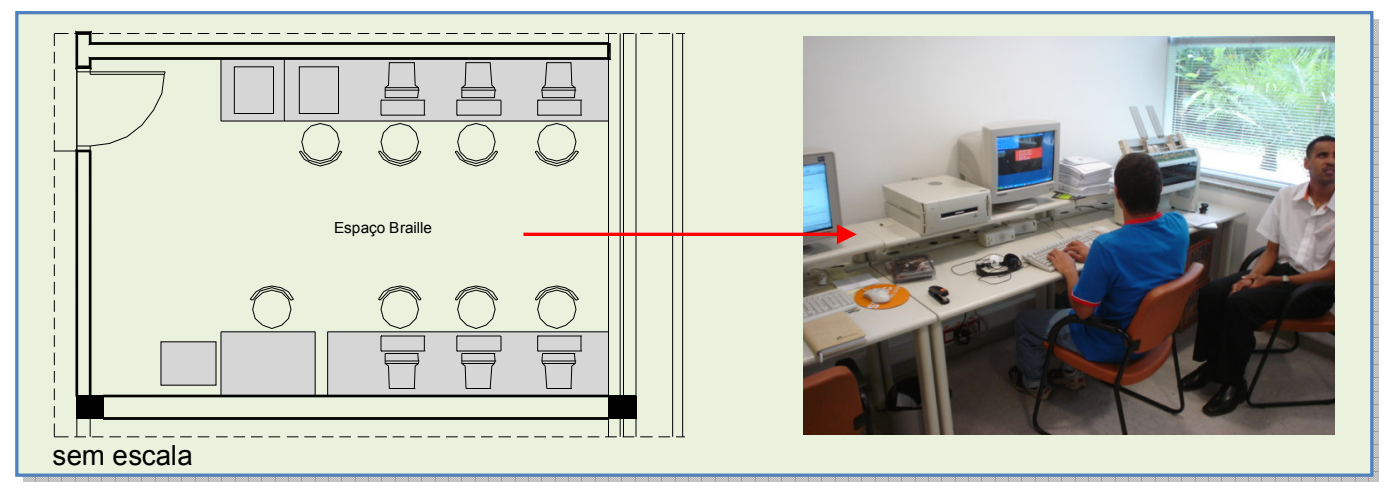

Figura 349 - Espaço Braille Biblioteca Senac/Santo Amaro: tecnologias de informação e comunicação 
Outro ambiente que aplica os conceitos e as ferramentas das tecnologias da informação no contexto do primeiro pavimento é sala que está localizada no setor direito do edifício, próxima à saída do elevador e da bateria de sanitários. O espaço conta com um total de $\mathbf{3 0}$ computadores em rede e está inserido nas atividades correlatas de ministração de cursos aos acadêmicos e usuários em geral, palestras, simpósios e, principalmente, ações aplicadas à disseminação dos meios informacional e comunicacional no âmbito da biblioteca universitária. No entanto, ao analisar in loco a utilização e a densidade efetiva de ocupação - aquela percebida pelas pessoas em seu entorno imediato - este pesquisador teve dificuldades no processo da aplicação e da coleta dos dados, porque o ambiente não está sempre em atividade, funcionando em horários e dias programados. Como os dias vistoriados compreendiam o final de novembro e começo de dezembro, período em que as atividades acadêmicas ganham menos intensidade, em função disso, optou-se em manter o contato direto com os alunos que utilizam o espaço e a direção da biblioteca, de forma a coletar informações não só de uma fonte, mas de duas. Segundo a percepção dos alunos, a sala propicia acesso adequado às tecnologias da informação, com quantidade suficiente de computadores e que estão de acordo com as atividades desenvolvidas de treinamento e atualização de programas informatizados. Eles argumentaram, contudo, que o ambiente poderia ser mais bem explorado, potencializando uma gama muito maior de eventos, encontros e cursos durante, inclusive, o período das férias escolares. Acrescenta-se que a direção sinaliza a existência de um plano estratégico nesta área, dirigindo esforços e implementando, aos poucos, ações no aumento das atividades deste ambiente.

Finalmente, o primeiro pavimento conta com um serviço especial informatizado, voltado especificamente ao atendimento do usuário, concernente às atividades de consulta à base de dados do acervo, informações cadastrais e apoio às informações acadêmicas, além de prestar serviços de comutação de livros, pesquisa bibliográfica, pesquisa de material digitalizado (periódicos e e-books) e agendamentos prévios dos espaços da biblioteca. No total são 4 computadores dispostos nas estações de trabalho, acompanhados de equipamentos auxiliares como impressora e scanner. Esse ambiente, além de remeter ao layout de uma "ilha", está localizado estrategicamente ao centro da edificação, no eixo que divide os dois lados do pavimento. Essa característica permite estabelecer, com os espaços circunvizinhos, uma relação de proximidade visual bastante intensa, já que todas as atividades ali desenvolvidas são visualizadas e acompanhadas por aqueles que estão em sua volta. 
Quanto à satisfação dos usuários em relação aos serviços informatizados oferecidos por esse ambiente, todas as opiniões foram positivas e categóricas, reafirmando duas vantagens básicas na eficiência dos serviços oferecidos: a primeira tem a ver com a inclusão das atividades informatizadas no primeiro pavimento, permitindo que o usuário utilize o ambiente sem a necessidade de locomoção até o pavimento térreo; a segunda indica o aspecto positivo da proximidade espacial entre o funcionário e o usuário inserido na "ilha" de atendimento, ou seja, a relação entre os dois atores, pela da percepção ambiental, desmistifica a posição superior do funcionário, "trazendo-o" mais próximo à realidade do usuário.

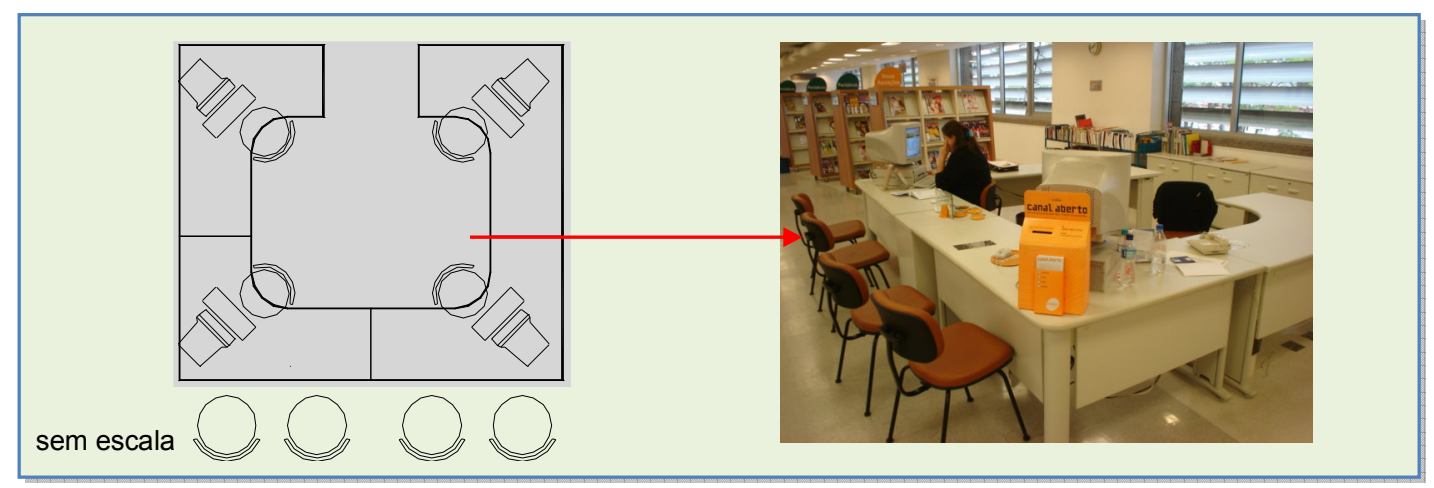

Figura 350 - "Ilha de atendimento" Biblioteca Senac/Santo Amaro: tecnologias de informação e comunicação 


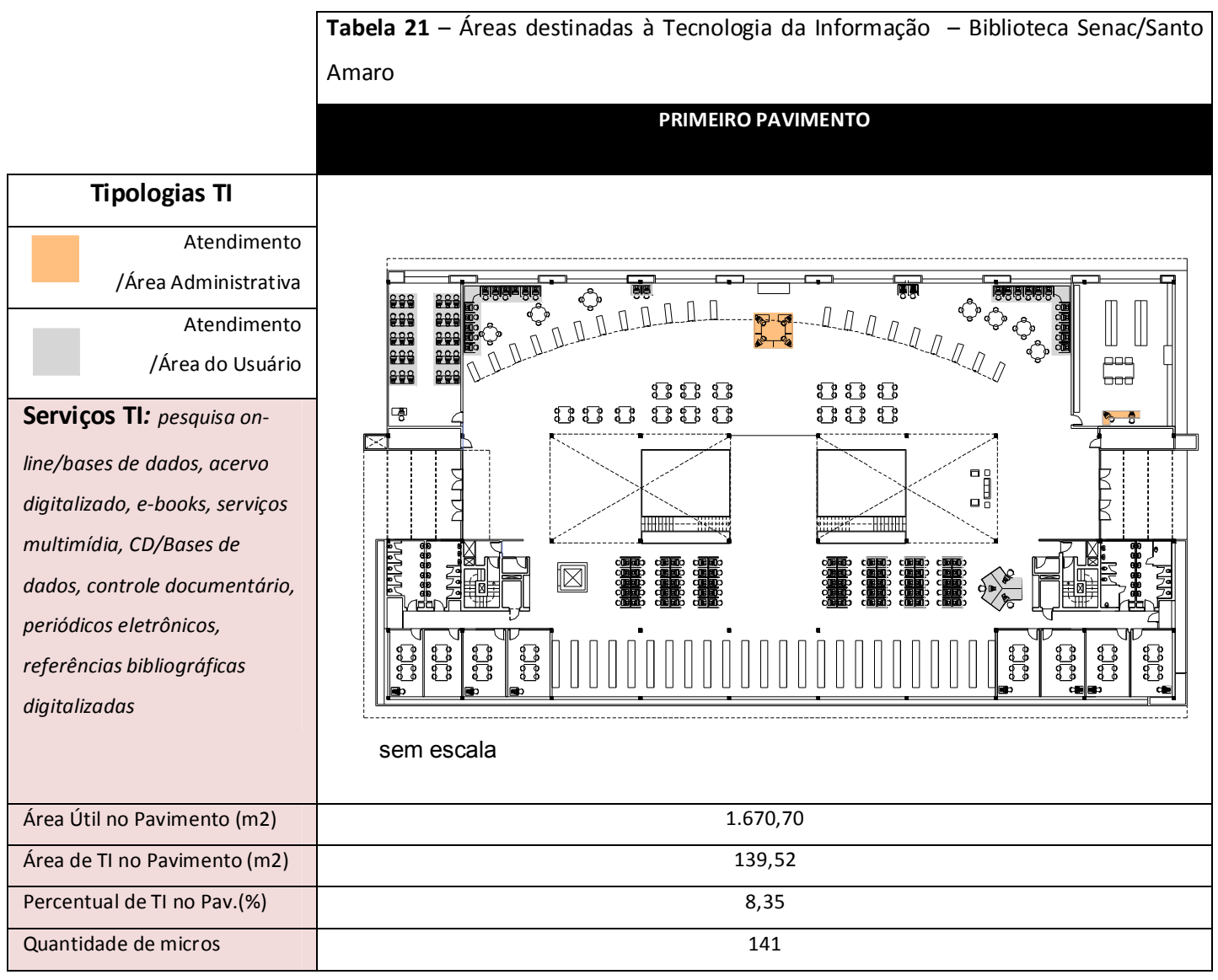

O segundo pavimento da Biblioteca do Senac/Santo, como acontece nos outros dois descritos anteriormente, vislumbra as mesmas ferramentas de aplicação das tecnologias de informação e comunicação, definidas pelos terminais de computadores para pesquisa on-line (internet), salas de estudo em grupo e atendimento personalizado ao usuário. O diferencial em relação aos outros pavimentos é a presença dos aplicativos informatizados no setor administrativo, com serviços aplicados aos procedimentos burocráticos, planejamento operacional da biblioteca, controle e aquisição de novos materiais, intercâmbio com as outras unidades de rede Senac e outras instituições, catalogação e indexação, etc. Além disso, os sistemas computacionais direcionam suas atividades na averiguação dos documentos e materiais bibliográficos a serem armazenados, freqüência de manipulação do acervo e exigências legais de tempo de guarda do material da biblioteca. 


\begin{tabular}{|c|c|}
\hline & $\begin{array}{l}\text { Tabela } 22 \text { - Áreas destinadas à Tecnologia da Informação - Biblioteca Senac/Santo } \\
\text { Amaro }\end{array}$ \\
\hline & SEGUNDO PAVIMENTO \\
\hline Tipologias TI & \\
\hline $\begin{array}{r}\text { Atendimento } \\
\text { /Área Administrativa }\end{array}$ & 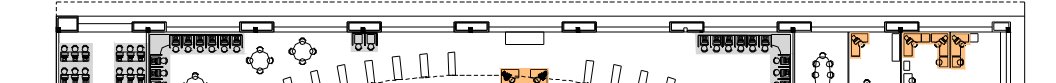 \\
\hline $\begin{array}{r}\text { Atendimento } \\
\text { /Área do Usuário }\end{array}$ & 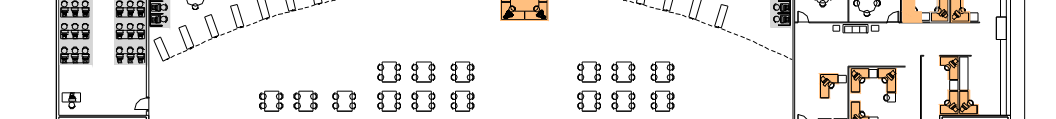 \\
\hline $\begin{array}{l}\text { Serviços TI: pesquisa on- } \\
\text { line/bases de dados, acervo } \\
\text { digitalizado, e-books, serviços } \\
\text { multimídia, CD/Bases de } \\
\text { dados, controle documentário, } \\
\text { periódicos eletrônicos, } \\
\text { referências bibliográficas }\end{array}$ & 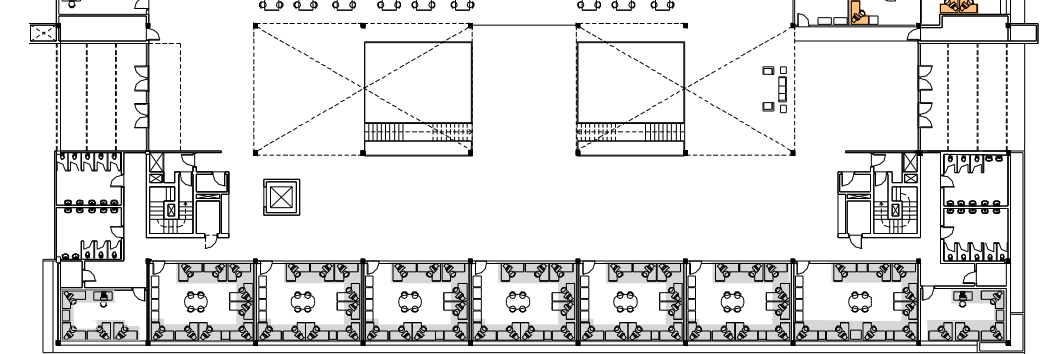 \\
\hline & sem escala \\
\hline Área Útil no Pavimento (m2) & $1.730,50$ \\
\hline Área de TI no Pavimento (m2) & 265,63 \\
\hline Percentual de TI no Pav.(\%) & $15,34 \%$ \\
\hline Quantidade de micros & 145 \\
\hline
\end{tabular}

Vale destacar ainda que as salas fechadas, dedicadas ao estudo em grupo e projetadas para atender às atividades acadêmicas e pesquisa na internet, garantem um dos melhores índices de satisfação entre os usuários, visto que dispõem de 9 computadores de ultima geração, com alta performance, softwares atualizados e instalações e equipamentos bem equipados. Contudo, não somente estes aspectos garantem um bom índice de satisfação, mas, sobretudo, a imagem positiva que esses ambientes exercem sobre a percepção do usuário, reinterpretando-o na tentativa de reproduzir a idéia de "refúgio" ou "proteção" no contexto da biblioteca.

Com relação ao percentual de TI - Tecnologia da Informação presente no ambiente, o segundo pavimento é o que agrega maior valor, 15,34\%, ou seja, esses índices comprovam a grande preocupação da instituição e, automaticamente, da própria direção em garantir um amplo programa de implantação dos sistemas computacionais, inserido no contexto dessa biblioteca universitária. Somados os percentuais de TI nos três pavimentos obtêm-se o valor de $\mathbf{3 6 , 0 7 \%}$, demonstrando que a aplicação das tecnologias de informação e comunicação, no caso da Biblioteca do Senac/Santo Amaro, é um processo irreversível de migração do suporte tradicional impresso para o 
meio eletrônico. Esse quadro também pode ser atestado no planejamento dos ambientes e dos layouts dos pavimentos, permitindo que o suporte eletrônico desenvolva procedimentos e produtos digitais, repositórios eletrônicos e diferentes formas de interação mediadas pelas tecnologias informacionais. Por outro lado, fica claro que o resultado das avaliações dos usuários comprova o aceite por parte deles, nas transformações e nas mudanças implementadas no edifício e que as habilidades para manejo de computadores e redes devem estar incorporadas no do dia-a-dia dos usuários.

Quanto aos resultados apresentados na Biblioteca da Unesp/Marília, sob o ponto de vista da utilização das tecnologias da informação e comunicação, os índices e as observações colhidas reforçam as condições desfavoráveis que se encontra este item na biblioteca analisada. Embora essa biblioteca esteja vinculada a uma instituição, como é o caso da Unesp, que continuamente tem procurado desenvolver e implantar programas de automação e informatização de suas unidades de informação, especificamente neste, percebeu-se certa contenção no uso das tecnologias de informática, não somente para automatizar às atividades bibliotecárias, mas também do uso delas para o aumento de acesso à informação para o usuário.

Analisando os gráficos dos índices de satisfação dos usuários existentes na Biblioteca da Unesp/Marilia, pode-se constatar o seguinte:

a- Quanto à quantidade de computadores, os piores valores estão entre os alunos, 38\% - Péssimo. Os mais positivos são entre os funcionários, 47\% Bom;

b- Com relação à localização dos equipamentos informáticos no ambiente de trabalho, $\mathbf{6 0} \%$ dos professores avaliam como Bom, sendo o índice mais positivo e os mais negativos entre os alunos, 35\% - Bom;

c- $\quad$ Quanto à velocidade de transmissão dos dados, a pior avaliação foi entre os alunos (39\% - Péssimo) e melhor percepção entre os professores (60\% Regular);

d- No item que relaciona a facilidade no manuseio dos programas/equipamentos informáticos, o índice mais baixo está vinculado entre os professores (55\% - Regular), por outro lado, a melhor avaliação fica entre os funcionários, $67 \%$ acham Excelente;

e- Quanto ao tamanho e a disposição espacial do posto de trabalho frente às atividades dos recursos informáticos demonstraram que, entre os 
professores, os índices são os mais baixos, 50\% - Regular e, os mais altos entre os funcionários, $\mathbf{5 0 \%}$ - Bom;

f- Quanto ao acesso do deficiente físico aos recursos informáticos, esse foi considerado o pior quesito entre todos, tendo sido avaliado pelos os alunos com $\mathbf{4 5 \%}$ de Péssimo e pelos funcionários com 75\%, de Ruim.

No contexto dos ambientes e das observações técnicas realizadas, o edifício contempla alguns serviços voltados à aplicação da tecnologia da informação, tanto nas atividades administrativas envolvidas pelos funcionários quanto dos serviços oferecidos aos usuários. Basicamente, os serviços distribuem-se nos dois pavimentos da biblioteca, sendo assim discriminados:

(1) - a primeira área, o balcão de atendimento e serviço de encomendas do material bibliográfico, fica localizada junto ao pavimento térreo, logo à entrada principal do edifício e conta com 3 computadores, 2 impressoras e 1 scanner. Ali se desenvolvem as atividades de pesquisa on-line/bases de dados, acervo digitalizado, controle de entrada e saída on-line e periódicos eletrônicos. Nesse local, ainda que a percepção do usuário seja positiva em relação aos serviços prestados, sugere-se aumento nos postos de atendimento e mais terminais de computadores, já que, em horários de grandes fluxos, como nos intervalos de aulas e no período noturno, o balcão de atendimento recebe uma grande quantidade de pessoas. O problema se agrava também porque, em determinadas situações, ocorre o cruzamento de fluxos de circulações entre a passagem de pessoas da entrada principal e a fila de atendimento do balcão. $\mathrm{O}$ ideal seria o remanejamento do balcão de atendimento com o objetivo de disponibilizar aumento na área do layout e ganho na qualidade nos serviços oferecidos, além de aumentar a quantidade de computadores. 


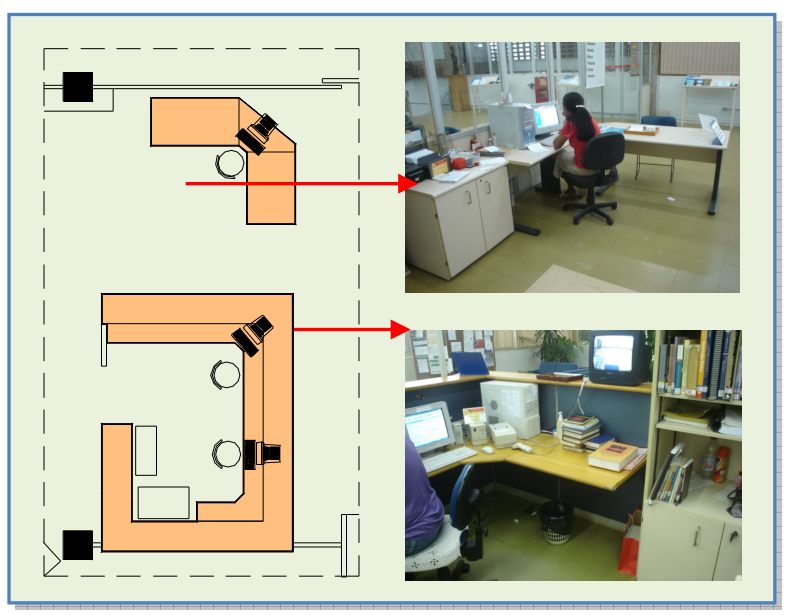

sem escala

Figura 351 - Hall de entrada balcão de atendimento e serviço de encomendas do material bibliográfico /BibliotecaUnesp/Marília: tecnologias e informação e comunicação

(2) - a segunda área é a sala de acesso à internet e disponibiliza a rede mundial de computadores e a pesquisa às bases de dados da biblioteca. Esse ambiente, inaugurado no final do ano de 2006, é fruto de cooperação entre uma instituição bancária e a direção da rede de bibliotecas da Unesp. A sala conta com $\mathbf{1 3}$ computadores de última geração, oferecendo serviços não só aos usuários da própria biblioteca, mas também dos cursos aos graduação e pós-graduação da unidade. Com relação à avaliação deste ambiente, os usuários têm uma excelente percepção e garantem que estão satisfeitos com os serviços de informática disponibilizados e com as várias atividades desenvolvidas vinculadas aos sistemas informacionais. Vale lembrar que, se não fossem as avaliações e as percepções positivas deste ambiente, as médias de satisfação deste quesito ficariam ainda mais baixas. Portanto, o modelo implantado e estruturado por esse serviço informatizado, comprova um caminho seguro a ser trilhado neste estudo de caso, embora alguns usuários tenham relatado algumas dificuldades na operação das máquinas em virtude da ausência do monitor da sala, como problemas com a senha de entrada, manuseio dos programas computacionais e a demora na busca e na navegação das informações na internet; 


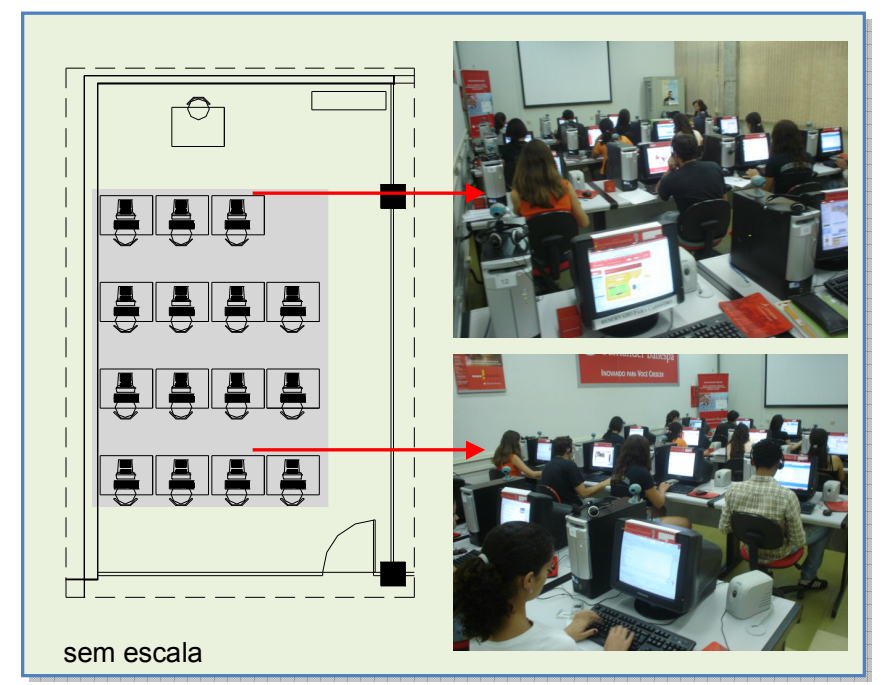

Figura 352 - Sala de internet/BibliotecaUnesp/Marília: tecnologias e informação e comunicação

(3) - a terceira área está localizada bem ao centro do pavimento térreo e agrega duas funções específicas: os terminais de consulta às bases de dados do acervo e o setor destinado ao apoio acadêmico e à comutação bibliográfica. Quanto às avaliações executadas, este ambiente foi o que recebeu a pior avaliação dos usuários. Segundo os insatisfeitos, o problema não está vinculado à localização dos equipamentos de informática no pavimento, mas refere-se ao fato de que a quantidade de computadores disponíveis e o desenho do layout adotado é deficiente. Soma-se a isso, como foi apresentado nos itens anteriores, o fato de que o local enfrenta dificuldades quanto à acessibilidade do deficiente físico, reflexos indesejáveis nos monitores e medidas dos mobiliários fora do padrão estipulado pela norma. Outra reclamação recorrente na opinião dos usuários, refere-se à velocidade utilizada para a transmissão dos dados nos sistemas computacionais que está aquém do mínimo necessário, transformando lenta a interface da informação. Neste caso, a solução deveria ser encaminhada para a reestruturação completa do ambiente, para se rever quantidades, layout e padrões computacionais, abrigando não só previsões tecnológicas para o aumento da demanda, como também a instalação de modernos equipamentos informacionais e comunicacionais; 


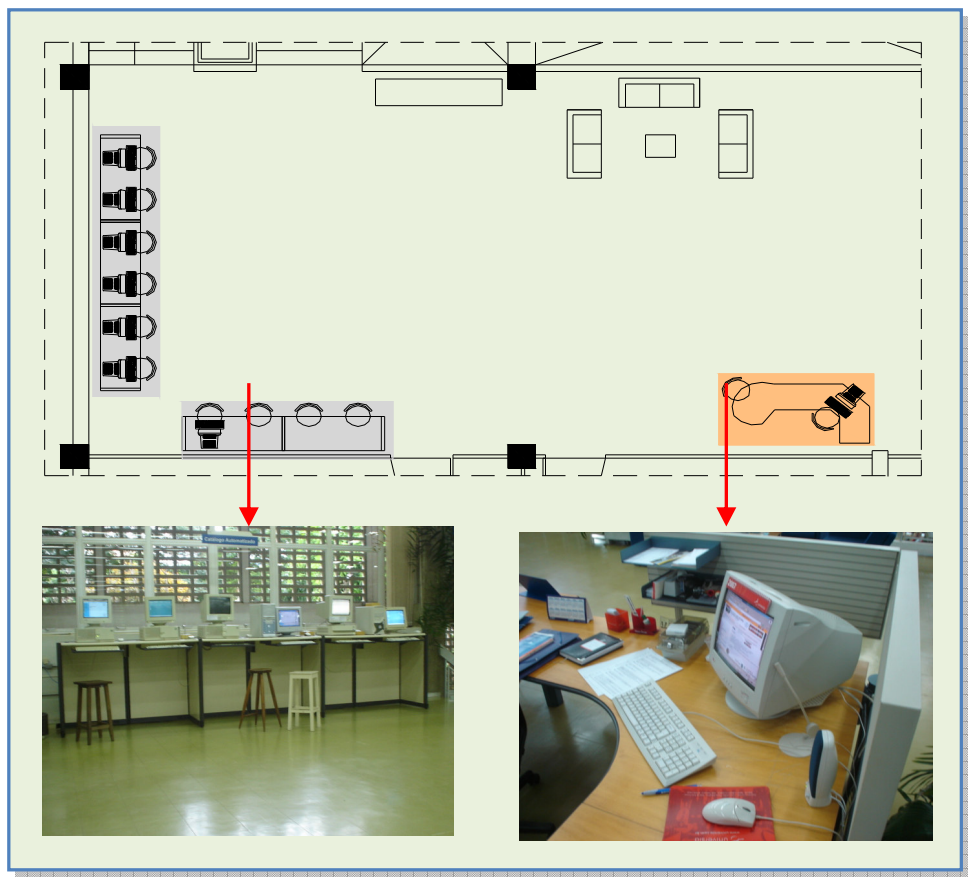

Figura 353 - Sala de internet /BibliotecaUnesp/Marília: tecnologias e informação e comunicação

(4) - na quarta e última área estão alocados os ambientes do setor administrativo, com atividades voltadas aos procedimentos burocráticos, controle e aquisição de novos materiais, intercâmbio com as outras unidades da rede de biblioteca da Unesp e outras instituições, catalogação e indexação. Os funcionários apontaram que, de um modo geral, as ferramentas computacionais disponíveis estão adequadas e satisfazem todos os trâmites e operações requisitadas. Porém, verificou-se no setor a existência de uma sala subutilizada, sendo hoje ocupada não só por computadores, mas também por móveis e armários sem função específica de armazenagem. Neste caso, o mais prudente seria reverter este espaço para a ampliação das atividades informatizadas, uma vez que a biblioteca sente a necessidade de destinar mais ambientes à infra-estrutura de tecnologia da informação. 


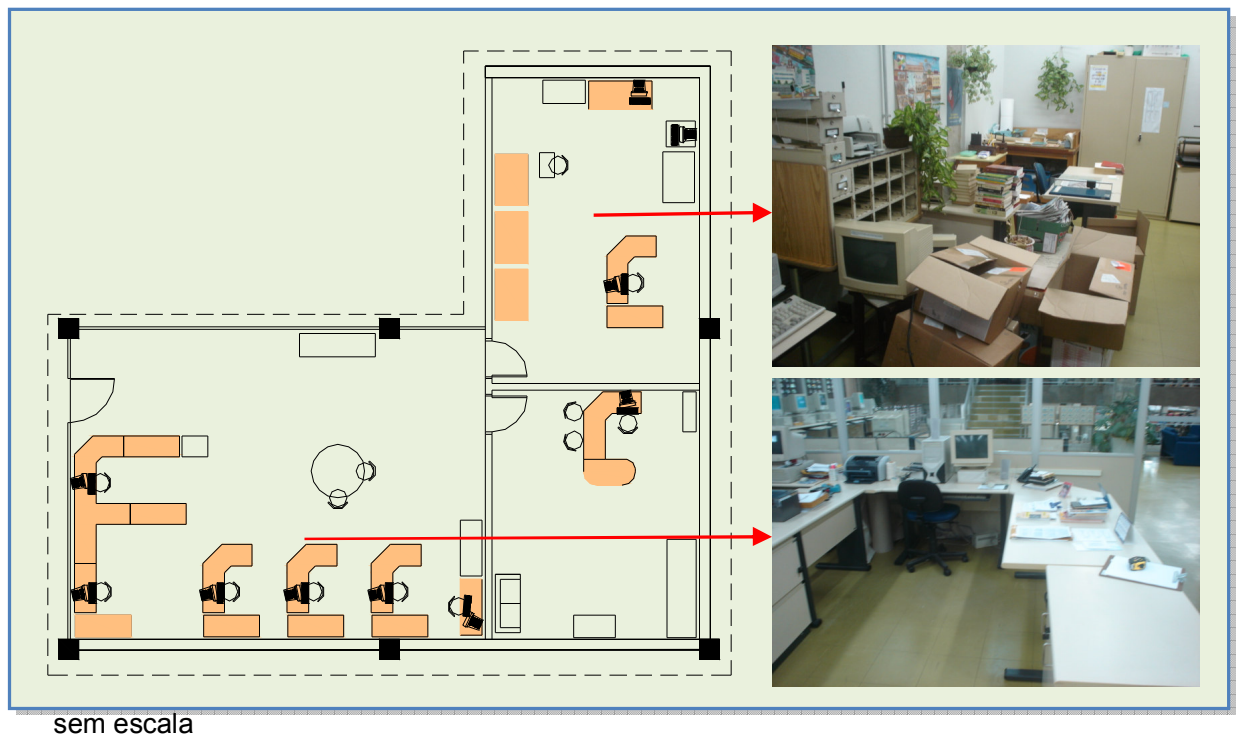

Figura 354 - Setor administrativo /BibliotecaUnesp/Marília: tecnologias e informação e comunicação

Os resultados apresentados evidenciam as dificuldades encontradas com relação ao uso das tecnologias e das ferramentas informacionais no contexto dos ambientes analisados da Biblioteca da Unesp/Marília. Preliminarmente, as avaliações reforçam a tese de que os problemas apresentados estão basicamente relacionados aos fatores funcionais, estruturais e dimensionais a disposição, a quantificação e a atualização dos equipamentos de informática, a falta de instrumentação específica ao usuário para lidar com as novas tecnologias informacionais, erros no gerenciamento ligados às questões de planejamento estratégico e financeiro da instituição e ausência do planejamento arquitetônico nas áreas direcionadas às tecnologias informacionais e comunicacionais. 

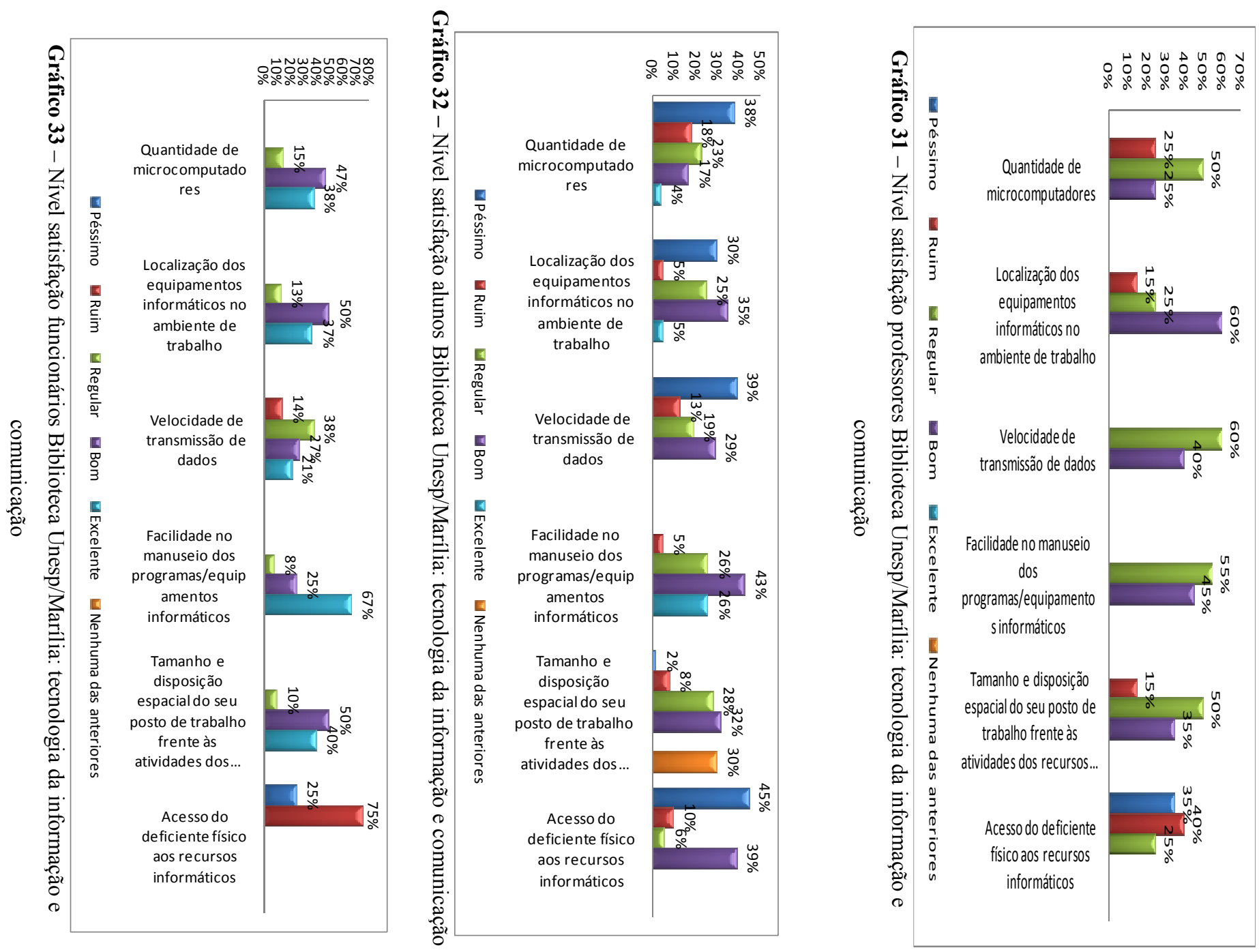


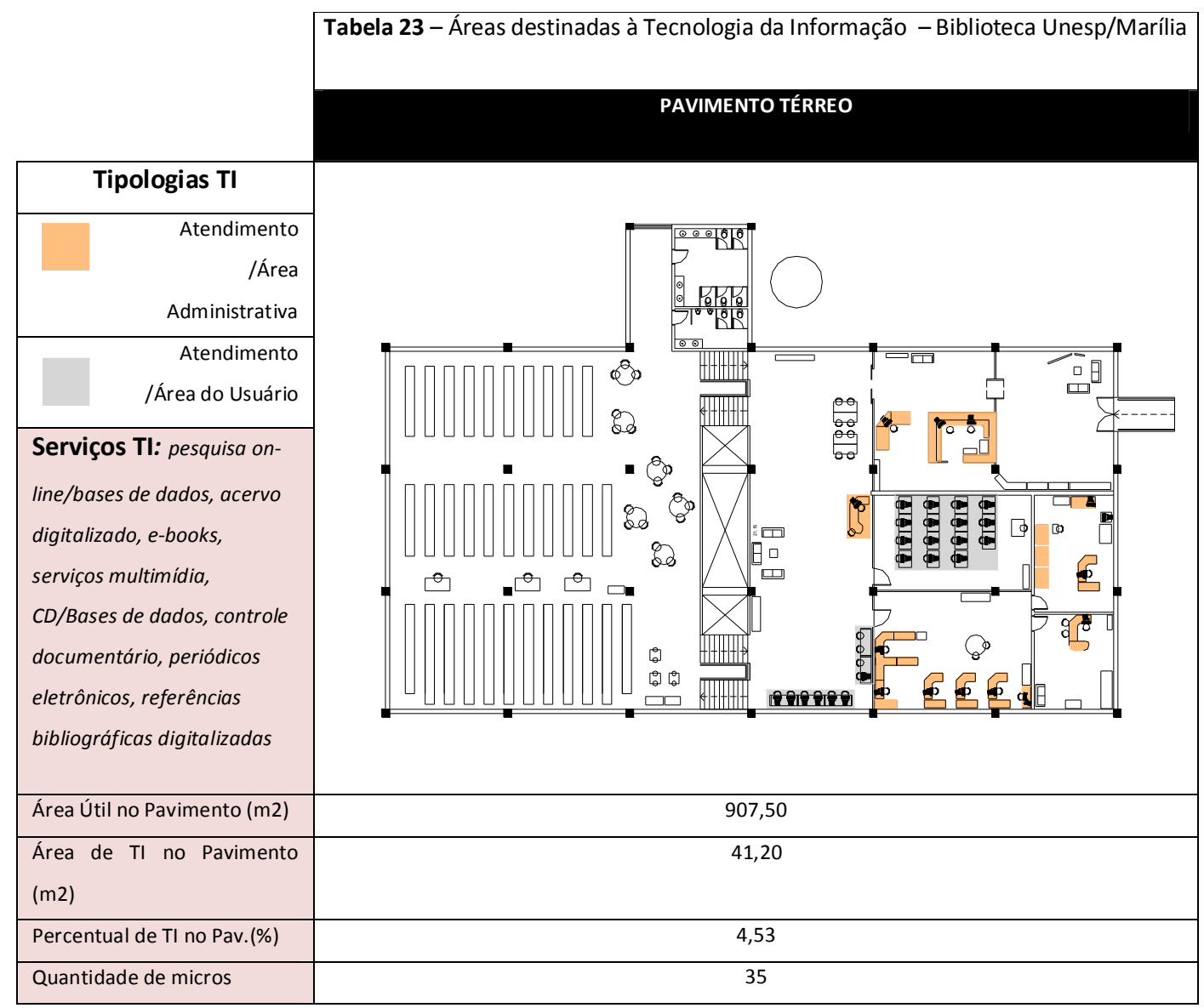




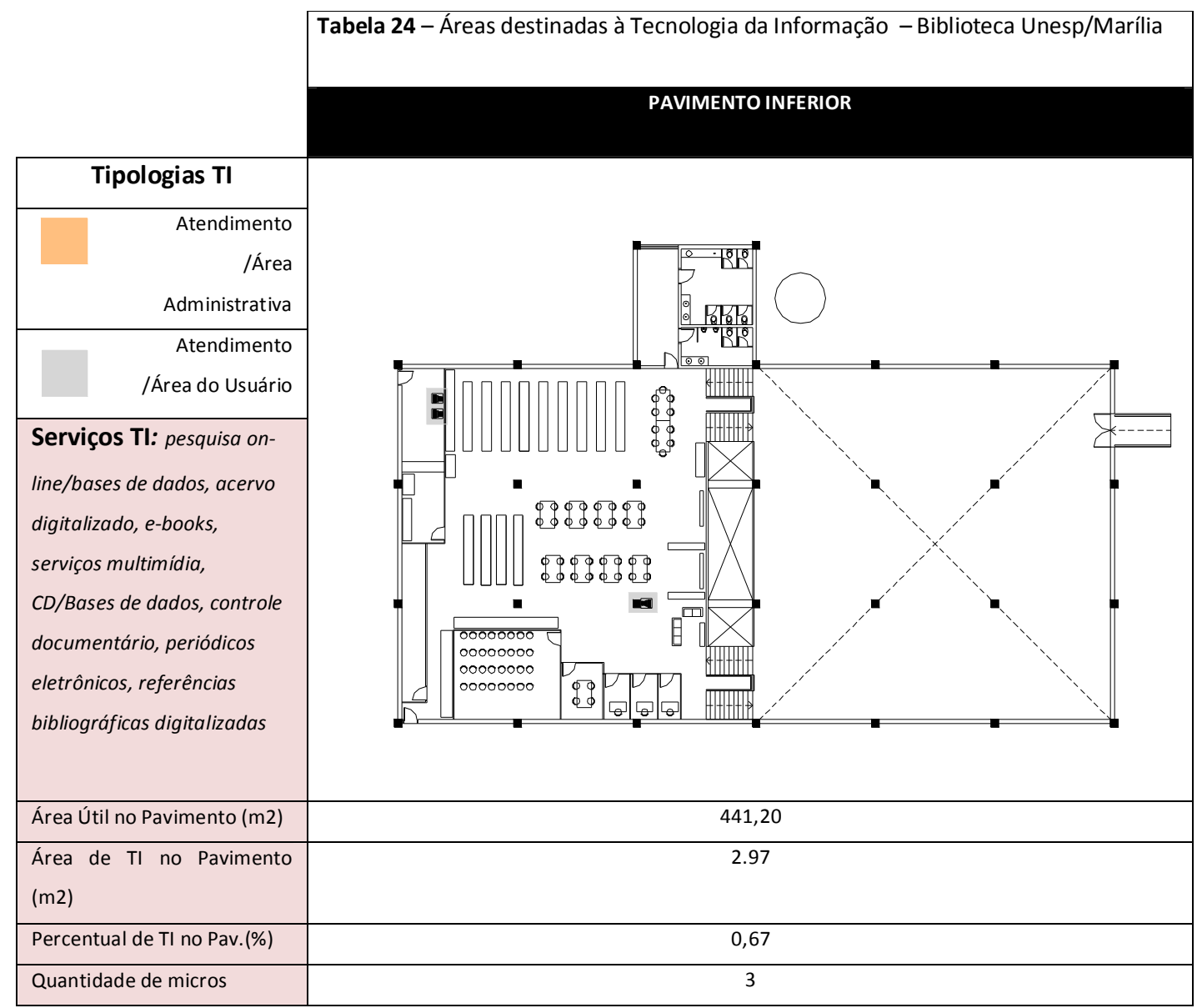




\section{CAPÍTULO 10 - DIAGNÓSTICO E RECOMENDAÇÕES DOS ESTUDOS DE} CASO

\subsection{Considerações Preliminares}

Nesta etapa da pesquisa, os resultados do diagnóstico foram consolidados por meio da análise e da avaliação de todo o conjunto de dados e informações coletados fruto do levantamento dos elementos funcionais e pelos usuários, ou seja, a fase do diagnóstico procedera-se no cruzamento, de cada item, dos resultados das informações técnicas do estudo de caso (descritos anteriormente) e da opinião dos usuários. $\mathrm{Na}$ análise, considerou-se também todo e qualquer dado coletado desde o início da pesquisa, como as entrevistas efetuadas com pessoas-chave dos edifícios escolhidos, mapa de descobertas e pessoas envolvidas diretamente com a administração, encarregados, chefes de setores, entre outros. Essas informações foram relevantes na medida em que forneceram subsídios nas análises técnicas e funcionais quanto à satisfação a partir da confirmação ou não das expectativas em relação ao desempenho percebido.

\subsection{Desenvolvimento do Diagnóstico}

Os procedimentos da pesquisa relacionados aos itens diagnósticos procuraram atingir dois objetivos fundamentais: primeiro, a possibilidade concreta de vislumbrar nas análises dos diversos elementos funcionais, os principais aspectos positivos e negativos do ambiente construído das bibliotecas universitárias analisadas, alicerçado principalmente, nas avaliações obtidas nas etapas anteriores; segundo, subsidiar nesta tese, a investigação e a detecção de futuros caminhos e diretrizes para projetos de bibliotecas universitárias brasileiras, verificando-se a aplicabilidade de muitos dos dados levantados para novos projetos semelhantes.

O Mapa de Descobertas, demonstrado no item 7.14, também facilitou no processo de diagnóstico dos fatores levantados, já que o método identificou questões de inadequações e adequações às situações existentes e outras variáveis, por meio de comentários e esquemas figurativos anotados na planta dos dois estudos de caso. No final, os elementos levantados pelo mapa de descobertas serviram de base para as futuras análises e observações dos diagnósticos finais. Além destes dados e 
informações, levantados ao longo de todo processo da pesquisa, as entrevistas informais ou estruturadas auxiliaram também na interpretação dos resultados presentes nos diagnósticos finais

\subsection{Utilização do Mapa de Descobertas}

A utilização desta metodologia almejou também, outro importante aspecto a ser considerado: a busca pela síntese e pela construção de uma comunicação mais fluída entre os agentes envolvidos no processo de análise e encaminhamento de possíveis propostas. Segundo Sanoff (apud VOORDT; WEGEN, 2005) a programação de um ambiente construído é um sistema de coleta e de processamento de informações que irá mostrar caminhos para o projeto, com intuito de agregar as necessidades dos usuários, dos contratantes e dos projetistas. Neste contexto, a compreensão clara das diversas propostas do ambiente construído, no âmbito dos diagnósticos realizados, necessariamente deve colaborar, tanto para projetistas quanto para usuários, alternativas concretas de possibilidades ou impossibilidades no processo projetual.

\subsubsection{Critérios para elaboração do Mapa de Descobertas}

No processo de montagem dos Mapas de Descobertas definiu-se que, para a melhor compreensão e a visualização dos dados pertinentes apresentados, cada pavimento dos edifícios analisados receberia um Mapa de Descoberta próprio, ou seja, dois mapas para a Biblioteca da Unesp/Marília (pavimento térreo e pavimento inferior) e três mapas para a Biblioteca do Senac/Santo Amaro (pavimento térreo, primeiro pavimento e segundo pavimento). Este procedimento possibilitou planejar e apresentar melhor a própria divisão dos principais ambientes envolvidos na pesquisa, reforçando e destacando com muito mais clareza, os elementos funcionais analisados e os registros fotográficos efetuados.

Os critérios para a escolha desses ambientes estão estreitamente ligados com os resultados das análises funcionais executadas e, evidentemente, fazem parte de todo o processo de organização e de tabulação dos dados da pesquisa. Portanto, o próximo passo foi atribuir para cada ambiente selecionado no Mapa de Descoberta, uma denominação referencial correspondente, vinculando o nome do ambiente, a foto, o diagnóstico comentado, as recomendações e as normas associadas. Além disso, 
procurou-se distribuir estrategicamente esses dados e informações ao redor das plantas dos edifícios analisados, como forma de se criar um instrumento visual didático e acessível às pessoas envolvidas no processo da avaliação. Cabe lembrar ainda que, nem todos os ambientes dos edifícios analisados foram discriminados nos Mapas de Descobertas, referenciando somente aqueles que, de certa forma, obtiveram significado representativo nas avaliações dos pontos positivos ou negativos.

\subsection{Quadro de Sínteses}

Fora à construção dos Mapas de Descobertas nos ambientes selecionados, foi elaborado um Quadro de Sínteses contendo, além das informações concernentes aos mapas, a inclusão de outros dados igualmente relevantes, como por exemplo, os itens funcionais avaliados e seus respectivos percentuais de análise, tanto positiva quanto negativa de cada ambiente correspondente. Portanto, o Quadro de Sínteses retrata não só o desempenho satisfatório (avaliação positiva), como também o desempenho insuficiente (avaliação negativa) do ambiente. Todo esse conjunto de informações, como no caso dos Mapas de Descobertas, consistiu no cruzamento, para cada item, da percepção dos usuários, nos resultados das avaliações e no levantamento técnico dos ambientes. Considerou-se também toda e qualquer informação coletada desde o início da pesquisa, como entrevistas com pessoas-chave e pessoas ligadas aos ambientes analisados. Nesse sentido, é possível dizer que, a classificação e a codificação dos dados presentes no Quadro de Sínteses pode ser entendida como um desdobramento dos Mapas de Descobertas, onde um instrumento se vincula ao outro reciprocamente, auxiliando e monitorando todo o processo de diagnóstico e recomendações.

Para a elaboração dos Gráficos das maiores e menores médias de avaliação dos ambientes, a partir dos Mapas de Descobertas e do Quadro de Sínteses, executou-se a somatória das avaliações de todos os pavimentos analisados, tanto da Biblioteca da Unesp/Marília (dois pavimentos) quanto da Biblioteca do Senac/Santo Amaro (três pavimentos), gerando automaticamente médias percentuais e uma visualização global do desempenho dos diversos itens avaliados. Além disso, estipulouse nesse Gráfico uma escala de valor entre $0 \%$ e $100 \%$, na qual a leitura dos itens com médias abaixo da média aceitável de 50\% representariam um desempenho insuficiente e os itens com desempenho satisfatório estariam acima da média mínima aceitável, ou 
seja, acima de 50\%. Portanto, ao final, foi possível arrolar duas listas relacionadas ao desempenho dos ambientes analisados: a primeira, que trata dos melhores desempenhos (avaliação positiva) e a segunda, com destaque para os espaços interiores que obtiveram as piores classificações de desempenho (avaliação negativa).

Com relação ao processo de diagnóstico e às recomendações dos estudos de caso, apresentados no final deste capítulo, estarão centrados nos resultados provindos dos índices de desempenho satisfatório (conceitos mais elevados) e dos quesitos de desempenho insuficiente (conceitos mais baixos). Será possível compor uma visão geral de todos os itens significativos, tantos positivos como negativos dos elementos componentes dos ambientes construídos escolhidos, objetivando assim, propor um plano de intervenções, ou seja, de curto, médio e longo prazo.

Portanto, à luz das exposições das informações relatadas anteriormente, apresentam-se a seguir, os diagnósticos relativos aos estudos de caso, contendo, os Mapas de Descobertas, os Quadros de Sínteses, os Gráficos de Avaliação e o Rol de Intervenções.

\subsection{Diagnóstico da Biblioteca da Unesp/Marília}

Utilizando o critério das maiores e menores percentuais, constadas por meio do Gráfico 34 e do Mapa de Descobertas (Anexos 07, 08 e 09) os resultados relacionados à Biblioteca da Unesp/Marília foram os seguintes:

1) - Itens com desempenho insuficiente (do menor para o maior):

- Quantidade e tamanho dos sanitários;

- Ar-condicionado;

- Acesso e adaptação do deficiente;

○ Conservação do mobiliário;

○ Temperatura;

- Largura e localização das escadas e corredores;

○ Iluminação artificial;

- Tecnologia da informação e comunicação

- Arquivos, estantes e armários;

- Segurança;

○ Iluminação natural. 
2) - Itens com desempenho satisfatório:

- Altura e dimensionamento das mesas nas áreas de trabalho;

○ Privacidade e comunicação;

○ Armazenamento de uso comum;

- Altura e à disposição dos equipamentos de informática;

- Sinalização interna da biblioteca;

- Áreas destinadas ao armazenamento no acervo;

○ Umidade;

- Espaço para encontros e contatos informais;

- Altura e tipos de regulagens das cadeiras. 
Quadro 17 - Síntese da avaliação de satisfação nas áreas do Mapa de Descoberta pavimento térreo - Biblioteca Unesp/Marília

\begin{tabular}{|c|c|c|c|c|c|c|c|c|c|c|}
\hline \multicolumn{11}{|c|}{ ITENS AVALIADOS } \\
\hline 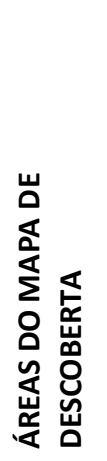 & 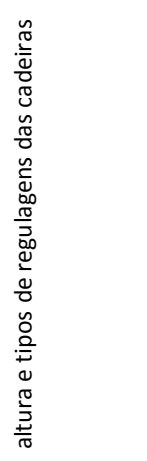 & 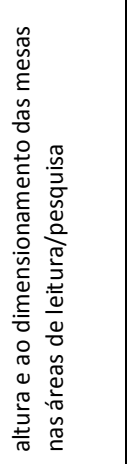 & 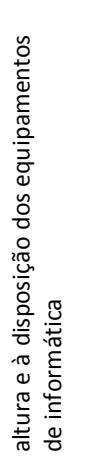 & 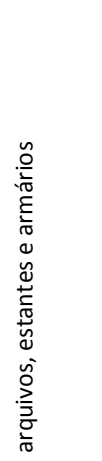 & 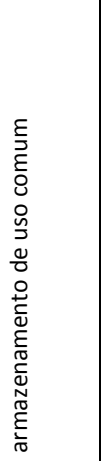 & 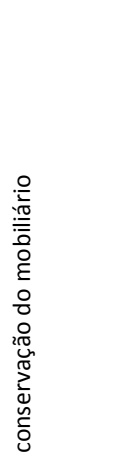 & 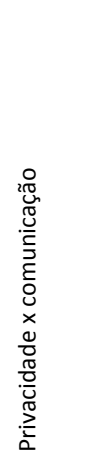 & 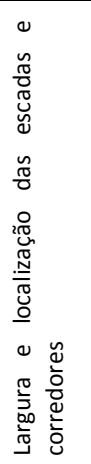 & 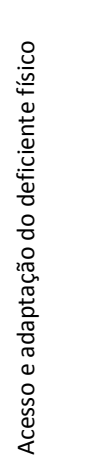 & 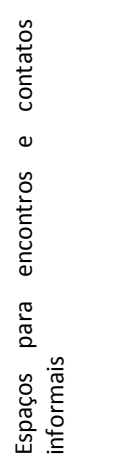 \\
\hline \multicolumn{11}{|l|}{ MD01 } \\
\hline \multicolumn{11}{|l|}{ MD02 } \\
\hline \multicolumn{11}{|l|}{ MD03 } \\
\hline \multicolumn{11}{|l|}{ MD04 } \\
\hline \multicolumn{11}{|l|}{ MD05 } \\
\hline \multicolumn{11}{|l|}{ MD06 } \\
\hline \multicolumn{11}{|l|}{ MD07 } \\
\hline \multicolumn{11}{|l|}{ MD08 } \\
\hline \multicolumn{11}{|l|}{ MD09 } \\
\hline \multicolumn{11}{|l|}{ MD10 } \\
\hline \multicolumn{11}{|l|}{ MD11 } \\
\hline \multirow{2}{*}{$\begin{array}{l}\text { Total } \\
\text { Avaliação } \\
\text { Positiva/ } \\
\text { Percentua } \\
\text { I }\end{array}$} & 8 & 6 & 8 & 5 & 6 & 3 & 6 & 4 & 1 & 9 \\
\hline & $72 \%$ & $54 \%$ & $72 \%$ & $45 \%$ & $54 \%$ & $27 \%$ & $54 \%$ & $36 \%$ & $9 \%$ & $81 \%$ \\
\hline \multirow{3}{*}{$\begin{array}{l}\text { Total } \\
\text { Avaliação } \\
\text { Negativa/ } \\
\text { Percentua } \\
\text { I } \\
\end{array}$} & 3 & 5 & 3 & 6 & 5 & 8 & 5 & 7 & 10 & 2 \\
\hline & $28 \%$ & $46 \%$ & $28 \%$ & $55 \%$ & $46 \%$ & $73 \%$ & $46 \%$ & $64 \%$ & $91 \%$ & $19 \%$ \\
\hline & \multicolumn{3}{|c|}{ Avaliação Negativa } & \multicolumn{7}{|c|}{ Avaliação Positiva } \\
\hline
\end{tabular}


Quadro 18 - Síntese da avaliação de satisfação nas áreas do Mapa de Descoberta pavimento térreo - Biblioteca Unesp/Marília

\begin{tabular}{|c|c|c|c|c|c|c|c|c|c|c|}
\hline & & & & ITENS & IVALIAD & & & & & \\
\hline 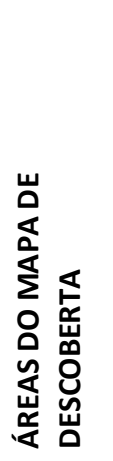 & 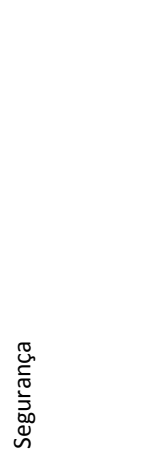 & $\begin{array}{l}0 \\
\frac{0}{0} \\
\frac{0}{0} \\
\frac{0}{0} \\
\frac{0}{0} \\
\frac{0}{0} \\
\frac{1}{4} \\
\end{array}$ & 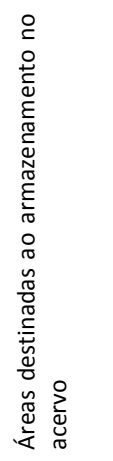 & 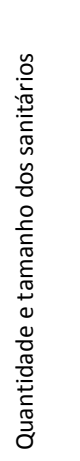 & 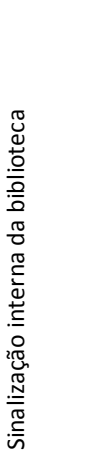 & 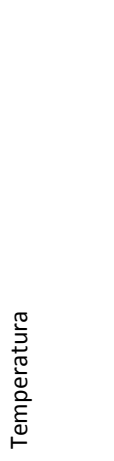 & $\begin{array}{l}\frac{0}{0} \\
\frac{\pi}{0} \\
\frac{0}{5} \\
\frac{0}{5}\end{array}$ & 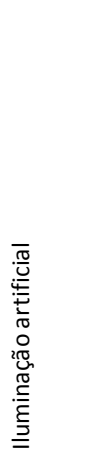 & 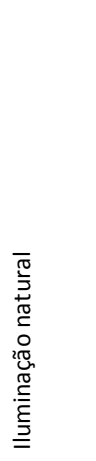 & 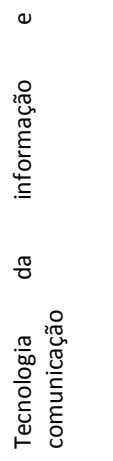 \\
\hline MD01 & & & & & & & & & & \\
\hline MD02 & & & & & & & & & & \\
\hline MD03 & & & & & & & & & & \\
\hline MD04 & & & & & & & & & & \\
\hline MD05 & & & & & & & & & & \\
\hline MD06 & & & & & & & & & & \\
\hline MD07 & & & & & & & & & & \\
\hline MD08 & & & & & & & & & & \\
\hline MD09 & & & & & & & & & & \\
\hline MD10 & & & & & & & & & & \\
\hline MD11 & & & & & & & & & & \\
\hline $\begin{array}{l}\text { Total } \\
\text { Avaliação }\end{array}$ & 5 & 2 & 7 & 1 & 7 & 3 & 8 & 4 & 5 & 5 \\
\hline $\begin{array}{l}\text { Percentua } \\
\text { I }\end{array}$ & $45 \%$ & $18 \%$ & $63 \%$ & $9 \%$ & $63 \%$ & $27 \%$ & $72 \%$ & $36 \%$ & $45 \%$ & $45 \%$ \\
\hline Total & 6 & 9 & 4 & 10 & 4 & 8 & 3 & 7 & 6 & 6 \\
\hline $\begin{array}{l}\text { Avaliação } \\
\text { Negativa/ } \\
\text { Percentua } \\
\text { I }\end{array}$ & $55 \%$ & $82 \%$ & $37 \%$ & $91 \%$ & $37 \%$ & $73 \%$ & $28 \%$ & $64 \%$ & $55 \%$ & $55 \%$ \\
\hline & Avaliação & gativa & & ção P & & & & & & \\
\hline
\end{tabular}


Quadro 19 - Síntese - avaliação de satisfação nas áreas do Mapa de Descoberta pavimento inferior - Biblioteca Unesp/Marília

\begin{tabular}{|c|c|c|c|c|c|c|c|c|c|c|}
\hline \multicolumn{11}{|c|}{ ITENS AVALIADOS } \\
\hline 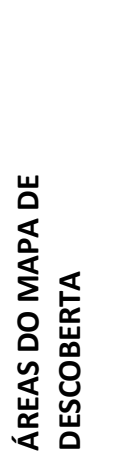 & 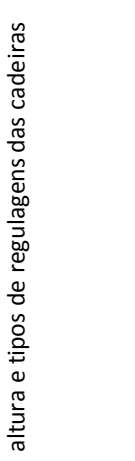 & 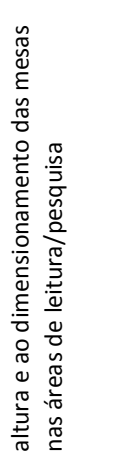 & 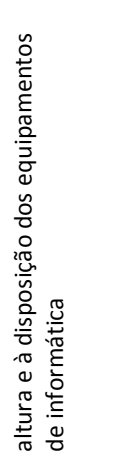 & 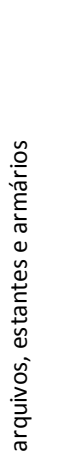 & 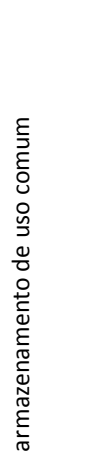 & 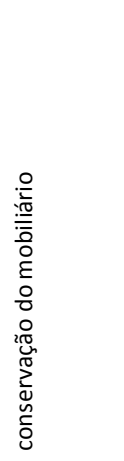 & 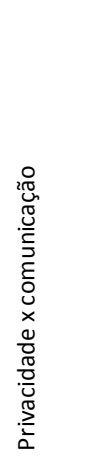 & 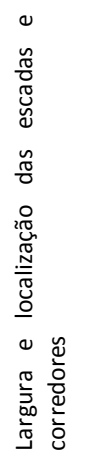 & 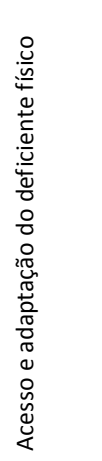 & 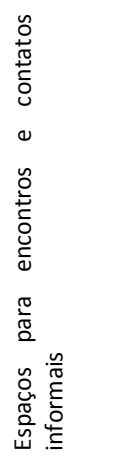 \\
\hline \multicolumn{11}{|l|}{ MD01 } \\
\hline \multicolumn{11}{|l|}{ MD02 } \\
\hline \multicolumn{11}{|l|}{ MD03 } \\
\hline \multicolumn{11}{|l|}{ MD04 } \\
\hline \multicolumn{11}{|l|}{ MD05 } \\
\hline \multicolumn{11}{|l|}{ MD06 } \\
\hline \multicolumn{11}{|l|}{ MD07 } \\
\hline \multicolumn{11}{|l|}{ MD08 } \\
\hline $\begin{array}{l}\text { Total } \\
\text { Avaliação } \\
\text { Positiva/ }\end{array}$ & 6 & 5 & 5 & 3 & 2 & 1 & 5 & 1 & 1 & 6 \\
\hline $\begin{array}{l}\text { Percentua } \\
\text { I }\end{array}$ & $77 \%$ & $55 \%$ & $55 \%$ & $33 \%$ & $33 \%$ & $11 \%$ & $55 \%$ & $11 \%$ & $22 \%$ & $66 \%$ \\
\hline Total & 2 & 3 & 3 & 5 & 6 & 7 & 3 & 7 & 7 & 2 \\
\hline $\begin{array}{l}\text { Avaliação } \\
\text { Negativa/ } \\
\text { Percentua } \\
\text { I }\end{array}$ & $23 \%$ & $45 \%$ & $45 \%$ & $67 \%$ & $67 \%$ & $89 \%$ & $45 \%$ & $89 \%$ & $78 \%$ & $34 \%$ \\
\hline
\end{tabular}


Quadro 20 - Síntese - avaliação de satisfação nas áreas do Mapa de Descoberta pavimento inferior - Biblioteca Unesp/Marília

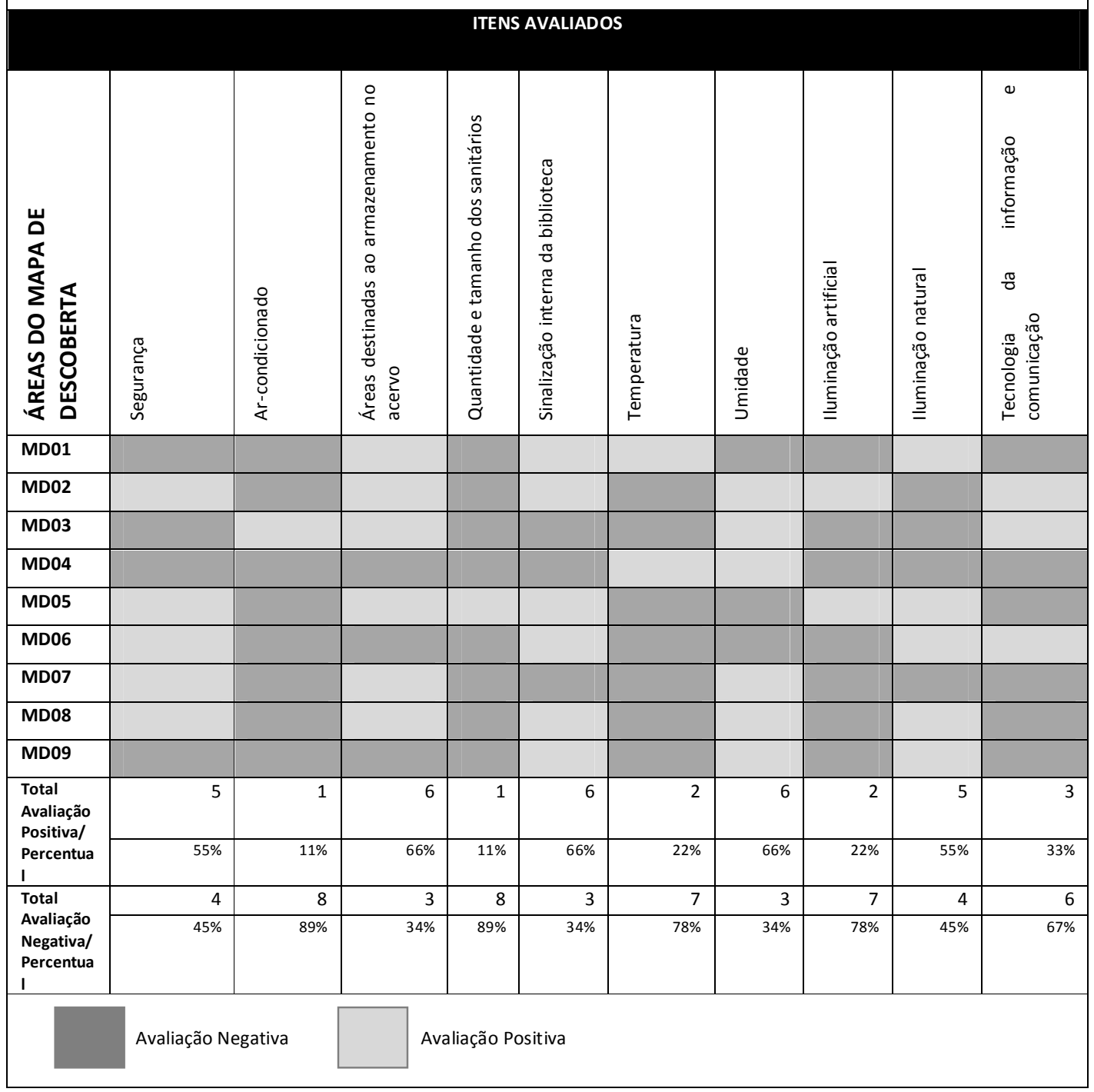




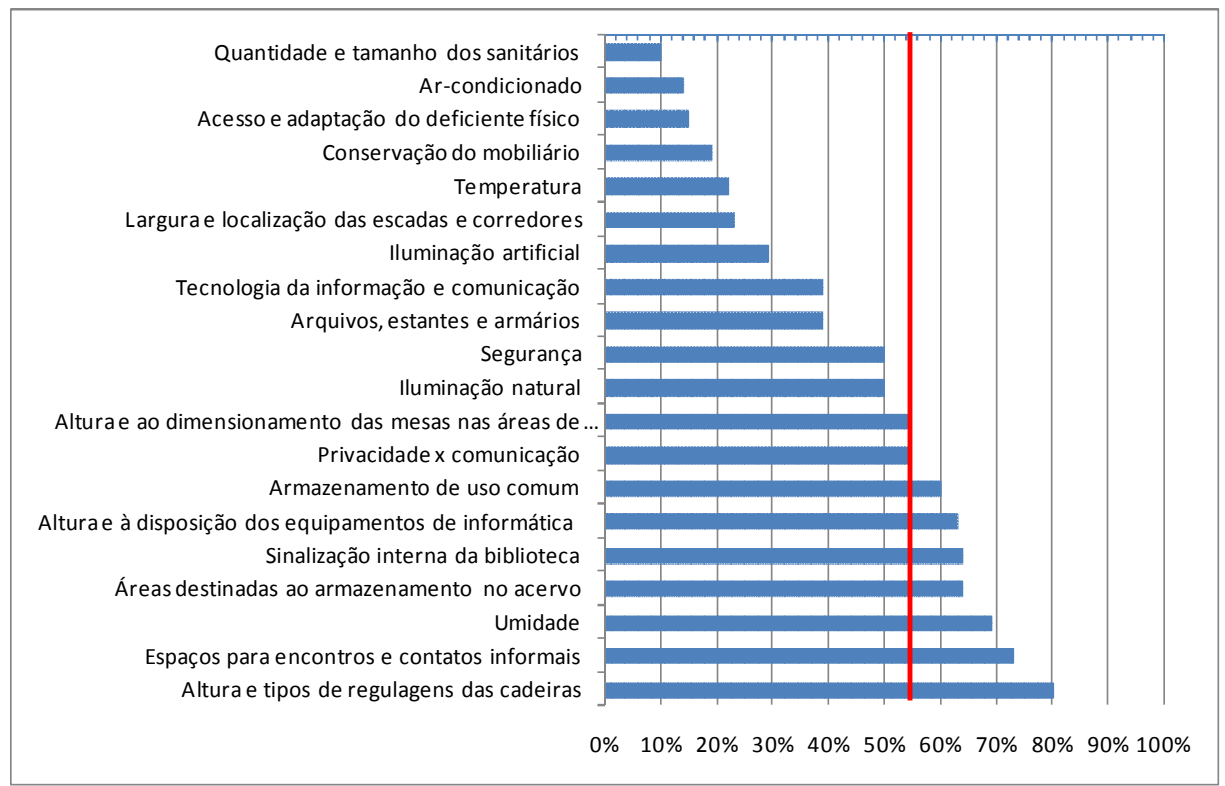

Gráfico 34 - Avaliação técnica e dos usuários das áreas do Mapa de Descobertas - Biblioteca Unesp/Marília

\subsection{Recomendações para Biblioteca da Unesp/Marília}

As recomendações para Biblioteca da Unesp/Marília, como foi explanado anteriormente, estão centradas nos dados coletados pelos diversos instrumentos utilizados na pesquisa, provindas das avaliações de desempenho físico e das percepções dos usuários. Como muitas das recomendações já foram sugeridas nos tópicos do capítulo anterior, quando da apresentação dos resultados da análise funcional, estas sugestões encontram-se listadas no Quadro 20 que se segue, apontando as principais deficiências encontradas e possíveis recomendações para saná-las, além de um plano de intervenções de curto, médio e longo prazo. Com relação aos prazos e considerando uma análise custo-benefício, estimou-se: intervençõe que apresentam custos elevados devem ser implementadas a longo prazo, 3 a 5 anos; intervenções a médio prazo de 1 a 2 anos; e como curto prazo, intervenções a serem executadas em um período de 6 meses a 1 ano; 


\begin{tabular}{|c|c|c|}
\hline \multicolumn{3}{|c|}{ Quadro 21- Recomendações - Biblioteca Unesp/Marília } \\
\hline PROBLEMA & RECOMENDAÇÕES & $\begin{array}{l}\text { NÍVEL DE } \\
\text { INTERVENÇÃO }\end{array}$ \\
\hline 1. Quantidade e tamanho dos sanitários & \multirow{2}{*}{$\begin{array}{l}\text { Construção de novas instalações sanitárias, } \\
\text { atendendo às exigências da norma. }\end{array}$} & \multirow[t]{2}{*}{ Longo prazo } \\
\hline $\begin{array}{l}\text { Sub-dimensionamento na quantidade de } \\
\text { sanitários nos dois pavimentos, fora das } \\
\text { normas do Código Sanitário do Estado de São } \\
\text { Paulo (1998). }\end{array}$ & & \\
\hline 2.Ar-condicionado & \multirow{2}{*}{$\begin{array}{l}\text { Melhorar o monitoramento, por parte dos } \\
\text { funcionários, das variações de temperatura } \\
\text { e umidade relativa, nas áreas do acervo e } \\
\text { nos ambientes de leitura e pesquisa e } \\
\text { isolamento acústico do sistema. }\end{array}$} & \multirow[t]{2}{*}{ Curto prazo } \\
\hline $\begin{array}{l}\text { Constantes interrupções de utilização do } \\
\text { sistema de ar-condicionado, reclamações } \\
\text { sobre a qualidade do ar em determinados } \\
\text { ambientes, ausência de circulação de ar em } \\
\text { determinados ambientes e desconforto do } \\
\text { ruído de fundo proveniente do equipamento. }\end{array}$ & & \\
\hline 3.Acesso e adaptação do deficiente & \multirow{3}{*}{$\begin{array}{l}\text { Realizar um amplo processo de } \\
\text { reestruturação junto ao ambiente da } \\
\text { biblioteca no sentido de se resolver os } \\
\text { problemas decorrentes da falta de } \\
\text { adequação às condições de acesso e } \\
\text { adaptação do deficiente físico. }\end{array}$} & \multirow{3}{*}{$\begin{array}{l}\text { Médio e longo } \\
\text { prazo }\end{array}$} \\
\hline $\begin{array}{l}\text { Inexistência de rampa e elevador para o } \\
\text { acesso ao mezanino, escadas não estão com } \\
\text { sinalização tátil, corrimãos não estão } \\
\text { adequados à norma*, sanitários não estão } \\
\text { adaptados ao padrão da norma*, larguras } \\
\text { entre as estantes fora da norma* vigente, } \\
\text { balcão de atendimento e bebedouros não } \\
\text { atendem a altura mínima exigida pela norma*, } \\
\text { determinados corredores não respeito os } \\
\text { valores mínimos da norma. * }\end{array}$ & & \\
\hline *NBR 9050/2004 & & \\
\hline 4.Conservação do mobiliário & \multirow{2}{*}{$\begin{array}{l}\text { Realizar a troca do mobiliário danificado, } \\
\text { evitando assim possíveis danos na } \\
\text { preservação do acervo bibliográfico e } \\
\text { padronização dos móveis. }\end{array}$} & \multirow[t]{2}{*}{ Médio prazo } \\
\hline $\begin{array}{l}\text { Mobiliário com problemas de desgaste e falta } \\
\text { de padronização. }\end{array}$ & & \\
\hline 5.Temperatura & \multirow{2}{*}{$\begin{array}{l}\text { Ajustar o sistema de ar-condicionado com } \\
\text { o objetivo de atender as áreas mais } \\
\text { prejudicadas; melhorar a circulação de ar } \\
\text { entre laje e telha, obstruída pela } \\
\text { platibanda e prover mais vegetação. }\end{array}$} & \multirow[t]{2}{*}{ Curto prazo } \\
\hline $\begin{array}{l}\text { Áreas de desconforto nos setores próximos } \\
\text { aos banheiros e nos ambientes da face oeste } \\
\text { (período da tarde). }\end{array}$ & & \\
\hline
\end{tabular}


Continuação

\begin{tabular}{|c|c|c|}
\hline $\begin{array}{l}\text { 6.Largura e localização das escadas e } \\
\text { corredores }\end{array}$ & \multirow{2}{*}{$\begin{array}{l}\text { Ajustar as distâncias entre as estantes do } \\
\text { acervo; adequar a largura da saída de } \\
\text { emergência localizada no pavimento } \\
\text { inferior; promover um rearranjo das } \\
\text { estantes com o objetivo de melhorar } \\
\text { aproveitamento dos percentuais de } \\
\text { ocupação das circulações. }\end{array}$} & \multirow[t]{2}{*}{ Curto prazo } \\
\hline $\begin{array}{l}\text { Largura entre estantes não segue um padrão } \\
\text { específico, registrando valores de } 0,70 \mathrm{~m} \text {, } \\
\text { outros de } 0,60 \mathrm{~m} \text { e outros de } 0,85 \mathrm{~m} \text {; saída de } \\
\text { emergência localizada do pavimento inferior } \\
\text { da biblioteca de } 0,90 \mathrm{~m} \text {, abaixo do que } \\
\text { determina a norma vigente; perdas e } \\
\text { desajustes nas percentagens de ocupação das } \\
\text { circulações. }\end{array}$ & & \\
\hline 7.Iluminação artificial & \multirow[b]{2}{*}{$\begin{array}{l}\text { Ajustar aos parâmetros da norma NBR } \\
5413 / 1992 \text {, juntamente com a confecção } \\
\text { de um projeto de instalação elétrica, com } \\
\text { objetivo de trazer qualidade nos } \\
\text { ambientes, tanto para os usuários bem } \\
\text { como para o acervo armazenado. }\end{array}$} & \multirow[t]{2}{*}{ Curto prazo } \\
\hline $\begin{array}{l}\text { Algumas luminárias existentes apresentam } \\
\text { desempenho luminoso aquém do esperado, } \\
\text { como também a intensidade de iluminação em } \\
\text { determinados locais não está totalmente } \\
\text { compatível; sala de internet do pavimento } \\
\text { térreo com incidência direta da iluminação } \\
\text { artificial proporciona o ofuscamento. }\end{array}$ & & \\
\hline $\begin{array}{l}\text { 8.Tecnologia da informação e } \\
\text { comunicação }\end{array}$ & \multirow{2}{*}{$\begin{array}{l}\text { Rever quantidades, layouts e padrões } \\
\text { computacionais; planejar e prever o } \\
\text { aumento da demanda no setor } \\
\text { computacional; instalar modernos } \\
\text { equipamentos informacionais e } \\
\text { comunicacionais; destinar mais ambientes } \\
\text { à infra-estrutura de tecnologia da } \\
\text { informação. }\end{array}$} & \multirow[t]{2}{*}{ Longo prazo } \\
\hline $\begin{array}{l}\text { Problemas relacionados à disposição, } \\
\text { quantificação e atualização dos equipamentos } \\
\text { de informática, falta de instrumentação } \\
\text { específica ao usuário para lidar com as novas } \\
\text { tecnologias informacionais, erros no } \\
\text { gerenciamento ligados às questões de } \\
\text { planejamento estratégico e financeiro da } \\
\text { instituição e ausência do planejamento } \\
\text { arquitetônico nas áreas direcionadas às } \\
\text { tecnologias informacionais e comunicacionais. }\end{array}$ & & \\
\hline 9.Arquivos, estantes e armários & \multirow[b]{2}{*}{$\begin{array}{l}\text { Averiguar a freqüência, a utilização, a } \\
\text { manipulação e as exigências do acervo } \\
\text { bibliográfico, em conjunto com o partido } \\
\text { arquitetônico do edifício, no sentido de } \\
\text { formatar possível aumento ou a proposta } \\
\text { da construção de um novo prédio. }\end{array}$} & \multirow[t]{2}{*}{ Longo prazo } \\
\hline $\begin{array}{l}\text { Capacidade da área destinada ao acervo } \\
\text { bibliográfico está lotada; restrição no espaço } \\
\text { físico para aumento do acervo; problemas } \\
\text { relacionados de alturas e larguras entre as } \\
\text { estantes. }\end{array}$ & & \\
\hline 10.Segurança & Incluir diretrizes de prevenção e de & Médio prazo \\
\hline
\end{tabular}


Continuação

\begin{tabular}{|c|c|c|}
\hline $\begin{array}{l}\text { Incompatibilidades relacionadas às normas de } \\
\text { segurança: "estrangulamento" dos corredores } \\
\text { do acervo bibliográfico; rotas de fuga } \\
\text { obstruídas por armários; inexistência de } \\
\text { alarmes sonoros e luminosos; inexistência de } \\
\text { chuveiros automáticos (sprinklers), não } \\
\text { observância quanto ao mínimo de saídas de } \\
\text { emergência. }\end{array}$ & $\begin{array}{l}\text { extinção do incêndio, principalmente nos } \\
\text { ambientes de rápida propagação de fogo } \\
\text { do acervo; implantar de saídas de } \\
\text { emergência e chuveiros automáticos } \\
\text { (sprinklers). }\end{array}$ & \\
\hline 11.Iluminação natural & \multirow{2}{*}{$\begin{array}{l}\text { Trocar os materiais de acabamento com } \\
\text { cores de tonalidades escuras, evitando os } \\
\text { baixos níveis iluminamento; mudar o } \\
\text { posicionamento dos computadores na área } \\
\text { de consulta, evitando o ofuscamento. }\end{array}$} & \multirow[t]{2}{*}{ Médio prazo } \\
\hline $\begin{array}{l}\text { Existência de reflexos indesejados nos } \\
\text { monitores de vídeo na área de Base de } \\
\text { Dados/Internet; quantidade iluminação } \\
\text { natural não é suficientemente capaz de chegar } \\
\text { às áreas centrais de leitura/pesquisa. }\end{array}$ & & \\
\hline
\end{tabular}

\subsection{Diagnóstico da Biblioteca do Senac/Santo Amaro}

Analisando o Gráfico 35, Mapa de Descobertas (Anexos 10, 11 e 12) e utilizando o critério das maiores e menores médias, é possível extrair os seguintes resultados relacionados à Biblioteca do Senac/Santo Amaro:

1)- Itens com desempenho insuficiente (do menor para o maior):

○ Ar-condicionado;

○ Temperatura.

2)- Itens com desempenho satisfatório (do menor para o maior):

○ Armazenamento de uso comum;

○ Umidade;

○ Largura e localização das escadas e corredores;

○ Sinalização interna da biblioteca;

○ Espaço para encontros e contatos informais;

- Altura e dimensionamento das mesas nas áreas de trabalho;

○ Iluminação natural;

- Áreas destinadas ao armazenamento no acervo;

○ Iluminação artificial;

○ Arquivos, estantes e armários; 
○ Privacidade e comunicação;

○ Altura e à disposição dos equipamentos de informática;

- Acesso e adaptação do deficiente;

- Altura e tipos de regulagens das cadeiras.

○ Conservação do mobiliário;

- Tecnologia da informação e comunicação

○ Segurança;

○ Quantidade e tamanho dos sanitários;

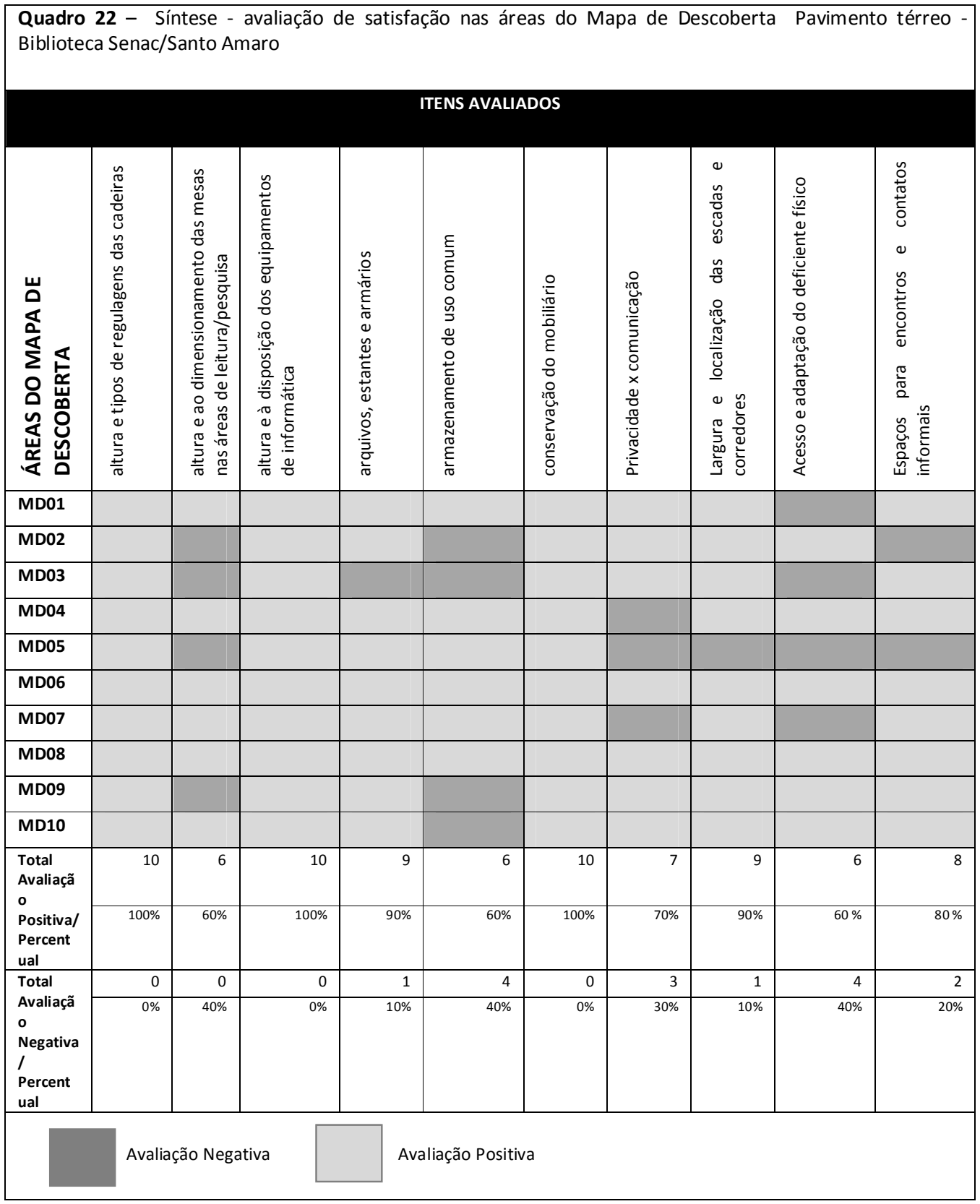


Quadro 23 - Síntese - avaliação de satisfação nas áreas do Mapa de Descoberta Pavimento térreo Biblioteca Senac/Santo Amaro

\begin{tabular}{|c|c|c|c|c|c|c|c|c|c|c|}
\hline \multicolumn{11}{|c|}{ ITENS AVALIADOS } \\
\hline 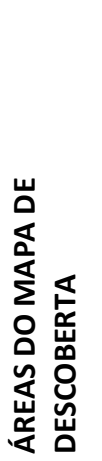 & 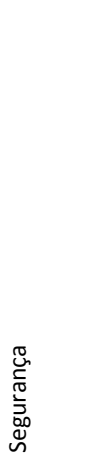 & 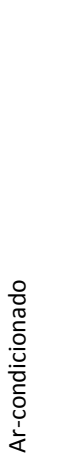 & 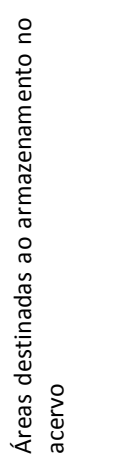 & 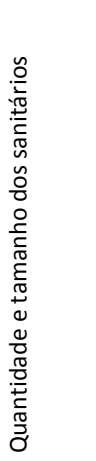 & 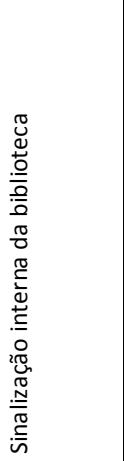 & 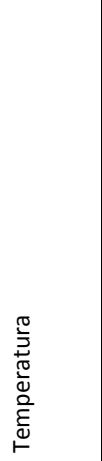 & $\begin{array}{l}\frac{0}{8} \\
\frac{\pi}{0} \\
\frac{0}{\xi}\end{array}$ & 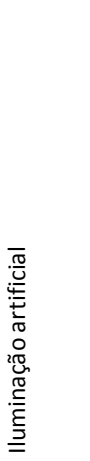 & 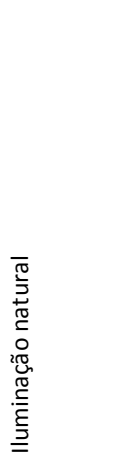 & 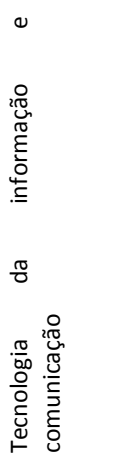 \\
\hline \multicolumn{11}{|l|}{ MD01 } \\
\hline \multicolumn{11}{|l|}{ MD02 } \\
\hline \multicolumn{11}{|l|}{ MD03 } \\
\hline \multicolumn{11}{|l|}{ MD04 } \\
\hline \multicolumn{11}{|l|}{ MD05 } \\
\hline \multicolumn{11}{|l|}{ MD06 } \\
\hline \multicolumn{11}{|l|}{ MD07 } \\
\hline \multicolumn{11}{|l|}{ MD08 } \\
\hline \multicolumn{11}{|l|}{ MD09 } \\
\hline \multicolumn{11}{|l|}{ MD10 } \\
\hline \multirow{2}{*}{$\begin{array}{l}\text { Total } \\
\text { Avaliaçã } \\
\text { o } \\
\text { Positiva/ } \\
\text { Percent } \\
\text { ual } \\
\end{array}$} & 10 & 6 & 8 & 10 & 7 & 5 & 5 & 8 & 9 & 10 \\
\hline & $100 \%$ & $60 \%$ & $80 \%$ & $100 \%$ & $70 \%$ & $50 \%$ & $5 \%$ & $80 \%$ & $90 \%$ & $100 \%$ \\
\hline \multirow[b]{2}{*}{$\begin{array}{l}\text { Total } \\
\text { Avaliaçã } \\
\text { o } \\
\text { Negativa } \\
\text { / } \\
\text { Percent } \\
\text { ual } \\
\end{array}$} & 0 & 4 & 2 & 0 & 3 & 5 & 5 & 2 & 1 & 0 \\
\hline & $0 \%$ & $40 \%$ & $20 \%$ & $0 \%$ & $30 \%$ & $50 \%$ & $50 \%$ & $20 \%$ & $10 \%$ & $0 \%$ \\
\hline & Avalia & 10 & & & liação Positi & & & & & \\
\hline
\end{tabular}




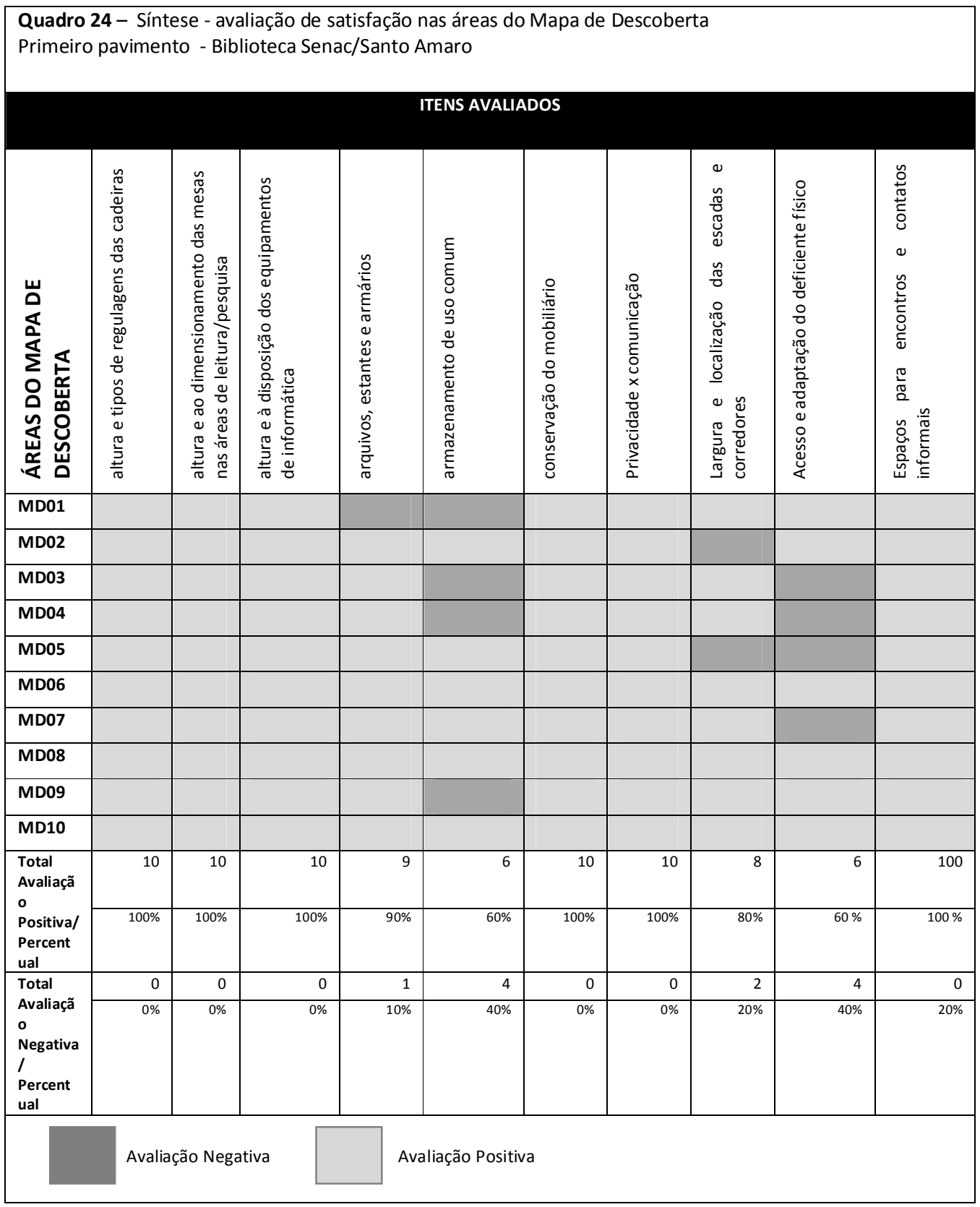




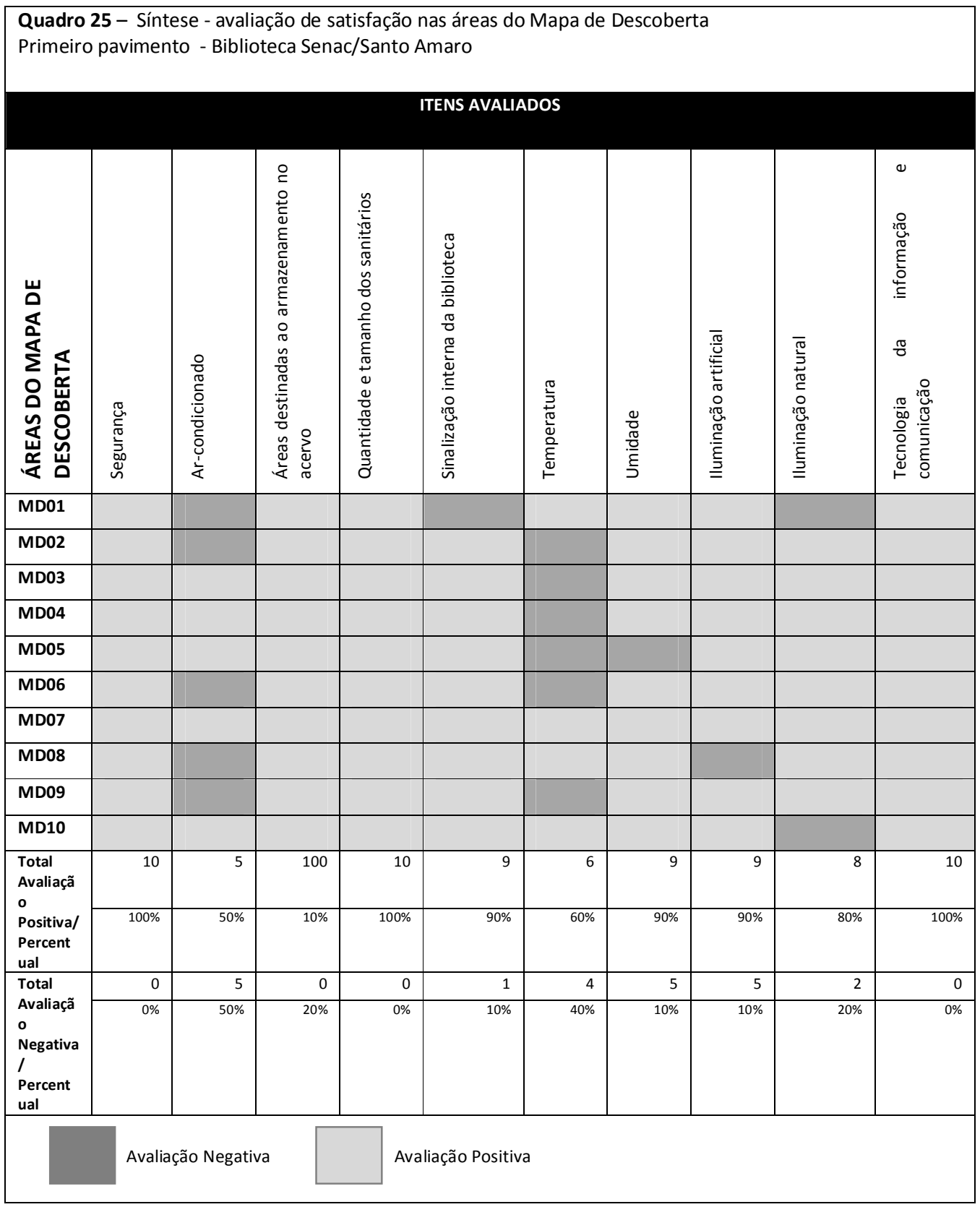


Quadro 26 - Síntese - avaliação de satisfação nas áreas do Mapa de Descoberta Segundo pavimento - Biblioteca Senac/Santo Amaro

\begin{tabular}{|c|c|c|c|c|c|c|c|c|c|c|}
\hline \multicolumn{11}{|c|}{ ITENS AVALIADOS } \\
\hline 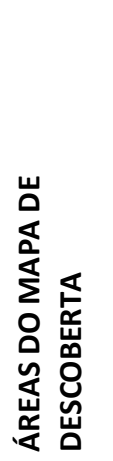 & 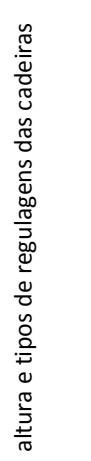 & 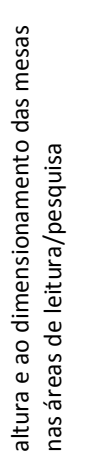 & 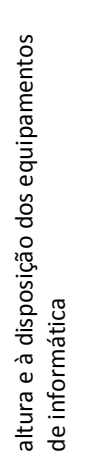 & 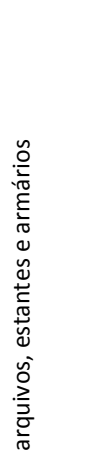 & 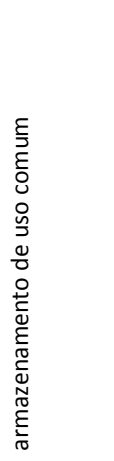 & 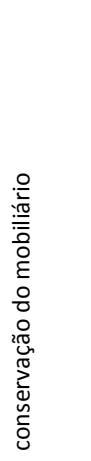 & 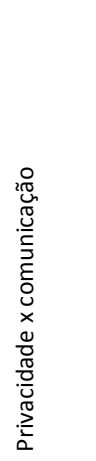 & 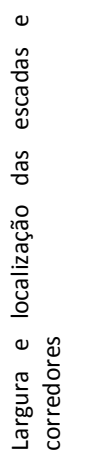 & 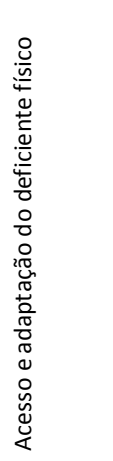 & 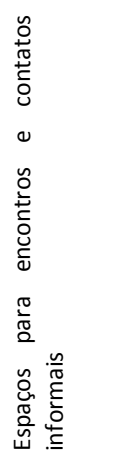 \\
\hline \multicolumn{11}{|l|}{ MD01 } \\
\hline \multicolumn{11}{|l|}{ MD02 } \\
\hline \multicolumn{11}{|l|}{ MD03 } \\
\hline \multicolumn{11}{|l|}{ MD04 } \\
\hline \multicolumn{11}{|l|}{ MD05 } \\
\hline \multicolumn{11}{|l|}{ MD06 } \\
\hline \multicolumn{11}{|l|}{ MD07 } \\
\hline \multicolumn{11}{|l|}{ MD08 } \\
\hline \multirow{2}{*}{$\begin{array}{l}\text { Total } \\
\text { Avaliação } \\
\text { Positiva/ } \\
\text { Percentua } \\
\text { I }\end{array}$} & 8 & 5 & 7 & 8 & 6 & 8 & 5 & 7 & 6 & 7 \\
\hline & $100 \%$ & $62 \%$ & $87 \%$ & $90 \%$ & $75 \%$ & $100 \%$ & $62 \%$ & $87 \%$ & $75 \%$ & $87 \%$ \\
\hline \multirow{2}{*}{$\begin{array}{l}\text { Total } \\
\text { Avaliação } \\
\text { Negativa/ } \\
\text { Percentua } \\
\text { I }\end{array}$} & 0 & 3 & 1 & 1 & 2 & 0 & 3 & 1 & 2 & 1 \\
\hline & $0 \%$ & $38 \%$ & $13 \%$ & $10 \%$ & $25 \%$ & $0 \%$ & $38 \%$ & $13 \%$ & $25 \%$ & $13 \%$ \\
\hline & Avali & Negat & & & iação Posi & & & & & \\
\hline
\end{tabular}


Quadro 27 - Síntese - avaliação de satisfação nas áreas do Mapa de Descoberta Segundo pavimento - Biblioteca Senac/Santo Amaro

\begin{tabular}{|c|c|c|c|c|c|c|c|c|c|c|}
\hline \multicolumn{11}{|c|}{ ITENS AVALIADOS } \\
\hline 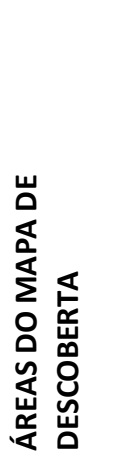 & 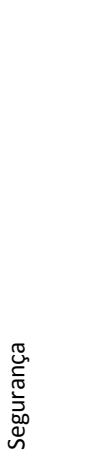 & $\begin{array}{l}\frac{0}{0} \\
\overline{0} \\
\frac{0}{0} \\
\frac{0}{0} \\
\frac{0}{0} \\
\frac{0}{0} \\
\frac{1}{4}\end{array}$ & 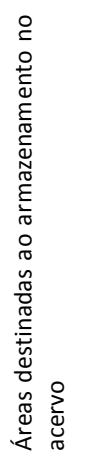 & 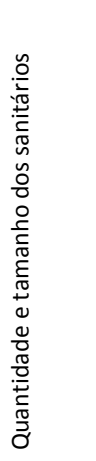 & 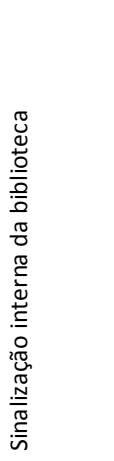 & 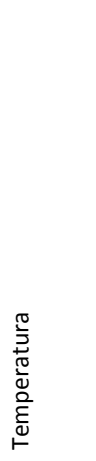 & $\begin{array}{l}\frac{0}{0} \\
\frac{\pi}{0} \\
\frac{0}{5}\end{array}$ & 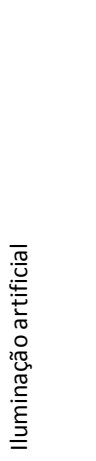 & 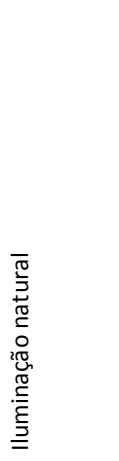 & 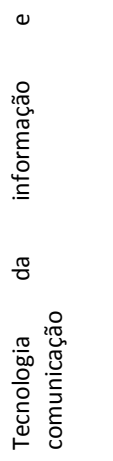 \\
\hline \multicolumn{11}{|l|}{ MD01 } \\
\hline \multicolumn{11}{|l|}{ MD02 } \\
\hline \multicolumn{11}{|l|}{ MD03 } \\
\hline \multicolumn{11}{|l|}{ MD04 } \\
\hline \multicolumn{11}{|l|}{ MD05 } \\
\hline \multicolumn{11}{|l|}{ MD06 } \\
\hline \multicolumn{11}{|l|}{ MD07 } \\
\hline \multicolumn{11}{|l|}{ MD08 } \\
\hline \multirow{2}{*}{$\begin{array}{l}\text { Total } \\
\text { Avaliação } \\
\text { Positiva/ } \\
\text { Percentua } \\
\text { I }\end{array}$} & 8 & 2 & 8 & 8 & 7 & 3 & 8 & 6 & 7 & 8 \\
\hline & $100 \%$ & $25 \%$ & $100 \%$ & $100 \%$ & $87 \%$ & $38 \%$ & $100 \%$ & $75 \%$ & $87 \%$ & $100 \%$ \\
\hline \multirow{3}{*}{$\begin{array}{l}\text { Total } \\
\text { Avaliação } \\
\text { Negativa/ } \\
\text { Percentua } \\
\text { I } \\
\end{array}$} & 0 & 6 & 0 & 0 & 1 & 5 & 5 & 2 & 1 & 0 \\
\hline & $0 \%$ & $75 \%$ & $0 \%$ & $0 \%$ & $13 \%$ & $62 \%$ & $10 \%$ & $25 \%$ & $13 \%$ & $0 \%$ \\
\hline & \multicolumn{3}{|c|}{ Avaliação Negativa } & Avalia & o Positiva & & & & & \\
\hline
\end{tabular}




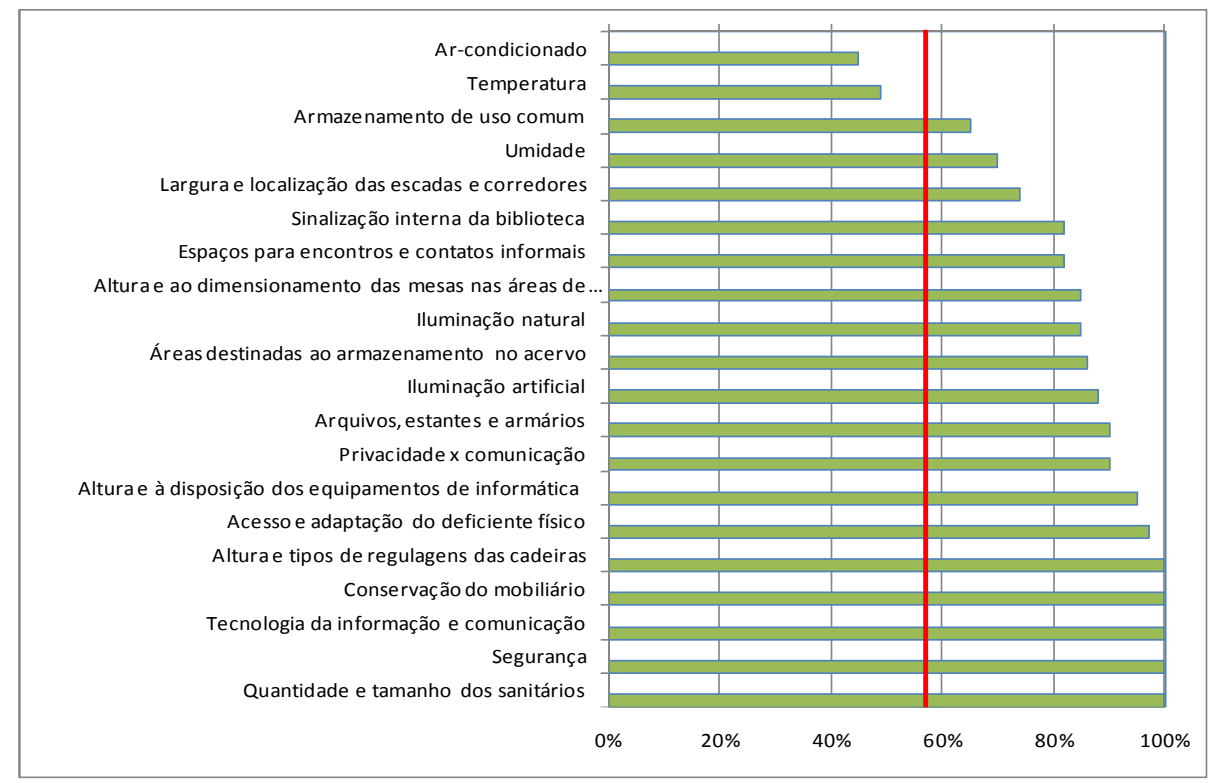

Gráfico 35 - Avaliação técnica e dos usuários das áreas do Mapa de Descobertas - Biblioteca Unesp/Marília

\subsection{Recomendações da Biblioteca do Senac/Santo Amaro}

Como no caso da Biblioteca da Unesp/Marília, as recomendações direcionadas à Biblioteca do Senac/Santo Amaro embasam-se nos dados coletados pelos diversos instrumentos utilizados na pesquisa, provindas das avaliações técnicas e das percepções dos usuários. Neste item, as recomendações sugeridas encontram-se listadas em forma de resumo na tabela que se segue, vislumbrando as principais deficiências detectadas e as possíveis recomendações a serem executadas, além do plano de intervenções de curto, médio e longo prazo.

\begin{tabular}{|c|c|c|}
\hline \multicolumn{3}{|c|}{ Quadro 28 - Recomendações - Biblioteca Senac/Santo Amaro } \\
\hline PROBLEMA & RECOMENDAÇÕES & $\begin{array}{l}\text { NÍVEL DE } \\
\text { INTERVENÇÃO }\end{array}$ \\
\hline 1.Ar-condicionado & \multirow{2}{*}{$\begin{array}{l}\text { Melhorar o monitoramento, por parte dos } \\
\text { funcionários, das variações de temperatura } \\
\text { e umidade relativa nos ambientes de } \\
\text { leitura e pesquisa }\end{array}$} & \multirow[t]{2}{*}{ Curto prazo } \\
\hline $\begin{array}{l}\text { Reclamações pontuais sobre a qualidade do ar } \\
\text { em determinados ambientes, ausência de } \\
\text { circulação de ar em determinados ambientes. }\end{array}$ & & \\
\hline 2.Temperatura & Ajustar o sistema de ar-condicionado com & Curto prazo \\
\hline
\end{tabular}




\begin{tabular}{|l|l|l|}
\hline Áreas de desconforto nos setores próximos a & $\begin{array}{l}\text { o objetivo de atender as áreas mais } \\
\text { sala de reprografia, nas escadas }\end{array}$ & $\begin{array}{l}\text { prejicadas; melhorar a circulação de ar } \\
\text { entre laje e telha, obstruída pela } \\
\text { enclausuradas. }\end{array}$ \\
platibanda e prover mais vegetação. & & \\
& & \\
\hline
\end{tabular}

Continuação 


\section{CAPÍTULO 11 - CONSIDERAÇÕES FINAIS E RECOMENDAÇÕES}

A pesquisa tem como foco a forma com que a arquitetura tem se relacionado com a questão da biblioteca universitária no contexto brasileiro, identificando suas intervenções, potencialidades e espacialidades. Ao mesmo tempo, busca uma melhor compreensão dos problemas relacionados à formulação de diretrizes para futuros projetos e possíveis camimhos desses ambientes no âmbito nacional. A avaliação do processo deu-se pela utilização de instrumentos que por meio de análises comparativas de exemplos nacionais e internacionais e estudos de caso, explicitam quais aspectos devem direcionar um plano de realinhamento e reposicionamento nas operações dos projetos de bibliotecas universitárias.

A estruturação da hípotese da pesquisa baseia-se no fato de que, por meio da avaliação do ambiente construído de bibliotecas universitárias, é possível determinar prováveis caminhos aos projetos arquitetônicos destes edifícios no contexto brasileiro, propondo e recomendando diretrizes ligadas às questões funcionais e comportamentais. As análises e as considerações feitas a seguir desmonstram de que forma a hipótese foi verificada.

Reafirma-se que a utilização de avaliações sistêmicas (estudos de caso) podem colaborar significativamente na instrumentação necessária para realimentação no processo de produção e uso de futuros ambientes de bibliotecas universitárias. Além da exploração dos métodos de avaliação do ambiente construído, para aferir as necessidades dos usuários quanto a problemas relacionados aos fatores comportamentais e funcionais, a pesquisa leva em consideração os aspectos que envolvem os contextos internacionais e nacionais da produção do espaço em bibliotecas universitárias. Ou seja, a proposta da pesquisa procura fixar também em sua frente de trabalho mais duas linhas de investigação, entendendo que a formação de uma base conceitual relevante ao tema, com emprego de análises comparativas, gera elementos suficientes para o esclarecimento da hipótese e os resultados e diagnósticos dos casos estudados. 


\title{
10.1 Quanto ao contexto internacional
}

\begin{abstract}
Mesmo considerando o universo das bibliotecas universitárias, internacionais com variações e contextos significativamente diferentes, os levantamentos realizados permitem demonstrar que, independente do tipo ou da área de conhecimento científico atendida, os espaços de bibliotecas universitárias internacionais têm focado suas atividades a dois grandes setores: o referencial e o cultural (LEMOS \&
\end{abstract} MACEDO, 2001). O primeiro setor, o referencial, tem disponibilizado informação estratégica, segura e precisa, a usuários e a instituições especializados nas áreas atendidas, para responder questões informacionais relevantes para o avanço do conhecimento. Tem realizado um amplo e apurado processo de disseminação da informação no âmbito da pesquisa, ensino e tecnologia (GREEN, 1993; BERNHARD, \& BRETON, 1994; CARVALHO, 1998; ALPHEN, F, 1998; CUNHA, 2007). Por outro lado, o setor cultural tem promovido e dado continuidade às atividades culturais, gerando produtos e serviços informacionais para o grande público. Neste caso, as atividades tem contribuído para o fortalecimento da identidade cultural das unidades universitárias, por meio do estímulo e da divulgação de diferentes formas de expressão artística local, regional e nacional (TOH, 1995; COOKE, 2001; GOMES, 2001; RIBENBOIM, 2001).

Em contrapartida, não somente os aspectos organizacionais desses edifícios têm trilhado novos caminhos, mas justamente as diretrizes arquitetônicas desses ambientes têm refletido rápidas e profundas transformações. Na maioria dos casos, o partido arquitetônico tem adotado a informação como elemento gerador dos espaços e dos ambientes construídos, além de responder às diversas exigências das atividades ligadas ao contexto dos produtos referencias e culturais. Neste caso, a metáfora da informação é apresentada como interativa e transformadora, reforçando a idéia de que os espaços devem ser constituídos com fluidez e permeabilidade, além de buscar em suas formas, transparência e flexibilidade. Ao mesmo tempo, os ambientes têm incorporado duas tipologias básicas: a primeira, relaciona-se aos espaços direcionados a atender às informações referenciais, gerando localizações mais "restritivas" e "fechadas", ou seja, tem permitido aos usuários destes setores maior privacidade nas ações executadas; a segunda, a tipologia dos espaços vinculados aos setores culturais, priorizados pela facilidade de acessibilidade aos ambientes, a não 
existência de barreiras visuais e sensação de amplitude. (WEHRPLOTZ, CANDIDO; BONO; 2001; MORIS, 2006).

Ainda, com relação às análises efetuadas referentes à linguagem dos espaços internos das bibliotecas universitárias exemplificadas, os caminhos projetuais têm apontado alterações significativas como, por exemplo: (a) - a distribuição espacial e o posicionamento dos equipamentos informáticos têm procurado utilizar o mesmo conceito dos escritórios de trabalho corporativo, dispostos no sentido de procurar a facilidade da reconfiguração das "estações de trabalho" e uma nova personalização do espaço (CONNIE, 2001; ORCIUOLI, 2006); (b) - os aspectos ligados ao conforto do mobiliário têm previlegiado a ligação direta com a tecnologia e a produtividade, em que a ergonomia é fator imprescindível nas atividades desenvolvidas (GRAHAM, 2006); (c) - na área do conforto ambiental o bem-estar não está associado apenas ao aspecto físico (temperatura, umidade, ventilação, iluminação), mas também ao design, performace e consumo (arquitetura biosustentável) (MAMBRINI, 2001; DEAN, 2004); (d) - as inovações tecnológicas computacionais têm permitido a instalação, nos ambientes e nos espaços, um conjunto significativo de equipamentos informáticos (computadores, impressoras, acessórios e softwares), implementando uma complexa rede de serviços e produtos informacionais nas áreas de conhecimento atendidas (GASCUEL, 1993; PUACZ \& BRADFIELD, 2000).

As análises efetuadas apontam ainda uma importante vertente seguida pelas bibliotecas universitárias internacionais: a própria imagem do edifício em relação ao contexto urbano. As soluções adotadas, em função das relações estabelecidas entre o edifício e o universo urbano, desenvolvem-se a partir dos conceitos de compatibilidade, adaptabilidade, acessibilidade e ambiência arquitetônica. Ambientes lúdicos e cenográficos configuram não somente uma visão passiva em relação aos acervos bibliográficos, mas também desempenham uma postura participativa das atividades desenvolvidas, no tocante à relação entre o edifício e a cidade (MALINCONICO, 1992; HAYCOCK, 1992; GREEN, 1993; WEB, 2000).

Apesar das próprias restrições estabelecidas pela pesquisa, no que se refere à análise dos edifícios de bibliotecas universitárias internacionais, pode-se detectar uma importante mudança de paradigma em função da atuação destes ambientes na área da arquitetura. Esse redirecionamento pressupõe entender a biblioteca universitária vinculada ao conceito de espaço-facilitador, na qual fomenta a divulgação 
de conhecimentos e implanta serviços e produtos informacionais e culturais para a sociedade.

\subsection{Quanto ao contexto nacional}

As aproximações e as análises feitas, no contexto da pesquisa, a respeito da arquitetura de bibliotecas universitárias brasileiras procuraram elucidar tendências e possíveis modelos de propostas construtivas na área. Obviamente, a presença desse tema possibilita respostas muito esclareçedoras, não só na primeira fase do trabalho da pesquisa, como também importantes contribuições ao final da tese, para ser a principal problemática da pesquisa.

A dificuldade de se efetuar a análise desses aspectos reside no fato de que poucos programas arquitetônicos têm sofrido uma transformação tão intensa quanto os edifícios de bibliotecas universitárias no Brasil (MIRANDA, 1998). Além disso, os poucos estudos sistemáticos de projetos e modelos direcionados às bibliotecas universitárias no Brasil têm gerado a necessidade de se apontem novos caminhos na formulação de projetos destes edifícios, calcados no compromisso de serem coerentes com seus contextos e inseridos na realidade brasileira (CUNHA, 2007).

Entretanto, a pesquisa demostrou que dar respostas às novas perspectivas de projetos de bibliotecas universitárias, no Brasil, engloba diretrizes não só no campo da arquitetura como estudos comportamentais do ambiente construído, fatores do espaço arquitetônico e análises dos planos urbanísticos destas edificações, estendendose, ainda, aos aspectos ligados à área da ciência da informação e biblioteconomia, como por exemplo, o uso correto de políticas de desenvolvimento de coleções, identificação da clientela e análise fiel do contexto da unidade de ensino superior. Assim, pensar a produção arquitetônica dos edifícios de bibliotecas no âmbito universitário brasileiro exige outros olhares sobre as questões que envolvem o espaço contemporâneo.

Ao longo das primeiras observações e impressões efetuadas na pesquisa, o que tem caracterizado os exemplos analisados nos projetos de bibliotecas universitárias brasileiras é aceitação real do caráter plural e diversificado que os programas arquitetônicos vêm impondo às disciplinas projetuais ligadas à informação e comunicação e, por conseguinte, a dependência dos conteúdos culturais locais, inclusos nos processos de gestão, procedimentos, suportes e os distintos meios organizacionais (DODEBEI, 2006; CUNHA, 2007). Não é demais ressaltar que a compreensão do 
desenvolvimento de intervenções arquitetônicas dos edifícios de bibliotecas universitárias, no âmbito das cidades, envolve a discussão de novas formas de atuação no espaço urbano. Por outro lado, o tema da biblioteca universitária brasileira vem aos poucos ocupando um importante papel nos processos de desenvolvimento de projetos e nas pesquisas em arquitetura e urbanismo, discutindo e reavaliando a qualidade desses ambientes e oferecendo timidamente, instrumentos sistematizados para esses futuros edifícios.

No contexto da pesquisa, no processo de entendimento e de elucidação das possíveis diretrizes para os ambientes de bibliotecas universitárias nacionais, as análises permitem compor um quadro sintético bastante relevante, explicitadas em três vertentes principais:

(a) - bibliotecas universitárias públicas/setorizadas de pequeno porte - edifícios que apostam em obras autônomas e inovadoras, incorporando soluções simples, materiais tradicionais /locais e programas arquitetônicos modestos, sem desqualificar o caráter dos acervos bibliográfico existentes;

(b) - bibliotecas universitárias privadas de grande porte - edifícios que expressam a força das instituições privadas universitárias na realidade brasileira, estipulando generosos programas arquitetônicos para esses ambientes e propondo uma arquitetura de "impacto" e "espetáculo" no âmbito espacial.

(c) - revitalizações destinadas às bibliotecas universitárias - projetos de revitalizações e adaptações em suas próprias sedes, reaproveitando e incorporando estruturas locais existentes, ompatibilizando novos programas aos espaços.

A partir das análises das bibliotecas universitárias no Brasil no contexto arquitetônico, associadas as características das três vertentes destes edifícios, detectados e mostrados anteriormente, é possível elucidar os seguintes pontos:

- $\quad$ Quanto aos aspectos das instalações e do planejamento arquitetônico - é perceptível o resgate, por parte de administradores e de gestores da área de bibliotecas universitárias, do planejamento arquitetônico desses locais, como forma de garantir e de adaptá-los às novas e constantes demandas dos programas informacionais. Os principais problemas enfrentados são derivados da insuficiência de instalações e dos espaços físicos destinados ao armazenamento de acervos bibliográficos, bem como, no provimento dos serviços direcionados aos seus usuários. (AUGOSTINHO, 1987; MIRANDA, 1998; FIALHO, 2000). 
- Quanto ao espaço arquitetônico - apesar de existirem bons edifícios de bibliotecas universitárias projetadas especificamente para este fim, em muitos casos a realidade tem apontado ambientes despreparados em relação aos aspectos vinculados ao armazenamento de coleções, o acesso, o uso, o direcionamento de fluxos serviços, dentre outros (RIBENBOIM, 2001).

- Quanto aos aspectos perceptivos - os estudos do espaço perceptivo e as análises da percepção ambiental, quando aplicados no processo projetual dos edifícios de bibliotecas universitárias, mostram-se adequados para o fornecimento de subsídios concretos de territorialidade, privacidade, identidade e ambiência (MOORE, 1984).

- Quanto ao crescimento do número de usuários - tanto das organizações privadas quanto das instituições públicas no setor educacional, muitos edifícios de bibliotecas não estão preparados para receber um contingente tão grande de pessoas (RUSSO, 1998; LEMOS \& MACEDO, 2001; OLIVEIRA, 2006).

- Quanto à organização do acervo informacional - o estabelecimento de equipes multidiciplinares nos contextos da arquitetura, da ciência da informação e da biblioteconomia com o objetivo de aprimorar e entender todo o processo de organização do acervo informacional de catalogação, indexação e disseminação da informação, começa a ganhar força no contexto dos novos projetos de bibliotecas universitárias ou das propostas de reforma e requalificação desses edifícios (DIAS, 1994; OLIVEIRA, 2006).

- Quanto às parcerias institucionais - os convênios estão localizados em todas as esferas da sociedade - federal, estadual e municipal - e objetivam dar apoio e suporte aos serviços de localização, seleção, tratamento e disponibilidade da informação, bem como a definição de estratégias de investimentos no universo da pesquisa (CUNHA, 2007).

\subsection{Quanto à aplicação da APO}

O entendimento da problemática da arquitetura da biblioteca universitária no âmbito nacional e a formulação de diretrizes para os futuros projetos destes ambientes, englobam além da abordagem nacional e internacional descritas anteriormente, a aplicação dos métodos da APO do ambiente construído, para aferir as 
necessidades dos usuários relacionados aos fatores comportamentais e funcionais (SILVER \& NICKEL, 2002; ENRIGHT , 2002; ROMÉRO \& ORNSTEIN, 2003; LACKNEYL \& ZAJFEN, 2005; SANNWALD, 2006; PROBE, 2006). O processo analítico do tema da pesquisa, lançando mão, primeiramente, de uma abordagem macro dos casos de bibliotecas univesitárias internacionais; na seqüência, um olhar focado nos exemplos nacionais destes edifícios e, finalmente, uma visão micro com recorte de dois estudo de caso, demonstra a necessidade de uma visão mais clara sobre o problema. A colocação desse encaminhamento evidencia uma análise que busca compreender, dentro das respostas (ou na ausência delas), um maior entendimento sobre a real importância de vários aspetos tratados nesta pesquisa

Os procedimentos metodológicos, utilizados durante a APO nos dois estudos de caso - na Biblioteca do Senac/Santo Amaro e na Biblioteca da Unesp/Marília, mostraram-se adequados aos objetivos da pesquisa. Contudo, como uma das intenções é fornecer uma visão estruturada de conhecimentos e estudos referentes ao aprimoramento dos métodos e das ferramentas aplicados às bibliotecas universitárias, são relacionadas, a seguir, observações referentes a cada etapa da pesquisa nos estudos de caso:

(1) - Quanto à aplicação dos questionários:

- na redução da quantidade total das questões, passando de 75 originais para 61 perguntas no final da pesquisa, restringindo-a somente aos elementos estritamente relacionados ao objeto do trabalho - aspectos funcionais das bibliotecas universitárias - conseguiu-se diminuir o tempo de preenchimento numa ordem bastante considerável;

- algumas perguntas relacionadas aos aspectos técnicos, as quais poderiam trazer respostas dúbias ou dificuldades no entendimento das informações, foram eliminadas ou substituídas com o objetivo de facilitar a interpretação e aumentar a confiabilidade das respostas;

- a necessidade de um questionário enxuto, implicou em questões não fossem detalhadas, como por exemplo, os fatores relacionados aos equipamentos informáticos, tipo de ar-condicionado, tipos de armários, entre outros;

- como alguns dos questionários na Biblioteca do Senac/Santo Amaro não foram distribuídos especificamente nos ambientes das bibliotecas 
analisadas, mas sim junto ao extrato de professores localizados nos departamentos de graduação e pós-graduação das unidades de ensino dos dois estudos de caso, a ausência de contato entre o pesquisador e o respondente foi limitador e reduziu certa confiabilidade das respostas;

- no caso específico da Biblioteca da Unesp/Marília, a distribuição do questionário e o aproveitamento das respostas foram mais produtivos, pelo fato de este pesquisador atuar diretamente no grupo de pesquisa "Unidades de Informação", vinculado ao programa de pós-graduação do curso de Biblioteconomia do campus o que possibilitou o acompanhamento sucessivo junto aos professores envolvidos na pesquisa;

- dentre os três extratos de população existentes no edifício da Biblioteca do Senac/Santo Amaro, aquele que apresentou maiores dificuldades de aplicação dos questionários e retorno do mesmo foi o grupo de alunos. Embora todos eles apresentassem grande disponibilidade e vontade de cooperação nas atividades da pesquisa, estavam entrando no período de férias escolares, o que acarretou certa descontinuidade nos trabalhos da pesquisa. Entretanto, no contexto do trabalho e no percentual dos extratos levantados junto aos usuários, esses pequenos desajustes não prejudicaram os resultados finais das avaliações;

(2) - Quanto aos grupos focais:

- Este instrumento apresenta vantagem realmente comprovada nos dois estudos de caso, decorrente da forma fluida e interativa estabelecida entre os componentes dos grupos;

- Somente no caso da Biblioteca do Senac/Santo Amaro, a ausência de alguns participantes (extrato de professores), em razão do pouco tempo disponível, limitou a abrangência da avaliação dos ambientes deste edifício.

(3) - Quanto à ocupação física, dos procedimentos das vistorías e das medições:

- Todos esses procedimentos se mostram eficientes, na medida em que fornecem subsídios importantes para o entendimento das avaliações efetuadas após os resultados de cada caso; 
(4) - Quanto à utilização dos parâmetros técnicos:

- Os parâmetros utilizados como referência nos ambientes dos estudos de caso, abrangendo os aspectos funcionais - mobiliário, tipo de mesa e cadeira, distância entre a circulação e privacidade no posto de trabalho assim como aspectos do conforto ambiental - temperatura, umidade, ventilação, iluminação natural e artificial, depois, dimensionamentos mínimos, arranjo espacial, sinalização interna e acessibilidade e por último, tecnologias da informação, podem ser utilizados não somente para os objetivos específicos desta pesquisa, mas também como suporte de desenvolvimento à formulação de diretrizes para futuros projetos e possíveis camimhos da construção de bibliotecas universitárias brasileiras.

(5) - Quanto à utilização do mapa de descobertas:

- Os procedimentos associados aos levantamentos fotográficos, às informações colhidas no local, às plantas gráficas dos edifícios escolhidos e à percepção dos usuários, agrupados numa seqüência de tópicos e de observações, servem como um importante insumo para a compreensão dos resultados da avaliação. Além disso, a aplicação deste instrumento mostrou-se bastante positiva pela busca da síntese e da construção de uma comunicação mais fluida entre os agentes envolvidos no processo de análise e encaminhamento das propostas desta pesquisa. Ressalta-se a visualização e a apreensão de códigos, imagens e textos, de forma sintetizada, utilizadas no contexto de uma APO, podem ser fundamentais na síntese dos levantamentos e dos diagnósticos parciais ou completos, auxiliando na determinação dos principais itens a serem priorizados nas recomendações.

As recomendações específicas por estudo de caso, apresentadas no capítulo anterior, visam elencar um rol de intervenções baseado nos resultados provindos dos índices de desempenho satisfatório (conceitos mais elevados) e dos quesitos de desempenho insuficiente (conceitos mais baixos). No final, é possível compor uma visão geral dos itens significativos, tantos positivos como negativos dos elementos componentes dos ambientes construídos escolhidos, objetivando assim, propor um plano de intervenções de curto, médio e longo prazos. Além disso, outros 
aspectos vinculados aos ambientes das bibliotecas universitárias analisadas merecem proposições de intervenções com o objetivo de minimizar agravantes relacionadas aos elementos funcionais como conforto ambiental, mobiliários, dimensionamentos, ergonomia, tecnologia da informação, acessibilidade, segurança, entre outros (ver Capítulo 9). Entretanto, conclusões sobre os estudos de caso podem reforçar não só aspectos pontuais, mas também construir um primeiro panorama geral à respeito dos elementos funcionais analisados, no caso, os da arquitetura de bibliotecas universitárias brasileiras. A seguir, relacionam-se as principais conclusões dos estudos de caso:

\section{- Dos aspectos funcionais:}

- layouts e medidas do mobiliário: do ponto de vista do usuário, o mobiliário atende às suas necessidades. Alguns comentários negativos e baixos índices de satisfação estão associados não à falta de ajustes ou tipologias de mesas e cadeiras, mas sim, ao tamanho da estação de trabalho e à sensação de se estar exposto em um espaço de passagem ou em corredores devassados. Especialmente na Biblioteca do Senac/Santo Amaro é possível concluir que as diversas atividades desenvolvidas nos ambientes, tanto aquelas direcionadas à pesquisa e à leitura, que exigem alto grau de concentração dos usuários, quanto aquelas que identificam a interação com os diversos indivíduos, guardam relação estreita entre as condições dos layouts e medidas do mobiliário e o bem-estar no ambiente de trabalho. Neste caso, como esses itens estão adequados e suficientes, o trabalho tende a ser mais produtivo. A questão do mobiliário das estantes da Biblioteca da Unesp/Marília merece ser melhor estudada, visando a minimizar três problemas básicos: a capacidade limite da área destinada ao acervo bibliográfico, o estado precário de conservação do mobiliário e a altura das bancadas do mobiliário na consulta on-line que está fora da norma vigente. Conclui-se que é urgente a averiguação da freqüência, da utilização e da manipulação do acervo, com o objetivo de planejar um possível aumento ou a proposta da construção de um novo prédio. A troca do mobiliário também é necessária, com o intuito de fixar um programa de padronização. E, finalmente, a altura do mobiliário que atende os serviços de consulta "on-line" deve ser adequada à norma estabelecida (ver Capítulo 9). Por outro lado, a Biblioteca do Senac/Santo Amaro destaca-se pela inovação e melhoria no sistema de comunicação visual das estantes, determinante dos bons resultados alcançados nas avaliações junto aos usuários. 
- Dos aspectos do conforto ambiental: - iluminação natural: como esse quesito é considerado um dos principais fatores de qualidade em ambientes de bibliotecas, a iluminação deve ser utilizada com critérios bem ajustados à norma vigente, possibilitando maior aproveitamento da luz natural e equilíbrio de incidência de iluminação nas coleções do acervo, evitando deterioração do material bibliográfico. Neste caso, dois pontos negativos foram detectados na Biblioteca da Unesp/Marília e necessitariam ser ajustados: reflexos indesejáveis nos monitores na área de Base de Dados on-line e quantidade insuficiente de iluminação natural nos ambientes centrais de leitura e de pesquisa. Na Biblioteca do Senac/Santo Amaro, o principal destaque são os brises metálicos instalados nas aberturas das janelas, que possibilitam o controle da incidência solar ao longo das quatro estações do ano; além disso, o sistema minimizou os efeitos indesejáveis da luz solar direta sobre os planos de trabalho (por exemplo, com o ofuscamento); - iluminação artificial: há necessidade de um melhor acompanhamento do projeto de luminotécnica, visando a controlar não só a correta intensidade, mas a qualidade de iluminação nos ambientes, principalmente nos casos apontados de reflexos ocasionados pela iluminação artificial, tanto nas áreas de pesquisa e leitura como nos setores do acervo bibliográfico. Essa situação é verificada prioritariamente na Biblioteca da Unesp/Marília, necessitando de intervenções para a solução dos problemas. Vale destacar que o tipo de luminária instalada na Biblioteca do Senac/Santo Amaro, por ser embutida no forro termo-acústico e formar um desenho modular no teto, foi a que apresentou melhor condição de conforto visual; - arcondicionado e temperatura: uma atenção especial deve ser dada nos dois estudos de caso. Primeiro, a execução de monitoramento e balanceamento do sistema, de forma que o ar se distribua uniformemente em todos os ambientes das bibliotecas. Além disso, esses ajustes podem acarretar maior economia no funcionamento do sistema de climatização e aumento da qualidade do ar interno. Ainda com relação à melhoria da qualidade de temperatura nos ambientes, deve ser considerada a possibilidade de se utilizarem sistemas naturais de circulação de ar, instalados entre a laje e a telha, sem prejudicar o desempenho do ar-condicionado.

- Dos aspectos de dimensionamentos mínimos, de arranjo espacial, de sinalização interna e de acessibilidade:

- acesso e adaptação do deficiente: ajustes devem ser efetuados na Biblioteca da Unesp/Marília, com o objetivo de realizar amplo processo de reestruturação e garantia 
de adequação das larguras dos corredores de todos os ambientes do edifício, altura dos equipamentos e mobiliários, espaços de manobra adequados, sanitários adaptados de acordo com o estabelecido pela norma NBR - 9050/2004 e sinalizações indicativas. Nos dois estudos de casos da pesquisa, os balcões de atendimento adaptados também devem receber ajustes à norma. Todos os ambientes pertencentes à Biblioteca do Senac/Santo, Amaro sob a ótica da acessibilidade e da adaptabilidade ao deficiente físico, estão sendo utilizados de maneira autônoma e segura; - largura e localização das escadas e corredores: na Biblioteca da Unesp/Marília os desajustes nas larguras mínimas e na localização das estantes do acervo são plenamente percebidos pelos usuários e comprovados nos índices de insatisfação. Tais aspectos estão intrinsicamente relacionados com a falta de planejamento arquitetônico e o desalinhamento entre a direção da biblioteca e a equipe técnica projetiva, evidenciando impactos negativos: insatisfação, perda da qualidade espacial e ineficiência da área destinada ao acervo bibliográfico. Sugere-se que as larguras entre as estantes do acervo principal sejam ajustadas à distância mínima de $90 \mathrm{~cm}$, conforme determina a norma vigente, promovendo um rearranjo na distribuição das estantes para que haja um melhor aproveitamento dos percentuais de ocupação das circulações; - segurança: em virtude dos resultados encontrados nas vistorias técnicas e nas considerações apontadas pelos usuários a respeito dos problemas relacionados à segurança (como "estrangulamentos" nos corredores, rotas de fuga fora da norma vigente e quantidade inferior de saídas de emergência), devem-se incluir, nos ambientes da Biblioteca da Unesp/Marília, diretrizes gerais de prevenção e extinção de incêndio adequados à norma. As recomendações específicas vinculadas à segurança devem ser implementadas não só neste estudo de caso, mas também em todo o contexto de bibliotecas universitárias, que é o foco da pesquisa, com a meta de evitar acúmulo muito grande de papel o que oferece a rápida combustão e propagação de fogo. No caso específico da Biblioteca do Senac/Santo, percebe-se que o sistema de circulação desempenha papel estratégico no funcionamento dos componentes de distribuição dos ambientes e evita, em certa medida, situações de circulações tortuosas e desperdício da comunicação dos usuários nos espaços; - quantidade e tamanho dos sanitários: no caso da Biblioteca da Unesp/Marília, a instituição deve reestruturar totalmente os quesitos relacionados à quantidade e ao tamanho dos sanitários, com o objetivo de atender às necessidades de seus usuários, bem como cumprir o que estabelece a lei, garantindo ambientes adequados para o livre funcionamento, inclusive no que se refere aos procedimentos de 
acesso às pessoas portadoras de deficiência de locomoção. Já na Biblioteca do Senac/Santo Amaro dois elementos influenciaram positivamente nas respostas dos usuários: primeiro, os sanitários são bem dimensionados, atendendo à legislação e, segundo, foram executados com materiais de acabamento de primeira e, além disso, estão em bom estado de conservação; - aréas de armazenamento: sérios problemas foram encontrados nos setores de armazenamento da Biblioteca da Unesp/Marília, e em função disso, recomenda-se que seja operacionalizado um estudo detalhado com relação a este item, quantificando as necessidades dos funcionários quanto ao espaço, ao tipo de sistema e de política de armazenagem, além de análise na previsão de crescimento do acervo. Na Biblioteca do Senac/Santo Amaro, o principal destaque para este item é que conta com um espaço específico de armazenamento localizado em todos os pavimentos, cujo o objetivo é suprir e armazenar o constante acúmulo de papel.

- Dos aspectos da tecnologia da informação e comunicação:

- principalmente neste momento, quando se discute e se amplia a inclusão da informação digital, com a utilização de periódicos digitais, open archives (arquivos abertos), bibliotecas digitais, imagens digitalizadas, biblioteca interativa e multimídia, a biblioteca universitária é desafiada a prover novas estruturais informacionais e arranjos espaciais bem diferentes daqueles tradicionalmente arrolados pelo controle bibliográfico. No caso da Biblioteca do Senac/Santo Amaro, os aspectos relacionados, nesse quesito, indicaram que o ambiente está bem servido no que se refere às atividades informáticas. Por outro lado, a Biblioteca da Unesp/Marília apresentou um quadro diverso. Sugere-se que sejam revistas quantidades, layouts e padrões computacionais para ser possível prever e instalar modernos equipamentos com infra-estrutura ajustada nas áreas da informática, a fim de fornecer serviços direcionados às novas tecnologias comucionais.

\subsection{Considerações finais e diretrizes gerais para bibliotecas universitárias brasileiras}

Como demostrado anteriormente, os estudos de caso permitiram aprofundar as questões relacionadas aos ambientes de bibliotecas universitárias, bem como discutir os aspectos vinculados às necessidades dos usuários e seus desdobramentos junto às áreas comportamentais e funcionais, conforme as 
características de cada caso. Ou seja, durante o processo de avaliação de desempenho dos estudos de caso entre uma biblioteca central uma instituição privada e uma biblioteca central de uma universidade pública, o objetivo não era formatar um modelo comparativo entre as duas, mas sim explicitar quais eram os aspectos positivos ou negativos dos elementos elencados. Entretanto, no decorrer das avaliações, tanto da Biblioteca da Unesp/Marília quanto da Biblioteca do Senac/Santo Amaro, os resultados puderam trazer à tona duas realidades reveladoras e instigantes para os elementos conclusivos da pesquisa.

Em primeiro lugar é possível apontar uma característica importante encontrada no edifício da Biblioteca da Unesp/Marília e efetivamemente comprovada na fase das análises dos edifícios de bibliotecas universitárias no Brasil: a edificação enquadra-se em um modelo vinculado à uma grande universidade de gabarito elevado, incorporando soluções simples, materiais tradicionais /locais e programas arquitetônicos modestos, sem desqualificar o caráter dos acervos bibliográficos existentes. Neste caso, ela está preocupada em trabalhar a favor da realidade em que se insere, com o compromisso de ser coerente com esse contexto e moldada à realidade brasileira. Neste sentido, a biblioteca opera dentro de um universo arquitetônico bastante restrito economicamente, tendo por característica a sobriedade, a ausência de ornamentos e, principalmente, a utilização de materiais sem apelo estético. Como esse padrão é encontrado nos outros blocos de edificações do campus universitário e também nas outras unidades da rede Unesp, evidentemente a biblioteca acompanha as mesmas diretrizes projetuais e os mesmos conceitos de partido arquitetônico. No entanto, apesar das restrições e padronizações oferecidas, observa-se que é possível implementar experiências significativas no âmbito da construção de bibliotecas em universidades públicas e apontar novos caminhos para esses contextos. (ver Capítulo 3, Biblioteca do Instituto de Economia da Universidade Estadual de Campinas). O respeito aos prérequisitos impostos pelos programas arquitetônicos destas instituições, bem como a compatibilização coerente aos contextos econômicos, físicos e organizacionais podem produzir uma arquitetura madura, consciente e criativa, ou mais ainda, uma arquitetura que possa oferecer melhores possibilidades para esses espaços, por meio do estabelecimento de padrões, diretrizes e métodos de aferimento de confiabilidade.

Mesmo verificando inúmeras inadequações relacionadas aos fatores funcionais analisados na pesquisa, uma parcela significativa de usuárisos da Biblioteca da Unesp/Marília demostraram uma vinculação afetiva e de identidade com o edifício, 
apesar de não terem, necessariamente, uma visão clara sobre os problemas funcionais enfrentados pela construção. Além disso, mesmo tendo consciência dos problemas existentes, acreditam em uma solução de médio ou longo prazos e estariam dispostos a participar efetivamente no planejamento arquitetônico de uma ampliação ou na construção de uma nova biblioteca. Essa percepção revela a imagem positiva que o edifício desempenha no seio da comunidade local universitária, entendendo a biblioteca como a própria extensão do usuário, parte de sua individualidade, de suas escolhas e de seus valores. Ou seja, o que fica implícito neste processo é que, na maioria das vezes, para o usuário, a biblioteca tem respondido satisfatoriamente às expectativas no fornecimento de informação e conteúdos confiáveis, em detrimento de uma arquitetura que nem sempre está adequada às questões funcionais/técnicas, bem como, desprovida de soluções sofisticadas de volumes ou apurado tratamento estético de suas fachadas.

Algumas das diculdades encontradas referem-se à intrínseca relação entre o modelo organizacional adotado - centralizado ou descentralizado (FERREIRA, 1980; MERCADANTE, 1990; FIALHO, 2000) - o planejamento arquitetônico implementado. Mesmo que a pesquisa não tenha focado sua investigação na análise detalhada da adoção de sistemas centralizados ou descentralizados de bibliotecas universitárias brasileiras, o modelo centralizado adotado pela Biblioteca da Unesp/Marília tem interferido e bloqueado ações concretas no planejamento arquitetônico da edificação, como a flexibilização no espaço do acervo, aumento nas áreas de sanitários, resolução dos problemas de acessibilidade, entre outros. Deve-se ressaltar que o modelo centralizado implantado neste caso, incorpora uma política de ação governamental idealizada e concretizada no começo da década de 80, época da construção desta biblioteca. A corrente daqueles que apontam as vantagens na adoção do sistema de centralização em bibliotecas universitárias levam em conta, entre outras coisas, a melhoria na qualidade dos serviços, a oportunidade de se ter uma biblioteca completa, evitando a duplicação desnecessária de todo tipo de material bibliográfico com bibliotecas setoriais e o emprego racional dos recursos financeiros disponíveis na aquisição de novos títulos. Entretanto, mesmo que o assunto do sistema de organização de bibliotecas universitárias continue a ser apresentado e discutidom sem se chegar a um acordo, o certo é que, neste estudo de caso, o modelo demostrou sua ineficiência ao longo do anos. A explicação se deve, provavelmente, porque o projeto e o programa arquitetônico original da biblioteca deveria atender somente a quatro cursos de gradução da unidade universitária, ou seja, o edifício operaria num contexto reduzido e 
extremamente modesto. Vale lembrar, na fase inicial dos levantamentos da pesquisa, o projeto original da biblioteca deveria contar com a proposta de construção de dois blocos, sendo a primeira etapa entregue em novembro de 1980, constando com as instalações atuais, e a segunda fase, entregue na seqüência com a construção do segundo bloco, conforme a demanda do acervo aumentasse. Contudo, as mudanças ocorridas na estrutura administrativa da universidade, a falta de verba alegada pela direção e o descaso do Estado no tocante ao atendimento de políticas direcionadas à construção de bibliotecas universitárias, emperrou todo o processo de planejamento arquitetônico da biblioteca para que pudesse ser modificada no atendimento das novas necessidades.

Outra questão que se levanta na Biblioteca da Unesp/Marília é a convivência com problemas derivados da necessidade de instalações e áreas físicas suficientes tanto para armazenar os novos serviços informáticos (microcomputadores, internet, bases de dados) (GALBINSKI, 1993; MACIEL, 1995). Os novos mecanismos causaram profundo impacto no espaço da biblioteca e, de certa forma, a direção passou a observar com cuidado o que deveria ser feito para adaptar suas instalações às novas e constantes demandas. Esse fato se deve, principalmente, porque a direção geral da instituição compreendeu a necessidade urgente de se estabelecerem na rede de bibliotecas da Unesp, políticas de inclusção digital e modernos programas informacionais, não só aplicados aos acervos disponíveis, mas também em todos os setores das operações administrativas. Neste sentido, o processo de automação da biblioteca, prioritariamente nos últimos 8 anos, começou a experimentar dois desafios para o planejamento de seus ambientes: o primeiro relaciona-se com a própria configuração arquitetônica da edificação, projetada inicialmente para atender às necessidades de um espaço com poucos equipamentos ou sem os sistemas de informação e comunicação, redes elétricas e iluminação requeridos para dar suporte ao elementos informáticos. O segundo desafio é que essas instalações foram projetadas para serem utilizadas durante várias décadas sem grandes alterações. Portanto, paradoxalmente, o problema maior não reside tanto no montante de investimentos em tecnologia da informação para a biblioteca - verbas estatais e parcerias entre empresas privadas foram firmadas ao longo desses anos - mas no fato de os ambientes disponíveis serem insuficientes para abrigar os novos microcomputadores ou terminais necessários à automatização do catálogo ou o oferecimento de serviços informacionais.

Muitos dos problemas enfrentados hoje na Biblioteca da Unesp/Marilia, relacionados à ineficiência no uso do espaço, (por exemplo, áreas reduzidas nas estações 
de leitura e pesquisa, a má distribuição e o pouco espaço de circulação entre as estantes) demonstram tanto o desequilibrio na organização dos tipos de uso quanto a dificuldade de prover o acesso à totalidade da informação gerada pela explosão bibliográfica no contexto da biblioteca. Em decorrência dessa fato, a percepção do usuário no tocante aos espaços que lhe são ofertados na Biblioteca da Unesp/Marília é extremamente prejudicada, reforçando idéia de que a adoção de ambientes mais flúidos, flexíveis e espaçosos, poderiam representar uma das principais prerrogativas a serem utilizadas. Com relação a isso, vários entrevistados relataram a preferência que tem em destinar à consulta ao acervo bibliográfico ao próprio funcionário da biblioteca, ao invés de ele mesmo executar essa função nos corredores que dão acesso às estantes. De qualquer maneira, mesmo que haja uma crescente demanda pelo armazenamento em arquivos eletrônicos e divulgação dos trabalhos diretamente na internet, a biblioteca continuará incorporando materiais de diversificados à sua coleção física.

As análises e as avaliações efetuadas na Biblioteca do Senac/Santo Amaro permitem elaborar um quadro revelador e viável para facilitar a compreensão dos possíveis caminhos para a construção e adequação de ambientes de bibliotecas universitárias no âmbito nacional.

O primeiro fato constatado é que o edifício se enquadra nos modelos de bibliotecas universitárias privadas de grande porte, concebidos principalmente para serem edifícios que expressem a força das instituições privadas brasileiras, e pautadas em generosos programas arquitetônicos e uma arquitetura de "impacto" e "espetáculo" no âmbito espacial. Suas composições espaciais são calcadas na idéia da grande visibilidade, ou seja, a obra como evento ou como acontecimento único, em que a arquitetura é encarada como uma resposta específica, circunstancial e de expressão particularizada. Neste caso, a Biblioteca do Senac/Santo Amaro procura formatar um caminho inusitado nas formas de composição e implantação no campus, nos elementos contrastantes das fachadas, como cheios e vazios e na relação dinâmica entre cores e texturas. Nesta abordagem, o partido arquitetônico da biblioteca procura desmembrar e recompor formas, além de atender às exigências programáticas de vãos, janelas e aberturas. Por meio da decomposição de formas, obtém-se justamente a "continuidade espacial" referida anteriormente, pela interpenetração dos espaços e a supressão de qualquer hierarquia de planos. Finalmente, remetendo-se aos aspectos da própria concepção dos projetos de bibliotecas universitárias, o partido arquitetônico adotado apresenta a informação como elemento gerador dos espaços e dos ambientes utilizados. 
A metáfora da informação é apresentada como interativa e transformadora no âmbito da sociedade e é reforçada na fluidez dos espaços propostos e na estruturação dos significados da intervenção arquitetônica. Assim, a biblioteca produz um espaço que assume francamente um compromisso social na consolidação do tecido urbano do campus sem retirar o seu caráter particular de biblioteca universitária

Internamente, nos ambientes onde são desenvolvidas as atividades relacionadas à pesquisa, leitura e consulta ao acervo bibliográfico, os espaços são concebidos em planta livre ou de "não parede", formatando a possibilidade de transparência e flexibilidade em todo o contexto espacial. As atividades em que se exige o atendimento ao grande público, o fornecimento e a prestação de serviço de informação, ficam vinculadas a estes grandes ambientes. Ou seja, a definição dos espaços internos da biblioteca parte do pricípio de que a fluidez do espaço e a fixação de volumes dinâmicos garantem o significado formal do partido arquitetônico. Esses conceitos de fluidez, transparência e interação também são rebatidos na relação entre o espaço interno e o espaço externo, nas grandes aberturas de janelas e nos panos de vidro presentes nos edifícios. Além de fazer cumprir a função de iluminação e ventilação dos espaços, este sistema permite dar qualidade aos espaços destinados aos usuários/leitores e aos eixos de ligação entre os vários ambientes.

Outra particularidade constatada na Biblioteca do Senac/Santo Amaro é a preocupação com as condições do conforto ambiental. A idéia está pautada na tese de que, projetos que garantem boas condições ambientais para que os seus usuários desempenhem melhor suas atividades, sentindo-se mais adaptados às condições espaciais. Nesse caso, a minoração da excessiva radiação solar no interior do edifício da biblioteca, utilizando ventilação natural como forma de corrigir o desconforto do clima e a redução da temperatura nos elementos espaciais, comprova o aprofundamento projetual positivo que os edifícios de bibliotecas universitárias no Brasil têm percorrido nas últimas duas décadas, aplicando soluções conscientes e adequadas aos programas arquitetônicos locais (MAMBRINI, 2001; SILVA, 2001).

Quanto aos aspectos funcionais configurados na Biblioteca do Senac/Santo Amaro, mais especificamente, aos elementos relacionados às áreas de armazenamento da coleção (acervo), dos locais destinados ao trabalho dos funcionários e dos locais de leitura para os usuários, percebe-se a biblioteca possibilita o entendimento completo das questões relacionadas. Além disso, percebeu-se a importância na estruturação de um novo conceito de ambiente na biblioteca, dotando-o 
de todas as facilidades decorrentes da implantação dos equipamentos de informática e dos sofisticados sistemas de comunicação (local e à distância) e preocupando-se com a adequação do mobiliário destinado às novas tecnologias informacionais $\mathrm{e}$ comunicacionais. Em conjunto com a área ciência da informação e biblioteconomia, os usuários podem ter acesso a uma rede de computadores interligados a importantes bases de dados informacionais espalhados pelo mundo inteiro e suporte informacional, como vídeos, cd-rom, DVDs, livros, além de contar com um atendimento preferencial a pessoas portadoras de deficiência visual (SLYCK \& AYRES, 1995; SANNWALD, 2001; VAN REENEN, 2002).

Ao final de uma avaliação como esta, que engloba inúmeros itens, diversos tipos de medições e várias tecnicas envolvidas, verifica-se que a aplicabilidade de muitas das informações e dos dados levantados na pesquisa suplantam os estudos de caso. Em vista disso, as experiências e as lições aprendidas durante todas essas análises não se limitam somente aos casos analisados, mas podem servir como insumos para novos projetos semelhantes, ou seja, comprovam a hipótese principal da tese que busca uma melhor compreensão dos problemas relacionados, formulando diretrizes para futuros projetos e possíveis camimhos para ambientes de bibliotecas universitárias no âmbito nacional. Portanto, a partir dos elementos apresentados anteriormente, é possível propor uma lista de diretrizes aplicadas ao planejamento e à construção de edifícios de bibliotecas universitárias no contexto brasileiro. Adotou-se como roteiro uma seqüência de itens subdivididos em dois grandes temas: as diretrizes administrativas e as diretrizes arquitetônicas. Assim, espera-se atingir os objetivos propostos para esta tese, a saber:

\section{1 - Diretrizes Administrativas:}

a- Diretrizes relativas a públicos

É possível que as bibliotecas universitárias brasileiras passem a contar com um número cada vez maior de graduandos e pós-graduandos nos próximos anos, em função do crescimento vertiginoso da área educacional. Portanto, estes ambientes deverão necessariamente responder às necessidades de uma população de jovens, orientada não exclusivamente à leitura passiva do suporte tradicional do papel, mas também acostumada a um tipo de aprendizado interativo e colaborativo, proveniente das mídias eletrônicas e comunicacionais. Fora isso, no futuro, novas demandas de usuários 
deverão aportar os edifícios de bibliotecas universitárias brasileiras, como adultosprofissionais interessados na instrução contínuada, no desenvolvimento de habilidades profissionais e constante atualização de seus conhecimentos (MALINCONICO, 1992; HAYCOCK, 1992; GREEN, 1993; MCLELLAN, 2002, CUNHA, 2007). A idéia da biblioteca universitária facilitadora, centrada não mais em si, mas focada na comunidade,tanto de estudantes quanto de pessoas vinculadas aos setores produtivos, sugerem mudanças no atendimento de usuários a serem executadas pelas próprias instituições.

\section{$b$ - Diretrizes relativas aos financiamentos}

Sérios fatores econômicos atingiram o setor das bibliotecas universitárias brasileiras, desde o início dos anos 90: aumento no custo de provisão do ensino, pesquisa e extensão das universidades, aumento no custo operacional das bibliotecas e diminuição dos recursos orçamentários públicos, prioritariamente no âmbito dos governos federal e estadual. Além disso, a situação tende a se agravar, considerando a necessidade de se equilibrar o orçamento público e reduzir o déficit governamental. De qualquer maneira, a biblioteca universitária no Brasil, independentemente da subordinação administrativa das IES, seja pública ou privada, deve procurar novas maneiras para controlar seus custos e fomentar novos recursos financeiros. Um dos principais exemplos verificados é a idéia de consórcio firmado entre agências de fomento e bibliotecas universitárias. Como exemplos se têm: o Probe - Programa de Biblioteca Eletrônica, consórcio entre as universidades públicas de São Paulo e a Bireme - Centro Latinoamericano e do Caribe em Ciências da Saúde, para a aquisição de assinaturas de periódicos eletrônicos; programas desenvolvidos pela FAPESP - Fundação de Amparo à Pesquisa do Estado de São Paulo - dando apoio à aquisição de equipamentos e tecnologias para às bibliotecas universitárias; o Goethe Instituto Cultural da República Federal da Alemanha, que tem programas de apoio e de treinamentos oferecidos às bibliotecas universitárias brasileiras e o CRUESP - Conselho de Reitores das Universidades Estaduais de São Paulo - constituído pelos reitores da USP, Unicamp e Unesp e pelos Secretários de Ciência e Tecnologia e da Educação,tem como principais objetivos a interação entre as universidades, agências de fomento e empresas privadas de tecnologia da informação, propondo possíveis formas de ação conjunta nas bibliotecas universitárias. 
c - Diretrizes relativas aos novos serviços oferecidos

Notadamente, as bibliotecas universitárias brasileiras devem estar preparadas para os novos serviços oferecidos no seio dela, agregando inúmeras possibilidades no contexto informacional e cultural. Desta forma, recomenda-se que a utilização das tecnologias de informação e comunicação seja intensificada, exemplificada pelas bibliotecas digitais, redes virtuais, arquivos abertos (open archives), repositórios digitais, entre outros. Fora isso, quanto aos processos administrativos da biblioteca universitária vinculados à tecnologia da informação e que são destinados à aquisição, à catalogação e à indexação de todo material bibliográfico, sugere-se que cada vez mais aprimorado e apurado, em função dos contextos locais existentes (DINIZ, 2001; CARROL, 2003; OLIVEIRA, 2006).

Em decorrência da automação das bibliotecas universitárias brasileiras (CUNHA,2007), recomenda-se às equipes de arquitetos, engenheiros e bibliotecários que ficaram destinadas à conceberem tais projetos que considerem os seguintes pontos:

- Prever a utilização de aplicações multimídia ou outros tipos de produtos/serviços no contexto local que demandam alta confiabilidade e velocidade de transmissão, garantindo redes de alta velocidade e acesso a grandes arquivos de dados

- Possibilitar de implantação de infovias, para o oferecimento de serviços destinados ao ensino à distância no ensino superior público e privado;

- Possibilitar de implementação de bibliotecas digitais no contexto do ciberespaço, permitindo a disponibilização de coleções, conteúdos e arquivos transferíveis, multimídia, imagens digitais, audiovisuais, animações e bases de dados. Além disso, aumento da tecnologia de redes eletrônicas, por meio do televideofone, acesso por microfone, terminais de equipamentos câmara e vídeo;

- Implantar os conceitos de flexibilidade e adaptabilidade na concepção espacial, reforçando seu apoio às novas mídias e aos recursos on-line.

Outro exemplo são os serviços oferecidos em conjunto com outras áreas de atuação, como nas ciências sociais, humanas, artes, exatas e tecnológicas. Nessas áreas, as bibliotecas universitárias devem reforçar os laços de parceria, objetivando a 
constante criação, preservação, integração, transmissão e ampliação do conhecimento e da informação. Neste caso, pode-se citar a existência de livrarias vinculadas às bibliotecas universitárias, que poderiam disponibilizar material bibliográfico não acessível para empréstimo nas bibliotecas.

\section{$d$-Diretrizes relativas aos tipos de acervo}

Apesar de ser um quesito relacionado às decisões da área administrativa, o tipo de acervo utilizado em bibliotecas universitárias tem ligação direta com o desempenho da edificação. Recomenda-se que o tipo de acervo adotado seja o aberto, ou seja, aquele em que desenho dos espaços sejam abertos e os usuários tenham livre acesso às prateleiras, retirando livros, pesquisando e consultando os locais de arquivos e comunicações. Neste aspecto, uma série de recomendações devem ser tomadas (SIMON, 1995, p. 191):

- Proporcionalizar e compatibilizar de forma coerente as áreas do acervo em conjunto com os ambientes adjacentes destinados à leitura, à pesquisa e áreas de circulação de pessoas;

- Cuidar do nível de ruído das áreas do acervo, preservando o conforto auditivo dos usuários que utilizam e recorrem aos livros das estantes;

- Planejar os elementos de distribuição do mobiliário, as soluções de rotas de circulação no interior do edifício e os pontos de iluminação artificial, de forma que eles possam estar ajustados ao sistema do acervo aberto;

- Fixar no projeto arquitetônico da biblioteca a diretriz da flexibilidade do acervo, com o objetivo de permitir futuras ampliações ou futuros ajustes em função do aumento da capacidade do acervo bibliográfico.

\section{2 - Diretrizes Arquitetônicas}

a - Diretrizes relativas quanto ao contexto urbano e o edifício: ao projetista edifício da biblioteca universitária no contexto nacional recomenda-se o respeito claro com os elementos do entorno de sua unidade educacional, considerados como lugares especiais, com uma forte identidade brasileira e qualidades amplamente reconhecidas pela população usuária nas cidades em que se inserem. Além disso, o éxito da biblioteca 
universitária dependerá, em boa medida, da adequação coerente dos aspectos relacionados à facilidade de acessos, à adequação às condições climáticas e topográficas do sítio, o respeito ao patrimônio natural ou construído existente, dos traçado urbanos e limites espaciais claramente definidos e a compatibilização acertada com atributos ambientais da paisagem urbana (WEHRPLOTZ, CANDIDO, BONO; 2001).

b - Diretrizes relativas quanto à colaboração do profissional/bibliotecário no projeto arquitetônico: a colaboração entre arquiteto e bibliotecário, presente nas fases iniciais e finais do projeto arquitetônico das bibliotecas universitárias (PRADO, 1992; MIRANDA, 1998), deve ser tomada como ponto fundamental, tanto em novas planificações quanto em requalificações ou reciclagens de edifícios. Nesse sentido, o profissional/bibliotecário deverá subsidiar toda a equipe de projetos com informações concernentes às suas necessidades, seus serviços, seus usuários, modos de acesso à leitura e pesquisa que se pretende, entre outros (CUNHA, 2007). Por outro lado, o arquiteto deve trazer soluções técnicas preliminares possíveis, considerando sempre aspectos de tecnologia da construção, preservação (no caso de edifícios históricos), segurança, acessibilidade aos acervos, circulação dos usuários, criação das redes de infomação digital, etc (ALLEN, 1995). Dentre as questões que devem ser amplamente discutidas entre esses profissionais, destacam-se:

- Definição da área de atendimento da biblioteca universitária;

- Número e freqüência aproximada de usuarios a serem atendidos.

- Pré-dimensionamento de ambientes, pavimentos e suas relações espacias preliminares;

- Cálculo do peso aproximado das coleções dos acervos em função do número de usuários pretendidos;

- O tipo de relação que se pretende manter com a comunidade e os horários de funcionamento ao público;

- O tipo de relação com o sistema bibliotecário;

- Número de funcionarios e espaços estimados dedicados a eles;

- Definição quanto ao tipo de projeto arquitetônico, nova construção ou reabilitação;

- Definição quanto ao modelo organizacional empregado (setorial ou centralizado). 
c-Diretrizes relativas quanto ao programa arquitetônico

A primeira diretriz decide de que maneira o programa arquitetônico das bibliotecas universitárias devem atuar junto aos contextos educacionais no cenário nacional, reafirmando sua missão primeira de transmissão de conhecimento, desenvolvimento da sociedade e disseminação da informação. Nesse contexto, as bibliotecas universitárias devem atuar, independente do tipo ou da área de conhecimento científico atendida, fornecendo aos usuários uma gama de serviços, agrupados em dois grandes setores - referencial e cultural. Informação referencial porque a biblioteca deve ser capaz de garantir que ela chegue rápida, confiável e segura àqueles que dela necessitam (CARVALHO, 1998).

Com relação aos ambientes encontrados no Setor Referencial, as bibliotecas universitárias devem conter:

- Espaços destinados à busca e à recuperação da informação: devem ser planejados e disponibilizados em ambientes capazes de desempenhar três sistemas básicos: o primeiro, levado a cabo pelo próprio usuário e, neste caso, as linhas principais de circulação e os locais de leitura devem estar estrategicamente bem posicionados; o segundo, envolve o trabalho de busca dos funcionários; e o terceiro, disponibiliza informações textuais, visuais e bases de dados digitais (ALMEIDA, 2000); Recomenda-se que sejam utilizados este último modelo, os sistemas digitais de busca, podendo ser implantados em terminais ou em equipamentos portáteis distribuídos ao longo de todos os espaços do edifício da biblioteca. O objetivo é formatar um conjunto arquitetônico integrado e articulado com a totalidade dos outros ambientes da biblioteca;

- Espaços destinados às salas de leitura e de pesquisa: como a comunicação é a função básica do edifício da biblioteca, esses ambientes devem ser concebidos em uma situação hierarquicamente dominante, valorizado pela forte relação entre a fonte da informação e o usuário. Em decorrência desse fato, os espaços destinados à leitura e pesquisa podem ganhar o conceito de flexibilidade espacial, principalmente, empregando-se mecanismos de articulação entre o mobiliário de mesas/cadeiras e o conjunto das estantes do acervo bibliográfico. De certa forma, é possível reforçar a própria relação entre informação-usuário por meio de uma atmosfera apropriada à leitura, pesquisa e transmissão de 
conhecimento (MORIS, 2005; GRAHAM, 2005; MALMAN, 2006; MCCOMB, 2006);

- Espaços destinados às salas individuais de leitura e de pesquisa: esses espaços devem ser definidos por cabines ou pequenas salas de estudos, caracterizados por atividades reflexivas, sensação de intimidade e concentração. Nas salas com dimensões mais reduzidas, indica-se que deve haver uma preocupação mais apurada no controle do conforto acústico e visual,bem como na qualidade da temperatura. Sempre que possível, esses ambientes podem receber instalações de computadores interligados em rede local ou internet, possibilitando o desenvolvimento atividades por parte dos usuários, pesquisa on-line e trabalhos acadêmicos (MAMBRINI, 2001);

- Espaços destinados a devolução do material bibliográfico: esses espaços requerem um cuidado especial por parte da equipe de projeto das bibliotecas universitárias, pois envolvem o transporte do material, o tipo de usuário, as características espaciais do edifício, o tipo de equipamento, etc (ALMEIDA, 2000). Ainda que possam ser executados manualmente pelos funcionários, a utilização de sistemas mecânicos de transporte garantem melhor performace. No caso de edifícios em vários pavimentos, sugere-se que se instalem monta-cargas ou elevadores, bem como rampas de acesso com a devida inclinação requerida pela norma vigente;

- Espaços destinados ao controle bibliográfico: em termos espaciais, esses locais devem manter boa visibilidade e bom posicionamento em relação aos usuários e aos responsáveis pelo serviço, além de serem desenhados em função do próprio tamanho da biblioteca. É importante que sejam utilizados sistemas digitais de computação, garantindo rapidez no acompanhamento dos fluxos de informações bibliográficas (VERGEIRO, 1997; ALMEIDA, 2000).

- Espaços destinados à consulta bibliográfica: são ambientes que devem agregar serviços destinados a atender usuários e leitores, dando ênfase no recebimento e análise das solicitações de serviço, detalhando as necessidades de cada usuário e especificando cada tipo de pesquisa ou de material bibliográfico. Isso implica o desenvolvimento de espaços que agreguem o conceito de facilidade na acessibilidade entre o usuário e o pessoal da biblioteca (ALMEIDA, 2000). 
- Espaços destinados à comutação bibliográfica: esses ambientes devem responder às atividades de empréstimo interbibliotecário entre outras unidades de informação, além de cooperar para que os usuários tenham acesso a um máximo possível de informação documental (ALMEIDA, 2000).

A biblioteca universitária brasileira deve funcionar também como pólo gerador de atividades culturais e criativas no ambiente informacional das universidades e da sociedade. Vale lembrar que, nas últimas décadas no Brasil, as universidades têm contribuído em uma ampla variedade de atividades, desde a economia até a proteção ambiental, da reconstrução de cidades ao entretenimento do público em geral. Essa gama de atividades certamente tem reflexos na biblioteca universitária brasileira, especialmente nos acervos e nas provisões de produtos e serviços informacionais. Não somente os espaços tradicionais são requisitados atualmente, mas devem também reunir novas modalidades de ambientes culturais, como auditórios multi-uso, sala de exposições permanente e temporárias, espaços de intercâmbios culturais, entre outros (COOKE, 2001; CUNHA, 2007)

\section{$d$-Diretrizes relativas aos aspectos funcionais}

- Adequação do tipo de mobiliário: o projeto deve direcionar e determinar um padrão de mobiliário realmente adequado às reais necessidades dos usuários, nas áreas de leitura/pesquisa e o setor administrativo (GRAHAM, 2005; WEHRPLOTZ, CANDIDO, BONO, 2006).

- Altura e tipos de regulagens das cadeiras: recomenda-se a utilização de modelos de cadeiras que permitam regulagens de altura, assento e braços, atendendo aos requisitos estabelecidos pela legislação vigente. Esses modelos devem proporcionar boas condições de usabilidade por parte dos usuários, colaborar na concentração do indivíduo e maior conforto ergonômico (NBR 13.967/1997)

- Altura e ao dimensionamento das mesas nas áreas de leitura/pesquisa: sugere-se que o dimensionamento e a quantidade de mesas nos setores de leitura, pesquisa e áreas administrativas respeitem as medidas impostas pela norma, proporcionando variações nos modelos, compatibilização do número de mesas de acordo com a quantidade de usuários e adequação do mobiliário às novas tecnologias informacionais e comunicacionais (NBR 13.965/13.966-1997). 
- Dimensionamentos dos arquivos, estantes e armários: recomenda-se que já na fase dos estudos preliminares de arquitetura das bibliotecas universitárias, os projetistas ajustem a conexão entre a área útil construída, os percentuais de ocupação das estantes e o processo de planejamento interno do edifício. Este procedimento é fator decisivo e direto para a qualidade espacial, de modo que as interferências no layout dos ambientes aconteçam de forma eficiente ao longo do ciclo de vida útil da biblioteca. Além disso, deve-se procurar uma averiguação mais aprofundada e integrada das coleções do acervo, da freqüência de manipulação e das exigências de armazenamento. A procura da inovação e da melhoria no sistema de comunicação visual das estantes pode trazer também benefícios junto aos usuários, principalmente na busca e na qualidade visual do acervo. Prever sempre que possível, nas áreas de armazenamento da biblioteca universitária, a presença de sistemas de arquivos deslizantes, de tal forma que se possibilite um número muito maior de armazenamento bibliográfico. Nos setores administrativos os esforços devem se concentrar não somente nos ajustes das especificações técnicas das dimensões dos armários (altura, profundidade e largura), mas também fatores diretamente ligados à percepção dos funcionários na disposição do layout dos armários no ambiente de trabalho (NBR - 12743 e NBR - 11678 ; NBR - 10518/1997).

- Estações de trabalho e áreas destinadas ao armazenamento de uso comum: neste item, deve-se perseguir um referencial mínimo de eficiência com relação às estações de trabalho e áreas destinadas ao armazenamento de uso comum, por meio de medidas e alturas do mobiliário coerentes com a norma vigente, percentual adequado do mobiliário destinado ao armazenamento, posicionamento e distribuição corretas das peças no ambiente e respeito às normas vigentes quanto às distâncias e as circulações existentes entre o mobiliário de armazenamento (NBR 13.961/1997).

- Conservação do mobiliário: o correto planejamento da preservação do mobiliário não deve ser visto como um elemento novo, mas sim como um componente de operações e de responsabilidade contínua da instituição. Além disso, as bibliotecas universitárias devem acompanhar constantemente o processo de conservação do mobiliário, com atenção à umidade relativa do ar do ambiente, limpeza das superfícies do mobiliário com soluções não agressivas e a utilização de estantes de metal esmaltado (OGDEN, 2001). 
- Privacidade e comunicação: como é considerado um dos aspectos-chave para a produtividade nas atividades desenvolvidas em bibliotecas universitárias, os problemas ocasionados pela falta de privacidade devem ser avaliados em conjunto com o entendimento dos usuários das diferentes atividades exercidas na biblioteca, tentando identificar possíveis caminhos a seguir, sejam estes direcionados às novas configurações espaciais ou aos novos modelos de apropriação do espaço. Ou seja, o redesenho destes ambientes, incluso o layout do mobiliário, deve fornecer uma maneira simplificada para viabilizar e determinar áreas adequadas para maior privacidade, concentração e integração de seus usuários (NBR 13.964/1997).

- Largura e localização das escadas e corredores: o sistema de circulação deve desempenhar papel estratégico no funcionamento dos diversos componentes de distribuição dos ambientes, evitando situações de circulações tortuosas e desperdício da comunicação dos usuários nos espaços. Fora isso, há a forte necessidade do partido arquitetônico cooperar igualmente na organização coerente dos fluxos de circulação, tanto nos deslocamentos dentro dos pavimentos (circulação horizontal) quanto nas conexões entre os três pavimentos (circulação vertical), além do posicionamento e do dimensionamento das rotas de fuga e da segurança contra incêndio. Nesse caso, recomenda-se uma averiguação mais aprofundada das medidas relacionadas aos corredores das salas ou dos arranjos dos mobiliários presentes nos projetos de bibliotecas universitárias, visando não só à adequação à legislação, mas também à melhoria nas condições de bem-estar e usabilidade do espaço (IT Instrução Técnica/ Corpo de Bombeiros; NBR 9050/2004; NBR - 9578; NBR 1141).

- Acesso e adaptação do deficiente físico: como o intuito da acessibilidade é permitir um ganho de autonomia e de mobilidade a uma gama bem maior de pessoas, até mesmo àquelas que tenham a sua mobilidade reduzida, para que usufruam os espaços com maior segurança, confiança e comodidade, este item requer um cuidado especial por parte da equipe de projetistas, principalmente, em se tratando de bibliotecas universitárias. Recomenda-se que se apliquem os critérios da NBR 9050/2004 e que os detalhes do projeto e os componentes principais da acessibilidade presentes no edifício reforçem a importância da introdução do Desenho Universal na concepção e execução do espaço da biblioteca.

- Espaços para encontros e contatos informais: no Brasil essas áreas têm sido cada vez mais valorizadas por serem consideradas espaços de encontro e de troca de 
experiências e informações entre os usuários. Entretanto, somente agora os novos projetos arquitetônicos de bibliotecas universitárias brasileiras estão agregando a importância de prever e conceber ambientes direcionados aos encontros e contatos informais. No planejamento desses ambientes recomenda-se que se preservem os quesitos mínimos de privacidade e adequação de níveis de ruído no ambiente. Fora isso, esses ambientes devem ser posicionados com fácil visualização e acesso a todos, além de serem agradáveis esteticamente, servindo como recurso terapêtico para reduzir as tensões e revitalizar as energias dos usuários ao longo do dia.

- Áreas destinadas ao armazenamento do acervo: os procedimentos para as áreas destinadas ao armazenamento do acervo devem buscar mecanismos que tenham a função de promover e de ajustar o sistema de armazenamento do acervo, minimizando e viabilizando ações concretas na procura, pesquisa e leitura do ambiente da biblioteca. Os procedimentos podem ser resumidos no planejamento com base no conhecimento do acervo e dos materiais, na identificação de prioridades, no estabelecimento de rotinas e procedimentos padronizados / política institucional, na capacitação das equipes da biblioteca e na promoção de instalações e equipamentos, inclusive de segurança de trabalho.

- Quantidade e tamanho dos sanitários: esses devem atender a dois elementos básicos: primeiro, devem ser bem dimensionados, atendendo à legislação e, segundo, devem ser executados com materiais de acabamento de primeira e, além disso, manter bom estado de conservação (Código Sanitário; NBR 9050/2004).

- Sinalização interna: recomenda-se que seja adotado um projeto específico de sinalização e comunicação visual, cooperando no oferecimento ao usuário de benefícios de localização, de orientação e de acesso aos serviços e produtos existentes, além de permitir o melhor nível de organização espacial do acervo bibliográfico, melhorando a qualidade do armazenamento e da disseminação de tudo que foi produzido e recebido no âmbito da biblioteca universitária (NBR 13434/1995).

- Segurança: o programa de segurança de um edifício de biblioteca universitária deve considerar a combinação dos elementos tecnológicos, arquitetônicos e operacionais, a fim de que eles possam dissuadir, impedir, atrasar e responder satisfatoriamente às ameaças. Com relação à preservação do acervo existente, é recomendável que se incluam diretrizes de prevenção e de extinção do incêndio, principalmente nos 
ambientes de rápida propagação de fogo, como é o caso de edifícios de bibliotecas. Além de analisar, de forma consciente e em conjunto com a instituição, usuários e funcionários, as condições específicas da obra, tais como: porte da edificação, número de usuários e tipo de utilização, além das exigências do crescimento do acervo (NR 23 - Proteção Contra Incendios - do Ministério do Trabalho (1978); ABNT NBR 9077/1993; NBR 13434/1995; NBR 13435/1995; Normas da CBPA Conservação Preventiva em Bibliotecas e Arquivos).

\section{$e$ - Diretrizes relativas ao conforto ambiental}

- Temperatura: as recomendações para as bibliotecas universitárias devem considerar as temperaturas mínimas e máximas ao longo do dia, tipologia dos materiais utilizados, orientação solar, ventos dominantes, climas, percentuais de vidros nas fachadas, tipos de cobertura, paisagismo, entre outros. Estes elementos, quando equilibrados e equacionados acertadamente, devem proporcionar excelentes condições de conforto térmico aos usuários. Além disso, o controle da temperatura é fundamental para evitar condições desfavoráveis às reações químicas e a proliferação de microorganismos que afetam a tempo de vida do livro.

- Ar-condicionado: nesta questão, o projeto de distribuição do ar-condicionado deve ser elaborado antes da ocupação do edifício, bem como o dimensionamento das vazões, tendo em vista um layout proposto inicialmente. As operações do sistema devem ser acompanhadas sistematicamente pelos técnicos responsáveis, no sentido de promover bem estar a um número maior de pessoas, já que operações dessa natureza resultam em mudanças em condições locais. Faz-se necessária a distribuição coerente dos pontos de insuflamento no âmbito do ambiente (NBR-6401)

- Iluminação natural: o projeto de iluminação natural deverá tirar proveito e controlar a luz disponível maximizando suas vantagens e reduzindo suas desvantagens nas bibliotecas universitárias. A definição da prioridade em termos de exposição à luz natural, valores de iluminâncias e distribuição necessária para as atividades em cada ambiente deverão ser estabelecidas, de maneira que, em alguns ambientes do acervo bibliográfico, a iluminação uniforme seja a mais recomendada e, nos setores de leitura, pesquisa e administração aconteça uma maior variação de iluminâncias. Além disso, sugere-se que se alterem as cores dos materiais de acabamento e que se trabalhe em tonalidades claras, melhorando os níveis de iluminamento nos ambientes 
principais do acervo e áreas de leitura e pesquisa. E finalmente, a norma recomenda que o projeto de iluminação natural não deve ser um conjunto de valores absolutos, mas uma medida da iluminação natural interna dos ambientes, mesclada com uma percentagem da iluminação externa (NBR 5461/1992).

- Iluminação artificial: deve-se buscar uma associação do sistema de iluminação artificial, em conjunto com a contribuição da fonte natural (iluminação natural), articulada com as características construtivas dos edifícios. Sua aplicação também deve ser ajustada ao projeto de instalação de forma correta, com objetivo de trazer qualidade nos ambientes, tanto para os usuários bem como para o acervo armazenado O planejamento espacial da biblioteca, no sentido de melhorar o desempenho luminoso artificial, deve ser implementado com atenção aos tipos de luminárias, à intensidade de iluminação em determinados locais de estudo e até mesmo à reorganização espacial dos ambientes de trabalho (NBR 5413/1992).

\section{e - Diretrizes relativas à tecnologia da informação e comunicação}

- Com relação à automação das bibliotecas universitárias brasileiras, representada pelas tecnologias de informação e comunicação, recomenda-se que essas sejam utilizadas como suporte ao acervo das referidas unidades de informação, com possibilidades de consultas a bases de dados on-line, trocas de mensagens eletrônicas e participação em videoconferências, entre outros recursos. Em termos arquitetônicos, as tecnologias de informação e comunicação podem ser distribuídas em terminais de computadores para pesquisa on-line (internet), nas salas fechadas de estudo em grupo com computadores interligados em rede e nos setores administrativos, com serviços aplicados aos procedimentos burocráticos, planejamento operacional da biblioteca, controle e aquisição de novos materiais. Por outro lado, as transformações e as mudanças implementadas no edifício devem prever novas habilidades para manejo de computadores e redes e serem incorporadas no do dia-a-dia dos usuários, uma vez que há necessidade de destinar mais ambientes à infra-estrutura de tecnologia da informação.

No caso do Brasil, os próximos anos serão um período de mudanças significativas no contexto das IES, em especial nos caminhos percorridos para a construção de bibliotecas universitárias. As conjecturas sobre o futuro desses edifícios, 
no âmbito nacional, reafirmam cada vez mais a necessidade de se criarem diretrizes ligadas às questões funcionais e comportamentais. Em vista disso, o tema deve merecer um plano de realinhamento e reposicionamento da operação de projeto, além da contemplação de perspectivas no fornecimento de novos serviços informacionais compatíveis com as necessidades de seus usuários. O elemento-chave será a capacidade de examinar as possibilidades de futuro, entendendo que o desafio abrange questões não só inerentes a um espaço físico que abrigue corretamente clientelas, acervos e necessidades distintas de cada contexto da unidade de ensino, mas também o esforço de remover os obstálucos que impedem a assimilação de novos paradigmas.

Em vista disso, existe uma discussão que não pode ser deixada de lado na questão do futuro da biblioteca universitária brasileira, como declara Morig (2007): a dependência do edifício às tecnologias de informação e comunicação e dos processos automatizados inerentes a essas tecnologias. $\mathrm{O}$ avanço dessas mídias tem possibilitado uma relação direta e interativa dos usuários da informação, tornando-os mais autônomos em relação aos serviços mediados pelos bibliotecários no processo de busca da informação. Cosme (2004) afirma que o modelo de biblioteca universitária baseado na rígida separação de seus ambientes e de suas funções, entrou definitivamente em crise nos últimos trinta anos. Em vista disso, os ambientes relacionados ao acervo bibliográfico e às salas de pesquisa e de leitura passaram a ter características abertas e flexíveis, contribuindo cada vez para a separação das áreas administrativas e técnicas. Além disso, a organização dos ambientes baseadas no fornecimento de serviços digitais e tecnológicos passa a incorporar os conceitos da planta livre e da flexibilidade, fazendo frente às profundas mudanças no âmbito da biblioteca universitária. Portanto, o edifício que emerge dessa consideração necessita combinar os elementos que fazem uma biblioteca universitária brasileira funcionar em um ambiente de rápida mudança, redimensionando seu papel na sociedade.

No âmbito das avaliações dos ambientes de bibliotecas universitárias, diversas pesquisas estão sendo conduzidas no exterior. Lackneyl \& Zajfen (2005) trabalham o tema da Avaliação Pós-Ocupação, investigando os aspectos relativos à funcionalidade espacial, conforto ambiental, disposição do acervo bibliográfico e, especialmente o nível de satisfação e as expectativas concernentes ao ambiente construído. No final, a pesquisa estabelece elementos finais de análises e recomendações, formatando um documento de planejamento para futuros projetos.

Sannwald (2001) enumera uma lista completa de elementos de 
verificação projetual, por meio da avaliação e da análise do ambiente construído, em projetos de bibliotecas universitárias, por intermédio da participação dos usuários. $\mathrm{O}$ autor denomina esta metodologia como "lista de verificação", compreendendo a possibilidade de avaliação de novas formas do desenho espacial da biblioteca universitária decorrentes das redes de computadores como, por exemplo, internet, bancos de dados e intranet.

Os resultados do PROBE (2006), direcionados à Avaliação PósOcupação em bibliotecas universitárias, reafirmam que é possível implementar um plano de ação na busca do controle de qualidade da construção desses edifícios e definir critérios mais precisos de desempenho do ambiente construído. É importante destacar que esses procedimentos apresentados pelo PROBE reforçam não só à aplicação de diretrizes técnicas, físicas e dimensionais, mas fundamentalmente critérios de desempenho, visando ao atendimento das necessidades dos usuários.

No Brasil, não existem até o momento pesquisas que aprofundem as questões relacionadas à aplicação de avaliações no âmbito da biblioteca universitária, a fim de produzir informações ao fornecimento de parâmetros de projeto e possibilidades de intervenções nesses edifícios. A realização de futuros estudos, a partir do conhecimento produzido desses ambientes e com a participação direta dos usuários nas decisões, pode ser um instrumento, ainda que preliminar, de mudança de paradigma no contexto da biblioteca universitária brasileira. Nesse processo de mudança, porém, não exime a participação direta tanto de projetistas quanto de profissionais ligados à área da ciência informação, para que as idéias e os objetivos que se desejam alcançar e quais as noções que devem embasar o projeto do espaço, equipamentos e serviços adequados desses edifícios sejam claros. Conhecimentos e experiências adquiridas são fontes importantes para o aprendizado e a compreensão da problemática. Ainda, para conceber a biblioteca universitária brasileira do futuro é preciso muito mais. Exige-se a libertação dos parâmetros antigos que muitas vezes impedem a concretização dos sonhos necessários. 



\section{REFERÊNCIAS}

ABIKO, A.K \& JOHN, V.M. Avaliação de Sistemas Construtivos e Pós-Ocupação. In: Anais do ENTAC'93 - Avanços em Tecnologia e Gestão da Produção de Edificações. São Paulo, ANTAC - Associação Nacional de Tecnologia do Ambiente Construído, 1993.

ABIKO, A.K. \& ORNSTEIN, S.W. (Eds). Inserção Urbana e Avaliação PósOcupação (APO) da Habitação de Interesse Social. São Paulo: Associação Nacional de Tecnologia do Ambiente Construído (Coletânea HABITARE/FINEP, Vol. 1). Financiadora de Estudos e Projetos. Faculdade de Arquitetura e Urbanismo da Universidade de São Paulo. http://habitare.infohab.org.br/projetos/publicacoes.asp.2002. Acesso em: 25 mar. 2004.

ABNT - Associação Brasileira de Normas Técnicas. NBR - 11678 - Divisórias leves internas moduladas - Verificação do comportamento sob ação de cargas provenientes de peças suspensas. Rio de Janeiro. 1991.

ABNT - Associação Brasileira de Normas Técnicas. NBR - 12743 - Móveis. Rio de Janeiro. 1992.

ABNT - Associação Brasileira de Normas Técnicas. NB - 1141 - Recomendações para armazenagem e exposição de documentos de arquivos. Rio de Janeiro. 1993.

ABNT - Associação Brasileira de Normas Técnicas. NBR - 14322 - Paredes de alvenaria estrutural - Verificação da resistência à flexão simples ou à flexocompressão. Rio de Janeiro. 1999.

ABNT - Associação Brasileira de Normas Técnicas. NBR - 6120 - Cargas para o cálculo de estruturas de edificações. Rio de Janeiro. 2000.

ABNT - Associação Brasileira de Normas Técnicas. NBR - 10518 - Informação e documentação - Guias de unidades informacionais. Rio de Janeiro. 2005.

ABNT - Associação Brasileira de Normas Técnicas. NBR - 11678 - Informação e documentação - Guias de unidades informacionais - Elaboração. Rio de Janeiro. 2005 . 
ADORNO, T; HORKHEIMER, M. Dialética do esclarecimento. Rio de Janeiro, Zahar, 1985.

ALA - American Library Association. Standards for Libraries in Higher Education. Chicago, http://www.ala.org/ala/acrl/acrlstandards/standardslibraries.htm, 2004. Acesso em: 01 mar. 2004.

ALPHEN, F. Centros Referenciais. Disponível em: $<$ http://www.icr.org.br/119/fenand.html $>$. Acesso em: 12/07/1998.

ALMEIDA, G.G. de. Avaliação Durante Operação (ADO) - Metodologia Aplicada aos Sistemas Prediais. São Paulo, EPUSP-CIVIL, 1994 (dissertação de mestrado).

ALMEIDA, M. M. Análise das interações entre o homem e o ambiente: estudo de caso em agência bancária. Dissertação de Mestrado, Florianópolis, Programa de PósGraduação em Engenharia de Produção. Universidade Federal de Santa Catarina, Fevereiro, 1995.

ALMEIDA, M.C.B.de. Planejamento de bibliotecas e serviços de informação. Brasília, Briquet de Lemos, 2000. 352 p.

ALUCCI, M.P. Conforto Térmico, Conforto Luminoso e Conservação de Energia Elétrica.São Paulo, FAUUSP, 1992 (Tese de Doutorado).

ANDRADE, C.M.de. Avaliação da Ocupação Física em Edifícios de Escritórios Utilizando Métodos Quali-Quantitativos: o Caso da Editora Abril em São Paulo. São Paulo: Faculdade de Arquitetura e Urbanismo da Universidade de São Paulo, 2000 (Dissertação de Mestrado).

ANDRADE, C.M.de. Avaliação de Desempenho em Edifícios de Escritórios: o ambiente de trabalho como meio para o bem-estar produtivo. São Paulo: Faculdade de Arquitetura e Urbanismo da Universidade de São Paulo, 2005 (Tese de Doutorado).

ANDRADE, LA.B, LONGO, W. P. \& PASSOS, E. Autonomia: um modelo explicativo para a ontologia da universidade. Universidade e Sociedade (ANDES), Brasília, v.21, p.73-84, 2000a. 
ANDRADE, C.M.de; ORNSTEIN, S.W.; GONÇALVES, J.C.S. Fatores de Desempenho do Ambiente de Trabalho: uma análise critica do caso brasileiro. Anais em CD-Rom do NUTAU 2004. Seminário Internacional promovido pelo NUTAU Núcleo de Tecnologia da Arquitetura e Urbanismo da USP. São Paulo, SP, Brasil. Outubro, 2004.

AGUSTIN LACRUZ, M. del C. Bibliotecas digitales y sociedad de la información. Scire, Zaragoza, v.4, n.2, p.47-62, jul.-dic. 1998.

AUGOSTINHO, V. Aclimatação ambiental dos prédios das bibliotecas centrais universitárias: especificações de construção seguidas após reformas. Brasília: UNB, 1987. 255 p. (Dissertação, Mestrado em Biblioteconomia).

BAZILLIO,N; RICHARD; CONNIE .Designing an Intelligent Library. In: Academic Libraries as High-tech Gateways: A Guide to Design \& Space Decisions, 41-52. 2d ed. Chicago: American Library Association, 2001.

BARBALHO, C. R. S. Biblioteca pública do Estado do Amazonas: a construção de sentido de seu edifício. (artigo) Disponível em:

$<$ http/www.ies.ufpb.br/ojs2/index.php/ies/article/view/155/149. Acesso em 12/05/06.

BECHTEL,R.; MARANS, R. MICHELSON, W. (eds). Methods in Environmental and Behavioral Research. Nova Iorque, EUA. Van Nostrand Reinhold, 1987.

BECKER, F. Post-occupancy evaluation: research paradigm or diagnostic tool.In: Building Evaluation, New York, Plenum Press, 1989, p. 127-134.

BENJAMIN, W. Walter Benjamin (textos), organização e introdução de F.Kothe. São Paulo, Ática, 1985, Série Sociologia.

BERCHEM, T. A missão das universidades na formação e no desenvolvimento culturais: a diversidade dentro da universalidade. Cadernos Plurais (Série Universidade - I). Rio de Janeiro: Editora da UERJ, setembro, 1990.

BERGMAN, M.K. White paper - the deep Web: surfacing hidden value. July, 2000. Bright Planet.com.LCC. 
BERNHARD, P. \& BRETON, L. The school media/information specialist. A comparison of standards guidelines about personnel, competencies, and education (International level, United States of America, France, United Kingdom, and English speaking provinces of Canada). School Library Media Annual (SLMA) 12(1994), 244-272.

BIBLIOTECA AMBROSIANA. Comune Milano. URL: http:www.comune.fi.it. Acesso em: 17/04/2006.

BIBLIOTECA CRANFIELD. URL:http:// www.cranfield.ac.uk. Acesso em:17/12/2006.

BIBLIOTECA DA UNIVERSIDADE CENTRO UNIVERSITÁRIO OTÁVIO BASTOS. URL: http www.unifeob.edu.br. Acesso em :08/04/2006.

BIBLIOTECA DA UNIVERSIDADE DE MÚRCIA. URL: http www.rmbm.org. Acesso em :08/04/2006.

BIBLIOTECA DA UNIVERSIDADE DE ONTÁRIO. URL: http. www.bradjohnson.ca. Acesso em :16/04/2006.

BIBLIOTECA DA UNIVERSIDADE DE OVIEDO. URL: http www. buo.uniovi.es. Acesso em :08/04/2006.

BIBLIOTECA DA UNIVERSIDADE DE VALÊNCIA. URL: http www. uv.es. Acesso em :15/04/2006.

BIBLIOTECA DA UNIVERSIDADE DE VIRGÍNIA. URL: http. info.med.yale.Edu. Acesso em :16/04/2006.

BIBLIOTECA DA UNIVERSIDADE DE YALE. URL: http. info.med.yale.Edu. Acesso em :15/04/2006.

BIBLIOTECA DA UNIVERSIDADE FEDERAL DA PARAÍBA. URL: http: www. ufpb.br. Acesso em :27/04/2006.

BIBLIOTECA DA UNIVERSIDADE FEDERAL DO MATO GROSSO. URL: http www. ufmt.br . Acesso em :27/04/2006. 
BIBLIOTECA DA UNIVERSIDADE FEDERAL DE MINAS GERAIS. URL: http: www. ufmg.br. Acesso em :04/04/2006.

BIBLIOTECA DA UNIVERSIDADE DE WASHINGTON. URL: http. www.washington.edu. Acesso em :16/04/2006.

BIBLIOTECA DA UNIVERSIDADE WILFRID LAURIER. URL: http. www.ibrary.wlu.ca/. Acesso em :15/04/2006.

BIBLIOTECA DE ÉFESO. URL: http: www.coloredhome.com/. Acesso em $: 16 / 03 / 2006$.

BIBLIOTECA DO ESCORIAL. URL: http:www8.madrid.org. Acesso em: 16/04/2006.

BIBLIOTECA DARWIN COLLEGE STUDY CENTRE. URL:http:// www.msm.cam.ac.uk Acesso em :17/12/2006.

BIBLIOTECA JOHN J. ROSS AND WILLIAN BLAKELLY URL:http:// www.law.asu.edu//.Acesso em: 08/03/2007.

BIBLIOTECA LAURENZIANA. URL: http:www.comune.fi.it. Acesso em $: 16 / 03 / 2006$.

BIBLIOTECA LEARNING RESOURCES CENTRE. URL:http:// www.rsh-p.com //.Acesso em :11/12/2006.

BIBLIOTECA MUNICIPAL DE ESTOCOLMO. URL: http. www.comune.fi.it Acesso em :04/04/2006.

BIBLIOTECA MUNICIPAL DE VIIPURI. URL: http. www.vitruvius.ch.Acesso em :04/02/2006.

BIBLIOTECA NACIONAL DA FRANÇA. URL: http: fr.wikipedia.org. Acesso em $: 17 / 04 / 2006$.

BIBLIOTECA NACIONAL UNIVERSITÁRIAS GOTTINGEN. URL:http:// www.sub.uni-goettingen.de/.Acesso em :15/12/2006. 
BIBLIOTECA PÚBLICA DE BOSTON. URL: http. www.jillianmyers.com.Acesso em :04/04/2006.

BIBLIOTECA REGIONAL TECHNICAL COLLEGE. URL: http://www.deblacamandmeagher.com./Acesso em :16/12/2006.

BIBLIOTECA SAINTE-GENEVIEVE. URL: http:www.comune.fi.it. Acesso em $: 16 / 03 / 2006$.

BIBLIOTECA SETORIAL DE CIÊNCIAS UNIVERSIDADE FEDERAL DE SANTA CATARINA. URL: http: www. ufsc.br. Acesso em :27/04/2006.

BIBLIOTECA SQUIRE. URL:http:// squire.law.cam.ac.uk.Acesso em :15/12/2006.

BIBLIOTECA UNED. URL:http:// biblioteca.uned.es//.Acesso em :11/12/2006.

BRAWNE, M. Library Builders. London: Academy Editions, 1997.

BROWN, C. Interior Design for Libraries Chicago: American Library Association, 2002.

BRUNA, G.C. Avaliação Pós-Ocupação de Espaços Semi-Público: a APO faz a diferença. In: ENTAC 93 - Encontro Nacional do Ambiente Construído, São Paulo: ANTAC, pp 847-854, 1993.

CARVALHO, M. C. R. de. Estabelecimento de padrões para bibliotecas universitárias. Fortaleza, UFC/Brasília, ABDF, 1981.

CALVINO, I. Seis propostas para o próximo milênio. São Paulo: Companhia das Letras, 1990.

CAMARGO, L. S. A; VIDOTTI, S. A. B. G.; CAMARGO, V. V. de. Arquitetura da informação para Bibliotecas Digitais: uma abordagem centrada no usuário. Disponível em: http:// libdigi.unicamp.br/document/ Acesso em 12 de agosto de 2005.

CAMBIAGHI, S.S. Desenho Universal: métodos e técnicas de ensino na Graduação de Arquitetura e Urbanismo. São Paulo, Faculdade de Arquitetura e Urbanismo da Universidade de São Paulo, 2004 (Dissertação de Mestrado). 
CARROL, F. L.. Guidelines for School Libraries. The Hague: IFLA Section of School

Libraries. The Hague: IFLA Section of School Libraries,2003. 37 pags. (IFLA Professional Reports, 20).

CARVALHO, M. Atendimento a questões especiais no serviço de referência da biblioteca de condepe-relato de uma experiência. R. de Biblioteconomia. Brasília, v 16, n; 1, p.113-124, jan./jun. 1998.

CASTELLS, M. "Fluxos, redes e identidades: Uma teoria crítica da sociedade informacional". In: Novas Perspectivas Críticas em Educação. Porto Alegre, Artes Médicas, 1996, pp. 4-32.

CHARLE, C; VERGER, J. História das universidades. São Paulo: UNESP, 1996.

CHARTIER, R. A ordem dos livros: leitores, autores e bibliotecas na Europa entres osSéculos XIV-XVIII, Brasília : UNB, 1994.

CHRETIEN, CL. A ciência em ação. Campinas: Papirus, 1994.

COHEN, U; RYSIN, L.V. Pesquisa em arquitetura. In: SNYDER, J. Introdução à Arquitetura, Rio de Janeiro: Campus, 1984, p.386-394.

COOKE, G. W. Art and Architectural heritage of the Sephardim in the United States. In: Bibliotecas de arte, arquitectura $y$ diseno: perspectivas actuales. IFLA Publications, Barcelona, 2001.

CORTEZ, M.T. Bibliotecas e centros de informação: técnicas de planejamento. São Paulo: Cortez, 1983. 152 p.

COSME, A. M. Los Espacios del Saber. Historia de la arquitectura de las bibliotecas. Madrid: Ediciones Trea, 2004.

CROCHIK, J.L. Preconceito - Indivíduo e cultura. São Paulo: Robe Editorial, 1997.

CRUZ, A \& ORNSTEIN, S.W. A Qualidade no Projeto Arquitetônico da Habitação Popular: insumos para a análise do desempenho funcional com base na Avaliação Pósocupação da autoconstrução. In: Anais do ENTAC'95. Rio de Janeiro, ANTAC Associação Nacional de Tecnologia do Ambiente Construído, 1995, p.275-280, vol.1. 
CUNHA, L.A. "Universidade e sociedade: Uma nova competência". Revista Adusp no 9. Abril 1997, pp. 22-25.

CUNHA, M. B. da. Desafios na construção de uma biblioteca digital. Ci. Inf., Brasília, v.28, n.3, p.257-268, set./dez.2000

CUNHA, M.B. da. Biblioteca Digital: bibliografia internacional anotada. Ciência da Informação, v. 28, n. 2, p. 195-213, 1997. URL: http: www. Ibict.br/cioline. Acesso em :02/03/2006.

CUNHA, M.B. da. Construindo o futuro: a biblioteca universitária brasileira em 2010. Ciência da Informação, v.29 n.1 Brasília jan./abr. 2007. URL: http: www. Ibict.br/cioline. Acesso em : 29/09/2007.

DEAN, E. Daylighting Design in Libraries. Los Angeles: Libris DESIGN, http://www.librisdesign.org/docs/daylightdessignlibs.pdf, 2005. Acesso em: 25 mar. 2004.

DESCRIÇÃO do Nou-Rau. Disponível em: <http://www.rau-tu-unicamp.br/nourau/des-pt.html>. Acesso em: 25 mar. 2004.

DINIZ, P. Biblioteca do futuro. Disponível em: $<$ http://www.cg.org.br/gt/gtbv/gtbv.htm>. Acesso em: 21/03/2001

DOBROWOLNY, M.B. Ambiente objetivo e ambiente subjetivo: para uma abordagem ecológica. In: Sinopses, São Paulo, FAUUSP, n.8, dez., 1985, p.163-189.

DODEBEI, V.L. Bibliotecas Universitárias Brasileiras: uma reflexão sobre seus modelos.Disponível em <http:// www.cinform.ufba.br/iv_anais/artigos/TEXTO11.htm., 2006. Acesso em: 18 maio 2006.

DUARTE, Fábio. Arquitetura e tecnologias de informação. São Paulo: Ed.UNICAMP, 1999.

ENRIGHT, S. Post-Occupancy Evaluation of UK Libray Building Projects: Some Examples of Current Activity. London: Liber Quarterly, http://www.kb.dk/liber/cumindex/vol12.htm, 2002. Acesso em: 25 mar. 2004. 
ESPINOSA, B. et al. Tecnologia documentales: memoria opticas. Madrid: TECNIDOC, 1994.

ETZIONI, A. Racionalismo e felicidade: o dilema da organização. In: Organizações modernas. São Paulo: Pioneira, 1980, p.9

FEDERAL FACILITIES COUNCIL. Learning from our buildings. A State-of thePractice Summary of Post-Occupancy Evaluation (Federal Council Technical Report, n 145). Washington, DC: National Academy Press, 2001.

FERREIRA, L.S. Bibliotecas Universitárias Brasileiras: análise das estruturas centralizadas e descentralizadas. São Paulo: Pioneira, 1980.

FIALHO, N. H. Universidade multicampi: modalidade organizacional, espacialidade e funcionamento. Salavador: Universidade Federal da Bahia, 2000 (Tese de Doutorado).

FIGUEREDO, N. Metodologia conceitual para a prevenção de erros no serviço de referência. Ciência da informação. Rio de Janeiro, v.6, n.2, p.87-98, 1997.

FORRESTER, V. O horror econômico. São Paulo, Ed. UNESP, 1997.

FUGITA, Mariângela S. L. Informação e Sociedade. www.ufpb.br/html/IS1520504/ Acesso em: 25 mar. 2006.

GASCUEL, Jacqueline. Un espace pour le livre: guide à l.intention de tous ceux qui construisent, aménagent ou rénovent une bibliothèque. Paris: Editions du Cercle de la Librairie, 1993. 413p.

GARCIA, M.L.A. Plano Nacional de Bibliotecas Universitária: planejamento e permanência. UNB, Brasília, 1991.

GALBINSKI, J. Planejamento físico de bibliotecas universitárias. Brasília, PROBIB 1993, $176 \mathrm{p}$.

GIORGI, M; VALENTI A; LUZI, D. Lê basi di dati internazionali sull'architettura: uno studio in corso. In: Atti Del seminário Europa 93: I'informazione per I' architettura, Venezia, 1993. 
GIROUX, H. Jovens, diferença e educação pós-moderna. In: Castells, M. Novas perspectivas críticas em educação. Porto Alegre: Artes Médicas, 1996, pp. 63-85.

GOERGEN, P. "A crítica da modernidade e a educação". In: Pro-Posições, n.2(20), 1996, v. 7, pp. 5-28.

GOMES, S.H.T. Centro referencial e cultural de Arquitetura: uma proposta para disseminação da informação. 2001. 167f. Faculdade de Filosofia e Ciências, Universidade Estadual Paulista, Marília, 2001 (Dissertação de Mestrado).

GOMES, S.H.T. Bibliotecas e Centros de Informação no contexto das demandas Telemáticas. In: Sigradi - Simposio de Grafia Digital, 2004, São Leopoldo. SIGRADI - Simposio de Grafia Digital. São Leopoldo-RS: UNISINOS, 2004.

GOMES, S.H.T. A Atuação das Bibliotecas e dos Centros de Informação no contexto das demandas Telemáticas e Informacionais. In: Simpósio Interfaces das Representações Urbanas em Tempos de Globalização, 2005, Bauru/SP. Bauru: Unesp/SESC/SP, 2005.

GOMES, S.H.T. Centro Referencial e Cultural de Arquitetura: uma proposta para disseminação da informação. In: XXI Congresso Brasileiro de Biblioteconomia, Documentação e Ciência da Informação, 2005, Curitiba/PR, 2005.

GREGOTTI, V. Território da arquitetura. São Paulo: Perspectiva, 1975.

GRAHAM, C. Furniture for Libraries. Los Angeles: Libris DESIGN, http://www.librisdesign.org/docs/FurnitureLibraries.pdf, 2005. Acesso em: 20 mar. 2006.

GRUPPI, L. Tudo começou com Maquiavel. Porto Alegre: L\&PM, 1980.

GREEN, T.C. Competencies for entry-level independent information professionals. An assessment by practicioners. Journal of Education for Library and Information Science 34(1993)2, 165-168

HABERMAS, J. Conhecimento e interesse. Rio de Janeiro: Zahar, 1982. O discurso filosófico da modernidade. Lisboa: Dom Quixote, 1990. 
HAYCOCK, K. What Works: Research about Teaching and Learning Through the School 's Library Resource Center. Vancouver: Rockland Press,1992.

HEDQF - Higher Education Design Quality Forum. Post-Occupancy Review of Buildings Report. Appendix on Forum Guidelines and Appendix on Sample Forum Report. http://www. heestates.ac.uk/partners/HEDQF/buildocc/report, 2006. Acesso em: 25 jan. 2006

HERSEY, P.; BLANCHARD, K.H. Psicologia por administradores. São Paulo: EPU, 1986.

IANNI, O. A sociedade global. Rio de Janeiro: Civilização Brasileira, 1993.

IFLA - The International Federation of Library Associations and Institutions. URL: http. www.ifla.org. Acesso em: 10/02/2005.

IFLA' 99 workshop \& discussion, the online discussion and information forum for Librarianship an Information Management. URL: http: www. liblin k.co.uk/ala2000workshop.html. Acesso em : 10/04/2006.

JACOB, C.; MARC, B. O poder das Bibliotecas. Rio de Janeiro: UFRJ, 2000.

KAUFMANN, E. Três arquitetos. São Paulo : UNESP, 1996.

KIDDER, L.(org.). Métodos de pesquisa nas relações sociais. (vol.1-Delineamentos de Pesquisa; vol.2-Medidas na Pesquisa Social; vol.3- Análise de Resultados). São Paulo: Ed. Pedagógica e Universitária, 1987.

KITO, A. Libraries, new concepts in architecture e design, Tokio: Ed. Meisei Publicatoins, 1995.

KRZYZANOWSKI, R.F. Biblioteca eletrônica de revistas científicas Internacionais: projeto do consórcio. Ciência da informação, Brasília, v. 27, n. 2, p. 193-197, maio./ago. 1998b.

KUMAR, K. Da Sociedade pós-industrial à pós-moderna. Rio de Janeiro: Jorge Zahar, 1997. 
LACKNEYL, J.A. \& ZAJFEN, P. Library Administration and Management http://www.findarticles.com/p/articles, 2005. Acesso em: 16 mar. 2006.

LANG, B. Library Buildings for the New Millennium, Mùnich: K. G. Saur, 2001.

LAWRENCE, S. \& GILES, L. Accessibility and distribution of information on the Web. Nature, n. 400, p. 107-109, 1999.

LE COADIC, Y.F. A ciência da informação. Brasília: Briquet de Lemos, 1996. 119 p.

LEITE, B.C.C. Análise do Desempenho de Edifícios de Escritórios Automatizados Através da Avaliação Pós-Ocupação. São Paulo: Faculdade de Arquitetura e Urbanismo da Universidade de São Paulo, 1997 (Dissertação de Mestrado).

LEMOS, A. A. Briquet de \& MACEDO, V. A. Amarante. Posição da biblioteca na organização operacional da universidade. Rev. Esc. Biblioteconomia UFMG, Belo Horizonte, 4(1):40-51, mar. 2001.

Libris Design. Los Angeles, http://www.librisdesign.org, 2006. Acesso em: 7 abril. 2006.

LÓPEZ YEPES, J. Universidad y socialización del saber: ventajas y retos del formato electrónico. Scire, Zaragoza, v.6, n.1, p.11-30, en.-jun.2000.

LOUREIRO, C. et al. Pesquisa de avaliação pós-ocupação em edificações escolares da rede pública da região metropolitana do Recife. In: Seminário Avaliação PósUso, Anais, FAUUSP, 1989, 113-116.

LYOTARD, J.F. A condição pós-moderna. Lisboa: Gradiva, 1985.

MACEDO, N. D.de. Princípios e reflexões sobre o serviço de referência e informação... Rev. Bras. Bibliotecon. Doc., São Paulo, v. 23, n. 1/4, p. 9-37, 1990.

MALINCONICO, S.M. What librarians need to know to survive in an age of technology. Journal of Education for Library and Information Science 33(1992)3,226-240. 
MALMAN, D. Lighting for Libraries. Los Angeles: Libris DESIGN, http://www.librisdesign.org/docs/LightingLibraries.pdf, 2005. Acesso em: 2 mar. 2006.

MAMBRINI, H. Bibliotecas: evolução histórica das tipologias e os aspectos de Conforto Ambiental. Disponível em: <http://www.ufrgs.br/propar/diseco.htm>. Acesso em: 21/02/2001.

MARCOVITCH, J. A universidade (im)possível. São Paulo: Futura, 1998.

MARTINS, W. A palavra escrita. São Paulo: Ática, 1996.

MEADOWS, A. J. A comunicação científica. Tradução de Antonio Agenor Briquet de Lemos. Brasília: Briquet de Lemos Livros, 1999. Tradução de: Communicating Research.

MELENDEZ, A. Com três faces distintas, anexo funcional adapta-se a centro de documentação. Projeto Design, [S. 1.], v. 281, jul. 2003 a.

MELENDEZ, A. Convertida, capela também mantém o uso e recebe com serenidade novas funções. Projeto Design, [S. 1.], v. 284, out. 2003b.

MELENDEZ, A. Biblioteca Universitária Projeto Design, [S. 1.], v. 311, jan. 2006.

MENDONÇA, A.W.P.C. A Universidade no Brasil. http://www.anped.org.br/rbe14/08-artigo 7.pdf. Acesso em: 24 de Março de 2006.

MENEGUELlo, C. A preservação do patrimônio e o tecido urbano. (parte 1). A reinterpretação do passado histórico. (artigo) Disponível em:< http://www.vitruvius.com.br/arquitextos/arq000/esp007.asp. Acesso em : 2/06/2006.

MERCADANTE, L. M. Z. (Coord.). Análise dos modelos organizacionais de bibliotecas universitárias nacionais. Brasília: PNBU, 1990.

MEIS, L.; LETA, J. O perfil da ciência brasileira. Rio de Janeiro: Ed. UFRJ, 1996.

MCCOMB, M. Library Security. Los Angeles: Libris DESIGN, http://www.librisdesign.org/docs/LibrarySecurity.pdf, 2005. Acesso em: 3 mar. 2006. 
MILANESI, L. Biblioteca. São Paulo: Atelie, 2002.

MINAYO, M.C.S.; SANCHES, O. Quantitativo-qualitativo: oposição ou complementaridade? Caderno Saúde Pública, n.9, julho/setembro, 1993, p. 239-262.

MINISTRY OF EDUCATION NEW ZEALAND - Examples of Post Occupancy Evaluations. Wellington, http://www.minedu.govt.n, 2006.

MIRANDA, Antonio. Biblioteca universitária no Brasil: reflexões sobre a problemática. In: Seminário Nacional de Bibliotecas Universitárias, 1. Anais, Niterói, 1988, p. 1758-189.

MIRANDA, A. Arquitetura de Bibliotecas: experiência brasileira. http://eprints.rclis.org/archive/00002439/01/arquitetura.pdf. Acesso em: 12 de Mar. 1998.

MOORE, G.T. Estudos de comportamento ambiental. In: SNYDER, J. Introdução à Arquitetura, Rio de Janeiro: Campus, 1984, p.65-88.

MORAES, R.B. O problema bibliotecas brasileiras. Brasília: ADF, 1983.

MORIGI.V. J. Tecnologias de informação e comunicação: novas sociabilidades nas bibliotecasuniversitárias.http://www.ibict.br/cienciadainformacao/viewarticle.php.

Acesso em: 1492007.

MORIS, B. Library Interior Finish Materials. Los Angeles: Libris DESIGN, http://www.librisdesign.org/docs/LibraryIntFinMat.pdf, 2005. Acesso em: 25 mar. 2006.

MOURA, É. Biblioteca recupera art nouveau paulistana no berço da FAU/USP. Projeto Design, [S. 1.], v. 275, jan. 2003.

NEIL, S. D. Libraries in the year 2010. New York: Futurist, oct.1981.

NCEF - National Clearinghouse for Educational Facilities. Building Type Basics for College and University Facilities.Washington, DC, http:// www.edfacilities.org, 2006. Acesso em: 14 out. 2006 
OLIVEIRA, S.M. Gerenciamento organizacional de Bibliotecas Universitária (artigo). Disponível em http:/// www.ufpe.br/snbu/silas.doc, 2006. Acesso em: 4 mar. 2006.

ORCIUOLI, A. Espaço digital. O presente dos futuros lugares.(artigo) Disponível em: <http://www.iaz.com/iaz/digitallife/003/portugues.html, 2000. Acesso em: 25 mar. 2006

ORNSTEIN, S.W.; ROMÉRO, M. Avaliação pós-ocupação do ambiente construído. São Paulo, Studio Nobel, Edusp, 1992.

ORNSTEIN, S.W. Avaliação pós-uso de conjunto para baixa renda. Planejamento \& Construção. São Paulo: Sinduscon-SP, N. 4, janeiro, 1993, p.25-29.

ORNSTEIN, S.W.; BRUNA, G.; LIMA; C.P.S. Espaços públicos e semipúblicos: uma experiência interdisciplinar (APO) como metodologia de projeto. Boletim Técnico 01, FAUUSP, 1994.

ORNSTEIN, S.W.; BRUNA, G.; ROMÉRO, M. Ambiente Construído e Comportamento: A Avaliação Pós-Ocupação e a Qualidade Ambiental. São Paulo: Nobel/FUPAM/FAUUSP, 1994.

ORNSTEIN, S.W.; BRUNA G.; ROMÉRO, M. Ambiente construído \& comportamento - a avaliação pós-ocupação e a qualidade ambienta, São Paulo, Studio Nobel, FAUUSP, FUPAM, 1995.

ORNSTEIN, S.W. Desempenho do ambiente construído, interdisciplinaridade e arquitetura. FAUUSP, São Paulo, 1996.

ORNSTEIN, S.W. Avaliação pós-ocupação (APO) no Brasil: estado da arte, desenvolvimento e necessidades futuras. In: NUTAU' 96 - Seminário Internacional, Anais, 1997, p.73-86.

ORNSTEIN, S.W. \& LUCCHESE, B. Avaliação do Desempenho de Edifícios de Escritórios na Grande São Paulo: análises dos principais agentes envolvidos na cadeia produtiva, do projeto ao uso. In: Seminário Internacional NUTAU'2000 - Tecnologia e Desenvolvimento (anais em CD-ROM). São Paulo: Núcleo de Pesquisa em Tecnologia da Arquitetura e Urbanismo da Universidade de São Paulo, 2000.

ORNSTEIN, S.W. Arquitetura, Urbanismo e Psicologia Ambiental: uma reflexão sobre dilemas e possibilidade da atuação integrada. São Paulo: Revista de Psicologia, 2005, 16(1/2), pp. 155-165. 
PAULA, Licia Pupo de. Novas tecnologias e bibliotecas: uma síntese. Revista Brasileira de Biblioteconomia e Documentação, São Paulo, v.25, n.1/2, p.42-53, jan./jun., 1992.

PRADO, H. Organização e administração de bibliotecas. 2.ed. São Paulo:T. Queiroz, 1992.

PEVSNER, N. História de las tipologias arquitectônicas. Barcelona: Gili, 1979.

PREISER, W. F. E; RABINOWITZ; WHITE, E. Post-occupancy evaluation, New York, Van Nostrand Reinhold, 1988

PREISER, W. F. E. Towards a performance-based conceptual framework for systematic POES. In: Building Evaluation, New York: Plenum Press, 1989, p. 1-8

PREISER, W. Health Center Post-Occupancy Evaluation: Toward Community -Wide Quality Standards. In: Anais do NUTAU'98 - Arquitetura e Urbanismo Tecnologias para o Século XXI, São Paulo, outubro/novembro de 1998. NUTAU FAUUSP, São Paulo, 1998. sp. (CD-ROM).

PREISER, W. F.E. Evaluating Universal Design Performance. In: PREISER, Wolfgang F.E.; VISCHER, Jacqueline C. (eds). Assessing Building Performance. Oxford, Inglaterra. Elsevier Butterworth-Heinemann, 2005, p.178.

PROBE - Post-Occupancy Review of Buildings and Their Engineering. York, http://www.usablebuildings.co.uk/, 2006. Acesso em: 19 mar. 2006.

PUACZ,J. H; BRADFIELD, C. Computers in Libraries, Los Angeles: Patrons, 2000.

RABINOWITZ, H. The uses and boundaries of Post-occupancy evaluation: an overview. In : Building Evaluation, New York: Plenum Press, 1989, p. 9-18. RAPOPORT, A . House form and culture. New Jersey, Prentice Hall, 1969.

REIS, A. T.; LAY, M.C.D. Principais fatores afetando a satisfação e o comportamento dos usuários em conjuntos habitacionais. In: ENTAC 95 - Encontro Nacional de Tecnologia do Ambiente Construído, Anais, Rio de Janeiro, ANTAC/UFRJ, Vol. 1, p. 307-312

REIS, A. T.; LAY, M.C.D. Métodos e técnicas para levantamento de campo e análise de dados: questões gerais. In: Workshop Avaliação Pós-Ocupação, Anais, ANTAC/NUTAU, São Paulo, 1994. 
RHEINGANTZ, P. A. Aplicação do Modelo de Análise Hierárquica COPETEC COSENZA na Avaliação do Desempenho de Edifícios de Escritórios. COPPE, Universidade Federal do Rio de Janeiro, Rio de Janeiro, 2000 (Tese de Doutorado em Engenharia de Produção).

RIBA - Royal Institute of British Architects. London, http://www.riba.org, 2006. Acesso em: 25 jun. 2006.

RIBENBOIM, Ricardo. Novos e antigos espaços. (artigo) Disponível em $:<$ http//www.minc.gov.br/textos/olhar/novosantigos.htm > Acesso em : 23/04/2001.

RIPPER FILHO, José Ellis. Ciência e tecnologia: por que? Como? In: MUSA, Edson Vaz et al. Ciência e Tecnologia: alicerces do desenvolvimento. São Paulo: Cobram, 1994, 164p.

ROCA, M; NOVES, M. R. Las bibliotecas de arquitectura en Catalunya: sua inícios y momento actual. In: Bibliotecas de arte, arquitectura y diseno: perspectivas actuales. IFLA Publications, Barcelona, 1995.

ROMÉRO, M. de A . A Contribuição da Avaliação Pós-Ocupação (APO) para a Qualidade do Projeto: Estudo de Caso de um Edifício de Escritórios. In: ENTAC 95 Qualidade e Tecnologia na Habitação, Rio de Janeiro: ANTAC, pp 269-274, 1995.

ROMÉRO, M. de A . O Edifício da EPUSP-CIVIL: Um Exercício da Metodologia da Avaliação Pós-Ocupação, São Paulo, FAUUSP, 1990 (Dissertação de Mestrado).

ROMÉRO, M. de A. Arquitetura, Comportamento e Energia: análise do desempenho energético e do nível de satisfação dos usuários em edifícios de escritório na cidade de São Paulo, utilizando procedimentos da Avaliação PósOcupação. São Paulo: Faculdade de Arquitetura e Urbanismo da Universidade de São Paulo, 1997 (Livre-Docência).

ROMÉRO, M. de A. A Arquitetura, o Conforto Ambiental e o Comportamento dos Usuários. In: Sinopses 34. São Paulo: Faculdade de Arquitetura e Urbanismo da Universidade de São Paulo, dezembro 2000, pp. 31-49.

ROMÉRO, M. de A; ORNSTEIN, S.W.(Coords.) Avaliação pós-ocupação. Métodos e técnicas aplicados à habitação social (Coleção Habitare). Porto Alegre, RS: Associação Nacional de Tecnologia do Ambiente Construído (ANTAC). http://habitare. infohab.org.br/projetos/publicacoes.asp, 2003. Acesso em: 28 fev. 2005. 
RUSSO, M. Bibliotecas universitárias brasileiras: diretrizes para o próximo milênio. São Paulo: Associação Paulista de Bibliotecários - APB, 1998a. (Ensaios APB, n. 53).

SALTER, C.M. Acoustics for Libraries. Los Angeles: Libris DESIGN, http://www.librisdesign.org/docs/AcousticsLibraries.pdf, 2005. Acesso em: 9 mar. 2006.

SANNWALD, W.W. Checklist of Library Building Design Considerations. Fourth Edition. Chicago, http://www.alastore.ala.org/, 2001. Acesso em: 10 mar. 2006.

SANOFF, H. Integrating Programming, Evaluation and Partcipation in Design - A Theory Z. Approach. Raleigh: Henry Sanoff, 1992.

SANOFF, H. Visual research methods. Washington, DC: National Clearinghouse for Educational Facilities. www.edfacilities.org, 2001. Acesso em: 9 mar. 2006.

SANOFF, H. School Design. New York: Van Nostrand Reinhold. 1994.

SARDENBERG, R. Conexão para a sociedade. São Paulo: Galileu, v. 12, n. 134, p. 36-39, Set. 2002.

SENAC. Serviço Nacional de Aprendizagem Comercial. http://www.sp.senac.br. 2006. Acesso em: 9 fev. 2007.

SERAPIÃO, F. Uso de pré-fabricados aproxima e contrapõe edifícios universitários. Projeto Design, [S. 1.], v. 308, out. 2005.

SILVA Fo., José Tavares da. Conservação preventiva de acervos Bibliográficos. Disponível em: <http://www.forum.ufrj.br/biblioteca/preservacao.html $>$. Acesso em: 24/04/2001.

SCARAZZATO, P.S. A APO e a iluminação ambiental. In: ENTAC - Encontro Nacional de Tecnologia do Ambiente. São Paulo: v.2, p. 835-838, 1993.

SCONUL - Society of College, National \& Universitym Libraries. London, http://www.sconul.ac.uk/, 2006. Acesso em: 14 mar. 2006. 
SILVER, S. \& NICKEL, L.T.. Surveying User Activity as a Tool for Space Planning in an Academic Library. University of South Florida, http://www.eric.ed.gov/ERICDocs/, 2002. Acesso em: 17 mar. 2006.

SIMON, A. C. Los archivos como fuente para el estudio de la arquitectura. In: Bibliotecas de arte, arquitectura y diseño, 189 - 200. Barcelona: IFLA Publications, 1995.

SLYCK, V; AYRES, A. Designing the Modern Library. In: Free to All: Carnegie Libraries \& American Culture, 1890-1920, 27-43. Chicago: University of Chicago, 1995.

SOMMER, R. \& SOMMER, B. A Pratical Guide to Behavior Research, NY, Oxford, 1997.

SPERANDIO, D. Administração universitária: a educação numa visão interdisciplinar. Caderno de Administração, Maringá, v. 3, n. 1, p. 49-51, ago. 1997.

TARAPANOFF, K. Planejamento de e para bibliotecas universitárias no Brasil: sua posição sócio-econônmica e estrutural. In: V Seminário Nacional de Bibliotecas Universitárias, Natal, 2. Anais, 1981, p. 9.

TAFURI, M. Teorias e História da arquitetura. Lisboa: Ed. Presence, 1988.

TEIXEIRA, L. As cores do discurso. Niterói: EDUFF, 1996. 242p.

TOBIAS, J. A. Universidade: formação humana e profissional. 1.ed. Presidente Prudente : UNOESTE, 1988.

TOFFLER, A. Guerra e Antiguerra. Rio de Janeiro: Record, 1994.

TOH, T. Cultural facilities: new concepts in architecture e design. Tokio, Ed. Meise Publications, 1995. $159 \mathrm{p}$.

UNESP. Universidade Estadual Paulista. São Paulo. http://www.unesp.br, 2006. Acesso em: 17 set. 2006. 
UNIVERSIDADE DE BERLIN. URL: http: www. pt.wikipedia.org/ .Acesso em: 13 mar. 2006.

UNIVERSIDADE DE BRASÍLIA - Faculdade de Arquitetura - Programa de pós - graduação.URL: www.unb.br/fau/pos_graduacao. Acesso em: 1 mar. 2006.

UNIVESIDADE DE COIMBRA. URL: http: www.etab.ac-caen.fr. Acesso em: 11 mar. 2006.

UNIVERSIDADE DE OXFORD. URL: http: www. geocities.yahoo.com. Acesso em: 11 mar. 2006.

UNIVERSIDADE DE SALAMANCA. URL: http: www.cultivate-int.org. Acesso em: 19 mar. 2006.

UNIVERSITÉ SORBONE. URL: http: www.polygraphicum.de. Acesso em: 9 mar. 2006.

VAN REENEN, J. Work and productivity in $21^{\text {st }}$ century. In:(Ed.). Digital libraries and virtual workplaces important initiatives for Latin America in the information age. Washington, DC: Inter-American Agency for Cooperation and Development, 2002. p.3-44.

VERGEIRO, W. Seleção de materiais de informação. Brasília: Briquet de Lemos, 1997. $230 \mathrm{p}$.

WANDERLEY, L. E. W. O que é universidade? São Paulo: Editora Brasiliense. 9. ed. - Coleção Primeiros Passos, 1988.

WARD, H. eds. New Library Buildings. London: Grosvenor Press, 1994.

WATSON, D.; CROSBIE, M. J.; CALLENDER, J. H., eds. Time-Saver Standards for Architectural Design Data: The Reference of Architectural Fundamentals. New York: McGraw-Hill, 1997

WEB, T.D. News Ware: Integrating Mass Communications and Library Resources. In:Building Libraries for the 21st Century: The Shape of Information, 105-121. Jefferson, NC: McFarland, 2000. 
WEHRPLOTZ, E.; CANDIDO, H.; BONO, L. Padrões de espaços em Biblioteca : acervo, usuários, funcionários. $h \mathrm{ttp}: / /$ campus.fortunecity.com/ mcat/102/index.htm. Acesso em: 11 mar. 2006.

WHITE, E. Post-occupancy evaluation from the client's perspective. In: Building Evaluation, New York, Plenum Press, 1989, p. 19-34.

ZEVI, B. Saber ver a arquitetura. São Paulo: Martins Fontes, 1996.

ZILLES, U. Fé e razão no pensamento medieval. Porto Alegre: Epipurgs, 1993.

ZIMRING, C. M. Post-occupancy evaluation and implicit theory: an overview. In: Building Evaluation, New York: Plenum Press, 1989, p. 113-126.

YIN, R.K. Estudos de caso: Planejamento e métodos. Porto Alegre: Bookman, 2001. 



\section{ANEXOS}

Roteiro check list

Roteiro grupos focais

Formulários de questionários

Roteiro de entrevistas

Mapa de descobertas 
01 - Roteiro CHECK LIST - Walkthrough

\section{USP UNIVERSIDADE DE SÃO PAULO}

Faculdade de Arquitetura e Urbanismo

Pesquisa de Doutorado

\section{CHECK LIST - Walkthrough}

Data: $1+1$
Biblioteca___
Pavimento_
Área

\section{1- ASPECTOS FUNCIONAIS}

\subsection{MOBILIÁRIO}

$\square$ Mesas

- Altura

- Espaço disponível para armazenamento de materiais

- Dimensionamento (largura $x$ comprimento)

- Distância entre você e a chefia imediata

- Estado de conservação e acabamentos

- Altura e disposição dos equipamentos de informática

\section{Cadeiras}

- Altura

- Tipologia

- Alternativas de regulagens

- Estado de conservação

- Dimensionamento (largura x comprimento)

- Distância entre as outras áreas de atividade

Armários (setor administrativo)

- Altura

- Tipologia

- Estado de conservação e acabamentos

- Dimensionamento (largura x comprimento)

- Distância entre as outras áreas de atividade

- Áreas de armazenamento 
- Altura

- Tipologia

- Estado de conservação e acabamentos

- Dimensionamento (largura x comprimento)

- Distância entre as outras áreas de atividade

- Áreas de armazenamento

- Larguras entres estantes

Biombos

- Dimensões (altura, largura e espessura)

- Acabamento

- Tipologia

Arquivos deslizantes

- Dimensões (altura, largura e espessura)

- Acabamento

- Tipologia

\subsection{DIMENSIONAMENTOS MÍNIMOS, ARRANJO ESPACIAL, SINALIZAÇÃO} INTERNA E ACESSIBILIDADE

Largura dos corredores

$\square$ Largura das escadas

Quantidade e tamanho de sanitários

Acesso e adaptação do deficiente físico e circulação

Tamanho do ambiente de trabalho

Aparência dos ambientes de trabalho (materiais e cores)

Espaços para reuniões formais na Biblioteca

$\square$ Saídas de emergência /Segurança da Biblioteca contra incêndio

\Sinalização interna da Biblioteca

$\square$ Espaço para armazenamento e almoxarifado

$\square$ Elevadores

\section{2 - CONFORTO AMBIENTAL}

Temperatura

Umidade

Ventilação

Iluminação natural 
Iluminação artificial

ar condicionado

\section{TECNOLOGIA DA INFORMAÇÃO (TI)}

Quantidade de microcomputadores

Localização

$\square$ Velocidade de transmissão de dados

$\square$ Facilidade no manuseio dos programas/equipamentos informáticos

Tamanho e disposição espacial no posto de trabalho

Acesso do deficiente físico aos recursos informáticos 
$\mathbf{0 2}$ - Roteiro aplicado nos grupos focais dos estudos de caso

\section{USP UNIVERSIDADE DE SÃO PAULO}

Faculdade de Arquitetura e Urbanismo

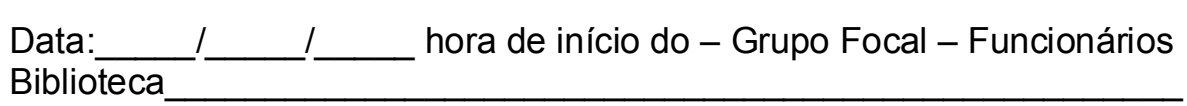

Participantes:

Moderador:

Funcionários:

\section{1 - PERFIL DO GRUPO FOCAL}

1.1. Sexo:

(1) Feminino $\%$

(2) Masculino $\%$

1.2. Escolaridade:

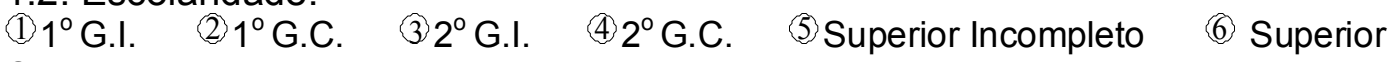
Completo

1.3. Idade:

(1) até 20

1.4. Tempo de trabalho na instituição:
(1) $<1$
(2) 1 a 5
(3) $>5$ a 10
(4) $>10$

1.5. Tipo de atividade que exerce na Biblioteca:

(1) Diretoria

(2) Bibliotecário(a)

(3) Técnico(a)

(4) Auxiliar

(5) Segurança

(6) Limpeza

(7) Outra (qual?)

\section{ROTEIRO DAS QUESTÕES}

\section{ASPECTOS FUNCIONAIS}

\section{MOBILIÁRIO}

01.De modo geral, você acha que o tipo de MOBILIÁRIO presente na Biblioteca é adequado para as atividades desenvolvidas? 
02. Em algum momento você participou dando sugestões sobre o tipo de MOBILIÁRIO para seu local de trabalho na Biblioteca?

03.0 que você acha da conservação do MOBILIÁRIO?

04.As medidas do MOBILIÁRIO estão adequadas ao trabalho na biblioteca?

05.As cadeiras são confortáveis? Tipo de ajustes, Modelos,etc.

06.As mesas possuem dimensões adequadas?

07.As mesas atendem às necessidades no posto de trabalho?

08.As distâncias entres as mesas de trabalho são adequadas?

09.As medidas dos armários atendem as necessidade de arquivamento?

10.As quantidades de mesas são suficientes?

11.Existe privacidade na sua área de trabalho?

\section{DIMENSIONAMENTOS MÍNIMOS, ARRANJO ESPACIAL, SINALIZAÇÃO INTERNA E ACESSIBILIDADE}

01.0 que você acha da largura e localização dos corredores e das escadas?

02. O que você acha da quantidade, tamanho e localização dos sanitários?

03.O que você acha do acesso do deficiente físico no edifício?

04. Você acha que a sinalização interna da biblioteca atende seus requisitos?

05.O que você acha dos espaços para encontros e contatos informais na biblioteca e espaços para reuniões formais na Biblioteca?

06. Você acha que os espaço para armazenamento e almoxarifado da biblioteca são suficientes?

\section{CONFORTO AMBIENTAL}

06. Como você avalia o conforto térmico na biblioteca?

07. lluminação no ambiente de trabalho?

08. O sol atinge seu posto de trabalho?

09. Qualidade do ar no ambiente?

10.Ocorrência de reflexos indesejados na tela do seu computador?

11. A operação do ar-condicionado (ruídos, temperatura, posicionamento)?

\section{TECNOLOGIA DA INFORMAÇÃO (TI)}

01.De modo geral, você acha que a Biblioteca está bem servida das diversas tecnologias informacionais como, microcomputadores, internet, bases de dados $\mathrm{e}$ redes digitais, terminais de consulta, etc.?

02.Você acha que a instituição tem procurado modernizar os recursos informáticos na Biblioteca? 
03.Em sua opinião, os recursos informáticos presentes na Biblioteca são suficientes para atender às necessidades no seu ambiente de trabalho?

04. Quantidade de microcomputadores Localização dos equipamentos informáticos no ambiente de trabalho Facilidade no manuseio dos programas/equipamentos informáticos 
$\mathbf{0 3}$ - Formulário de questionário aplicado aos professores ${ }^{1}$

\section{USP UNIVERSIDADE DE SÃO PAULO}

Faculdade de Arquitetura e Urbanismo

\section{AVALIAÇÃO PÓS-OCUPAÇÃO}

- $\quad$ Este trabalho destina-se à avaliação e à análise dos edifícios de bibliotecas e as suas sugestões são fundamentais para este processo.

- $\quad$ Não é necessário se identificar.

Data: _ _ _ _ _ _ _ _ hora de início do preenchimento do questionário:

Ficha n.-

\section{1 - PERFIL DO RESPONDENTE}

1.1. Sexo:

(1) Feminino (2) Masculino

1.2. Ministra aulas nos cursos de:

(1) Graduação (2) Pós-Graduação

1.3. Idade do entrevistado:

$\begin{array}{lllll}\text { (1) até } 20 & (2)+20 \text { a } 30 & (3)+30 \text { a } 40 & \text { (4) }+40 \text { a } 50 & \text { (5) } \text { mais de } 50\end{array}$

1.4. Há quanto tempo você usa o edifício:

\begin{tabular}{|l|l|l|}
\hline & \\
\hline
\end{tabular} Anos Meses

\section{$-$}

\section{2-ASPECTOS FUNCIONAIS}

\subsection{MOBILIÁRIO}

2.1.1.De modo geral, você acha que o tipo de MOBILIÁRIO presente na Biblioteca é adequado para as atividades desenvolvidas?

(1) não (2) um pouco

2.1.2. Em algum momento você participou dando sugestões sobre o tipo de MOBILIÁRIO para seu local de trabalho na Biblioteca?

(1) não (2) um pouco totalmente

2.1.3. No quadro abaixo, marque suas impressões quanto à?

\begin{tabular}{|l|c|c|c|c|c|c|}
\hline & Péssimo & Ruim & Regular & Bom & Excelente & $\begin{array}{c}\text { Nenhuma } \\
\text { das }\end{array}$ \\
\hline
\end{tabular}

\footnotetext{
${ }^{1}$ Adaptado de Andrade (2005).
} 


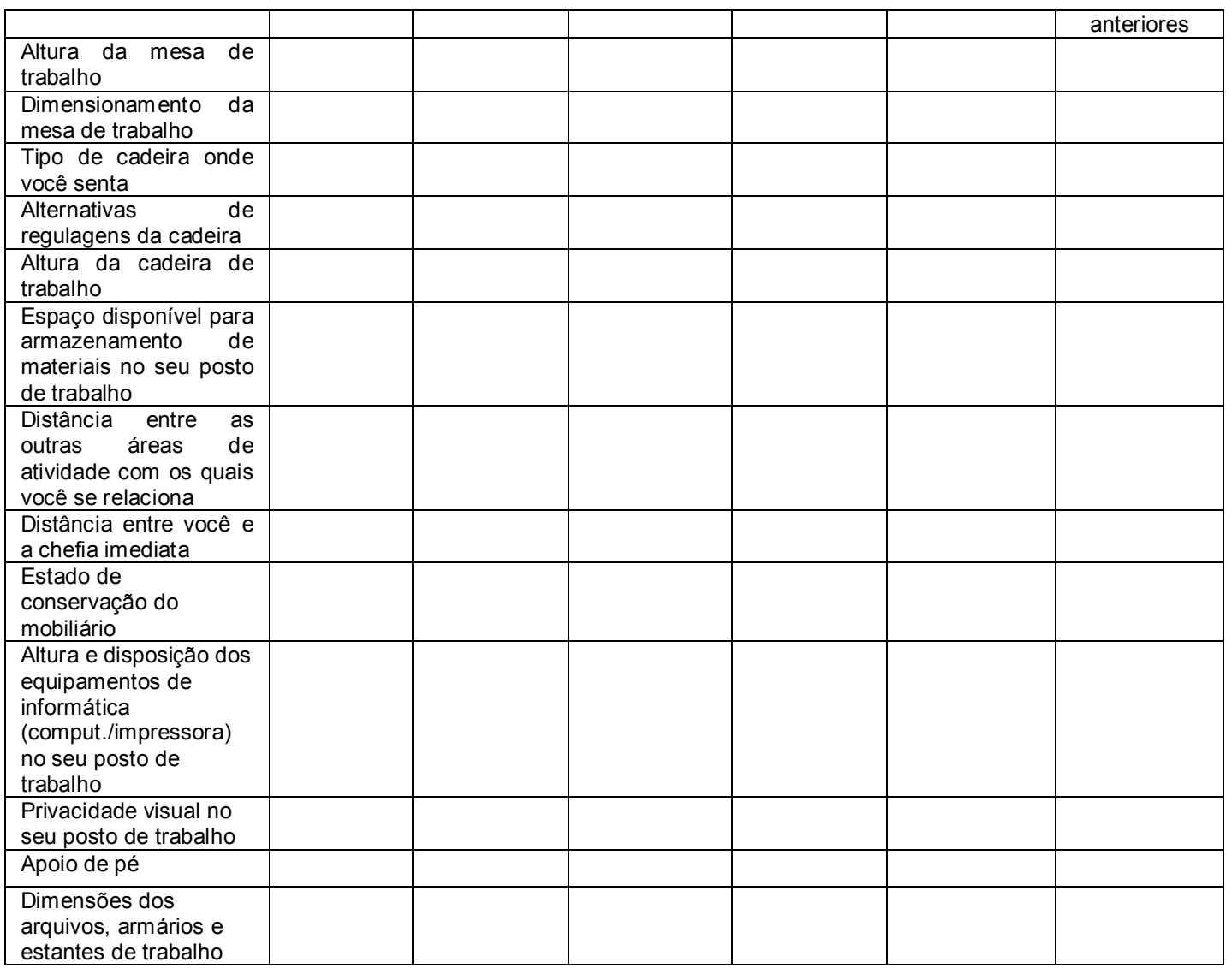

\subsection{CONFORTO AMBIENTAL}

2.2.1. No seu ambiente de trabalho, como você avalia os itens relacionados abaixo na época do VERÃO?

\begin{tabular}{|c|c|c|c|c|c|c|}
\hline & Péssimo & Ruim & Regular & Bom & Excelente & $\begin{array}{c}\text { Nenhuma das } \\
\text { anteriores }\end{array}$ \\
\hline Temperatura & & & & & & \\
\hline Umidade & & & & & & \\
\hline Ventilação & & & & & & \\
\hline Iluminação natural & & & & & & \\
\hline Iluminação artificial & & & & & & \\
\hline
\end{tabular}

2.2.2. No seu ambiente de trabalho, como você avalia os itens relacionados abaixo na época do INVERNO?

\begin{tabular}{|l|l|l|l|l|l|l|}
\hline & Péssimo & Ruim & Regular & Bom & Excelente & $\begin{array}{c}\text { Nenhuma das } \\
\text { anteriores }\end{array}$ \\
\hline Temperatura & & & & & & \\
\hline Umidade & & & & & & \\
\hline Ventilação & & & & & & \\
\hline Iluminação natural & & & & & & \\
\hline Iluminação artificial & & & & & & \\
\hline
\end{tabular}

2.2.3. Como você avalia trabalhar em um local com ar condicionado?

(1) pouco satisfatório (2) satisfatório (3) muito satisfatório (4) nenhuma das anteriores

2.2.4.Como você avalia a interferência do ruído interno (edifício) no seu ambiente de trabalho?

(1) não há interferência (2) ocorrem ocasionalmente (3) ocorrem $50 \%$ do tempo

(4) ocorrem frequentemente. 
2.2.5.Como você avalia a interferência do ruído externo (edifício) no seu ambiente de trabalho?

(1) não há interferência (2) ocorrem ocasionalmente (3) ocorrem $50 \%$ do tempo

(4) ocorrem frequentemente.

\subsection{DIMENSIONAMENTOS MÍNIMOS, ARRANJO ESPACIAL, SINALIZAÇÃO INTERNA E ACESSIBILIDADE}

\begin{tabular}{|c|c|c|c|c|c|c|}
\hline & Péssimo & Ruim & Regular & Bom & Excelente & $\begin{array}{l}\text { Nenhuma } \\
\text { das } \\
\text { anteriores }\end{array}$ \\
\hline $\begin{array}{l}\text { Largura dos corredores } \\
\text { no seu ambiente de } \\
\text { trabalho }\end{array}$ & & & & & & \\
\hline Largura das escadas & & & & & & \\
\hline Localização das escadas & & & & & & \\
\hline Quantidade de sanitários & & & & & & \\
\hline Tamanho dos sanitários & & & & & & \\
\hline $\begin{array}{l}\text { Acesso do deficiente } \\
\text { físico e circulação }\end{array}$ & & & & & & \\
\hline $\begin{array}{l}\text { Tamanho do ambiente } \\
\text { de trabalho }\end{array}$ & & & & & & \\
\hline $\begin{array}{l}\text { Aparência dos } \\
\text { ambientes de trabalho } \\
\text { (materiais e cores) }\end{array}$ & & & & & & \\
\hline $\begin{array}{l}\text { Localização das salas de } \\
\text { reunião }\end{array}$ & & & & & & \\
\hline $\begin{array}{l}\text { Espaços para reuniões } \\
\text { formais na Biblioteca }\end{array}$ & & & & & & \\
\hline $\begin{array}{l}\text { Espaços para encontros } \\
\text { e contatos informais na } \\
\text { Biblioteca }\end{array}$ & & & & & & \\
\hline $\begin{array}{l}\text { Áreas de descanso/lazer } \\
\text { disponíveis }\end{array}$ & & & & & & \\
\hline Saídas de emergência & & & & & & \\
\hline $\begin{array}{lll}\text { Sinalização interna da } \\
\text { Biblioteca }\end{array}$ & & & & & & \\
\hline $\begin{array}{l}\text { Segurança da Biblioteca } \\
\text { contra incêndio }\end{array}$ & & & & & & \\
\hline $\begin{array}{l}\text { Adaptação da Biblioteca } \\
\text { ao uso do deficiente } \\
\text { físico }\end{array}$ & & & & & & \\
\hline $\begin{array}{lr}\text { Espaço } & \text { para } \\
\text { armazenamento } & \text { e } \\
\text { almoxarifado } & \end{array}$ & & & & & & \\
\hline & & & & & & \\
\hline
\end{tabular}

\subsection{TECNOLOGIA DA INFORMAÇÃO (TI)}

2.4.1.De modo geral, você acha que a Biblioteca está bem servida das diversas tecnologias informacionais como, microcomputadores, internet, bases de dados e redes digitais, terminais de consulta, etc.?

(1) não (2) sim

2.4.2. Você acha que a instituição tem procurado modernizar os recursos informáticos na Biblioteca?
(1) não
(2) $\operatorname{sim}$

2.4.3. No seu posto de trabalho, com que freqüência você utiliza os recursos informáticos.?
(1) nunca
(2) ocasionalmente
(3) $50 \%$ do tempo
(4) sempre 
2.4.4.Em sua opinião, os recursos informáticos presentes na Biblioteca são suficientes para atender às necessidades no seu ambiente de trabalho?

$\begin{array}{ll}\text { (1) não } & \text { (2) } \\ \text { sim }\end{array}$

2.4.5. Na sua avaliação classifique, conforme critério abaixo, os itens apontados, de acordo com a sua importância na sua utilização dos recursos informáticos na Biblioteca?

(1) não importante (2) pouco importante (3) importante (4) muito importante
( ) Bases de dados/CD-ROM
( ) Bases de dados/Internet
( ) e-Books
( ) Periódicos eletrônicos
( ) Catálogos eletrônicos
( ) Equipamentos multimídia
( ) Tele-conferência
( ) Correio eletrônico
(som,imagem)

2.4.6. No quadro seguinte assinale suas impressões quanto à TECNOLOGIA DA INFORMAÇÃO (TI) no seu ambiente de trabalho?

\begin{tabular}{|l|l|l|l|l|l|l|}
\hline & Péssimo & Ruim & Regular & Bom & $\begin{array}{c}\text { Excelente } \\
\text { Nenhuma } \\
\text { das } \\
\text { anteriores }\end{array}$ \\
\hline $\begin{array}{l}\text { Quantidade de } \\
\text { microcomputadores dos }\end{array}$ & & & & & \\
\hline $\begin{array}{l}\text { Localização } \\
\text { equipamentos de } \\
\text { informáticos no ambiente } \\
\text { de trabalho }\end{array}$ & & & & & \\
\hline $\begin{array}{l}\text { Velocidade } \\
\text { transmissão de dados }\end{array}$ & & & & & \\
\hline $\begin{array}{l}\text { Facilidade no manuseio } \\
\text { dos } \\
\text { programas/equipamentos } \\
\text { informáticos }\end{array}$ & & & & & \\
\hline $\begin{array}{l}\text { Tamanho e disposição } \\
\text { espacial do seu posto de } \\
\text { trabalho frente às } \\
\text { atividades dos recursos } \\
\text { informáticos }\end{array}$ & & & & & & \\
\hline $\begin{array}{l}\text { Acesso do deficiente } \\
\text { físico aos recursos } \\
\text { informáticos }\end{array}$ & & & & & & \\
\hline
\end{tabular}

\section{Agradecemos muito à sua valiosa cooperação.}


04 - Formulário de questionário aplicado aos alunos ${ }^{2}$

\section{USP UNIVERSIDADE DE SÃO PAULO}

Faculdade de Arquitetura e Urbanismo

\section{AVALIAÇÃO PÓS-OCUPAÇÃO}

- $\quad$ Este trabalho destina-se à avaliação e à análise dos edifícios de bibliotecas e as suas sugestões são fundamentais para este processo.

- $\quad$ Não é necessário se identificar.

Data:___ _ _ _ _ _ _ hora de início do preenchimento do questionário:

Ficha n.-

\section{1 - PERFIL DO RESPONDENTE}

\subsection{Sexo:}

(1) Feminino (2) Masculino

1.2. Está cursando:

(1) Graduação Pós-Graduação

1.3. Idade do entrevistado:

$\begin{array}{lllll}\text { (1) até } 20 & (2)+20 \text { a } 30 & (3)+30 \text { a } 40 & \text { (4) }+40 \text { a } 50 & \text { (5) mais de } 50\end{array}$

1.4. Há quanto tempo você usa o edifício da Biblioteca:

\begin{tabular}{ll|l|l|l}
$\square$ & Anos
\end{tabular}

\section{-}

\section{2-ASPECTOS FUNCIONAIS}

\subsection{MOBILIÁRIO}

2.1.1.De modo geral, você acha que o tipo de MOBILIÁRIO presente na Biblioteca é adequado para as atividades desenvolvidas?

(1) não (2) um pouco totalmente

2.1.2. Em algum momento você participou dando sugestões sobre o tipo de MOBILIÁRIO para seu local de trabalho na Biblioteca?

(1) não (2) um pouco totalmente

2.1.3. No quadro abaixo, marque suas impressões quanto à?

\begin{tabular}{|l|c|c|c|c|c|c|}
\hline & Péssimo & Ruim & Regular & Bom & Excelente & $\begin{array}{c}\text { Nenhuma } \\
\text { das }\end{array}$ \\
\hline
\end{tabular}

\footnotetext{
${ }^{2}$ Adaptado de Andrade (2005).
} 


\begin{tabular}{|l|l|l|l|l|l|}
\hline & & & & & \\
\hline Altura da mesa & & & & & \\
\hline $\begin{array}{l}\text { Dimensionamento da } \\
\text { mesa }\end{array}$ & & & & & \\
\hline $\begin{array}{l}\text { Tipo de cadeira onde } \\
\text { você senta }\end{array}$ & & & & & \\
\hline $\begin{array}{l}\text { Alternativas de } \\
\text { regulagens da cadeira }\end{array}$ & & & & & \\
\hline $\begin{array}{l}\text { Altura da cadeira de } \\
\text { trabalho }\end{array}$ & & & & & \\
\hline $\begin{array}{l}\text { Espaço disponível para } \\
\text { armazenamento de } \\
\text { materiais no seu posto } \\
\text { de trabalho }\end{array}$ & & & & & \\
\hline $\begin{array}{l}\text { Distância entre as } \\
\text { outras áreas de } \\
\text { atividade com os quais } \\
\text { você se relaciona }\end{array}$ & & & & & \\
\hline $\begin{array}{l}\text { Estado de } \\
\text { conservação do } \\
\text { mobiliário }\end{array}$ & & & & & \\
\hline $\begin{array}{l}\text { Altura e disposição dos } \\
\text { equipamentos de } \\
\text { informática } \\
\text { (comput./impressora) } \\
\text { no seu posto de } \\
\text { trabalho }\end{array}$ & & & & & \\
\hline $\begin{array}{l}\text { Privacidade visual no } \\
\text { seu posto de trabalho }\end{array}$ & & & & & \\
\hline Apoio de pé & & & & & \\
\hline $\begin{array}{l}\text { Dimensões dos } \\
\text { arquivos, armários e } \\
\text { estantes de trabalho }\end{array}$ & & & & & \\
\hline
\end{tabular}

\subsection{CONFORTO AMBIENTAL}

2.2.1. No seu ambiente de trabalho, como você avalia os itens relacionados abaixo na época do VERÃO?

\begin{tabular}{|l|l|l|l|l|l|l|}
\hline & Péssimo & Ruim & Regular & Bom & $\begin{array}{c}\text { Excelente } \\
\text { Nenhuma das } \\
\text { anteriores }\end{array}$ \\
\hline Uemperatura & & & & & & \\
\hline Umidade & & & & & & \\
\hline Ventilação & & & & & & \\
\hline Iluminação natural & & & & & & \\
\hline
\end{tabular}

2.2.2. No seu ambiente de trabalho, como você avalia os itens relacionados abaixo na época do INVERNO?

\begin{tabular}{|l|l|l|l|l|l|l|}
\hline & Péssimo & Ruim & Regular & Bom & $\begin{array}{c}\text { Excelente } \\
\text { Nenhuma das } \\
\text { anteriores }\end{array}$ \\
\hline Temperatura & & & & & & \\
\hline Umidade & & & & & & \\
\hline Ventilação & & & & & & \\
\hline Iluminação natural & & & & & & \\
\hline Iluminação artificial & & & & & & \\
\hline
\end{tabular}

2.2.3. Como você avalia trabalhar em um local com ar condicionado?

(1) pouco satisfatório (2) satisfatório (3) muito satisfatório (4) nenhuma das anteriores

2.2.4.Como você avalia a interferência do ruído interno (edifício) no seu ambiente de trabalho?

(1) não há interferência (2) ocorrem ocasionalmente (3) ocorrem $50 \%$ do tempo

(4) ocorrem frequentemente. 
2.2.5. Como você avalia a interferência do ruído externo (edifício) no seu ambiente de trabalho?

(1) não há interferência (2) ocorrem ocasionalmente (3) ocorrem $50 \%$ do tempo

(4) ocorrem frequentemente.

\subsection{DIMENSIONAMENTOS MÍNIMOS, ARRANJO ESPACIAL, SINALIZAÇÃO INTERNA E ACESSIBILIDADE}

\begin{tabular}{|c|c|c|c|c|c|c|}
\hline & Péssimo & Ruim & Regular & Bom & Excelente & $\begin{array}{c}\text { Nenhuma } \\
\text { das } \\
\text { anteriores }\end{array}$ \\
\hline Largura dos corredores & & & & & & \\
\hline Largura das escadas & & & & & & \\
\hline Localização das escadas & & & & & & \\
\hline Quantidade de sanitários & & & & & & \\
\hline Tamanho dos sanitários & & & & & & \\
\hline $\begin{array}{l}\text { Acesso do deficiente } \\
\text { físico e circulação }\end{array}$ & & & & & & \\
\hline Tamanho dos ambientes & & & & & & \\
\hline $\begin{array}{lr}\text { Aparência } & \text { dos } \\
\text { ambientes (materiais e } \\
\text { cores) }\end{array}$ & & & & & & \\
\hline $\begin{array}{l}\text { Localização das salas de } \\
\text { reunião }\end{array}$ & & & & & & \\
\hline $\begin{array}{l}\text { Espaços para reuniões } \\
\text { formais na Biblioteca }\end{array}$ & & & & & & \\
\hline $\begin{array}{l}\text { Espaços para encontros } \\
\text { e contatos informais na } \\
\text { Biblioteca }\end{array}$ & & & & & & \\
\hline $\begin{array}{l}\text { Áreas de descanso/lazer } \\
\text { disponíveis }\end{array}$ & & & & & & \\
\hline Saídas de emergência & & & & & & \\
\hline $\begin{array}{l}\text { Sinalização interna da } \\
\text { Biblioteca }\end{array}$ & & & & & & \\
\hline $\begin{array}{l}\text { Segurança da Biblioteca } \\
\text { contra incêndio }\end{array}$ & & & & & & \\
\hline $\begin{array}{l}\text { Adaptação da Biblioteca } \\
\text { ao uso do deficiente } \\
\text { físico }\end{array}$ & & & & & & \\
\hline $\begin{array}{lr}\text { Espaço } & \text { para } \\
\text { armazenamento } & \mathrm{e} \\
\text { almoxarifado } & \end{array}$ & & & & & & \\
\hline $\begin{array}{l}\text { Tempo de espera no } \\
\text { elevador }\end{array}$ & & & & & & \\
\hline
\end{tabular}

\subsection{TECNOLOGIA DA INFORMAÇÃO (TI)}

2.4.1.De modo geral, você acha que a Biblioteca está bem servida das diversas tecnologias informacionais como, microcomputadores, internet, bases de dados e redes digitais, terminais de consulta, etc.?
(1) não
(2) $\operatorname{sim}$

2.4.2. Você acha que a instituição tem procurado modernizar os recursos informáticos na Biblioteca?
(1) não
(2) $\operatorname{sim}$

2.4.3. No seu posto de trabalho, com que freqüência você utiliza os recursos informáticos.?
(1) nunca
(2) ocasionalmente
(3) $50 \%$ do tempo
(4) sempre 
2.4.4.Em sua opinião, os recursos informáticos presentes na Biblioteca são suficientes para atender às necessidades no seu ambiente de trabalho?

$\begin{array}{lll}\text { (1) não } & \text { (2) } \\ \text { sim }\end{array}$

2.4.5. Na sua avaliação classifique, conforme critério abaixo, os itens apontados, de acordo com a sua importância na sua utilização dos recursos informáticos na Biblioteca?

(1) não importante (2) pouco importante (3) importante (4) muito importante

( ) Bases de dados/CD-ROM

( ) Periódicos eletrônicos

( ) Tele-conferência
( ) Bases de dados/Internet
( ) Catálogos eletrônicos
( ) Correio eletrônico

( ) e-Books

( ) Equipamentos multimídia (som,imagem)

2.4.6. No quadro seguinte assinale suas impressões quanto à TECNOLOGIA DA INFORMAÇÃO (TI) no seu ambiente de trabalho?

\begin{tabular}{|c|c|c|c|c|c|c|}
\hline & Péssimo & Ruim & Regular & Bom & Excelente & $\begin{array}{l}\text { Nenhuma } \\
\text { das } \\
\text { anteriores }\end{array}$ \\
\hline $\begin{array}{ll}\text { Quantidade } & \mathrm{de} \\
\text { microcomputadores }\end{array}$ & & & & & & \\
\hline $\begin{array}{l}\text { Localização dos } \\
\text { equipamentos } \\
\text { informáticos no ambiente } \\
\text { de trabalho }\end{array}$ & & & & & & \\
\hline $\begin{array}{ll}\text { Velocidade } & \text { de } \\
\text { transmissão de dados } & \\
\end{array}$ & & & & & & \\
\hline $\begin{array}{l}\text { Facilidade no manuseio } \\
\text { dos } \\
\text { programas/equipamentos } \\
\text { informáticos }\end{array}$ & & & & & & \\
\hline $\begin{array}{l}\text { Tamanho e disposição } \\
\text { espacial do seu posto de } \\
\text { trabalho frente às } \\
\text { atividades dos recursos } \\
\text { informáticos }\end{array}$ & & & & & & \\
\hline $\begin{array}{lrr}\text { Acesso do } & \text { deficiente } \\
\text { físico aos } & \text { recursos } \\
\text { informáticos } & \\
\end{array}$ & & & & & & \\
\hline
\end{tabular}


05 - Formulário de questionário aplicado aos funcionários ${ }^{3}$

\section{USP UNIVERSIDADE DE SÃO PAULO}

Faculdade de Arquitetura e Urbanismo

\section{AVALIAĈ̃̃O PÓS-OCUPAÇÃO}

- $\quad$ Este trabalho destina-se à avaliação e à análise dos edifícios de bibliotecas e as suas sugestões são fundamentais para este processo.

- $\quad$ Não é necessário se identificar.

Data: _ _ _ _ _ _ _ _ hora de início do preenchimento do questionário: Ficha n.-

\section{1 - PERFIL DO RESPONDENTE}

1.1. Sexo:

(1) Feminino (2) Masculino

1.2. Escolaridade:

(1) $1^{\circ}$ G.I. (2) $1^{\circ}$ G.C. (3) $2^{\circ}$ G.I. (4) $2^{\circ}$ G.C. (5) Superior Incompleto (6) Superior Completo

1.3. Idade do entrevistado:

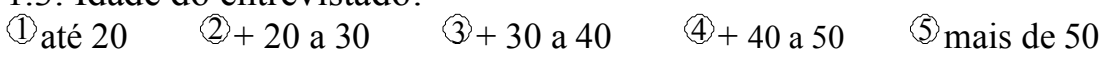

1.4. Tempo de trabalho na instituição:
(1) $<1$
(2) $1 \mathrm{a} 5$
(3) $>5$ a 10
(4) $>10$

1.5. Tipo de atividade que exerce na Biblioteca:

(1) Diretoria

(2) Bibliotecário(a)

(3) Técnico(a)

(4) Auxiliar

(5) Segurança

(6) Limpeza

(7) Outra (qual?)

\section{2-ASPECTOS FUNCIONAIS}

\subsection{MOBILIÁRIO}

\footnotetext{
${ }^{3}$ Adaptado de Andrade (2005).
} 
2.1.1.De modo geral, você acha que o tipo de MOBILIÁRIO presente na Biblioteca é adequado para as atividades desenvolvidas?
(1) não
(2) um pouco
(3) totalmente

2.1.2. Em algum momento você participou dando sugestões sobre o tipo de MOBILIÁRIO para seu local de trabalho na Biblioteca?

(1) não (2) um pouco totalmente

2.1.4. No quadro abaixo, marque suas impressões quanto à?

\begin{tabular}{|c|c|c|c|c|c|c|}
\hline & Péssimo & Ruim & Regular & Bom & Excelente & $\begin{array}{l}\text { Nenhuma } \\
\text { das } \\
\text { anteriores }\end{array}$ \\
\hline \multicolumn{7}{|l|}{$\begin{array}{l}\text { Altura da mesa de } \\
\text { trabalho }\end{array}$} \\
\hline \multicolumn{7}{|l|}{$\begin{array}{l}\text { Dimensionamento da } \\
\text { mesa de trabalho }\end{array}$} \\
\hline \multicolumn{7}{|l|}{$\begin{array}{l}\text { Tipo de cadeira onde } \\
\text { você senta }\end{array}$} \\
\hline \multicolumn{7}{|l|}{$\begin{array}{l}\text { Alternativas } \\
\text { regulagens da cadeira }\end{array}$} \\
\hline \multicolumn{7}{|l|}{$\begin{array}{l}\text { Altura da cadeira de } \\
\text { trabalho }\end{array}$} \\
\hline \multicolumn{7}{|l|}{$\begin{array}{l}\text { Espaço disponível para } \\
\text { armazenamento de } \\
\text { materiais no seu posto } \\
\text { de trabalho }\end{array}$} \\
\hline \multicolumn{7}{|l|}{$\begin{array}{l}\text { Distância entre as } \\
\text { outras áreas de } \\
\text { atividade com os quais } \\
\text { você se relaciona }\end{array}$} \\
\hline \multicolumn{7}{|l|}{$\begin{array}{l}\text { Distância entre você e } \\
\text { a chefia imediata }\end{array}$} \\
\hline \multicolumn{7}{|l|}{$\begin{array}{l}\text { Estado de } \\
\text { conservação do } \\
\text { mobiliário }\end{array}$} \\
\hline \multicolumn{7}{|l|}{$\begin{array}{l}\text { Altura e disposição dos } \\
\text { equipamentos de } \\
\text { informática } \\
\text { (comput./impressora) } \\
\text { no seu posto de } \\
\text { trabalho }\end{array}$} \\
\hline \multicolumn{7}{|l|}{$\begin{array}{l}\text { Privacidade visual no } \\
\text { seu posto de trabalho }\end{array}$} \\
\hline \multicolumn{7}{|l|}{ Apoio de pé } \\
\hline $\begin{array}{l}\text { Dimensões dos } \\
\text { arquivos, armários e } \\
\text { estantes de trabalho }\end{array}$ & & & & & & \\
\hline
\end{tabular}

\subsection{CONFORTO AMBIENTAL}

2.2.1.No seu ambiente de trabalho, como você avalia os itens relacionados abaixo na época do VERÃO?

\begin{tabular}{|c|c|c|c|c|c|c|}
\hline & Péssimo & Ruim & Regular & Bom & Excelente & $\begin{array}{c}\text { Nenhuma das } \\
\text { anteriores }\end{array}$ \\
\hline Temperatura & & & & & & \\
\hline Umidade & & & & & & \\
\hline Ventilação & & & & & & \\
\hline Iluminação natural & & & & & & \\
\hline Iluminação artificial & & & & & & \\
\hline
\end{tabular}

2.2.2. No seu ambiente de trabalho, como você avalia os itens relacionados abaixo na época do INVERNO?

\begin{tabular}{|l|l|l|l|l|l|l|}
\hline & Péssimo & Ruim & Regular & Bom & Excelente & $\begin{array}{c}\text { Nenhuma das } \\
\text { anteriores }\end{array}$ \\
\hline Temperatura & & & & & & \\
\hline Umidade & & & & & & \\
\hline
\end{tabular}




\begin{tabular}{|l|l|l|l|l|l|l|}
\hline Ventilação & & & & & \\
\hline Iluminação natural & & & & & & \\
\hline Iluminação artificial & & & & & & \\
\hline
\end{tabular}

2.2.3. Como você avalia trabalhar em um local com ar condicionado?

(1) pouco satisfatório (2) satisfatório (3) muito satisfatório (4) nenhuma das anteriores

2.2.4.Como você avalia a interferência do ruído interno (edifício) no seu ambiente de trabalho?

(1) não há interferência (2) ocorrem ocasionalmente (3) ocorrem 50\% do tempo (4) ocorrem frequentemente.

2.2.5.Como você avalia a interferência do ruído externo (edifício) no seu ambiente de trabalho?

(1) não há interferência (2) ocorrem ocasionalmente (3) ocorrem 50\% do tempo (4) ocorrem frequentemente.

\subsection{DIMENSIONAMENTOS MÍNIMOS, ARRANJO ESPACIAL, SINALIZAÇÃO INTERNA E ACESSIBILIDADE}

\begin{tabular}{|c|c|c|c|c|c|c|}
\hline & Péssimo & Ruim & Regular & Bom & Excelente & $\begin{array}{l}\text { Nenhuma } \\
\text { das } \\
\text { anteriores }\end{array}$ \\
\hline $\begin{array}{l}\text { Largura dos corredores } \\
\text { no seu ambiente de } \\
\text { trabalho }\end{array}$ & & & & & & \\
\hline Largura das escadas & & & & & & \\
\hline Localização das escadas & & & & & & \\
\hline Quantidade de sanitários & & & & & & \\
\hline Tamanho dos sanitários & & & & & & \\
\hline $\begin{array}{l}\text { Acesso do deficiente } \\
\text { físico e circulação }\end{array}$ & & & & & & \\
\hline $\begin{array}{l}\text { Tamanho do ambiente } \\
\text { de trabalho }\end{array}$ & & & & & & \\
\hline $\begin{array}{l}\text { Aparência } \text { dos } \\
\text { ambientes de trabalho } \\
\text { (materiais e cores) }\end{array}$ & & & & & & \\
\hline $\begin{array}{l}\text { Localização das salas de } \\
\text { reunião }\end{array}$ & & & & & & \\
\hline $\begin{array}{l}\text { Espaços para reuniões } \\
\text { formais na Biblioteca }\end{array}$ & & & & & & \\
\hline $\begin{array}{l}\text { Espaços para encontros } \\
\text { e contatos informais na } \\
\text { Biblioteca }\end{array}$ & & & & & & \\
\hline $\begin{array}{l}\text { Áreas de descanso/lazer } \\
\text { disponíveis }\end{array}$ & & & & & & \\
\hline Saídas de emergência & & & & & & \\
\hline $\begin{array}{l}\text { Sinalização interna da } \\
\text { Biblioteca }\end{array}$ & & & & & & \\
\hline $\begin{array}{l}\text { Segurança da Biblioteca } \\
\text { contra incêndio }\end{array}$ & & & & & & \\
\hline $\begin{array}{l}\text { Adaptação da Biblioteca } \\
\text { ao uso do deficiente } \\
\text { físico }\end{array}$ & & & & & & \\
\hline $\begin{array}{lr}\text { Espaço } & \text { para } \\
\text { armazenamento } & \mathrm{e} \\
\text { almoxarifado } & \end{array}$ & & & & & & \\
\hline $\begin{array}{l}\text { Tempo de espera no } \\
\text { elevador }\end{array}$ & & & & & & \\
\hline
\end{tabular}




\subsection{TECNOLOGIA DA INFORMAÇÃO (TI)}

2.4.1.De modo geral, você acha que a Biblioteca está bem servida das diversas tecnologias informacionais como, microcomputadores, internet, bases de dados e redes digitais, terminais de consulta, etc.?

(1) não (2) sim

2.4.2. Você acha que a instituição tem procurado modernizar os recursos informáticos na Biblioteca?

(1) não $\quad$ (2) $\operatorname{sim}$

2.4.3. No seu posto de trabalho, com que freqüência você utiliza os recursos informáticos.?

(1) nunca (2) ocasionalmente (3) $50 \%$ do tempo (4) sempre

2.4.4.Em sua opinião, os recursos informáticos presentes na Biblioteca são suficientes para atender às necessidades no seu ambiente de trabalho?

(1) não (2) $\operatorname{sim}$

2.4.5. No quadro seguinte assinale suas impressões quanto à TECNOLOGIA DA INFORMAÇÃO (TI) no seu ambiente de trabalho?

\begin{tabular}{|l|l|l|l|l|l|l|}
\hline & Péssimo & Ruim & Regular & Bom & Excelente & $\begin{array}{c}\text { Nenhuma } \\
\text { das } \\
\text { anteriores }\end{array}$ \\
\hline $\begin{array}{l}\text { Quantidade } \\
\text { microcomputadores de }\end{array}$ & & & & & & \\
\hline $\begin{array}{l}\text { Localização dos } \\
\text { equipamentos } \\
\text { informáticos no ambiente } \\
\text { de trabalho }\end{array}$ & & & & & & \\
\hline $\begin{array}{l}\text { Velocidade de de } \\
\text { transmissão de dados }\end{array}$ & & & & & & \\
\hline $\begin{array}{l}\text { Facilidade no manuseio } \\
\text { dos } \\
\text { programas/equipamentos } \\
\text { informáticos disposição }\end{array}$ & & & & & & \\
\hline $\begin{array}{l}\text { Tamanho espacial do seu posto de } \\
\text { trabalho frente às } \\
\text { atividades dos recursos } \\
\text { informáticos do deficiente }\end{array}$ & & & & & & \\
\hline $\begin{array}{l}\text { Acesso do dos recursos } \\
\text { fisico aos } \\
\text { informáticos }\end{array}$ & & & & & \\
\hline
\end{tabular}

$\underline{\text { Agradecemos muito à sua valiosa cooperacão. }}$ 
06 - Roteiro de entrevistas

\section{USP UNIVERSIDADE DE SÃO PAULO}

Faculdade de Arquitetura e Urbanismo

Data: $1 / 1 \_$hora de início do -

Participante:

\section{MOBILIÁRIO}

01.De modo geral, você acha que o tipo de MOBILIÁRIO presente na Biblioteca é adequado para as atividades desenvolvidas?

02.As medidas do MOBILIÁRIO estão adequadas ao trabalho na biblioteca?

03.As cadeiras são confortáveis? Tipo de ajustes, Modelos,etc.

04.As mesas possuem dimensões adequadas?

05.As mesas atendem às necessidades no posto de trabalho?

06.As distâncias entres as mesas de trabalho são adequadas?

07.As medidas dos armários atendem as necessidade de arquivamento?

08.As quantidades de mesas são suficientes?

\section{DIMENSIONAMENTOS MÍNIMOS, ARRANJO ESPACIAL, SINALIZAÇÃO}

INTERNA E ACESSIBILIDADE

01.0 que você acha da largura e localização dos corredores e das escadas?

02. O que você acha da quantidade, tamanho e localização dos sanitários?

03.0 que você acha do acesso do deficiente físico no edifício?

04. Você acha que a sinalização interna da biblioteca atende seus requisitos?

05.0 que você acha dos espaços para encontros e contatos informais na biblioteca e espaços para reuniões formais na Biblioteca?

\section{CONFORTO AMBIENTAL}

01. Como você avalia o conforto térmico na biblioteca?

02. Quanto à lluminação?

03.Qualidade do ar no ambiente?

04. Quanto à ventilação?

05. A operação do ar-condicionado (ruídos, temperatura, posicionamento)? 


\section{TECNOLOGIA DA INFORMAÇÃO (TI)}

01.De modo geral, você acha que a Biblioteca está bem servida das diversas tecnologias informacionais como, microcomputadores, internet, bases de dados e redes digitais, terminais de consulta, etc.?

02.Você acha que a instituição tem procurado modernizar os recursos informáticos na Biblioteca?

03.Em sua opinião, os recursos informáticos presentes na Biblioteca são suficientes para atender às necessidades no seu ambiente de trabalho?

04. Quantidade de microcomputadores Localização dos equipamentos informáticos no ambiente de trabalho Facilidade no manuseio dos programas/equipamentos informáticos 